МІНІСТЕРСТВО ОСВІТИ I НАУКИ УКРАЇНИ

Сумський державний педагогічний університет імені А.С.макаренка

\title{
ДОШКІЛЬНА ТА ПОЧАТКОВА ОСВІТА В СУЧАСНОМУ ПЕДАГОГІЧНОМУ ПРОСТОРІ
}

Монографія

Суми 2020 
УДК 373.2/.3.091

Д 55

Друкується згідно з рішенням вченої ради

Сумського державного педагогічного університету імені А.С. Макаренка (протокол № 8 від 24 лютого 2020 р.)

\section{Рецензенти:}

Т. О. Пушкарьова - Член-кореспондент НАПН України, доктор педагогічних наук, профресор, начальник відділу проектної діяльності Інституту модернізації змісту освіти, м. Київ;

Л. В.Коваль - Заслужений працівник освіти і науки України, доктор педагогічних наук, профессор, декан факультету психологопедагогічної освіти та мистецтв Бердянського державного педагогічного університету.

\section{Наукові редактори:}

О. В. Лобова - доктор педагогічних наук, профресор, професор кафедри дошкільної і початкової освіти Сумського державного педагогічного університету імені А. С. Макаренка;

С. М. Кондратюк - кандидат педагогічних наук, профресор, профресор кафедри дошкільної і початкової освіти, директор Навчальнонаукового інституту педагогіки і психології Сумського державного педагогічного університету імені А. С. Макаренка.

д55

Дошкільна та початкова освіта в сучасному педагогічному просторі: [монографрія] / за заг. ред. О.В.Лобової, С. М. Кондратюк. СумДПУ імені А.С. Макаренка, 2020. - 352 с.

ISBN 978-966-698-286-8

DOI 10.24139/978-966-698-286-8/2020

У монографрії представлено результати широкого кола актуальних наукових пошуків вітчизняних фрахівців у галузі дошкільної та початкової освіти. У підрозділах видання розкрито педагогічні стратегії, теоретичні та методичні основи виховання, навчання та розвитку дітей дошкільного й молодшого шкільного віку; визначено різноманітні психолого-педагогічні аспекти дошкільної та початкової освіти; схарактеризовано актуальні проблеми підготовки майбутніх фахівців дошкільної та початкової освіти у сучасному педагогічному просторі.

Видання адресовано широкому колу науковців і педагогівпрактиків, що працюють у галузі дошкільної та початкової освіти, викладачам і студентам відповідних спеціальностей у закладах вищої педагогічної освіти. 
ВСТУП

РОЗДІЛ 1 ПЕДАГОГІЧНІ СТРАТЕГІЇ ФОРМУВАННЯ

ОСОБИСТОСТІ ДІТЕЙ ДОШКІЛЬНОГО ВІКУ

Білер О.С.

РОЗВИТОК КРЕАТИВНОСТІ ЯК БАЗОВОЇ ЗДІБНОСТІ

ДІТЕЙ СТАРШОГО ДОШКІЛЬНОГО ТА МОЛОДШОГО

ШКІЛЬНОГО ВІКУ

Вертель А. В., Вертель М. Ю.

ПСИХОЛОГО-ПЕДАГОГІЧНІ ОСОБЛИВОСТІ СОЦІАЛІЗАЦІЇ

ДІТЕЙ ДОШКІЛЬНОГО ВІКУ, ПОЗБАВЛЕНИХ

БАТЬКІВСЬКОГО ПІКЛУВАННЯ

Гаврило О. І.

ПСИХОЛОГІЧНІ І ПЕДАГОГІЧНІ ОСНОВИ ДОСЛІДНИЦЬКОЇ

ДІЯЛЬНОСТІ ДІТЕЙ ДОШКІЛЬНОГО ВІКУ

Кондратюк С. М.

ПЕДАГОГІЧНІ УМОВИ СТАТЕВО-РОЛЬОВОЇ СОЦІАЛІЗАЦІЇ

СТАРШИХ ДОШКІЛЬНИКІВ

Шаповалова О.В.

ТЕОРЕТИЧНІ ОСНОВИ ФОРМУВАННЯ КУЛЬТУРИ

СПОЖИВАННЯ У ДІТЕЙ СТАРШОГО ДОШКІЛЬНОГО ВІКУ

РОЗДІЛ 2 ТЕОРІЯ ТА МЕТОДИКА ПОЧАТКОВОЇ ОСВІТИ:

РЕАЛІЇ, ПРОБЛЕМИ ТА ПЕРСПЕКТИВИ

Боряк О.В.

МЕТОДИКА РОБОТИ З РОЗВИТКУ МОВЛЕННЯ МОЛОДШИХ

ШКОЛЯРІВ 3 ІНТЕЛЕКТУАЛЬНИМИ ПОРУШЕННЯМИ

Булатова Л. О.

ПЕДАГОГІЧНІ УМОВИ ФОРМУВАННЯ МУЗИЧНО-ІНТОНАЙЦІЙНИХ

УЯВЛЕНЬ МОЛОДШИХ ШКОЛЯРІВ

Бутенко В. Г.

ФОРМУВАННЯ ЗДОРОВОГО СПОСОБУ ЖИТТЯ

МОЛОДШИХ ШКОЛЯРІВ ЗА ПЕДАГОГІЧНОЮ СПАДЩИНОЮ

В. О. СУХОМЛИНСЬКОГО

Данько Н.П.

ДІАГНОСТИКА НАВЧАЛЬНИХ ДОСЯГНЕНЬ УЧНІВ

ПОЧАТКОВИХ КЛАСІВ З МУЗИЧНОГО МИСТЕЦТВА.

Колишкіна А. П.

ТЕОРЕТИЧНІ ЗАСАДИ ВЗАЕМОДІЇ СІМ'Ї ТА ШКОЛИ У ФОРМУВАННІ ЕКОЛОГІЧНО ДОЦІЛЬНОЇ ПОВЕДІНКИ МОЛОДШИХ ШКОЛЯРІВ 
Лобова О. В.

ОСОБЛИВОСТІ МИСТЕЦЬКОЇ ОСВІТИ УЧНІВ В УМОВАХ

НОВОЇ УКРАЇНСЬКОЇ ШКОЛИ (ЗА ПІДРУЧНИКАМИ «МИСТЕЦТВО»,

1 ТА 2 КЛАСИ)

Павлущенко Н. М.

ОСОБЛИВОСТІ ФОРМУВАННЯ ЕСТЕТИЧНИХ СМАКІВ

МОЛОДШИХ ШКОЛЯРІВ ЗАСОБАМИ ФОЛЬКЛОРУ 204

Парфілова С. Л.

ТЕОРЕТИКО-МЕТОДИЧНІ ЗАСАДИ РОЗВИТКУ

ЛІТЕРАТУРНО-ТВОРЧИХ ЗДІБНОСТЕЙ МОЛОДШИХ

ШКОЛЯРІВ

220

РОЗДІЛ З АКТУАЛЬНІ ПРОБЛЕМИ ПІДГОТОВКИ МАЙБУТНІХ

ФАХІВЦІВ У ГАЛУЗІ ДОШКІЛЬНОÏ ТА ПОЧАТКОВОЇ ОСВІТИ.

Васько О. О.

ФОРМУВАННЯ ГОТОВНОСТІ МАЙБУТНЬОГО ВЧИТЕЛЯ ДО

РОЗВИТКУ ТВОРЧОГО МИСЛЕННЯ МОЛОДШИХ

ШКОЛЯРІВ ПРИ ВИВЧЕННІ МАТЕМАТИКИ.

Вітюк В. В.

СУЧАСНІ ПІДХОДИ ДО НАВЧАННЯ В МЕТОДИЧНІЙ

СИСТЕМІ ФОРМУВАННЯ ПРАВОПИСНОÏ КОМПЕТЕНТНОСТІ

МАЙБУТНІХ УЧИТЕЛІВ ПОЧАТКОВОЇ ШКОЛИ 256

Гулей О. В., Никифооров А. М.

ФОРМУВАННЯ ХУДОЖНЬОЇ ЕТНОКУЛЬТУРИ МАЙБУТНІХ

ФАХІВЦІВ ПОЧАТКОВОЇ ОСВІТИ ЗАСОБАМИ НАРОДНОГО

МИСТЕЦТВА (НА ПРИКЛАДІ РІЗЬБЛЕННЯ).

Пушкар Л.В.

ТЕАТРАЛЬНО-ІГРОВА ДІЯЛЬНІСТЬ ЯК ЗАСІБ ФОРМУВАННЯ

МУЗИЧНИХ КОМПЕТЕНЦІЙ ФАХІВЦІВ ДОШКІЛЬНОЇ ОСВІТИ.

Рогальська Н. В.

ОСОБЛИВОСТІ ВИКОРИСТАННЯ НАДБАНЬ ЕТНОПЕДАГОГІКИ

У ПРОФЕСІЙНІЙ ПІДГОТОВЦІ МАЙБУТНІХ ВИХОВАТЕЛІВ

ДІТЕЙ ДОШКІЛЬНОГО ВІКУ

Тарасенко Г.С., Нестерович Б.І.

КОМПЕТЕНТНІСНИЙ ПІДХІД ДО ПРАКТИЧНОЇ ПІДГОТОВКИ

ВЧИТЕЛЯ ПОЧАТКОВОЇ ШКОЛИ В КОНТЕКСТІ ЗАВДАНЬ

МУЗИЧНО-ЕСТЕТИЧНОГО ВИХОВАННЯ МОЛОДШИХ ШКОЛЯРІВ ... 319

Харькова Є.Д.

МОДЕЛЬ ФОРМУВАННЯ ГОТОВНОСТІ МАЙБУТНІХ ВИХОВАТЕЛІВ ЗАКЛАДІВ ДОШКІЛЬНОЇ ОСВІТИ ДО ВИКОРИСТАННЯ ІНТЕРАКТИВНИХ ТЕХНОЛОГІЙ 334 


\section{ВСТУП}

Реалії сьогодення свідчать про те, що ми живемо у просторі колосальних трансформацій, які торкаються всього спектру буття людини. На фоні політичних, соціально-економічних та культурних перетворень у суспільстві відбувається реформування всієї освітньої системи.

Найкардинальніші зміни відчувають на собі галузі дошкільної та початкової освіти, які реагують на ці виклики динамікою свого розвитку: варіативністю змісту і фрорм організації освітнього простору, неперервністю процесів навчання й виховання, зміцненням особистісної орієнтації змісту і технологій навчання, поглибленням індивідуалізації та диференціації освітніх маршрутів кожного учасника освітнього процесу. Тобто сучасний етап розвитку освіти в нашій країні, радикальні зміни в соціокультурному житті суспільства в цілому вимагають певного переосмислення ідей, концепцій, адаптації педагогічних технологій до нових умов, у яких працюють сучасні заклади дошкільної та початкової освіти.

У монографої викладається досвід системних досліджень вітчизняних фахівців у галузі дошкільної та початкової освіти. Так, перший розділ книги присвячено визначенню педагогічних стратегій формування особистості дітей дошкільного віку, серед яких: розвиток креативності як базової здібності дітей старшого дошкільного та молодшого шкільного віку; психолого-педагогічні особливості соціалізації дітей дошкільного віку позбавлених батьківського піклування; психологічні і педагогічні основи дослідницької діяльності дітей дошкільного віку; педагогічні умови статево-рольової соціалізації старших дошкільників; теоретичні основи формування культури споживання у дітей старшого дошкільного віку.

У другому розділі розкрито теоретичні та методичні основи виховання, навчання та розвитку дітей дошкільного й молодшого шкільного віку. Висвітлено особливості мистецької освіти учнів в умовах Нової української школи, фрормування естетичних смаків молодших школярів засобами фольклору. Представлено комплексну диференційовану систему формування та корекції мовленнєвої діяльності молодших школярів 3 інтелектуальними порушеннями (легким та помірним ступенями розумової відсталості). Визначено багатоманітні психолого-педагогічні аспекти початкової освіти. 
У третьому розділі розкрито актуальні проблеми підготовки майбутніх фахівців дошкільної та початкової освіти у сучасному педагогічному просторі: розглянуто проблеми професійної підготовки педагогічних кадрів на основі компетентнісного підходу; порушено питання готовності майбутнього вихователя та вчителя до використання інноваційних технологій ту сучасних методик у закладах дошкільної та початкової освіти; досліджено проблему фрормування художньої етнокультури майбутніх фрахівців початкової освіти засобами народного мистецтва.

Запропонована читачеві монографрія $€$ гідною відповіддю колективом авторів на потребу в системному осмисленні актуальних проблем дошкільної та початкової освіти. Колективна праця «Дошкільна та початкова освіта в сучасному педагогічному просторі» буде цікавою й корисною широкому колу науковців і педагогівпрактиків, що працюють у галузі дошкільної та початкової освіти, викладачам і студентам відповідних спеціальностей у закладах вищої педагогічної освіти. 


\title{
РОЗДІЛ 1 \\ ПЕДАГОГІЧНІ СТРАТЕГІЇ ФОРМУВАННЯ \\ ОСОБИСТОСТІ ДІТЕЙ ДОШКІЛЬНОГО ВІКУ
}

\section{РОЗВИТОК КРЕАТИВНОСТІ ЯК БАЗОВОЇ ЗДІБНОСТІ ДІТЕЙ СТАРШОГО ДОШКІЛЬНОГО ТА МОЛОДШОГО ШКІЛЬНОГО ВІКУ}

\author{
Білер О.С. \\ кандидат педагогічних наук, старший викладач, \\ Сумський державний педагогічний університет імені А.С. Макаренка
}

Сучасний період розвитку суспільства, оновлення всіх сфрер його соціального і духовного життя потребує якісно нового рівня освіти, який би відповідав міжнародним стандартам. Все частіше говорять про креативність, як базову якість особистості і це не випадково, адже життя в епоху науково-технічного прогресу стає різноманітнішим і складнішим [36] та характеризує особистість не сукупністю стандартних, звичних дій, а гнучкості мислення, швидкої орієнтації та адаптації до нових умов, творчого підходу до вирішення проблем. Креативність сприймається вже ніяк природня схильність, талановитість отримана від народження, а як здатність, що можна розвинути впродовж життя. Сприймаючи креативність, як одну із необхідних якостей фрахівця XXI століття здатного творчо здійснювати професійну діяльність, зрозумілим стає необхідність її розвитку. Насьогодні вчені все більш схиляються до думки, що найсприятливіший період для розвитку креативності $€$ дошкільний та молодший шкільний вік, оскільки в цей період розвитку діти ще не мають сталих рамок та чітко сформованих логічних схем, що в подальшому можуть стримувати розвиток креативності.

Незважаючи на значну кількість публікацій, проблема розвитку креативності дітей старшого дошкільного та молодшого шкільного віку висвітлена в науковій літературі недостатньо. Це пов'язано в першу чергу з тим, що система роботи з розвитку креативності продовжує формуватися. Отже, постає потреба в розвитку креативності дітей старшого дошкільного та молодшого шкільного віку як передумови фоормування фрахівця XXI століття, це й обумовило вибір теми дослідження.

Ще й досі не існує чіткого розмежування понять «креативність», «творчість» і суміжних з ними, тому метою цього етапу цього 
дослідження було здійснення теоретичного аналізу сутності провідних понять теми дослідження, встановлення їх структури, компонентів тощо. Відповідно до напряму дослідження, провідними поняттями були визначені: креативність, творчість, розвиток, розвиток креативності дітей старшого дошкільного та молодшого шкільного віку.

До трактування поняття «креативність» спостерігаються різні підходи, зокрема: по-різному визначають його місце в структурі особистості, рівень усвідомлення проявів креативності, а також джерела та умови його розвитку. Незважаючи на різноманітність підходів, ми можемо визначити низку спільних поглядів учених щодо аналізованого феномена.

Так дослідники розглядають креативність як:

$>$ загальну здатність до творчості (Л. Єрмолаєва-Томіна, С. Сисоєва, О. Ярошинська, Л. Байтімерова, В. Дружинін, Л. Пузеп, О. Кононко, О. Куцевол, В. Фрицюк, І. Подорожна, О. Приходько, Л. Виготський, К. Батовріна, К. Korniłowicz, S. Popek, M. ModrzejewskaŚwigulska, W. Limont, J. Kaufman, A. Tokarz);

властивість особистості (Дж. Гілфрорд, Е. Nęcki, Е. Торренс, $€$ Є. Гергель);

здатність особистості виходити за межі заданої ситуації, створювати оригінальні цінності (Ф. Баррон, Д. Богоявленська, С. Медник, В. Моляко, В. Сластьонін, Л. Байтімерова, Л. Пузеп, О. Кульчицька, І.Гриненко, О. Дунаєва, Н. Добровольська, Н. Вишнякова, І. Шахіна, Л. Виготський, Е. Фромм, К. Szmidt);

$>$ процес прояву власної індивідуальності (О. Яковлєва, О. Войтенко, К. Szmidt) [25].

Уперше термін «креативність» було вжито психологом Д. Сімпсоном, учений уважав, що «креативність» - це здатність людини відмовитися від стереотипних способів мислення, «здатність до руйнування загальноприйнятого, звичайного порядку походження ідей у процесі мислення» [16, С. 632].

Одне з найперших визначень креативності надав американський учений, профресор Стенфордського університету Джон Као: «Креативність - це цілісний процес генерації ідей, їх розвитку та перетворення на цінності. Цей процес поєднує в собі те, що люди називають новаторством». Він відзначає одночасно мистецтво породження нових ідей і науку відточування цих ідей до стадії відтворення в дійсності [25].

Відповідно до тематики цього дослідження цікавим $€$ визначення Н. Малої [18], яка зазначає, що креативність - це розумова й практична діяльність, результатом якої $\epsilon$ генерація нових, оригінальних ідей, цінностей, виявлення нових фрактів у відповідь на потреби організації, чи наявні у неї можливості, а також фрормування i розвиток творчого потенціалу особистості, що приводить до 
ефективної діяльності. Основними чинниками креативності, із погляду науковця є: спадкові, когнітивні, особистісні, мотиваційні, середовищі, зовнішні та внутрішні, об'єктивні й суб'єктивні.

Таким чином науковець визначає креативність як вид діяльності, проте дещо іншого погляду дотримується В. Павленко [26], який описує креативність як природну властивість особистості, що існує від початку життя людини; це найвища фоорма активності особистості; характеристика особистості. Завдяки креативності людина виражає свій внутрішній світ, змінюючи його.

Український учений В. Моляко [23, С. 25] визначає креативність як здібність, що відображає глибинну можливість людей створювати оригінальні цінності, приймати нестандартні рішення. Він виділяє сім ознак креативності: оригінальність, еврестичність, франтазію, активність, сконцентрованість, чіткість, чуттєвість.

Отже, спираючись на наведені вище твердження, можемо зазначити, що вони не створюють концептуальної ясності щодо поняття «креативність». Слід зазначити, що в науко-педагогічній літературі поняття «креативність» сьогодні все більш застосовується як синонім до слова «творчість». Так, у словнику іноземних слів креативність [англ. creative - творчий; лат. creatio (creationis) створення] тлумачиться як творчий [13]. Проте, із нашого погляду, це все ж таки різні поняття, що і підтверджує думка В. Павленко, який зазначає, що спостерігається тенденція до розрізнення понять «креативність» і «творчість», де останнє розглядається в більш широкому контексті.

Креативність, за Р. Стернберг [32], $є$ процесом деталізації творчого продукту та надання йому конкретної предметної форми.

У психологічній енциклопедії креативність визначається як рівень творчої обдарованості, прояву здібностей до творчості, що виявляються у мисленні, спілкуванні, окремих видах діяльності та $є$ відносно стійкою характеристикою особистості [29, С. 181].

Схоже визначення ми знаходимо у педагогічному словнику. Креативність тлумачиться як творчі можливості (здібності) людини, що можуть виявлятися у мисленні, почуттях, спілкуванні, окремих видах діяльності, характеризувати особистість загалом чи її окремі сторони, продукти діяльності, процес їх створення. Креативність розглядається як найважливіший і відносно незалежний фактор обдарованості, що рідко відображається в тестах інтелекту й академічних досягненнях. Креативність визначається не стільки критичним ставленням до нового з точки зору існуючого досвіду, скільки сприйнятливістю до нових ідей [27, С. 269].

В енциклопедії освіти зазначено, що креативність - це творчий дух, творчий потенціал індивіда, його творчі здібності, що виявляються не тільки в оригінальних продуктах діяльності, а й у мисленні, почуттях, спілкуванні з іншими людьми [12, С. 432]. 
Натомість, в Українському педагогічному словнику С. Гончаренка [9, С. 326] подається таке визначення творчості: «Творчість - це продуктивна людська діяльність, здатна породжувати якісно нові матеріальні та духовні цінності суспільного значення».

Подібне визначення, тільки доповнене, можемо знайти в психологічному словнику за редакцією В. Войтка: «Творчість психічний процес створення нових цінностей, ніби продовження і заміна дитячої гри. Діяльність, результатом якої $є$ створення нових матеріальних і духовних цінностей. Будучи, по суті, культурноісторичним явищем, має і психологічний аспект - особистісний i процесуальний. Припускає наявність у суб'єкта здібностей, мотивів, знань і умінь, завдяки яким створюється продукт, що відрізняється новизною, оригінальністю, унікальністю. Вивчення цих властивостей особистості показало важливу роль уяви, інтуїції, неусвідомлюваних компонентів розумової активності, а також потреби особистості в самоактуалізації, у розвитку й розширенні своїх творчих можливостей» [30, С. 186].

Зважаючи на все вищезазначене цікавою $€$ думка К. Шмідта [40], який зазначає, що концепція креативності близька до концепції творчості. Креативність - це здатність людини генерувати нові, цінні продукти (речі, ідеї, методи роботи та ін.), «zdolność człowieka do w miarę częstego generowania nowych i wartościowych wytworów (rzeczy, idei, metod działania itd.)».

К. Шмідт [40] підкреслює, що поняття «креативність» стосується лише людини, а не продукту творчого процесу. Дослідник виділяє декілька характеристик, які фрормують образ креативної людини, зокрема це: особливий спосіб сприйняття світу (наприклад, здивування, захоплення, свіжість погляду); відкритість і терпимість до двозначності; незалежність і сміливість; відсутність страху перед невідомим; спонтанність і експресивність; здатність сконцентруватися й захопитися завданням; доброзичливе почуття гумору; соціалізація і готовність діяти для інших і 3 іншими; можливість інтеграції протилежностей.

О. Антонова [4, С. 28] поділяє думку К. Шмідта та вважає, що креативність правильніше визначати не стільки як певну творчу здібність або їх сукупність, скільки як здатність до творчості. Науковець визначає креативність як творчі можливості людини, що можуть виявлятися в мисленні, почуттях, спілкуванні, окремих видах діяльності, характеризувати особистість загалом або її окремі сторони. Це здатність породжувати незвичні ідеї, відходити від традиційних схем мислення, швидко вирішувати проблемні ситуації. Креативність розглядається як найважливіший і відносно незалежний чинник обдарованості.

Доречною також $є$ думка К. Шмельова [37], саме він визначав сутність творчості у відкритті чогось якісного нового, що має значну 
цінність, а креативність, як уміння генерувати нові ідеї. У цьому сенсі «креативний», не те ж саме, що «творчий».

Слід також звернути увагу на те, що багато вчених не визнають фракт існування креативності як автономної, універсальної здібності. Вони вважають, що творчість завжди безпосередньо пов'язана 3 певним видом діяльності. Тобто, на їхню думку, не можна говорити про творчість узагалі: $€$ художня творчість, наукова творчість, технічна творчість тощо. Однак більшість учених схиляються до думки, що природа творчості єдина, а тому і здатність до творчості універсальна. Навчившись діяти у сорері мистецтва, техніки чи в інших видах діяльності, людина легко може перенести цей досвід у будь-яку іншу сфреру. Саме тому здатність до творчості розглядається як відносно автономна, самостійна здібність [26].

Таким чином, підводячи підсумок, ми можемо зазначити, що хоча поняття «креативність» і «творчість» дуже близькі за змістом, усе ж вони мають певні відтінки у значенні. Основою творчого процесу $\epsilon$ натхнення автора, його здібності. Тобто творчості не існує без натхнення. У свою чергу, основою креативності $\epsilon$ прагматизм, тобто доцільність, корисність вихідного продукту. Творчі люди залежать від настрою та власних емоцій. Під креативністю розуміємо загальну здатність людини до інновацій та творчості у різних сфрерах ії діяльності. Креативність - це не лише здатність створювати щось нове, але це й уміння створювати щось нове з певною метою. Це дає нам змогу зробити припущення, що здатність та уміння можна розвинути, й як наслідок зробити безпосередньою складовою особистості як здатність до аналізу чи вміння синтезувати.

Якщо триматися цього припущення, то за логікою дослідження слід розглянути поняття розвиток загалом, та розвиток дітей старшого дошкільного та молодшого шкільного віку зокрема. Зазначимо, що науковці дотримуються єдиної думки, щодо визначення поняття розвиток, вважаючи, що це складний процес об'єктивної дійсності за результатом якого $€$ виникнення якісно нового, поступальний процес сходження від нижчого до вищого, від простого до складного.

Доцільною $є$ також думка Г. Костюка [14], який визначає розвиток, як безперервний процес, що виявляється у кількісних змінах людської істоти, тобто збільшення одних і зменшення інших ознак (фрізичних, фрізіологічних, психічних тощо). Однак він не зводиться до кількісних змін, до зростання того, що вже $\epsilon$, а включає «перерви безперервності», тобто якісні зміни. Кількісні зміни зумовлюють виникнення нових якостей, тобто ознак, властивостей, які утворюються в ході самого розвитку і зникнення старих.

Розвиток має наступні характеристики розвитку : процес - рух від простого до складного, від недосконалого до більш досконалого, від старого якісного стану до нового, від простих фрорм відображення дійсності до духовної досконалості; джерело - боротьба 
протиріч; умови - внутрішні і зовнішні, взяті в єдності; фактори спадковість, середовище, виховання; діалектика - перехід кількості в якість і навпаки.

Таким чином, можемо дійти висновку, що розвиток це сталий процес який веде до якісно нових утворень і має відбуватися відповідно до певних умов, а саме розвиток особистості залежить від спадковості, середовища та виховання. Його джерелом і внутрішнім змістом $€$ різноманітні внутрішні та зовнішні суперечності. Вони виявляються у психічних процесах збудження i гальмування, в емоційній сфрері - у відчуттях задоволення і незадоволення, радості і горя. Особистість активно розвивається, відчуваючи суперечності між своїми прагненнями та можливостями, якщо визначені умови дотримано, то розвиток відбувається упродовж усього життя.

Зазначимо, що розвиток креативності, як і будь-який розвиток, має свої особливості в кожному віковому періоді, причому різні фактори, що впливають на його динаміку, в тому або іншому періоді, можуть набувати первинного значення, проте період активного розвитку загалом, та креативного зокрема, все ж таки припадає на окреслений нами період.

Зважаючи на вищезазначене, надамо вікову характеристику дітей старшого дошкільного та молодшого шкільного віку, відповідно до тематики нашого дослідження. В окреслений період у психіці дитини з'являються принципово нові утворення. Це довільність психічних процесів - уваги, пам'яті, сприйняття тощо - і здатність, що випливає звідси, керувати своєю поведінкою, а також змінювати уявлення про себе як у самосвідомості, так і в самооцінці.

Розвиток особистості передбачає появу психічних новоутворень у діяльності суб'єкта. Коли дитина привласнює психічні новоутворення, то іï особистість ускладнюється, відбувається розгортання внутрішнього плану, який має кожна людина. Тільки у дитини, включеної в соціальні відносини, розвиваються вищі психічні функції. Розвиток їх зумовлюється генезисом, активністю особистості й особливостями навчально-виховного процесу. Завдяки процесу опосередковування відбувається розвиток вищих психічних функцій. Опосередкування передбачає, що дитина привласнює культурні засоби у власній фоомі особистісної активності [15].

Слід зазначити, що окреслений період, вважається періодом розвитку наївної креативності дитини, що базується, з одного боку, на яскравих образах, емоційності, імпульсивності й жвавості поведінки дитини, а з іншого - на незнанні законів логіки, загальних закономірностей явищ, відсутності жорстко закріплених правил мислення. Разом із тим, розвиток більш тісних зв'язків із мовленням, формування доцільності у виникненні продуктів уяви, креативності, прагнення до наслідування інших і нормативності поведінки у окреслений період створюють умови виникнення креативності. 
Досліджуючи особливості мислення зазначимо, що образи мислення у цьому віці надзвичайно яскраві, живі, тісно пов'язані 3 почуттями[2]. Оскільки, мислення наочно-образне, з елементами словесно-логічного на основі яких починає формуватися й образносхематичне. Розвиватися й категоріальне мислення, встановлюються зв'язки між поняттями «причина-наслідок». Діти можуть виконувати завдання на передбачення. Розвивається функція мислення символами, що є підґрунтям для створення різних в тому числі й креативних моделей.

Найвіддаленіша схожість між тим, що сприймає дитина, та її попередніми враженнями викликає бурхливий потік нових асоціацій. Діти надзвичайно довірливо ставляться до своїх витворів франтазії [24]. В. Сухомлинський говорив: «Дітям не треба багато говорити, не слід багато їм розповідати, слово - не цяцька, а словесне перенасичення одне з найшкідливіших перенасичень. Дитині треба не тільки слухати слово вихователя, але й мовчати, в цю мить вона думає, осмислює почуте та побачене».

Слід також зазначити, що в дітей цього віку дуже швидко розвивається пізнавальна активність. У творчій, і в будь-якій іншій діяльності дитині властива всеохоплююча допитливість: від «Що це таке?» до «Хочу знати все!». Пізнавальна активність у дітей старшого дошкільного віку спрямована не тільки на пізнання окремого предмета чи явища, а й на розпізнання його устрою, причини, мети, призначення, способу використання тощо (Н. Бібік, Т. Дуткевич, М. Марусинець, Г. Щукіна) $[5 ; 11 ; 19 ; 38]$. Це обумовлено тим, що їм уже $є$ чим оперувати у своїх роздумах (наявність сорормованих знань), цьому сприяє й сприймання яке стає цілеспрямованим, осмисленим, аналітичним. Увага стає стійкою. Запам'ятовування вже свідоме та цілеспрямоване. Образна пам'ять являється чи не головним видом пам'яті в цьому віці.

У цьому віці стрімко розвивається смислова пам'ять. Ії̈ ефрективність залежить від правильного розуміння інформації, що дається для запам'ятовування. Неможна оминути увагою й той фракт, що це сентизований період для розвитку уяви, дитина починає створювати власні образи та керувати ними. Діти здатні вигадувати цікаві історії, оповідання; складати вигадані ними конструкції не звертаючись до зразка, також активно розвивається творча уява, дитина накопичує досвід взаємодії з довкіллям у його фрізичних та соціальних аспектах.

Л. Виготський уважав, що основою творчої діяльності та уяви $€$ рекомбінація життєвого досвіду. Психолог виділяв два види діяльності людини: 1) репродуктивну, що полягає у відтворенні відомих прийомів поведінки та вражень, що запам'яталися; 2) комбінуючу ( або творчу) діяльність, якою виступає уява. Як зазначає дослідник, все створене 
уявою завжди будується з елементів, що запозичені з дійсності та утримуються у минулому досвіді людини. Тому педагогічним завданням, на його думку, $\epsilon$ розширення досвіду дитини, що $є$ матеріалом для розвитку фантазії [20, С. 3 - 11]. Творча активність з'являється у дітей як наслідок впливу креативогенних (сприятливих) факторів, які супроводжують її діяльність ще змалку.

У цей час стрімко зростає й розумова активність дітей. Дитина починає робити описові розповіді, опираючись на сюжет, що намальований на картинці. Самостійно переказує нею почуте. Щодо мислення як творчості, то воно виникає, коли людина потрапляє у проблемно-конфрліктну ситуацію. Я. Пономарьов зазначає, що експериментальне моделювання таких ситуацій $є$ одним зі способів творчого мислення людини. Процес творчого мислення здійснюється за умов його самоорганізації, джерелом якої $є$ пізнавальна активність особистості як цілісного «Я», що саморозвивається. «Я» спонукає до саморозвитку під час розв'язання творчих завдань на основі подолання особистісних конфліктів, які виникають у зв'язку із неможливістю безпосереднього їх вирішення і потребують активної особистісної самоперебудови. Відбувається певне переосмислення як спосіб активного втілення «Я» у проблемно-конфрліктній ситуації. Це визначає самозміну й саморозвиток суб'єкта, що трактує переосмислення як рефлексію [28].

Спираючись на вищезазначене, можемо стверджувати, що проблема розвитку креативності старших дошкільників та учнів початкових класів торкається величезного спектру питань, що пов'язані з феноменом розвитку особистості. Нам близький підхід К. Батовріної, Л. Виготського, О. Куцевол, В. Дружиніна, О. Кононко, І. Подорожної, Л. Пузеп, які визначають креативність як здатність до творчості: яка проявляється в різних сорерах активності й розглядається як відносно незалежний фактор обдарованості та $€$ умовою самореалізації особистості, як уміння породжувати різноманітні оригінальні ідеї й продуктивні шляхи їх застосування.

Отже, відповідно до вікових особливостей розвитку дітей окресленого вікового періоду та визначену нами сутність поняття креативність, можемо охарактеризувати поняття креативність дітей старшого дошкільного та молодшого початкового віку, як уміння генерувати нові ідеї, готовність до непередбачуваних рішень, допитливість, здатність до коментування процесу та результату діяльності, мотивацію досягнень, розвинуту уяву, а також здатність до створення творчого образу, який відрізняється оригінальністю, варіативністю, гнучкістю та рухливістю.

Далі, за логікою цього дослідження, проаналізуємо складові креативності загалом та визначимо складові розвитку креативності дітей старшого дошкільного та молодшого шкільного віку, зокрема. Саме тому далі проаналізуємо дослідження Дж. Гілфорда, який 
виділив шість основних параметрів креативності, серед них:

1) здатність до виявлення і постановки проблем; 2) здатність до генерування великої кількості ідей; 3) гнучкість - продукування різноманітних ідеї; 4) оригінальність - спроможність продукувати віддалені асоціації, незвичні відповіді, відповідати на подразники нестандартно; 5) здатність удосконалити об'єкт, додаючи деталі; 6) уміння вирішувати проблеми, тобто здатність до аналізу і синтезу [8].

У свою чергу, Е. Торренс визначив параметри креативності: легкість (швидкість виконання тестових завдань), гнучкість (число переключень з одного класу об'єктів на інший у ході відповідей), оригінальність (оригінальність виконання завдань) й точність (точність виконання завдань) [25].

Досліджуючи складові креативності А. Савенков [17] враховує такі їі характеристики, як: продуктивність - здатність до продукування максимально великої кількості ідей. Цей показник не $є$ специфічним для творчості, але зрозуміло: чим більше ідей, тим більше можливостей для вибору з них найбільш оригінальних; гнучкість здатність переходити від одного класу явищ до іншого, часто дуже далеко за змістом. Творча людина, безумовно, повинна вміти гнучко змінювати і стратегію, і тактику дослідницького пошуку; оригінальність - здатність висувати нові, неочікувані ідеї, що відрізняються від широкого загалу; рівень «розробки» ідеї. Творчі особистості умовно можуть бути поділені на дві категорії: одні вміють краще продукувати оригінальні ідеї, інші - детально, творчо розробляти існуючі.

Досліджуючи структуру креативності, Л. Пузеп [31, С. 7 - 8], дивиться на проблему через іншу призму, так він виділяє сім взаємопов'язаних компонентів, що $є$ основою креативної діяльності: креативні здібності як основа творчого процесу, креативна мотивація як вияв креативних здібностей, креативна спрямованість як мотиваційна орієнтація у творчій діяльності; креативна установка як прийняття творчої ситуації, креативно-вольовий акт як подолання внутрішніх перешкод у реалізації креативних здібностей, креативна активність як пошук нестандартних шляхів вирішення проблем, рівень креативних домагань, що характеризує труднощі творчих завдань.

А. Матюшкін [21] розглядає повну структуру продуктивного циклу креативного мислення: породження проблеми - формулювання проблеми - пошук рішення - розуміння (інсайт) - обґрунтування (інтерпретація) - реалізація рішення. Проте, ця структура відображає лише складові креативного мислення, тому не забезпечує охоплення розвитку креативності вцілому.

За теорією креативності Т. Любарта та Р. Стернберга [32, С. 99 124] iï розвиток забезпечується наявністю таких взаємопов'язаних компонентів: 1) здібності, які поділяються на синтетичні (уміння поновому бачити проблему, дивергентне мислення), аналітичні (уміння аналізувати й оцінювати ідеї), практично-контекстуальні (уміння 
знаходити абстрактним ідеям практичне застосування); 2) знання, спираючись на які людина може креативно використовувати теоретичні відомості на практиці; 3) мислення (сміливість думок, рухливість розуму); 4) особистісні якості, серед яких найважливішими є уміння долати перепони й невпевненість, виправдано ризикувати; 5) мотивація, що допомагає людині зосередитися на творчій роботі; 6) навколишне (оточуюче) середовище, оскільки без підтримки середовища креативність не може виявитися і розвиватися.

Інший підхід до розкриття структури креативності обрав Д. Трефренджер [41], який за основу взяв чотири взаємопов'язані елементи, що поєднували велику кількість особистісних властивостей. Він означив компоненти як характеристики (генерування й занурення в ідею, відкритість і мужність, «дослуховування до внутрішнього голосу»), операції (прийоми й методи генерування ідей, розв'язання проблем, прийняття рішень), контекст (культура, середовище, клімат, оточення), результати (ідеї, рішення, продукти). Ця структура вбачається нам досить розмитою, оскільки важко зрозуміти як розвинути та виміряти, наприклад, складову «дослуховування до внутрішнього голосу».

В. Антонішена [3, С. 97 - 106] виділила в структурі креативності такі компоненти: когнітивний, емоційно-ціннісний, практичнодіяльнісний. Кожен компонент визначається певними показниками: когнітивний включає знання способів вирішння завдань, знання алгоритму вирішення проблеми, розуміння сутності проблеми, бачення нового в звичайному, аналізу та синтезу); емоційно-ціннісний містить інтелектуальні і креативні здібності, творчий потенціал, інтерес до невідомого, відстоювання своєї думки; практично-діяльнісний визначається вмінням давати кілька правильних відповідей на одне запитання, приймати думку іншого, відстоювати свою думку, комбінувати, моделювати, удосконалювати, створювати нові об'єкти.

Як зазначає Г. Гарднер [7] креативність зазвичай не передбачає високого рівня «загального інтелекту», а значно тісніше корелюють зі специфрічними видами інтелекту - лінгвістичним, музичним, логікоматематичним, просторовим, тілесно-кінестатичним, внутрішньо особистісним та міжособистісним.

Проаналізувавши пропоновані науковцями складові креативності можемо зазначити, що у межах нашого дослідження найбільш повною $€$ складові визначені Т. Любартом і Р. Стернбергом, проте і їх зміст має бути переглянутий та доповнений відповідно до вікових особливостей розвитку дітей старшого дошкільного та молодшого шкільного віку. Так, говорячи, про здібності, слід зазначити, що синтетичні здібності, а саме дивергентне мислення, притаманне дітям цього віку, натомість як уміння аналізувати та оцінювати ідеї розвинене недосконало, що можна сказати й про практично-контекстуальні здібності. 
Щодо компоненту знання, то на цьому етапі життя вони не стримують креативність, а тому не $є$ першочерговою умовою для розвитку креативності, скільки навіть не знаючи властивостей певного об'єкту діти можуть запропонувати його креативне використання, проте важливим стає ії особистий досвід отриманий упродовж життя, тому ми вважаємо за доцільне додати його до структури креативності дітей старшого дошкільного та молодшого шкільного віку.

Аналізуючи компонент мислення, нами було визначено, що він, дійсно $€$ невід'ємною складовою креативності дітей старшого дошкільного та молодшого шкільного віку, проте поряд з ним, із нашого погляду також слід назвати творчу уяву, сприйняття та пам'ять, оскільки вони є невід'ємними складовими креативності. У зв'язку з чим, вважаємо за доцільне замінити складову мислення на складову пізнавальні процеси.

Розглядаючи складову особистісні якості, зауважимо, що відповідно до вікових особливостей дітей цього періоду, першою має бути цікавість та бажання створювати щось нове, генерувати певні ідеї, оскільки дитина цього віку, ще не здатна об'єктивно оцінити ступінь ризику тощо.

Щодо складової мотивація, то зазначимо, що вона $є$ рушійною силою для розвитку креативності підтриманою, зі свого боку, навколишнім середовищем, адже саме воно орієнтує та спрямовує розвиток дітей.

Таким чином, структура креативності дітей старшого дошкільного та молодшого шкільного віку, із нашого погляду, має складатися із 7 компонентів, а саме: знання, здібності, пізнавальні процеси (мислення, творча уява, сприйняття, пам'ять тощо), особистісні якості, особистий досвід, мотивація та навколишнє середовище (див. рис. 1).

Визначивши структуру розвитку креативності дітей старшого дошкільного та молодшого шкільного віку далі розглянемо стадії розвитку креативності дітей старшого дошкільного віку, узагальнені на основі аналізу наукових доробок педагогів та психологів, ними є: перша стадія: наслідування - копіювання готового. Потрапляючи у нову ситуацію, дитина репродукує готовий спосіб дії, повторює його за дорослим заради досягнення бажаного результату. Друга стадія: творче наслідування - внесення елементів новизни, прояв самодіяльності без внесення істотних змін у запропоновану іншими схему дій, зразок, ідею. Це - перша заявка дитини про себе, своє бажання самовиразитися. Саме на цій стадії вона ознайомлюється 3 різними варіантами здійснення креативної діяльності, визначає свої переваги, відповідно до власних схильностей та вмінь. Третя стадія: репродуктивна креативність - уміння взяти за основу запропоновану схему (ідею), але істотно ії̈ переробити, внести зміни. Тут дитина відпрацьовує переробку існуючих ідей, пропускаючи їх крізь себе, перевіряє їх відповідність вимогам ситуації, вносить елементи 
новизни й оригінальності. Четверта стадія: справжня творчість, створення нового. Вона недоступна дошкільникові: адже створити оригінальну ідею можна лише на піку свого креативного розвитку й у сфрері своїх інтересів, здібностей [22, С. 77-78].

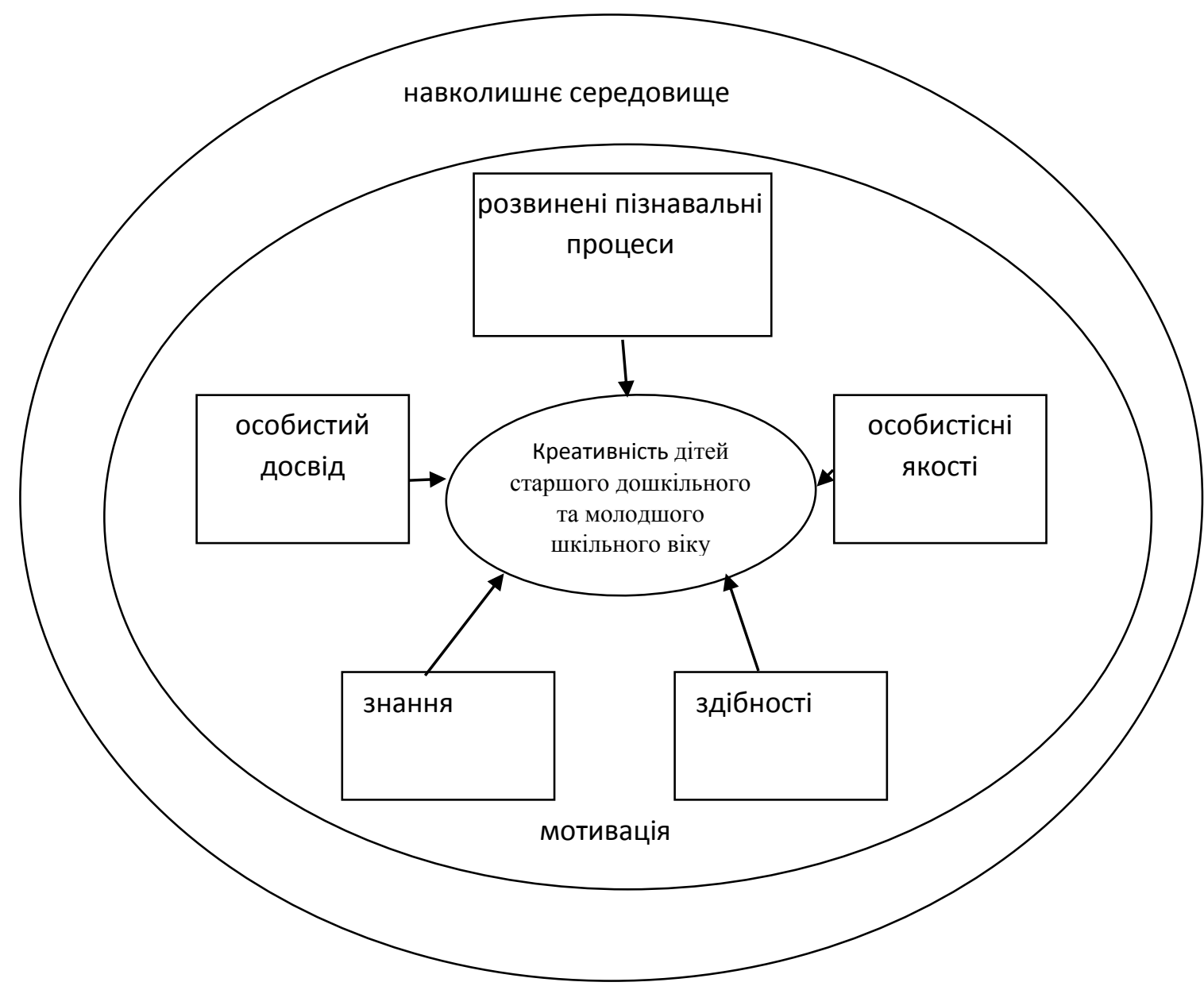

Puс. 1. Структура креативності дітей старшого дошкільного та молодшого шкільного віку

Оскільки навчальні впливи перш за все регламентуються базовими програмами, нами було здійснено дослідження можливостей розвитку креативності дітей старшого дошкільного та молодшого шкільного віку відповідно до існуючих Базових програм та визначено орієнтацію освітян на формування в дітей креативності як загальної здібності, як здатності до конструктивної перетворювальної активності та охоплення ними всіх визначених складових креативності.

Проаналізувавши програми, ми дійшли висновку, що вони тією чи іншою мірою торкаються проблеми розвитку креативності, проте не ілюструють конкретних засобів для досягнення цієї мети, не несуть системного характеру, що, у свою чергу, знижує їх ефрективність у цьому напрямі.

Багато педагогів мають величезний досвід роботи, але оптимізувати навчальний процес, підвищити ефективність обсягу та 
форм роботи з дошкільниками та молодшими школярами майже неможливо, керуючись лише традиційними, здебільшого застарілими, методами та прийомами виховання та навчання дітей. Тому науковий пошук спрямував нас до аналізу можливостей використання елементів технології розв'язання винахідницьких задач (ТРВ3). Для прояву дитиною творчої активності, важливо забезпечити їй розвивальне середовище. 3 цією метою доцільно використовувати розвивальні завдання; правильно оцінювати досягнення дітей у творчій діяльності; не переривати творчого процесу; утримуватися від використання негативних оцінок під час прояву дитиною творчої активності; без критики приймати всі дитячі твердження, не зловживати гальмівним впливом критичних зауважень; створити ситуації вільного спілкування, обміну думок.

У контексті цього дослідження, ми погоджуємося з думкою Н. Ардашевої [1, С. 345], яка зазначає, що ТРВ3 ставить за мету формування сильного мислення і виховання творчої особистості, підготовленої до розв'язання складних проблем у різних сорерах діяльності. В.Сухомлинський [33] зазначав: «Духовне життя дитини повноцінне лише тоді, коли вона живе у світі гри, казки, музики, франтазії, творчості. Ми повинні вчити і виховувати так, щоб дитина почувала себе шукачем і відкривачем знань...». Як зазначає І. Дичківська [10, С. 56], ТРВ3 - це педагогіка співтворчості, дорослий при цьому (вихователь чи вчитель) - своєрідний поводир, але в той же час іде позаду. Тут немає вчителів та учнів, $є$ одна спільна справа навчитися логіки, гнучкості мислення та певної креативності. Діти мудреці й фрілософи від народження. I цю творчу зарядженість дитини нам, дорослим, необхідно розвинути, не розгубити, не розплескати, заохотити. Головне - зрозуміти, що дитина, яка думає, шукає, вирішує свої проблеми, - це нормально! А творчий розвиток навчить будь-яку людину прогнозувати наслідки кожного кроку. Досвід показує, що на базі програми, за якою працює педагог будь-якої вікової групи, можна впроваджувати елементи ТРВ3, вкладаючи в них відповідний зміст.

TPB3 - це технологія, що навчає новим прийомам винахідництва; технологія, якій можна і потрібно навчати. Суть цієї технології полягає у фрормуванні системного, діалектичного мислення, розвитку творчої уяви, винахідницької кмітливості. Використання ії має не просто розвинути франтазію дітей, а навчити їх мислити системно, творчо, розуміти єдність і протиріччя навколишнього світу, бачити і вирішувати проблеми, бути відкритим до всього нового, що є основою інноваційної компетентності учнів відповідно до Державного стандарту початкової освіти (інноваційність - передбачає відкритість до нових ідей) [34].

Система ТРВ3 зацікавила сучасних педагогів і психологів, які адаптували ії для роботи з дітьми спочатку в школі, а потім і в дитячому садку. Роботи Г. Альтшуллера стали основою так званої 
творчої педагогіки. Згодом з'явилися спеціальні дослідження (В. Бухвалов, Б. Злотін, С.Ладошкіна, А. Нестеренко, Т. Сидорчук, Л. Шрагіна, М. Шустерман), в яких була розроблена серія методів, засобів і прийомів навчання дітей на базі ТРВЗ.

Вважаємо за доцільне розглянути принципи на яких ґрунтується ТРВЗ.

Свободи вибору (коли дитині надається право вибору, але 3 двома важливими умовами: діяльність повинна бути бездоганною моральною і право вибору повинно врівноважуватись свідомою відповідальністю за свій вибір; дитина старшого дошкільного чи молодшого шкільного віку з більшим бажанням робить те, що сама запропонувала; мотивація та ефективність освітнього процесу значно підвищується).

Відкритості (використання у навчанні відкритих запитань, що не мають однозначної відповіді, завдань, які стимулюють самостійне генерування ідей).

Діяльності (засвоєння дітьми знань, умінь та навичок переважно у формі активності, не передача педагогом готових знань, а вміння генерувати ідеї, шукати відповідь; коли ми стимулюємо дітей вирішувати велику кількість творчих завдань, кількість переходить у якість і виробляється автоматизм використання алгоритмів і прийомів

Принцип зворотного зв'язку дає можливість вихователю контролювати процес засвоєння дітьми мислиннєвих операцій та відстежувати ступінь зацікавленості задачею, розуміння і засвоєння матеріалу. Яскравими показниками в цьому випадку є емоційний стан дитини, ознаки перемикання уваги; ії запитання; пояснення, якими вона супроводжує продуктивні види діяльності.

Ідеальності (або принцип найбільшої корисності - один 3 найголовніших принципів ТРВ3, який припускає, що все робиться саме - без витрат і без розплати, тобто ідеально)

У межах цього дослідження вважаємо за доцільне додати ще один принцип ТРВ3, а саме принцип «Я сам»: людина повинна сама i завжди виконувати закони честі, сама собі допомагати, сама про себе непокоїтися, сама себе охороняти. Сама приймати рішення. Сама побачити, сама зробити відкриття, сама відчути, сама здогадатися, сама вибрати, сама зробити. У педагогіці принцип «Я сам» відповідає природному прагненню дитини старшого дошкільного віку до самостійності. Дитина краще усвідомлює та запам'ятовує те, що сама для себе відкрила, сама здогадалася, сама створила. Цікавою також є думка Л. Виготського [6, С. 215] про те, що дитина дошкільного та молодшого шкільного віку приймає програму навчання тією мірою, якою ця програма стає їі власною. Стосовно дитини концепція ТРВ3 понад усе ставить принцип природовідповідності, згідно з яким педагог, навчаючи дитину, повинен знати і враховувати їі природу. 
Аналізуючи визначені принципи, можемо зазначити, що ТPB3 докорінно змінює стиль роботи з дітьми, робить їх вільними, вчить думати, шукати, розв'язувати свої проблеми самостійно.

На сьогодні педагоги практикують різні погляди на зміст роботи з використання ТРВ3, у межах нашого дослідження цікавою $є$ думка Л. Ткаченко [34] та Т. Юхимець [39], які поділяють зміст роботи з використання елементів технології ТРВ3 у освітньому процесі на 4 основні етапи.

На І етапі вчать дитину знаходити і розв'язувати суперечності, не боятися негативного в об'єкті та явищі; вчать бачити світ у взаємозв'язку його компонентів; формують вміння бачити навколишні ресурси (засоби, можливості тощо).

На II етапі дошкільнята «оживлюють» за допомогою елементів TPB3 предмети та явища, приписуючи одним якості інших і навпаки, а також відкидають непотрібні і шукають найкращі варіанти.

III етап передбачає вирішування казкових завдань і придумування казок. Дитину вчать уникати сумного закінчення казки, не змінюючи при цьому сюжет.

На IV етапі дитина знаходить вихід з будь-якої життєвої ситуації, спираючись на набуті знання та інтуїцію, використовуючи нестандартні, оригінальні рішення.

Проте не можна стверджувати, що це повний зміст роботи з ТРВ3, оскільки слід зважати на те, що розроблено безліч методів та засобів роботи завдяки яким педагог разом з дітьми може знаходити логічний вихід з будь-якої ситуації. ТРВ3 - це активна оптимістична життєва позиція, яка допомагає дати відповідь на запитання: «Що я хочу?»,

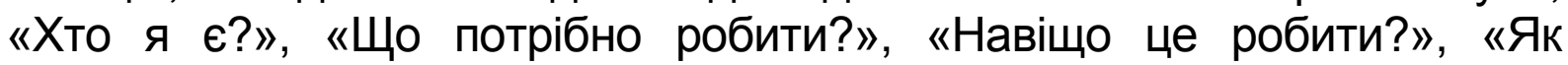
робити?», «З чого робити?».

Беручи до уваги все вищезазначене можемо визначити, охарактеризувати та виявити алгоритм роботи 3 методами та відповідно їм засобами роботи з дітьми старшого дошкільного та молодшого шкільного віку в межах елементів ТРВЗ.

Метод асоціацій чи каталогу - метод дозволяє більшою мірою вирішити проблему навчання творчого розповідання. Розглянемо алгоритм роботи за цим методом з дітьми окресленого періоду вихователь / вчитель ставить питання дітям через які буде створюватися сюжет на основі книжки, що обрали для обговорення (текст має бути прозаїчним з мінімальною кількістю ілюстрацій або без них і це не обов'язково має бути казка чи художній твір); - учні шукають в книзі відповіді, довільно вказуючи пальцями в будь-яке місце на сторінці або зачитувати їх. Слід зазначити, що слова можуть траплятися будь-які, ніяк не пов'язані між собою. Керуючий педагогічним процесом може перетворювати одні частини мови в інші тощо; - компонуючи отримані слова діти створюють нову історію. Ця робота проводиться в швидкому темпі, використовуються 
різні емоційні реакції на кожне нове словосполучення.

Наступним розглянемо метод спроб і помилок. Сутність цього методу полягає у розв'язанні проблемного завдання через добір різноманітних варіантів вирішення. Безсистемно перебираючи різні варіанти: «А якщо зробити так?» Це найдавніший і найпростіший метод пошуку нових рішень. Удаються до нього для розв'язання завдань нижчого рівня, де досить перебрати один-два десятки варіантів. Використовуючи метод спроб і помилок, можна пропонувати будь-які рішення, якими б безглуздими вони не здавалися на перший погляд, це перший крок до творчості. Так, наприклад, може бути запропонована наступна ситуація - «Ти загубився на площі серед натовпу людей. Що робити?» або «Пташеня випало з гнізда. Як вчинити?»

На основі цього методу було винайдено наступний метод контрольних запитань, що є удосконаленим варіантом методу спроб і помилок, а також одним із методів активізації творчого мислення за допомогою заздалегідь підготовленого списку навідних запитань. Перелік навідних запитань (спроб), за допомогою яких діти підходять до виконання поставленого завдання, дуже різноманітний (зміна предмета за допомогою максимізації, мініатюризації, «оживлення», зміни властивостей тощо). Наприклад, контрольними запитаннями можуть бути такі: Що було б, якби слон став маленьким?, Що було б, якби звірі вміли розмовляти?

Метод - оператор РЧВ (розмір, час, вартість) - метод допомагає сфрормувати цілісну картину світу, розвиває мислення, так як учить бачити взаємодію об'єктів в єдності і протистоянні, усвідомлювати рух часу, а також розуміти і оцінювати роль і місце кожного об'єкта. Значення системного аналізу: допомагає розібратися, 3 яких частин складається (підсистема) i елементом якого цілого (надсистема) є об'єкт (система); знайомить з діями і фрункціональними властивостями окремих частин, дозволяє зрозуміти, в які підсистемі і системі ці частини об'єднуються, яку вертикаль (від низу до верху) утворюють [39].

Метод фоокальних об'єктів. Суть його полягає у перенесенні властивостей одного предмета на інший. Фокальним (лат. focus осередок) називають об'єкти, що перебувають у фрокусі, в центрі уваги. Це, по суті, $€$ модифрікованими прийомом винесення (внесення). Вибираємо якийсь об'єкт, називаємо його фокальним, і на цей об'єкт, як у фоккус збиральної лінзи, проектуємо властивості декількох інших об'єктів або явищ, підібраних довільним чином. Послуговуючись цим методом, ставлять такі завдання:

$>$ придумати щось нове, видозмінюючи або вдосконалюючи реальний об'єкт;

$>$ познайомити дітей з чимось новим або закріпити здобуті раніше знання, розглядаючи предмет у незвичному ракурсі; 
скласти розповідь або казку про об'єкт, який розглядається, використовуючи знайдені ознаки (повністю або частково);

проаналізувати художній твір або картину;

розробити новий вид заняття, прогулянки, рухливої гри тощо, обравши словосполучення, яке найбільше подобається або відповідає меті.

Словосполучення добирають несподівані. Розробляючи новий вид діяльності, необхідно чітко окреслити, що саме обмірковується форма чи зміст. Використовуючи метод фрокальних об'єктів, слід дотримуватись такого алгоритму роботи:

розглядаючи або змінюючи будь-який об'єкт, мимоволі обрати інший предмет (кілька предметів), який не стосується фокального слова;

для вибору іншого предмета (кількох предметів) дітям пропонують картинки, іграшки, яскраві предмети;

надати 5 - 10 визначень вибраного предмета (Який він (вона, воно, вони)?);

дібрані ознаки прикладають до слова у фокусі; отримані словосполучення розглядають й аналізують;

коли потрібне або цікаве словосполучення знайдено, надати фокальному слову відповідних якостей.

Для цього ввести до фокального об'єкта не властиві йому елементи, які зумовлюють його видозміну [35].

Метод морфологічного аналізу. У роботі з дошкільнятами цей метод дуже ефрективний для розвитку творчої уяви, франтазії, подолання стереотипів. Суть його полягає в комбінуванні різних варіантів характеристик певного об'єкта при створенні нового образу цього об'єкта. «Добре - погано» - учить в будь-якому об'єкті, явищі, якості бачити обидві сторони: позитивну і негативну [39]. Так, наприклад, можна запропонувати старшим дошкільникам описати Колобка за допомогою різних аналізаторів (дітям можна запропонувати казку, в якій Колобок потрапив у чарівну країну, де живуть Ротик, Вушка, Носик, Оченята, Ручки, і попросити від імені цих мешканців розказати про Колобка).

Таким чином, можемо зазначити, що цей метод застосовується з метою визначення можливих варіантів розв'язання проблеми та забезпечує творчий підхід до її вирішення.

Метод моделювання маленькими чоловічками (метод ММЧ). Це один із методів моделювання, який широко використовуються у TPB3. Можливості його допомагають пояснити внутрішню будову предметів і речовин, фізичну суть явищ і процесів, що відбуваються у живій та неживій природі (наприклад, як утворюється пара, електричний струм). Суть методу ММЧ полягає в тому, що дитина має уявити, що всі речовини, предмети, об'єкти, явища складаються 3 безлічі живих, мислячих маленьких чоловічків. Вони можуть 
пересуватися або виконувати якісь дії. ті, що утворюють тверду речовину або предмет, міцно тримаються за руки, і щоб роз'єднати їх, треба докласти певних зусиль.

Метод ММЧ використовують для пояснення сутності певного процесу, ситуації, для проведення пізнавальних занять, занятьекспериментів, уроків-ігор з природознавства, математики, зображувальної діяльності, для навчання дітей старшого дошкільного віку грамоти. При навчанні грамоти можна уявити у вигляді чоловічків звуки, частини мови, словосполучення, речення. При цьому краще використовувати позначки, які придумали самі діти. Можна влаштувати конкурс на найзрозуміліше зображення. За допомогою ММЧ закріплюють знання про склад слова: корінь - твердий чоловічок, не змінюється; префрікс і суфікс - газоподібні, вони то $є$ в слові, то відсутні; закінчення - рідкі чоловічки, вони змінюються, немов перетікають від слова до слова [35].

Наступним розглянемо зміст методу - прийоми франтазування. Цей метод добре використовувати при навчанні дітей творчому розповіданню. Придумувати, франтазувати краще не наосліп, а 3 використанням конкретних прийомів: - винахідницька задача; зменшення - збільшення об'єкта; - навпаки (добрий Вовк і зла Червона Шапочка); - дроблення - об'єднання (вигадування нової іграшки 3 частин старих іграшок або неймовірної тварини окремі частини якої $\epsilon$ частинами інших тварин); - оператор часу (уповільнення - прискорення часу: намалюй себе через багато років, намалюй свою майбутню дитину або якою була твоя мама в дитинстві); - динаміка - статика (оживлення неживих об'єктів і навпаки тощо). Діти вже самі здатні вибрати об'єкт, а потім оживити його, придумати назву тощо [39].

Розглянувши вищезазначені методи та відповідні їм, прийоми та засоби ТРВ3, можемо дійти висновку, що елементи ТРВ3 покликані не змінювати існуючу базову програмунавчання, а переглянути підхід до навчання та виховання максимально збільшивши їх ефрективність. У межах цього дослідження можемо дійти висновку, що системне використання елементів ТРВ3 сприятиме підвищенню рівня креативного розвитку дітей старшого дошкільного та молодшого шкільного віку.

\section{Список використаних джерел}

1. Альтштулер Г. С. Верткин И. М. Как стать гением: Жизненная стратегия ворче ской личности. Минск, 1994. 497 с.

2. Андрющенко Т.К. Диференціація при здійсненні креативного розвитку дошкільників: досвід, проблеми, перспективи. Черкаси: ОІПОПП, 2010. 226с.

3. Антонішина В. Л. Структурний аналіз креативності дітей старшого дошкільного віку. Наукові праці Чорноморського державного університету імені Петра Могили комплексу «Києво-Могилянська академія». Сер. «Педагогіка». 2011. Т. 173. Вип. 161. С. 76-79.

4. Антонова О.Є. Сутність поняття креативності: проблеми та пошуки / О.Є. Антонова. Теоретичні і прикладні аспекти розвитку креативної освіти у 
вищій школі: монографрія: за ред. О.А. Дубасенюк. Житомир: Вид-во ім. І. Франка, 2012. С.14-41.

5. Бібік Н. М. Переваги і ризики запровадження компетентнісного підходу в шкільній освіті. Український педагогічний журнал. 2015. № 1. С. 47-58.

6. Выготский Л.С. Педагогическая психология. Москва, Педагогика. 1991. 480 с.

7. Гарднер Г. Структура разума: теория множественного интеллекта. М.: ООО «И. Д. Вильямс». 2007. 512 с.

8. Гилфорд Дж. Три стороны интеллекта: пер. с англ. Э. А. Голубевой // Психология мышления / ред. А.М. Матюшкина. Москва : Прогресс, 1965. 456 с.

9. Гончаренко С. У. Український педагогічний словник. К.: Либідь, 1997. 376 с.

10. Дичківська І. Іноваційні педагогічні технології. Київ: Академвидав, 2004. 126 с.

11. Дуткевич Т. В. Дитяча психологія: навч. посіб. К.: Центр учбової літератури, 2012. 424 c.

12. Енциклопедія освіти / за ред. В. Кременя. - К. : Юрінком Інтер, 2008. 1040 с.

13. Комлєв Н. Г. Словник іноземних слів. Москва: ЭКСМО-Пресс, 2000. 1308 с.

14. Костюк, Г. С. Навчально-виховний процес і психічний розвиток особистості. К., 1989. $608 \mathrm{c}$.

15. Кульчицька О.І. Дивергентне мислення як умова розвитку творчості дітей молодшого шкільного віку. Обдарована дитина. 1999, № 1. С. 2-6.

16. Курочкина А.Ю. Исследования креативности: постановка проблемы экономики: сб. науковых статей по итогам Международной научной конференции (г. С.-Петербург, 19-20 мая 2009 г.) / под. общ. ред. профр. Н.А. Горелова, проф. О.Н. Мелькова. Москва: Изд-во «Креативная экономика», 2009. С. 630-639.

17. Литвиненко С. Креативність як загальна здібність до творчості: сучасні підходи. // Збірник наукових праць полтавського державного педагогічного університету імені В.Г. Короленка. Серія «Педагогічні науки». випуск 3 (50). Полтава, 2006. С.215-219.

18. Мала Н.Т. Креативність як складова ефективного управління. Електронний науковий архів Науково-технічної бібліотеки Національного університету «Львівська політехніка», 2011. С.18-23

19. Марусинець М., Іванова В. Динаміка розвитку творчого мислення у дошкільному та молодшому шкільному віці. Вісник післядипломної освіти [Електронний ресурс], 2010., Вип. 1(2). С. 232-240.

20. Маршицька В. В., Орлова Г. В. Теоретичні основи фрормування креативності у дітей старшого дошкільного віку. Теоретико-методичні проблеми виховання дітей та учнівської молоді. 2015., Вип. 19(1). С. 363-372.

21. Матюшкин А.М. Концепция творческой одаренности. Вопросы психологии. 1989. , № 6. С. 29-33.

22. Міщиха Л.П. Творчий потенціал у період пізньої дорослості : монографія. ІваноФранківськ : Місто НВ, 2014. 400с.

23. Моляко В.О. Психологічна готовність до творчої праці. Київ: Знання УРСР, 1989. $36 \mathrm{c}$.

24. Нечипорук Н.І., Томей О.П. Розвивальні ігри для дошкільників. Х.: Видавнича група «Основі», 2007. 192 с.

25. Павленко В.В. Креативність: сутнісна характеристика Креативна педагогіка: наук.-метод. журнал / академія міжнародного співробітництва 3 креативної педагогіки «Полісся». Житомир, 2016. Вип. 11. С.120-131.

26. Павленко В.В. Розвиток креативності молодших школярів: монографія / за ред. профр. О.Є. Антонової. Житомир, 2017. 158 с.

27. Педагогічний словник / за ред. М. Ярмаченка. Київ : Педагогічна думка, 2001. 516 c. 
28. Психология творчества / под ред. Я. А. Пономарева. М. : Педагогика, 1990. $224 \mathrm{c}$.

29. Психологічна енциклопедія / автор-упоряд. О. Степанов. Київ: «Академвидав», 2006. -424 c.

30. Психологічний словник / за ред. В.І. Войтко. К.: Вища школа, 1982. 215 с.

31. Пузеп Л.Г. Психологические механизмы развития креативной личности: автореф. дисс. ...кандидата психол. наук: спец. 19.00.01 «Общая психология, психология личности, история психологии». Омск, 2006. 23 с.

32. Стернберг Р. Григоренко Е. Модель структуры интеллекта Гилфорда: структура без фрундамента. Основные современные концепции творчества $и$ одаренности / ред. Д.Б. Богоявленская. Москва : «Молодая гвардия», 1976. C. 111-126.

33. Сухомлинский В. А. Сердце отдаю детям : изд. 2-е. - Киев : Рад. школа, 1972. $243 \mathrm{c}$.

34. Ткаченко Л.М. Сучасне заняття в закладі дошкільної освіти з використанням технології ТРВ3 Інноваційні технології в дошкільній освіті: збірник абстрактів Міжнародної науково-практичної інтернетконференції, (м. ПереяславХмельницький, 28-29 березня 2018 р.) / за заг. ред. Л. О. Калмикової, Н. В. Гавриш. Переяслав-Хмельницький: ДВНЗ «Переяслав-Хмельницький державний педагогічний університет імені Григорія Сковороди». 2018. С. $140-142$.

35. Цимерман І.Л., Ковтун Є.Ф. Креативний розвиток дошкільнят засобами ТРВЗ. Суми, СОІППО. 2009. 71 с.

36. Чепур О. С. Креативний розвиток дітей дошкільного віку. Науковий вісник Ужгородського університету : серія: Педагогіка. Соціальна робота / [редкол.: Козубовська І.В. (гол. ред.) та ін.]. Ужгород: Видавництво УжНУ «Говерла», 2011, Вип. 23. С. 202-204.

37. Шмелева Н. Б. Ценностные ориентации, мотивации и психологические установки в профессиональной подготовке социального работника. Российский журнал социальной работы. 1997, № 1. С. 115-124.

38. Щукина Г. И. Активизация познавательной деятельности учащихся в учебном процессе: учеб. пособие для студ. пед. ин-тов. М.: Просвещение, 1979. 160 с.

39. Юхимець Т. О. Виховуємо творчу особистість. Постметодика. 2009, № 1. C. 27-34.

40. Szmidt K.J. ABC kreatywności. Difin, Warszawa, 2010. S. 8-10.

41. Assessing creativity: a guide for educators / D. Treffinger, G. Young, E. Selby, C. Shepardson. - Storrs : The National Research Center on the Gifted and Talented, 2002. 1997 p. 


\title{
ПСИХОЛОГО-ПЕДАГОГІЧНІ ОСОБЛИВОСТІ СОЦІАЛІЗАЦІЇ ДІТЕЙ ДОШКІЛЬНОГО ВІКУ, ПОЗБАВЛЕНИХ БАТЬКІВСЬКОГО ПІКЛУВАННЯ
}

\author{
Вертель А. В. \\ кандидат фрілософських наук, доцент, \\ Сумський державний педагогічний університет імені А. С. Макаренка \\ Вертель М. Ю.
}

Директор, Сумський міський центр соціальних служб для сімї, дітей та молоді

Педагогіка розуміє соціалізацію як процес, який забезпечує включення в ту чи іншу соціальну групу або спільноту. Соціалізація являє собою розвиток людини протягом усього ії життя у взаємодії 3 навколишнім середовищем, в процесі якого вона засвоює соціальний досвід та активно реалізує себе, змінюючи і життєві обставини. Соціалізація відбувається за допомогою спілкування, а також шляхом ідентифрікації людини з суспільством і відокремленням особистості в ньому.

Психолого-педагогічний погляд на соціалізацію розкриває змістовну конкретику цього процесу, доводить механізми, які пов'язані з умовами соціалізації (середовище, простір) та позиції особистості в цьому процесі (активність, пасивність, пристосування), підкреслюючи демократичний (добровільний) гуманний характер соціалізації. На думку Н. Голованової, соціалізація особистості, з одного боку, - це засвоєння людиною цінностей, норм, правил поведінки, які притаманні в даний час конкретній спільноті, соціальній групі, та відтворення соціальних зв'язків та соціального досвіду, в ході якого створюється конкретна особистість.

3 іншого боку, соціалізація - це формування та розвиток особистості. На перший план виходять власна активність суб'єкту соціалізації, процеси засвоєння соціального досвіду в ході активного саморозвитку особистості, залучення особи в життя спільноти на демократичних принципах спільної діяльності в освітньому середовищі, розширення впливу сукупності умов, в яких проживає та розвивається людина, її розвиток протягом всього життя у взаємодії з навколишнім середовищем в процесі засвоєння соціальних норм, культурних цінностей, а також власний розвиток, самореалізація в тій спільноті, до якої людина належить.

Підкреслюється активний характер соціалізації людини, в ході якої вона не лише засвоює соціальний досвід, але й повноцінно реалізує себе, впливаючи, в тому числі, і на життєві обставини [6, с. 272].

На відміну від виховання, яке являє собою спеціальне 
формування особистості у відповідності з прийнятним ідеалом, соціалізація охоплює процес і результати взаємодії індивіду з усією сукупністю соціальних впливів на людину. Так, виокремлюють основні напрями соціалізації, які дають назви її видам: поведінкова, емоційночуттєва, пізнавальна, побутова, морально-етична, міжособистісна, статево-рольова, професійна, сімейна, політична.

Ідеї соціальної обумовленості виховання особливо характерні для соціально-педагогічної думки. Розвиток концепції соціальної детермінації експліковано у дослідженнях С. Шацького, А. Луначарського, К. Ушинського, Л. Толстого. К. Ушинський підкреслював значимість народних традицій, звичаїв, культури для морального виховання дитини [25, с. 416$]$.

Психолого-педагогічні аспекти проблеми соціалізації розглядалися Л. Виготським, Л. Божович, Д. Елькониним. Так, Л. Виготський піднімає питання про взаємодію особистості і середовища. Він підкреслює діалектичну взаємодію двох відносно автономних, але нерозривно пов'язаних один 3 одним етапів розвитку - натурального та соціального. Л. Виготський вважає помилкою, коли середовище розглядається як щось зовнішнє по відношенню до дитини, як сукупність об'єктивних, безвідносно до дитини існуючих та впливаючих на неї умов [5].

Фундаментальні дослідження проблеми соціалізації особистості дітей експліковані І. Коном представляють фрілософські, соціологічні, етнографрічні, культурологічні, педагогічні основи для подальшого вивчення і розвитку теорії та практики цього процесу. Соціалізацію вчений розглядає як процес фрормування цілісної особистості, обумовленої сукупністю суспільних відносин, які відбуваються як в соціально-контролюючих, так і в стихійних, спонтанних формах $[9$, с. 56]. Особливу увагу в процесі соціалізації необхідно приділити вихованню вільної особистості, яка може зробити вибір, прийняти відповідальне рішення, поважати вибір інших, вміти протиставити свій вибір тиску ззовні.

На думку Б. Вульфова «до важливих механізмів соціалізації дошкільника можна віднести: соціальну адаптацію, яка забезпечує не лише спадковий зв'язок поколінь, але й $є$ здатністю до фрізичного, морального, соціального виживання як готовність обрати вірні способи існування, зберігаючи активну позицію як в існуючих так і в очікуваних або непередбачуваних обставинах» [4, с. 54].

Педагогічну аперцепцію, мета якої в тому, що ситуація успіху, яку дитина здійснила завдяки власному вибору та закріпила в змістовному досвіді, а також пов'язане з цим позитивне сприйняття свого «Я» (синдром переможця), визначають усі послідуючі сприйняття та вчинки в аспекті позитивного погляду на світ, суспільство і самого себе. Крім того, механізмами соціалізації є: наслідування, біологічні потреби (психічні фактори) та престиж, покора, практична вигода (соціальні 
фрактори) (по Г. Тарду), ідентифрікація та відокремлення особистості. Такий спектр механізмів соціалізації свідчить про надзвичайну складність самого процесу соціалізації особистості як похідного від структурно-змістовного багатства людини, а також обумовлює з свого боку, педагогічну можливість впливу на особистість з максимальним врахуванням всіх фракторів [22].

Результат процесу соціалізації - складне питання і потребує окремого розгляду, тому що саме з цього виникають поняття критеріїв та показників соціалізації. В якості критеріїв і показників соціалізації пропонується використовувати відношення дитини до суспільства, соціально-значущої діяльності; ступінь активності життєвої позиції; спрямованість особистості на предмет соціальних відносин; ступінь сфрормованості соціального досвіду [14].

Соціальний розвиток являє собою складне й суперечливе явище: постійно відтворюється протиріччя двох сторін - соціалізації та індивідуалізації. Соціалізація та індивідуалізація - це психологічні механізми соціального розвитку людини. Соціалізація - це привласнення дитиною норм і правил людського суспільства, а індивідуалізація - відкриття, розуміння, усвідомлення і становлення себе як суб'єкта. Саме в процесі соціального розвитку відбувається перехід соціального досвіду в цінності і установки конкретного індивіда, де індивід виступає в якості активного суб'єкта присвоєння даного досвіду. Відбувається сприйняття соціокультурних цінностей, їх застосування, що сприяє становленню соціальної сутності людини [15].

Соціалізація - це процес «входження» дитини в суспільство, придбання нею певного соціального досвіду у вигляді знань, цінностей, правил поведінки. Соціальний розвиток дитини $є$ тривалим і дуже складним процесом. 3 одного боку, будь-яке суспільство, зацікавлене в тому, щоб кожна дитина, прийнявши і засвоївши систему соціальних і моральних цінностей, ідеали, норми і правила поведінки, змогла жити в цьому суспільстві, стати його повноправним членом. 3 іншого боку, на становлення особистості дитини великий вплив мають і різні стихійні, спонтанні процеси, що відбуваються в нашому житті.

Незважаючи на специфріку різних наукових шкіл, в цілому дослідники одноголосно говорять про те, що соціалізація - це суспільний процес, який $є$ найважливішим атрибутом дитинства. $€$ й інші базові положення, які $\epsilon$ фрундаментом вивчення соціалізації дитинства. Ці положення зафіксовані в якості загальноприйнятих. Авторитетні та досвідчені науковці наступним чином визначають поняття соціалізації:

процес засвоєння та асиміляції індивідом протягом його життя соціальних норм і культурних цінностей (аксіологічна складова) того суспільства, до якого він належить;

процес засвоєння, подальшого розвитку та трансляції індивідом 
соціально-культурного досвіду;

> багатоаспектний процес становлення особистості, навчання і засвоєння індивідом цінностей, норм, установок, зразків поведінки, які властиві даному суспільству, соціальній спільноті, групі;

складний, багатогранний процес включення людини в соціальну політику, набуття нею соціальних якостей, засвоєння суспільного досвіду і реалізації власної сутності за допомогою виконання певної ролі - в безпосередній практичній діяльності;

$>$ процес засвоєння індивідом зразків та моделей соціальноконвенціональної поведінки, психологічних механізмів, соціальних норм і цінностей, необхідних для успішного функціонування індивіда в суспільстві [2].

Велике значення в розумінні процесу соціалізації мають концепції, які роблять акцент на ролі соціального середовища у фрормуванні особистості дитини.

Соціалізацію можна визначити як «процес фрормування умінь i соціальних установок індивідів, відповідних їх соціальним ролям». Можна визначити механізми соціалізації, використовуючи критерій їх позитивності. Позитивні механізми фрормують бажані якості соціального суб'єкта:

$>$ імітація - усвідомлене прагнення дитини копіювати певну модель поведінки дорослих;

>ідентифрікація - спосіб засвоєння дітьми поведінки батьків (а також поведінку інших значущих дорослих), установок i цінностей як своїх власних. Аналізуючи механізми соціалізації, необхідно акцентувати увагу на значимості найближчого оточення в формуванні особистості дитини [1].

Розглядаючи проблему соціалізації та ії співвідношення 3 вихованням, А. Мудрик визначає ії як розвиток і самореалізацію людини протягом усього життя в процесі засвоєння і відтворення культури суспільства. Можна розглянути процес соціалізації як сукупність чотирьох складових:

1. стихійна соціалізація людини у взаємодії і під впливом об'єктивних обставин життя, суспільства, змісту, характер і результати якої визначаються соціально-екологічними i соціокультурними реаліями;

2. відносно спрямована соціалізація, коли держава робить певні економічні, законодавчі, організаційні заходи для вирішення своїх завдань, які об'єктивно впливають на зміну можливостей і характер розвитку, на життєвий шлях тих чи інших вікових груп (визначаючи обов'язковий мінімум освіти, вік її початку);

3. відносно соціально контрольована соціалізація - планомірне створення суспільством і державою правових, організаційних, матеріальних і духовних умов для розвитку людини (виховання); 
4. свідома зміна поведінки людини, що має асоціальний або антисоціальний вектор (самовдосконалення, саморуйнування), відповідно до індивідуальних ресурсів і відповідно чи всупереч об'єктивним умовам життя [14].

Отже, під соціалізацією розуміють процес засвоєння індивідом певної системи знань і норм, що дозволяють здійснювати свою життєдіяльність адекватним для суспільства способом. Процес соціалізації істотно залежить від установок, традицій і норм, прийнятих в суспільстві, що регулюють вимоги, які пред'являються суспільством до людини і забезпечують її включення в діяльність соціуму. В процесі соціалізації фрормується особистість. Для дитини, позбавленої батьківського піклування, яка виховується в дитячому будинку, мікрочинники соціалізації мають іншу значимість, ніж для дитини, що виховується в традиційних умовах сім'ї. Найбільш значущими об'єктами соціалізації для дитини в дитячому будинку стає колектив, однолітки, вихователі.

При цьому відбувається соціальне самовизначення вихованців вибір ними свого місця в суспільстві і подальше включення їх в систему суспільних відносин на основі сформованих у них інтересів і потреб. Формування уявлень дитини про ті чи інші соціальні ролі не може бути чимось другорядним. У дітей позбавлених батьківського піклування ці уявлення, в силу відомих причин і обставин, часто бувають невірними і спотвореними. Відсутність у такої дитини успішних взаємовідносин 3 близьким оточенням закономірно призводить до деформації уявлень про її значимість у суспільстві.

Труднощі соціалізації - це цілий комплекс деформацій, який важко подолати, з якими дитина стикається при оволодінні тією чи іншою соціальною роллю. Причинами виникнення таких проблем $є$ найчастіше невідповідність вимог що пред'являються до дитини, а також характером її відносин з соціумом. Труднощі оволодіння соціальною роллю виникають найчастіше тоді, коли відсутня інформація про зміст цієї ролі, коли наявна інформація не відповідає дійсності або у дитини немає можливостей випробувати себе в цій соціальній ролі [19].

В умовах дитячого будинку кількість травмуючих ситуацій, з якими стикається дитина в процесі соціалізації, подвоюється. Це відбувається тому, що сама організація життя дітей в дитячому будинку влаштована так, що у дитини формується переважно тільки одна рольова позиція - позиція сироти, що не має підтримки і схвалення в своєму оточенні. Ця роль ставить дитину в статус «утриманця» і блокує прояв ії потенційних можливостей. Іншими словами, вихованець дитячого будинку, виходячи за поріг установи, вміє «бути сиротою», тобто сподівається на заступництво, не обтяжуючи себе пошуками власних внутрішніх ресурсів. У науковому співтоваристві це явище отримало назву «вивченої безпорадності». 
Діти, позбавлені батьківського піклування, які потрапляють в дитячий будинок, відчувають шкідливий вплив різних життєвих ситуацій. $€$ такі, які ніколи не бачили своїх батьків і, отже, мають найвіддаленіше уявлення про роль батька і матері в житті дітей.

Визначимо поняття «дитина-сирота» та «дитина, позбавлена батьківського піклування». Відповідно до Закону України від 13 січня 2005 року № 2342-IV «Про забезпечення організаційно-правових умов соціального захисту дітей-сиріт та дітей, позбавлених батьківського піклування», дитина-сирота - дитина, в якої померли чи загинули батьки. Діти, позбавлені батьківського піклування, - діти, які залишилися без піклування батьків у зв'язку з позбавленням їх батьківських прав, відібранням у батьків без позбавлення батьківських прав, визнанням батьків безвісно відсутніми або недієздатними, оголошенням їx померлими, відбуванням покарання в місцях позбавлення волі та перебуванням їх під вартою на час слідства, розшуком їх органами Національної поліції, пов'язаним з відсутністю відомостей про їх місцезнаходження, тривалою хворобою батьків, яка перешкоджає їм виконувати свої батьківські обов'язки, а також діти, розлучені із сім'єю, підкинуті діти, батьки яких невідомі, діти, від яких відмовилися батьки, діти, батьки яких не виконують своїх батьківських обов'язків з причин, які неможливо з'ясувати у зв'язку з перебуванням батьків на тимчасово окупованій території України, в районах проведення антитерористичної операції та безпритульні діти [7].

Діти, які якийсь час виховувалися в сім'ї, але втратили батьків, зберігають про них добру пам'ять, що також впливає на їхню поведінку. Стиль життя батьків, модель сім'ї, в якій діти роблять свої перші кроки, дуже важливі для подальшого життя людини [17].

На так званих «соціальних» сиріт, які потрапили до інтернатного закладу, продовжує впливати сім'я, і сім'я, як правило, неблагополучна. Діти розуміють всю складність сімейного неблагополуччя, фактори сім'ї та середовища негативно впливають на забезпечення потреб дитини, в тому числі емоційних. Проте, діти довіряють своїм батькам, шукають виправдання їх асоціальній поведінці. У таких дітей формується помилкове враження про оточуючих людей, замкнутість, озлобленість, соціальне відчуження.

Перебування дітей в закладах державного утримання - процес досить складний і важкий для маленької людини. У дитини, що виховується в дитячому будинку, практично немає особистого простору, що б давало їй можливість побути на самоті. Частково та умовно особистим простором можна вважати фрагмент стіни над ліжком, який дитина може прикрасити на власний розсуд, і тумбочку з особистими речами, порядок і вміст якої контролюється вихователем. Життя в дитячому будинку змушує дітей постійно перебувати «на публіці» [1].

У більшості випадків, навіть саме планування приміщень дитячого 
будинку не передбачає наявність власної території з чітко позначеним «персональним» простором, доступ до якого може мати тільки дитина. Жорстко регламентований в такому закладі і режим проживання, який пунктуально визначає, коли його мешканцям слід вставати, приймати їжу, грати, вчитися, спати тощо і не дозволяє враховувати індивідуальні особливості дитини [18].

Іншими словами, проживання дитини в інтернатному закладі виключає для дитини можливість самостійно регулювати порядок контактів із зовнішнім світом відповідно до власних потреб. Це може перешкоджати формуванню і розвитку тих здібностей, які роблять людину унікальною особистістю, індивідуальністю. Розмивається розуміння дитиною динаміки власних станів. Постійне перебування в системі вимушених контактів спотворює межі особистого простору дитини, що робить принципово неможливим звернення дитини до власного світу для відновлення психоемоційного ресурсу. Організація життя в дитячому будинку передбачає необхідність виконувати чітко окреслені соціальні ролі, серед яких превалює роль вихованця. Перебуваючи в межах цієї ролі, дитина втрачає здатність до прояву власної індивідуальності, що не дозволяє їй в подальшому будувати власне життя, на основі своїх власних особистісних ресурсів [11].

Саме тому в Україні розпочато процес деінституалізації, який передбачає заміну системи інституційного догляду дитини на систему, яка забезпечує догляд і виховання дитини в сімейному середовищі або наближеному до сімейного. Цей процес будується на дотриманні найкращих інтересів дитини, запобіганні потрапляння дітей до інституційних закладів, міжвідомчій взаємодії. Деінституалізація передбачає розвиток превентивних послуг для дітей і сімей у громаді, орієнтованих на задоволення потреб дитини та захист ії інтересів.

Коли дитина потрапляє до інтернатного закладу, то вона стикається як із внутрішніми, так і з зовнішні труднощами для успішної соціалізації. До найбільших деформацій зв'язків із соціумом призводить втрата «базової довіри до світу», в зв'язку з чим переривається розвиток таких характеристик особистості, як самостійність, ініціативність, соціальна компетентність, вміння працювати [1].

Причини виникнення труднощів входження дитини в систему соціальних відносин можуть бути самими різними, але перш за все вони пов'язані 3 неадекватним сприйняттям дітьми, які залишилися без піклування батьків тих вимог, які висуває до них їхнє оточення. Певні специфічні риси в поведінці та розвитку дітей, які виховуються в дитячих будинках, зберігаються у них не тільки протягом усього перебування в установі, а й в подальшому дорослому житті. На успішність соціалізації та інтеграції дітей, які залишилися без піклування батьків, впливає рівень їх освітньої підготовки, рівень оволодіння соціально-побутовими навичками, а також особливості їх психічного розвитку, які сформувалися у них за час перебування в 
дитячому будинку [8].

Відомо, що визначальним в соціалізації особистості вважається дошкільний вік. Саме в цей період відбувається інтенсивний духовний розвиток, закладаються головні ціннісні орієнтири особистості, формується характер, ставлення до себе, до своєї сім'ї, до оточуючих.

Можна розглянути соціальний розвиток дітей дошкільного віку в культурологічній парадигмі освіти. Соціальне виховання як організований процес направлений на реалізацію спільної мети «виведення» людини за межі її тваринної сутності та залучення до цінностей соціальної культури.

Ключовими складовими поняття «соціалізація особистості» $є$ :

$>$ засвоєння досвіду суспільного життя і суспільних відносин;

$>$ активна участь в засвоєнні соціальних відносин, у фрормуванні певних соціальних норм, ролей і функцій, в розвитку умінь i навичок, необхідних для їх успішної реалізації;

> розвиток саморегуляції: становлення самосвідомості та активної життєвої позиції;

сім'я, дошкільні заклади освіти, школа, трудові та інші колективи як інститути соціалізації.

Можна виділити наступні механізми соціального розвитку дітей дошкільного віку:

а) соціальна орієнтація;

б) рефлекторна регуляція;

в) наслідування;

г) емоційна ідентифрікація;

д) нормативне регулювання;

е) індуктивна регуляція;

є) соціальний досвід;

ж) контроль;

з) оцінка;

к) рефлексія.

Сорормованість всіх перерахованих механізмів і буде визначати рівень соціального розвитку дитини дошкільного віку. Таким чином, слід зазначити, що основними завданнями в системі організації ігрової, предметної, образотворчої та інших видів діяльності поряд із завданнями розвитку цих діяльностей стоять завдання особистісного розвитку дітей.

Так, Є. Степанов, до соціальних якостей особистості дитини відносить комунікативні навички: проявляти активність в спілкуванні, вміти слухати і розуміти мову, будувати спілкування з урахуванням ситуації, легко входити в контакт з іншими. Педагоги і психологи виділяють значимі соціальні якості дитини, які сприяють успішній адаптації в соціумі: самостійність, активність у стосунках 3 оточуючими, ініціативність, як прагнення до лідерства, самоконтроль, вміння оцінювати себе і контролювати свої дії, комунікабельність, 
емпатійність [23].

Потреба в самоствердженні та визнанні їх можливостей з боку дорослих $€$ характерною для дітей старшого дошкільного віку. Вже визнано необхідним освітнім завданням - формування ініціативності дошкільнят. Підтримка індивідуальності і ініціативи дітей $є$ однією 3 вимог до умов реалізації освітньої програми для дітей старшого дошкільного віку. 3 упевненістю можна відзначити, що необхідним $є$ : створення умов для вільного вибору дітьми діяльності і учасників для спільної діяльності; прийняття дітьми рішень, вираження ними своїх почуттів і думок, а також підтримку дитячої ініціативи і самостійності. Засвоєнню дітьми самостійності сприяє опанування дітьми умінь визначити мету (або прийняти ії від педагога), обміркувати шлях до ії̈ досягнення, здійснити свій задум, оцінити отриманий результат з позиції мети.

Таким чином, в ході системного аналізу соціалізації особистості дитини (в історичному та сучасному аспектах) нами було встановлено, що на сьогодні недостатньо розроблено механізм даного процесу на основі взаємодії сім'ї та закладу дошкільної освіти, недостатньо визначені умови ефективного фрункціонування системи соціального виховання дітей дошкільного віку в умовах закладу дошкільної освіти.

$\mathrm{Ha}$ підставі вищезазначеного, ми можемо зробити наступні проміжні висновки:

а) під соціалізацією дітей дошкільного віку ми розуміємо спеціально організований процес, спрямований на засвоєнні дитиною зразків поведінки, психологічних установок, соціальних норм, цінностей, вмінь, навиків, які дозволяють їм в подальшому успішно функціонувати в суспільстві;

б) показниками соціалізації $€$ три критерії: когнітивний (ступінь усвідомлення цілі конкретного виду діяльності, інтеріоризація соціального досвіду); мотиваційний або емоційний (відношення особистості до характеру та результату конкретного виду соціальної діяльності, задовільність міжособистісними відносинами, спонукання до участі в соціальних відносинах, прагнення до самовизначення та самореалізації); діяльнісний (інтенсивність участі в діяльності, участь в пошуку та реалізації своїх можливостей);

в) особливості соціалізації дитини дошкільного віку - створення необхідних та достатніх психолого-педагогічних умов: включення дітей в опанування соціального досвіду в процесі спільної діяльності (набуття навичок спільної діяльності); створення ситуації успіху (формування впевненості у собі, почуття власної гідності, позитивного відношення до світу, розуміння емоційного стану оточуючих); розвиток рефлексійних вмінь, які стимулюють інтерес дитини до себе, інтерес до однолітків, до дітей в групі закладу дошкільної освіти. 
Зазначений вище матеріал дозволяє перейти до більш детальної аналітики особливостей розвитку дітей дошкільного віку позбавлених батьківського піклування, а також до аналізу педагогічних засобів та засобів соціалізації, які цим дітям необхідні.

Виховання в інтернатному закладі суперечить ідеї формування самостійної особистості, незалежно від волі та добрих намірів керівництва та педагогічних працівників закладу. Дитина, позбавлена батьківського піклування, яка виховується в інтернатному закладі, завжди перебуває у підпорядкуванні, залежності від дорослих, які несуть за неї юридичну відповідальність, не може діяти без їх дозволу. Тому зусилля педагогів спрямовані переважно на виховання дисциплінованості, слухняності та розвиток пізнавальної сфрери особистості. Це, безперечно, важливо для будь якої людини, але розвиненість цих якостей не забезпечить успішної соціалізації дитини в закладі інституційного догляду [20].

Аналіз розвитку дітей, позбавлених батьківського піклування, так званих «соціальних сиріт», які складають більшість вихованців дитячих будинків, свідчить про те, що неприйняття батьками дитини призводить до тяжких наслідків. Прояв цього спостерігається практично у всіх сорерах життєдіяльності. В своїх дослідженнях Е. Мінкова наводить емоційний портрет вихованця дитячого будинку (дитини, яка позбавлена батьківського піклування), який характеризується такими рисами, як:

1. Бідна гама емоцій, одноманітність емоційно-експресивних засобів спілкування.

2. Схильність до частої зміни настрою.

3. Одноманітність та стереотипність емоційних проявів.

4. Емоційна поверховість, яка згладжує негативні переживання та сприяє їхньому швидкому забуттю.

5. Неадекватні форми емоційного реагування на похвалу та зауваження.

6. Підвищена схильність до тривоги, занепокоєння.

7. Основне спрямування позитивних емоцій - отримання все нових та нових задоволень.

8. Нестабільність емоційних стосунків з оточуючими.

9. Нерозуміння емоційного стану іншої людини.

10. Надмірна імпульсивність, афективна вибуховість $[13$, с. 80].

Важливішою проблемою, яка об'єднує дітей-сиріт та дітей, позбавлених батьківського піклування, є слабке здоров'я, «...66,7\% вихованців державних дитячих закладів мають хронічне захворювання та стоять на диспансерному обліку, 62\% дітей-сиріт та дітей, позбавлених батьківського піклування мають порушення центральної нервової системи, в тому числі діяльності головного мозку - 32,5\%, зору $-25,4 \%$ та інше» [13, с. 123].

У дітей-сиріт та дітей, позбавлених батьківського піклування, 
спостерігається зниження пізнавальної активності, обмеження кругозору, викривлені спогади про себе в минулому, мізерні уявлення про майбутнє. Ці діти майже не відрізняються від однолітків рівнем мислення, але оперування образами викликає у більшості з них серйозні труднощі. Психологи відзначають властиву цим дітям крайню ситуативність розумових дій, яка визначається або предметним оточенням, або прямими вказівками дорослого, нерозвинену уяву, відсутність пізнавальної ініціативи і цілеспрямованості.

Серйозною проблемою виховання дітей в умовах дитячого будинку є питання статевої ідентифікації дітей. У дошкільному віці дитина вперше усвідомлює себе представником тієї чи іншої статі. У цей період дуже важливо присутність рольових еталонів для наслідування, з яких дитина бере приклад статево-рольової поведінки і на які вона орієнтується.

Дослідження сорери спілкування, проведені В. Матюхіною, показали що дитина, яка виховується в умовах закладу інтернатного типу, як правило, не засвоює навички продуктивного спілкування. Відчуженість, порушення емоційних контактів з оточуючими аж до повної відсутності тенденції до співпраці, відсутність навичок спілкування - ось далеко не повний перелік відхилень у розвитку. Характеризуючи ділові контакти дітей 3 дорослими, В. Матюхина зазначає, що вони виникають пізно і здійснюються в примітивній формі. Активність у співпраці, прагнення і здатність що-небудь робити разом з дорослими у дітей не виникає. Контакти з однолітками також бідні за змістом, і мало емоційно насичені [12, с. 76].

Діти дошкільного віку позбавлені батьківського піклування, які виховуються в дитячому будинку, відстають у розумовому і фрізичному розвитку. Однак правильний підхід до їх виховання може, в деякій мірі, мінімізувати ці негативні наслідки, особливо у дівчат. $€$ істотні відмінності у вербальних навичках, інтелекті, поведінкових реакціях між хлопцями і дівчатами.

у дітей позбавлених батьківського піклування, можуть спостерігатися такі психологічні проблеми: комунікативні труднощі; деструктивні тенденції особистості; схильність до маніпулювання; брехливість; страх бути покинутим; труднощі при прийнятті рішень; агресивність; схильність до боротьби за владу і відстоювання своїх прав; підвищена сексуальність. Психологічне відчуття «сирітства» не закінчується в дитинстві. При нестачі уваги і турботи вони будуть домагатися їх і в зрілому віці. Так само це одна з причин, по якій дітисироти часто відмовляються від своїх дітей. Ось деякі з проблем, 3 якими можуть зіткнутися діти в зрілому віці: труднощі у відносинах; правові проблеми; професійні проблеми; бездомність, депресивні і тривожні стани; відмова від власних дітей; сексуальна розбещеність; наркоманія та алкоголізм та інші залежності; відсутність навичок адаптивної поведінки в кризових ситуаціях. Ще однією проблемою, 
можна назвати таке явище, як «інституційний аутизм», що полягає в прояві рис аутизму при виході дитини з інституційного середовища (наприклад, усиновлення) [24].

У дослідженнях Е. Мінкової наводиться узагальнений образ випускника дитячого будинку (в будь-якому віці), складений на основі аналізу наукових досліджень і практичних спостережень. Його характерні особливості:

а) відсутність досвіду соціальних контактів з людьми;

б) труднощі в спілкуванні;

в) несформованість потреби і здатності працювати;

г) споживацький стиль життя, нерозуміння матеріальної сторони життя;

д) відсутність особистісного досвіду нормального життя в родині;

е) недорозвинення індивідуальності;

є) відсутність морального імунітету до умов негативної середовища;

ж) поганий стан здоров'я [13, с. 9-10].

А. Шахманова виділила основні причини, які провокують розвиток негативних якостей особистісного розвитку вихованців дитячих будинків:

1. Соціальні умови колишнього життя в неблагополучних сім'ях або на вулиці. Багато дітей пережили найсильніші стресові ситуації, душевні травми, які наклали відбиток на їхню психіку під час потрапляння до дитячого закладу. Уже в державному дитячому закладі на дітях особливо позначається дефіцит спілкування. В особливо найгіршому становищі перебувають немовлята, які в умовах будинку дитини позбавлені біологічного контакту з матір'ю, до того ж вихователі не в змозі, у зв'язку з великою завантаженістю, забезпечити дітям необхідну кількість і якість спілкування 3 оточуючими людьми. Емоційний стан дітей ускладнюється тугою за домівкою, за батьками, навіть якщо батьки не сумлінно виконували свої обов'язки по догляду за дитиною.

2. Замкнутість в стінах навчального закладу. 3 одного боку, це виправдано прагненням захистити дітей від негативного впливу вулиці, але з іншого, сприяє фоомуванню мізерних дитячих уявлень про навколишній світ, невміння адекватно орієнтуватися в ньому.

3. Постійне перебування в колективі, особливо в умовах переповненості груп. Дитина часто не має можливості побути наодинці сама з собою. Щохвилинне перебування на людях веде до виснаження нервової системи, виникненню і збільшенню різного роду порушень психіки.

4. Характер роботи деяких вихователів, які тяжіють над усіма діями дитини жорсткою регламентацією, відстежують кожен ії̈ крок, вибудовують життя в дитячому будинку на застереженнях та заборонах, багато роблять самі за дітей, замість того щоб всіляко 
спонукати їх та розвивати ініціативність. Коли дитина позбавлена батьківського піклування постійно відчуває прес чужої волі, переважання колективних форм спілкування з індивідуальними, вона стає пасивною і бездіяльною [26, с. 192].

Яким чином позначається перебування дитини в дитячому будинку на змісті ігрової діяльності? Невеликий досвід взаємодії із зовнішнім середовищем не дає дитині можливості фрормувати великий список ігрових сюжетів і ролей. Численні спостереження показують, що зміст ігор у вихованців дитячого будинку найчастіше обмежується маніпуляціями з іграшками. Такі фрорми гри, як сюжетна і колективна гра, розвинені дуже слабо.

До числа найбільш актуальних проблем розвитку вихованців інтернатних установ дослідники відносять труднощі соціалізації. Під труднощами соціалізації розуміють комплекс труднощів дитини при оволодінні тією чи іншою соціальною роллю. Причини виникнення цих труднощів вони вбачають в невідповідності вимог до дитини в процесі іiї взаємовідносин з соціумом і готовності дитини до цих відносин. Соціальна ситуація розвитку дитини в дитячому будинку або інтернаті при відсутності нормальних для неї контактів (сім'я, друзі, сусіди тощо) призводить до того, що образ ролі створюється на основі суперечливої інформації, яку одержує дитина позбавлена батьківського піклування з різних джерел. У зв'язку з цим часто фрормуються невірні образи соціальних ролей і помилкове уявлення про власну соціальну роль як сироти. Ця роль часто реалізується людиною протягом усього життя. У грі велику роль мають емоційна сфера та сфрера творчого мислення. Ігри дитячих будинків бідні на образи і емоційну різноманітність. Іншими словами можна стверджувати (i це твердження підкріплюється численними дослідженнями), що ігрова діяльність дітей-сиріт та дітей позбавлених батьківського піклування, неповноцінна, вона не використовує задатки і можливості дитини і не дає тих своїх ефректів, які можна спостерігати в ігровій діяльності дітей, які виховуються в сім'ях [3].

Діти дошкільного віку з інтернатних установ інтелектуально менш розвинені, вони проявляють ослаблені розумові здібності, які проявляються в невмінні відчувати час, імпульсивності, в труднощі концентрувати увагу. За даними зарубіжних дослідників, діти позбавлені батьківського піклування, проявляють уповільнений розвиток свідомості і соціальної зрілості. Продовжуючи дослідження і спостерігаючи за дітьми, які після 4 років були усиновлені, вчені показали, що діти дуже сильно прив'язуються до своїх нових батьків, але при цьому у них продовжують виявлятися соціальні проблеми як і у однолітків, які не живуть в сім'ях [27].

У дітей старшого дошкільного віку, які позбавлені батьківського піклування проявляється затримка мовного розвитку, знижується темп фрізичного розвитку, що призводить до значного відставання в 
психічному і фрізичному розвитку. Діти дошкільного віку позбавлені батьківського піклування, які виховуються в дитячому будинку, відстають у розумовому і фрізичному розвитку. Однак правильний підхід до їх виховання може, в деякій мірі, мінімізувати ці негативні наслідки, особливо у дівчаток. $€$ істотні відмінності у вербальних навичках, інтелекті, поведінкових реакціях між хлопцями і дівчатами [21].

Тести на інтелект показують відмінності між дівчатами, які виховуються в прийомних сім'ях та в умовах дитячого будинку, в той же час у хлопців суттєвих відмінностей не виявлено. Вчені вважають, що це пов'язано з більш сильною схильністю хлопців до поведінкових розладів (гіперактивність, агресія), а дівчаток до емоційних (тривожність). На думку вчених, дівчата більш сприйнятливі до проживання в прийомних сім'ях, що знижує негативні прояви більше, ніж у хлопців.

Можна виділити наступні ознаки, які часто виявляються у дітей дошкільного віку позбавлених батьківського піклування. Вони виділені в проблеми розвитку психіки і поведінки дітей.

Проблеми в розвитку свідомості дітей:

1) не виявляють занепокоєння з приводу агресивності або жорстокої поведінки. Це виражається в тому, що вони виправдовують жорстокість по відношенню до інших, самі проявляють ії;

2) не відчувають почуття провини, порушуючи правила, вважаючи, що вони не винні, а порушувати правила нормально (брати чужі речі, віднімати один у одного потрібні предмети тощо);

3) перекладають вину на інших [28].

Контроль над діями:

1) не вміють контролювати себе, не дотримуються обмежень, просять інших контролювати їх дії і вчинки;

2)демонструють недостачу передбачення, не можуть пояснити, які будуть наслідки вчинків, як відреагують інші, які наслідки це буде мати для них самих;

3) мають проблеми із зосереджуванням на якійсь справі [16].

Розвиток самооцінки:

1) не можуть отримувати задоволення від добре зроблених завдань;

2) вважають, що вони нічого не заслуговують;

3) вважають, що вони не здатні що-небудь змінити і від них нічого не залежить;

4) не вміють веселитися, частіше сумують, мають високий рівень особистісної та ситуативної тривожності [28].

Міжособистісне спілкування:

1) не довіряють іншим людям та одноліткам;

2) вимагають від інших значущих дорослих любові, але при цьому не допускають довірливих відносин, не розкриваються перед іншими;

3) виявляють ворожу залежність; 
4)бажають контролювати все, що відбувається навколо, має місце постійне почуття пильності, бути напоготові;

5) виявляють необґрунтовану соціальну зрілість, діляться своїм досвідом і багато розповідають про те, що вони робили в минулому [16].

Особливості прояву почутmів дітей:

1) зазнають труднощів у визначенні власних почуттів, не можуть описати, що вони відчувають, розповісти про свої почуття;

2) відрізняються бідністю емоційного досвіду;

3) зазнають труднощів в вираженні власних почуттів, особливо гніву, смутку, суму, радості;

4) мають ускладнення при диференціації почуттів інших, не можуть описати, що відчуває інша людина [10].

Особливості мислення:

1) труднощі у використанні мислення, сповільненість його розвитку;

2) зазнають труднощів, думаючи про майбутнє;

3) не можуть оволодіти багатьма поняттями, узагальненнями.

Прояв проблем у розвитку:

1) труднощі в розвитку мови, навичках самообслуговування;

2) труднощі в особистісному і соціальному розвитку, відрізняються низьким рівнем соціальної компетентності з багатьох питань [28].

Формулюючи особливості дітей дошкільного віку, які залишилися без піклування батьків, можна вказати на основні проблеми, які перешкоджають успішній соціалізації:

1. Недостатній інтелектуальний розвиток може полягати і виражатися в ослабленні або в недостатній сформованості, нерозвиненості пізнавальних процесів, нестійкості уваги, слабкої пам'яті, слабо розвинутого мислення (наочно-образного, вербального та ін.), низькій ерудиції. Причиною низького інтелектуального розвитку може бути відсутність нормального соціально-педагогічного середовища (педагогічна занедбаність). Відсутність належної уваги до інтелектуального розвитку дитини може привести до серйозного відставання в навчанні.

2. Спільна діяльність і спілкування дітей дошкільного віку 3 однолітками. У грі діти позбавлені батьківського піклування менш уважні до дій і станів партнера, часто зовсім не помічають образи, прохання і навіть сліз однолітка. Перебуваючи поруч, грають порізно. Спільні ігри носять, в основному, процесуальний характер; відсутня рольова взаємодія в грі; навіть включаючись в який-небудь загальний сюжет, діти діють від себе, а не від імені рольового персонажа. По операційному складу (по здійснюваних діях) така діяльність дуже нагадує рольову гру, але за суб'єктивним, психологічним змістом суттєво відрізняється від неї. Контакти в грі зводяться до конкретних звернень та зауважень 3 приводу дій однолітка (дай, дивися, посунься тощо). 
3. Проблема статевої ідентифікації дітей дошкільного віку позбавлених батьківського піклування. Стереотипи жіночої та чоловічої поведінки входять в самосвідомість через досвід спілкування і ідентифікацію 3 представниками своєї статі. У дитячих будинках діти ізольовані від цих орієнтацій. Дошкільнята вже добре знають про свою приналежність до статі, прагнуть затвердити себе як хлопчика чи дівчинку, в цьому вони мало відрізняються від дітей, які виховуються в родині. Однак якісно статева ідентифрікація має істотні відмінності. Якщо діти в сім'ї ідентифікуються 3 їх батьками, з близькими родичами і 3 однолітками, то діти, позбавлені батьківського піклування, ідентифікуються, перш за все, зі своїми однолітками, тобто хлопчиками і дівчатками з групи.

4. Проблеми морального розвитку особистості вихованців. Проблеми морального розвитку починаються 3 безвідповідальності, придушенні і ображанні слабших, в зниженні емпатії, здатності до співчуття, співпереживання i, в цілому, в недостатньому розумінні або неприйняття моральних норм, правил і обмежень.

5. Адаптація. Під труднощами адаптації фахівці розуміють комплекс труднощів дитини при оволодінні тією чи іншою соціальною роллю. Освоюючи ці ролі, людина соціалізується, стає особистістю. Відсутність нормальних для звичайної дитини контактів (сім'я, друзі, сусіди) призводить до того, що образ ролі створюється на основі суперечливої інфрормації, одержуваної дитиною з різних джерел.

6. Проблеми емоційно-вольового розвитку вихованців. Найбільші труднощі і відхилення від нормального становлення особистості вихованців дитячих будинків відзначаються всіма дослідниками в емоційно-вольовій сфері: в порушенні соціальної взаємодії, невпевненості в собі, зниження самоорганізації, цілеспрямованості, недостатній розвиток самостійності («сили особистості»), неадекватною самооцінкою. Подібні порушення проявляються емоційній напруженості, психічному стомленні, емоційному стресі.

\section{Список використаних джерел}

1. Абельбейсов В.А. Социализация детей-сирот и детей, оставшихся без попечения родителей, в детских сиротских учреждениях. М.: Издательство «Новые технологии», 2013. $206 \mathrm{c.}$

2. Андреева Г. М. Социальная психология. М.: Наука, 2004. 324 с.

3. Андреенкова Н.В. Проблема социализации личности. Социальные исследования. 2000. Вып. 3. С. 132-141.

4. Вульфров Б. З. Основы педагогики в лекциях, ситуациях, первоисточниках: учебное пособие. - М.: Издательство РАО, 1997. 288 с.

5. Выготский Л. С. Собрание сочинений. В 6 томах. Т.2. Проблемы общей психологии / под ред. В. В. Давыдова. М.: Педагогика, 1982. 504 с.

6. Голованова Н. Ф. Социализация и воспитание ребенка: учебное пособие для студентов высших учебных заведений. СПб.: Речь, 2004272 с.

7. Закон України від 13 січня 2005 року № 2342 - IV «Про забезпечення організаційно-правових умов соціального захисту дітей-сиріт та дітей, позбавлених батьківського піклування». 
8. Иванова Т. А. Организация безопасного пространства в специализированных учреждениях для детей-сирот. Проблемы онтогенеза личности в образовательном пространстве: материалы научно-практической конференции. Ставрополь: Вече, 2007. С. 156-159.

9. Кон И. С. Междисциплинарные исследования. Социология. Психология. Сексология. Антропология. Ростов на Дону: Феникс, 2006. 608 с.

10. Кононенко Н. В. Умения детей-сирот реально оценивать действительность и характер жизненных проблем. Здоровье и образование в XXI веке, «Здоровье населения - среда обитания». Майкоп: Изд-во АГУ, 2006. С. 102-103.

11. Куричкис И. В. Особенности управления процессом социализации детейсирот и детей, оставшихся без попечения родителей: автореферат дис. ... канд. социолол. наук: 22.00.08. Санкт-Петербург, 2004. 20 с.

12. Матюхина В. В. Возрастная социальная психология. Дошкольное воспитание. 1993. № 10. С. 62-68.

13. Минкова Э. А. Особенности личности ребенка, воспитывающегося вне семьи. Очерки о развитии детей, оставшихся без родительского попечения. М.: ТОО «Симе», 1995. С. 9-10.

14. Мудрик А.В. Социализация и воспитание подрастающих поколений. М.: Знание, 1990. 44 с.

15. Мудрик А. В. Социальная педагогика / под ред. В.А. Сластенина. М.: Академия, 2000. 192 с.

16. Нуретдинова Л. Г. Гуманизация воспитательного пространства детского дома: дис. ... канд. пед. наук: 13.00.01. Казань, 2001. 254 с.

17. Присяжная Н.В. Сироты в коррекционных учреждениях: социализация и последующая адаптация в обществе: дис. ... канд. социол. наук: 22.00.04. Москва, 2008. 182 с.

18. Салыкова К. С. Педагогические проблемы социальной реабилитации детейсирот. Теория и практика формирования культуры детей и подростков. Вестник Института культуры детства ЧГАКИ. Челябинск. Вып. 8. 2007. C. $130-140$.

19. Солодникова И.В. Социализация личности: сущность и особенности на разных этапах жизни. Социологические исследования. 2007. № 2. С. 28-33.

20. Соціальна робота із вразливими сім'ями та дітьми: посібник 2-х ч.; Ч. 2. / А. В. Аносова, О.В.Безпалько, Т. П. Цюман та ін. / за загальною редакцією Т. В. Журавель, 3. П. Кияниці. К.: Обнова, 2017. 352 с.

21. Социально-психологические проблемы сиротства и стратегия помощи. Аналитический доклад. М.: Министерство образования, 2003. 16 с.

22. Социологическая психология: уч. пособ. для студ. высших заведений, обучающихся по психологии. М.: Издательство МОДЭК, 1999. 124 с.

23. Степанов Е. Н., Лузина Л. М. Педагогу о современных подходах и концепциях воспитания. М.: Педагогика, 2002. 93 с.

24. Травникова Н.Г. Психологическая адаптация выпускников детского дома: дис. ... канд. психол. наук: 19.00.01. СПб., 1999. 201 с.

25. Ушинский К. Д. Педагогические сочинения: в 6 т. Т. 1 / сост. С. Ф. Егоров. М.: Педагогика, 1990. 416 с.

26. Шахманова А. Ш. Воспитание детей-сирот дошкольного возраста / под ред. С. А. Козловой. М.: Издательский центр «Академия», 2005. 192 с.

27. Шибаева Л. В. Программа психологической реабилитации детей-сирот в школах-интернатах. М.: Педагогическое агентство, 2006. 162 с.

28. Юницкий В.А. Психологические особенности детей, потерявших родителей: дис. ... канд. психол. наук: 19.00.07. Москва, 1992. 233 с. 


\title{
ПСИХОЛОГІЧНІ I ПЕДАГОГІЧНІ ОСНОВИ ДОСЛІДНИЦЬКОї ДІЯЛЬНОСТІ ДІТЕЙ ДОШКІЛЬНОГО BIKY
}

\author{
Гаврило О. І. \\ кандидат біологічних наук, доцент, \\ Сумський державний педагогічний університет імені А. С. Макаренка
}

В останні десятиріччя акцент очікування суспільства від роботи закладів дошкільної освіти змістився на всебічний розвиток особистості дитини. Однак підготовка до шкільного навчання залишається актуальною в дошкільній освітні. Йдеться не про накопичення певних знань і умінь, що будуть використані у школі, а саме про вміння отримувати знання, тобто, пізнавальний розвиток дошкільника. Увага до розвитку дослідницької діяльності дітей допоможе їм успішно засвоювати матеріал, підвищить ефективність їх когнітивних здібностей та вмінь досліджувати навколишній світ.

Психологами і педагогами доведено, що дошкільник розвивається в діяльності. Для того, щоб дитина реалізувала власні задатки i здібності, необхідно урізноманітнити ії діяльність. Варто пам'ятати, що не будь-яка діяльність сприяє розвитку. Тому для педагогів головною метою стає застосування ефективних способів педагогічного впливу, які дозволили б поставити дитину у позицію активного суб'єкта діяльності. Одним із засобів розвитку суб'єктної позиції дитини в сучасному закладі дошкільної освіти $€$ дослідницька діяльність в ознайомлені з природою. У процесі цієї діяльності у дошкільнят формуються знання про навколишній світ: дитина починає збагачувати свій досвід уявленнями про особливості природного довкілля, отримує емоційні враження та власне вчиться усвідомлювати емоції, керувати власною поведінкою. Тому саме дошкільний період $є$ головним у формуванні першооснови природничо-наукових знань у дітей, екологічного мислення, свідомості та екологічної культури.

У нормативних документах, що стосуються дошкільної освіти, наприклад, Базовому стандарті дошкільної освіти, Концепції дошкільного виховання, Законі України «Про освіту» тощо визначаються завдання і критерії розвитку дослідницьких умінь у дітей.

Саме поняття дослідницької діяльності багатоаспектне, тому при визначенні її існують різні точки зору, в залежності від того, на чому акцентується увага дослідника. Зокрема, можемо бачити визначення, що стосуються психологічної сутності дослідницької діяльності, котра являє собою «особливий вид інтелектуально-творчої діяльності, яка виникає в результаті функціонування механізмів пошукової активності й ґрунтується на основі дослідницької поведінки» [25]; або 
«перетворювальна діяльність мислення, яка відповідає пізнавальним мотивам та особистісним потребам дитини, спрямована на виявлення сутності досліджуваних явищ, процесів, відрізняється персоніфрікованістю, творчістю, комунікабельністю» [29, с. 76]; творчий процес спільної діяльності двох (або більше) суб'єктів з пошуку рішення невідомого, у ході якого здійснюється міжсуб'єктний обмін культурними змістами і цінностями, переживаннями, способами діяльності, а результатом $\epsilon$ фрормування наукового світогляду й актуалізація особистісного потенціалу залучених до цього процесу суб'єктів пізнання [5]. 3 точки зору багатьох дослідників проблеми, дана діяльність неодмінно є творчою: пов'язана з «виконанням творчого, дослідницького завдання із заздалегідь невідомим рішенням» [26, с. 9]; «діяльність, яка безпосередньо пов'язана з розв'язанням творчого дослідницького завдання, що немає наперед відомого результату (у різних галузях науки, техніки, мистецтва) та передбачає етапи, характерні для наукового дослідження (визначення проблеми, ознайомлення 3 літературними джерелами та їх опрацювання, формулювання гіпотези, власне проведення дослідження, аналіз його результатів і остаточне узагальнення, фрормулювання висновків, конкретна суспільно корисна, масова чи природоохоронна робота дошкільників за результатами здійсненого дослідження)» [5].

Існують також погляди, які зводять дослідницьку діяльність дошкільників саме до процесу досягнення педагогічних цілей: наприклад, Д. Ельконін в першу чергу бачив її як діяльність, в якій «відбувається лише перевідкриття наукових знань або теорій» [28, с. 20]; інші педагоги - як «специфічний вид пізнавальної діяльності, який використовує навчальне дослідження в якості головного способу досягнення освітнього результату під час вивчення будь-якої теми або предмета в різних ланках освіти» [22, с. 6].

$\mathrm{Ha}$ нашу думку, найголовніші складові природознавчої компетентності особистості, котра $€$ метою педагогічної діяльності колективів не тільки закладів дошкільної освіти, але й системи освіти в Україні в цілому, включає в себе визначення О. Заболотного, який бачить дослідницьку діяльність як «інтеграційний компонент особистості, який характеризується єдністю знань цілісної картини світу, вміннями, навичками наукового пізнання, ціннісного ставлення до його результатів і розвиненим інтелектом, що забезпечує іiї самовизначення й саморозвиток» [цит. за 6, с. 28].

Однак варто звернути увагу на те, що даний вид діяльності має значення не лише як процес, але й як рівнозначні йому результати іï здійснення. Обидві сторони даного поняття ураховані в тлумаченні Н. Яришевої [30]. Вона розглядає дослідницьку діяльність як специфрічну людську діяльність, яка регулюється свідомістю й активністю особистості, спрямована на задоволення пізнавальних, інтелектуальних потреб; продуктом діяльності $є$ нове знання, отримане відпо- 
відно до поставленої мети, об'єктивних законів і наявних обставин, що визначають реальність та досяжність мети; має конкретні способи і засоби дій, пов'язані з постановкою проблеми, виявленням об'єкта дослідження, проведенням експерименту, описом і поясненням фактів, формулюванням гіпотези, перевіркою отриманого знання.

Мета дослідницької діяльності полягає в отриманні нового знання конкретного чи узагальненого характеру про оточуючий світ. Дослідженням завжди починається з пізнавальної потреби, мотивації пошуку, передбачає виявлення певної проблеми чи протиріччя, вивчення й пояснення невідомого. Продуктом дослідницької діяльності $€$ нове знання, отримане відповідно до поставленої мети, суб'єктивних законів і наявних обставин, що визначають реальність і досяжність мети.

Дослідницька діяльність, що здійснюється з освітньою метою, передбачає дотримання етапів, які $€$ характерними для наукового дослідження: визначення проблеми, ознайомлення з літературними джерелами та їх опрацювання, формулювання гіпотези, власне проведення дослідження, аналіз його результатів і остаточне узагальнення, фрормулювання висновків, екстраполяція їх на широке коло подібних явищ та конкретне використання результатів дослідження.

На нашу думку, організація дослідницької діяльності у закладах дошкільної освіти має враховувати вікові можливості дітей та реалізовуватися з дотриманням таких етапів: етап виявлення проблеми (протиріччя) та усвідомлення ії (його) змісту; етап застосування відомих дітям знань і способів діяльності для вирішення проблеми (подолання протиріччя); етап формулювання припущення або висунення гіпотези щодо способу чи результату розв'язання проблеми (подолання протиріччя); етап послідовного виконання дій з виявлення істинності чи хибності висунутого припущення (сфрормульованої гіпотези); етап формулювання висновків на основі отриманих даних.

Окрім етапів організації дослідницької діяльності також виокремлюються дії, за допомогою яких вона реалізується. Аналіз наукових джерел виявив різні підходи до визначення сукупності дій, які лежать в основі дослідницької діяльності. За О. Савенковим, це постановка проблеми, вивчення теорії, добір методик дослідження і практичне оволодіння ними, збір матеріалу, його аналіз і узагальнення, формулювання висновків [23, с. 5].

Н. Поліхун та В. Дем'яненко [9] виділяють етапи дослідницької діяльності детальніше: ознайомлення з проблемами, вибір тематики, напрямку дослідження, вивчення теорії питання (формулювання проблеми, гіпотези, мети та завдань, визначення об'єкта, предмета дослідження, формулювання теми); планування роботи з дослідження (дослідження, інформаційний пошук за ключовими поняттями; вибір методів дослідження; складання проекту дослідницької роботи, планування експерименту тощо); практична робота з проведення експериментального дослідження (збирання даних та аналіз даних, 
обговорення результатів, визначення невирішених проблем); офрормлення результатів дослідження (структурування зібраних матеріалів, складання змісту наукового звіту, оформлення роботи); презентація дослідницької роботи (підготовка мультимедіапрезентації, доповіді тощо). Чітко окреслено дії дітей як складові діяльності у працях А. Карлащук. Сюди включені: постановка проблеми, добір й практичне оволодіння методами дослідження, добір відомостей, аналіз, узагальнення, фрормулювання висновків [12]. М. Каратаєва розглядає дослідницьку діяльність як певний різновид проекту та визначає як спеціально організовану спільну навчальнопізнавальну діяльність дошкільників і педагога 3 проектування індивідуального або колективного дослідження в рамках таких етапів: 1) постановка особистісно значущих освітніх завдань (ініціатив); 2) планування ходу й способів дослідження; 3) визначення очікуваних результатів; 4) розгортання діяльності; 5) створення конкретного продукту. На переконання автора, проектно-дослідницька діяльність $€$ діяльністю з проектуванню дослідження. В якості базової обирається модель та методологія дослідження, розроблена й прийнята в певній сорері науки, яка характеризується наявністю декількох стандартних етапів, присутніх у будь-якому науковому дослідженні [11].

Враховуючи специфіку роботи з дітьми дошкільного віку, ми схиляємося до виділення п'яти етапів дослідницької діяльності. До переліку дій можна віднести дії з формулювання мети діяльності, яка ґрунтується на усвідомленні змісту проблеми; передбачення способу (способів) її розв'язання (приміром, опрацювання різних джерел, проведення досліду (спостереження), здійснення опитування тощо) та (або) висловлення припущень щодо можливих результатів діяльності; планування послідовного виконання діяльності (що спочатку, а що потім), виконання запланованого, аналіз і узагальнення отриманих даних, фоорулювання висновків.

Результатом дослідницької діяльності може виступати: нова інфрормація про об'єкти дослідження (прямий продукт); нова інформація про інші об'єкти й про інші властивості досліджуваного об'єкта, які не були предметом дослідження; набуття знань про саму дослідницьку діяльність та практичний досвід ії здійснення; пізнавальний та особистісний розвиток дослідника (формування особистісних психічних утворень).

Склад дослідницьких умінь також характеризується варіативністю, їх виділяють та об'єднують досить по-різному: операційні, організаційні, практичні, комунікативні (В. Литовченко); інтелектуальнодослідницькі, інформаційно-рецептивні, продуктивні (І. Зимня); аналітико-синтетичні, інформаційні, діагностичні, прогностично-проектувальні, креативно-інноваційні (М. Фалько); аналітико-синтетичні, інформаційні, спеціальні, комунікативні, прогностичні, креативні, рефрлексивні (В. Базелюк); операційно-методичні, інформаційно- 
аналітичні, діагностико-прогностичні, оцінно-рефрлексивні (І. Раєвська).

У наукових роботах також розглядається питання розрізнення дослідницької та пошукової діяльності. Зокрема, Р. Кондратенко зазначає, що елементарні дослідницькі завдання, що виконуються дітьми дошкільного віку, є однією з форм організації їхньої пошукової діяльності. А от пошукова діяльність, на його думку, значно ширша, це «активна пізнавальна діяльність вихованців у здобутті нових знань, способів пізнання, яка потребує пізнавальної самостійності, визначає такі форми організації пошукової діяльності: розв'язування пізнавальних і проблемних завдань, евристичні бесіди, методи аналогії, дискусії, самостійне ознайомлення з новим матеріалом, елементарні дослідницькі завдання; проектна діяльність» [14, с. 12].

Отже, дослідницька діяльність здійснюється як вихователем, так і вихованцями. I в першому, і в другому випадках йдеться про суб'єктивно нові результати. А відтак, смислове поле базового поняття «дослідницька діяльність» доцільно представити двома блоками. Перший із них стосується дослідницької діяльності наукового характеру, яка в незначній кількості випадків поширюється й на діяльність педагога як потенційного науковця в майбутньому. Натомість другий блок смислового поля поняття «дослідницька діяльність» включає в себе дослідницьку діяльність дошкільників та дослідницьку діяльність педагога як професіонала, який, досліджуючи ефрективність змодельованого ним процесу, постійно удосконалює власні підходи до організації діяльності дошкільників.

Дослідницьку діяльність дошкільників трактується як вид пізнавальної діяльності 3 розв'язання протиріччя пізнавальнопошукового характеру, яке набуває форми навчального дослідження й являє собою незначну частину процесу наукового пізнання, доступного для сприймання, розуміння й виконання вихованцями. Виконання педагогом дослідницької діяльності базується на діях розумових (бачити суперечність і фрормулювати проблему; конкретизувати об'єкт і предмет дослідження; визначати мету й завдання роботи; формулювати гіпотезу; планувати й організовувати власну діяльність, порівнювати, аналізувати, синтезувати, абстрагувати, узагальнювати, спостерігати, співставляти тощо; співвідносити результат власної діяльності з метою й оцінювати його; взаємодіяти з вихованцями в процесі дослідницької діяльності; здійснювати самоконтроль, саморегулювання; формулювати висновки) та практичних (опрацьовувати різні джерела інформації; здійснювати моделювання, проводити спостереження, ставити експеримент, аналізувати й узагальнювати дані, які було отримано). Ефективність їх виконання суттєво впливає на процес організації вихователем дослідницької діяльності дошкільників.

Психологічні особливості розвитку дослідницьких здібностей дошкільника визначаються специфрікою розвитку мотиваційних, 
інтелектуально-творчих і поведінкових характеристик. У дошкільному віці поведінка дитини характеризується ситуативністю, нестійкістю, мимовільністю. Це визначає характер процесу й розвитку дослідницького пошуку: його стрімкість, ситуативність, короткочасність і зв'язок з інтересом до діяльності.

У дошкільному віці наочно-дійове й наочно-образне мислення домінують над відносно слабко представленим словесно-логічним мисленням, що визначає характер дослідницької діяльності дитини. Дошкільник може логічно правильно міркувати, робити висновки й умовиводи, коли вирішує зрозумілі, цікаві для нього дослідницькі завдання й при цьому спостерігає доступні його розумінню фракти. Також психологічним розвитком дитини визначаються особливості прояву поведінкових характеристик: самостійності, що полягає в здатності дитини без сторонньої допомоги бачити проблему й, виходячи з неї, ставити мету, не чекаючи підказок і вказівок від інших людей, активно відстоювати свою точку зору; критичність, що дозволяє діяти без шаблонних способів дії, допомагає виявляти й коригувати помилки, вивчати питання ґрунтовно; наполегливість, що полягає в здатності постійно й тривало досягати мети, не знижуючи енергію при виникненні труднощів; концентрація уваги, під якою розуміється зосередженість свідомості на об'єктах, що припускає підвищення рівня сенсорної, інтелектуальної, рухової активності; схильності до спостережень, що полягає в умінні дитини помічати суттєві, характерні, навіть малопомітні властивості предметів і явищ.

Під фрізіологічною готовністю до здійснення дослідницької діяльності, за узагальненими даними, розуміється біологічний вік, загальний фрізичний розвиток (здатність до довготривалих фрізичних зусиль), розвиток моторики тіла, фрізіологічний розвиток центральної системи.

Відповідно до міркувань В. Калошина, психологічна готовність до сприймання навчального матеріалу містить такі складові: суб'єктивну (бажання бути дослідником, готовність до нових форм взаємовідносин) та об'єктивну (розвиток загальних здібностей, цікавість, яскравість уяви, сприймання, увага та досвід керування нею, пам'ять, мова, здатність до елементарних розумових операцій) [10]. Також у психологічній готовності до пізнавальної діяльності виділяють такі компоненти: мотиваційно-емоційний (цікавість до пізнання нового, інтерес до дослідницької діяльності, стійка мотивація до занять, емоційна стійкість) (Н. Бадмаєва); психомоторний (готовність до засвоєння наукових знань через зороворухову координацію і моторну активність на макро- та макрорівнях) (В. Клименко, Л. Роговик, О. Кочерга).

У структурі психологічної готовності виділяють: перцептивну зрілість, вміння концентрувати увагу, вербальний і невербальний компоненти в розумовому розвитку (В. Арсланьян), аналітичне мислення, загальні учбові та пізнавальні здібності (В. Крутецький), 
раціональне відношення до дійсності, сформованість ігрової діяльності на попередніх етапах розвитку (Д. Ельконін); розумові задатки та здібності, які визначають індивідуально-психологічні особливості дитини та забезпечують швидкість засвоєння знань ( $Є$. Ільїн); мотиваційно-вольову готовність, яка визначається вмінням дитини контролювати себе, керувати внутрішніми й зовнішніми діями; рівень сформованості відповідальності, самосвідомості, самооцінки, емоцій, які супроводжують процес дослідницької діяльності.

За Н. Тализіною, «дитина поступово вчиться робити те, що необхідно, а не те, що їй би хотілося, тобто, навчається керувати своєю поведінкою. Також вихователь вимагає від дитини не тільки розв'язати задачу, але й обґрунтувати ії̈ правильність. Це поступово формує здатність усвідомлювати те, що вихованець робить та що зробив. Таким чином, дошкільник поступово вчиться дивитись на себе ніби збоку й наче очима іншої людини та оцінювати свою діяльність» [27, с. 141].

Дослідницькі здібності проявляються також в глибині і міцності оволодіння прийомами дослідницької діяльності. Причому мова йде не тільки про саме прагнення до пошуку, але й про вміння оцінювати (обробляти) його результати, будувати свою подальшу поведінку в умовах розвитку ситуації, спираючись на них. Дослідницьке уміння розуміють як уміння застосовувати прийом відповідного наукового методу пізнання в умовах вирішення проблеми, у процесі виконання дослідницького завдання. До основних дослідницьких умінь і навичок відносять: уміння бачити проблему; ставити запитання; висувати гіпотези; давати визначення поняттям; класифікувати; спостерігати; проводити експерименти; аналізувати отриманий у ході дослідження матеріал; робити висновки й умовиводи; доводити й захищати свої ідеї. Вони складають основу успішного здійснення дослідницької діяльності. Н. Голуб зазначає, що при здійсненні будь-якої інтелектуальної діяльності при потребі в отриманні нових знань людиною, перш за все, рухає мотив [7]. Мотив - усвідомлена потреба, суб'єктивне відображення потреби. Джерелом спонукальної сили мотиву виступають потреби (А. Леонтьєв). Згідно О. Брежневої «мотив - те, заради чого здійснюється діяльність, на відміну від мети, на яку ця діяльність спрямована, тобто мотивом називається все те, що спонукає активність дитини - і оцінка, й іграшка, й інтерес, і прагнення до схвалення, і прийняте дитиною рішення, і почуття обов'язку» $[4$, с. 12$] .3$ розглянутих досліджень випливає, що мотив це активний процес психологічного і (або) фрізіологічного плану, який визначає активність людини, її спрямованість.

Очевидно, що для успішного розвитку дослідницької діяльності у дітей дошкільного віку важливо використовувати мотивацію. Мотивація може бути як внутрішньою, так і зовнішньою. Зовнішня мотивація виражається у відношенні до суб'єкта при будь-якій ситуації, при 
певних обставинах, а внутрішня мотивація пов'язана зі змістом діяльності. Таким чином, ми бачимо, що мотивація безпосередньо впливає на розвиток дослідницьких умінь дитини.

На думку багатьох вчених, найбільш ефективно пізнавальні мотиви розвиваються в дошкільному віці. У цей період складаються певні особистісні механізми поведінки, які виражаються в супідрядності мотивів, одні з яких виходять на перший план, а інші можуть займати підлегле становище. Згідно особливостей даного вікового періоду, до старшого дошкільного віку виникає досить стійка ієрархія мотивів. Тобто дитина вже може відмовитися від будь-якої привабливої для неї мети чи діяльності, і виконувати більш значущу для оточуючих роботу, навіть якщо вихованець сам того не бажає.

П. Гальперін звертає увагу на те, що мотиви можуть бути спрямовані як від самої дитини, так і від оточуючих людей. Дорослий може вплинути на фрормування тих чи інших мотивів у дітей. «Продуктивність дослідницької діяльності залежить від того, в якій мірі сприймає й виявляє себе дитина в якості суб'єкта власної активності» [5, с. 19]. У той самий час ефективність дослідницької діяльності дошкільника визначається його соціальною, психологічною та фізіологічною готовністю до процесу засвоєння знань, формування умінь і навичок, оволодіння способами діяльності.

Під соціальною готовністю розуміють знання правил суспільної поведінки та їхнє дотримання, знання про навколишнє середовище, готовність сприймання нової соціальної ролі, готовність до спілкування і взаємодії з іншими (вихователем та однолітками), вміння давати оцінку своїй діяльності, здатність до виконання ролі дитини. На думку О. Леонтьєва, соціальна готовність підкріплюється не тільки набуттям нових знань і умінь, а й появою нових потреб та інтересів, підпорядкованістю мотивів, які визначають поведінку й розвиток дитини; здатністю до саморегуляції та прийняттям нового соціального статусу - дослідника [17]. За Н. Горобченко, соціальна готовність дитини до дослідницької діяльності пов'язана зі зміною характеру взаємовідносин з дорослим і новим колективом однолітків [8]. О. Кононко вказує на те, що в соціальному розвитку досягнення дитиною готовності до дослідницької діяльності визначаються мотивами, які спонукають до їі здійснення [15].

Необхідними умовами позитивного ставлення до дослідницької діяльності називають включення дошкільників в оцінну діяльність, яка $\epsilon$ важливим компонентом їхньої активності (М. Дригус); створення емоційно-позитивного клімату в діяльності, застосуванням позитивного оцінного судження педагога про діяльність дитини (Н. Зубалій); організація діяльності дошкільників, за якої кожна дитина може задовольнити свої соціальні потреби, реалізувати суспільно значущі мотиви (Н. Пророк); переживання успіху в дослідженні, що спонукає дитину до подальшої активної пізнавальної діяльності (негативне 
ставлення до окремих напрямків вивчення часто мотивується відсутністю успіху в даній галузі знань, що по суті виражає ставлення до себе, та надто високою складністю навчального матеріалу); стан задоволеності даною діяльністю (почуття пізнавального зростання, компетентності в результаті засвоєння знань, здатність оцінити власні досягнення в дослідницькій діяльності); загальне позитивне ставлення до дослідницької діяльності; зміст і структура навчального матеріалу (чинники збереження та підтримання пізнавальних мотивів, що виникають в процесі дослідницької діяльності) (М. Морозов).

О. Карпичева наголошує на тому, що дослідницька діяльність характеризується ознаками ситуації досягнення, які мають такий вияв: у ситуації досягнення суб'єкт має отримати певний результат, який можна зафіксувати, оцінити; результат оцінюється відповідно до стандарту оцінки поведінки індивіда в даній ситуації; вимоги, які пред'являються індивіду в ситуації досягнення, у міру складні дозволяють отримати результат, доклавши певних зусиль. «На підставі власної суб'єктивної оцінки дитина відносить або не відносить ситуацію дослідницької діяльності до класу ситуацій досягнення і, як наслідок, обирає чи не обирає поведінку, що характеризується такими ознаками: переживання спрямованості (бажання або примушення) на отримання результату; необхідність докладання зусиль для вирішення завдання; виникнення специфічних афективних реакцій під час здійснення процесу та по досягненню результату; відчуття здатності виконати поставлене завдання» [13].

До молодшого шкільного віку в процесі дослідницької діяльності з'являються специфічні новоутворення. 3 поняттям «новоутворення» ряд психологів пов'язують новий тип діяльності дитини, що характеризує їі вік, зміни в їі особистості та ті психічні явища, які вперше виникають у даному віці. Мета, до якої рухається психічний розвиток дошкільника - це «формування довільності й усвідомленості всіх психічних процесів та їх інтелектуалізація, внутрішнє опосередкування, яке відбувається завдяки первинному засвоєнню системи понять (розвивається довільна пам'ять, увага, мислення, довільною стає організація діяльності) та фрормування рефлексії. Довільність виявляється в умінні свідомо ставити цілі, відшукувати і знаходити засоби їх досягнення, долати труднощі й перешкоди» [24]. У дошкільника кінцевий результат діяльності на початку взаємодії відсутній, його ще немає, отже він не може бути системотвірним чинником. Сам процес взаємодії - це реалізація внутрішнього плану дій, процес, у ході якого дитина-суб'єкт виконує певні дії та отримує відповідь, включає цю відповідь у свій образ світу, знаходить їі місце. Створюється образ як системна властивість взаємодії, тобто, здійснюється перенесення структури відображуваного об'єкта до суб'єкта, внаслідок чого вплив на суб'єкта учіння, який сам ініціює взаємодію, залишає слід у його свідомості й зумовлює характер 
взаємодії (тривала або короткочасна) розглядає об'єкт вивчення з того боку, який його цікавить у першу чергу.

Процес дослідницької діяльності дошкільника характеризується пізнавальною активністю, яка, за В. Гузєєвим та А. Остапенко, має вияв у чотирьох способах його здійснення. Внутрішній спосіб (внутрішня дослідницька діяльність): зміст цього способу може бути виражений словами «досліджую сам»; зовнішній спосіб (екстраактивна дослідницька діяльність) - «мені допомагають досліджувати); також інший спосіб зовнішньої взаємодії у дослідницькій діяльності інтраактивна («я допомагаю досліджувати»); чергування зовнішніх способів дослідницької діяльності (інтерактивна діяльність) - взаємна допомога в дослідженні [цит. за 18, с. 282] .

Самостійність в дослідницькій діяльності виявляється, з одного боку, у спрямованості дитини на внутрішню мобілізацію власних сил для вирішення без сторонньої допомоги посильних віку завдань, а 3 іншого - в адекватному мотивуванні дій, упевненості, незалежності та відносній стійкості до сторонніх впливів. Дії дитини в дослідницькій діяльності характеризуються як самостійні, якщо виконуються без сторонньої допомоги або керівництва, супроводжуються критичним ставленням до сторонніх впливів, прагненням відійти від шаблонних рішень і знайти нові способи розв'язання поставленої проблеми, аналізом і оцінюванням їх відповідності власним поглядам, які дитина може відстояти. Сфрормовані дослідницькі здібності, серед яких найбільш значущими є здатність швидко орієнтуватися в ситуації, творчо підходити до вирішення проблем, вміння знаходити й аналізувати інформацію, дозволяють дитині активно діяти, перетворювати й творити. Основи їх розвитку закладаються вже у старшому дошкільному віці, який характеризується особливою чутливістю до засвоєння навколишньої дійсності і активністю дошкільника. 3 великим інтересом діти беруть участь у дослідницькій роботі, проявляючи допитливість і бажання експериментувати.

Дослідницька діяльність дозволяє організувати освітню діяльність так, щоб дитина змогла ставити питання й самостійно знаходити відповіді на них. Набуваючи досвіду використання процесів дослідницької діяльності, діти тренуються в побудові концептуальних ідей про навколишній світ і взаємодію з ним.

Таким чином, аналізуючи наукові дослідження, можна зробити загальний висновок, що психологічні особливості розвитку дослідницьких здібностей дошкільника визначаються специфікою розвитку мотиваційних, інтелектуально-творчих та поведінкових характеристик. У процесі розвитку дітей дошкільного віку дослідницька діяльність виступає в багатоаспектній ролі: і як засіб захопливого навчання, і як сильний мотив до інтелектуального й тривалого розвитку пізнавальної діяльності, і як передумова фрормування готовності особистості до безперервного навчання. У період 
дошкільного дитинства взаємодія з педагогом зберігає провідну роль у розвитку дитини. Педагогу важливо в процесі навчання підтримувати пізнавальну активність, створювати дітям умови для самостійного пошуку інформації. Адже знання фрормуються як результат взаємодії суб'єкта (дитини) з тією чи іншою інформацією, а надання такої інформації здійснюється дорослим. Саме привласнення інформації через ії зміну, доповнення та самостійне застосування в різних ситуаціях і породжує знання.

Відповідно ефективність дослідницької діяльності у дітей дошкільного віку забезпечується реалізацією наступних педагогічних умов:

а) фрормуванням пізнавального інтересу дітей дошкільного віку в дослідницькій діяльності, спрямованої на розвиток мотиваційної сорери особистості;

б)спеціально створеним розвивальним предметно-просторовим середовищем;

в) реалізацією партнерських взаємовідносин всіх учасників освітнього процесу (педагогів, батьків, вихованців).

На думку А. Боднар та Н. Макаренко, пізнавальний інтерес - це емоційно усвідомлена, вибіркова спрямованість особистості, звернена до предмета або діяльності [2]. В структурі пізнавального інтересу вимальовується прагнення до пізнання, до нових, більш повних $\mathrm{i}$ глибоких знань. Систематичний розвиток пізнавального інтересу формує позитивне ставлення до навчання. Пізнавальний інтерес має пошукової характер. Під його впливом у дитини виникають питання, відповіді на які дитина активно шукає. При цьому дослідницька діяльність здійснюється 3 захопленням, емоційним підйомом. Пізнавальний інтерес позитивно впливає не тільки на процес і результат діяльності, а й на перебіг психічних процесів - мислення, уяву, пам'ять, увагу.

Аналіз наукових напрацювань 3. Плохій дає підстави зробити висновок про те, що кожне навчальне завдання гіпотетично може використовуватися для організації дослідницької діяльності в тому разі, якщо вихователь спрямує активність дошкільників або дитини під час виконання завдання на відкриття суб'єктивно нових знань і способів дій, розширивши в такий спосіб мету їхньої діяльності [20]. Наприклад, завдання на порівняння визначених об'єктів доповнить встановленням ефрективного способу здійснення порівняння; до завдання на визначення головного в тексті додасть визначення оптимального способу запам'ятовування виокремленої інформації; завдання на узагальнення знань розширить уміння упорядковувати інформацію внаслідок пошуку ефективних способів його здійснення (самостійне складання таблиці, схеми чи відтворення в малюнку).

У разі використання навчально-дослідницького завдання як засобу організації дослідницької діяльності в закладі дошкільної освіти процес відкриття вихованцями суб'єктивно нових знань і способів дій 
характеризується достовірністю здійснення. Дослідницьким завданням ми вважаємо спеціально створену навчальну ситуацію, яка складається з ряду взаємопов'язаних навчальних проблем. Зміст завдання може бути «одягнений» у оболонку в фрормі вправ, задач, дидактичних ігор, дослідів, спостережень, практичних робіт чи екскурсій. Однак враховуючи обмежений досвід дітей дошкільного віку в засвоєнні методики пошукової діяльності, кожну форму навчальної проблеми необхідно супроводжувати планом ії розв'язання: це можуть бути запитання, вказівки, інструкції, алгоритми тощо. Дослідницькі завдання сприяють пізнавальній самостійності дошкільників і взаємодії з іншими та спрямовують їхні дії в напрямі фоормулювання проміжних і кінцевих висновків з метою відкриття суб'єктивно нових знань і способів дій.

Навчально-дослідницькі завдання, які доцільно запроваджувати в ЗДО, мають особливості, відрізняючись за формою організації їх виконання (індивідуальні, парні, групові, міжгрупові). Також визначається часовий проміжок, що відводиться на вирішення взаємопов'язаних навчальних проблем, які визначають зміст завдання (наприклад, неперервний час на усі завдання, чи передбачені часові інтервали між вирішенням окремих навчальних проблем). Завдання включають різні типи структурних одиниць навчального матеріалу: вони можуть бути однотипними, як система вправ чи система задач (дослідів, дидактичних ігор тощо), можуть бути змішані. За характером змісту навчального матеріалу виділяються емпіричні завдання, що базуються на спостереженнях, теоретичні (передбачають пояснення, доведення, встановлення закономірних зв'язків і відношень на основі опрацьованої інформації), практичні (практичне застосування знань, способів дій у змінених умовах), а також змішані.

Слід враховувати, що досліди можуть виконувати дві фрункції: ілюстративну (закріплення знань, умінь і навичок, які було засвоєно вихованцями раніше) та дослідницьку (оволодіння новими знаннями і способами дій). Звісно, найбільша ймовірність відкриття вихованцями суб'єктивно нових знань і способів дій виникає під час реалізації дослідницької функції аналізованого засобу. Варто враховувати й те, що проведення дослідів слугує основою для живого споглядання (фріксування даних, які спостерігаються під час проведення досліду); здійснення розумових дій (аналізу, синтезу, узагальнення, класифікації тощо); перевірки істинності чи хибності припущень, які попередньо були сорормульовані вихованцями. Зазначене свідчить про те, що проведення досліду може розглядатися і як процес відкриття вихованцями суб'єктивно нових знань і способів дій, і як процес формування готовності дітей відкривати для себе суб'єктивно нові знання і способи діяльності.

Друга з необхідних умов розвитку дослідницької діяльності організація розвивального предметно-просторового середовища. Основними вимогами, до розвивального середовища $є$ забезпечення 
розвитку активної самостійної дитячої діяльності. Зараз педагогічні колективи закладів дошкільної освіти постійно шукають способи найбільш доцільно обладнати та організувати розвивальний простір для експериментування й дослідження довкілля.

Рекомендації педагогів стосовно куточка дослідницької діяльності (міні-лабораторії) стосуються виділення місця для постійної виставки, де також розміщують міні-музей, в якому можуть знаходитися різні колекції цікавих для дітей експонатів, рідкісних предметів (частини рослин, пір'я, камінці, черепашки тощо). Необхідно врахувати наявність місця для приладів. Основним обладнанням куточка $€$ прилади-помічники, такі як мікроскопи, лупи, компас, ваги, пісочний годинник, магніти; технічні матеріали: гайки, скріпки, болти, гвіздки, барвники харчові й нехарчові (гуаш, акварельні фрарби); медичні матеріали: піпетки, колби, дерев'яні палички, шприци (без голок), мірні ложки, гумові груші та інші матеріали. Звичайно ж, місце для зберігання природних і «неприродних» матеріалів (камінчики, черепашки, шишки, пір'я, мох, листя, дріт, шматочки шкіри, хутра, тканини, пластмаси, пробки); місце для неструктурованих матеріалів. Матеріали даної зони розподіляються за наступними напрямками: «пісок» i «вода», «звук», «магніти», «папір», «світло», «скло й пластмаса», «гума» [3]. Місце для проведення дослідів повинно бути просторим, щоб за ним могло поміститися декілька дітей як мінімум. Краще, щоб це місце могло бути мобільним, для забезпечення огляду з усіх сторін при демонстрації проведення експерименту. Відповідно до плану, усі матеріали міні-лабораторії поступово змінюються за потреби.

В ході дослідницької діяльності дошкільники не тільки отримують фактичні знання про явища і об'єкти природи та навчаються методиці наукового освоєння довкілля. Вони вчаться спілкуватися і співпрацювати на досягнення спільної мети, керувати своєю поведінкою і мотивами, відстоювати власні погляди, доводити їх, замислюватися над причинами невдач та робити висновки на основі результатів досліду. Саме тому правильно дібране обладнання та матеріали сприяють активній зацікавленості дітей, розширенню горизонтів пізнання, досвіду взаємодії з об'єктами природи.

Однак під час створення осередку, а також при організації і проведенні дослідницької діяльності необхідно дотримуватися загальних педагогічних і гігієнічних принців, зокрема, варто звернути увагу на врахування вікових особливостей, безпеку для життя й здоров'я дітей, достатню забезпеченість усім необхідним, доступність розташування, здатність до трансформації.

Говорячи про зміст організації дослідницької діяльності дітей, доцільно наголосити на необхідності створення картотеки експериментів і дослідів. Напрацювання, розроблені у ході дослідів. $\epsilon$ методичним посібником для вихователів 3 метою підготовки й організації пошуково-дослідної діяльності._Картки містять: мету й 
завдання досліду (експерименту), його зміст, список необхідного обладнання та матеріалів, інформацію про очікувані результати. Картотека допомагає визначити види дослідів, доступних для дітей певної вікової групи, класифрікувати їх за темами і програмовим змістом. Це лише сприятиме активному впровадженню принципу системності освіти, оскільки вивчення природного довкілля відбуватиметься послідовно і поступово, з можливістю включення дослідів у різні форми організації діяльності дітей.

Таким чином, розвивальне предметно-просторового середовище $€$ одним із важливих компонентів розвитку пізнавальних інтересів та умінь дитини дошкільного віку в дослідницькій діяльності. Одними 3 найважливіших принципів побудови розвивального середовища ми вважаємо забезпечення взаємодії дитини 3 навколишнім світом, спілкування з дорослими, спільної діяльності дітей, реалізація різних освітніх програм.

Третьою педагогічною умовою розвитку дослідницької діяльності в ознайомлені 3 довкіллям дітей дошкільного віку ми назвали партнерські взаємини усіх учасників освітнього процесу. Партнерство певна фрорма взаємодії, співпраці, взаємин у процесі досягнення спільно поставлених цілей, в основі яких лежать такі принципи: рівноправність партнерів при прийнятті рішень; вибір шляхів вирішення завдань на основі довіри й компромісу; поваги й взаємного врахування інтересів, толерантність до позиції партнера; взаємовигідність і зацікавленість сторін у співпраці; добровільність прийняття взаємних зобов'язань; відповідальність сторін за виконання прийнятих зобов'язань.

Сучасний етап розвитку дошкільної освіти передбачає тісну взаємодію двох виховних інститутів - сім'ї та дошкільного закладу - 3 метою різнобічного розвитку особистості дитини з урахуванням ії можливостей і здібностей. Дитина вчиться тільки у тих, кому довіряє, хто для нього авторитетний. А це означає, що саме батьки $€$ його найкращими вихователями. Тому виникає необхідність спрямування роботи на співпрацю закладів дошкільної освіти та сім'ї, на противагу заміни дитячим садком батьків у їх значущості для пізнавального розвитку дитини.

Плануючи роботу з батьками, вихователь вирішує різноманітні за спрямованістю завдання. Це:

$>$ допомога батькам відповідно до проблем, що виникають при вихованні дітей, краще орієнтуватися в різних життєвих ситуаціях;

просвіта сім'ї та надання методичних матеріалів: ігор, вправ, дослідів, які розвивають пізнавальні процеси у дітей і їх емоційну сфреру);

навчити батьків прислухатися до своїх дітей, їх почуттів, допомогти встановити довірчі відносини з дитиною. 
Необхідні принципи взаємодії ЗДО з сім'єю випливають із головної мети обох сторін - виховання творчої, розвиненої особистості: доброзичливий стиль спілкування; індивідуальний підхід; співробітництво, а не наставництво; ретельна підготовка до кожного заходу; динамічність.

Перевагами нової системи взаємодії ЗДО з сім'єю є: позитивний емоційний настрій педагогів і батьків на спільну роботу з розвитку й виховання дітей; врахування індивідуальності кожного дитини; самостійний вибір батьками напрямків розвитку й виховання дитини; зміцнення внутрішньосімейних зв'язків, емоційного спілкування, знаходження спільних інтересів і занять; можливість реалізації єдиної програми розвитку і виховання дитини в ЗДО і сім'ї; можливість врахування типу родини й стилю сімейних відносин; відкритість дитячого садка для сім'ї; співпраця педагогів і батьків у розвитку та вихованні дітей; створення активного розвивального середовища, активних форм спілкування дітей і дорослих, що забезпечують єдині підходи до розвитку дитини в сім'ї та ЗДО; діагностика загальних і індивідуальних проблем у розвитку, навчанні та вихованні дитини [19].

Залучаючи сім'ї вихованців до участі у дослідницькій діяльності дітей в ЗДО, педагог повинен пояснити, що дитяча дослідницька діяльність, на відміну від експериментування дітей шкільного віку, має свої особливості. Дану діяльність не можна жорстко регламентувати, потрібно враховувати індивідуальні відмінності, які $€$ між дітьми. Результати дослідів не $є$ самоціллю, необхідно враховувати право дитини на помилку й застосовувати адекватні способи залучення дітей до занять, особливо тих, у яких $є$ проблеми з координацією рухів або сфрормованістю розумових операцій. Також специфікою цієї діяльності $\epsilon$ спільна робота дорослих і дітей, допомога дітям, робота дорослого за вказівкою дітей (наприклад, при демонстраційних експериментах), свідоме допущення педагогом неточностей у роботі тощо).

У будь-якому випадку, роль педагога в ході досліду $є$ провідною, без керівництва дослідницька діяльність зводиться до маніпулювання предметами, і переважно не має пізнавальної цінності. Однак вихователь залишається на задньому плані, не втручаючись помітно у хід діяльності, даючи дітям можливість побути вченими, освоїти способи пізнання світу. Такі дії педагога слугують позитивному розвитку мотивації дитини до експериментальної діяльності.

Підводячи підсумки нашого дослідження, можна зробити наступні висновки. Нами були розкриті психологічні особливості дітей дошкільного віку, що дозволяють цілеспрямовано розвивати дослідницьку діяльність, іiї структуру з точки зору психології та педагогіки. Ми виділили деякі педагогічні умови, дотримання яких в освітньому процесі ЗДО дозволить успішно залучати дітей до дослідницької діяльності та стимулювати потяг вихованців до отримання знань. 


\section{Список використаних джерел}

1. Баранова Э. А. Изучаем детские вопросы. Дошкольное воспитание. 2017. № 12. C. 13-20.

2. Боднар А. Я., Макаренко Н. Г. Шляхи формування пізнавального інтересу особистості в процесі професійного самовизначення. Наукові записки НаУКМА. Педагогічні, психологічні науки та соціальна робота. 2014. Т. 162. С. 32-37.

3. Богуш А. М., Гавриш Н. В. Методика ознайомлення дітей з предметним довкіллям : підручник. К. : Видавничий Дім "Слово", 2010. 408 с.

4. Брежнева О. Формирование познавательной активности у старших дошкольников. Дошкольное воспитание. 2014. № 2. С. 12-16.

5. Гальперин П. Я. Основные результаты исследований по проблеме «Формирование умственных действий и понятий». М. : Изд-во МГУ, 1965. 52 с.

6. Гладченко О. М. Ознайомлення дошкільників із навколишнім світом: до Базової програми «Я у Світі». Харків : Видавнича група «Основа», 2011. 191 с.

7. Голуб Н. М. Використання пізнавальних завдань випереджаючого характеру в процесі навчання дітей 6-річного віку : дис. ... канд. пед. наук :13.00.02. Харків, 2005. 243 c.

8. Горобченко Н. Використання дослідницьких методів на уроках як дієвий спосіб забезпечення творчого розвитку особистості. Початкова школа. 2012. № 2. C. $42-43$.

9. Дем'яненко В., Поліхун Н. Дослідницька діяльність учнівської молоді - запорука успішного розвитку українського суспільства. Педагогічні інновації: ідеї, реалії, перспективи. 2016. Вип. 2. С. 57-63.

10. Калошин В. Ф. Пошукова активність - основа творчості. Обдарована дитина. 2001. № 3. C. 2-5.

11. Каратаєва М. Проектування - перспективна технологія. Дошкільне виховання. 2013. № 12. С. 13-20.

12. Карлащук А. Ю. Формування дослідницьких умінь школярів у процесі розв'язування математичних задач з параметрами : автореф. дис. ... канд. пед. наук : 13.00.02. Київ, 2001. 19 с.

13. Карпичева Е. Л. Роль экспериментальной деятельности в познавательном развитии дошкольника. Дошкольная педагогика. 2012. №4. С. 28-31.

14. Кондратенко Р. Метод проектів у роботі з батьками. Дошкільне виховання. 2008. № 5. C. 10-20.

15. Кононко О. Л. Соціально-емоційний розвиток особистості (в дошкільному дитинстві) : навч. посіб. для вищ. навч. закладів. К.: Освіта, 1998. 255 с.

16. Кудрявцев В. Т. Проблемное обучение: истоки, сущность, перспективы. М.: Знание, 1997. 79 с.

17. Леонтьев А. Н. Деятельность. Сознание. Личность. М. : Политиздат, 1975. $304 \mathrm{c}$.

18. Методика обучения и воспитания в области дошкольного образования : учебник и практикум для вузов / под ред. Н. В. Микляевой. М. : Юрайт, 2020. $452 \mathrm{c}$.

19. Методичні аспекти реалізації Базової програми розвитку дитини дошкільного віку «Я у Світі». К: видавництво «Світич», 2011. 234 с.

20. Плохій 3. П. Виховання екологічної культури дошкільників. К. : Ред. журн. «Дошкільне виховання», 2002. 211с.

21. Поддьяков А. Н. Исследовательское поведение: стратегии, познания, помощь, противодействие, конфликт. М.: Эребус, 2006. 187 с.

22. Проектні технології у дошкільному навчальному закладі / упорядник Ю. Д. Буракова. Х.: Вид. група «Основа», 2009. 234 с. 
23. Савенков О. Пробудити дослідника в дитині. Дошкільне виховання. 2013. № 2. C. 2-7.

24. Савчин М. В., Василенко Л. П. Вікова психологія : навч. посіб. К. : Академвидав, 2005. $360 \mathrm{c}$.

25. Семенова Т. М. Детское экспериментирование как средство познавательного развития дошкольников. Дошкольная педагогика. 2012. № 12. С. 17-21.

26. Талызина Н. Ф. Управление процессом изучения знаний. М. : Изд-во МГУ, 1975. 343 c.

27. Формування первинних екологічних уявлень у дошкільників : методичний збірник перспективного педагогічного досвіду з проблеми екологічної освіти дітей дошкільного віку / за ред. Р. О. Романчук. Запоріжжя, 2014. 310 с.

28. Эльконин Д. Б. Избранные педагогические труды / под ред. В.В.Давидова, В. П. Зинченка. М.: Педагогика, 1989. 554 с.

29. Якобсон С. Г. Взаимоотношения детей в совместной деятельности. М., 1976. $160 \mathrm{c}$.

30. Яришева Н. Ф. Методика ознайомлення дітей з природою : навч. посібник. К.: Вища школа, 1993. 255 с. 


\title{
ПЕДАГОГІЧНІ УМОВИ СТАТЕВО-РОЛЬОВОЇ СОЦІАЛІЗАЦІЇ СТАРШИХ ДОШКІЛЬНИКІВ
}

\author{
Кондратюк С. М. \\ кандидат педагогічних наук, профресор, \\ Сумський державний педагогічний університет імені А. С. Макаренка
}

Проблема статево-рольової соціалізації в культурологічному контексті залишається однією 3 найскладніших й водночас недостатньо розробленою фахівцями різних галузей. Це пояснюється, 3 одного боку, багатовимірністю, багатоаспектністю вказаної проблеми; з іншого - відсутністю чітко визначених концептуальних засад дослідження вказаного явища, змісту й структури поняття «статево-рольова соціалізація»; 3 третього - дефіцитом експериментальних досліджень означеного напряму, наслідком чого $€$ відсутність валідних методик вивчення вказаного феномену.

Аналіз наукового доробку провідних вітчизняних та зарубіжних фахівців дозволяє класифікувати статево-рольову соціалізацію як набуття дитиною соціального досвіду і реалізацію нею соціальних зв'язків через знання, цінності, норми і традиції поведінки; активне засвоєння та відтворення моральних норм статево-рольової поведінки та реалізація відповідних суспільних стандартів, які проявляються у соціально-прийнятих та схвалюваних форм поведінки в одностатевих та різностатевих угрупованнях.

Найбільш детально онтогенез процесу статево-рольової соціалізації дітей різних вікових категорій представлено в основних теоріях: соціального навчання, когнітивного розвитку та соціальних очікувань.

В основі соціального біхевіоризму закладено, що відповідна поведінка дитини формується через моделювання, ідентифікацію, наслідування батьківської. Прихильники соціального біхевіоризму вважають, що дитина ідентифікує себе з обома батьками, 3 однолітками, братами та сестрами. I відповідно до цього будує свої стосунки з представниками своєї та протилежної статі. Дитина засвоює специфічні моделі, а не соціальні ролі [8].

Саме суспільство підкреслює значущість нормовідповідної статевої поведінки та занять представників своєї статі, вимагає відповідності цим вимогам. Але статево-рольова соціалізація не буде відбудеться, якщо у дитини несформована статева ідентифікація та свідомість про належність до певної статі.

Вивчаючи статево-рольову диференціацію та враховуючи прояви та якості маскулінності, науовці роблять висновок (який цілком доцільно застосувати також і до фремінності): «маскулінність і пов'язані 3 нею соціальні очікування (експектації) $€$ похідними не від властивостей індивіда, а від особливостей чоловічої соціальної ролі». 
Тим часом, попри більший соціальний тиск на хлопців, набуття типових для статі властивостей становить для них меншу складність, ніж для дівчаток. Це можна пояснити тим, що вимоги до поведінки хлопців, як правило, чіткіші й виразніші, частіше підкреслюються; подруге, в оточенні зберігається більший престиж чоловічої ролі, що посилює прагнення опанувати саме ії, а не менш престижну - жіночу. Дослідники звертають увагу на відмінності в батьківському та материнському впливі у процесі формування особистості дитини. Батько сприймається і насправді буває жорсткішим і авторитарнішим, ніж мати. Психологічна близькість із батьком спостерігається рідше, ніж з матір'ю. Вплив батька на виховання дітей у більшості сімей нижчий, ніж вплив матері [5].

Статеві стереотипи для дітей дошкільного віку діють як соціальні норми. Нормативний і інформативний тиск змушує підкорятися встановленим статевим ролям. Дія нормативного тиску полягає у тому, що особистість старається відповідати статевим ролям, щоб отримати соціальне схвалення і уникнути несхвалення. Інформаційний тиск впливає тоді, коли дитина починає розуміти та враховувати статеві норми правильними, тому що знаходиться під впливом соціальної інформації.

Зазначимо, що на фрормування статево-рольової соціалізації дітей дошкільного віку мають значний вплив стереотипи. За визначеннями досліджуаного френомену, статево-рольові стереотипи - це цінності, мотиви, типи поведінки, що розглядаються як більш характерні представникам однієї статі, у порівнянні з іншою. Саме стереотипи визначають стиль поведінки чоловіків (хлопчиків) і жінок (дівчат) i, таким чином, відображають зразки, через які сприймається і оцінюється соціальна активність представників кожної статі [2].

Основною структурною і функціональною одиницею індивідуальних статево-рольових стереотипів $€$ статево-рольові уявлення. Вони безпосередньо впливають на формування статевих ролей і статевої ідентичності, виступаючи в якості когнітивної складової зазначених елементів психологічної статі. На основі статево-рольових уявлень і стереотипів, засвоєння статевих ролей фрормується статева самосвідомість індивіда. Засвоєння дитиною неадекватних уявлень про себе як представника певної статі, про статеві і рольові відмінності між хлопчиками і дівчатками спричиняє відхилення всіх структурних елементів психосексуального розвитку особистості і може призвести до порушення сексуальної орієнтації в період статевого дозрівання [3].

Пом'якшення статево-рольових стереотипів важливе для нормального соціального і емоціонального розвитку дошкільника. Жорсткі стереотипи обмежують загальний розвиток, помітно збіднюють інтелектуальний потенціал дитини. Дорослі можуть допомагати дітям позбуватися їх, пояснюючи значення тієї чи іншої соціальної ролі для самої дитини і для оточуючих її людей [10]. 
Як зазначають сучасні українські науковці, підпорядкування статевим нормам може спостерігатися в поведінці, але не в системі вірувань (поступливість), або і в поведінці, і в системі вірувань (схвалення, інтерналізація), або може визначатися бажанням бути схожим на однолітка або рольову модель (ідентифікація). «Легше всього можливо стати статевотипизірованим, якщо вже $\epsilon$ досвід критичного переживання статевої соціалізації, коли певне відхилення від статевої ролі продукувало жорсткі соціальні наслідки» [2].

Отже, у структурі статево-рольової соціалізації наявні три базові компоненти: статева самосвідомість, статева ідентиорікація та статева приналежність.

3 метою визначення особливості статево-рольової соціалізації дошкільників, впливу дошкільного навчального закладу та родини на рівні статево-рольової соціалізованості дітей старшого дошкільного віку було проведено педагогічне дослідження. Відповідно теоретичних засад і принципів організації і побудови експериментального дослідження було визначено педагогічні умови, що передбачали ефективне виховання статево-рольової соціалізації старших дошкільників у закладі дошільної освіти та сім'ї. 3-поміж них: включення хлопчиків і дівчат у спільні різні види діяльності (навчально-пізнавальну, театрально-ігрову, комунікативну, трудову); адекватна мотивація спільної ігрової діяльності; залучення батьків до спільної роботи з активізації знань та вмінь дітей щодо статево-рольової соціалізованості.

Програма фрормувального експерименту здійснювалася у двох напрямах: робота з дошкільниками, робота з батьками. Формами роботи 3 дошкільниками виступали тематичні заняття, сюжетнорольові ігри, розваги та свята, сумісна діяльність хлопчиків і дівчаток; з батьками - ділові ігри, консультації з питань виховання, написання міні-творів, обговорення виховних систем, обмін досвідом сімейного виховання.

Крім того, програма формувального експерименту була спрямована на: створення розвивального середовища, побудову виховного процесу на основі врахування вимог сучасного суспільства до виховання майбутніх чоловіків та жінок; формування в дітей дошкільного віку адекватного прийняття себе як представника певної статі та однолітка протилежної, розвиток гордості і поваги до представників своєї та протилежної статі. Здійснення цих завдань можливо за допомогою розробленої освітньо-виховної роботи 3 педагогічним колективом і батьками в умовах ЗДО і сім'ї, різноманітних методів.

Для отримання ефективності впровадження інновацій, технологій та розвивальних методик у навчально-виховний процес необхідно виявити та впровадити педагогічні умови. На думку класичної науки, педагогічна система може фрунціонувати при дотриманні відповідних умов, які підвищують ефект впливу, навчання [9]. Згідно тверджень 
науковців, педагогічні умови розглядаються як єдність об'єктивного і суб'єктивного, внутрішнього і зовнішнього, виділяючи ціннісносмислові, організаційні, дидактичні та поведінкові характерстики.

Ряд дослідників об'єднують педагогічні умови у дві групи: зовнішні та внутрішні. Зовнішні - відповідають за середовище та обставини, в якому здійснюється процес соціалізації; внутрішні відображаються у психічній діяльності особистості дошкільника, його психологічних особливостях. Саме тому ми спираємося на загальноприйняті методологічні положення i наукові погляди, які стосуються дослідницької теми [3; 4; 6].

Відповідно теоретичних засад і принципів організації і побудови експериментального дослідження було визначено педагогічні умови, що передбачали ефрективне виховання статево-рольової соціалізації старших дошкільників у закладі дошільної освіти та сім'ї. 3-поміж них такі як:

включення хлопчиків і дівчаток у спільні види діяльності (освітньо-пізнавальну, театрально-ігрову, комунікативну, трудову);

адекватна мотивація спільної ігрової діяльності;

залучення батьків до спільної роботи з активізації знань та вмінь дітей щодо статево-рольової соціалізованості.

Оскільки програма формувального експерименту здійснювалася у двох напрямах: робота з дошкільниками, робота з батьками, об'єктом впливу виступав виховний процес закладу дошкільної освіти, що забезпечувало реалізацію процесу статево-рольової соціалізації. Саме цей напрям роботи був підґрунтям і основою всього освітнього процесу. Запроваджені форми роботи і організації педагогічного процесу мали свою доцільність та не мали різких відмінностей від традиційних, які використовували в закладі дошкільної освіти та прийнятих у родинному колі. Цим напрямом передбачалася реалізація системи виховних впливів, спрямованих на оволодіння дошкільниками моделлю нормовідповідної поведінки та статево-рольової соціалізації, налагодженню конструктивної взаємодії з однолітками.

Робота з батьками мала на меті розкриття важливості статеворольової соціалізації дошкільників як необхідної умову розвитку особистості та адаптації до сучасного життя. Передбачалася педагогічна просвіта батьків та ії реалізація у різних фрормах за встановленою системністю та послідовністю.

Проведення тематичних батьківських зборів, бесід-консультацій, вечорів запитань та відповідей, написання міні-творів передбачало не тільки теоретичний розгляд актуальних питань статево-рольової соціалізації дошкільників, а й також практичне розв'язування та аналіз ситуацій, які виникають у дітей під час спілкування та взаємодії.

Крім того, співпраця вихователів та батьків націлювалась на отримання таких результатів: прийняття особистості дитини, іiї 
індивідуальних проявів як представника певної статі; виховання потреби у проявах та відповідностях нормам статево-рольової поведінки; стимулювання дитини до проявів такої поведінки 3 представниками обох статей, узгодженість дій у сумісній діяльності; створення і підтримання у сім'ях досліджуваних клімату, якій сприятиме статево-рольовій соціалізованості дитини; стимулювання дітей до позитивних взаємин та взаємодії між представниками обох статей.

Як провідна діяльність дошкільника - гра була основним контекстом реалізації статево-рольової соціалізації і саме в ній дитина має можливість самовизначення та реалізації.

Вихідною позицією визначення змістового аспекту формування статево-рольовій соціалізованості дітей старшого дошкільного віку (6 років) як представників певної статі стали результати обстеження дітей у всіх ссрерах діяльності (спілкування, ігрова, трудова, художня).

Найнижчими і невтішними виявились результати розвитку уявлень про якості мужності й жіночості за показниками культури статево-рольової поведінки і навичками сформованості моральних орієнтацій дітей (показник статево-рольової соціалізації). Саме ці аспекти і підлягали експериментальному дослідженню на етапі формувального експерименту.

Наступним кроком було опрацювання методики її реалізації у освітньому процесі закладу дошільної освіти. Після цього треба було визначити ряд критеріїв, які б характеризували розроблену систему і провести формувальний експеримент для оцінки ії основних параметрів.

Як зазначалось, формувальний експеримент здійснювався протягом 2018-2019 навчального року, для експериментальної роботи нами було відібрано дітей старшого дошкільного віку, які відвідували заклад дошільної освіти протягом цього періоду (15 осіб експериментальна група і 15 - контрольна).

Започатковуючи експеримент, ми насамперед виокремили тематику розповідей, обов'язкових для всіх груп закладу дошільної освіти та дібрали до них матеріал, розробили мовленнєві діалогічні ситуації. Проілюструємо приклади декількох ситуацій.

Ситуація «Знайомства», форми етикету: як тебе (Вас) звати; як твоє (Ваше) ім'я; як твоє (Ваше) прізвище; давай з тобою (Вами) познайомимося; я хочу з тобою (з Вами) познайомитись; мені хотілося б з тобою (з Вами) познайомитись; я хотів би (мені хотілося б) познайомитись 3 тобою (Вами); дозволь(-те) 3 тобою (з Вами) познайомитись. Реакції-відповіді: мені дуже приємно познайомитись 3 тобою (з Вами); мені дуже приємно, що я 3 тобою (з Вами) познайомився(-лась); я радий(-а) з тобою (з Вами) познайомитись; мені також дуже приємно з з тобою (з Вами) познайомитись. 
Ситуація «Вибачення», фрормули мовленнєвого етикету: вибачте; вибачте будь-ласка; вибачте, що потурбував; вибач, будь ласка, я ненавмисне; вибач мені, будь ласка, я не хотів(ла); даруйте мені; пробач(-те) мені, будь ласка; прошу вибачення; перепрошую; я хотів(-ла) би попросити у вас вибачення; я хочу вибачитись перд тобою (перед Вами); якщо ти (Ви) можеш(-те), вибач(-те) мені; не сердься на мене. Реакції-відповіді: будь ласка; я приймаю твої (Ваші) вибачення; добре; гаразд.

Застосовані ігрові методи сприяли входженню кожної дитини 3 площини одностатевих угруповань у різностатеві.

Тематичні розповіді (для загальних та національних груп) на заняттях з розвитку мовлення.

\section{«Країна Мужності та Жіночості».}

\section{Розповідь «Чи подобається мені бути хлопчиком / дівчинкою?»}

Мета: фрормувати у дитини вміння описувати представників обох статей, обґрунтовувати свої прагнення відповідати вимогам до своєї статі.

Словник: хоробрий, сміливій, добрий, уважний, ввічливий; добра, лагідна, привітлива, доброзичлива.

Матеріал: ілюстрації героїв-хлопчиків (героїв-дівчаток).

Хід розповіді. Дитині пропонується розповісти про себе як про представника певної статі, обґрунтувати свої думки та судження. Вона висловлюється ставлення до себе, а також до представників протилежної статі, фрормулює їхні якості.

\section{Розповідь «Ким я хочу бути?»}

Мета: стимулювати дитину у висловлюваннях про себе у майбутньому як людину та представника певної статі.

Словник: справедливий, дружелюбний, самостійний, активний, відповідальний.

Матеріал: ілюстрації героїв казок, мультфрільмів, фрахівців.

Хід розповіді. Дитина розповідає про себе у майбутньому: яким він (вона) бачить себе чоловіком (жінкою); якою він (вона) хоче бути людиною (особистістю).

\section{Розповідь «На кого я схожий / схожа?»}

Мета: продовжувати формувати у дитини уявлення про зовнішні статеві відмінності чоловіків та жінок, вчити аргументувати свої судження щодо відповідності статі.

Словник: мамо, тато, рідні (брат, сестра та інші), герой.

Матеріал: фотографрії дітей, сімейні фротографіії.

Хід розповіді. Дитині пропонується проаналізувати зовнішні відмін- 
ності дітей та дорослих, довести свою схожість з батьками та представниками обох статей.

\section{Розповідь «Що вміє хлопчик / дівчинка?»}

Мета: продовжувати фрормувати уявлення у дітей про статеву диференціацію, особливості поведінки та діяльності хлопчиків і дівчат у сумісній діяльності.

Словник: поступатися, втішати, допомагати, дружно грати, бути привітливим та необразливим.

Матеріал: картки зі зображенням дітей у проблемних ситуаціях, фотографії дітей у сумісній діяльності.

Хід розповіді. Кожній дитині видається картка та фотографрія хлопчика і дівчинки, про яких треба об'єктивно розповісти. У своїй розповіді дитина розкриває конструктивні дії дітей обох статей.

\section{Розповідь «З чого зроблені наші хлопчики, дівчатка»}

Мета: стимулювати дитину у висловлюваннях, описах основних рис та характерних якостей дітей обох статей.

Словник: сила, пустощі, відважність, ніжність, соромливість, капризи.

Матеріал: ілюстрації героїв-хлопчиків (героїнь-дівчаток).

Хід розповіді. Дітям пропонується розповісти про себе як про представника певної статі, обґрунтувати свої думки та судження. Діти висловлюють ставлення до себе, а також до представників протилежної статі, фрормулюють їх якості.

\section{Заняття 3 розвитку мовлення (фрагмент).}

Мета: активізувати словник дітей формулами мовленнєвого етикету в діалогічному спілкуванні.

Словник: будь ласка; вибач мені, будь ласка; я перепрошую, я не навмисне; вибачте мені, будь ласка, ви не могли б..; я перепрошую, що турбую, але мені необхідно...; дай мені, будь ласка...; вибач, ти не могла б дати мені...; вибач, що турбую, ти не міг би...; зроби ласку.

Хід заняття. Дітям пропонувалось низку ситуацій для обговорення:

- Микиті батько подарував на день народження іграшковий автомобіль (карт). Еміне побачила його і каже: Дай мені також покататися? Як ви думаєте, що зробив Микита? А що сказала Еміне?

- Артур поспішав додому (вдягався біля шафи) і ненавмисне штовхнув Софрію, так, що вона впала і боляче вдарилась. Як ви думаєте, що зробив Артур? А що відповіла дівчинка?

Введення і закріплення формул мовленнєвого етикету відбувалось на заняттях з художньої літератури, в етичних бесідах. Проілюструємо прикладами. 


\section{Заняття 3 художньої літератури.}

Тема: Уважність (продовження: побажання, поздоровлення).

Мета: збагатити словник дітей фрормулами мовленнєвого етикету в ситуації побажання, поздоровлення, компліменту, навчити їх доречно використовувати в мовленні.

Словник: я бажаю тобі; поздоровляю від щирого серця; дякую за поздоровлення; ось тобі мій подарунок; у тебе гарна посмішка (голос, прекрасні очі); ти чудово танцюєш (співаєш, граєшся); дякую за комплімент; приємно це чути.

Після цього вихователь запитує, чи вміють діти говорити один одному компліменти, хвалити один одного. Пропонується ігрова вправа «Скажи комплімент»: діти стають у коло і по черзі говорять один одному компліменти (за вибором дитини).

Матеріал: сюжети, ілюстрації.

\section{Гра «Розмова по мобільному телефрону».}

Мета: активізувати словник дітей фоомулами мовленнєвого етикету; стимулювати ініціативність у комунікативно-мовленнєвій діяльності.

Словник: вітаю; доброго здоров'я; так; я тебе слухаю; Світланко, це ти?; не хворій; сподіваюсь, ми скоро побачимось; запрошую тебе до себе на день народження; дякую.

Матеріал: іграшкові мобільні телефони.

Хід гри. Дітям дається завдання подзвонити до хворого друга, втішити його, після цього запросити на день народження, яке відбудеться за тиждень, день.

На другому етапі - діяльнісно-поведінковому - відбувалось занурення дітей в активну комунікативно-мовленнєву та ігрову діяльність.

На цьому етапі робота велась на заняттях з розвитку мовлення, в художньо-мовленнєвій і театрально-ігровій діяльності. Проілюструємо прикладами.

Проілюструємо приклад сценарних ігор.

\section{Сиенарна гра «Аліна запрошує Едема на день народження».}

Мета: стимулювати ініціативність у комунікативно-мовленнєвій діяльності.

Словник: активізація формул мовленнєвого етикету в ситуаціях привітання, запрошення, подяки, прощання.

Матеріал: атрибути до ігор.

Хід гри. Гра проходить у декілька етапів.

1. Вихователь повідомляє: Едем гуляв вулицею і раптом зустрів Аліну з мамою, яка несла в руках торт. Вони дуже поспішали. Аліна і Едем були хорошими друзями (вони жили в одному домі, але відвідували 
різні групи дитячого садку) і дуже зраділи, побачивши одне одного. Едем запитав, куди вони так поспішають. Аліна відповіла, що додому, щоб встигнути підготуватися до приходу гостей. У неї сьогодні день народження. Аліна запросила Едема на свій день народження. Едем подякував і обіцяв прийти. Вони попрощались до вечора.

2. Вихователь уводить готові фрагменти бесіди, дає початок розмови.

- Привіт, Аліна! Дуже радий тебе бачити!

- Привіт, Едем! Я також дуже рада тебе зустріти!

3. Діти колективно складають репліки, спираючись на зміст діалогу. Вихователь допомагає їм.

4. Діти обирають ролі Аліни та Едема, інсценують діалог.

Тематичні ігри-драматизації, направлені на розвиток вмінь та навичок адекватної статево-рольової поведінки. «Взірці поведінки дорослих чоловіків та жінок».

\section{Гра «Святкова сімейна вечеря».}

Мета: фрормувати у дитини навички адекватно вести себе в організації вечері, закріпити вміння у практичній взаємодії з батьками (представниками обох статей).

Матеріал: атрибутика до гри, іграшковий кухонний набір.

Хід гри. Діти сумісними зусиллями розподіляють ролі між собою, надають інструкцію до виконання і змісту кожної ролі. Гра проходить у декілька етапів.

1. Вихователь повідомляє: Сьогодні в нашій родини святкова вечеря, яка присвячується новій посаді мами. Мамо і тато робили все разом: покупали та обирали продукти, прикрашали стіл та готували улюблені страви (мами, батька). Як справжня господарочка, мама спекла наш сімейний пиріг з рибою, а ми з батьком у той час допомагали їй сервірувати стіл.

2. Вихователь уводить готові фрагменти діалогу, дає початок розмови у грі.

- Мамо, я дуже радію за тебе, тому що ти довго працювала і прикладала зусиль для цього! (привітання сина, дочки).

- Тому у нас сьогодні буде святкова вечеря! (привітання батька).

- Мамо, ми з татом почнемо накривати на стіл, поки ти будеш готувати наш улюблений пиріг!

3. Діти колективно складають репліки, спираючись на зміст діалогу. Вихователь допомагає їм, якщо діти потребують цього.

4. Діти обирають ролі батька, мами і дітей, інсценують діалог та гру. 


\section{Гра «Обираємо подарунок другу (подрузі)».}

Мета: стимулювати ініціативність і активність дитини у емоційних реакціях, виборі подарунку; доказати правильність свого вибору.

Матеріал: іграшки, листівки, олівці.

Хід гри. Створювалась імпровізована ситуація. Обирались діти (за бажанням кожної дитини), які будуть виконувати ролі одержувача подарунка та того, хто буде його вибирати та дарувати. Діти грали в парах: хлопчик - хлопчик, хлопчик дівчинка., дівчинка - дівчинка.

При кожній ситуації з дітьми обох статей, дитина пояснювала свій вибір, її правильність.

Наведемо приклади тематичних сюжетно -рольових ігор.

Широкий діапазон сюжетно-рольових ігор в групах ЗДО свідчить про обізнаність дітей щодо змісту статевих та соціальних ролей, правил дотримання обраної ролі та її виконання. Дії дошкільників загальних та національних груп у сумісній ігровій діяльності схожі за своїм змістом, сюжетною лінією.

\section{Гра «Армія» («Поліція»).}

Мета: формувати навики нормовідповідної поведінки відносно змісту обраної ролі; продовжувати стимулювання активності дітей у сумісній діяльності (хлопчиків та дівчаток) та розуміти цінність кожного партнера.

Матеріал: атрибутика до гри.

Хід гри. Діти сумісними зусиллями розподіляють ролі між собою, домовляються про виконання і зміст кожної ролі, пропонують варіації розвитку сюжету гри. Гра проходить у декілька етапів 3 різним складом дітей, де кожний склад дитячого колективу грає за своїм сюжетом.

\section{Гра «Лікарня».}

Мета: стимулювати активність дитини у емоційних реакціях, сприяти відтворюванню зразків поведінки працівників лікарні, поглибити знання дітей щодо діапазону ролей (незалежно від статі дитини).

Матеріал: іграшки, атрибутика для ігор.

Хід гри. Діти домовляються та розподіляють ролі між собою, узгоджують дії та сюжетну лінію виконання, зміст кожної ролі. За своїм змістом гра вже знайома дітям, тому у процесі ії розгортання пропонуються ускладнення та різномаїття варіацій. Гра передбачає декілька етапів з різним складом дітей та варіаціями сюжету. 
Мета: стимулювати активність дитини у позитивних реакціях до партнерів у грі, розвивати сюжетну лінію у сумісній діяльності (хлопчиків та дівчаток).

Матеріал: атрибутика до гри.

Хід гри. Діти самостійно розподіляють ролі між собою (з рівним розподілом ролей між хлопчиками та дівчатками), домовляються про виконання кожної ролі, зміну партнерів. У разі відхилення гравця від змісту обраної ролі діти разом вирішували та пропонували майбутні дії та вчинки героя. Гра проходить у декілька етапів.

Створення в дитячому колективі «Клубу справжніх хлопчиків», «Клубу справжніх дівчаток».

1 етап - вибір досліджуваними необхідних якостей для представників обох статей. Методом оцінювання і аналізу хлопчики обирають ті якості, які необхідні майбутньому чоловіку, дівчатка майбутнім жінкам.

2 етап - самооцінювання якостей і входження в клуб за обраними фішками. Методом експертних оцінок (співвідношення: фрішкаякість) діти самостійно оцінюють себе, співвідносять з реаліями у поведінці та діях у сумісній діяльності.

3 етап - вибори керівника кожного Клубу. Голосуванням дошкільники (хлопчики і дівчата окремо) обирають керівника свого Клубу.

Mета: самостійно обрати якості для представників обох статей. Оцінити себе за обраними якостями (фрішок), проранжувати їх та співвіднести з собою: кожна якість представника певної статі відповідає жетону. Кількість жетонів визначає дитина, яка виявляє, що $\epsilon$ найголовнішим для неї в умовах сьогодення. Згідно з цим дитина відносить себе до членства Клубу або ні (все визначається самостійно, без допомоги дорослого).

Інструкція дитині: Опиши, будь ласка, себе таким, яким ти сьогодні був як хлопчик / дівчинка. Чи відповідають твої вчинки / дії поведінці справжнього чоловіка / жінки?

Обладнання: фрішки (фрігури різної фрорми), конверт, бланк зі словами-якостями особистості хлопчика та дівчинки.

Якості хлопчика (фрішки): мужність, доброзичливість, ввічливість.

Якості дівчинки (фрішки): ласкавість, поступливість, емоціональність.

Всередині окремої культури, суспільства головне місце займають варіації в статево-рольовій ідеології, які обумовлені освітою, приналежністю до визначеного покоління і впливом культури інших суспільств. Але в багатьох випадках у дітей, як у представників обох статей, виникають проблеми щодо вміння трансформувати деякі навички поведінки, ролі в різних видах 
діяльності, які в майбутньому можуть знадобиться у житті.

Для старших дошкільників у налагодженні взаємин, спілкування та спільної діяльності важливим показником виступає особиста симпатія, діти не звертають увагу на етнічну або національну приналежність майбутнього партнера у грі, діалозі та занятті.

Приклади сімейних конкурсів.

1) «Мій знайомий герой».

Змагання між чоловіками-батьками однієї групи. Сини допомагають своїм батькам. Батьки поділяються на 2 (дві) команди.

Завдання для виконання: презентація кожної команди; розповідь батьків про синів, синів про батьків (смаки, улюблені страви, книги, хобі, риси характеру); підняття вантажу; чищення овочів та нарізання салату; пришивання ґудзика; запрошення дівчини на танець; складання тексту про маму; сервірування столу та запрошення дівчинки / мами.

Конкурс оцінюють журі: 3 мами і 3 дівчинки. Методом експертної оцінки вираховується середне статистичне за результатами усіх завдань.

2) «Моя найкраща героїня».

Змагання між жінками-матерями однієї групи, їх дочки допомагають їм в конкурсі. Мами поділяються на 2 (дві) команди.

Завдання для виконання: презентація команд; розповідь дівчаток про свою матір, ії характер; заповнити кошик продуктами для будь-якої страви (по жеребкуванню); конкурс страв (дівчата 3 мамами розповідають про страву, яку вони приготували на конкурс); конкурс найкращої колискової; конкурс на кращий танець мами з дочкою.

Конкурс оцінюють журі: 3 батьків і 3 хлопчика. Методом експертної оцінки вираховується середне статистичне за результатами усіх завдань.

Усі запропоновані заходи були впроваджені у експериментальні загальні групи. Беручи за увагу специфічність ставлення батьків дітей 3 національних груп, нами було впроваджено додатковий цикл тематичних лекцій, бесід щодо виховання статево-рольової соціалізованості та створення умов гармонійної соціалізації дітей старшого дошкільного віку.

Тематичні малюнки, спрямовані на фрормування статевої ідентифрікації дітей (для змішаних та національних груп): «Портрет моєї мами; мого батька»; «Сімейний портрет»; «Я в дитячому садочку».

У зображувальній діяльності дошкільники закріплювали власні уявлення про статеву диференціацію, відображали себе як представника певної статі, своє відношення до представників протилежної статі. Широкий діапазон тематичних малюнків дозволяв та сприяв закріпленню позитивних рис дитини як представника певної статі та етносу. 
Отже, для того, щоб процес статево-рольової соціалізації відображав логіку, зміст, структуру, специфічність даного френомену у старших дошкільників, треба дотримуватися послідовного, систематичного та поетапного впливу педагогічних умов в закладі дошкільної освіти.

Зауважимо також, що програмою фрормувального етапу дослідження передбачалася активізація батьків, але різнилися способами та формами ії̈ досягнення, змістовим наповненням.

Створення сприятливого психологічного клімату, корегування дій та поведінки дітей, довіра один до одного - необхідна педагогічна умова для подальшої результативної роботи. Різнопланова за змістом робота з батьками надавала їм можливість побачити реальний стан існуючої проблеми, свою дитину у реальному житті, зрозуміти ії вчинки та побачити результати корегування небажаної поведінки дитини як представника певної статі.

Запропонована програма роботи з батьками мала на меті розширити їх обізнаність 3 проблеми формування у старших дошкільників критеріїв статево-рольової соціалізації в умовах сімейного виховання та проблеми формування у старших дошкільників етнічної ідентифрікації; активізувати до участі в життєдіяльності дитячого колективу, сприяти позитивним взаєминам між дітьми та вихованню поважного відношення до представників протилежної статі.

3 батьками передбачалося індивідуальне консультування (за означеною проблемою), тематичні бесіди, проводились вечори запитань та відповідей. У бесідах та консультаціях батькам розповідали та пояснювали причини невідповідності статево-рольової поведінки власної дитини вимогам сучасного суспільства, необхідних рис та якостей майбутнім чоловікам та жінкам.

У ході контрольного етапу дослідження виникла необхідність співставити матеріали спостереження за реальними діями, вчинками хлопчиків і дівчаток старшого дошкільного віку, нормовідповідною статево-рольовою поведінкою, що спонукало до використання методу бесіди. Діти відповідали на запитання такого ж змісту, які на етапі констатації зі зміною інфрормаційного матеріалу. Для співставлення отриманих даних ми вдалися до методу порівняльного аналізу та математичної обробки отриманих результатів.

Реалізація завдань і змісту етапів забезпечила позитивні зрушення у фрормуванні рівнів статево-рольової соціалізованості дітей. Акцентуючи увагу на специфрічність сценарних та сюжетно-рольових ігор, тематичних ігор-драматизацій, ми вважали показовим вибір партнера-однолітка своєї та протилежної статі, взаємодії з ними.

Результати контрольного етапу дослідження показали, що рівні статево-рольової соціалізованості дітей суттєво змінився під впливом запропонованої програми фрормувального експерименту. 
Аналіз результатів відповідей дітей показав, що більшість дошкільників експериментальної і контрольної груп не припустилися помилок у відповідях на кожне запитання стосовно своєї статевої ідентифрікації. Це засвідчує, що у дітей в даному віці вже сфрормовано образ свого «Я» як представника відповідної статі, уявлення про зміст статевих ролей, вимог суспільства до чоловіків та жінок (статева диференціація).

Щодо вибору партнера-однолітка у сумісній діяльності та спілкуванні, визначення друзів показники в експериментальній та контрольній групах відрізняються. Вагомим у виборі партнера виступає стать однолітка, ойого / її дії та вчинки. Дитина ставиться до партнера позитивно, який проявляє ініціативу, зацікавленість у сумісній діяльності, бажання дотримуватися правил гри. Саме такі прояви є для дітей складними та потребують зусиль у конструктивних діях.

Дослідження показало, що побудову міжособистісних взаємин обумовлює наявність навичок спілкування у сумісній діяльності. Ставлення до однолітків своєї статі $\epsilon$ досить позитивним та бажаним; ставлення до представників протилежної статі стало дружним та не таким категоричним, яке було на початку констатувального етапу експерименту.

Запропонована програма роботи з батьками мала на меті розширити їх обізнаність 3 проблеми фрормування у старших дошкільників рівні статево-рольової соціалізованості в умовах сімейного виховання та проблеми формування у старших дошкільників статево-рольової ідентифікації; активізувати до участі в життєдіяльності дитячого колективу, сприяти позитивним взаєминам між дітьми та вихованню поважного відношення до представників протилежної статі.

\section{І. Рольова гра «Вечір у колі сім'ї».}

1) Повідомлення теми гри та ії̈ змісту.

Син або дочка прийшли з дитячого садка. Їм хочеться відпочити після напруженого дня, не хочеться вислуховувати і виконувати будь-які вимоги старших. Усі бажання зводяться до того, щоб дивитися телевізор, їсти улюблене, зачинитися у своїй кімнаті і слухати музику або спілкуватися через Інтернет з друзями та знайомими. Вони хочуть пізно лягати спати і не відповідати на запитання батьків типу: «Куди ти йдеш?», «Коли повернешся?».

Дитина не хоче вішати одяг у призначеному для цього місця, не кажучи вже про допомогу по господарству і виконання домашніх завдань. І, що є досить очевидним, їй не хочеться спілкуватися із батьками, які повсякчас бурчать і щось вимагають.

Батьки, повертаючись додому після роботи, також прагнуть хоч на якийсь час стати «дітьми»: відчувати себе комфортно і затишно у своїй домівці, не вислуховувати вимог чи проблем від своїх близьких. Мабуть, кожному із вас знайома така ситуація. 
І дитина, і батьки живуть разом, постійно перетинаються в кімнаті, на кухні...

2) Розподіл ролей (батьки, діти, представники старшого покоління; експерти).

3) Проведення гри.

4) Підведення підсумків.

II. Індивідуальна вправа «Який я батько (мати)».

Існує серія тренувальних вправ, які допомагають батькам краще усвідомити власний «образ». Так, приміром, на їхню думку, він (вона) гарний батько (мати), досить комунікативна людина, любить своїх дітей, намагається якомога краще виховувати їх. Але контакти з ними, їх змістове наповнення і наслідки не завжди Вас задовольняють, а іноді викликають і негативні почуття. Чому це відбувається? Може якісь особливості Вашого характеру, особисті риси і якості певним чином впливають на ці стосунки? Спробуйте з'ясувати це.

\section{III. Вправа «Подарунок».}

Слово педагога: Я хочу надати Вам можливість виявити дружні почуття один до одного. Для цього оберіть когось з однолітків, кому б ви хотіли зробити невеликий подарунок. Не розповідайте заздалегідь про того, кого Ви обрали. У Вас $є 20$ хвилин, щоб придумати подарунок. Це може бути щось готове або таке, що Ви зробити своїми руками. Важливо, щоб Ви зосередилися на тій людині, якій хочете зробити подарунок. Тепер по черзі передайте один одному свої подарунки.

Запитання для обговорення:

- Яким був процес вручення подарунків?

- Хто не одержав жодного подарунку? Як він (вона) на це зреагував (ла)?

- За допомогою яких ще засобів Ви виявляли своє позитивне ставлення один до одного?

Якщо, на початок експерименту батьки із груп закладу дошкільної освіти в тематичних анкетах надавали більш бажану характеристику власній дитини, то під час формувального етапу вони розуміли неадекватність відповідей відносно з реальним.

У зоні уваги знаходились молоді (за віком) батьки, батьки-одинаки, які виховували єдину дитину. Саме ця категорія демонструвала та мала невідповідність у бажаних та реальних характеристиках власної дитини. Вони демонстрували поверхні знання стосовно кола друзів дитини, її симпатій та антипатій, бажань та проблем, які існують в даному дитячому колективі. Їх цікавила статусна позиція власної дитини у дитячому колективі, а не ієрархія стосунків, від якої залежить перше. Діти таких батьків знаходяться на егоцентричному рівні статево-рольової поведінки, проявляли егоїзм у взаєминах 3 дорослими та однолітками. 
3 такими батьками передбачалося індивідуальне консультування (за означеною проблемою), тематичні бесіди, проводились вечори запитань та відповідей. У бесідах та консультаціях батькам розповідали та пояснювали причини невідповідності статево-рольової поведінки власної дитини вимогам сучасного суспільства, необхідних рис та якостей майбутнім чоловікам та жінкам.

Це говорить про те, що дошкільники розуміють та бачать чітку різницю між поняттями і змістом статевих та соціальних ролей. Результати заключного етапу експерименту свідчать про суттєве покращення рівня культури статево-рольової поведінки в експериментальних групах.

На прикінцевому етапі було проведено контрольні зрізи з метою виявлення ефективності визначених педагогічних умов статеворольової соціалізації дошкільників. Дітям були запропоновані завдання до кожного з виокремлених нами критеріїв і показників аналогічно констатувального етапу. За даними контрольного зрізу у дітей експериментальної групи було виявлено відчутні позитивні зміни, що вплинули на загальну характеристику рівнів статево-рольової соціалізованості дошкільників.

Для перевірки достовірності отриманих під час фрормувального експерименту висновків дослідження проведений статистичний аналіз який дав можливість встановити, що найбільшої ваги мають значення, здобуті 3 тими досліджуваними, які характеризуються високими показниками критеріїв кожного типу (кількість останніх дорівнює понад половину складу експериментальної групи в контрольному зрізі).

Таким чином, одержана різниця результатів експериментальної і контрольної груп $є$ суттєвою. У ході фрормувального експерименту досліджувані показали міцне і глибоке засвоєння знань щодо культури статево-рольової соціалізації, уміння їх застосовувати в нових ситуаціях, проектувати свої відношення та стосунки у різних видах діяльності.

Висновок. Таким чином, перевірено і підтверджено ефективність педагогічних умов виховання статево-рольової соціалізованості старших дошкільників. Проведене дослідження не охоплює всього комплексу проблем статево-рольової соціалізації старших дошкільників. Подальшого вивчення потребує питання підбору форм, методів і прийомів статево-рольового виховання дітей дошкільного віку.

\section{Список використаних джерел}

1. Бех І. Д. Духовні цінності в розвитку особистості. Педагогіка і психологія. 1997. № 1. С. 130-137.

2. Говорун Т.В. Соціалізація статі як психологічна проблема. Педагогіка $i$ психологія. 2001. № 2 (31). С. 5-13.

3. Гончаренко А. М. Хлопчики й дівчатка: міжособистісні взаємини. Дошкільне виховання. 2007. № 4. С. 8-10. 
4. Діти і соціум: Особливості соціалізації дітей дошкільного і молодшого шкільного віку: моногр. / за ред. А. М. Богуш, Л. О. Варяниця, Н. В. Гавриш. Л. : Альмаматер, 2006. 368 c.

5. Кононко О. Л. Розвиток статевої свідомості хлопчиків і дівчаток у дошкільний період. Вихователю про психологію та педагогіку сексуального розвитку дитини: наук.-метод. зб. К. : ІЗМН, 1996. С. 91-110.

6. Кононко О.Л. Статева самосвідомість як складова морального розвитку дошкільника. Теоретико-методологічні проблеми виховання дітей та учнівської молоді: зб. наук. пр. К. : Пед. думка, 2000. С. 234-238.

7. Кравець В.П. Гендерна педагогіка: навч. посібник. Тернопіль : Джура, 2003. $416 \mathrm{c}$.

8. Олійник Л. Статева соціалізація дошкільнят. Дошкільне виховання. 2008. № 1. C. 7-10.

9. Сайко Н.О. Особливості соціалізації дітей дошкільного віку в процесі підготовки до школи. Школа першого ступеня: теорія і практика: матеріали Міжнародної конференції Переяслав-Хмельницького держ. пед. ін.-ту. Переяслав-Хмельницький, 2002. 200 с.

10. Титаренко Т.М. Хлопчики і дівчатка: психологічне становлення індивідуальності. К. : Знання, 1989. 28 с. 


\title{
ТЕОРЕТИЧНІ ОСНОВИ ФОРМУВАННЯ КУЛЬТУРИ СПОЖИВАННЯ У ДІТЕЙ СТАРШОГО ДОШКІЛЬНОГО ВІКУ
}

\author{
Шаповалова О.В. \\ кандидат педагогічних наук, доцент, \\ Сумський державний педагогічний університет імені А. С. Макаренка
}

У нормативних освітніх документах (Закони України «Про освіту», «Про дошкільну освіту», «Національна стратегія розвитку освіти в Україні на період до 2021 р.», «Базовий компонент дошкільної освіти» тощо) наголошено, що метою сучасної дошкільної освіти $\epsilon$ формування різнобічно розвиненої, життєво компетентної особистості, яка здатна діяти в повсякчас змінюваному довкіллі. Серед завдань виховання й розвитку дітей дошкільного віку виокремлено й такі: формування у дітей дошкільного віку безпеки праці, оволодіння навичками практичної діяльності, основами культури споживання.

Актуальність даної теми полягає в тому, що в умовах глобального поширення масової культури, ключовими цінностями якої виступають розваги та споживання, необхідно спрямовувати молоде покоління на чітке фрормування в дітей старшого дошкільного віку соціально значущих цінностей, знань, норм і зразків поведінки, правильного поєднання в споживані матеріального і духовного, що має стати цілеспрямованим і систематичним педагогічним процесом. Проблема розвитку культури споживання багатогранна.

3 позиції психології, фрілософії та педагогіки нею займалось багато науковців, а саме: В. Мясіщев, Д. Кікнадзе, В. Радаєв, П. Фресс та Ж. Піаже, А. Леонтьев, А. Здравомислов, Т. Марченко, Ю. Резник, Е. Смірнов, А. Абрамова, Ю. Васильєв, Л. Кураков, А. Нісімчук, І. Сасова, Н. Хроменков, Ю. Шаронін, Б. Шемякін, А. Шпак. Проблемам соціалізації дітей, присвячені дослідження В. Воробйова, О. Волжиніна, І. Дементьєвої, Л. Карцева, П Козирьова та багатьох інших.

Вони розглядали культуру споживання як один 3 аспектів оволодіння вищою освітою та розвитку базової культури людини, відображенням якої є перехід до особистісно-орієнтованого утворення, яке забезпечує єдність і зв'язок духовного та соціокультурного простору, оволодіння знаннями, вміннями та навичками, розробку дидактичної системи, спрямованої на досягнення загальної мети діяльності вищої школи як соціального інституту.

Питання фрормування споживчих знань у дітей старшого дошкільного віку висвітлено в дослідженнях, присвячених економічному вихованню дошкільників (О. Галахова, Т.Галговська, В. Гербова, Н.Грама, Г.Григоренко, Р. Жадан, Н. Кривошея, Ю. Лелюк, Л. Лохвицька, Н. Побірченко, А. Сазонова, І. Сасова, Г. Шатова та ін.). Питання дошкільної педагогіки в закладах дошкільної освіти показано 
переважно в публіцистичних та практико зорієнтованих джерелах. Однак, аналіз спеціальної літератури показав, що проблема основ культури споживання у дітей старшого дошкільного віку в теорії і практиці педагогіки не отримала достатнього висвітлення. Між тим, досліджувана проблема різноманітна і складна. Вимагається науково обґрунтоване виділення теоретико-методологічних основ споживчої культури, розгляд специфіки педагогічних умов, засобів, форм і методів навчання.

Для визначення етимології поняття «основи культури споживання особистості» потрібно провести аналіз таких термінів, як «культура» та «споживання». Термін «культура» (від лат. cultura - оброблення, виховання, освіта, розвиток, шанування), специфічний спосіб організації та розвитку людської життєдіяльності, уявлень у продуктах матеріальної та духовної праці, у системі соціальних норм і закладів, у духовних цінностях, у сукупності ставлення людей до природи, між собою та до самих себе. Культура характеризує також особливості свідомості, поведінки й діяльності людей у конкретних сферах суспільного життя («культура праці, екологічна культура, політична культура»), - так це поняття трактовано у фрілософському енциклопедичному словнику [1, с. 89].

Культура може фіксувати спосіб життєдіяльності всього суспільства в цілому (суспільна культура), соціальної групи (наприклад, культура класу) чи спосіб життєдіяльності окремого індивіду (особиста культура). Поняття «культура» пройшло довгий час, з'явившись в європейській суспільній думці лише в другій половині XVIII ст. Спочатку воно являло собою цілеспрямований вплив людини на природу, потім виховання й освіту самої людини, пізніше воно стало показником особистої досконалості людини. В епоху Відродження під досконалістю культури почали розуміти відповідність гуманістичному ідеалу людини, а надалі - ідеалу просвітителів [2, с. 96].

У сучасній культурології подано глибокий аналіз еволюції поняття «культура», починаючи від античних часів і завершуючи сьогоденням. Наукова література містить значну кількість потрактувань цього поняття. У період із 1871 по 1919 роки запропоновано сім визначень поняття «культура», у наступні 1920-1950 роки - 157 визначень, а в 1968 році А. Моль нарахував 250 визначень [15, с. 228].

Культура на думку $Є$. Іоніна - це сукупність стійких форм соціальної взаємодії, закріплених у нормах і цінностях, засоби комунікації, які часто передаються від покоління до поколінню. Вона проявляється в існуванні відносно стійких форм, моделей споживання. На відміну від інстинктів, культура не передається у спадщину, з нею не народжуються. Культурі індивід навчається в процесі всього життя у соціальному середовищі. Цей процес освоєння культури називають соціалізацією. Він включає освоєння, тобто пізнання і прийняття норм, цінностей, засобів спілкування. 
«Культурна людина» - це той, хто освоїв норми, цінності, мову даної культури чи субкультури. Це свого роду «звання», яке дають оточуючі, визнаючи успіхи даного індивіда в соціалізації. «Некультурна людина» - це та, хто не змогла або не схотіла засвоїти норми та цінності середовища, в якому вона живе. Це негативний ярлик, клеймо. Присвоюючи такі звання, люди заохочуються до прийняття в даному середовищі певної форми поведінки, виявляють бажання вести себе не так, «як прийнято» [5, с. 65].

Аналіз сутності культури дає уможливлює виокремлення ії основних взаємопов'язаних аспектів: культура - народжене суспільством, властиве суспільству соціальне явище, що відображає його якісну характеристику й збагачує духовне життя людини; культура - процес творчої діяльності людини, спрямований на пізнання довкілля й самої людини в цьому світі, на отримання об'єктивної та достовірної інформації про довкілля; культура покликана допомогти людині не лише пізнати світ і саму себе, а й визначити своє місце в цьому світі, сфрормувати світоглядні установки; культура містить матеріально-духовні цінності, що досягнуті людиною в процесі освоєння світу, а також передбачає розвиток та виховання відповідних ціннісних орієнтацій; культура, створюючи необхідні для орієнтації людини у світі норми поведінки й оцінки, забезпечує регулювання соціальних відносин людей; культура $є$ потужним чинником розвитку людських сутнісних сил, формування людини в людині - саме в цьому полягає її гуманістичний зміст. Окресливши загальні підходи до розуміння сутності культури, можна дати ії̈ визначення в широкому й вузькому значенні. У широкому значенні, це поняття являє собою сукупність видів, способів і результатів духовно осмисленої та творчоперетворювальної діяльності людини й соціуму. Воно постає невід'ємним компонентом й умовою людського буття.

У процесі соціально-історичного розвитку суспільства утворюються компоненти його культури: духовної (знання та наукові ідеї, світоглядні орієнтації та ідеали, мова й культурні традиції, соціальні норми й правила) і матеріальної (способи діяльності й технології виробництва, продукти й предмети, необхідні для підтримки життєдіяльності людей) [14, с. 124]. У вузькому сенсі, культура, з одного боку, слугує для виділення специфрічної сфери людського буття - сфрери його дійсного самоствердження та самосвідомості. 3 іншого боку, це визначення культури конкретизується в її потрактуванні як особливий вид діяльності, відмінної від матеріального виробництва. Культура тут постає сферою, в якій виробляються духовні цінності і в якій вони реалізуються, тобто соціальноорганізованою фрормою духовного виробництва [15, с. 79]. 
Інакше кажучи, культура - це атмосфрера соціокультурного поля макро рівня (товариство, етнічна спільнота тощо), яка нав'язує індивідам певні форми поведінки, бажання та способи задоволення універсальних (загальнолюдських) потреб. В психології, як зазначає Г. Фортунатов, споживча культура розглядається як особливий психічний стан індивіда, що змушує відчувати або усвідомлювати їм «напругу», «незадоволеність», «дискомфорт», - тобто відображення в психіці людини невідповідності між внутрішніми і зовнішніми умовами діяльності. Тому потреби і $є$ збудником активності, що має на меті усунення такої невідповідності. Це можливо шляхом використання реальних можливостей насичення потреб, а за відсутності таких можливостей шляхом придушення або заміщення даної потреби іншою, найбільш близькою до неї [20, с. 312]. Різноманітні проблеми споживання, споживчої поведінки знайшли відображення у працях сучасних українських науковців Е. Донченко, Ю. Пачковського, О. Щерби, де проаналізовано мотиваційні теорії особистості в процесі споживання. Порушено питання про не адаптованість західної реклами до українських реалій і наголошено на тому, що необхідним $\epsilon$ вивчення регіональних відмінностей споживачів. Розглядаються особливості символів та гендерного аспекту, відображених у національному рекламному продукті. Споживання стає, свого роду ланкою, частиною більш широкого символічного обміну, в який залучено всіх членів суспільства. Концепт «споживання» підсумовує багато положень, властивих теоріям споживання, він $\epsilon$ певним початком, носієм різноманітних фрорм майбутньої організації, полем перетину форм і шляхів розвитку суспільства, відносин між людьми.

У людському суспільстві споживання тісно переплітається 3 культурою. Деякі автори заявили про «моралізацію ринків», маючи на увазі, що виробники й споживачі - основні учасники ринку приділяють все більше уваги іншим чинникам, окрім одержання вигоди. Будучи вираженням взаємозв'язку суб'єкта та умов його діяльності, споживання виявляє себе в неусвідомлюваних потягах $\mathrm{i}$ усвідомлених мотивах поведінки. Людські потреби за В. Мясищевим, як правило, мають предметну спрямованість, якій передує «пошукова поведінка»; загальна, неконкретизована потреба, яка стимулює пошук певних способів і предметів ії задоволення.

Найважливіша особливість споживання - ії динамічний характер, мінливість, розвиток на базі задоволених потреб, нових, більш високих, що пов'язані з включенням особистості в різні форми та сфери діяльності. Дуже цікава психологія мотивів споживання, або психологія споживача тому, що частина нашого суспільства прагне до досягнення матеріальних благ вже не заради насущного хліба, а для підтримки якогось статусу, накопичення заощаджень. У класичній педагогіці (А. Макаренко, И. Песталоцці, С. Русова, В. Сухомлинський, К. Ушинський та ін.) культура споживання особистості розглядається у 
зв'язку з її моральним та трудовим вихованням. У дитини виховується бережливе ставлення до речей, повага до праці людей, у результаті якої з'явилися ці речі. Формуються уявлення про необхідність робити вибір серед безлічі власних бажань, ураховуючи при цьому бажання інших, спрямовувати результати власної діяльності на покращення свого життя та близьких людей, орієнтуючись на інтереси суспільства. У зв'язку із цим культура споживання розглядається як складник культури поведінки Якби людині достатньо було б бути несхожим на всіх, як визначає К. Ізард, то після не надто довгих умовиводів можна прийти до висновку, що вже з народження кожен індивід унікальний. I ця унікальність тільки посилюється з віком і розвитком.

Тобто, швидше за все поштовхом $є$ бажання відповідати якомусь образу, який є частиною суспільства. I при досягненні цього рівня, після придбання омріяної речі, почуття задоволеності собою не досягається. Важливо зрозуміти, що споживання сьогодні, в умовах постіндустріального суспільства, пов'язано не стільки з багатством і розкішшю, а з соціальною конструкцією ідентичності людини, з тим, як він створює образ самого себе. Споживче товариство, до якого увійшла наша країна, це просто нова система соціокультурних зв'язків, при якій соціальна ідентифікація (щодо зв'язкові уявлення людей про себе і про те, як їх сприймають інші) побудована вже не на системі розподілу праці і виробництва (я - робітник, фермер, офісний працівник), а поза робочим місцем: будинки, в розвагах, спорті, в одязі та інтер'єрі квартири, тобто на способі споживання. Це не проблема багатих - а їх відмінності від бідних.

У споживчому суспільстві споживають усі - і бідні, можливо, більше, в усякому разі, їх бажання не менш наполегливі, ніж у «багатих» [16, с. 101]. Бажання споживати те, а не це, диктується специфрічним набором культурних символів і цінностей. Це щось пов'язане з культурою, це бажання, що купується через соціалізацію. Сьогодні, на думку Д. Кікнадзе, ми опиняємося в новому типі суспільства, в якому ідеологія споживання накладається на «народну специфріку». Це і свій, особливий набір культурних символів, цінностей, кодів. Це і велика відмінність у формах проявів нового між великими містами та іншою частиною країни; між порівняно нечисленними соціальними шарами і основною масою населення. Нарешті, в 50-е і 60-і роки споживче товариство в Америці і Європі фрормувалося на тлі економічного підйому, наше ж формується на тлі економічного спаду. Проблема споживання народилася не сьогодні і стала проблемою набагато раніше, ніж з'явилися не тільки сьогоднішні суспільства, а й сучасна наука. Перші феномени споживання як значимого соціального процесу пов'язані з новими багатими в США наприкінці XIX століття і жителями європейських мегаполісів того ж часу. Перші наслідували європейським зразкам розкоші. Другі споживали, щоб протистояти переважною силам мегаполісу, відрізнятися, щоб бути поміченим. У 
нових, характерних для розвинутої споживчого товариства класифікаціях на перший план виходить вже не соціально-економічна група, а такі поняття, як «стиль життя», вік, наявність або відсутність дітей, інтереси. Від «об'єктивного» опису споживача фахівці переходять до точки зору самих споживачів на себе, як споживачі оцінюють себе самі через об'єкти споживання.

Як зазначає Д. Піндайк, якщо раніше поняття «стилю життя» означало той чи інший поведінковий образ певної статусної групи, то в сучасній споживчій культурі він позначає індивідуальність, самовираження і стиль самосвідомості. Тіло, одяг, мова, машина, місце відпочинку повинні розглядатися як ознака індивідуального смаку і стилю власника, споживача. Забезпечується все більш широкий вибір (управління яким перетворилося на рід мистецтва) не тільки для тих, хто народився після 60-х, але і для людей середнього та літнього віку. Ми рухаємося до суспільства без строго встановлених статусних груп, до суспільства, в якому той чи інший стиль життя вже не буде пов'язаний з тими чи іншими фіксованими групами [18, с.105]. Споживання сьогодні практично загубило зв'язок із задоволенням якогось вже існуючого набору потреб.

В. Радаєв вважає, що люди намагаються стати тими, ким вони хочуть бути, купуючи речі, які, як вони уявляють, допоможуть їм створити і утримати ідею самих себе, свій образ. Передчуття покупки, бажання найчастіше приносить більше задоволення, ніж сам акт придбання. Це означає, що у споживання немає меж. Наївно було б припускати, що воно може бути насичене та задоволено. Нав'язливе прагнення споживати є наслідком деяких психологічних причин або чогось подібного і не викликане тільки силою наслідування.

Споживання є чимось невгамовним тому, що це повністю ідеальна практика, яка не має нічого спільного (після певного моменту) ні 3 задоволенням потреб, ні з принципом реальності. Отже, бажання приборкати споживання або виробити норми системи потреб є наївний і абсурдний моралізм. Отже, споживаються ідеї, а не речі, споживання пов'язане з культурними знаками і відносинами між знаками. Оскільки це ідеальна практика, у неї не може бути кінцевим, фрізичного насичення. Споживання ґрунтується на бажанні того, що відсутнє, чим більше людина споживає, тим більше буде бажати споживати, і ця тенденція зберігається навіть при економічному спаді.

На думку Є.Ільїна існує два основних аспекти поведінки споживача: задоволення потреб і виконання бажань. Поведінка споживача, де виняткову роль відіграють потреби, навряд чи вимагає докладного пояснення. Достатнім буде зібрати дані про те, коли, де і що придбав споживач. Коли ж ми хочемо відповісти на запитання, чому він так вчинив, ми вже маємо справу з більш складним феноменом мотивації. Бажання керують значною частиною нашої споживчої поведінки. Спад, достаток і інфляція можуть бути як 
наслідками, так і причинами поведінки та психології споживача. Розуміння причин, переваг і виявлення бажань, вимагає об'єднання економіки, антропології і психології. Відповіді на питання «чому» найчастіше мають відношення до бажань, ніж до потреб. Щоб глибше проникнути в психологію потреб, необхідно враховувати ряд фракторів, один з яких принцип гештальта [6, с. 71].

3 психологічної точки зору, люди, економічне становище яких поліпшується, незмінно чи погіршується, насправді належать до трьох абсолютно різних категорій, навіть якщо вони заробляють в даний час абсолютно однаково. За кожним товаром стоїть ідея, наголошує К. Обуховський. Те, що залишається в уявленні споживача після масованого впливу реклами конкретної марки товару - це образ товару: мелодія, ритм, загальна конфігурація, тло, кандидат або країна. Це більш ніж розпливчастий феномен. Множинні наукові дослідження показали, що ми схильні миттєво змінювати свою думку і інтерпретацію нейтрального твердження, коли дізнаємося, що з ним асоціюється людина, яка нам подобається чи не подобається. Ми реагуємо скоріше на ідентифікаційну характеристику повідомлення, ніж на його утримання [17, с.123].

3. Фрейд описує людей, що виділяються тим, що в їхньому характері виявляється, як правило, присутність наступних трьох рис: вони дуже акуратні, ощадливі й уперті. Кожне з цих висловів, власне кажучи, вже само по собі відноситься до цілого ряду або невеликої групи рисочок характеру, що стоять в тісному відношенні один до одного. Акуратність позначає тут не тільки фрізичну охайність, але також і сумлінність у виконанні іншого роду дрібних зобов'язань: на людей «акуратних» в цьому сенсі можна покластися; протилежні в цьому відношенні риси: безладність, недбалість. Ощадливість може доходити до розмірів скупості; впертість іноді переходить в завзятість, до якої легко приєднується схильність до гніву і мстивості.

Останні дві властивості - ощадливість і впертість - пов'язані одна з одною тісніше, ніж з першою, з акуратністю, та й у всьому комплексі вони представляють більш сталу складову частину, але тим не менш здається безсумнівним, що всі ці три властивості пов'язані між собою, що вони якимось чином становлять одне ціле [19, с.180]. Значимість високого рівня споживання як сигнал про здібності людини різний для різного роду занять. Заробіток і здібності, за які найбільше цінують людину, що займається науковими дослідженнями, не обов'язково жорстко взаємопов'язані. Стимул, який спонукає людину витрачати вільні гроші на предмети споживання, що привертають увагу оточуючих, обернено пропорційний обсягу та надійності незалежної інформації про його здібності, доступною іншим людям. Чим більше інформації мають люди про якусь людину, тим меншою мірою вони пов'язують свої оцінки їх здібностей з їх стилем споживання. Оскільки надійність інформації про людину з роками зростає, частка доходів на 
предмети споживання, що привертають увагу оточуючих, 3 віком зменшується. Більш досконала схема витрат у літніх людей свідчить як про зниження корисності сигналів про їх здібності, так і про їх мудрості, одержуваної з роками.

Споживання, що привертає увагу оточуючих, яке розцінюється як сигнал про здібності людини, нагадує класичну дилему ув'язненого. Щоб справити добре враження, недостатньо надіти чистий і добре зшитий костюм. Слід придбати щось більш ефектне, ніж те, що носять інші. Це стимулює кожного менше заощаджувати і більше витрачати на одяг. Внаслідок цього споживання, що привертає увагу, буде, по суті, характеристикою місця, займаного людиною в суспільстві.

У недалекі часи промислових революцій, коли відбулися принципові зміни у світі речей (поділ праці, поява мануфактури і перших машин i, отже, серійного виробництва), людина жадібно увірувала, що порятунок у праці та накопичених результатах цієї праці. В індустріальному суспільстві з'явилася ідея прогресу - ідея розвитку від простого до складного, від поганого до хорошого. Прогрес в уявленні, що майбутнє краще сьогодення. У XX столітті у людини з'явилася нова надія на порятунок: зростання капіталістичного виробництва, концентрація капіталу, освіта супер-держав призвели до постіндустріальної моделі світу.

Д. Кикнадзе вказує, що криза гуманістичного розуміння розуму i прогресу, як це не парадоксально, була обумовлена самим науковотехнічним прогресом. Приміром, в природознавстві виникнення загальної теорії відносності Ейнштейна і квантової механіки, відкриття ролі ДНК у передачі спадковості, а також останні досягнення кібернетики і зростання ролі інформаційних наук. I в той же час інформація стає ставкою в глобальній битві за владу. Потоки знання циркулюють подібно грошам. Одним з перешкод на шляху знань стає держава, яка все більше сприймається як шум. Прийняття рішень поступово від керівників держав переходить до невеликої групи топменеджерів транснаціональних корпорацій. Типовими ознаками сьогоднішньої дійсності стає відродження інтересу до субкультур, що носять амбівалентний характер [9, с. 89].

Продовжуючи свою думку Д. Кикнадзе зазначає, що через споживання реальні речі, відносини, почуття підміняються сьогодні їх копією, порожнистою оболонкою. Відбувається своєрідна «сублімація змісту в фрорму». Це і $€$ симулятор, який замінює природний світ його штучною подобою. Втрачається принцип реальності речей, їх замінюють фетиш, імідж, модель, проект. Бренд як симуляція спокуси еротизує світ речей, наділяючи їх новим штучним змістом. В результаті межі між образом і реальністю розмиваються, фрормуючи нову гіперреальність, перетворюючи світ в якийсь калейдоскоп [9, с. 91]. 
За словами К. Обуховського, згідно історичній науці, людина спочатку тягнеться не до пізнання, не до істини, а до мрії, до міфу, який допомагає переносити тяготи життя. Реальне знання тут виключається, тому що воно знаходиться у кричущому протиріччі 3 бажанням і надією людини. На його думку «людина бажає, а потім лише пізнає те, що бажає», боротьба з міфрами - помилкове завдання, явно приречене на невдачу. Звільнити мислення від міфів, ілюзій, означає надати людині погану послугу, позбавити ії впевненості в собі. «Людині необхідно покривало ілюзій, бо без них індивід не здатний прилаштуватися до навколишнього світу». Помилка допомагає людині орієнтуватися, потім закріплюється у звичаях і сприймається як загальноприйнята істина [17, с. 165].

Отже, чіпляння за життя і страх перед смертю, бажання щастя й видалення від страждань - ось корені, 3 яких виростають як примітивний міф і найтонші фрілософські спекуляції, так і споживання - як ще одна суєтна спроба вирішення «по-справжньому серйозної психологічної проблеми». Частина суспільства прагне в споживанні придбати якийсь образ і статус певного соціального рівня, інша частина прагне реалізувати свою індивідуальність через ексклюзивність предметів. Третя частина з'єднує поняття мрії з бажанням придбання певних речей. Але всі жадають гармонійної, ідеалізованої картини, коли суспільство у вигляді найближчого оточення слухає і приймає той образ, який людина видає йому. Вихованість основ культури споживання у дітей старшого дошкільного віку як процес цілеспрямованої, систематичної взаємодії дорослих (вихователів, батьків) і вихованців, під час якої відбувається набуття дітьми стійких навичок культури споживання в побуті, соціумі, різних видах діяльності [7, с.124].

Таким чином, культура являє собою не лише художньо-творчий процес (мистецтво), а, передусім, звичаї, цінності, погляди, норми, що панують у суспільстві. Це специфічний спосіб організації та розвитку людської життєдіяльності, представлений у продуктах матеріальної та духовної праці, це система відносин між людиною та природою, людиною та суспільством, людиною та людиною. Найважливіша особливість споживання - її динамічний характер, мінливість, розвиток на базі задоволених потреб, нових, більш високих, що пов'язані 3 включенням особистості в різні форми та сфери діяльності Культуру споживання в цілому можна визначити як сукупність матеріальних та духовних благ, знань, норм і цінностей споживчої поведінки, які встановилися в суспільстві.

Культура споживання має динамічний процес, розвиток якого здійснюється на базі задоволення потреб у діяльності, культурі, цінностях тощо. Це також надіндивідуальна реальність, що створюється людьми як безпосередньо, так і за допомогою соціальних інститутів - держави, бізнесу, навчання тощо. Гармонізація 
естетичних, пізнавальних і моральних потреб - необхідна умова формування культури споживання особистості.

На нашу думку питання виховання основ культури споживання широко висвітлено в дошкільній педагогіці. Аналіз досліджень дозволив визначити позицію дошкільної педагогіки в проблемі дослідження основ культури споживання. Сучасні наукові розвідки Т. Бабаєва, О. Герасимова, М. Зацепіна, С. Козлова, М. Крулехт, Д. Фельдштейн, Т. Фуряєва доводять, що дошкільне дитинство $€$ сензитивним періодом для пізнання основ культурних цінностей та власне введення дитини в простір культури.

Так, на думку М. Крулехт, культура дошкільника $є$ інтегральною якістю особистості, яка виховується з дитинства та базується на засадах морально-духовних цінностей. Автор наголошує, що 3 урахуванням вікових особливостей старших дошкільників можна вирішувати завдання виховання основ культури споживання та розглядати цю діяльність як формування досвіду взаємодії [10, с.80]. За словами вченого, поєднання когнітивного, мотиваційного та ціннісно-смислового компонентів культури споживання знаходять своє відображення в діях дітей, у їхній споживчій поведінці.

Саме діяльнісний компонент стає показником того, на якому рівні дитина засвоїла знання економічного змісту, наскільки усвідомила необхідність обирати серед низки своїх бажань і чим керується під час цього вибору, які цінності для неї $€$ пріоритетними, як вона орієнтується на них у різних соціально-економічних ситуаціях. Крім того, зміст діяльнісного компонента спрямовано на розвиток уміння встановлювати позитивні відносини із суб'єктами процесу споживання, здійснювати соціально доцільні дії [10].

Обґрунтовуючи зміст поняття «культура споживання» в дітей дошкільного віку, А. Крулехт визначив, що виховання основ культури споживання становить формування складного особистісного утворення, основою якого $є$ система усвідомлених цінностей дитини, зумовлене віковими особливостями. Автор уважає, що для дошкільників 5-6 років значущими ситуаціями використання матеріальних ресурсів можуть бути ситуації конструювання 3 «бросового» матеріалу.

Ураховуючи доступність та привабливість конструювання для дітей, ситуації, що потребують розумного використання наявних ресурсів набувають особливого значення для результативності цієї роботи [11, с.15]. На наш погляд, слушною ідеєю $€$ модульна організація розвивального середовища для експериментування та творчого конструювання дітьми старшого дошкільного віку. Завдання 3 економії ресурсів, мінімальної утилізації відходів дитина ставить перед собою самостійно в комплексі загального творчого завдання. Отже, дитина «занурюється» в атмосферу важливої для неї діяльності, набуває первинного досвіду культури споживання під час свого 
діяльнісного рішення. На думку вчених, основа культури споживання дошкільників містить кілька взаємопов'язаних компонентів.

Варіанти компонування трапляються різні, але, аналізуючи зміст, можна сказати, що розподіл компонентів $€$ досить типовим, можна поділити таким чином: емоційно-ціннісний, когнітивний, мотиваційнодіяльнісний. Емоційно-ціннісний компонент включає ставлення дитини до цінностей матеріальної культури, досвід користування з якими набуває в процесі діяльності. Когнітивний компонент пов'язаний із знаннями у ссрері культури споживання, їх усвідомленням та розумінням необхідності в різних життєвих ситуаціях.

Мотиваційно-діяльнісний - усвідомлені дії, завдяки яким дитина реалізує досвід культури споживання. Особливого значення в цьому зв'язку набуває бажання дотримуватися правил культури споживання та наслідувати їх у будь-яких обставинах. На думку А. Крулехта, саме діяльнісний компонент формує структурно-змістові характеристики культури споживання. Учений довів це, звертаючи особливу увагу на конструктивну діяльність дітей старшого дошкільного віку із «бросовим» матеріалом, де стрижнем соціального досвіду дитини $є$ свідома діяльність [11].

Отже, за результатами досліджень учених, виховання основ культури споживання в дітей старшого дошкільного віку відбувається за умови поєднання мотиваційного, когнітивного та діяльнісного компонентів. Означені компоненти знаходяться в тісному взаємозв'язку і доповнюють один одного. Проблему фрормування в дошкільників первинного економічного досвіду вивчала А. Сазонова. На її думку, перинний економічний досвід дітей старшого дошкільного віку містить мотиваційний (наявність у дитини інтересу до економічної сфрери життя 3 наявними знаннями й уміннями в цій галузі), інформаційний (наявність економічних уявлень, володіння елементарними економічними поняттями, розуміння основних економічних процесів та законів), операційний складники (сорормованість економічних дій, елементарних умінь та навичок економічної діяльності. Вивчення проблеми економічного виховання в умовах дитячого садка провела Р. Жуковська [4, с.205].

Пошук методів та прийомів формування ощадливості дитини здійснено в умовах тісної взаємодії з батьками вихованців. При цьому розглядається необхідність виховувати в дітей вміння зберігати потрібні речі для себе й для інших в умовах трудового виховання, приучення до порядку, виховання відповідальності за збереження речей. Автори (Т. Богдан, Н. Найдьон) наголошують на важливості формування в дітей дошкільного віку елементарного економічного досвіду, який потім стане базою для подальшої успішної соціалізації та економічного виховання особистості. Основним видом набуття елементарного економічного досвіду вчена визначає гру. 
У зв'язку із цим завдання економічної освіти вирішується засобами ігрової діяльності, ігрових прийомів, за допомогою яких закладаються основи економічного образу мислення в дитини дошкільного віку, пізнання нею власного «Я» у великому світі економічних цінностей. Р. Жуковська наводить вимоги до ігор економічної спрямованості. Серед них: дотримання поетапності впровадження ігор економічної спрямованості в навчально-виховний процес; обов'язкова термінологічна підтримка щодо ключових економічних понять; максимальна наближеність ігор до інтересів дітей; упровадження різних соціальноекономічних ролей та оцінка ситуації з різних позицій тощо.

Крім того, важливими вважаємо практичні рекомендації вченої 3 добору завдань та ситуацій економічної спрямованості для використання в роботі з дітьми старшого дошкільного віку для пізнавальної, предметно-практичної, зображувальної, художньо-мовленнєвої, театрально-ігрової діяльності [4]. Питанням фрормування первинних економічних знань дітей дошкільного віку та визначення змісту економічної освіти в дошкільному закладі присвячено праці Л. Галкіної, О. Дибіної, Є. Курак, А. Смоленцевої, Г. Шатової та ін. Зауважимо, що науково обґрунтовані закономірності, зміст, фрорми та методи формування економічних знань у старших дошкільників найбільш змістовно описано Л. Галкіною.

У своєму дослідженні автор розкриває умови, які забезпечують успішне засвоєння елементарних економічних знань, як:

1) системно-діяльнісний підхід;

2) побудова педагогічного процесу на основі спеціально розробленої системи, яка поєднує мету, зміст, форми та методи навчання на засадах взаємодії за типом педагог - дитина - батьки;

3) створення економічної предметно-просторової розвивальної середи; 4) технологія навчання дітей елементарним економічним знанням на етапах (емоційно-мотиваційний, когнітивний, діяльнісно-ігровий).

Автор вважає за мету та результат педагогічного процесу формування системи елементарних знань в галузі економіки. Критеріями, які визначають рівень знань дітей, є обізнаність (точність, повнота, об'єм, розмірність), усвідомленість (упевненість, логічність), дієвість (активність), умілість (використання отриманих знань в ігровій діяльності). Дослідник підкреслює, що економічна освіта сприяє розвитку економічного мислення та фрормуванню економічної культури, яка поєднує економічні знання та навички, що сприяють фрормуванню економічно значущих якостей особистості [3].

Логіка такої роботи, її зміст та організаційні заходи побудовані на послідовному методологічному підґрунті, у якому визначено й конкретизовано поняття «економічна освіта», «економічні знання», «економічна діяльність». Важливими умовами успішного фрормування елементарних економічних знань у дошкільників авторка вважає встановлення взаємодії за типом «педагог - дитина - батьки» та 
відповідну технологію, яка сприяє навчанню дітей елементарних економічних знань.

Е. Курак розглядала заняття 3 фрормування основ економічної культури як основну діяльність старших дошкільників. При цьому робив акценти саме на те, що вказані заняття повинні носити інтегрований характер. Таким чином ознайомлення дітей з основами економіки відбувається в тісному зв'язку із звичними для розкладу дошкільного навчального закладу заняттями. Як от: математика, розвиток мовлення, образотворча діяльність, ознайомлення 3 навколишнім [12, с. 80].

В Україні питання економічного виховання дітей дошкільного віку досліджували Н. Бєляєва, Н. Грама, Г. Григоренко, Р. Жадан, Н. Кривошея, Ю. Лелюк, А. Сазонова. Аналізуючи дисертаційні роботи з проблеми економічного виховання дошкільників, можна виявити кілька підходів до цієї проблеми. Так, Н. Бєляєва обґрунтувала можливість економічного виховання дітей 6-7 років в умовах дошкільного навчального закладу на засадах системного, аксіологічного та діяльнісного підходів.

Успішність економічного виховання дошкільників, на її думку, спирається на надання початкових уявлень про економічні явища, поступове цілеспрямоване залучення дітей до моральних цінностей суспільства. Авторка визначає поняття економічне виховання як педагогічний процес, спрямований на формування моральноекономічних якостей особистості: бережливості, відповідальності, підприємництва, а також засвоєння знань про економічне життя людей, зорієнтоване на ціннісні настанови.

Дослідниця описує педагогічні умови, що сприяють економічному вихованню дітей, як-от: наявність в освітньо-виховному процесі цілісної моделі економічного виховання дітей, що включає в себе системо-утворювальні ланки: мета, зміст, діяльність, педагогічні умови та прогнозований результат; створення виховного середовища, спрямованого на фрормування таких морально-економічних якостей особистості, як ощадливість, відповідальність, діловитість, підприємливість, що забезпечують життєдіяльність у суспільстві; організація та насичення видів дитячої діяльності (ігрової, трудової, пізнавальної) інфрормація про економічне життя сім'ї, людей, суспільства і розвиток на цій основі пізнавального інтересу до позитивних норм і цінностей соціально-економічного суспільства; взаємодія дошкільного навчального закладу і сім'ї у становленні економічної вихованості у дітей. Комплексний підхід до процесу економічного виховання висвітлено А. Сазоновою.

У науковому дослідженні, присвяченому формуванню первинного економічного досвіду дітей старшого дошкільного віку, пріоритет надано ігровій діяльності. Обґрунтовуючи поетапну систему ігор економічної спрямованості, учена пропонує поступове впровадження 
різних видів ігор для кожного 3 етапів формування первинного економічного досвіду дітей. Так, дидактичні ігри, що сприяють формуванню елементарних економічних понять, упроваджуються на першому етапі роботи й поступово доповнюються ситуативними, сюжетно-рольовими іграми, які спрямовані на засвоєння типових засобів розв'язання життєвих економічних завдань.

Методичною знахідкою дослідження вважаємо використання ігорстратегій для збагачення досвіду дій дітей у різноманітних соціальноекономічних ситуаціях. За А. Івановою, важливими категоріями економічного виховання дошкільників $є$ бережливість, відповідальність, винахідливість. Так, бережливість як якість максимально ілюструє інтеграційне поєднання економічного та морального компонентів виховання. Вона має своє вираження у збереженні особистого, суспільного майна, економному використанні ресурсів та матеріалів; у позитивному ставленні до речей, природи, результатів власної праці та праці інших людей. Учена пропонує формувати зміст економічного виховання у формі елементарних знань, наприклад, навчити правильного ставлення до грошей, засобів їх заробляння та розумного використання; пояснити зв'язок між економічними та етичними категоріями: праця, гроші, ціна, з одного боку, та моральними - бережливість, чесність, економність, заощадливість, щедрість - 3 іншого; виховувати поведінку в реальних життєвих ситуаціях, розвивати розумні потреби [8, с.45].

Дослідження Р. Жуковської доводять важливість виховання в дітей бережливості. Авторка розглядала цю проблему в моральному та економічному аспектах виховання, звертала увагу на те, як діти ставляться до особистих речей та суспільного майна. Р. Жуковська довела, що формуванню бережливості сприяють знання про речі як результат діяльності людей праці, про особистісні якості працівника.

Зазначимо, що відповідальність як якість має моральний початок, відтворює здібності дитини відповідати за власні вчинки та поширюється на соціальну сферу діяльності особистості. Відповідальність фрормується як результат вимог до особистості. Усвідомлені вимоги перетворюються на внутрішню мотивацію поведінки дитини. Так, Н. Кривошея підкреслювала, що у старшому дошкільному віці діти починають виділяти себе в трудовій діяльності в системі взаємин. На ії думку, вирішення проблеми економічного виховання дошкільників слід розглядати як завдання трудового та морального виховання.

До важливих категорій економічного виховання можна віднести вміння налагоджувати та зберігати взаємини. На думку Ю. Лелюк, економічне мислення потрібно формувати саме з дошкільного віку, адже всі будуть членами суспільства: відповідно споживачами або виробниками, роботодавцями або найманими працівниками, інвесторами або лише тими, хто збирає гроші [13, с. 63]. Дослідниця 
аналізує досвід дошкільної економічної освіти за кордоном. У Швеції ставиться акцент на вихованні розумного споживача (дітей вчать не витрачати гроші на цукерки, а харчуватися корисною і здоровою їжею: фрруктами, овочами, вчать готувати з них салати). На спеціальних заняттях дітей вчать бережливому ставленню до одягу і взуття, що дозволяє економити сімейний бюджет.

Дошкільна економічна освіта в Японії починається з екскурсії на фабрику, на біржу праці, в банк, де дітей знайомлять із працею дорослих людей [13]. Для створення позитивного ставлення та звички до праці найважливіше значення, на думку Е. Радіної, має приклад дорослого. Отже, проведений аналіз першоджерел дозволив дійти висновку, що економічне виховання дітей старшого дошкільного віку цілісний педагогічний процес, спрямований на засвоєння ними елементарних економічних знань, набуття власного первинного економічного досвіду, розвиток ціннісного ставлення до праці, формування моральних якостей (працелюбність, відповідальність, ощадливість, дисциплінованість), що сприяє розвитку особистості. Система виховних впливів щодо економічного виховання має бути зорієнтована на сучасні вимоги, актуальний рівень майбутнього (проектованого) розвитку економіки, ураховувати (проектовані або майбутні) потреби особистості в суспільстві.

Висновок. Таким чином, економічне виховання дітей дошкільного віку включає три взаємопов'язані та взаємозумовлені компоненти. А саме: когнітивний, моральний, діяльнісний. Перший із них зорієнтовано на забезпечення дітей елементарними економічними знаннями та усвідомлення їхньої цінності. Моральний компонент передбачає формування ціннісних уявлень про працю, природу, родину, внутрішніх мотивів до дії, переконань, розвиток моральних якостей (працелюбність, відповідальність). Діяльнісний (виконання завдань в ігровій формі, рішення ситуацій, виконання практичної роботи).

Отже, у дітей старшого дошкільного віку формування основ культури споживання $€$ процес цілеспрямованої, систематичної взаємодії дорослих (вихователів, батьків) і вихованців, під час якого відбувається набуття дітьми стійких навичок культури споживання в побуті, соціумі, різних видах діяльності. Культура споживання не зводиться до формального виконання правил. Вона тісно пов'язана 3 бажаннями, можливостями та усвідомленим наслідуванням кращих прикладів культури споживання.

\section{Список використаних джерел}

1. Вовк Н. В. Підготовка майбутнього вчителя технологій до формування культури споживання в учнів загальноосвітньої школи: дис. канд. пед. наук: 13.00.04. Слов'янськ, 2016. 220 с.

2. Галузинський В. М. Євтух М.В. Основи педагогікі та псіхології віщої школи в Україні: Наукова думка, 1995. 345 с.

3. Галкина Л. Н. Формирование элеметарных экономических знаний у детей старшего дошкольного возраста: автореф. дис. канд. пед. наук: 13.00.07. 
Челябинск, 1999. 225 с.

4. Жуковская Р. И. Воспитание бережного отношения к личным вещам и общественному достоянию. К.: Просвещение, 1968. С. 205-262.

5. Іонін Л. Г. Соціологія культури. Думка, 1996. 173 с.

6. Ільїн Є. П. Мотівація и мотиви. СПб. Київ, 2000. 187 с.

7. Іванчук С. А. До проблеми визначення рівнів вихованості основ культури споживання у дітей старшого дошкільного віку. Людинознавчі студії зб. наук. пр. Педагогіка. Дрогобич: Вид. від. ДДПУ ім. І. Франка, 2016. Вип. 3/35. С. $118-127$.

8. Іванова А. В. Педагогічний огляд проблеми економічного виховання дошкільників. матеріали I Міжнар. наук.-практ. конф. Луганськ. Знання, 2006. С. 43-45.

9. Кикнадзе Д. О. Потреби, поведінка, виховання. Київ. Думка, 1968. 278 с.

10. Крулехт М. В. Проблема целостного развития ребенка-дошкольника как субъекта трудовой деятельности: монографрія, СПб. Акцидеит, 1995. 80 с.

11. Крулехт А. А. Конструирование из бросового материала как средство воспитания основ культуры потребления у мальчиков 5-6 лет: автореф. дис. канд. пед. наук: 13.00.07. Елец, 2009. 20 с

12. Курак Е. А. Экономическое воспитание дошкольников. Київ. Сфрера, 2002. 80 с.

13. 13.Лелюк Ю. М. Сучасні проблеми дошкільної економічної освіти в Україні. Економічна освіта: проблеми і перспективи: матеріали II Міжнар. наук.-практ. конф. Черкаси, 2001. С. 63-66.

14. Леонтьєв О. М. Філософрія психології: з наукової спадщини. Наукова думка, 1994. 228 c.

15. Моль А. Социодинамика культуры . Издательство ЛКИ, 2008. 416 с.

16. Ольшанський В. Б. Особистість і соціальні цінності в 2 т. Думка, 1966. 532 с.

17. Обуховський К. Психологія потягів людини. Владос, 1972. 478 с.

18. Піндайк Д. І. Психологія Споживача. СПб. Київ, 2003. 279 с.

19. Фрейд 3. Вступ до психоаналізу. Київ. Основи, 1998. 709 с.

20. Фортунатов Г. А. Проблема потреб в психології особистості, «Питання психології». К. Наукова думка, 1961. 543 с. 


\title{
РОЗДІЛ 2 \\ ТЕОРІЯ ТА МЕТОДИКА ПОЧАТКОВОЇ ОСВІТИ: РЕАЛІЇ, ПРОБЛЕМИ ТА ПЕРСПЕКТИВИ
}

\author{
МЕТОДИКА РОБОТИ З РОЗВИТКУ МОВЛЕННЯ \\ МОЛОДШИХ ШКОЛЯРІВ 3 ІНТЕЛЕКТУАЛЬНИМИ \\ ПОРУШЕННЯМИ
}

\author{
Боряк О.В. \\ доктор педагогічних наук, доцент, \\ Сумський державний педагогічний університет імені А.С. Макаренка
}

Порушення мовлення дітей із особливими освітніми потребами (ООП) залишається актуальною проблемою сьогодення. У зв'язку зі змінами нормативно-законодавчої бази та гуманізації відносин в освітньому просторі виникає потреба в подальшому вдосконаленні процесу навчання, виховання й розвитку цієї категорії дітей, одне 3 провідних місць серед яких займають діти з інтелектуальними порушеннями - розумовою відсталістю різного ступеню тяжкості.

Специфіка порушень мовленнєвої діяльності (ПМД) у дітей 3 інтелектуальними порушеннями (ДІП) визначається, насамперед, особливостями вищої нервової діяльності та психічного розвитку, до яких належать: слабкість замикальної фрункції кори головного мозку, слабкість процесів внутрішнього гальмування, інертність нервових процесів, порушення взаємодії першої та другої сигнальних систем, зниження регулюючої функції мовлення, яка в нормі відіграє важливу роль у розвитку дитини. Названі особливості $є$ основними чинниками недорозвитку мовлення цієї категорії дітей (Н. Баль, Л. Баряєва, В. Баудіш, О. Боряк, Б. Брьозе, С. Геращенко, І. Дмитрієва, А. Єгорова, С. Ільїна, Г. Каше, Н. Кравець, Р. Лалаєва, В. Ліпакова, В. Лубовський, О. Лурія, О. Мамічева, М. Матвєєва, С. Миронова, І. Омельянович, М. Певзнер, В. Петрова, Г. Піонтківська, І. Позднякова, М. Савченко, В. Синьов, Є. Соботович, М. Стразулла, В. Тищенко, О. Хохліна, Д. Шульженко, A. Clarke, M. Levis, S. Rosenberg, G. Pruthi, T. Ernest Newland та ін.).

Порушення мовленнєвої діяльності ДІП мають системний характер. Їм притаманний недорозвиток мовлення як цілісної функціональної системи, наявні порушення всіх його компонентів: фонетико-фронематичного, лексико-семантичного, логіко-граматичного, характерні порушення як імпресивного, так і експресивного, як усного, так і писемного мовлення. В обраної категорії дітей несформовані всі операції мовленнєвої діяльності: має місце слабкість мотивації, 
зниження потреби в мовленнєвому спілкуванні, грубо порушене програмування мовленнєвої діяльності, створення внутрішньої програми мовленнєвих дій, їі реалізація та контроль за мовленням; порівняння отриманого результату 3 попереднім задумом, його відповідність мотиву й меті мовленнєвої діяльності (А. Аксьонова, Л. Баряєва, О.Боряк, Л. Вавіна, В. Воронкова, С. Геращенко, М. Гнєзділов, О. Граборов, І. Дмитрієва, Г. Дульнєв, І. Єременко, С. Конопляста, Н. Кравець, Р. Лалаєва, О. Мамічева, С. Миронова, М. Певзнер, В.Петрова, О.Проскурняк, В. Синьов, Є. Соботович, В. Тищенко, Т. Ульянова та ін.).

Під час багаторічних досліджень нами було розроблено та апробовану комплексну системи діагностики, формування та корекції мовленнєвої діяльності молодших школярів із інтелектуальними порушеннями - розумовою відсталістю легкого та помірного ступенів тяжкості. Цю систему було покладено в основу корекційнорозвивальної роботи з обраною категорією дітей як в спеціальних так і інклюзивних закладах освіти.

Представлена комплексна диференційована система фоормування та корекції мовленнєвої діяльності молодших школярів 3 інтелектуальними порушеннями (легким та помірним ступенями розумової відсталості) розрахована на вчителів-логопедів, дефектологів спеціальних закладів загальної середньої освіти. Окремі матеріали системи можуть використовуватися фахівцями відповідного профілю закладів інклюзивної освіти, де навчаються молодші школярі з легким ступенем розумової відсталості, фахівцями інклюзивноресурсних центрів (IРЦ).

Було доведено, що результативність процесу формування та корекції мовленнєвої діяльності молодших школярів 3 інтелектуальними порушеннями можлива за умов:

> відповідності корекційно-розвивальної роботи програмним вимогам, використання відповідних форм, методів і прийомів, урахування вікових, індивідуальних мовленнєвих та психофізичних особливостей дітей;

реалізації корекційної спрямованості освітнього процесу, впровадження індивідуального та диференційованого підходу, дотримання вимог до його здійснення: систематичного та всебічного вивчення, володіння різноманітними елементами педагогічної техніки (вербальними й невербальними прийомами впливу);

диференційовано-індивідуального оцінювання досягнень учнів, відповідно до показників розвитку мовленнєвих компетентностей;

розробки індивідуальних корекційно-розвивальних програм роботи 3 урахуванням пізнавальних можливостей та індивідуальної динаміки поступального розвитку молодшого 
школяра з легким ступенем розумової відсталості (для закладів інклюзивної освіти);

взаємозв'язку в роботі педагогічного колективу, практичного психолога (за необхідністю фрахівців медичного профрілю психіатра, психоневролога);

$>$ успішної адаптації учнів шляхом двостороннього емоційного контакту вчителя-логопеда (дефектолога): тактовного, доброзичливого ставлення до дитини, позитивної емоційної оцінки будь-якого ії досягнення;

> співпраці вчителя-логопеда (дефектолога) 3 батьками, спрямованої на підвищення ефрективності корекційнорозвивальної роботи, шляхом повідомлення про актуальні та потенційні можливості кожної дитини, залучення батьків до сумісної роботи в межах співпраці «учитель-логопед - дитина батьки» [5; 6; 7; 12].

Завдання вчителя-логопеда (дефектолога) закладу освіти:

$>$ створення єдиного корекційно-розвивального простору;

$>$ обладнання предметно-розвивального середовища, яке стимулює мовленнєвий, пізнавальний і особистісний розвиток учня;

$>$ пропаганда уроків із розвитку мовлення серед батьків, педагогів;

$>$ інтегрування зусиль педагогів, батьків, учнів 3 метою формування та корекції мовленнєвої діяльності.

Можна виділити специфічні особливості корекційно-розвивальної роботи з обраною категорією дітей: постійний пошук індивідуальних підходів до учня, уроки з розвитку мовлення носять комбінований та ігровий характер, фрормування наслідувальної діяльності, організація контексту уроку, спостереження за внутрішнім станом дитини, моделювання ситуацій досягнення, повільний темп формування нових навичок, постійна затребуваність придбаних навичок [4].

У процесі формування та корекції мовленнєвої діяльності вирішуються такі завдання:

формування в учнів фонетичної компетентності (закріплення вимови збережених звуків, виправлення вимови порушених звуків);

$>$ розвиток фонематичного сприймання;

$>$ фрормування навичок звуко-складового аналізу та синтезу;

$>$ формування лексичної компетентності (збагачення та актуалізація експресивного та імпресивного словників);

формування граматичної компетентності (корекція граматичних порушень);

розвиток діамонологічної компетентності (зв'язного мовлення, активної свідомої мовленнєвої діяльності);

розвиток просодичної сторони мовлення; 
попередження/виправлення специфічних розладів писемного мовлення [10, с. 15-16].

У достатній кількості джерел методичного спрямування визначено посадові обов'язки вчителів-логопедів закладів дошкільної, загальної середньої освіти [8; 10].

Організація корекційно-розвивального процесу. Відповідно до Типової освітньої програми [11], подано Типовий навчальний план початкової освіти для спеціальних закладів (класів) загальної середньої освіти 3 українською мовою навчання дітей 3 інтелектуальними порушеннями $[11$, с. 7], відповідно до якого, освітня галузь «Корекційно-розвиткова робота» включає предмет - розвиток мовлення, з чотирьохгодинним тижневим навантаженням. «Розподіл навчальних годин за темами, розділами, вибір форм і методів навчання вчитель визначає самостійно, враховуючи пізнавальні здібності та можливості учнів 3 порушеннями інтелектуального розвитку, конкретні умови роботи, забезпечуючи водночас досягнення корекційно-розвивальних завдань та орієнтовних очікуваних результатів» [11, с. 6].

31 по 15 вересня вчитель-логопед, дефектолог, практичний психолог, класовод (вчитель початкових класів) проводять обстеження дітей, яким за висновками ІРЦ (ПМПК) рекомендовано навчання за відповідною програмою (для легкого або помірного ступенів розумової відсталості), новоприбулих дітей. Учителем-логопедом (дефектологом) визначається актуальний стан мовленнєвого розвитку, заповнюється відповідна документація.

Чотири рази на тиждень, з підготовчого по четвертий класи, проводяться уроки з розвитку мовлення за класно-урочною системою навчання. Тривалість уроків визначена частиною п'ятою статті 16 Закону України «Про загальну середню освіту» і становить: підготовчі класи - 30 хв., перші класи - 35 хв., другі - четверті класи - 40 хв.

Форми організації уроків - підгрупові або фронтальні, залежно від наповнюваності класу учнями 3 мовленнєвими порушеннями. За розкладом, корекційно-розвивальна робота здійснюється з 11 години (для підготовчих класів), після 12 - для перших - четвертих класів, після завершення основного розкладу навчальних предметів.

Готуючись до уроку педагог повинен:

визначити тему та мету уроку;

визначити основні етапи уроку, забезпечити їх взаємозв'язок і послідовність;

визначити фонетичний, лексичний і граматичний матеріал згідно з темою та метою уроку;

підібрати відповідний наочний матеріал;

продумати й підготувати використання дидактичного матеріалу (ігор, вправ, завдань); 
передбачити прийоми, які забезпечують індивідуальний підхід і спонукають дітей до активної мовленнєвої та пізнавальної діяльності.

Наприкінці вересня проводиться психолого-педагогічний консиліум (керівник закладу або заступник директора з навчально-виховної роботи, класовод, психолог, учитель-логопед (дефектолог), під час якого вчитель-логопед (дефектолог) знайомить фрахівців із результатами обстеження, стратегічними напрямами здійснення корекційно-розвивальної роботи.

Ефективність і результативність корекційно-розвивальної роботи залежить від здійснення комплексного підходу (колективного впливу на учнів з боку вчителя-логопеда (дефектолога), вчителя початкових класів, вихователя, практичного психолога, музичного керівника, батьків, у деяких випадках - лікарів, інструктора з ЛФК).

3 цією метою, на початок навчального року вчитель-логопед проводить консультування (виступи на педагогічних радах), щодо інформування педагогів закладу освіти про специфіку та прояви порушень мовлення в учнів, визначення стратегії інтегрованої взаємодії фрахівців. Протягом навчального року (не менше трьох разів на навчальний рік) відбуваються наради щодо подальшої тактики здійснення сумісної корекційно-розвивальної роботи.

У зошиті взаємозв'язку вчитель-логопед фіксує завдання для всіх учнів класу (групова робота), індивідуальні завдання для окремих дітей. Це можуть бути: дихальні вправи, вправи артикуляційної гімнастики, вправи на розвиток загальної та дрібної моторики пальців і кистей рух, вправи на розвиток артикуляційної моторики, мімічної мускулатури, фронопедичні вправи на розвиток сили та висоти голосу, вправи на закріплення й автоматизацію правильної вимови звуків, розширення словника, вправляння навичок словозміни та словотворення.

Важливим, на нашу думку, $є$ сумісне планування й визначення корекційної мети до уроків з інших навчальних предметів, спрямованої на провідні психічні процеси, які виступають базисом для мовленнєвої діяльності; закріплення та відпрацювання різних складових мовленнєвої діяльності.

Під час здійснення комплексного підходу до процесу формування й корекції мовленнєвої діяльності обраної категорії дітей необхідно поєднувати психокорекційну роботу з корекційно-розвивальною. Це стосується сумісної співпраці вчителя-логопеда (дефектолога) практичного психолога протягом усього навчального року.

Особливості мовленнєвої діяльності зумовлюють необхідність сумісної співпраці вчителя-логопеда (дефектолога) з учителем музики: впровадження на уроках музичного мистецтва елементів логоритміки. Учитель музики під час роботи з учнями з порушеннями мовлення може вирішувати низку завдань логокорекційного (корекційно- 
розвивального) впливу: розвиток тембрового слуху, голосу, співочого діапазону, почуття ритму, слухової уваги, фонематичного слуху, артикуляційної моторики, мовленнєвого дихання, ротового видиху, дикції тощо. Обов'язковою рекомендацією $€$ сумісне планування змістовної наповнюваності уроків: педагоги повинні знати, яка група звуків (звук) відпрацьовується на уроках із розвитку мовлення, яка лексична тема вивчається в певний період часу. Приблизний план здійснення міжпредметних зв'язків уроків розвитку мовлення з іншими навчальними предметами подано в таблиці 1.

Аналізуючи й оновлюючи змістовну наповнюваність уроків розвитку мовлення ми виявили певні протиріччя, які, на нашу думку, негативно впливають на якість фронетико-фонематичної сторони мовлення обраної категорії дітей.

У логокорекційній роботі існує певна технологія послідовності роботи над постановкою/виправленням звуків, в основу якої покладена та послідовність, яка визначена природнім фрізіологічним процесом фрормування звуковимови в дітей у нормі. Якщо спиратися на комплексний підхід до розвитку мовлення молодших школярів 3 інтелектуальними порушеннями, то найбільші інтегровані зв'язки встановлюються 3 навчальними предметами мовно-мовленнєвого спрямування - формування навичок читання й письма.

В основу букварного періоду опанування грамотою покладений аналітико-синтетичний метод, в основі якого покладена певна періодизація вивчення звуків і букв, яка не співпадає з етапами логокорекційної роботи. Виникає певна розбіжність, коли учень 3 інтелектуальними порушеннями на уроках із розвитку мовлення опановує вимовою та слуховим аналізом одних звуків, а на уроках формування навичок читання й письма - вивчає зовсім інші, артикуляційно складні звуки. Як результат, відсутні або спотворені в звуковимові звуки на уроках закріплюються, що ускладнює та подовжує роботу над фонетико-фонематичною стороною мовлення на невизначений термін.

Окремим напрямом роботи в аспекті комплексного впливу на розвиток мовлення ДІП МШВ є взаємозв'язок між учителем-логопедом (дефектологом) та батьками.

Сьогодні батьки дітей із порушеннями мовлення, завдяки великому масиву інформації в Інтернет-джерелах, вважають себе достатньо освіченими щодо порушень мовлення та прийомів їх корекції. При цьому, самі батьки, як правило, провокують певні ускладнення в мовленнєвому розвитку своїх дітей. Не володіючи методиками виправлення та постановки звуків "домашні логопеди» сприяють появі в мовленні дітей великої кількості спотворень: горлової, міжзубної, бічної вимови, замін тощо, які потім важко корегуються, особливо в ДІП. 
Міжпредметні зв'язки уроків розвитку мовлення та інших навчальних предметів (1-й семестр, 1 клас)

\begin{tabular}{|c|c|c|c|c|}
\hline Клас & $\begin{array}{l}\text { Навчальний } \\
\text { предмет }\end{array}$ & $\begin{array}{l}\text { Дата } \\
\text { прове- } \\
\text { дення } \\
\text { (місяць) }\end{array}$ & Тема уроку & Напрями корекційно-розвивальної роботи \\
\hline \multirow[t]{3}{*}{1} & \multirow[t]{3}{*}{$\begin{array}{l}\text { Навчання } \\
\text { грамоти } \\
\text { (Формування } \\
\text { навичок читання } \\
\text { й письма) }\end{array}$} & вересень & $\begin{array}{l}\text { Робота за серією малюн- } \\
\text { ків з теми «Ввічливі } \\
\text { слова». Моделювання } \\
\text { різних ситуацій «Добрий } \\
\text { ранок!», «Добрий день!» }\end{array}$ & $\begin{array}{l}\text { Розвиток загальної та дрібної моторики; } \\
\text { Формування лексичної компетентності: розширення активного } \\
\text { словника ввічнивими словами: «Добрий, день, дорий ранок, } \\
\text { дякую, будь-ласка» }\end{array}$ \\
\hline & & жовтень & $\begin{array}{l}\text { Називання предметів } \\
\text { «Хто це?». Власні імена } \\
\text { членів родини. Сімейний } \\
\text { альбом }\end{array}$ & $\begin{array}{l}\text { Формування лексичної компетентності. Лексична тема } \\
\text { «Родина»: розширення словника іменами членів родини, які } \\
\text { відповідають на запитання «Хто це?» }\end{array}$ \\
\hline & & листопад & $\begin{array}{l}\text { Робота з предметними } \\
\text { малюнками «Осінь». } \\
\text { Складання цілих речень }\end{array}$ & $\begin{array}{l}\text { Формування лексичної компетентності: лексична тема «Осінь». } \\
\text { Розширення словника прикметників ознаками осені. } \\
\text { Формування діалогічної компетентності. Складання простих } \\
\text { речень зі слів, наданим початком, за сюжетним малюнком } \\
\text { тощо }\end{array}$ \\
\hline & & листопад & $\begin{array}{l}\text { Розгляд і називання } \\
\text { натуральних предметів } \\
\text { на дотик з теми «Овочі» }\end{array}$ & $\begin{array}{l}\text { Формування лексичної компетентності. Лексична тема } \\
\text { «Овочі»: словник іменників: картопля, морква, капуста, буряк, } \\
\text { помідор. Словник прикметників: великий, малий, круглий, } \\
\text { довгастий, червоний, жовтий тощо }\end{array}$ \\
\hline & & грудень & $\begin{array}{l}\text { Називання предметів та } \\
\text { їх дій. Робота з } \\
\text { предметними } \\
\text { малюнками }\end{array}$ & $\begin{array}{l}\text { Логоритмічні вправи: проговорювання віршованих текстів із } \\
\text { простукуванням або проплескуванням. } \\
\text { Формування лексичної компетентності: словник іменників } \\
\text { назвами неживих предметів, які відповідають на запитання } \\
\text { «Що це?» }\end{array}$ \\
\hline & Я досліджую світ & вересень & $\begin{array}{l}\text { Довкілля. Світ навколо } \\
\text { мене: природа, люди, }\end{array}$ & $\begin{array}{l}\text { Формування фонетичної компетентності: розрізнення } \\
\text { мовленнєвих і немовленнєвих звуків; звуконаслідування в }\end{array}$ \\
\hline
\end{tabular}




\begin{tabular}{|c|c|c|c|}
\hline & & речі. Такий різний світ & $\begin{array}{l}\text { мовленні. } \\
\text { Формування лексичної компетентності: розширення словника } \\
\text { словами, що позначають предмети навколишньої дійсності }\end{array}$ \\
\hline & жовтень & $\begin{array}{l}\text { Хто я, моє ім'я та } \\
\text { прізвище }\end{array}$ & $\begin{array}{l}\text { Формування лексичної компетентності: розширення словника } \\
\text { іменників, прикметників. } \\
\text { Формування діамонологічної компетентності: складання } \\
\text { діалогу - розповіді за темою «Хто я» }\end{array}$ \\
\hline & листопад & $\begin{array}{l}\text { Фрукти: груша. Ознаки, } \\
\text { колір, фрорма, розмір, } \\
\text { твердість, гладкість, } \\
\text { смак, запах }\end{array}$ & $\begin{array}{l}\text { Формування лексичної компетентності: розширення словника } \\
\text { іменників за лексичною темою «Овочі», прикметників за } \\
\text { основними ознаками. Формування діамонологічної } \\
\text { компетентності: складання описової розповіді за наданими } \\
\text { словами, початком, схемою з опорою на предметні малюнки } \\
\text { або предмети }\end{array}$ \\
\hline & листопад & $\begin{array}{l}\text { Тварини. Зовнішній } \\
\text { вигляд }\end{array}$ & $\begin{array}{l}\text { Формування лексичної компетентності: розширення словника } \\
\text { іменників за лексичною темою «Свійські тварини», } \\
\text { прикметників за основними ознаками. Формування } \\
\text { діамонологічної компетентності: складання описової розповіді } \\
\text { за наданими словами, початком, схемою з опорою на } \\
\text { предметні малюнки }\end{array}$ \\
\hline $\begin{array}{l}\text { Соціально- } \\
\text { побутове } \\
\text { орієнтування }\end{array}$ & вересень & $\begin{array}{l}\text { Орієнтування в школі: } \\
\text { їдальня, спортивна зала }\end{array}$ & $\begin{array}{l}\text { Орієнтування в просторі: засвоєння основних напрямів - зліва, } \\
\text { справа, вгорі, внизу. } \\
\text { Формування лексичної компетентності: розширення словника } \\
\text { назвами приміщень школи }\end{array}$ \\
\hline & жовтень & $\begin{array}{l}\text { Основи догляду за } \\
\text { власним житлом } \\
\text { (застилання ліжка, } \\
\text { правила отримання } \\
\text { порядку у власних речах) }\end{array}$ & $\begin{array}{l}\text { Формування лексичної компетентності: розширення словника } \\
\text { за лексичною темою «Меблі». } \\
\text { Формування граматичної компетентності: словозміни: } \\
\text { узгодження іменників і дієслів, відмінювання іменників однини з } \\
\text { дієсловами за відмінками }\end{array}$ \\
\hline & листопад & Гігієна тіла & $\begin{array}{l}\text { Формування просторово-орієнтаційних навичок по відношенню } \\
\text { тіла до оточуючих предметів та об'єктів. } \\
\text { Формування лексичної компетентності: розширення словника } \\
\text { іменників назвою частин тіла }\end{array}$ \\
\hline
\end{tabular}




\begin{tabular}{|c|c|c|c|c|}
\hline & & грудень & $\begin{array}{l}\text { Послідовність одягання } \\
\text { та роздягання }\end{array}$ & $\begin{array}{l}\text { Формування лексичної компетентності: словника дієслів. } \\
\text { Формування граматичної компетентності: узгодження іменників } \\
\text { і дієслів за родами, часом. } \\
\text { Формування діамонологічної компетентності: складання } \\
\text { діалогу за темою «Послідовність одягання» }\end{array}$ \\
\hline & & січень & $\begin{array}{l}\text { Підбір одягу відповідно } \\
\text { до сезону }\end{array}$ & $\begin{array}{l}\text { Формування лексичної компетентності: розширення словника } \\
\text { за лексичною темою «Одяг». } \\
\text { Формування граматичної компетентності: словозміни: } \\
\text { узгдження іменників і дієслів, відмінювання іменників однини } 3 \\
\text { дієсловами за відмінками }\end{array}$ \\
\hline \multirow[t]{5}{*}{1} & $\begin{array}{l}\text { Музичне } \\
\text { мистецтво }\end{array}$ & вересень & Звуки живої природи & $\begin{array}{l}\text { Формування мовленнєвого дихання з опорою на співацьку } \\
\text { поставу: носового вдиху, ротового видиху. } \\
\text { Розвиток чуття ритму. } \\
\text { Формування фонетичної компетентності: приспівування } \\
\text { голосних різною манерою виконання (довго, коротко, м'яко, } \\
\text { гостро), з різною силою голосу }\end{array}$ \\
\hline & & вересень & Звуки голосу & $\begin{array}{l}\text { Розвиток слухового сприймання: розрізнення джерела, сили } \\
\text { звучання. } \\
\text { Розвиток фонематичного сприймання: розрізнення голосних і } \\
\text { приголосних, дзвінких і глухих. } \\
\text { Формування фонетичної компетентності: проспівування } \\
\text { ланцюжка голосних, ланцюжка прямих складів. } \\
\text { Розвиток чуття ритму, тембрального слуху }\end{array}$ \\
\hline & & жовтень & $\begin{array}{l}\text { Українські народні } \\
\text { інструменти }\end{array}$ & $\begin{array}{l}\text { Логоритмічні вправи: виконання рухів під музику з } \\
\text { римодекламацією в } \\
\text { різному темпі, з різною силою голосу. Розвиток просодичної } \\
\text { сторони мовлення: сили, висоти, тембральної окраси, } \\
\text { ритмічного офрормлення. }\end{array}$ \\
\hline & & листопад & Де живуть звуки? & $\begin{array}{l}\text { Розвиток слухового сприймання, просодичної сторони } \\
\text { мовлення, мовленнєвого дихання, чуття ритму }\end{array}$ \\
\hline & & грудень & Музичні регістри & Розвиток тембрального слуху, тембральної окраси голосу \\
\hline
\end{tabular}


Інші батьки, які, на їх думку, володіють певними знаннями, висувають завищені вимоги до фахівців, які працюють з їх дітьми, при цьому уникають прикладання особистих зусиль, які б сприяли просуванню дитини в опануванні мовленням.

$€$ батьки, які пасивні по відношенню до дитини, і навпаки, $€$ такі, які висувають завищені очікування, щодо загального психомовленнєвого розвитку своєї дитини.

Крім загально інформаційної роботи: консультацій із питань навчання й виховання; оформлення стендів, «папок-пересувок» та іншого наочного матеріалу - педагог здійснює й додаткові форми роботи з батьками.

Першою такою фрормою роботи $є$ пояснення завдання вчителялогопеда (дефектолога), специфіки уроків із розвитку мовлення, особливостей мовленнєвого розвитку в нормі та при порушеному розвитку. Важливо, щоб робота щодо інформування батьків проводилася постійно й систематично. 3 цією метою ми пропонуємо таку форму співпраці з батьками, як «Батьківська школа» (або «Освіторій для батьків дітей із порушеннями мовлення»). Відповідно до цієї форми роботи на навчальний рік планується певна кількість (не менше трьох) виступів учителів-логопедів (дефектологів) під час батьківських зборів, які, як правило, у СЗЗСО проводяться один раз на місяць.

Комплексний підхід до формування та корекції мовленнєвої діяльності ДІП МШВ подано на рис. (рис. 1).

У межах «Батьківської школи» - проведення відкритих уроків (Днів відкритих дверей). Як показав досвід, корисно поєднувати уроки зі зборами, тоді батьки з більшою зацікавленістю ставляться до їхнього відвідування.

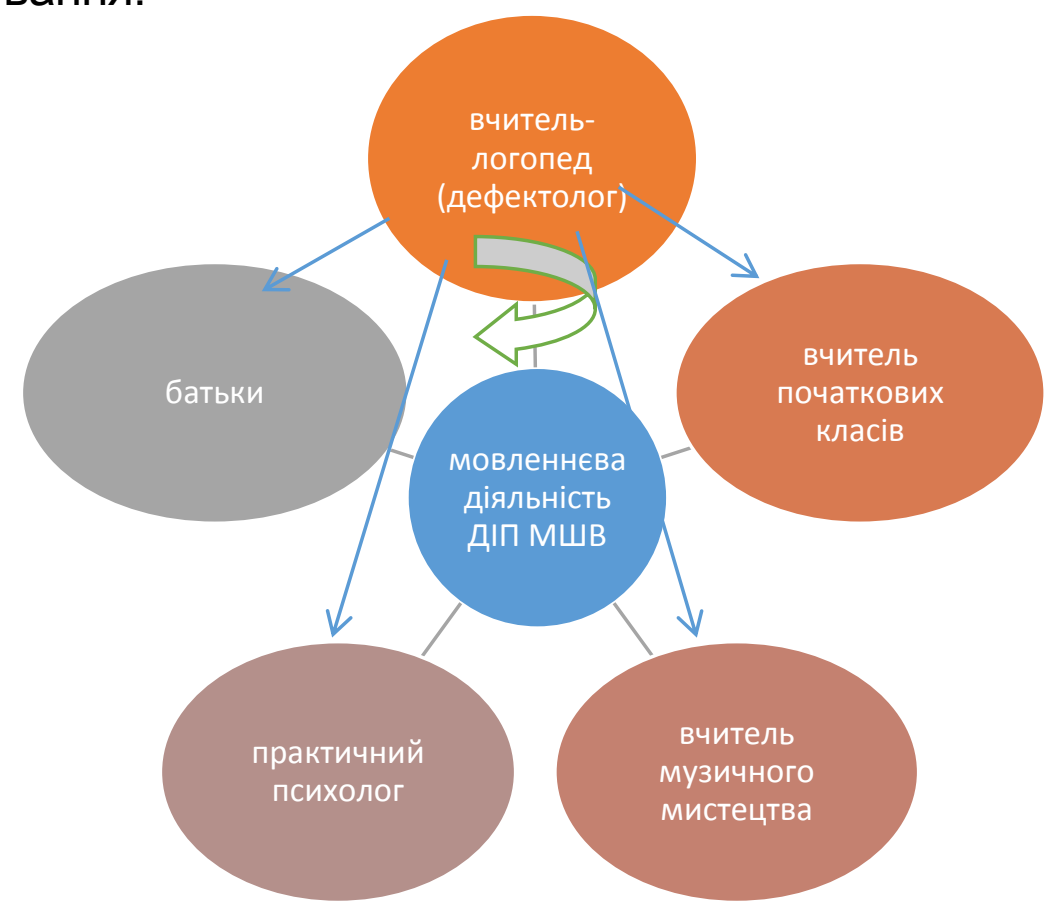

Рис. 1. Комплексний підхід до фрормування та корекції мовленнєвої діяльності ДІП МШВ 
Але основною, на нашу думку, самою дієвою формою співпраці 3 батьками є зошити взаємозв'язку (за аналогією із зошитами вчителів початкових класів і вихователів). Важливо переконувати батьків у необхідності закріплення того матеріалу, що записаний у зошиті, тому що без оволодіння цими знаннями й навичками неможливо просуватися далі в навчанні, але при цьому, під час індивідуальних консультацій, бажано проводити 3 батьками роз'яснювальну роботу. Відповідно до цього, раз на місяць, планується консультативний день, під час якого за бажанням батьків проводяться індивідуальні консультації.

Гострою $є$ проблема фрорми організації уроків із розвитку мовлення, під час яких і здійснюється відповідна корекційнорозвивальна робота, оскільки в межах класно-урочної системи виникають труднощі під час комплектації груп для корекційнорозвивальних уроків (різні рівні розвитку мовленнєвої діяльності, проявів порушень мовлення в учнів з одного класу), здійснення індивідуальної корекційно-розвивальної роботи (постановки/ виправлення звуковимови).

Одним із найголовніших завдань навчання дітей із легким i помірним ступенями розумової відсталості $€$ розвиток, формування й корекція мовленнєвої діяльності, а саме компетентностей мовленнєвої діяльності: словникового запасу або лексичної компетентності, граматичної будови мовлення або граматичної компетентності, вимови звуків або фонетичної компетентності, зв'язного мовлення або діамонологічної компетентності, писемного мовлення.

Програму з розвитку мовлення розроблено 3 урахуванням особливостей психічного, пізнавального, мовленнєвого розвитку, підготовленості дітей із інтелектуальними порушеннями до навчання. 3 урахуванням того, що розвиток цих дітей відбувається особливо повільно в перші роки навчання, Програма з розвитку мовлення передбачає врахування темпів формування й корекції мовленнєвої діяльності - впродовж п'яти років (у підготовчому, 1-4 класах). Зокрема, зміст матеріалу в Програмі 3 розвитку мовлення, розподілений з урахуванням ступенів розумової відсталості - легкого та помірного, таким чином:

$>$ пропедевтично-обов'язковий (підготовчий) етап триває: 1 рік (підготовчий клас - для РВД із легким ступенем) та 2 роки (підготовчий - 1 клас - для РВД із помірним ступенем);

змістовно-корекційний (основний) етап триває: 2 роки (1-2 клас - для РВД із легким ступенем) та 2,5 роки (2 - І-й семестр 4 клас - для РВД із помірним ступенем РВ);

функціонально-мовленнєвий (заключний) етап триває: 1 рік (4 клас) - для РВД із легким ступенем; для РВД із помірним ступенем він розпочинається в II семестрі 4 класу та поширюється на 5-6 клас. 
Цей розподіл $є$ умовним, тому у випадку, якщо в дітей із помірним ступенем розумової відсталості процес формування й корекції мовленнєвої діяльності буде відбуватися швидше, на 4 клас можна залишити весь функціонально-мовленнєвий етап, і навпаки, якщо результати фрормування й корекції мовленнєвої діяльності будуть низькими фрункціонально-мовленнєвий етап продовжується в старших класах.

Зміст Програми з розвитку мовлення передбачає урахування індивідуальних можливостей учнів (психічних, пізнавальних, мовленнєвих), забезпечує оптимальну динаміку розвитку мовленнєвої діяльності; передбачає варіативність його використання в початковій школі (на основі можливості перерозподілу навчального матеріалу відповідно до індивідуальних можливостей молодших школярів). Поетапне формування й корекція як основа розвитку мовленнєвої діяльності розглядається з точки зору врахування індивідуальних особливостей молодших школярів із легким і помірним ступенями розумової відсталості. Формування й корекція мовленнєвої діяльності $\epsilon$ важливою умовою досягнення кінцевих результатів - формування мовленнєвих компетентностей, як запоруки самостійного вживання мовлення, як засобу комунікації.

Реалізація Програми з розвитку мовлення здійснюється на основі забезпечення корекційно-розвивальної спрямованості розвитку мовленнєвої діяльності зазначеної категорії дітей з урахуванням різних сфер особистості: пізнавальної (розв'язування в процесі мовленнєвої діяльності пізнавальних завдань у наочно-дійовому, наочно-образному та вербально-логічному планах; дотримання етапів оволодіння й удосконалення усного та писемного мовлення; формування й удосконалення усного зв'язного мовлення на основі провідних пізнавальних (мисленнєвих) процесів); сенсомоторної (формування вмінь звуко-буквеного та звуко-складового аналізів, оволодіння лексико-граматичною стороною мовлення на основі слухової, тактильної, зорової чутливості; розвиток дрібної моторики пальців і кистей рук); емоційно-вольової (формування інтонаційно-мелодійної сторони мовлення, з метою висловлювання й розуміння відчуттів і емоцій; розвиток небайдужого ставлення до персонажів під час прослуховування та переказу текстів, які містять емоційно забарвлені компоненти, акцентують на них увагу, відтворюють більшу виразність, ніж інші частини тексту; розвиток тенденції співпереживання та співчуття); особистісної (формування позитивного ставлення до вживання мовлення як засобу комунікації, готовності доводити розпочатий вислів до кінця; усвідомленої навчально-практичної мовленнєвої діяльності тощо); соціальної поведінки (формування системи свідомості), усвідомлення й узагальнення соціально ціннісних поведінкових актів, дій, почуттів через мовленнєву діяльність). 
В основу Програми 3 розвитку мовлення покладений формувально-корекційний розвиток загальноприйнятих чотирьох видів мовленнєвої діяльності, які і стали її провідними напрямами: слуханняаудіювання (розуміння) (розвиток фронематичних процесів, розвиток слухової пам'яті й усвідомленого сприймання мовлення, розвиток звуко-буквеного аналізу й синтезу, розвиток уваги до морфологічного складу слова, словозміни та словотворення), говоріння (формування/корекція навичок правильної звуковимови, збагачення й уточнення словникового запасу, робота над граматичною структурою речення, формування вміння правильного вживання простих поширених речень, розвиток діамонологічного (зв'язного) усного мовлення), читання (формування поскладового, автоматизованого читання), письма (формування графічних навичок письма), профрілактика/корекція специфічних розладів писемного мовлення та формування на цій основі вживання мовлення як засобу спілкування.

Основні завдання й напрями роботи 3 розвитку мовлення молодших школярів з інтелектуальними порушеннями викладено в програмному розділі «Мовленнєва діяльність», який є структурною частиною програми для кожного 3 початкових класів. Розділ складається з чотирьох підрозділів. У кожному з них визначено зміст навчального матеріалу, а також вимоги щодо рівня загальноосвітньої підготовки учнів.

У підрозділі «Слухання-розуміння усного мовлення (аудіювання)» визначено зміст роботи з аудіювання: слухання, сприймання й розуміння усного мовлення та знання, вміння й навички 3 цього виду мовленнєвої діяльності, яких мають набути учні підготовчого, 1-4 класів.

У підрозділ «Говоріння» визначено зміст роботи з розвитку усного діалогічного й монологічного мовлення: формуванню вмінь керувати своїм голосом, спілкуватися в діалогічній формі, дотримуватися правил мовленнєвого етикету, переказувати прочитаний чи прослуханий текст, складати власні усні висловлювання на доступну для кожної вікової групи тему.

Саме в цьому підрозділі подано основний зміст роботи щодо формування та корекції компетентностей мовленнєвої діяльності: фонетичної, лексичної, граматичної, діамонологічної.

До підрозділу «Читання» включено навчальний матеріал, спрямований на вдосконалення навички читання як виду мовленнєвої діяльності: вимовляння слів відповідно до орфоепічних норм; правильне інтонування речень, різних за структурою та метою висловлювання; змістовий поділ речень за допомогою пауз, мелодики тощо.

Метою підрозділу «Письмо» $є$ формування в молодших школярів умінь будувати писемні зв'язні висловлювання: писати під диктування, самостійні (або з допомогою вчителя) перекази, розповіді. 
Основний зміст цих підрозділів подано в напрямі попередження/ виправлення специфічних розладів писемного мовлення.

Мета Програми - визначити зміст навчального матеріалу процесу формування та корекції мовленнєвої діяльності молодших школярів із легким та помірним ступенями розумової відсталості, спрямованого на розвиток мовно-мовленнєвих компетентностей обраної категорії дітей.

Для досягнення зазначеної мети передбачається виконання таких завдань [9]:

$>$ формування в учнів мотивації вивчення мови;

$>$ забезпечення розвитку всіх видів мовленнєвої діяльності (слухання, говоріння, читання, письма) на основі фрормування та/або корекції, 3 урахуванням психолінгвістичного підходу, відповідно до якого, мовленнєва діяльність $€$ одним з видів пізнавальної діяльності та являє собою самостійну діяльність зі специфічною мотивацією та структурою (мовленнєві дії, мовленнєві операції, мовленнєвий акт, мовленнєва ситуація);

формування комунікативних умінь і навичок;

соціально-культурний розвиток особистості;

формування вміння вчитися.

За визначенням Н. Рощиної, комунікативно-мовленнєві вміння це вміння, необхідні для ефективного здійснення мовленнєвої діяльності в умовах міжособистісної взаємодії, тобто в різних ситуаціях спілкування: з різною метою, в різних умовах, з різними співрозмовниками. Основою комунікативно-мовленнєвих умінь $€$ частковомовленнєві вміння (звуковимовні, орфоепічні, лексичні, граматичні) та загальномовленнєві (уміння слухати-розуміти, говорити, читати, писати) [9].

Робота з розвитку мовлення як складова частина всієї системи корекційно-розвивального впливу має завданням розширення знань і уявлень про навколишній світ, накопичення соціального досвіду, розвиток пізнавальної діяльності й активності цієї категорії дітей. Тому робота з розвитку мовлення повинна включатися до завдань, спрямованих на вирішення основних корекційних завдань, що стоять перед закладами освіти.

У зв'язку з тим, що в ДІП провідним порушенням $€$ недорозвинення пізнавальної діяльності, весь процес роботи з розвитку мовлення повинен бути спрямований на формування розумових операцій аналізу, синтезу, порівняння, абстрагування, узагальнення. 3 урахуванням характеру порушень мовлення корекційно-розвивальна робота повинна проводитися над мовленнєвою діяльністю в цілому [1]. На кожному уроці 3 розвитку мовлення ставляться завдання формування та/або за такими напрямами: фоонетико-фонематичний, лексико-граматичний, діамонологічний.

Зміст навчального матеріалу Програми з розвитку мовлення подано за лінійно-концентричним принципом: виклад за безперервною 
послідовністю матеріалу від простого до складного відповідно до принципів послідовності, систематичності, доступності, який передбачає повторне вивчення певних розділів, тем для більш глибокого їх засвоєння.

Програма з розвитку мовлення розроблена з диференціацією змісту навчального матеріалу: для дітей із легким та помірним ступенями розумової відсталості.

Робота з розвитку мовлення при легкому ступені* повинна бути спрямована на формування значення слів, граматичних категорій i понять, розуміння мовлення та збільшення на цій основі обсягу імпресивного словника, збагачення активного словника, профрілактики аграматизмів і розвитку зв'язного мовлення [1].

Провідна роль відводиться фоонематичному розвитку: формування диференційованого фонематичного сприйняття, спрямованості уваги на звукове оформлення мовлення, фонематичного аналізу й на цій основі - формування чітких фонематичних уявлень, подолання порушень звуковимови, попередження виникнення специфічних розладів писемного мовлення.

Розвиток фоонетичної компетентності (звуковимови) при легкому ступені розумової відсталості - процес тривалий і складний. Приділяється увага розвиткові чітких уявлень про звуковий склад слова, виділення звуку зі слова, визначення місця звуків у словах, уточненню змісторозрізнювальної функції звуків мовлення.

Підготовчий етап роботи передбачає розвиток загальної, дрібної, мовленнєвої моторики, розвиток слухового сприйняття, уваги, пам'яті, роботу над правильним мовленнєвим диханням, формуванням довготривалого плавного видиху в ігрових і голосових вправах.

Розвиток артикуляційної моторики здійснюється у двох напрямах: розвиток кінетичної основи руху й кинестетичної основи артикуляційних рухів (без дзеркала).

Обов'язковим етапом роботи є диференціація звуків: уточнення вимовної диференціації звуків, розвиток слухової диференціації.

Розвиток лексичної компетентності (словникового запасу) здійснюється за такими напрямами: збагачення словникового запасу, уточнення значення слів, розвиток семантики слова, формування лексичної системності й семантичних полів [1].

Розвиток граматичної компетентності (граматичної будови мовлення). У процесі формування словозміни звертається увага на зміну іменників за числами, відмінкові закінчення іменників, вживання прийменників, узгодження іменників із дієсловами та прикметниками, зміна дієслова за особами, числами, родами тощо.

Починати роботу 3 фрормування словотворення слід зі зменшувально-пестливих форм іменників. Далі використовуються вправи з утворення прикметників від іменників, дієслів із префріксами, споріднених слів. 3 метою розвитку уявлень про глибинно-семантичну 
структуру речень, необхідно працювати над смисловим змістом ситуації, відтвореної на малюнку.

Дітей за допомогою питань учать виділяти суб'єкт дії, об'єкт дії та відносини між ними. Під час навчання побудови речень добре використовувати опору на зовнішні схеми, ідеограми, тобто матеріалізацію структури мовленнєвого висловлювання.

Розвиток діамонологічної компетентності (зв'язне мовлення) при легкому ступені розумової відсталості рекомендується розпочинати з матеріалів діалогічного, ситуативного мовлення, пізніше контекстного, монологічного в такій послідовності:

розвиток уміння аналізувати наочну ситуацію, виділяти головне й суттєве, основне та другорядне;

формування вміння розташовувати смислові компоненти в певній послідовності;

розвиток здатності утримувати смислову програму в пам'яті (запам'ятовування послідовності картинок, перекази текстів);

$>$ перекодування кожного елемента смислової програми в мовну форому [3].

Р. Лалаєва рекомендує таку послідовність у роботі над зв'язним текстом: переказ з опорою на серію сюжетних малюнків, переказ за сюжетною картинкою, переказ без опори на наочність, переказ на основі деформованого тексту; розповідь за серією сюжетних картинок, розповідь за сюжетною картинкою, самостійна розповідь [1].

Розвиток навичок читання й письма в дітей із легким ступенем розумової відсталості повинна бути тісно пов'язана з розвитком у них пізнавальної діяльності, аналізу, синтезу, порівняння, узагальнення й абстрагування. Так, широко використовується порівняння фонетично близьких звуків, аналіз структури речень, звукоскладової структури слова, розвиток зорово-просторового аналізу й синтезу [1].

Попередження / усунення специфічних розладів писемного мовлення проводиться в тісному зв'язку з корекцією порушень усного мовлення як системи.

Робота з розвитку мовлення дітей 3 помірним ступенем** розумової відсталості $€$ створення предметного мовлення, навчання дітей словам - назвам предметів навколишнього світу, словами назвам дій із предметами. Дитину треба навчити вимовляти слова й короткі речення. Ці слова й речення повинні мати практичний сенс, бути пов'язані з життям дитини, з їі діями з предметами.

Першочерговими завданнями роботи з розвитку мовлення при помірному ступеню розумової відсталості $\epsilon$ : розвиток артикуляційної моторики; розвиток імпресивного мовлення; розвиток експресивного мовлення (Л. Зайцева, В. Ліпакова, А. Маллер, Л. Шипіцина та ін.) [1].

Розвиток артикуляційної моторики. Поступово потрібно привчати дитину до активних рухів органами артикуляції. Вправи виконуються перед дзеркалом: учитель-дефектолог показує дитині 
рухи, які слід виконати, пропонуючи повторити їх. Вправи слід суворо дозувати, не перевтомлювати дитини, починати з тих вправ, які в неї легше виходять, і переходити до подальших вправ тільки після того, як засвоєні попередні.

Ураховуючи, що в дітей із помірним ступенем розумової відсталості обличчя нерідко амімічне, необхідне спеціальне тренування мімічної мускулатури (надути щоки, втягнути їх; підняти брови, розслабити; зморщити лоба, розслабити; заплющити очі, примружити одне око, потім інше тощо). Усі вправи доцільно проводити в ігровій формі. Вибір гри та іiї проведення повинні здійснюватися 3 урахуванням розумових і мовленнєвих можливостей дитини.

У багатьох дітей украй нерозвинена регулююча фрункція мовлення. Вони насилу розуміють усні інструкції. У таких випадках необхідно, щоб дитина діяла разом з учителем-дефектологом або за показом чи інструкцією, що супроводжують артикуляційну гімнастику, при цьому вони повинні бути короткими [1].

Розвиток імпресивного мовлення. Для розвитку в дитини розуміння мовлення потрібно: взаємодія дитини з об'єктами: іншою особою, предметами, із самим собою як об'єктом; виконання словесних доручень дорослого; розуміння мовлення як акту спілкування, його активне сприйняття й відповідь. Розуміння мовлення не виникає в дітей із помірним ступенем розумової відсталості самостійно. Насамперед, слід навчити дитину фріксувати погляд на обличчі співрозмовника, дивитися під час спілкування в його очі.

Робота з розвитку навичок сприйняття мовлення включає в себе такі напрями: розвиток уміння слухати те, про що говорять; розвиток уміння реагувати на жести й виконувати прості вказівки; розвиток уміння вибирати з різних предметів або картинок те, що потрібно; розвиток уміння виконувати вказівки, у яких $є$ слова, що позначають дії; розвиток уміння виконувати вказівки, у яких $\epsilon$ слова, що позначають ознаки предметів; розвиток уміння виконувати вказівки, у яких $є$ слова, що позначають місце розташування предметів; розвиток уміння диференціювати різні граматичні фрорми; розвиток уміння розуміти зв'язне висловлювання.

Розвиток експресивного мовлення. Першочергову роль відіграє наслідування мовлення вчителя. Наслідуючи, дитина вчиться вимовляти звуки, а потім складати слова й речення. Робота з розвитку мовлення повинна бути частиною звичайної повсякденної діяльності. Розвиток експресивного мовлення включає роботу з фрормування здатності висловлювати власні бажання спочатку за допомогою окремих звуків, потім слів, що належать до різних частин мовлення, словосполучень, речень, уміти вимовляти різні звуки, розпочинати й підтримувати розмову. Розмовляючи з дитиною, треба робити паузи, даючи їй можливість вимовляти звуки за наслідуванням. 
До методичних прийомів фрормування в дітей правильного мовлення належать такі її види, як сумісне, відображене, хорове мовлення. При сумісному мовленні дитина разом з учителем вимовляє раніше сказану фрразу, при відображеному - дитина самостійно повторює почуте речення. Ці прийоми сприяють формуванню в дітей нормованого темпу, правильній артикуляції та дикції, дотримання пауз, логічного наголосу. Для того, щоб підвищити мовленнєву активність зазначеної категорії дітей, треба ставити дітей у такі ситуації, коли мовлення необхідне, включати мовлення в гру. Одночасно вчительлогопед (дефектолог) веде роботу 3 фрормування словника, використовуючи прийменники, прикметники й деякі прислівники; складати прості речення.

Таким чином, специфріка роботи з розвитку мовлення в спеціальних навчальних закладах освіти обумовлена, з одного боку, характером порушення вищої нервової діяльності, психопатологічними особливостями дитини з розумовою відсталістю, насамперед зниженням рівня аналітико-синтетичної діяльності, з іншого - особливостями мовленнєвого розвитку та структурою мовленнєвого порушення [1].

Розвиток мовлення як окремий напрям корекційно-розвивальної роботи з розумово відсталими дітьми в умовах початкової освіти має враховувати варіативність зазначених порушень усного (фонетикофонематичний недорозвиток, системний недорозвиток легкого, середнього, тяжкого ступенів важкості, заїкання) та специфічні розлади писемного мовлення. Оскільки лише на основі повноцінного мовлення та вживання його як засобу спілкування стає можливим системне формування комунікативних дій в учнів із розумовою відсталістю в навчальній діяльності й у позаурочний час.

Ураховуючи зміни, що відбуваються в системі загальної середньої освіти - поширенням інклюзивної освіти, до якої інтегруються діти 3 інтелектуальними порушеннями, а саме з легким ступенем розумової відсталості зміст навчальної Програми розроблений таким чином, що його можна використовувати під час корекційно-розвивальних занять в інклюзивних класах. 3 огляду на це, було визначено й загальні вимоги до критеріїв оцінювання навчальних досягнень учнів.

Під час визначення та обґрунтування критеріїв оцінювання навчальних досягнень учнів ми керувалися довідником науководослідницької лабораторії інклюзивної освіти, м. Рівне [2].

У ньому зазначається, що відповідно до Державних вимог до рівня загальноосвітньої підготовки учнів, що реалізуються в критеріях оцінювання навчальних досягнень, в основній школі використовуються критерії оцінювання навчальних досягнень, до яких належать: змістовий (обсяг знань); операційний (уміння, навички - предметні, навчально-пізнавальні, контрольно-оцінні); мотиваційний (ставлення до кінцевого результату діяльності й опанування способом діяльності). 
Розвиток мовлення відбувається в результаті формування й корекції мовленнєвої діяльності розумово відсталих учнів під час спеціально організованого навчання. Для об'єктивного оцінювання навчальних досягнень із розвитку мовлення необхідне врахування основних критеріїв змістового, операційно-організаційного та стимулюючомотиваційного компонентів навчальної діяльності школярів.

Найбільш адекватними показниками змістового компонента при визначенні рівня розвитку мовлення $€$ показники сформованості компонентів зв'язного усного мовлення повнота, правильність і усвідомленість.

Під повнотою розуміється відтворення обсягу навчального матеріалу, визначеного навчальною програмою; відтворення всіх характеристик, ознак об'єкта вивчення (від фррагментарного до відтворення в повному обсязі) [3].

Усвідомлення розглядається як розуміння, мисленнєвий процес, спрямований на виявлення в мовленнєвій діяльності загальних, істотних властивостей та зв'язків і здобуття знань про них.

Під правильністю розглядається критерій, згідно 3 яким оцінюється рівень сфрормованості мовленнєвої діяльності відповідно до вимог навчальної програми.

Актуальним в оцінюванні навчальних досягнень розумово відсталих учнів $є$ операційно-організаційний компонент, а саме рівень самостійності відтворення мовленнєвого матеріалу. Самостійність виконання завдань передбачає контроль учителем учнів під час застосування теоретичних знань і пов'язаних із ними вмінь і навичок, допомогу їм на практичному (спільне виконання дії з учителем), вербальному (пояснення, підказка, вказівка), загальному (підтримка, схвалення, активізація уваги) рівнях і допомогу в окремих випадках [3].

Щодо стимулюючо-мотиваційного компонента, важливими критеріями $€$ стимулювання В учнів бажання поліпшити власну мовленнєву діяльність, розвиток пізнавальної активності, фоормвання позитивних мотивів до самостійного вживання розгорнутого усного й писемного мовлення.

Важливим показником в оцінюванні знань і вмінь розумово відсталих школярів $€$ їх міцність, адже лише ті знання, вміння й навички, які дитина може відтворити в необхідний момент у різних життєвих ситуаціях, свідчать про немеханічне заучування матеріалу, а свідоме й ґрунтовне його засвоєння.

\section{Список використаних джерел}

1. Боряк О. В. Діагностика, формування й корекція мовленнєвої діяльності дітей із порушеннями інтелектуального розвитку молодшого шкільного віку теорія i практика: [монографрія]. Суми: Вид-во СумДПУ імені А. С. Макаренка, 2018. $458 \mathrm{c}$.

2. Критерії оцінювання досягнень учнів початкових класів з особливими освітніми потребами, які навчаються у загальноосвітніх школах в умовах інклюзї̈. Довідник науково-дослідницької лабораторії інклюзивної освіти. / Упорядники: 
Л. О. Савчук, І. В. Юхимець, Л. І. Яценюк. Рівне: РОІППО, 2012. 330 с.

3. Критерії оцінювання навчальних досягнень учнів початкових класів 3 порушеннями розумового розвитку: навчально-методичний посібник / О. В. Чеботарьова, Г. О. Блеч та ін.; за ред.: О. В. Чеботарьової, І. В. Гладченко. К.: ІСП НАПН України, 2016. 81 с.

4. Методичні рекомендації щодо організації логопедичної роботи в центріреабілітації дітей-інвалідів. Специфіка логопедичної роботи. URL: http://www.krok.org.ua/files/File/Rehabcentre/Met_logo.htm

5. Організаційно-методичні засади освітнього процесу у спеціальних закладах освіти в 2018/2019 навчальному році: лист Міністерства освіти і науки України від 06 серп. 2018 р. № 1/9-485. URL: file:///C:/Users/OKCAHA/ Downloads/5b698a4ae513d690291310\%20(1).pdf

6. Про затвердження Державного стандарту початкової освіти: Постанова Кабінету міністрів України від 21 лютого 2018 р. № 87. URL: https://www.kmu.gov.ua/ua/npas/pro-zatverdzhennya-derzhavnogo-standartupochatkovoyi-osviti

7. Програма 3 корекційно-розвиткової роботи «Розвиток мовлення» для підготовчих, 1-4 класів спеціальних загальноосвітніх навчальних закладів для дітей із затримкою психічного розвитку / І. М. Омельченко, Л. О. Федорович. К, 2016. 187 с.

8. Рібцун Ю. В. Урахування класифікацій мовленнєвих порушень у диференційній діагностиці. Український логопедичний вісник: зб. наук. пр. 2012. Вип. 3. C. 51-58.

9. Рощина Н. О. Формування мовленнєвої діяльності молодших школярів. URL: http://abrikosovka.ucoz.ru/load/formuvannja_movlennevoji_dijalnosti_molodshikh_s hkoljariv_dopovidach_roshhina_n_o/1-1-0-40

10. Стахова Л. Л. Методичні рекомендації щодо організації корекційнорозвивальної роботи в групах компенсуючого типу для дітей з порушеннями мовлення. Організація корекційно-розвивальної роботи в групах для дітей із порушеннями мовлення. Суми, 2018. С. 15-22.

11. Типова освітня програма початкової освіти дітей 3 порушеннями інтелектуального розвитку. Київ, 2018.2 URL: http://lib.iitta.gov.ua/711423/1/Типова\%20програма_1\%20кл.pdf

12. Чеботарьова О. Особливості корекційно-реабілітаційної роботи з учнями із порушеннями опорно-рухового апарату. Дефектологія. Особлива дитина: навчання і виховання. 2013. № 3. С. 16-20. 


\title{
ПЕДАГОГІЧНІ УМОВИ ФОРМУВАННЯ МУЗИЧНО- ІНТОНАЙЦІЙНИХ УЯВЛЕНЬ МОЛОДШИХ ШКОЛЯРІВ
}

\author{
Булатова Л. О. \\ кандидат педагогічних наук, доцент, \\ Сумський державний педагогічний університет імені А. С. Макаренка
}

Музичне виховання займає одне з центральних місць у формуванні духовної культури сучасного покоління, його смаків, цінностей, потреб, традицій. Неможливо переоцінити роль активної музичної діяльності особистості, спілкування з музикою у розвитку її пізнавально-творчих можливостей, свідомому осягненні естетичної цінності художніх образів, фрормуванні здатності інтерпретувати ідейний задум творів.

Як відомо, в процес сприймання музики включається досвід безпосередніх переживань i роздумів людини, який поступово накопичуючись збагачує емоційно-чуттєву, інтелектуальну і вольову їі сорери. Тож, свідоме сприймання музики стає важливим елементом у засвоєнні втіленого в музиці досвіду попередніх поколінь, розширенню меж розуміння і прийняття цінностей сучасного світу, стимулює потребу до самовираження й самовдосконалення.

Сприйняття $€$ чуттєвим відображенням предметів і явищ об'єктивної дійсності в сукупності притаманних їм властивостей та особливостей при їх безпосередній дії на органи чуття. Музичне сприйняття, у зв'язку зі специфікою об'єкта сприйняття - музики, поняття значно ширше, ніж безпосереднє почуттєве відображення дійсності, бо відбувається водночас у фрормі почуттів, уявлень, абстрактного мислення та зумовлене духовним світом людини, яка сприймає цей твір, її досвідом як музичним так і життєвим, музичними здібностями. То б то, музичне сприйняття відбувається через взаємозв'язок емоційних і раціональних процесів, переживання i осмислення, перцептивних і інтелектуальних дій.

Багато науковців (А. Леонтьєв, С. Костюк, Б. Теплов та інші) поділяють думку, що сприйняття це процес активної дії, який потребує непростої аналітичної роботи слухача, здатності відслідковувати розвиток музичних інтонацій і тем. Тож вирішити непросту проблему пізнання музичної думки можливо при осягненні і розумінні людиною інтонаційної природи музики та фрормування у неї музично-слухових і образно-інтонаційних уявлень.

Вагомий внесок в дослідження сутності сприймання музики як процесу осмислення музично-інтонаційних уявлень внесли: Б. Асафр'єв, Н. Гродзенська, Л. Кадцин, О. Костюк, Ю. Кремльов, Л. Кулаковський, І. Ляшенко, Є. Назайкінський, О. Ростовський, А. Сохор, Б. Теплов, В. Шацька та інші. Так, Ю. Кремльов зазначав, 
що: 1) інтонація - основа музики і найбільш специфічний її чинник; 2) інтонація досягає свого розквіту за допомогою логіки музичного мислення, розвиваючись у музичні фрорми; 3) інтонація стає музикою тільки через логіку та через становлення музичного образу [4, с. 51-52]. Розглядаючи дане питання 3 точки зору фоормування інтонаційної культури школярів цінності набуває думка О. Критської, яка відмічала, що для того, щоб високохудожні твори стали зрозумілими для учнів, необхідно зробити їх невід'ємною частиною музично-слухового досвіду дитини [11].

На важливість життєво-музичного та інтонаційно-слухового досвіду для активного сприймання музики наголошував неодноразово Д. Кабалевський, який розглядає сприйняття як основу музичної культури, що обумовлюється розвитком музичного мислення, виховуванням в учнів музичної грамотності. Тобто - це здатність сприймати музику як живе, образне мистецтво, народжене життям і нерозривно $з$ життям зв'язане; це особливе «почуття музики», яке дозволяє сприймати ії емоційно, відрізняти в ній гарне від поганого; це здатність на слух визначати характер музики і відчувати внутрішній зв'язок між характером музики і характером її виконання; це здатність на слух визначати автора незнайомої музики, якщо вона характерна для певного автора, його творів, з якими учні вже знайомі [5]. Отже, автор наголошував на необхідності розуміння дітьми головної особливості музики - ії інтонаційної природи.

Зазначимо, що сьогодні сучасна школа у музикознавчому вихованні і розвитку учнів, спирається на концепцію інтонаційного осягнення і розуміння музичного мистецтва. Перед вчителем стоїть задача, використовуючи інтонаційний підхід навчити учнів саме через інтонацію проникати в саму суть музичних творів, установлювати зв'язок з життєвими явищами оточуючого світу. Це має стати основою свідомого сприймання музики, активізації процесу творчої інтерпретації художнього твору у відповідності з життєво-музичним досвідом школярів та сприяти розвитку їх художньо-образного мислення.

В зв'язку з цим, слід наголосити, що сприймання музики, її емоційне переживання, спирається як на знання й музичний досвід слухача, так і на сфрормованість певного типу слухових уявлень. 3 цього приводу В. Медушевський відзначав, що музичний уривок не може бути сприйнятий як веселий або скорботно-героїчний, якщо його структура не буде відповідати нашим уявленням про веселе чи скорботно-героїчне [7].

Науковцями неодноразово засвідчувалося, що незчисленні художні враження отриманні школярем з самого раннього дитинства нікуди не зникають, а накладаються один на одне та поступово збагачуються і поглиблюються, що в подальшому сприяє утворенню асоціативних зв'язків між ними. Також відмічалось, що в свідомості слухачів не містяться цілі музичні твори, а відкладається складний, 
дуже мінливий комплекс музичних уявлень, в які і входять різноманітні «фрагменти музики, але які в сутності і складають усний музичноінтонаційний словник» [1].

Можна погодитися з такою важливою думкою, що існування певного набору знайомих інтонацій складає своєрідний «інтонаційний словник епохи» та відіграє дуже важливу роль не тільки в процесі історичного розвитку музики, але і в процесі ії свідомого сприйняття кожним індивідуумом. Отже, щоб розуміти музику необхідно мислити інтонацією.

Про необхідність інтонаційного мислення для забезпечення активного сприймання музики постійно наголошували науковці, серед яких виділяються праці Б. В. Асаф'єва, М. Г. Арановського, О. Бєлобородової, Т. А. Баришевої, Л.В.Горюнової, В.В.Медушевського, А. Н. Сохора, Р.Г. Тельчарової, В. М. Холопової, Є. В. Назайкинського, В.А. Пілічаускаса, Г.М.Ципіна та інших. В роботах підкреслювалось, що основою музичного мислення $\epsilon$ інтонація і розвиток кожного індивідуума потрібно розглядати як формування музичного інтонування і музичного мислення. Саме інтонаційна природа визначає специфріку музичного мислення. Асаф'євська теорія здатності розуміти музику як мистецтво «інтонаційного змісту», дає нам можливість розглядати формування емоційно-образного осмислення музики учнями з точки зору рівня сфрормованості у них музично-інтонаційних уявлень і інтонаційнообразного досвіду, який базується на зв'язку музики з життям.

Хто досить реально чує внутрішню духовно-інтонаційну єдність у конкретному музичному матеріалі твору, підкреслював В. Медушевський, той може вважати себе справжнім музикантом. Бо він вміє інтонаційно мислити, а не лише механічно повторювати чи випадково відтворювати музику. Інтонаційно мислити - це означає чути життя в звуках, через узагальнену інтонацію ліричного героя відчувати його душу, дивитися на світ його очима. Саме так у музиці здійснюються дивовижний і специфрічний для мистецтва ефект художнього сприймання» [3].

Таким чином, можна наголосити, що сприймання музики як специфічна пізнавальна діяльність, не тільки надає інформацію, поглиблює знання про світ, про музику різних країн, композиторських шкіл, збагачує особистість новим емоційно-чуттєвим досвідом, а й розвиває ії мислення, природні здібності, дає простір для самовиявлення і творчої інтерпретаційної діяльності в процесі спілкування з музичним мистецтвом. Основою цього спілкування $\epsilon$ музична інтонація, яка акумулює в собі музично-естетичні цінності.

Тож, розглядаючи особливості формування музично-інтонаційних уявлень дітей молодшого шкільного віку слід окреслити ряд необхідних педагогічних умов, які б могли забезпечити ефективність цього процесу на уроках музичного мистецтва в умовах 
загальноосвітньої школи. Під педагогічними умовами ми розуміємо такі спеціально створені умови, за яких здійснюється активізація мисленнєвої, емоційної й вольової сорери дитини, відбувається глибоке занурення й осягнення ідейно-художнього змісту музичних творів, усвідомлення виразної значимості мелодико-інтонаційної основи музики, збуджується потреба активного сприймання й відтворення музики, бажання виявляти власні переживання в процесі її інтерпретації й оцінювання.

Спираючись на сучасні наукові методико-теоретичні підходи, накопичений практичний досвід, умови організації навчальновиховного процесу в загальноосвітніх закладах освіти, специфіку сприймання музики молодшими школярами серед умов формування музично-інтонаційних уявлень дітей на уроках музичного мистецтва ми виділили наступні:

1) стимулювання інтересу до спілкування з музикою і бажання розуміти її мову;

2) накопичення музично-слухових уявлень і вражень учнів як основи створення і розширення «інтонаційного словника»;

3) створення ситуацій емоційного переживання музичного змісту 3 метою усвідомлення виразного значення інтонацій та накопичення інтонаційно-образного слухового досвіду;

4) розширення асоціативних уявлень через стимулювання моторнорухової діяльності учнів, як основи інтерпретації особистих переживань;

5) опора на повторюваність музично-інтонаційних зразків художніх образів на основі співставлення однотипних і контрастних музичних творів.

Розглянемо більш детально означені умови та методи, що забезпечують їх реалізацію в процесі навчальної діяльності на уроках музичного мистецтва.

1. Стимулювання інтересу до спілкування 3 музикою i бажання розуміти їі мову.

Відомо, що ставлення людини до того чи іншого виду діяльності $\epsilon$ суб'єктивним станом, яке вона відчуває до неї, до ії змісту, процесу, результату, творчим можливостям. Ставлення тісно пов'язане 3 потребнісно-мотиваційною сфрерою особистості, їі інтересами. Як складне структурне утворення мотив зумовлюється завданнями, в які включається учень. С. Рубінштейн справедливо підкреслював, що мотив міститься саме в ставленні до задачі, мети і обставинамумовам, при яких дія виникає [9, с. 564] Тому. наскільки значима для людини та чи інша діяльність, який інтерес вона виявляє до неї можна говорити про ії̈ цінність для неї.

Зазначимо, проблема інтересу у навчанні постійно акцентується науковцями (Л. Виготським, О. Киричуком, Н. Морозовою, Г. Щукіною та ін.), висвітлюється його роль у стимулюванні не тільки пізнавальної 
активності, а й всіх психічних процесів людини. Саме інтерес змушує до пошуку і творчості, стимулює протікання мисленнєвих процесів, $є$ джерелом інтелектуальної активності, мобілізує творчі сили на пошук рішення пізнавальних завдань, позитивно впливає на якість i глибину знань та водночас виступає умовою до саморозвитку, самовиявлення, самореалізації.

В практиці музичного навчання питання стимулювання інтересу пов'язуються з доступністю і зрозумілістю навчального матеріалу, наявністю в ньому цікавої пізнавальної інфооммації, емоційної привабливості пізнавального процесу в цілому. До речі, важливо акцентувати увагу саме на емоційній стороні навчального процесу як регуляторі діяльності учнів, оскільки емоційні переживання можуть як активізувати, так і гальмувати сприймання, пам'ять, мислення, уяву, а головне впливати на потреби, мотиви, інтереси учнів.

В цьому контексті особливого важелю набуває характер викладення нового матеріалу вчителем, здатність зробити розповідь захоплюючою, актуальною для учнів. Тому, багатою мірою сприймання змісту музики школярами залежитиме від здатності вчителя вміло використовувати багатство власної інтонаційної палітри мови, міміки, жестів, пластики тіла, артистизму. Водночас, активізація спілкування дітей з музикою потребує від вчителя здатності викликати у них здивування, зацікавленість, відчуття успіху від співпраці, відчувати підтримку і схвалення. В зв'язку з цим, актуальності набувають методи художньої розповіді, роз'яснення, створення асочіативних зв'язків, залучення наочно-ілюстративного матеріалу. Завдяки художній розповіді посилюється зацікавленість дітей музикою, активізується образне уявлення, навчальний матеріал стає більш доступним. Так, наприклад, використовуючи художню розповідь під час прослуховування і порівняння різнохарактерних творів (прийом контрасту) Є. Адамцевича «Запоріжський марш», С. Рахманінова «Італійська полька», Я. Степового «Колискова» ми маємо можливість збагатити уявлення дітей про відмінності мелодико-інтонаційної мови музики, її залежності від характеру художніх образів, їх настроїв, емоційної насиченості. Доповнюючи сприймання музики залученням ілюстративного матеріалу (О. Бубнов «Тарас Бульба», М. Вейстлінг «Перший танок», світлини з зображенням матері 3 дитиною), що перекликаються по образному змісту з творами робить сприйняття більш зрозумілим, емоційно насиченим, сприяє усвідомленню ролі засобів виразності у створенні образу в мистецьких творах, закріплює асоціативні зв'язки, збагачує музично-слухові уявлення.

Особливо важливо у збудженні інтересу дітей до музики, має стати стимулюванні їх бажання виявляти своє ставлення до почутого, що можливо при використанні бесіди про твори, обговоренні їх художнього змісту, залучення прийомів утворення емочійного фоону та ефректу актуальності. 
Виходячи 3 того, що у учнів початкових класів наочно-дійове мислення то провідною у розвитку їх інтересу до музики, бажання спілкуватися з нею має стати ігрова діяльність, яка забезпечить емоційність навчання, легкість закріплення знань і вмінь дітей. Водночас, врахування особливостей пам'яті (наочно-образна) і уваги завдяки використанню яскравого, виразного наочного матеріалу дозволить зробити навчальний процес не тільки цікавим, а й більш зрозумілим і доступним дітям.

\section{2. Накопичення музично-слухових уявлень і вражень учнів як основи створення «інтонаційного словника».}

Допомогти дитині увійти в світ музики, навчити свідомому спілкуванню з музичим твором, сприяти розумінню виразного смислу музичної мови, збагатити ії̈ досвід емоційних переживань $є$ одним 3 головних завдань вчителя. В зв'язку 3 цим, особливого значення набувають процеси сприймання, розуміння та інтерпретації змісту музики. Тому для вчителя важливо озброїти учнів механізмами спілкування 3 музичним мистецтвом, «прочитання» й відкриття для себе його виразного образного змісту, що не можливо без ссрормованості музично-слухових і художньо-інтонаційних уявлень.

Як справедливо відмічав Б. Асаф'єв, виховання слухових навичок (поступове вкорінення у свідомість учнів-слухачів основних співвідношень звукових елементів, що організують рух музики, як необхідних для її сприймання) - $€$ необхідним для свідомого сприймання і розуміння музики. Автор звертав увагу на необхідність засвоєння найважливіших видів співвідношень: ритмічних, ладових, тональних, динамічних, темпових, тембрових тощо, спочатку спрямовуючи сприймання по образній лінії, а потім допомагаючи спостерігати помічену або схоплену слухом властивість [2, с. 70]. В зв'язку $з$ цим, доцільним буде обирати для сприймання такі музичні твори, де найбільш яскраво простежується та чи інша особливість музичної мови (ритм, темп, лад, мелодія та ін.) i, особливо, різноманітність музичних інтонацій за характером й настроєм як носіїв художньої образності.

Успішність сприймання музики учням, усвідомленість художньоінтонаційних образів, які складають зміст музичного твору залежить також від здатності уважно спостерігати за змінами в музиці, характерними особливостями їі мови. Тому залучення дітей до бесіди про музику, створення ситуацій, що викликають у них бажання розповісти про свої враження від неї, сприятиме, з одного боку, пізнавальній активності і водночас спрямовуватиме увагу маленьких слухачів на найголовніші співвідношення музичних елементів, що звучать. 3 іншого боку, це дасть можливість добитися збагачення їх як музично-інтонаційного досвіду в єдності з емоційним, так і росту музичного мислення в цілому. Пасивне слухання поступово буде змінюватися усвідомленим сприйманням музики, бажанням розуміти ії,, 
адекватно переживати ї̈ емоційний зміст, що, в свою чергу, зробить інтерес до спілкування з музичним мистецтвом необхідною потребою у житті дитини, розширить межі чуттєвого пізнання оточуючого світу.

Як вже відмічалося, музично-інтонаційні уявлення спираються на накопичені музично-слухові уявлення, які $€$ особливо важливими для пізнавальних процесів. Тож розуміння музичної мови, усвідомлення засобів ії виразності має базуватися на накопиченні стійких типів звукоутворень поряд з опрацьованим досвідом їх застосування. Тому, використання музичних творів різних за жанрами, стилями, художньообразними характеристиками, емоційним забарвленням стане необхідною основою збагачення «інтонаційного словника» учнів. При цьому, маємо наголосити, що усвідомлення сутності інтонації в музиці досягається на основі розуміння взаємозв'язку інтонаційної виразності, звуковисотної точності та емоційної насиченості інтонації. Тож, для максимального розуміння і свідомого засвоєння музичного навчального матеріалу під час сприймання музичних творів важливо забезпечувати єдність життєвого і музичного досвіду молодших школярів на основі розкриття й роз'яснення життєвої природи інтонації.

Наприклад, співставлення контрастних творів «Польки» і «Тарантели» П. Чайковського 3 «Дитячого альбому» і українських народних пісень «Сомко-дрімко» $\mathrm{i}$ «Котику сіренький» дає можливість учням закріпити знання і уявлення про особливості музичної мови у відповідності до конкретних настроїв запропонованих музичних образів, усвідомити інтонаційні особливості в єдності з ладовим колоритом, темпо-ритмічними відмінностями, динамічними відтінками, різноманітністю регістрового звучання.

3 метою навчити школярів находити взаємозв'язок між виражальними засобами художнього матеріалу та мелодикоінтонаційним матеріалом музичного твору ефективним може бути застосування методу інтонаційного осягнення музики в поєднання 3 методом комплексного впливу мистецтв. По-перше, використання різних видів мистецтв дозволяє розкрити основні зв'язки між різними видами мистецтв (спільність тем, зв'язок художніх ідей, спорідненість художніх образів, відповідність засобів виразності). Та головне, що окремі види мистецтв не повторюють і не дублюють один одне, а доповнюють і збагачують їх новими засобами, активізують емоційність сприйняття. Наприклад, дітям пропонується прослухати дві різнохарактерні фортепіанні п'єси «Дощик» В. Косенко і «Осінній дощик» М. Парцхаладзе та визначити, який з них найбільш відповідає настрою поетичного тексту:

Тиша...Щось шепоче вітер,

За вікном гойдає вітер.

І зітхає дуже гірко

На вербі пожовкла гілка.

Дощик ронить тихі сльози 
На хатини , на покоси.

Річка хвилі ледь колише -

Береже осінню тишу...

Порівнюючи засоби виразності, настрої, що виникають в ході. слухання творів, спираючись на вже набуті музично-слухові уявлення маленькі школярі набувають навичок інтерпретації інтонаційнообразного змісту творів, усвідомлюють виразну значимість музичних інтонацій у створені того чи іншого настрою, характеру.

Як важливий момент у закріпленні навичок учнів самостійно оперувати інтонаційним матеріалом, відповідно до емоційного навантаження змісту твору, реагувати на зміни характеру музики може стати метод утворення емоційних паралелей. Основа його полягає в доборі музичних творів емоційно пов'язаних між собою. Принцип тематичної спорідненості, як важлива умова, сприяє стимулюванню творчої уваги учнів, створює єдину психологічну атмосореру для сприйняття різних творів, які $\epsilon$ близькими за емоційними характеристиками, накопиченню зразків відповідних інтонацій і пов'язаних з ними різних елементів музичної мови (ладу, мелодії, темпу, ритму, динаміки, тембру, регістру тощо). Отже, діти поступово усвідомлюють, що музичний твір передає інформацію засобами музичної мови, а образ створюється за допомогою системи сполучень інтонацій, які $є$ носієм музичної думки.

3. Створення ситуацій емоційного переживання музичного змісту 3 метою усвідомлення виразного значення інтонацій та накопичення інтонаційно-образного слухового досвіду.

Зрозуміти музичний твір - значить, перш за все, відчути, емоційно пережити його і вже на цій підставі розмірковувати над ним - зазначав Б. М. Теплов. Саме через емоційну захопленість дитина включається в розумовий процес. Недарма Л.С. Виготський називав музичне мистецтво «центральною, розумною емоцією».

Слід відзначити, що емоційна реакція на інтонацію, проникнення в ії виразну сутність - вихідний пункт процесів музичного мислення, але ще не саме мислення. Це є поки що не більше чим відчуття первинна форма орієнтиру у сфері звукової виразності (Г. Ципін.). Оскільки мислення у всіх своїх різновидах починається з відчуття, необхідно визнати відчуття музичної інтонації свого роду сигналом до будь-яких музично-розумових дій. Усі вони спираються, врешті-решт, на здатність людини чуттєво сприймати виразний смисл музичної інтонації, емоційно відкликатися на неї. Все в мистецтві звукових образів - багатство музичних засобів, різноманітність елементів - має інтонаційну основу [12]. Отже, інтонаційна природа $€$ найхарактернішою особливістю музики. Погляд на музичне мистецтво як інтонаційне мистецтво, специфріка якого полягає в тому, що воно втілює емоційно-смисловий зміст музики подібно до того, як внутрішній стан людини втілюється в інтонаціях мови, обґрунтував Б. В. Асафр'єв 
[1, с. 189]. Він підкреслював, що процес пізнання художньо-образного змісту музичного твору має спиратися, перш за все, на інтонаційні, а потім на аналітичні операції. Тож розвиваючи музичний слух важливо не тільки навчити дітей розрізняти тембри, гармонії, мелодії, інтонації, але й накопичувати слуховий досвід емоційних вражень, чуттєвих переживань, що ними викликаються.

Тож, говорячи про результативність спілкування з музикою важливого значення набуває виховання у учнів здатності до емоційнообразного сприймання музики шляхом усвідомлення інтонації як семантичного знаку музичного змісту, його інтонаційної ідеї (жанрстиль-твір) [10]. При цьому, суттєвим моментом у сприйманні музики учнями є емоційне переживання ії змісту. Здатність відчути «іншого» в музичному творі реалізується через співпереживання, спонукає до нового бачення оточуючого світу. Саме переживання «іншого» відкриває діалог, художню комунікацію слухача з твором.

Переживання творів мистецтва індивідуальне для кожної дитини, та при цьому, учні початкової школи не завжди здатні адекватно емоційно пережити і відчути зміст прослуханої музики, тому виникає потреба створити необхідні навчально-виховні ситуації, які б забезпечували відповідний емоційний відгук на музику, розуміння художньо-образного змісту твору, сприяли накопиченню досвіду естетичного сприймання. Естетичну ситуацію ми розглядаємо як спільну діяльність учителя і учнів, коли створюються умови, в результаті яких учні отримують досвід не тільки художньо-образного сприймання, збагачення емоційно-почуттєвої сфери, але й закріплюються необхідні навички мисленнєвої діяльності, стимулюється потреба висказувати власні судження й оцінки на музичні твори.

Зустріч з музичним твором завжди викликає певні емоційні реакції, нові враження у слухачів, тому атмосфера на уроці має бути яскравою, цікавою, емоційно наповненою, а слово вчителя - образним, зрозумілим, доступним для сприймання дітей. Важливим, при цьому, $є$ вміння вчителя розкрити виразне значення емоційного змісту музичних інтонацій, їх зв'язок з тими почуттями, які слухач переживає в даний момент сприймання музики, акцентувати увагу на їх ролі у створенні характеру й настрою образу.

Наприклад, використання різнохарактерних творів («Танець феё Драже» П. Чайковського, «Попутна пісня» М. Глінки, «Веселий селянин» Р. Шумана, «Ранкова молитва «ПЧайковського», Ведмідь» В. Ребікова) з яскравими мелодико-інтонаційними, темповими, ладогармонійними, тембральними відмінностями, з одного боку, активізує емоційні переживання дітей, сприяє усвідомленню ними виразної значимості музичної мови, розвиває здатність впізнавати через особливості музичної мови конкретні образи, їх характери. 3 іншого на основі збагачення інтонаційно-образних уявлень накопичується художньо-естетичний досвід спілкування з музичним мистецтвом. 
Доцільним у стимулюванні емоційних переживань, забезпечення їх адекватності настрою музи, на -нашу думку, може стати використання методу умовні моделі характеру музики. Суть методу в тому, щоб через утворення емоційних асоціацій між картинамимоделями (рисунки, репродукції картин) і настроєм й характером музики допомогти учням усвідомити емоційні стани, що передає музика, зрозуміти власні відчуття від почутого. Застосування ілюстративного матеріалу дає можливість активізувати особистий життєвий досвід дитини і визвати почуття, які зрозумілі і вже пережиті раніше ними. Водночас слід наголосити, що такі моделі не можна дорівнювати змісту музичного твору, вони лише виражають настрій, який може бути близьким до музичного образу. Тож, активізація зорового сприйняття і закріплення його у слові (під час обговорення діти обирають слова-синоніми за шкалою В. Ражнікова, які найбільш, на їх думку, відповідають якісним властивостям музичного змісту) дає поштовх, по-перше, для розвитку здатності осмислювати власні емоційні реакції, що виникають у свідомості дитини під час сприйняття мистецтва у вигляді почуттів, настрою, уявлень, асоціацій, а по-друге, сприяє усвідомленню й запам'ятовуванню характерних особливостей музики, ії емоційно-почуттєвої сорери.

Зазначимо, що орієнтація на внутрішній світ дитини потребує конструювання специфічних педагогічних ситуацій, які б активізували в навчально-виховному процесі потребу самовиявлення, самовираження. Тому так важливо розвивати у учнів здатність осмислювати свої індивідуальні реакції від взаємодії з мистецтвом. В цьому контексті доречним може стати використання методу емпатії (вживання, вселення в стан іншої людини). За допомогою чуттєвообразних та розумових уявлень учень намагається «переселитися» у вивчаємий об'єкт, відчути і зрозуміти його зсередини. Умовою успішного застосуванню цього методу $є$ певний стан учнів, створений учителем настрій. Вжитися в сутність освітніх об'єктів (квітки, дерева, хмаринки, птаха, людських образів тощо) допомагає використання висловлювань, наприклад: «Уявіть собі, що ви...». Думки, почуття, відчуття, які з'являються при цьому і $є$ «освітнім продуктом» учня, який може бути виявленим в усній, письмовій, руховій музичній чи малюнковій фрормі. Отже, спостереження образу у даному випадку переходить у самоспостереження учня, якому вдається ототожнювати себе з образом. Цей метод сприяє розвитку як мислення і розуміння морально-естетичних й художніх явищ з різних точок зору, так і вчить включати в пізнання не тільки розум, але й почуття.

Слід звернути увагу ще на важливий момент, коли учні мають навчитися не тільки сприймати окремі інтонації, виявляти їх настрій, характер, але й самостійно аналізувати розвиток музичного образу, розуміти роль інтонацій у цьому процесі. Так, наприклад, після прослуховування симфонічної сюїти «Ранок» Е. Гріга під час аналізу 
музики необхідно акцентувати увагу дітей, як композитор використовуючи різні музичні засоби виразності відтворює схід сонця. Порівнюючи звучання інтонацій на початку звучання твору (тихі, спокійні, світлі), що виконуються тільки фрлейтою і гобоєм з тим, якими вони стають завдяки включенню нових тембрів інших інструментів, посиленню сили звучання, збагаченню новим колоритом гармонії, насиченню всієї фрактури маленькі школярі починають усвідомлювати сутність мелодико-інтонаційного розвитку музики, його взаємозв'язок із змінами в художньому образі, який хотів передати композитор засобами музичної мови.

\section{4. Розширення асоціативних уявлень через стимулювання моторно-рухової діяльності учнів як основи інтерпретації особистих переживань.}

Вплив музики на особистість складається з численних художніх вражень, які накладаються одне на одне, поступово збагачуючись $\mathrm{i}$ поглиблюючись. Водночас сила впливу музики залежить від культури слухача, його музичного досвіду, наявності умінь і навичок самостійної музичної діяльності, рівня розвитку музичних здібностей, доступності художніх образів, розумових здібностей, від яких залежить глибина осягнення музичної думки в процесі сприймання творів.

Зміст музичного твору, як відзначалося раніше, складають художньо-інтонаційні образи, що втілені в різноманітних інтонаціях. При цьому, важливо зауважити, що цілісний музичний образ виникає лише при певному поєднанні компонентів музичної мови. Не можна не погодитися 3 думкою В.В. Медушевського, який музичний образ розглядав як систему життєвих (емоційних, рухових, сенсорних, мовних, ситуативних тощо) асоціацій, які знаходять своє втілення у музичному матеріалі - моделюються в музичних засобах i продовжують у них відношення, названі «синтаксисом образу» [7, с. 27]. Слід зауважити, що складність самого процесу образного сприймання музики пояснюється тим, що являє собою комплексну психічну діяльність. Так, завдяки мисленню, дитина усвідомлює що сприймає; мова допомагає зрозуміти предмет сприймання; почуття виробити певне ставлення до того що сприймається; воля організовує цей процес; уявлення допомагають відтворити образи предметів, сприйнятих раніше; пам'ять дозволяє запам'ятати i пригадати раніш пережиті почуття, образи, думки, рухи, знання тощо. Тож всі пізнавальні психічні процеси особистості взаємодіють між собою під час сприймання музики й сприяють ї̈ свідомому опануванню. Особливої уваги, в зв'язку з цим, заслуговують асоціації, як невід'ємна складова процесу сприйняття. Асоціація (від лат. association - з'єдную, зв'язую) - $€$ закономірним зв'язком двох або кількох психічних процесів, котрі проявляються у тому, що виникнення одного з них викликає появу іншого або інших. Тобто, можна говорити про зв'язок між окремими подіями, явищами, що закріплені в нашій 
пам'яті. Без цих зв'язків неможлива діяльність пам'яті, оскільки запам'ятовування будь-якого предмета чи образу відбувається в зв'язку $з$ іншими предметами. До того ж, виникаючи, асоціації доповнюють емоційну реакцію, роблячи ії сильнішою і яскравішою. Як відмічав О.Костюк, переживання, що $€$ первинним явищем при сприйманні твору, частково може бути і вторинним, з'являючись як реакція на асоціацію [6]. Тому важливо враховувати виникнення зорових, чи предметних асоціацій як допоміжних у процесі осягнення музичного твору. Науковці з цього приводу зауважують, що асоціації, які виникли на неінтонаційній основі неможливо вважати музичними, оскільки вони тільки опосередковано доповнюють ті переживання та настрої, що виникають в процесі музичного сприймання. Та при цьому, наголошувалось, що стійкі звуко-комплекси, які склалися в ході розвитку музики набувають певних життєво-асоціативних зв'язків і стають шляхом завдяки якому слухач має можливість збагнути смисл концепцій композитора [1, с. 267].

В практиці музичного виховання дієвим засобом накопичення асоціативних уявлень стало використання графрічного зображення мелодичного рисунку та інших елементів музичної мови. Так, під час слухання музичного твору школярам пропонується «креслити» мелодичну лінію в повітрі, або стежити указкою по заздалегідь підготовленому рисунку музичної теми, відтворювати ії самостійно в зошиті чи на дошці, залучаючи при цьому різні кольори. Суть моделювання засобами рисунку полягає в тому, що співставляючи різні кольори і характер ліній діти намагаються не тільки усвідомити, що хотів «змалювати» композитор, які настрої виразити, який характер твору відтворити, а й мають можливість передати власні відчуття i емоції. Водночас, відтворюючи емоційно-динамічний план твору, особливості мелодійного руху, виділяючи через різні відтінки кольору найхарактерніші засоби виразності музики, учні накопичують i розширюють асоціативний досвід, навчаються свідомо оперувати асоціаціями, що виникають в ході сприймання музики та на їх основі глибше розуміти художній зміст твору. Тож, створюючи асоціативні паралелі учні розширюють межі художньої свідомості, навчаються мислити творчо і нестандартно.

Водночас маємо звернути увагу, що під час сприймання музики на неї реагує весь організм людини. Наприклад, рух $є$ також одним 3 засобів самовираження та проявленням ставлення до музики, переживання ії. Враховуючи психофрізіологічні особливості молодших школярів можна засвідчити, що рух для них $є$ першим кроком до розуміння музичного мистецтва, так як розуміння виникає, головним чином, на основі моторного відгуку і спричинених ним асоціацій. Отже включення моторно-рухової діяльності в навчальний процес (ігри, інсценування, танцювальні рухи, пластичне інтонування) сприятиме активізації й утворенню яскравих асоціацій, 
які в подальшому допоможуть учням в повній мірі відчути й пережити образний зміст музики.

Відтворюючи через пластику тіла, рухи, міміку різні за настроєм і характером образи дитина має можливість, з одного боку, більш свідомо і глибоко пережити й виразити свої емоції (суму, радості, бадьорості, веселощів, ніжності, спокою тощо), а з іншого, збагатити асоціативний досвід, що ґрунтується на раніш пережитому нею життєвому досвіді. Тож рухова пластика тіла завдяки синтезу слухання і виконання активізує процеси сприймання музики. Пропускаючи музику через рухову діяльність, відтворюючи ії мелодико-інтонаційні елементи, маленький слухач, по-перше, конкретизує музичний образ, який завдяки цьому стає йому близьким і зрозумілим, а по-друге, виявляє потребу інтерпретації особистих переживань.

Наприклад, використання ігрової діяльності, що поєднує рухову активність і театралізацію дає можливість дитині виразити себе і свої почуття через пластику тіла й міміки, та водночас створити яскравий емоційний образ персонажу. Так, рухово-сценічна гра «Іде, іде дід» може використовуватися як стимулююча пошуково-творчу діяльність, бо кожна дитина має можливість засобами власної моторики тіла посвоєму відтворити й продемонструвати художній образ, привнести в нього своє бачення зовнішнього вигляду й характеру (веселого, хитрого, немічного, войовничого тощо) персонажу.

Поряд з цим, успішними можуть бути творчі завдання, коли учні завдяки руховій діяльності усвідомлюють елементи будови музики. Наприклад, після прослуховування п'єси Д. Кабалевського «Зайчик дражнить ведмежатко» учням пропонується порівняти дві мелодичні лінії та виявити їх інтонаційні відмінності, після чого через власні рухи передати характери образів. Це дає можливість їм краще зрозуміти зміст діалогу між персонажами, глибше відчути власні емоції, прослідкувати залежність музичних інтонацій від характеру кожного образу.

Важливим моментом у розвитку здатності учнів інтерпретувати власні переживання і ставлення до музики $\epsilon$ також активізація образних асоціацій на основі раніш накопиченого життєвого досвіду, які виникають під час сприймання учнями музики (наприклад, «Пташка» Е. Гріга, «Сміливий вершник» Р. Шумана, «Танок молодого бегемота» i «Клоуни» Д. Кабалевського, «Політ джмеля» М. Римського-Корсакова), сприяють через вербалізацію характерів образів (пошук потрібних визначень-епітетів) більш точному відчуттю образного змісту музичних інтонацій цих творів.

5. Опора на повторюваність музично-інтонаційних зразків художніх образів на основі співставлення однотипних i контрастних музичних творів.

Поглиблення сприймання музики дітьми, як зазначають науковці, йде від комплексного жанрово-ситуативного враження до диферен- 
ційованого сприймання музичних творів [8, с. 342]. Пояснюється, що як правило музика асоціюється не з яскраво усвідомлюваними, чітко видимим, відчутими образами-уявленнями, а з невиразними комплексними відчуттями часто емоційного характеру, які не встигають піднятись до рівня усвідомлення. I лише при наступному самоаналізі ці приховані компоненти сприймання можуть набувати форми наочного уявлення, образного метафоричного визначення [8, с. 180].

Також слід звернути увагу, що більшість учнів молодшого віду на перших порах не виділяють мелодизм музики, ії ритмічну організацію, емоційну узагальненість інтонаційного розвитку. Реагуючи на музику безпосередньо, активно, молодші школярі ще не усвідомлюють емоційні стани, які нею викликані, а лише визначають загальний характер музики та її настрій. Сприймаючи музичний твір цілісно, як єдиний музичний образ діти не вміють вичленяти окремі засоби виразності та визначати їх роль у створенні музичного образу. Як засвідчує практика, діти починають шукати у звучанні «зоровий образ», реальний рух, подію, які більш звичні для їх розуміння і інтерпретації музики. Тобто, дитина співвідносить почуте з тими емоційно-образними категоріями, які вона набула в своєму попередньому життєвому досвіді. Тому важливо розширювати образнослуховий емоційний досвід через накопичення відповідних музичноінтонаційних зразків. Виділяючи найзначиміші у інтонаційному відношенні елементі музики, які складають основу певного художнього образу, неодноразово повторюючи їх звучання на прикладах близьких за настроєм і змістом творів різних композиторів, вчитель сприятиме поступовому накопиченню слухових інтонаційних зразків, впізнаваємості їх, та на цій основі розумінню й забезпеченню адекватності переживань учнів таких (або подібних) настроїв, емоційних відчуттів в незнайомих творах.

Ефективність співставлення однотипних музичних творів зумовлена виділенням, усвідомленням та запам'ятовуванням інтонаційної своєрідності художніх образів, композиторського стилю, жанрової належності, художньої теми. Водночас, залучення творів за контрастною ознакою, тобто знаходження відмінних рис, мелодикоінтонаційних особливостей дає змогу школярам зрозуміти роль кожного елемента музичної мови у створенні відповідного образу.

Наприклад, залучаючи метод ескізного і фррагментарного виконання творів (добираються твори за схожим інтонаційним матеріалом) можна закріплювати слухові уявлення школярів, що дасть можливість в подальшому учням самим виділяти їх в музичній тканині незнайомих творів. Завдяки повторюваності знайомих елементів музичної мови в звучанні різних творів близьких за характером, настроєм, змістом художніх образів у школярів поступово закріплюються слухові уявлення, що робить спрймання музики усвідомленим, більш зрозумілим і чуттєво наповненим. 
Не менш ефективним методом у закріпленні музичноінтонаційних уявлень $є$ метод вокального інтонування, коли учні проспівують фррагменти музичних творів. То б то, «пропускаючи через себе» мелодії, що втілюють у собі інтонаційно-типові риси притаманні певному образу у школярів фрормуються необхідні музично-інтонаційні уявлення про «зерно-інтонацію» всього твору, емоційна чуйність до настрою музичного образу. Поряд з цим, має сенс проспівувати різні зразки окремих характерних інтонацій (сумні, закличні, маршові, спокійні-колискові тошо) з подальшим розпізнаванням їх в музичних творах як знайомих, так і не знайомих. Завдяки відтворенню знайомих інтонацій голосом, повторенню їх у учнів не тільки розвивається музичний слух, музичні здібності, пам'ять, але й поступово набувається усвідомлення жанрових ознак музики (пісенності, танцювальності, маршовості), музичного почерку того чи іншого композитора, його епохи.

Таким чином, навчання школярів усвідомленому сприйманню музики на основі розуміння ії інтонаційної природи, формування стійких музично-інтонаційних уявлень, збагачення музично-слухового й асоціативного досвіду, стимулювання емоційно виразної моторнорухової діяльності відкриває нові можливості розвитку їх творчого мислення і музичної культури в цілому.

\section{Список використаних джерел}

1. Асафьев Б. В. Музыкальная форма как процесс. Кн. 1,2. Ленинград: Музика, 1971. $376 \mathrm{C}$.

2. Асафььев Б. В. Избранные статьи о музыкальном просвещении и образовании. 2-е издание. Ленинград: Музыка, 1973. 144 с.

3. Восприятие музики: Сб. ст. / Ред.-сост. В. Н. Максимов. Москва: Музыка, 1980. $191 \mathrm{c}$.

4. Интонация и музыкальный образ / Под общей ред. Б. М. Ярустовского. Москва, 1965.

5. Кабалевский Д. Воспитание ума и сердца: Кн. для учителя. Москва: Просвещение, 1984. 195 с.

6. Костюк А.Г. Восприятие мелодии: мелодические параметры процесса восприятия музыки. Киев: Наукова думка, 1986. 192 с.

7. Медушевский В. В.К проблеме семантического синтаксиса // Сов. музыка. 1973. №3. С. 20-29.

8. Назайкинский Е.О психологии музыкального восприятия. Москва: Музыка, 1972. $384 \mathrm{c}$.

9. Рубинштейн С. Л. Основы общей психологии. Москва: Учпедгиз. 1946. 704 с.

10. Спіліоті О. В. Формування музично-інтонаційного мислення майбутніх вчителів музики у процесі фрахової підготовки: автореф.дис. ... канд. пед наук. Київ: Б. в. 2012. $20 \mathrm{c}$.

11. Школяр Л. В. Теория и методика музикального образования детей. Москва: Наука, 1999. $80 \mathrm{c.}$

12. Щербакова А. И. Феномен музыкального искусства в становлении и развитии культуры: автореф. дис. ... д-ра культурологии. Краснодар, 2012. 52 с. 


\title{
ФОРМУВАННЯ ЗДОРОВОГО СПОСОБУ ЖИТТЯ МОЛОДШИХ ШКОЛЯРІВ ЗА ПЕДАГОГІЧНОЮ СПАДЩИНОЮ В. О. СУХОМЛИНСЬКОГО
}

\author{
Бутенко В. Г. \\ кандидат педагогічних наук, старший викладач, \\ Сумський державний педагогічний університет імені А. С. Макаренка
}

Здоров'я людини - один із найважливіших показників благополуччя суспільства. Водночас, сучасні соціально-економічні та екологічні кризи в країні спричинили значне погіршення здоров'я населення, особливо дітей, що зумовлює необхідність посилення уваги до збереження і зміцнення фрізичного, психічного, соціального та духовного здоров'я молодших школярів, формування в них умінь і навичок здорового способу життя.

Основним завданням сучасної школи стає виховання компетентної особистості, яка не тільки володіє знаннями, а й уміє застосовувати їх у повсякденному житті, діяти адекватно ситуаціям, адаптуватися до складних соціальних умов, долати життєві труднощі, підтримувати власне здоров'я на належному рівні, надавати опір негативним впливам. Для його розв'язання необхідно створювати відповідні умови, забезпечувати органічне поєднання освітнього та оздоровчого процесів. У зв'язку з цим, є надзвичайно актуальним та своєчасним звернення до науково-практичної спадщини В. Сухомлинського, педагогічні, публіцистичні та літературні праці якого збагатили здоров'язбережувальну педагогіку України новими положеннями і думками.

Аналіз теоретичних доробків і систем практичної діяльності дають підстави стверджувати, що проблему збереження здоров'я дитини в творчості В. Сухомлинського досліджують Л. Акімова, А. Богуш, В. Буряк, В. Горащук, М. Дубіна, О.М.Іонова, В. Кравцов, В. Кузь, С. Литвинець, Н. Побірченко, Ю. Соловйов, О Сухомлинська, О. Чернишов та ін. У своїх працях дослідники одноголосно висловлюють думку про величезну цінність і актуальність творчого доробку видатного українського педагога, про необхідність вивчення, осмислення і впровадження його ідей в масову педагогічну практику.

У контексті обґрунтування досліджуваної проблеми передбачено характеристику ключового поняття «здоровий спосіб життя» та звернення до його теоретичного визначення. Етимологічний аналіз наукової категорії «здоровий спосіб життя» свідчить, що поняття «здоровий» розглядається у Великому тлумачному словнику сучасної української мови як «корисний для здоров'я» [7, с. 455]. Визначення терміна «спосіб» характеризується як «певна дія, прийом або система 
прийомів, що дає можливість зробити, здійснити що-небудь, досягти чогось» [7, с. 1375]. Стосовно дефініції «жити», то згідно з «Великим універсальним словником української мови» він має праслов'янське коріння і визначається у спорідненості з такими термінами як литовське «видужувати» (ставати здоровим), словацьке «лікувати» (спрямовувати до здоров'я), українське - вести той чи інший спосіб життя [11, с. 608]. Враховуючи етимологію поданих слів, нами встановлено, що в сукупності вони означають життя, зорієнтоване на здоров'я, тобто здоровий спосіб життя.

Здоровий спосіб життя людини активно досліджувався як видатними педагогами минулих століть (А. Дістверг, Я. Коменський, Дж. Локк, Й. Песталоцці, Ж.-Ж. Руссо та ін.), так і сучасними вченими різних галузей наук. На підставі аналізу досліджень науковців (А. Ошкіної, Н. Соловйової, О. Шукатки) встановлено, що в останні роки у вивченні здорового способу життя умовно виокремлено три основних напрями: фрілософрсько-соціологічний, медико-біологічний, психолого-педагогічний. Однак, на думку дослідників, чіткої межі між ними немає, оскільки вони спрямовані на вирішення однієї проблеми зміцнення здоров'я індивіда. Вивчаючи фрілософсько-соціологічні дослідження, нами визначено, що здоровий спосіб життя в них трактується як певна глобальна соціальна проблема, об'єктивна потреба соціального розвитку, а основна увага зосереджена на ідеальних компонентах, які визначають стан здоров'я індивіда. Сутність поняття «здоровий спосіб життя» розкривається Д. Ізуткіним, А. Степановим за допомогою терміна «життєдіяльність». Здоровий спосіб життя цими вченими подано як типові й істотні для даної суспільно-економічної фрормації фооми життєдіяльності людей, які сприяють повноцінному виконанню ними соціальних функцій i досягненню активного довголіття [12].

Медико-біологічний напрям відображає діяльнісний аспект здорового способу життя, тобто усвідомлений вибір комплексу профрілактичних оздоровчих заходів, які забезпечують гармонійний розвиток і зміцнення здоров'я особистості. Ґрунтовний аналіз поняття «здоровий спосіб життя» зроблено Б. Чумаковим, який визначає його як «типові форми і способи повсякденної життєдіяльності людини, які зміцнюють і вдосконалюють резервні можливості організму, забезпечуючи тим самим успішне виконання своїх соціальних і професійних функцій незалежно від політичних, економічних і соціальнопсихологічних ситуацій» [23, с. 23]. Обмежившись поведінковим аспектом як суттєвою ознакою досліджуваного поняття, А. Смирнов визначає здоровий спосіб життя як «найбільш оптимальну систему поведінки людини в повсякденному житті, яка дозволяє їй максимально реалізувати свої особистісні якості для досягнення духовного, фрізичного та соціального благополуччя» [15, с. 19]. Науковці Т. Бондар, Н. Полєтаєва є прибічниками групи фрормулювань, 
які визнають за основу здорового способу життя - умови життя, які впливають на здоров'я [5, с. 7].

3 позиції досліджуваного предмета нам найбільше імпонують трактування поняття «здоровий спосіб життя» представниками психолого-педагогічного напряму, які вважають, що для збереження здоров'я надзвичайно важливим $€$ навчання збереження здоров'я, мотивація до здорового способу життя, обґрунтування необхідності розробки здоров'язбережувальних методик та технологій, визначення системи засобів з охорони та зміцнення здоров'я дітей. Зокрема, засновник сучасної валеологічної освіти І. Брехман вважає, що необхідно вчити людину набувати знання і виробляти навички, які $€$ важливими для здоров'я. Він наполягає на тому, щоб навчання здоров'ю було «неперервним протягом усього життя, диференційованим для різного віку і нестандартним», «... для здоров'я потрібні такі знання, які б стали буттям» [6, с. 52]. Комплексне визначення поняття здорового способу життя, необхідне для розуміння системи педагогічної роботи, дає Т.Бабюк, яка трактує цю категорію «як складне новоутворення особистості, у якому в органічній єдності взаємодіють інтелектуальні, емоційні, мотиваційні і вольові процеси, що відіграють важливу роль у формуванні здоров'я» і свідчить про «гармонійне формування цього феномену в умовах спеціально організованої діяльності» [2]. Проаналізувавши подані визначення поняття «здоровий спосіб життя», можемо зазначити, що це важлива складова формування особистості в цілому і дитини молодшого шкільного віку, зокрема.

У пошуках шляхів збереження i зміцнення здоров'я дітей, профілактики захворювань, формування здорового способу життя дітей звертаємося до талановитого вчителя В.Сухомлинського і знаходимо відповіді на всі запитання. Адже на першому плані у педагогічній діяльності В. Сухомлинського стояла проблема фізичного розвитку й здоров'я дітей. «... Турбота про здоров'я - це найважливіша праця вчителя. Від життєдіяльності, бадьорості дітей залежить їхнє духовне життя, світогляд, розумовий розвиток, міцність знань, віра у власні сили...», - зазначав педагог-новатор [19, с. 100]. Його фундаментальні праці («Проблеми виховання всебічно розвиненої особистості» (розділ «Турбота про здоров'я молодого покоління, фрізичний розвиток», книга «Сто порад учителю» (розділ «Як спонукати до самовиховання у фізичній культурі»), «Серце віддаю дітям (розділ «Фізична і психологічна культура підлітка»), «Людина ніби вдруге народжується») педагогічна громадськість сприймає як керівництво до організації системної роботи у вихованні підростаючого покоління, яка включає особливо важливі і значимі напрями в світлі реалізації здоров'язбережувальної освіти: формування здоров'язбережувального середовища; освіта в аспектах здоров'я і забезпечення безпеки життєдіяльності; взаємодія з родиною; підготовка гуманного педагога. 
У спадщині В. Сухомлинського важливе місце посідають його роздуми щодо розвитку дитини, самовираження, а в більш широкому розумінні - виховання індивідуальності, яка повністю реалізує власні задатки. Саме тому педагог радив учителю здійснювати індивідуальний підхід, вивчати кожну дитину, вміти побачити і розвинути її індивідуальність. 3 цього приводу він писав, «що у житті не буде жодної нещасливої дитини, якщо класний керівник докопається до «золотої жилки» в кожному вихованцеві й допоможе йому знайти себе» [20, с. 422].

В умінні бачити в кожному вихованцеві індивідуальність В. Сухомлинський розумів здатність педагога сприймати цю індивідуальність такою, якою вона є: з усіма її позитивним і негативним потенціалом, з усіма радощами і бідами, успіхами і невдачами, приємними чи неприємними для педагога реальностями [21, с. 420654]. Під індивідуальністю він розумів сукупність індивідуальнопсихічних особливостей, що надають індивіду унікальності, неповторності. До індивідуальності особистості вихованця В. Сухомлинський відносив [17, с. 209]:

$>$ стан розвитку і здоров'я психічного і фрізичного;

$>$ історію життя вихованця;

> статеві відмінності: вияви (фрізичні, психічні, соціальні) дівчат і хлопців, специфріка їхнього внутрішнього розуміння належності до тієї чи іншої статі, вияви статевої поведінки, емоційний стан повинен бути зрозумілим і прийнятним педагогами і батьками;

> своєрідність якостей особистості: специфіка перебігу психічних процесів (відчуття, сприйняття, уява, увага, пам'ять, мислення, усне й писемне мовлення, емоційно-вольова ссрера), спрямованість особистості (потреби, мотиви, інтереси, нахили, переконання, світогляд), задатки та здібності (умови та можливості їхнього розвитку вдома, у школі, у позашкільних закладах; можливість самореалізації), специфіка характеру та темпераменту;

> виховне середовище: дім, найближче побутове оточення, школа, позашкільні заклади, дитячі об'єднання.

Увага до кожної індивідуальності, вдумливе ставлення до позитивних і негативних рис, недоліків кожної дитини можуть забезпечити зміцнення її здоров'я, творчий розвиток та успіх у навчанні й вихованні. На його думку, без знання дитини, без глибокого розуміння всієї складності явищ, які відбуваються в її душі, виховання стає сліпим і тому беззмістовним.

Потрібно знати дитину, «знати здоров'я дитини, знати індивідуальні риси іï мислення, знати сильні і слабкі сторони їі розумового розвитку» [16, с. 217]. Однак проникнення педагога в духовний світ дитини, вивчення її мислення, почуттів, характеру, волі, інтересів - справа надзвичайно складна. Щоб пізнати дитину, потрібно 
постійно її бачити, вивчати, спостерігати за нею. «...Спостерігайте, спостерігайте і ще раз спостерігайте. Спостерігайте, як взаємодіють два світи - світ навколишньої природи, праці суспільних відносин і внутрішній духовний світ людини. Спостерігайте, як дитина думає і переживає, якими складними, часом звивистими шляхами пробивають собі дорогу струмочки думки в її голові. Умійте читати найменші порухи думки, почуттів, переживань у кожному русі дитини і особливо в їі очах» $[18$, с. 214$]$.

Пізнати і сприйняти дитину такою, якою вона $€$ - важлива умова реалізації оздоровчої функції школи. «Не намагайтеся змінити, переломити, перебудувати те, що створила в своїй таємничій майстерні природа, - здебільшого ця перебудова може призвести до хворобливих явищ» [16, с. 214]. Зміцнення і збереження здоров'я дитини як важливої умови розвитку її творчості відбувається, на думку В. Сухомлинського, значною мірою завдяки дотриманню санітарногігієнічних вимог у повсякденному житті, в тому числі у режиму праці та відпочинку, як чинників, що сприяють єдності фрізичного, духовного та творчого розвитку школяра.

Так, першою умовою збереження здоров'я дітей були заняття на відкритому повітрі, на зелених лужках, оточених 3 усіх боків виноградом. Неприпустимо було, щоб учні молодших класів займалися розумовою працею в закритому приміщенні більше 3 годин. Для цього $€$ альтанки. Викладачі школи не припускали, щоб молодші школярі виконували домашнє завдання протягом 4-5 годин, тому що це калічить дитину, згубно позначається на її здоров'ї [16, с. 149].

Заняття на свіжому повітрі не лише позитивно впливають на здоров'я школярів, а й сприяють розвитку творчого самовираження. Милування красою природи створюють у дітей позитивний емоційний стан, викликають радість, спонукають до творчості: складати вірші, казки, оповідання, малювати, створювати «щось своє», притаманне дитині як індивідуальності. В. Сухомлинський писав, що складаючи казки, розповіді, створюючи словесний образ, дитина «не просто вправляється у словесній творчості, вона виявляє свій інтелектуальний світ, утверджує свою гідність» [16, с. 149].

Велике значення для здоров'я, інтелектуального та творчого розвитку дитини має, на думку В. Сухомлинського, різноманітність видів розумової праці, чергування праці й відпочинку. Найоптимальнішим початком робочого дня він вважає такий: підйом о 5.30 ранку; ранковий туалет; зарядка і сніданок (до 20 хвилин); виконання домашніх робіт (півтори-дві години до виходу в школу); дорога до школи (5-30 хвилин), що є першим значним відпочинком. Особливу увагу приділяє В. Сухомлинський використанню різних видів розумової праці, чергуванню праці й відпочинку в процесі шкільного життя (чергування уроків за ступенем складності і за характером розумової праці, періодів набування знань з періодами застосування 
знань, 30-хвилинні перерви посередині навчального дня тощо).

Другу половину дня діти за рекомендаціями педагогів мали займатися цікавою, творчою працею, при цьому здебільшого на свіжому повітрі. Необхідність виконання домашніх завдань перед класними заняттями В. Сухомлинський пояснює тим, що звільнення другої половини дня від інтенсивної навчальної розумової праці $\epsilon$ вирішальною умовою зміцнення здоров'я [22]. Такий відпочинок стає цілющим джерелом повноти духовних сил, оптимізму, бадьорості, фрізичного здоров'я.

В. Сухомлинський надавав великого значення позитивним емоціям, що сприяють покращенню здоров'я дітей та, водночас, їх творчому розвитку. На його думку, атмосфрера емоційного комфорту в процесі навчання включає такі компоненти: позитивні емоції, пов'язані зі школою і перебуванням у ній; позитивні емоції, зумовлені рівними, діловими стосунками школяра з учителем, відсутністю конфрліктів; емоції, пов'язані з розумінням кожним учнем своїх можливостей у досягненні успіхів у навчанні; позитивні емоції, пов'язані з новим навчальним матеріалом; позитивні емоції, що виникають при оволодінні учнями прийомами самостійного здобування знань.

Учитель, вважав В. Сухомлинський, повинен уміти створити в учнів внутрішній стан емоційного піднесення, інтелектуального натхнення, бо без цього заняття спричинятимуть тільки байдужість, а нечутлива розумова праця приноситиме тільки втому. Він рекомендував виховувати так, щоб дитина почувала себе шукачем i відкривачем знань. Тільки за цієї умови одноманітна, напружена, втомлива праця школяра забарвлюється радісними почуттями й приносить маленькій людині переживання творця.

На переконання В. Сухомлинського, розвиток творчих здібностей багато в чому залежить від спілкування, яке відбувається між дитиною і педагогом. Він визначав людське спілкування як «надзвичайно широке, багатогранне задоволення потреби людини в людині». Саме вчитель і має створити таке життєрадісне шкільне життя через спілкування з природою, щоденні відкриття чогось нового, відчуття успіху в певному виді діяльності, радістю творення добра оточуючим і, зрештою, відчуттям щастя від усвідомлення своєї потрібності людям.

В. Сухомлинський не уявляв собі виховання здорової особистості, iï творчого розвитку без того, щоб кожний вихованець не досяг визначного успіху в тому виді діяльності, яка найповніше виражає, розкриває його нахили й обдарування. Він відзначав: «Тільки там, де маленька людина переживає почуття гордості від того, що вона в чомусь досягла визначних успіхів, виявила себе, - в індивідуальному духовному житті ми бачимо те, що треба називати енергією думки... Радість розумової праці - ось що стає доступним людині, якщо ії духовне життя пройняте почуттям оптимістичної впевненості у власних силах, почуттям власної гідності» $[17$, с. 78$]$. 
Очікуванням радості має бути осяяне все життя і діяльність дитини. Радість у навчальній праці сама собою не виникає, для цього потрібен успіх. Успіх у навчанні - єдине джерело внутрішніх сил дитини, що породжує енергію для подолання труднощів і бажання вчитися. Тому створення ситуації успіху, вважав В. Сухомлинський, - це основа педагогічної взаємодії. Він відзначав, що радість успіху $є$ могутньою емоційною силою. Тому потрібно турбуватися про те, щоб внутрішня сила дитини ніколи не вичерпувалась. Якщо її немає, то, зауважував В. Сухомлинський, не допоможуть ніякі педагогічні хитрощі.

Підсумовуючи вищезазначене, зауважимо, що за педагогічними поглядами В. Сухомлинським реалізація здоров'язбережувальних ідей сприяє розвитку дитини молодшого шкільного віку, має істотний потенціал для становлення особистості. Цей потенціал полягає в меті, оновленому та здоров'язбережувальному змісті освіти, ії фрормах та методах, які сприяють формуванню: творчої спрямованості особистості, що передбачає усвідомлення нею значення насамперед творчих, гуманістичних потреб, мотивів, цілей як провідних у іiї розвитку та майбутній життєдіяльності; творчої самосвідомості, що проявляється у самопізнанні та адекватній самооцінці власної діяльності і поведінки у соціокультурному і соціоприродному середовищі; постійному зростанні потенціалу діяльності стимулювання інтересу і бажання систематично здобувати нові знання, вмінню творчо їх застосовувати, фрормування умінь експериментувати та вести різноманітні дослідження відповідно віковим можливостям учнів молодших класів.

Обґрунтування педагогічних умов фрормування здорового способу життя молодших школярів за педагогічною спадщиною В. Сухомлинського визначено одним 3 основних завдань нашого дослідження. Тому ми вважаємо доцільним розкрити це питання комплексно і пропонуємо відповідні умови, які подані в таблиці 1.

Одним із важливих напрямів діяльності школи В. Сухомлинський вважав реалізацію першої умови - удосконалення розвиваючого предметно-просторового середовища закладу освіти. Особливу роль у формуванні пріоритету цінностей здоров'я та здорового способу життя людини відіграє освіта завдяки своїй спроможності забезпечувати навчання як різних груп населення впродовж усього життя, так i фрахівців різних галузей на всіх етапах їх професійної діяльності [10].

Чим вище середній рівень освіти в певному соціальному середовищі, тим кращі узагальнені показники здоров'я воно демонструє. Природно, що піклування про власне і громадське здоров'я неможливе без знання того, чому це необхідно і як це робити. Притому доцільно розуміти поняття освіти в даному контексті не тільки як освіту суто валеологічну, а значно ширше - як загальну освіту в цілому. Чим ширше знання основних природничих, наукових, 
філософських, гуманітарних положень, тим більше можливостей створювати у суспільстві системне уявлення про проблему здоров'я взагалі. Крім того, поняття освіти потрібно розуміти комплексно: і як надання інформації, і як навчання методам, прийомам і навичкам здорового способу життя, і як виховання в дусі безумовного пріоритету цінностей індивідуального й громадського здоров'я в усіх його проявах, сорерах, рівнях [10]

Таблиця 1

\section{Педагогічні умови формування здорового способу життя молодших школярів за педагогічною спадщиною \\ В. Сухомлинського}

\begin{tabular}{|c|c|}
\hline Педагогічна умова & Мета застосування \\
\hline $\begin{array}{c}\text { Удосконалення } \\
\text { розвиваючого предметно- } \\
\text { просторового середовища } \\
\text { закладу освіти }\end{array}$ & $\begin{array}{l}\text { Забезпечення освітнього потенціалу простору } \\
\text { школи, класу, а також території для } \\
\text { формування здорового способу життя } \\
\text { молодших школярів. }\end{array}$ \\
\hline $\begin{array}{c}\text { Суб'єкт-суб'єктна взаємодія } \\
\text { вчителів, молодших } \\
\text { школярів і батьків щодо } \\
\text { формування здорового } \\
\text { способу життя }\end{array}$ & $\begin{array}{l}\text { Створення єдності педагогічного впливу на } \\
\text { здобувача для фрормування здорового способу } \\
\text { життя шляхом залучення найближчого } \\
\text { середовища. }\end{array}$ \\
\hline $\begin{array}{c}\text { Педагогічний супровід } \\
\text { формування здорового } \\
\text { способу життя молодших } \\
\text { школярів }\end{array}$ & $\begin{array}{l}\text { Реалізація педагогічного супроводу, при якому } \\
\text { провідна діяльність спрямована на } \\
\text { формування в молодших школярів моделей } \\
\text { поведінки (вчинку): система бесід про людину і } \\
\text { особливості людського організму; оптимальне } \\
\text { чергування розумової і фрізичної праці; } \\
\text { оздоровча } \\
\text { фрізкультурних занямованість } \\
\text { культури, ранкової зарядки, фрізкультхвилинок, } \\
\text { динамічних перерв; утвердження у свідомості } \\
\text { учнів необхідності дбайливого ставлення до } \\
\text { власного здоров'я і здоров'я інших; активна } \\
\text { пропаганда і утвердження здорового способу } \\
\text { життя. }\end{array}$ \\
\hline
\end{tabular}

Необхідність дотримання санітарно-гігієнічних вимог щодо обладнання й оснащення приміщення для проведення уроків, що сприяє збереженню здоров'я, ефрективній організації розумової діяльності. Він наполягав на постійному провітрюванні приміщень, де проходять уроки, де діти відпочивають. На його думку, внаслідок тривалого перебування дитини у приміщенні, тобто «кисневого голодування», можуть виникнути проблеми з очима, порушення обміну речовин, а тому дитина втрачає здатність до зосередженої розумової праці. Саме тому учні школи тривалий час перебували на свіжому повітрі, особливо восени й у весняні і літні дні. В організації навчання В. Сухомлинський звертає увагу на правильне чергування видів 
діяльності, встановлення індивідуального для кожної дитини режиму праці й відпочинку, активізацію учнів через фрізичну працю, рух, ходьбу, біг, гру - оскільки без втоми не може бути здоров'я [14, с. 48-49].

Друга умова - суб'єкт-суб'єктна взаємодія вчителів, молодших школярів і батьків щодо формування здорового способу життя, обґрунтовується тим, що В. Сухомлинський надає величезного значення постійним бесідам з батьками про здоров'я учнів, оскільки турбота про здоров'я дитини неможлива без зв'язку із сім'єю [4, с. 103]. Піклуючись про здоров'я молодших школярів, В. Сухомлинський приділяв велику увагу питанням загартовування дітей, нейефективнішими засобами яких уважав: влітку - ходьбу босоніж, купання у відкритих водоймах, будь-якої пори року - вітамінізоване харчування, рухливі ігри, працю й прогулянки. У школах педагог радив створити «зелені класи», «куточки мрії», ігрові майданчики, частіше проводити екскурсії у «світ природи», організовувати працю та відпочинок у «саду здоров'я». Вдома - влаштовувати відкриті альтанки для ігор. Педагог уважав, що правильний режим, повноцінне харчування, фрізична загартованість - усе це оберігає дитину від захворювань і сприяє ії повноцінному розвитку.

Роль сім'ї у фоомуванні здорового способу життя неможливо переоцінити. Формування здорового способу життя $\epsilon$ одним із важливих напрямів сімейного виховання. Багато в чому формування здорового способу життя залежить від традиційної складової цього впливу: стилю життя сім'ї, способу організації життя, характеру взаємостосунків між подружжям, участі обох батьків у вихованні, правильної організації вільного часу сім'ї, ставлення батьків до вживання алкоголю, паління, застосування наркотичних речовин. Отже, спосіб життя сім'ї в основному обумовлює і спосіб життя дітей. На спосіб життя сім'ї, а отже і дитини, впливає й структура самої сім'ї. Національне опитування «Спосіб життя молоді», яке було проведено Громадською організацією «Український інститут соціальних досліджень імені Олександра Яременка», виявило, що тільки дві третини молоді проживають у повних сім'ях [8].

Загальновідомо, а також виявлено в результатах цього опитування той фракт, що батьки для різних груп підлітків та молоді $€$ одним з основних джерел інформації з багатьох питань. Крім того, саме до батьків, в першу чергу, звертаються молоді люди зі своїми проблемами та труднощами. У важкій ситуації діти очікують від батьків порад та допомоги з різноманітних проблем, тому досить часто батькам доводиться виконувати функції не лише дорослих друзів та вчителів, а й психолога, лікаря, довідкового бюро та «швидкої допомоги». Очевидно, що сім'я має двосторонній вплив на спосіб життя молодої людини: 3 одного боку, сім'я виступає як захисний чинник, що перешкоджає появі та розвитку шкідливих звичок, з другого - як особливий чинник, що стимулює розвиток шкідливих звичок у 
дітей. Захисні чинники сім'ї найбільшою мірою проявляються у тому випадку, коли: між членами сім'ї існують добрі, відверті стосунки; виховання дітей передбачає прояв душевного тепла, виключає постійні ультимативні претензії; батьки вірять у життєві успіхи дітей, проявляють високі батьківські очікування; діти, з одного боку, включені до прийняття сімейних рішень, 3 іншого - мають власні завдання стосовно інших членів сім'ї; стосунки між батьками базуються на емоційній взаємній підтримці; ставлення батьків до дітей базується на реальній зацікавленості, увазі до їхніх проблем та обмежуються не тільки розмовами, а безпосередньою участю у різних аспектах життя дітей [9, с. 4-49.].

Негативний вплив сім'ї на спосіб життя дітей, насамперед, пов'язаний з внутрішньою кризою сім'ї: сімейною дезорганізацією, яка призводить до того, що сім'я перестає вирішувати навіть елементарні проблеми утримання дитини; сімейними конфліктами, які $є$ причиною різних стресів у дітей; проявом насилля (фрізичного, психічного, сексуального); відсутністю почуття любові та взаєморозуміння між членами сім'ї; наявністю шкідливих звичок (алкоголізм, наркоманія тощо) серед членів сім'ї; невимогливістю та непослідовністю санкцій стосовно проявів шкідливих для здоров'я звичок у дітей, слабка дисципліна в сім"ї; нереалізованим очікуванням стосовно розвитку та успіхів дитини [9]. Очевидно, що сім'я відіграє величезну роль у житті окремої особистості і суспільства в цілому. Вона, являючи собою важливий елемент соціальної ситуації розвитку кожної людини, забезпечує як особистісний розвиток окремої людини, так і відіграє визначну роль у фрормуванні патогенних ситуацій та психічних порушень. Психологічно здорова особистість може бути вихована тільки у відповідному оточенні.

Третя умова - педагогічний супровід формування здорового способу життя молодших школярів, обґрунтовано тим, що В. Сухомлинський вирішального значення надає особистості вчителя, його здібностям відчувати іншу людину, вмінням володіти собою й ситуацією. Виховати в собі ці вміння педагог може, якщо буде знати про власне здоров'я, особливості нервової системи й серця, а також не буде допускати, щоб проростало насіння таких негативних явищ, «як похмурість, перебільшення чужих пороків, гіперболізація «ненормальних» дитячих намірів і дій... - погана звичка вимагати від дитини те, що можна вимагати тільки від дорослого». Це потребує від учителя «постійного проникнення в складний духовний світ людини, яке ніколи не припиняється» [13, с. 58]. Розлад здоров'я в педагога, на думку В. Сухомлинського, починається 3 недоброзичливості, підозрілості, озлобленості, які виснажують душу, ослаблюють нерви. «Якщо вам не пощастило уникнути цього, - говорив Василь Олександрович, - ви станете жовчною, дратівливою, похмурою істотою, праця перетвориться для вас у каторгу, у вас з'явиться сто 
виразок і сто пороків» $[13$, с. 60$]$. Він визначає і засоби застереження від цього, стверджуючи, що «оптимізм, віра в людину - невичерпне джерело творчої енергії, нервових сил, здоров'я вихователя й вихованця» [18, с. 431]. Питання зміцнення здоров'я дітей не сходили 3 порядку денного педагогічної ради Павлиської школи, постійно розглядались на заняттях психологічного семінару, де обговорювались «Здоров'я і духовне життя дитини»; «Режим праці і відпочинку»; «Харчування і здоров'я дитини»; «Попередження захворювання серця»; «Слух і зір дитини»; «Діти з уповільненими мислительними процесами» та ін. Про стан здоров'я першокласників на педагогічній раді доповідав лікар. Діти, у яких були виявлені слабкість серцево-судинної системи, дихальних шляхів, порушення обміну речовин, неврози, перебували під постійним наглядом.

Не можна не погодитись з видатним педагогом, що проблема розвитку здоров'я має й зворотний бік: здоров'я величезною мірою залежить від духовного життя, від гармонії здорового тіла й здорового духу: «Турбота про людське здоров'я, тим більше про здоров'я дитини, - це не просто комплекс санітарно-гігієнічних норм і правил, не перелік вимог до режиму, харчування, праці, відпочинку. Це, насамперед, турбота про гармонійну повноту всіх фрізичних і духовних сил, і вінцем цієї гармонії є радість творчості» [20, с. 450].

Педагог закликав ураховувати той зв'язок, який існує між здоров'ям і розумовою працездатністю дитини: «Досвід переконав нас у тому, що приблизно у 85 \% усіх невстигаючих учнів головна причина відставання у навчанні - поганий стан здоров'я, якесь нездужання або захворювання, найчастіше зовсім непомітне й таке, що можна вилікувати тільки спільними зусиллями матері, батька, лікаря і вчителя» [22, с. 48]. Саме тому кожен вид діяльності, кожен спосіб навчання і виховання В. Сухомлинський розглядав з позицій їхнього можливого негативного впливу на самопочуття дітей і їх фрізичний розвиток. Особливе піклування видатний педагог виявляє до дітей, в яких хворобливий стан позначається на поведінці.

Наголошуючи на безпосередній залежності духовного життя дитини від ії здоров'я, В.Сухомлинський багато уваги приділяє педагогічно доцільній організації процесу навчання, методам викладання у школі. Запорукою здорового виховання, за В. Сухомлинським, є, насамперед, навчання учнів відповідно до їх вікових особливостей. Так, специфрікою молодших школярів $\epsilon$ «художнє, образне, емоційно насичене мислення», тому «істина, в якій узагальнюються предмети та явища оточуючого світу, стає особистим переконанням дітей за умови, що вона одухотворена яскравими образами, що впливають на почуття». Отже, розумові здібності дитини мають розвиватися через «пізнання серцем» [16, с. 318].

Особливе місце мають посідати музика, що $\epsilon$ «джерелом благородства серця й чистоти душі» [20, с. 62], та малювання, яке $€$ 
одним із засобів розвитку творчого мислення, уяви, естетичного бачення світу. Не менш важливе значення для здорового розвитку дитини педагог надає «одухотвореному думкою фізичному труду» художній праці, заняттям ремеслами, що пробуджують дитину, формують уміння й навички в різних галузях людської діяльності. Різноманітна праця є також ефективним засобом розвитку розуму, культури мислення. Василь Олександрович попереджає про недопустимість у школі поспіху, нервозності, метушливості, оскільки «прискорений» темп непосильний і шкідливий навіть для цілком здорових дітей. «Надмірне розумове напруження призводить до того, що в дітей тьмяніють очі, затуманюється погляд, рухи стають млявими. І ось дитина вже ні на що не здатна, їй аби тільки на свіже повітря, а вчитель тримає їі «в голоблях» і підганяє: швидше, швидше...» [16, с. 49].

Необхідно індивідуально підходити до кожного учня, бачити розумову роботу кожної дитини; піклуватися про повсякчасний розвиток знань; не допускати, щоб навчання перетворювалося на нескінченне надолужування пропущеного, не підтягувати без кінця «хвости»; надавати учневі вільний час, необхідний йому, як повітря для здоров'я. В. Сухомлинський відстоював гуманний підхід до дитини, активно виступаючи проти засилля авторитарної педагогіки, яка нерідко є причиною конфліктних ситуацій, педагогічних неврозів. У статті «Не бійтеся бути ласкавими!» він 3 тривогою писав: «Покрикування, нервозність, запальність подекуди стали звичними у взаєминах учителя з учнем» [22, с. 352].

Він був непримиренним до зневажливого, грубого ставлення до дітей, підкреслюючи, що «крик у стінах школи - це дрімуче педагогічне безкультур'я». I ще про один важливий аспект збереження психічного і фізичного здоров'я дітей, про який писав В. Сухомлинський, об'єктивну доброзичливу оцінку навчальних досягнень учнів. Педагоггуманіст пропонував не поспішати з виставленням негативної оцінки: «Ніщо так не пригнічує дитину як усвідомлення безперспективності. Не закривайте двійкою шлях до успіху! Оцінкою не можна карати за небажання вчитися, а тим паче за невміння вчитися».

Василь Олександрович запропонував ефективні шляхи зміцнення здоров'я дітей, удосконалення фізичного виховання учнів (апробовані в Павлиській середній школі):

система бесід про людину і особливості людського організму; оптимальне чергування розумової і фізичної праці;

оздоровча спрямованість системи фізкультурних занять: уроків фізичної культури, ранкової зарядки, фрізкультхвилинок, динамічних перерв;

створення широкої мережі спортивних секцій і залучення школярів до активної участі в них; 
спортивні ігри, змагання, спартакіади (легка атлетика, гімнастика, плавання, верхова їзда; катання на ковзанах і лижах, велосипеді; зимові розваги, побудова снігової фортеці тощо);

утвердження у свідомості учнів необхідності дбайливого ставлення до власного здоров'я і здоров'я інших;

активна пропаганда і утвердження здорового способу життя; створення позитивного психологічного мікроклімату.

Отже, педагогічними умовами зміцнення здоров'я молодших школярів у виховній системі В. Сухомлинського $\epsilon$ : створення багатофакторного середовища, атмосфери гуманності і духовності; раціональна організація праці та відпочинку; використання природних факторів; індивідуально-диференційований підхід до дітей; забезпечення емоційного комфорту дітей на уроках та в позаурочний час, створення у дитини відчуття повної безпеки та моральної підтримки, стимулювання ситуацій прагнення до успіху на основі врахування реальних сил і можливостей дитини; взаємозв'язок усіх видів діяльності в процесі зміцнення здоров'я; опора на самовиховання школярів; виховний вплив особистості вчителя; взаємодія школи і сім'ї у зміцненні здоров'я дітей. Таке поєднання різноманітних напрямів у загальноосвітній школі дозволяє виховувати гармонійно розвинуту дитину.

Визначаючи здоровий спосіб життя молодших школярів як мету і результат формування здорового способу життя молодших школярів в освітньому процесі, нами визначено критерії, показники та рівні сорормованості означеного процесу.

Слід зауважити, що для цього, насамперед, необхідно визначити структуру здорового способу життя молодших школярів. У більшості психолого-педагогічних досліджень загальна структура певних утворень, складових, якостей тощо містить конкретні компоненти. В. Черній виокремлює три компоненти, пов'язані із відомою тріадою «знаю, хочу, можу». Компонент, що охоплює уявлення, знання, відомості про предмет дослідження, отримав назву когнітивного, пізнавального, знаннєвого; компонент, що відображає окремі цінності, систему життєвих цінностей, емоції особистості, мотивацію емоційно-ціннісний, мотиваційний, мотиваційно-ціннісний; компонент, пов'язаний із вчинками, поведінкою - поведінковий, діяльніснопрактичний, діяльнісно-поведінковий тощо.

У контексті нашого дослідження, подано перелік показників сформованості здорового способу життя за педагогічною спадщиною В. Сухомлинського (див. табл. 2).

Відповідно до таблиці 2 можна стверджувати, що сутність компонентів здорового способу життя молодших школярів за педагогічною спадщиною $\quad$ В. Сухомлинського має полягати у наступному: 
для когнітивного компонента - у сукупності уявлень, знань про себе, здоров'я, здоровий спосіб життя, фрактори, що впливають на здоров'я, визначають спосіб життя, значення здоров'я та здорового способу життя для людини і т.п.;

для емоційно-ціннісного - у сукупності емоцій, переживань, почуттів, пов'язаних із здоров'ям та способом життя, місця здоров'я у системі життєвих цінностей особистості і т. п.;

для поведінкового - що характеризується сукупністю вчинків і дій, від яких залежить збереження, зміцнення, формування здоров'я або його виснаження.

Таблиця 2

Критерії та показники сформованості здорового способу життя молодших школярів за педагогічною спадщиною В. Сухомлинського

\begin{tabular}{|c|c|c|}
\hline $\begin{array}{l}\text { Компоненти } \\
\text { сформованості } \\
\text { здорового } \\
\text { способу життя }\end{array}$ & $\begin{array}{l}\text { Критерії } \\
\text { сформованості } \\
\text { здорового } \\
\text { способу життя }\end{array}$ & $\begin{array}{c}\text { Показники критеріїв сорормованості } \\
\text { здорового способу життя }\end{array}$ \\
\hline \multirow{3}{*}{ Когнітивний } & \multirow{3}{*}{$\begin{array}{c}\text { Уявлення та знання } \\
\text { про здоров'я та } \\
\text { здоровий спосіб } \\
\text { життя }\end{array}$} & $\begin{array}{l}\text { Уявлення та знання про складові } \\
\text { здоров'я, його значення для життя } \\
\text { людини. }\end{array}$ \\
\hline & & $\begin{array}{l}\text { Уявлення та знання про фоктори, що } \\
\text { впливають на здоров'я молодшого } \\
\text { школяра у процесі навчання. }\end{array}$ \\
\hline & & $\begin{array}{l}\text { Уявлення та знання про здоровий } \\
\text { спосіб життя молодшого школяра, його } \\
\text { значення для життя людини. }\end{array}$ \\
\hline \multirow{3}{*}{$\begin{array}{l}\text { Емоційно- } \\
\text { ціннісний }\end{array}$} & \multirow{3}{*}{$\begin{array}{l}\text { Вмотивованість до } \\
\text { збереження } \\
\text { здоров'я }\end{array}$} & $\begin{array}{l}\text { Місце здоров'я в системі життєвих } \\
\text { цінностей молодшого школяра. }\end{array}$ \\
\hline & & $\begin{array}{l}\text { Інтерес до проблем здоров'я у процесі } \\
\text { життєдіяльності молодшого школяра. }\end{array}$ \\
\hline & & $\begin{array}{l}\text { Мотивація на здоровий спосіб життя } \\
\text { молодшого школяра. }\end{array}$ \\
\hline \multirow{3}{*}{ Поведінковий } & \multirow{3}{*}{$\begin{array}{c}\text { Здоров'язбережу- } \\
\text { вальні } \\
\text { дії та вчинки }\end{array}$} & $\begin{array}{l}\text { Дотримання норм і правил здорового } \\
\text { способу життя у школі та вдома. }\end{array}$ \\
\hline & & $\begin{array}{l}\text { Саморегуляція } \\
\text { здоров'язбережувальних дій та вчинків. }\end{array}$ \\
\hline & & $\begin{array}{l}\text { Відповідальна поведінка в усіх сфрерах } \\
\text { життєдіяльності щодо збереження і } \\
\text { зміцнення власного здоров'я та } \\
\text { здоров'я інших. }\end{array}$ \\
\hline
\end{tabular}

Відповідно до таблиці 2 можна стверджувати, що сутність компонентів здорового способу життя молодших школярів за педагогічною спадщиною В. Сухомлинського має полягати у наступному: 
для когнітивного компонента - у сукупності уявлень, знань про себе, здоров'я, здоровий спосіб життя, фактори, що впливають на здоров'я, визначають спосіб життя, значення здоров'я та здорового способу життя для людини і т.п.;

> для емоційно-ціннісного - у сукупності емоцій, переживань, почуттів, пов'язаних із здоров'ям та способом життя, місця здоров'я у системі життєвих цінностей особистості і т. п.;

$>$ для поведінкового - що характеризується сукупністю вчинків і дій, від яких залежить збереження, зміцнення, формування здоров'я або його виснаження.

Спираючись на дослідження М. Антонець [1, с. 10-13], І. Беха [3, с. 124-129], до компонентів здорового способу життя молодших школярів нами добрані такі критерії: для когнітивного компоненту - знання та уявлення про здоров'я та здоровий спосіб життя, для емоційно-ціннісного - вмотивованість до збереження здоров'я, для поведінкового - здоров'язбережувальні дії та вчинки.

Критерій «Уявлення та знання про здоров'я та здоровий спосіб життя» характеризує сформованість уявлень та знань про складові здоров'я (фізичне, соціальне, психічне і духовне здоров'я), здорового способу життя, про вплив різних чинників на здоров'я людини, зокрема, вплив різних способів спілкування (в тому числі й інтернетспілкування), передбачає надання переваги тому чи іншому джерелу інформування про здоров'я, розуміння дитиною значення здоров'я для свого життя, життя батьків і загалом, життя людини, для її самореалізації та успішності у професійній кар'єрі.

Критерій «Вмотивованість до збереження здоров'я» поєднує у собі ціннісну і емоційну складові сформованості здорового способу життя, які знаходяться в основі фрормування таких особистісних утворень як ставлення, наприклад, ставлення до власного здоров'я та здоров'я інших, ставлення до здорового способу життя, ставлення до фізичної культури тощо. Його характерною ознакою можна вважати наявність і рівень сформованості пізнавального інтересу до проблем, що стосуються збереження, зміцнення i фрормування власного здоров'я. Переживання, емоції, що виникають під час різних явищ і подій, які мають відношення до збереження, зміцнення та формування здоров'я особистості, відіграють значну роль у формуванні мотивації до виконання того чи іншого виду діяльності.

Причому, для формування здорового способу життя молодших школярів важливими $\epsilon$ як позитивні емоції, переживання, так і негативні. Якщо радісні, піднесені емоції закріплюють навички здорового способу життя, сприяють намаганню повторити такі ситуації в процесі своєї життєдіяльності, то емоції смутку, горя, страху, больові відчуття - навпаки, сприяють виробленню поведінкової стратегії уникнення таких ситуацій і подій. Для цього критерію важливим є місце здоров'я в системі життєвих цінностей особистості. 
За сукупністю таких показників критерію «Вмотивованість до збереження здоров'я» можна визначити наявність чи відсутність мотивації на здоровий спосіб життя, рівень сформованості потреби до збереження і зміцнення власного здоров'я та здоров'я інших.

Критерій «Здоров'язбережувальні дії та вчинки» визначає не лише усвідомлення переваг здорового способу життя, норм і правил суспільного життя (це функція когнітивного компоненту), а й їх систематичне дотримання. За цим критерієм можна визначати відповідність дій і вчинків молодших школярів складовим здорового способу життя, рівень самовиховання і самореалізації щодо збереження фрізичного, соціального, психічного та духовного здоров'я, відповідальності учня за власну поведінку вдома, в школі, на вулиці тощо.

Відповідно до структури здорового способу життя молодших школярів нами пропонується виокремити рівні сформованості досліджуваного френомену: високий, середній та низький, їх сутність подано в таблиці 3.

Таблиця 3

Рівні сформованості здорового способу життя молодших школярів за педагогічною спадщиною В. Сухомлинського

\begin{tabular}{|c|c|}
\hline Рівні & Сутність рівнів \\
\hline Високий & $\begin{array}{l}\text { Правильні уявлення і знання щодо основ фізичного, психічного, } \\
\text { соціального, духовного здоров'я, здорового способу життя, } \\
\text { життєдіяльності організму, зацікавленості у проблемах } \\
\text { збереження і зміцнення здоров'я, усвідомлення необхідності } \\
\text { збереження здоров'я і вмотивованість на дотримання здорового } \\
\text { способу життя, вчинки та дії характеризуються проявами } \\
\text { збереження і зміцнення здоров'я. }\end{array}$ \\
\hline Середній & $\begin{array}{l}\text { Переважно уявлення побутового рівня, базові знання щодо } \\
\text { здоров'я та його компонентів, здорового способу життя, } \\
\text { життєдіяльності організму. Учні проявляють нестійкий інтерес до } \\
\text { питань збереження і зміцнення здоров'я. Здоров'я належить до } \\
\text { провідних цінностей молодшого школяра, але, як правило, } \\
\text { характеризується декларативністю. Молодші школярі переважн } \\
\text { дотримуються норм і правил здорового способу життя, періодично } \\
\text { вони згадують про необхідність піклування щодо власного } \\
\text { здоров'я, але зовнішні обставини сильно можуть вплинути на них. }\end{array}$ \\
\hline Низький & $\begin{array}{l}\text { Низький рівень засвоєння знань про здоров'я та його складові, } \\
\text { уявлення про здоров'я далекі від правильного розуміння. Вони } \\
\text { проявляють слабкий інтерес до проблем здоров'я або загалом } \\
\text { негативно сприймають все, що стосується здоров'я, здорового } \\
\text { способу життя, формування здорового способу життя молодших } \\
\text { школярів; серед мотивів здоров'язбережувальні займають одне } \\
\text { останніх місць. Такі учні мають низький рівень відповідальності за } \\
\text { власні дії та вчинки, які характеризуються спонтанністю, } \\
\text { ситуативністю та багато в чому залежать від впливу близького } \\
\text { соціального оточення. }\end{array}$ \\
\hline
\end{tabular}


Отже, вивчення й відродження теоретико-практичної педагогічної спадщини В. Сухомлинського, творче використання його плідних ідей сучасними дослідниками $\epsilon$, безумовно, корисним підґрунтям для реалізації завдань збереження та зміцнення здоров'я та фрормування здорового способу життя молодших школярів. Досвід педагога важливий і, стосовно сьогоднішнього дня, можливий тільки за умови глибокого розуміння та творчому осмисленні його педагогічної системи для виховання й формування фрізично і психічно здорової особистості.

\section{Список використаних джерел}

1. Антонець М. Проблема охорони здоров'я школярів у педагогічній спадщині Василя Сухомлинського. Початкова школа. 2012. № 9. С. 10-13.

2. Бабюк Т.Й. Наступність у вихованні здорового способу життя старших дошкільників та молодших школярів : дис. ... канд. пед. наук : 13.00.07. Київ, 2013. $230 \mathrm{c}$.

3. Бех І. Духовні цінності в розвитку особистості. Педагогіка і психологія. 1997. № 1. C. 124-129.

4. Бєлєнька Г. В., Богініч О. Л., Машовець М. А. Здоров'я дитини від родини : як виховувати в сім'ї здорову дитину від народження до повноліття. К. : СПД Богданова А. М., 2006. 220 с.

5. Бондар Т. С. Методологічні аспекти процесу формування та збереження здоров'я дітей і молоді. Фізичне виховання в школі. 2011. № 6. С. 5-9.

6. Брехман И.И. Философрско-методологические аспекты проблемы здоровья человека. Вопросы философрии. 1982. № 2. С. 48-53.

7. Великий тлумачний словник сучасної української мови/ уклад. і голов. ред. В. Т. Бусел. К. : Ірпінь : ВТФ «Перун», 2009. 1736 с.

8. Горащук В. П. Теоретичні та методичні засади формування сформованості здорового способу життя школярів : дис. ... д-ра пед. наук : 13.00.01. Луган. нац. пед. ун-т ім. Тараса Шевченка. Х., 2004. 414 с.

9. Дембіцька Л., Петрова О. Здоров'язбережувальні технології в освітньому середовищі: основи здоров'я. 2-й клас : матеріали до уроків. Початкова освіma. 2015. № 23(767). С. 4-49.

10. Дермельова К. О. Єдність навчального і виховного компонентів як засіб соціалізації сучасної дитини. Засоби навчальної та науково-дослідної роботи. Випуск 38. 2012. С. 21-26.

11. Загоруйко О.Я. Великий універсальний словник української мови. Харків : ТОРСІНГ ПЛЮС, 2010. 768 с.

12. Изуткин Д. А., Степанов А. Д. Критерии здорового образа жизни и предпосылки его формирования. Сов. здравоохранение. 1981. № 5. С. 24-32.

13. Мазченко А. Використання спадщини В. О. Сухомлинського на шляху впровадження здоров'язбережувальних технологій. Рідна школа. 2012. № 7. С. 58-60.

14. Мосіяшенко В.А., Курок О. І., Задорожна Л.В. Історія педагогіки України в особах: навчальний посібник. Суми: ВТД «Університетська книга», 2005. $266 \mathrm{c}$.

15. Смирнов А. В. Поурочное планирование программы по основам здорового образа жизни в курсе ОБЖ общеобразовательных учреждений. Основы безопасности жизнедеятельности. 2000. № 2. С. 8-14.

16. Сухомлинский В. А. Павлышская средняя школа: обобщение опыта учебновоспитательной работы в сельской средней школе. М.: Просвещение, 1979. $393 \mathrm{c}$. 
17. Сухомлинський В. О. Духовний світ школяра. Вибрані твори в 5-ти томах. К. : Радянська школа, 1977. Т. 1. С. 209-400.

18. Сухомлинський В. О. Народний учитель. Вибрані твори в 5-ти томах. К.: Радянська школа, 1977. Т. 5. С. 239-255.

19. Сухомлинський В. О. Серце віддаю дітям / Василь Сухомлинський. - К., 1977. $269 \mathrm{c}$.

20. Сухомлинський В.О. Моя педагогічна система. Радянська школа. 1988. № 7. С. 79-84; № 8. С. 87-91; № 9. - С. 86-91.

21. Сухомлинський В.О. Сто порад учителеві. Вибрані твори в 5-ти томах. К.: Радянська школа, 1976. Т. 2. С. 420-654.

22. Сухомлинський В. О. Проблеми виховання всебічно розвиненої особистості. Вибрані твори в 5-ти томах. К. : Радянська школа, 1977. - Т. 1. С. 62-206.

23. Чумаков Б. Н. Введение в валеологію. М.: Российское педагогическое агентство, 1997. 237 с. 


\title{
ДІАГНОСТИКА НАВЧАЛЬНИХ ДОСЯГНЕНЬ УЧНІВ ПОЧАТКОВИХ КЛАСІВ 3 МУЗИЧНОГО МИСТЕЦТВА
}

\author{
Данько Н.П. \\ кандидат педагогічних наук, доцент, \\ Сумський державний педагогічний університет ім. А.С. Макаренка
}

Дослідження стану музичного навчання молодших школярів у контексті здійснення інтегрованого підходу проводились на базі Національного педагогічного університету імені М.П. Драгоманова, Сумського НВК №9 «Веснянка», Сумської загальноосвітньої школи № 15, Котелевецької гімназії №1. В експериментальному дослідженні приймало участь 267 респондентів (з них 102 студенти, 91 учень, 38 батьків, 36 учителів музики й початкових класів). Констатувальний експеримент складався з двох етапів ( пошукового та діагностичного).

У проведенні констатувального експерименту, що полягав у кількісному та якісному аналізі ефективності здійснення інтегрованого музичного навчання молодших школярів, використовувалась комплексна методика, що містила: педагогічне спостереження, анкетування, інтерв'ю, тестування, аналіз творчих робіт учнів. Для отримання достовірних даних було розроблено анкети, тести, проведено спостереження за навчально-виховним процесом, експертні опитування.

У ході констатувального експерименту встановлено рівні сфрормованості інтегрованої навченості мистецтва молодших школярів. Відповідно до визначених критеріїв та показників сформованості обґрунтовано суттєві ознаки достатнього, середнього та низького рівнів означеного френомену.

Загальна мета констатувального експерименту полягала у визначенні особливостей організації існуючого музичного навчання в початковій школі в контексті інтеграції різних видів мистецтва та діяльностей, що їх забезпечують; підготовки інформаційно-практичної бази для перевірки умов ефективності інтегованого навчання музики молодших школярів, існуючих рівнів сформованості ї музичноінтегрованих навичок.

Відповідно до мети, нами були розроблені такі завдання:

1) провести педагогічне спостереження за процесом музичних занять в початковій школі;

2) здійснити аналіз навчальної документації (навчальних програм, підручників, посібників) щодо наявності методик інтегрованого навчання молодших школярів на уроках музики, творчих завдань, пояснення спільного та різного між видами мистецтв;

3) проаналізувати обізнаність вчителів початкових класів, вчителів музики та майбутніх вчителів початкових класів щодо проблеми інтегрованого навчання музики молодших школярів; 
4)визначити реальний стан обізнаності батьків щодо необхідності мистецьких занять як засобу культурного розвитку дітей;

5) здійснити аналіз наявних рівнів сорормованості компонентів інтегрованої навченості музики молодших школярів;

6) визначити ставлення учнів до різних видів музичного мистецтва і мистецтва взагалі та ставлення вчителів до проведення інтегративних занять з музичного мистецтва;

7) визначити ступінь готовності майбутніх вчителів до впровадження в шкільну практику інтегрованого принципу навчання музики, фрормуванню в молодших школярів інтегрованих знань, навичок, умінь з метою формування в їх свідомості цілісної художньої картини світу і культурного простору.

Перший етап констатувального експерименту - пошуковий, передбачав здійснення діагностичної розвідки для отримання фрактів, що впливають на якість навчання та кінцевого результату - цілісності знань і музично-інтегрованих навичок учнів початкових класів, сфрормованості в них культурологічного досвіду.

У процесі вирішення даних завдань була спроектована поетапна діагностика пошукового експерименту, яка містила цілу низку педагогічних мікродосліджень, що включили: аналіз навчальної документації, проведення бесід, інтерв'ю з вчителями, анкетування учнів, батьків, вчителів. На цьому етапі важливого значення набули процеси виявлення спрямованості пізнавально-мотиваційної ссрери учнів, домінуючі пізнавальні інтереси в мистецькій діяльності - ступінь реалізації на практиці мотиваційно-спонукального компоненту.

На вихідному, першому етапі пошукового експерименту був здійснений аналіз навчальної документації. В результаті аналізу було виявлено, що переважна більшість змісту навчальних програм та підручників спрямована на засвоєння учнями відповідної системи знань про музичне мистецтво, формування умінь і навичок вокальної, вокально-хорової діяльності, слухання музики, котрі виступають основою у формуванні інтегрованих знань, що мають сприяти формуванню цілісної картини світу молодших школярів та їх художнього простору

Виявлення індивідуальних творчих здібностей, інтересів, смаків, уподобань підростаючого покоління, що відповідає цілям особистісноорієнтованої гуманістичної спрямованості сучасної педагогіки $\epsilon$ пріоритетними завданнями в процесі викладання уроків з музичного мистецтва. I навпаки, необґрунтована диференціація мистецького матеріалу, розірваність, мозаїчність знань учнів, непослідовність у мистецько-педагогічних діях учителя гальмують художньо-творче становлення особистості учня.

3 метою уточнення результатів аналізу навчальної документації, на другому етапі були застосовані наступні методи: інтерв'ю 3 вчителями та бесіди з дітьми, батьками, спрямовані на виявлення 
причин, що гальмують забезпечення ефективності навчання музики молодших школярів у напряму реалізації інтегрованих підходів.

У результаті бесід з батьками учнів, більшість опитуваних $(42,4$ \%) зазначали, що причинами низької успішності учнів є низький рівень інтересу дітей, відсутність активності, віддання переваги телеінтернет-засобам отримання інформації. Інші респонденти $(28,8 \%)$ вказали на недостатню мотивацію до мистецької, творчої діяльності, причиною якої $€$ нерозуміння значення мистецтва, його специфіки та налаштування навчального процесу на репродуктивну діяльність.

Лише незначна частка батьків (28,8 \%) вбачають причини загальної неуспішності у перевантаженні учнів об'ємом необхідної навчальної інформації, обмеженою кількістю годин для вивчення. При цьому деякі з опитуваних (19,2\%) підкреслили неможливість займатися розвитком творчих здібностей школярів за умови переповнених класів та невмінням дорослих зацікавити учнів мистецтвом й процесом творчої діяльності.

Під час бесід із учнями, метою яких було з'ясування ставлення дітей до уроків музики, виявлення найцікавіших для них видів мистецької, музичної діяльності та наявності складних завдань для виконання, що впливає на успішність навчальної діяльності. Бесіди проводилися у вільній формі. Була визначена загальна тема обговорення щодо мотивів занять мистецтвом, видами художньотворчої діяльності та з'ясування рівня обізнаності учнів про мистецтво. Результати опитування дали змогу з'ясувати, що більша частина учнів (62\%) виявляють інтерес до мистецтва, але не усвідомлюють чітко його специфіку, наявною є невизначеність у виборі «улюбленого» виду мистецької діяльності. Значна кількість реципієнтів не змогли назвати улюблений вид мистецької діяльності.

У результаті індивідуального інтерв'ювання вчителів, яке передбачало свободу діагностичної комунікації, більшість опитуваних $(42 \%)$ зазначили, що причинами «розірваності, поверховості» знань учнів $є$ низька навчальна мотивація. Інші респонденти (30\%) вказали на відсутність інформації щодо методики використання інтегрованого підходу, здійснення інтегрованих технологій в початковій школі; відсутність методичних вказівок щодо розвитку творчих здібностей, неможливість здійснення індивідуального підходу за браком часу й великим обсягом навчальних тем при ситуації переповнення класів. Лише невелика частина (28\% ) вчителів вбачають причину загальної неуспішності учнів у недостатній розробленості змісту мистецької освіти та протиріччі, що полягає між потребами сучасного суспільства в розвиненій, творчій особистості та відсутності належних умов, які б забезпечили формування такої особистості.

Під час інтерв'ю з батьками ми 3'ясували, що більшість із них бажали б створити належні умови для творчого розвитку дітей, але не мають належних знань та не володіють інформацією щодо виявлення 
індивідуальних здібностей, правильного визначення особистісного шляху розвитку дитини. Батьки очікують педагогічної допомоги, фахової підтримки з боку вчителів щодо фрормування та розвитку особистості дітей. Слід відмітити, що існує значний відсоток таких батьків, які взагалі не замислюються над причинами і можливими шляхами поліпшення якості мистецької освіти та здійснення процесу творчого розвитку школярів, про що свідчить неусвідомленість або відсутність вказаних причин. Таким чином, можемо констатувати той факт, що майже всі (75\%) учасників запропонованих нами бесід та проведених інтерв'ю пов'язують успішність мистецького навчання із впливом зовнішніх фракторів.

У результаті інтерв'ювання батьків і бесід із вчителями початкових класів та вчителями музики, виявлено, що незначна частина опитуваних $(19 \%, 26 \%)$ співвідносить залежність успішності навчальної діяльності учнів із рівнем сформованості навчальної мотивації, інтересу до мистецької діяльності. За результатами анкетування вчителів була з'ясована загальна картина організації та здійснення інтегрованого навчання молодших школярів. В анкетуванні приймали участь вчителі початкових класів та вчителі музики, що викладають в початкових класах. Анкета складалась з 5 питань. На питання «Чи проводите ви інтегровані уроки?» позитивно відповіли всі 100\%. Кожен учитель зазначив елементи навчальних дисциплін, які входять до інтегрованих уроків («Я і Україна», «Образотворче мистецтво», «Музичне мистецтво», «Трудове навчання», «Навколишній світ», «Читання»). Найчастіше вчителями проводяться інтегровані уроки 3 читання, образотворчого мистецтва та трудового навчання. На питання «Які види мистецтв використовуєте на інтегрованих уроках?» вчителі відповіли: музичне мистецтво (80 \%), образотворче мистецтво $(95 \%)$, літературне мистецтво (62\%), театральне мистецтво $(65 \%)$, декоративно-прикладне мистецтво (30\%).

Кожен з респондентів використовує під час інтегрованих уроків елементи різних видів мистецтв. Отже найбільше вчителями на уроках використовуються елементи образотворчого мистецтва. На другому місті - елементи музичного та театрального мистецтва, а на третьому - літературне мистецтво, четвертому - елементи декоративно-прикладного мистецтва.

На питання «Чи варто молодшим школярам спочатку пояснювати існування різних видів мистецтв, а потім вже пропонувати їх вивчати ізольовано?» більша частина відповіла позитивно. Більшість респондентів вважають, що спочатку дітям слід пояснити сутність мистецтва, як явища культури, розглянути особливості різних видів мистецтв, а потім вивчати їх ізольовано. Інші надали негативну відповідь. На запитання «Чи пропонуєте Ви учням творчі завдання за вибором?» позитивно відповіли (50\%) вчителів, інколи (25\%); ні $(25 \%)$. Вчителі розуміють необхідність існування завдань за вибором, але не 
завжди їх застосовують, посилаючись на брак часу.

Серед видів поліхудожньої діяльності, які пропонуються на уроках учням, вчителі відмітили наступні: малювання музичного образу (50\%), створення словесного портрету казкових героїв, музичного, художнього образів (35\%), передача музичного змісту засобами акторської майстерності (15\%). Більшість респондентів висловили думку про те, що варто в початковій школі запровадити інтегроване вивчення мистецтва, у змісті якого цілісно подавалися б різні види мистецтва та формувалися початкові навички творчої діяльності молодших школярів. Позитивну відповідь надали майже всі опитувані $(98 \%)$, вагалися (2\%); негативної відповіді не було. Вчителі, які позитивно відповіли на дане запитання вважають, що це допоможе уявити дітям різноманіття видів мистецтва, усвідомити його цілісність. Вони вважають також, що це буде сприяти всебічному розвитку учнів, їх світогляду, збагатить уяву, мислення. Отже більшість опитаних вчителів вважає, що такі заняття потрібні, оскільки це допоможе сорормувати у дітей загальне уявлення про мистецтво.

3 метою визначення ставлення учнів до мистецьких занять, спрямованість їх на мистецько-творчу діяльність було проведено анкетування учнів. У анкетуванні приймали участь 91 учень. Мета анкети №1 для учнів початкових класів полягала у визначенні початкового рівня знань про різні види мистецької діяльності, виявленні їх «улюблених» видів мистецької діяльності, наявності стійкого інтересу до мистецьких занять, до музичної діяльності. За результатами анкети половина респондентів (50\%) виявили інтерес до мистецької діяльності в різних її видах. Також, була виявлена значна кількість дітей із низьким і середнім рівнем інтересу до мистецьких занять.

Аналіз анкетних даних учнів свідчить про те, що вони виявляють інтерес до мистецької діяльності, хоча серед видів діяльності називають різні: спів, малювання, танець, акторську гру. У результаті обробки даних виявилося, що більше половин учнів (65\%) дійсно захоплюються мистецькими заняттями. Учні із стійким інтересом мають потребу в заняттях мистецтвом, при чому проявляють особливе зацікавлення одним або декількома видами мистецької діяльності одночасно.

Результати проведеного анкетуванні учнів №1 показали, що серед різних видів мистецької діяльності діти обрали: малювання $(49,14 \%)$, спів (32, $76 \%)$, танець $(33,67 \%)$, а також діти вказали, що люблять навчатися (41\%) і грати (23\%). Серед видів діяльності, запропонованих дітям у всіх відповідях переважають спів та малювання. Ми припускаємо, що малювання $€$ психологічно необхідним, одним із провідних видів діяльності молодших школярів, яке їх захоплює. Але, хоча, малювання $є$ домінантним видом художньотворчої діяльності, учні також виявили інтерес і до співу, танцю, акторської діяльності. Відповіді охопили всі запропоновані види 
мистецької діяльності, що надає можливості стверджувати необхідність врахування інтересів дітей.

На питання «чим займаєтесь у вільний час разом з батьками?» учні відповіли, що разом з батьками у вільний час найчастіше малюють $(38,22 \%)$, слухають музику $(30,45 \%)$, танцюють $(15,47 \%)$, виготовляють поробки (37\%), співають (20\%). Отже на першому місті посідають такі види діяльності, як малювання та виготовлення поробок, на другому - слухання музики, читання, на третьому - спів, танець. Найчастіше учні малюють, а рідше співають та танцюють, хоча ці види діяльності - спів і танець $€$ важливими традиційними українськими засобами художньо-естетичного, національного виховання і розвитку молодого покоління. Співу і танцю не надається належної уваги. Найбільше учні цього віку малюють. Цей факт свідчить про природну необхідність молодших школярів у даному виду творчої мистецької діяльності.

Серед улюблених уроків молодші школярі визначили: уроки малювання (90\%), уроки читання (88\%), музики (17\%). Низький відсоток названих учнями уроків музики дозволив припустити, що на таких уроках не враховуються інтереси дітей, їх індивідуальні особливості. На питання «професію кого з митців ти обрав би?», серед представлених варіантів професій митців учні обрали такі: художника - $10 \%$, співака - $5 \%$, композитора - $1 \%$, актора $-2 \%$, хореограсра $-2 \%$.

Реалізуючи мету і завдання пошукового експерименту, здійснюючи детальний аналіз навчальної документації, систематизацію та узагальнення результатів бесід, інтерв'ювання, анкетування, нами зроблено наступні попередні узагальнення:

1) відсутність усвідомлення вчителями важливості фрормування позитивної мотивації мистецької навчальної діяльності молодших школярів гальмує фрормування позитивної мотивації, стійкого навчального інтересу, що пов'язано з низьким рівнем знань педагогів про особливості, мету, зміст інтегрованого навчання, знань психологічних особливостей мистецької та творчої діяльності й неспроможність створити відповідні педагогічні умови, які б сприяли ефрективному навчанню та розвитку молодших школярів;

2) невелика кількість батьків вважають за потрібне їх дітям займатися мистецтвом, виконувати творчі завдання, хоча $є$ такі, що усвідомлюють цінність мистецьких знань, значення музики як виду мистецтва, що сприяє розвитку особистості дитини, її творчого потенціалу;

3) вчителі молодших класів та вчителі музики зазначили необхідність розробки методики здійснення інтегрованого навчання та визначення відповідних педагогічних умов, які забезпечили б ефективність здійснення інтегрованого навчання та творчого розвитку школярів; 
4) більшість опитуваних учнів виявили інтерес до занять мистецтвом, хоча не всі віддали перевагу музиці.

Результати пошукового експерименту підтвердили практичну значущість досліджуваної проблеми для теорії й методики інтегрованого навчання музики молодших школярів й зумовили розробку діагностичного етапу констатувального дослідження, мета якого полягала у розробці діагностичної методики і визначені рівнів сформованості інтегрованої навченості молодших школярів у відповідності до критеріїв і показників досліджуваного френомену.

Визначення ссрормованості структурних компонентів інтегрованого музичного навчання відбувалося на основі встановлених відповідних критеріїв. Насамперед варто внести визначеність у зміст терміну «критерій». У загальноприйнятому розумінні критерій - це ознака, на основі якої здійснюється оцінка чого-небудь, мірило оцінки. Критерій (criterion - засіб, судження) грецького походження, $є$ ознакою, на підставі якої здійснюється оцінка визначення або класифікація певних об'єктів. При цьому під ознакою розуміють зовнішній прояв, за якими їі можна впізнати, визначити або описати. Показник вимірювання свідчить про те, що саме фріксується числом, отриманим внаслідок вимірювання.

О. Савченко визначає критерії як реальні, точно обрані ознаки, величини, котрі виступають вимірниками об'єктів оцінювання [9] І. Ісаєв визначає критерії як ознаки, на основі яких здійснюється оцінка, судження Ю. Туранов, В. Уруський вважають, що критерії це мірило оцінювання вказаних параметрів, котрі описуються певним показниками. На основі теоретичного аналізу і враховуючи мету дослідження, ми виходили з того, що критерії - це якості, властивості, ознаки об'єкта, що вивчається, які надають можливість зробити висновки про стан і рівень його сформованості та розвитку; показники - це кількісні та якісні характеристики сформованості кожної якості, властивості, ознаки об'єкту, котрий вивчається, тобто міра (ступінь) сорормованості того чи іншого критерію (В. Загвязинський, І. Ісаєв, В. Раєвський, В. Лозова та ін..) Отже, критерії - це якості, властивості, ознаки досліджуваного об'єкта, які дозволяють робити висновки про його стан, рівень розвитку і функціонування; показники - це кількісні та якісні характеристики сформованості кожної якості, властивості, ознаки досліджуваного об'єкта, тобто ступінь сформованості того чи іншого критерію.

Діагностичний експеримент проходив у кілька етапів, що було зумовлено компонентною структурою досліджуваного френомену й спрямований на діагностику мотиваційно-спонукального, змістовопроцесуального, творчо-результативного компонентів. Кожен етап констатувального експерименту переслідував досягнення певної мети, виконання ряду дослідницьких завдань. 
3 метою з'ясування рівнів сформованості мотиваційноспонукального компоненту інтегрованого навчання музики (відповідний критерій - міра особистої потреби учнів у мистецькотворчій діяльності), нами було окреслено зміст його показників. Діагностування означеного критерію здійснювалось на базі авторських діагностичних завдань, створених шляхом модифікації відповідних методик. У процесі констатувального експерименту були модифріковані діагностичні завдання щодо інтересу та мотивації учнів.

Перший показник - ставлення, стійкий інтерес до мистецтва. Інтерес до цієї форми пізнання світу активізує пізнавальну діяльність, спонукаючи учнів до мистецької, мистецько-творчої діяльності. Саме інтерес «...забезпечує спрямованість на усвідомлення цілей діяльності, і тим самим, сприяє орієнтуванню, ознайомленню з новими фактами, більш повному і глибокому відображенню дійсності» [9].

Достатній рівень сфрормованості інтересу характеризується позитивним ставленням до занять мистецько-творчою діяльністю, активною цілеспрямованістю на виконання музичних, творчих, поліхудожніх завдань; стійким пізнавальним інтересом, потребою в мистецьких заняттях. Достатній рівень характеризує наявність стійкого бажання учнів займатися мистецькою, творчою діяльністю, виконувати музичні, мистецько-творчі завдання. Достатнім рівнем на констатувальному етапі експерименту володіє незначна частина учнів (12\%). Вони характеризуються позитивним ставленням, стійким інтересом до музичних занять, прагненням здійснювати різні види музичної, мистецької, творчої діяльності.

Респондентів середнього рівня відрізняє інша мотивація до вивчення. Їх інтерес спрямовано на отримання похвали вчителя, батьків та отримання позитивних оцінок. Представники даного рівня склали переважну більшість $(56,9 \%)$, майже третина учнів $(31,3 \%)$ проявили недостатній інтерес до вивчення музики. Такі діти, залежно від навчальної ситуації, проявляють інтерес лише до окремих фактів та видів діяльності.

Низький рівень інтересу продемонстрували діти з низьким рівнем активності, яким характерна пасивність, байдужість до запропонованих різних видів завдань. Вони фрагментарно сприймають навчальний матеріал, не виконують творчі завдання, не відповідають на запитання, відволікають інших учнів. (30\%).

Другий показник мотиваційно-спонукального компоненту наявність мотивів навчально-мистецької діяльності учнів $€$ вельми значущим, оскільки забезпечує особистісну спрямованість учнів на мистецько-творчу діяльність. Усвідомлене керування мистецьким вибором об'єктивно впливає на навчальну активність та підвищення результатів мистецької, мистецько-творчої діяльності. Діагностування означеного критерію здійснювалося на базі авторських діагностичних завдань, створених шляхом модифікації відповідних методик. 
У нашому дослідженні особливого значення набуває позиція О. Савченко щодо визначення поняття «мотив». Мотив - це спонукання до діяльності. Саме мотиви спрямовують, організовують пізнання, надають йому особистісного значення. Розрізняють зовнішні та внутрішні мотиви. Зовнішні мотиви - це мотиви, які безпосередньо не пов'язані з діяльністю, але впливають на ії успішність, наприклад, позитивне ставлення дітей до школи, прагнення бути дорослим. Внутрішні мотиви пов'язані із процесом учіння, його результатами. Причому внутрішня мотивація учіння в молодших школярів нестійка, інтерес виявляється переважно до результату. Наполегливість у досягнені навчальної мети молодші школярі виявляють залежно від ситуацій: цікаве завдання, підтримка дорослих, змагальність [9, с.131-132].

Найбільш значущою для ефективності навчальної діяльності $€$ мотивація, зумовлена інтелектуальною ініціативою і пізнавальними інтересами. Навчання молодших школярів полівмотивоване, тобто дитиною керують залежно від ситуації, різні мотиви. Серед пізнавальних мотивів керованим і найзначнішим $\epsilon$ пізнавальний інтерес. [9. с.136].

У результаті аналізу отриманих даних, можна констатувати, що достатній рівень позитивної мотивації сформовано у 15\% опитуваних дітей. Діти даного рівня демонструють наполегливість, певний інтерес, зосередженість протягом всього заняття. Вони розуміють, що займатися мистецькою діяльністю потрібно для того, що б навитися співати, грати на інструменті, читати нотний текст, малювати, танцювати, тобто набути вмінь, навичок мистецької діяльності, бути культурною людиною.

Середній рівень мотивації зафіксовано у 19\% учнів. Для учнів із середнім рівнем сформованості мотивів характерно невизначення «улюбленого» виду мистецької діяльності, фрагментарний прояв активності на уроці, прояв неусвідомленого ставлення до мистецької діяльності. Досить вагомий відсоток 44,4\% становить група учнів із низьким рівнем мотивації. Серед мотивів, які називали учні, $\epsilon$ й негативні, такі як наприклад , «навчаюся грати тому, що примушують», «тому, що подружка теж грає», «батьки пообіцяли купити велосипед». Такі мотиви називали учні, які виявили низький рівень мотивації. Для них характерними $є$ низький рівень активності протягом всього уроку, незацікавленість мистецькою діяльністю, відсутність «улюбленого» виду мистецтва, байдужість до виконання творчих завдань.

Високий рівень продемонстрували лише $7,8 \%$ учнів зміст їх відповідей повністю відповідав високим узагальненим показникам даного рівня.

Третій показник мотиваційно-спонукального компоненту - вияв пізнавальної активності молодших школярів до занять мистецькими діяльностями, що визначалось зацікавленістю учнів молодших класів у 
отриманні якісних художньо-образних уявлень і практичних навичок 3 різних видів мистецької діяльності.

За зведеними результатами першого етапу констатувального експерименту можна виявити кількісні і якісні показники сфрормованості мотиваційно-спонукального компоненту інтегрованого навчання музики молодших школярів.

Достатній рівень сорормованості мотиваційно-спонукального компоненту характеризується високою активністю учнів на уроках музики, позитивним ставленням до мистецької діяльності, стійкою особистісною готовністю до виконання мистецьких творчих завдань, наявністю стійкого інтересу до мистецтва, потреби у спілкуванні 3 творами мистецтва та виконанні самостійно мистецьких завдань. На констатувальному етапі педагогічного дослідження до високого рівня було віднесено 14, 1\% досліджуваних.

Середній рівень сорормованості мотиваційно-спонукального компоненту відзначається пасивним ставленням до творчої мистецької діяльності. Учні не визначилися з «улюбленим» видом мистецької діяльності, всі види мистецької, творчої діяльності виконують за наявності зовнішньої мотивації з боку педагога. Респондентів даного рівня налічується 50,3\%.

Низький рівень сорормованості мотиваційно-спонукального компоненту характеризується проявом негативного ставлення й пасивного ставлення до мистецьких занять, неможливістю самостійно виконати творче завдання, ігноруванням виконання навчальних завдань взагалі. Такі учні проявляють слабкий ситуативний інтерес до мистецької діяльності, який

проявляється під час ігрових, сюрпризних моментів на уроці. До низького рівня мотиваційно-спонукального компоненту віднесено $35,6 \%$ досліджуваних.

У результаті порівняння кількісної характеристики рівнів сорормованості мотиваційно-спонукального компоненту на початковому етапі діагностики цілісності мистецьких знань учнів, можемо зазначити, що серед молодших школярів виявлена переважна більшість учнів із низьким (35,6\%) і середнім $(50,3 \%)$ рівнем мотивації до мистецької творчої діяльності.

Мета наступного етапу діагностики в межах констатувального експерименту передбачала діагностування показників змістовопроцесуального компоненту, спрямованих на виявлення уміння оперувати набутими знаннями у різних видах діяльності ( малювання музичних образів, створення словесного портрету музичних образів, передача музичного змісту засобами жестів, рухів); інформованість про особливості засобів мистецької виразності та вираження художнього образу засобами різних видів діяльності; якість виконання завдань за вибором, поліхудожніх індивідуальних уподобань. 
Отже, критерієм змістово-процесуального компоненту виступає міра здатності учнів до усвідомлення та оцінювання спільного в мистецтві, що віддзеркалюється в таких показниках, як: інформованість про особливості засобів мистецької виразності та взаємозв'язок різних видів мистецтва; уміння накопичувати знання й навички відшукування ключових змістових складових тематичного наповнення навчальної інформації; уміння оперувати набутими знаннями у різних видах мистецької діяльності (малювання музичних образів, створення «словесного портрету» музичних образів, передача музичного змісту засобами жестів, рухів, кольору). Діагностичні зрізи були проведені у процесі здійснення уроків музики в початкових класах, під час виконання учнями навчальних, мистецьких, творчих завдань. Протягом діагностичного експерименту було проведено анкетування, опитування учнів.

Вимірювання першого показника змістово-процесуального компоненту - вияву інфрормованості про особливості засобів мистецької виразності та взаємозв'язок різних видів мистецтва, що відбувалися на етапі констатувального експерименту, здійснювались за допомогою анкетування учнів, аналізі творчих робіт, що сприяло визначенню наявності навичок вираження художнього образу засобами різних видів мистецтв.

Таким чином, запропоновані питання анкет дозволили нам виміряти наявність інфрормованості молодших школярів про особливості засобів мистецької виразності у контексті фрормування змістово-процесуального компоненту інтегрованого навчання.

Було з'ясовано рівні проінформованості учнів початкових класів щодо засобів мистецької виразності та вираження художнього образу засобами різних видів мистецтв. Окрім анкет учням було запропоновано виконати ряд завдань, що базуються на відпрацюванні мисленнєвих операцій аналізу і порівняння (намалювати образ запропонованої музичної п'єси, порівняти зміст запропонованих пісні та вірша на задану тему, знайти різницю між художнім і музичним образами, порівняти дві музичні п'єси, тощо). Результати виконання означеного завдання засвідчили, що респонденти володіють інформацією про особливості засобів мистецької виразності та власне вираження художніх образів засобами різних видів мистецтв на досить низькому рівні.

Невелика частина учнів $(0,96 \%)$ виявила проінформованість стосовно характерних особливостей засобів мистецької виразності та мала змогу виконати творчі завдання стосовно вираження художніх образів засобами різних видів мистецтва. Переважна більшість респондентів (20\%) вказують на недостатність інформації щодо специфічних особливостей різних мистецьких засобів і відповідно не виявили вміння виражати художні образи засобами інших видів мистецтв. Оскільки учні не розуміють вище зазначених 
особливостей, відповідно вони не можуть виконувати завдання на вираження художнього образу одного мистецтва в художньому образі іншого виду мистецтва. Так частина опитаних ( 9,04\%) вказали на відсутність знань про особливості засобів мистецької виразності в різних видах мистецтва.

Другий показник змістово-процесуального компоненту - уміння учнів оперувати набутими знаннями в різних видах мистецької діяльності (малювання музичних образів, створення «словесного портрету» музичних образів, передача музичного змісту засобами жестів, рухів, кольору) визначали за допомогою таких методів дослідження, як: анкетування, аналіз творчих робіт та виконання навчальних завдань учнів.

Під час інтегрованих уроків музики передбачається виконання різних видів мистецької, творчої діяльності. Так учням пропонуються наступні види діяльності: слухання музики, аналіз музичного твору, вивчення музичної грамоти, спів, малювання, рухи під музику, виконання творчих, навчальних завдань, вивчення теоретичних основ мистецтва.

Трактуючи зміст поняття «знання», Гончаренко С. визначає його як: «особливу форму духовного засвоєння результатів пізнання, яка характеризується усвідомленням їх істинності» [5, с. 184]. Знання виражаються у поняттях, судженнях, умовиводах, концепціях, теоріях. Невід'ємними якостями справжніх знань є їх систематичність, усвідомленість, осмисленість. Вони $€$ одним із джерел нахилів і інтересів людини, необхідною умовою розвитку здібностей обдарувань [5, $184-185]$.

3 метою визначення обізнаності учнів стосовно знань про мистецтво передбачалося: виявлення знань назв різних видів мистецтв, основних понять та термінів, жанрів мистецтва, видів мистецької діяльності, професій митців.

Важливість формування цілісних знань про мистецтво, цілісної картини світу школярів змушує переглянути традиційний зміст навчальної дисципліни «Музика» на предмет наявності інтегрованих знань про мистецтво як багатогранне явище. Так учні молодшого шкільного віку мають знати, що мистецтво - це явище культури, яке складається 3 різні видів. Діти мають усвідомити, що всі види мистецтва взаємопов'язані і доповнюють один одного; в кожному 3 видів мистецтва закладені художні образи, а митці використовують специфічні засоби виразності в межах кожного окремого мистецтва. Знаючи специфрічні особливості різних видів мистецтва, учні краще зрозуміють та запам'ятають специфіку музичного мистецтва.

Діагностування наступного показника - уміння оперувати набутими знаннями у різних видах діяльності, здійснювалося шляхом залучення методу діагностичного опитування відносно рівня обізнаності із комплексом знань щодо основ мистецтва, його видів, жанрів, основних видів виразності. 
Уміння - це здатність належно виконувати певні дії, заснована на доцільному використанні людиною набутих знань і навичок. Уміння передбачає використання раніше набутого досвіду, певних знань [216, с. 468]. Вивчення навчального предмета, виконання вправ, самостійних робіт виробляє в учнів уміння застосовувати набуті знання. Уміння - засвоєння суб'єктом способів виконання практичних і теоретичних дій на основі знань і життєвого досвіду; формується вправлянням, передбачає застосування у звичайних та змінених умовах [5, с. 364].

3'ясування наявності сфрормованості уміння оперувати набутими знаннями, яке відбувалось на основі діагностичного опитування «Діагностика уміння застосовувати набуті знання», базувалось на твердженні, що інтегровані знання про мистецтво молодших школярів мають включати такі основні поняття: образ, ритм, форма, композиція, види мистецтва.

За умови ознайомлення учнів із поняттями на рівні мистецтвознавчої пропедевтики та в єдності 3 практичним застосуванням отриманих знань в учнів має бути ссрормовано комплекс умінь. Так, у молодших школярів мають бути сформовані такі уміння: передавати в кольорі настрій музичної п'єси; визначати музичний лад, відображаючи його в малюнках; підбирати словасиноніми до музичного образу; відтворювати динаміку, настрій музичного твору за допомогою жестів, міміки, рухів; створювати ілюстрації відповідно куплетам розучуваної пісні; імпровізувати танцювальні рухи під музику; визначення форми музичного твору та відтворення ії у графічному малюнку; за допомогою різних ліній відображати «ведення музичної мелодії; підбираючи риму до слів, відтворювати ії за допомогою вокальної імпровізації; відображення мелодії за допомогою засобів виразності інших видів мистецтва; виконання у ролях пісні; вміння визначати основний зміст творів; уміння порівнювати твори різних видів мистецтв (щоб знати однакове, відмінне, подібне); вміння аналізувати результати власної діяльності; уміння оцінювати свої досягнення; уміння рефлексувати; уміння самоконтролю.

На думку Краєвського В. саме під час провідної для молодшого школяра художньо-практичної діяльності (спів, гра на інструментах, виконання практичної роботи в галузі образотворчої діяльності) відбувається ефективне засвоєння необхідних знань, набуття вмінь, їх повторення та закріплення, формується естетичний досвід учнів [7, с. 62].

Масол Л. вважає, що: «Універсальні поняття естетики та мистецтвознавства - ритм, гармонія, композиція, форма, динаміка, контраст, симетрія є фундаментом єдності й взаємодії мистецтв, фрактором художньо-дидактичної інтеграції» [8,с. 53]. «Коректне зіставлення понять, порівняння їх значень у різних видах мистецтва 3 
обов'язковою опорою на конкретні художні приклади, особистісний естетичний досвід дають змогу учням збагатити емоційно - образне відчуття художніх творів й поглибити їхнє розуміння мистецьких явищ та зв'язків між ними.» [8, с. 54].

Виходячи з логіки нашого дослідження на початку даного етапу констатувального експерименту необхідно було виявити наявність сфрормованого тезаурусу. 3 цією метою було проведене діагностичне опитування «Діагностика наявності знань про особливості різних видів мистецтва та видів мистецької діяльності».

Згідно означеного діагностичного опитування респондентам було запропоновано заповнити спеціально створену таблицю, в якій потрібно визначити відповідність запропонованих понять (професій та видів діяльності, предметів та видів мистецтва) та заповнити таблицю «Як я запам'ятав навчальний матеріал?», згідно якої була встановлена самооцінка рівня знань учнів з конкретно названих тем. Базовими поняттями обрали: «види мистецтв», «образ», «композиція», «ритм».

Проведення вищезазначеного діагностичного опитування засвідчило низький рівень сфрормованості загальних знань. Адже у завданні респондентам пропонувалось охарактеризувати зміст уже відомих понять. Відповіді учнів відтворили неповну картину володіння знаннями про види мистецтв, види мистецької діяльності й особливості засобів виразності. У повній мірі правильні відповіді надала невелика кількість учнів $(0,96 \%)$; частково правильними виявилися більша частка $(24,28 \%)$.

Діагностичне опитування засвідчило, що найбільшу складність для респондентів склала група спеціальних, маловживаних понять. У повній мірі це стосувалося таких понять, як: «композиція», «ритм», «мелодія». Абсолютна більшість опитаних (74,76\%) практично не володіють термінологією, не усвідомлюють значення понять, особливостей видів мистецької діяльності. Відповідно уміння оперувати набутими знаннями виявило небагато учнів $(0,96 \%)$, які усвідомили необхідний об'єм знань. Інші респонденти виявили часткові знання й змогли застосувати їх у деяких запропонованих завданнях.

Завдання, за допомогою яких перевірялась наявність умінь були такі: домалювати пейзаж Олівця, вигадати казку про мешканців музичної країни, наспівати мелодію чарівної пісеньки, поєднати лінією у відповідності назви мистецтв та професій митців, знайти зайве слово. 3 метою визначення обізнаності дітей щодо специфіки мистецтва, усвідомлення ними особливостей музичного мистецтва, та його відмінність від інших видів мистецтва було проведено анкетування учнів. За результатами анкети у половини учнів ( $50 \%)$ виявлена сфрормована мотивація до мистецької діяльності в різних її видах. Крім того, виявлена значна кількість дітей із низьким і середнім рівнем мотивації до мистецьких занять. 
Анкетування учнів дозволили з'ясувати рівень знань учнів про основи мистецтва, усвідомлення специфріки та взаємозалежності його видів. Результати анкетування учнів свідчать про те, що вони продемонстрували поверховість, розірваність знань; схильність до репродуктивного змісту виявилась домінуючою (85\%). Внаслідок детального аналізу якісних і кількісних даних обробки результатів, було виявлено недостатне усвідомлення учнями цілісності мистецтва. Така «розірваність» знань пояснюється відсутністю методичного забезпечення здійснення процесу інтегрованого навчання, а також недостатньою обізнаністю вчителів щодо проблеми здійснення педагогічної інтеграції та розвитку творчих здібностей учнів початкових класів.

Результати опитування надали змогу з'ясувати, що більша частина учнів (62\%) із задоволенням співають, слухають музику, позитивно ставляться до уроків музики. Але майже всі учні не усвідомлюють сутність поняття «мистецтво», існування його різновидів та їх взаємозв'язок. Так деякі учні поняття «мистецтво» пов'язують із «мистецтвом боксу», «мистецтвом вишивки», «цирковим мистецтвом». Учні не розуміють ролі мистецтва в житті людини. У результаті опитування дітей було виявлено, що уявлення дітей про мистецтво майже не сформовано, вони не розуміють, що на уроках музики, образотворчого мистецтва вивчають мистецтво. Навіть учні 3 класу асоціюють слово «мистецтво» з такими словами, як: «в'язання», «карате», "рушник», а учні першого класу - із словами: «мама», «молоко». Дітям важко назвати улюблені види творчої діяльності. Серед запропонованого ряду видів творчої діяльності більшість з них назвали малювання. Таким чином ми з'ясували, що учні молодшого шкільного віку пов'язують світ мистецтва із видами спорту, словамиіменниками, що починаються на літеру «м», замість видів мистецької діяльності називають інші види діяльності, не мають цілісне уявлення про мистецтво. Також було виявлено, що знання про мистецтво у дітей 1 та 3 класів майже не відрізняються.

Третій показник змістово-процесуального компоненту - уміння накопичувати знання й навички відшукування ключових змістових тематичного наповнення навчальної інформації, досліджувався за допомогою аналізу результатів навчальної діяльності учнів, методу педагогічного спостереження на уроках музики в початкових класах. Результати вимірювання засвідчили, що 12\% респондентів, виконавши завдання за вибором, виявили фантазію, творче мислення, зробили самостійний вибір необхідних засобів, прийомів та технік.

Козій М. пояснює, що специфріка особистісно-орієнтованого навчання вимагає розглядати навчання не тільки як результат, а й як процес і засіб саморозвитку і самоактуалізації особистості учнів. Учень при цьому має обирати напрямки навчальної діяльності. 3 метою більш повної само актуалізації особистості дитини, згідно ії 
індивідуально-фрізіологічних особливостей і потреб. Оскільки учні на уроці мають не тільки опановувати певною системою знань, умінь, навичок, але й навчитись їх використовувати. [6, с. 1-2].

Виконуючи завдання сучасної загальноосвітньої школи, ми намагаємося забезпечити максимальний розвиток здібностей кожного учня. Створюючи кожному учневі можливість досяпти певного успіху відповідно до індивідуальних здібностей та особливостей, на уроках ми пропонували учням для виконання різні творчі завдання на вибір, відповідно різним інтересам, уподобанням учнів. Це надало можливості створити сприятливі умови для навчання, атмосфреру успіху, сорормувати позитивну стійку мотивацію до мистецької діяльності. Кожен учень мав можливість обрати обирати собі завдання, яке на його думку, він може виконати. Успішне виконання запропонованих завдань свідчить про певний рівень навченості.

Учням були запропоновані такі завдання: створити словесний портрет музичного образу, передати у кольорі зміст музичної п'єси, підібрати слова для опису музичного образу. Якість виконання завдань на творчому рівні вимірювалася за такими напрямами:

1. вираження образу засобами різних видів мистецтв;

2. визначення необхідних прийомів, технік, засобів виконання завдань;

3. прояв власного бачення мистецького твору;

4. залучення засобів виразності різних видів мистецтва;

5. усвідомлене ставлення до творів мистецтв.

3 метою виявлення поліхудожніх уподобань учнів ми залучали їх до художньо-творчої діяльності, враховуючи при цьому специфіку сприйняття кожним школярем того чи іншого виду мистецтва, індивідуальні уподобання, задатки дітей. Аналізуючи результати другого етапу дослідницького експерименту, ми зробили такі попередні узагальнення:

$>$ формування в учнів системи розрізнених знань, умінь і навичок не забезпечує формування художнього світогляду, духовнорозвиненої особистості;

фрормування інтегрованих знань ( цілісних знань) молодших школярів здебільшого носить інтуїтивний характер, позбавлений наукового підґрунтя. Діти тяжіють до поліхудожньої діяльності, не усвідомлюючи особливості видів мистецтва, своїх індивідуальних потреб;

відсутність усвідомлення вчителями важливості формування позитивної мотивації мистецької навчальної діяльності молодших школярів не сприяє фрормуванню цілісної картини світу, інтегрованих знань учнів, що пов'язано з низьким рівнем знань педагогів про особливості, мету, зміст інтегрованого навчання та неспроможність створити відповідні педагогічні умови, які б сприяли ефрективному навчанню. 
Другий етап діагностування в межах констатувального експерименту дозволив визначити рівні ссрормованості змістовопроцесуального компоненту: достатній рівень (10\%) сорормованості змістово-процесуального компоненту, середній рівень $(48 \%)$ та низький рівень( 42\%).

Стан сорормованості третього творчо-результативного компоненту, в основу котрого покладено критерій, що визначає ступіть художнього висвітлення власних творчих здобутків у мистецькоінтегрованій діяльності та наступні показники: 1) наявість індивідуального творчого досвіду музичної діяльності; 2) уміння й навички художньо-оцінювального ставлення до навчальної інформації інтегрованого характеру; 3) прояв самостійності щодо усвідомлення учнями особистостої емоційно-рефрлксивної значущості створених навчальних фоорм та їх мистецької інтегрованої наповненості. Цей компонент досліджувався за допомогою анкетування, співбесід, аналізу робіт під час виконання ними творчих завдань та під час проходження педагогічної практики студентами в початковій школі.

3 метою виявлення поліхудожніх уподобань ми залучали учнів до художньо-творчої діяльності, враховуючи при цьому специфіку сприйняття кожним учнем того чи іншого виду мистецтва, індивідуальні уподобання, нахили дітей. Учням були запропоновані такі завдання:

1. за допомогою кольорів відтворити в малюнку настрій музичного твору;

2. підібрати слова для створення словесного портрету музичного образу;

3. придумати казку про мешканців музичної країни;

4. разом із чарівницею Музикою скласти свою пісеньку;

5. допомоти Олівцю реставрувати картину й підібрати до неї музичний супровід;

6. створити колективну казку про мешканців світу мистецтва;

7. склади колискову для веселих ноток.

За результатами першого показника творчо-результативного компоненту (наявність індивідуального творчого досвіду музичної діяльності) було з'ясовано, що 9,9\% респондентів, яких ми віднесли до високого рівня, на відмінно виконавши завдання за вибором, виявили франтазію, творче мислення, зробили самостійний вибір необхідних художніх засобів, прийомів та технік, що підтвердило наявність у них індивідуального творчого досвіду музичної діяльності. Низький рівень першого показника третього компоненту продемонстрували $38 \%$ учнів, середній - 31\%, достатній рівень було виявлено в 21,1\% учнів.

Для з'ясування результатів другого показника творчорезультативного компоненту ( наявність умінь і навичок художньооцінювального ставлення до навчальної інфоормації інтегрованого характеру) учням пропонувалось послухати фррагменти з балету П. Чайковського «Лускунчик» ( Танець «Танець Феї Драже», «Баба яга» і фррагмент з балету В. Гомоляко «Кіт у чоботях». Дітям треба 
було розповісти про свої враження від прослуханих творів, оцінити твір, пояснити свою думку, визначились з музичними образами. Після чого подивитись відео фррагменти цих балетів і порівняти свої уявлення 3 танцювальними образами, музикою i костюмами виконавців, пояснити чим вони відрізняються.

Незважаючи на те, що завдання виявилось достатньо складним, діти з цікавістю віднеслись до його виконання, але малорозвинена художньо-образна уява, обмежений словниковий запас та недорозвинене асоціативне мислення в 42,3\% дітей засвідчили їх низький рівень другого показника творчо-результативного компоненту; $37 \%$ дітей були віднесені до середнього рівня. Наявність художньообразного мислення та наявність умінь і навичок художньооцінювального ставлення до навчальної інформації інтегрованого характ5еру достатнього рівня продемонстрували 20, 4\% дітей і високого рівня - 1,3\% учнів молодших класів. Не зважаючи на переважну більшість (68,3\%) показників низького і середнього рівнів, ми мали надію на суттєве покращення даного показника, враховуючи зацікавленість дітей цим видом діяльності та за умови запровадження експериментальної методики і створення спеціальних педагогічних умов.

Найбільш складним для виконання молодшими школярами виявився третій показник творчо-результативного компоненту ( прояв самостійності усвідомлення учнями особистої емоційно-рефлексивної значущості створених нових навчальних фрорм та їх мистецької інтегрованої наповненості). Як з'ясувалось, діти на уроках музики майже не аналізували свою музичну, зокрема й мистецьку діяльність взагалі з позиції особистої рефлексії - ні в процесі репродуктивного відтворення ні в процесі створення нових фрорм мистецькоінтегрованої діяльності, що спричинило певні трудн6ощі і нерозуміння багатьма учнями потреби у виконанні цього завдання. Прозвучали такі репліки щодо того, що це не потрібно, без цього можемо обійтися. Це засвідчило той фракт, що на уроках музики використовувався прийом керованої рефрлексії ( не розроблялись схеми інтегрованого використання різних видів мистецтв, що підкорялись одній темі і не озвучувались способи рішення творчих завдань та роздуми про варіанти їх розв'язання.

Результати констатувального експерименту дозволили виявити 3 рівні сфрормованості творчо-результативного компоненту. Так, достатній рівень (9\%) характеризує дітей і об'єднує учнів з яскраво вираженим творчим спрямуванням. Учні цієї категорії з інтересом вирішують творчі завдання, оскільки вони є для них привабливими. Досвід творчої діяльності підкріплюють стійким інтересом до різних видів художньої діяльності. Роботи цих дітей оригінальні, відрізняються від традиційних. У творчій діяльності висувають нестандартні рішення виконання завдань. Учні виявляють ініціативу, активність, беруть участь у різних видах музичної, мистецької 
діяльності. Вони мають стійкий інтерес до самостійного вирішення завдань та оцінки своєї діяльності. Діти з інтересом розв'язують творчі завдання, виявляють ініціативу; пропонують свої власні варіанти виконання творчих, навчальних завдань; демонструють стійкий інтерес до різних видів художньо-творчої діяльності. Такі, учні виявляють високий рівень активності, емоційність під час виконання завдань, радість від спілкування з мистецтвом. Роботи цих дітей оригінальні, вони пропонують оригінальні ідеї, назви власних продуктів творчої діяльності, самостійно виконують завдання, здатні до самоорганізації.

Середній рівень. Учні цього рівня характеризуються нестабільним творчим спрямуванням. Вони частіше із захопленням виконують завдання, які їм подобаються. Заняття мистецтвом приваблюють дітей, але вони не мають стійких художніх переваг. За умови стимуляції з боку вчителя, учні охоче створюють оригінальні продукти, хоча частіше їх роботи носять репродуктивний характер; ними проявляється усвідомлення своїх дій.

Низький рівень. Діти цього рівня відрізняються невизначеністю щодо улюблених видів творчої мистецької діяльності. Вони демонструють слабкий прояв інтересу до виконання творчих завдань. До занять мистецтвом ці діти не виявляють ніякої зацікавленості; у процесі художньої діяльності не проявляють елементарної схильності до творчості. Їх знання про види мистецької, творчої діяльності мінімальні.

Аналіз результатів констатувального експерименту, спостереження за роботою вчителів та власний педагогічний досвід спонукали нас до припущення про те, що причинами низького рівня сорормованості цілісних знань учнів початкових класів $€$ недостатність розуміння педагогами стратегії його розвитку, обмеженість методів і прийомів, які вони використовують; недостатній інтерес батьків до навчання та розвитку своїх дітей; відсутність у школярів стійкої позитивної мотивації творчої, мистецької діяльності.

Таким чином, під час проведення констатувального експерименту визначилися три рівні сформованості інтегрованої навченості музики молодших школярів, структура котрої складається 3 трьох компонентів: мотиваційно-спонукального, змістово-процесуального, творчо-результативного. Достатнім рівнем сформованості інтегрованої навченості володіє незначна частина учнів (17\%). Вони характеризуються позитивним ставленням, стійким інтересом до мистецтва, проінформованістю про специфріку засобів мистецької виразності та взаємодію різних видів мистецтва, уміннями накопичувати знання й навички відшукування ключових змістових складових тематичного наповнення навчальної інформації і засобів музичної виразності певного образу, настрою та вміннями їх художньо поєднувати; інтегративністю знань, умінь та навичок і самостійністю їх практичного використання. Учні творчо вирішують навчальні завдання, виявляючи при цьому ініціативу в пошуках найбільш оптимальних 
форм, систематично використовують інтегровані зв'язки, беруть активну участь у поза навчальній мистецькій діяльності.

Середньому рівню відповідає 63,3\% учнів. Молодші школярі, що досягли даного рівня, виявляють позитивне ставлення до окремих видів мистецтва, мають достатні знання, але не завжди вміють використовувати їх комплексно, відчувають труднощі у визначенні засобів мистецької виразності, що гальмує повноцінне опанування. Вони вирізняються продуктивним характером вирішення навчальних завдань, частковим самостійним умінням їх з'ясування. Використання індивідуального досвіду музичної діяльності у навчально-дієвих формах $\epsilon$ частковим, а використання інтегративних звуків здійснюється методом сприйняття помилок, адже не вистачає навичок музичної діяльності.

Учні цього рівня характеризуються нестабільним творчим спрямуванням. Вони частіше із захопленням виконують завдання, які їм подобаються. Заняття мистецтвом приваблюють дітей, але вони не мають стійких художніх переваг. За умови стимуляції з боку вчителя, учні охоче створюють оригінальні продукти, хоча частіше їх роботи носять репродуктивний характер.

Низький рівень має 19,8\% школярів початкових класів. У таких учнів відсутне позитивне ставлення до навчально-виховної діяльності, недостатнє бажання вивчення явищ музичного мистецтва, інтерес до музики не сорормований, мотиви навчання мають прагматичний характер. У цих школярів низький рівень музичних знань, умінь та навичок комплексного оперування ними у практичній діяльності. Учні цього рівня вирішують завдання лише за інструкцією вчителя, що свідчить про їх пасивність у навчально-виховній діяльності.

Діти цього рівня відрізняються невизначеністю щодо улюблених видів творчої діяльності. Вони демонструють слабкий прояв інтересу до виконання творчих завдань. До занять мистецтвом ці діти не виявляють ніякої зацікавленості, у процесі художньої діяльності не проявляють схильності до творчості. Їх знання про види мистецької, творчої діяльності мінімальні.

Таким чином, аналіз результатів констатувального експерименту, спостереження за роботою вчителів та власний педагогічний досвід спонукали нас до попередніх узагальнень і висновків про те, що причинами низького рівня музично-інтегрованих цілісних знань учнів початкових класів $є$ :

$>$ недостатність розуміння вчителями: важливості впливу мистецтва на розвиток гармонійної, висококультурної особистості; недостатня обізнаність вчителів в інтегративних методах, прийомах та способах їх використання на уроках музики; нерозуміння ними важливості фрормування позитивної мотивації мистецької навчальної діяльності молодших школярів, що не сприяє формуванню цілісної картини світу, інтегрованих знань учнів і пов'язано з низьким рівнем знань педагогів про 
особливості, мету, зміст інтегрованого навчання, спричинює їх неспроможність створити відповідні педагогічні умови, які сприяли б ефрективному навчанню музики;

в свою чергу, фрормування в учнів системи розрізнених знань, умінь і навичок, що має місце в практиці навчання музики, не забезпечує фрормування художнього світогляду духовнорозвиненої особистості, тому формування музично-інтегрованих знань молодших школярів здебільшого носить інтуїтивний характер, позбавлений певного підґрунтя. Діти тяжіють до поліхудожньої діяльності, не усвідомлюючи особливості видів мистецтва, своїх індивідуальних естетичних потреб, особистої рефлексії в навчанні музики;

> низький рівень знань майбутніх вчителів 3 інтегрованого навчання молодших школярів потребує обов'язкового введення в навчальні плани педагогічних інститутів і мистецькопедагогічних фракультетів спеціальних навчальних курсів щодо інтеграції музичного навчання школярів різного віку, з метою забезпечення їх профресійної майстерності;

$>$ недостатній інтерес батьків та їх незацікавленість до навчання музичному мистецтву своїх дітей, нівелює формування у них позитивної мотивації до творчої мистецької діяльності та не розвиває їх різнобічно.

Все вище сказане суттєво гальмує процес художнього i культурного розвитку молодших школярів, не задовольняє їх естетичні потреби, шкодить їх духовному збагаченню.

\section{Список використаних джерел}

1. Данько Н.П. Інтегративний художньо-естетичний предмет «Світ мистецтва» як нова фрорма педагогічного процесу. / Збірник наукових праць. СДПУ ім. А.С. Макаренка. - Суми, 2000.

2. Данько Н.П. Гра у процесі художньо-естетичного виховання учнів шестирічного віку (на прикладі інтегрованого курсу "Світ мистецтва» / Педагогічні науки. Збірник наукових праць. - Суми, 2001. - С. 316-325.

3. Данько Н.П. Психолого-педагогічні особливості впровадження інтегрованих курсів у навчально-виховний процес початкової школи./ Педагогічні науки. Збірник наукових праць. СДПУ ім. А.С. Макаренка - - Суми, 2005. - С.211-218.

4. Данько Н.П. Гра в процесі викладання курсу «Світ мистецтва» / Н.П. Данько // Початкова школа. - № 2. - 2008. - С. 25-27.

5. 5/ Український педагогічний словник. Гончаренко С.У. - Рівне: Волинські обереги, 2011. - 552 с.

6. 6/ Козій М., Якилешек В. Деякі аспекти новітньої парадигми навчання // Директор школи. - 1999. - № 36. С. 1-2.

7. 7/ Краевский В.В., Хуторской А.В. Основы обучения. Дидактика и методика. 2- е издание. АКАДЕМА. Москва. Издательский центр «Академия». 2008. - 347 с.

8. Масол Л.М. Загальна мистецька освіта: теорія і практика: монографія / АПН України, Інститут проблем виховання. Київ.: Промінь, - 2006. - 432 с.

9. Савченко О.Я. Дидактика початкової школи. Київ. Видавництво «Генеза». 1999. C.136-137. 


\title{
ТЕОРЕТИЧНІ ЗАСАДИ ВЗАЄМОДІЇ СІМ'Ї ТА ШКОЛИ У ФОРМУВАННІ ЕКОЛОГІЧНО ДОЦІЛЬНОЇ ПОВЕДІНКИ молодших школяРів
}

\author{
Колишкіна А. П. \\ кандидат педагогічних наук, старший викладач, \\ Сумський державний педагогічний університет імені A. C. Макаренка
}

Сучасна парадигма освіти спонукає освітню галузь, навчальний заклад і сім'ю до конкретних кроків на шляху формування екологічної культури особистості загалом і її екологічно доцільної поведінки зокрема. Екологічно спрямоване, особистісно орієнтоване виховання учнів початкових класів у школі й сім'ї можливе лише за умови спеціальної підготовки вчителів початкових класів, удосконалення виховної майстерності батьків.

У даному дослідженні, екологічно доцільну поведінку молодших школярів розглядаємо, як дії та вчинки під час безпосередньої та опосередкованої взаємодії з природою, пов'язані між собою ціллю збереження природи, обумовлені характерним для учнів початкових класів непрагматичним суб'єкт-суб'єктним ставленням до об'єктів природи або зовнішньо унормовані дорослими (учителем, батьками). Дослідження проблеми формування екологічно доцільної поведінки школярів дає можливість виокремити особливості зазначеного процесу для учнів початкових класів.

Реалізація цієї мети не буде вдалою без свідомої педагогічної позиції батьків, які повинні вбачати у спілкуванні дітей з природою не тільки мету - формування гуманного ставлення до неї, але й засіб гармонійного розвитку особистості дитини. Тому виникає необхідність дослідити можливості сім'ї щодо формування екологічно доцільної поведінки учнів початкових класів, а також виявити, як школа, з одного боку, керує цим процесом, а з іншого - використовує досвід батьків у процесі екологічного виховання у позаурочний час.

У становлення теоретичних положень щодо виховного потенціалу сім'ї, як зазначає А. Гранкін, значний внесок зробили А. Макаренко, В. Сухомлинський, Ш. Амонашвілі. Ці педагоги надають перевагу суспільному вихованню і наголошують на необхідності педагогічної допомоги батькам, виокремлюють виховну функцію сім'ї як одну 3 найбільш важливих.

Ці погляди зумовили значну увагу до виховного потенціалу сім'ї на сучасному етапі розвитку педагогічної науки. Дослідники В. Семенов, Ж. Сулейменова наголошують на розширенні взаємодії різних соціальних інститутів із сім'єю з метою спільного розв'язання проблем виховання підростаючого покоління. Як зазначає А. Харчев, специфіка 
сімейного виховання полягає в тому, що воно більш емоційне за змістом, ніж суспільне [30]. Основні засади концепції дослідникасоціолога полягають у наступному:

розуміння сім'ї як провідної форми соціальної спільності у невиробничій сфрері людського буття;

> розгляд стабільності сім'ї як наслідку впливу на неї зовнішніх і внутрішніх сил, які можуть ії̈ зміцнювати або послаблювати;

$>$ аналіз сім'ї як соціального інституту і малої групи 3 виокремленням її специфрічних (народження і виховання дітей) i неспецифічних (господарсько-побутова, економічна, первинний соціальний контроль, духовне спілкування, надання соціального статусу, дозвіллєва, емоційна, сексуальна) фрункцій.

У наведений концепції простежуються структурно-фрункціональні, необіхевіористські та інтеракційні засади, які акцентують увагу на аналізі фрункцій сім'ї як соціального інституту і малої соціальної групи.

До цього трактування певною мірою близьке визначення сім'ї, запропоноване С. Голодом [6, с. 5]. Концепція дослідника спирається на гуманістичний підхід і наголошує на необхідності завважування індивідуально-особистісної складової сімейного колективу. Згідно 3 цією концепцією сім'я розуміється як сукупність індивідів, поєднаних хоча б одним із трьох видів відносин: кровного споріднення, породження та якості.

Сім'я володіє особливими засобами, умовами та методами виховання. У даному контексті О. Іванов запевняє, що характеристика особистості дитини та дорослого (який виростає з цієї дитини) багато в чому визначається соціально-економічним станом сім'ї, культурним та освітнім рівнем батьків, характером стосунків між старшими та молодшими, моральною свідомістю батьків та їхньою етичною поведінкою, духовними інтересами та ціннісними орієнтаціями. В свою чергу, Н. Волкова, І. Гребенников доводять, що сім'я регулює процес морального й інтелектуального розвитку особистості, сприяє активізації позитивних впливів, здатна більш ефективно, ніж інший соціальний інститут, нейтралізувати дію негативних зовнішніх чинників. Моральний розвиток дитини в сім'ї відбувається не тільки завдяки свідомому впливу батьків, які висувають різні вимоги, але і стихійно, під впливом умов життя [3; 27].

Аналізуючи проблеми взаємодії сім'ї і суспільства, В. Савка та Н. Уманець окреслюють такі її риси:

$>$ сім'я має розглядатися як система відносин, взаємодій, спрямованих як у їі середину, так і назовні - щодо інших соціальних утворень, суспільства загалом. Сім'я $є$ самостійним соціальним інститутом, зокрема посередником у відносинах особистостей - членів сім'ї та суспільних структур;

ці відносини не усталені остаточно, форми їх вияву, обсяг, інтенсивність постійно змінюються; 
> основними чинниками, які визначають розвиток сім'ї та сімейних відносин, $є$ тип соціально-економічної, політичної та соціокультурної організації суспільства, традицій, що домінують у ньому;

сім'я $€$ пластичним соціальним інститутом, який прагне до збереження своєї цілісності за будь-яких соціальних умов. Вона хоча частково й пристосовується до них, але завжди зберігає певну самостійність щодо тих суспільних впливів, які ії не задовольняють, дестабілізують, і певним чином сама здатна впливати на соціальне довкілля [26].

Сім'я $€$ тим середовищем, де починає фрормуватися особистість дитини, процес виникнення якої $є$ процесом перетворення біологічно заданого матеріалу силами соціальної дійсності, що існує до, поза й зовсім незалежно від цього матеріалу. Для підвищення ефективності виховного впливу сім'ї необхідно, щоб школа та суспільство надавали батькам допомогу щодо засвоєння основних принципів і змісту виховання в сучасних соціально-економічних умовах України.

Значний внесок у розробку ідеї взаємодії школи та сім'ї зробив І. Гребенников. Він виділяє основні ознаки цього процесу: «процес виховання стає більш цілісним, безперервним, забезпечуючи послідовність і єдність педагогічного впливу на учнів у школі, родині, суспільстві; більш органічне поєднання та взаємозбагачення суспільного та сімейного виховання; помітно зменшується сфера стихійного некерованого впливу на дітей». Саме І. Гребенников уперше ввів поняття «педагогічна культура батьків», під якою він розумів «такий рівень педагогічної підготовленості батьків, який відбиває ступінь їх зрілості як вихователів та виявляється в процесі сімейного і суспільного виховання дітей» [7, с. 25].

Теоретичні питання взаємодії школи та сім'ї широко розглядаються в сучасній вітчизняній педагогіці, зокрема визначаються тенденції щодо зміни характеру взаємодії виховних інститутів. Так, О. Сухомлинська, аналізуючи теоретичні проблеми сучасного виховання, звертає увагу на «логіку розвитку сьогоднішнього школознавства, що свідчить про тенденцію переміщення центру виховної роботи зі школи, яка перетворюється винятково на освітній інститут, у сім'ю, у позашкільні заклади» [29, с. 5].

Школа - це заклад освіти, що забезпечує потреби громадян у загальній середній освіті [20], і $є$ тим основним соціальним інститутом, який реалізує мету загальної середньої освіти, спрямовуючи свою діяльність (частково) на екологічне виховання особистості.

У сучасній українській школі екологічною інформацією наповнені різною мірою практично всі предмети початкової школи, і формування екологічно доцільної поведінки молодших школярів може здійснюватися засобами цих предметів. Проте не увесь матеріал, закладений у цих предметах, однаково сприятливий для фрормування зазначеної поведінки. Також існує низка екологічних проблем, 
вивчення яких не передбачено шкільними програмами, проте елементарна обізнаність з цих питань необхідна школярам.

Так, курси «Навколишній світ», «Природознавство», «Я досліджую світ», «Я у світі» несуть головне навантаження у розкритті екологічних проблем. Вони сприяють формуванню уявлень та понять про цілісність світу, природне і соціальне оточення як середовище життєдіяльності людини; ознайомлюють учнів з охороною і збереженням природи рідного краю, України, Землі, з системою цінностей у ставленні до природи, людей, самого себе; спрямовують практичну діяльність учнів, пов'язану 3 охороною природи та збереженням свого здоров'я; сприяють формуванню досвіду творчої діяльності учнів, оволодінню узагальненими способами дій, розвитку активного пізнавального ставлення до природного та соціального оточення, вихованню екологічної культури молодшого школяра, поведінки, адекватної моральним, етичним, естетичним нормам і гуманістичними цінностям у ставленні до навколишнього світу. Програми курсів передбачають формування вмінь застосовувати спеціальні методи пізнання природи: спостереження за природними явищами і процесами, проведення дослідів, експериментів у природі, екскурсій в поле, ліс. Молодші школярі вчаться охороняти рослинний і тваринний світ, збирати насіння для підгодовування птахів узимку, робити годівнички для птахів, висаджувати дерева і кущі, турбуватися про чистоту річок, ставків, морів, повітря, ґрунту, прибирати квартиру, стежити за своїм здоров'ям, вчаться правилам безпечної поведінки на воді, 3 невідомими речовинами, правилам поведінки зі свійськими тваринами тощо.

Проте аналіз змісту навчальних програм початкової школи, анкетування і бесіди з вчителями дають підстави стверджувати, що вивчення деяких екологічних проблем не передбачено шкільними програмами, проте вони необхідні у повсякденному житті молодших школярів, впливають на формування екологічно доцільних поведінкових дій і вчинків. Програмами передбачена недостатня кількість практичних методів роботи, екскурсій у природу, спрямованих на розвиток емоційно-ціннісної та вчинково-діяльнісної сфрери особистості молодшого школяра, вдосконалення екологічно доцільних поведінкових дій, навичок і звичок, переходу їх у звичні форми поведінки молодших школярів.

Отже, отримані учнями під час уроків знання й уміння потребують закріплення на рівні сім'ї та безпосереднього впровадження в життя разом із батьками. Тому вважаємо, що разом зі школою за формування екологічно доцільної поведінки відповідає сім'я як реальний суб'єкт екологічного виховання особистості. Важливе місце у даному процесі належить взаємодії сім'ї і школи, яка сприяє узгодженню і взаємопідсиленню виховних впливів, що надходять від батьків і вчителів як провідних «виховних агентів». 
Взаємодія сім'ї та школи - складна проблема, що пройшла тривалий розвиток, набуваючи різного сенсу, характеризуючись різними підходами до ії розв'язання на різних етапах поступу суспільства. I сьогодні взаємодія цих двох інститутів не втрачає своєї актуальності, наповнюючись новим змістом, що зумовлено процесами, які відбуваються в системі освіти, в сім'ї.

У нашій роботі взаємодію сім'ї та школи розглядали як пріоритетний засіб виховання у молодших школярів екологічної поведінки. 3 огляду на це, виникає необхідність визначення сутності, змісту цього процесу, основних фрорм і методів його реалізації в контексті впливу на дитину з метою формування екологічно доцільної поведінки.

3 фрілософського погляду, взаємодія тлумачиться як категорія, що відображає процеси дії різних об'єктів один на одного, їхню взаємозумовленість, зміну стану, взаємоперехід. При цьому кожна із сторін виступає як причина іншої і як наслідок одночасного зворотного впливу протилежної сторони. Тобто, взаємодія передбачає якоюсь мірою рівносильний взаємний вплив об'єктів один на одного і зумовлює рівномірний їх розвиток [13, с.84].

Стосовно проблеми нашого дослідження під взаємодією сім'ї та школи ми розуміємо обопільний вплив суб'єктів навчальновиховного процесу (учителів, батьків та учнів), який ґрунтується на гуманістичних суб'єкт-суб'єктних відносинах, узгоджених діях, 3 метою збереження природи.

Про актуальність проблеми взаємодії сім'ї та школи засвідчує ії відображення в змісті Державної національної програми «Освіта» (Україна XXIст.), де організація родинного виховання розглядається як важлива ланка виховного процесу, що має реалізовуватися через «забезпечення педагогічного всеобучу батьків» [8, с.17].

Не оминається вона увагою і в інших державних актах. Так, у Законі України «Про освіту» наголошується на тому, що «батьки мають право: вибирати навчально-виховний заклад для неповнолітніх дітей; обирати і бути обраними до органів громадського самоврядування в закладах освіти; звертатися до органів державного управління i громадського самоврядування з питань навчання, виховання дітей, сприяти здобуттю дітьми освіти в загальноосвітніх навчально-виховних закладах...» [22]. Хоча в Законі прямо не згадується взаємодія сім'ї та школи як така, закладені в його статтях положення безпосередньо орієнтовані на реалізацію цього процесу й перебувають у прямій залежності від успішної його реалізації.

Перспективний підхід до розуміння внутрішньо-сутнісної природи взаємодії був запропонований Б. Ломовим. На його думку, констатуючим принципом взаємодії $€$ не система перемежованих дій (впливів) кожного 3 учасників, «які розвиваються паралельно (симетрично), а саме взаємна дія суб'єктів, котрі вступають у неї як партнери» [17, с. 107]. Тобто, «розрізати» взаємодію, відокремлюючи 
діяльність одного учасника від діяльності іншого, неможливо, тому що це означало б відійти від аналізу сутності цього процесу.

У словнику В. Орлянського, взаємодія визначається, як сукупність процесів впливу різних об'єктів один на одного, їх взаємозумовленість та зміна стану чи взаємоперехід, а також породження одним об'єктом іншого. Якості об'єкта можуть проявитися і бути пізнаними лише у взаємодії з іншими об'єктами. Взаємодія $€$ «інтегруючим фактором, за допомогою якого відбувається поєднання частин у певний тип цілісності - структуру» [18, с. 47].

Взаємодія завжди має інтерсуб'єктивний характер, тобто реалізується як система відносин, головними ознаками якої є:

$>$ предметність (наявність спільної конкретної мети, що зумовлює спільність дій у ході її досягнення);

ситуативність, або регламентованість конкретними обставинами: тривалістю, інтенсивністю, нормами та правилами взаємодії;

> рефрлективність (рефлексивна багатозначність) - можливість бути виявом як суб'єктивних намірів, так і наслідком спільної участі суб'єктів у колективній діяльності;

експлікованість - можливість спостереження, реєстрації конкретних дій індивідів, суб'єктів взаємодії [16, с. 82].

Реалізація відносин у конкретній діяльності відбувається у формі взаємного обміну діями, який визначає зовнішній (формальний) бік взаємодії. Саме такий обмін (навичками, вміннями) $є$ підґрунтям матеріального, практичного аспекту взаємодії, а інформаційний аспект постає як обмін думками, почуттями, цінностями.

Близьким до поняття «взаємодія» $€$ «спільна діяльність». На думку Т. Кравченко, якщо в першому випадку йдеться про взаємний вплив суб'єктів один на одного, який зумовлює їх рівномірний розвиток, то спільна діяльність передбачає узгоджену діяльність для досягнення спільної мети [14, с. 159].

Принципи, на яких ґрунтується спільна діяльність школи та сім'ї, проаналізовані Н. Кураповою, Л. Паноріловою. Такими принципами є: органічний зв'язок діяльності школи і сім'ї; поєднання фрорм індивідуальної, групової та масової роботи; опора на позитивні якості батьків, учнів, на позитивний досвід у вихованні дітей; принцип паралельної дії вчителів на батьків, суспільства на батьків, батьків на батьків.

Якщо під час взаємодії неможливо відокремити діяльність одного учасника від діяльності іншого, то під час спільної діяльності суб'єкти можуть діяти розрізнено, однак сукупність їхніх дій має забезпечувати досягнення спільної мети. Отже, передусім, взаємодія це не тільки вплив людей один на одного, але і безпосередня організація їхніх спільних дій, що дозволяє групі реалізувати загальну для її членів діяльність. 
За уявленнями О. Бодальова i В. Ляудіс, взаємодія завжди складається 3 двох компонентів: змісту і стилю. Зміст взаємодії визначає, навколо чого або з приводу чого розгортається та чи інша діяльність. Стиль взаємодії вказує на те, як людина взаємодіє 3 оточуючими. У такому разі можна вести мову про продуктивний i непродуктивний стиль взаємодії. Продуктивний стиль являє собою плідний спосіб контакту партнерів, сприяє встановленню і зміцненню стосунків, які грунтуються на взаємній довірі, розкриттю особистісних потенціалів і досягненню високих результатів спільної діяльності. Непродуктивний стиль взаємодії - неплідний спосіб контакту партнерів, що блокує реалізацію особистісних потенціалів і досягнення оптимальних результатів спільної діяльності.

Зміст взаємодії розкривається, якщо вона втілена у певній спільній діяльності, вважає Г. Андреєва. Взаємодія - це той елемент спілкування, що фріксує як обмін інформацією, так і організацію спільних дій, тобто комунікація відбувається під час спільної діяльності. У працях американських соціальних психологів (Дж. Тібо і Г. Келлі), які досліджувались Г. Андрєєвою, подані моделі так званої діадичної взаємодії (взаємодії в діаді). Сутність запропонованого підходу полягає в тому, що:

> будь-які міжособистісні стосунки $€$ взаємодією, реальним обміном поведінковими реакціями в межах певної ситуації;

взаємодія 3 більшою ймовірністю триватиме і позитивно оцінюватиметься учасниками, якщо вони отримують від неї вигоду;

взаємодія триватиме, якщо для кожного партнера набутки перевищуватимуть витрати;

взаємодія контролюється наслідками, при цьому партнери впливають на результати один одного.

Структурний опис взаємодії поданий також у трансакційному аналізі (аналізі спілкування) Е. Берна. Учений розглядає взаємодію під час спілкування через динаміку міжособистісних позицій партнерів, які позначаються як Батько, Дорослий, Дитина. За умови, коли трансакції збігаються (мають «додатковий» характер), тобто коли партнер звертається до іншого як Дорослий і той відповідає з такої ж позиції, взаємодія вважається ефективною.

Натомість, коли один з учасників взаємодії презентується іншому з позиції Дорослого, а той, у свою чергу, відповідає з позиції Батька, то взаємодія порушується й узагалі може припинитися (трансакції тут є такими, що «перетинаються»). Показниками ефективності стають також адекватне розуміння ситуації й адекватний стиль дії в ній. Таким чином, ефрективність взаємодії залежить від адекватності сприйняття суб'єктами взаємодії одне одного й адекватної оцінки ситуації, за якої відбувається взаємодія. 
Як вважає Г.Дьяконов, причинна зумовленість $€$ головною особливістю взаємодії, коли кожна зі сторін сприймається як причина іншої та як наслідок одночасного зворотного впливу іншої сторони, що визначає розвиток об'єктів та їх структур. Якщо при взаємодії виявляється суперечність, то вона стає джерелом саморуху i саморозвитку явищ і процесів [10].

Для педагогічних досліджень взаємодії характерне поєднання причинно-наслідкового і змістового підходів: простежується фрілософське трактування взаємодії як процесу впливу одних предметів і явищ на інші в певній сорері діяльності. Так, у педагогічному дослідженні, присвяченому взаємодії соціальних інститутів, В. Семенов визначає взаємодію як «процес, який відбувається щонайменше між двома системами в певному проміжку часу, коли зміна стану систем відбувається не тільки узгоджено (з однаковою структурою процесу, повторенням його ступенів, що може бути зумовлене й схожим загальним генезисом систем), а взаємозумовлено» $[28$, с. 18$]$.

Натомість фрілософи (М. Булатов, В. Цикін) стверджують, що взаємодія може зумовлюватися зв'язками, які не є причинними, а такими, що виражають функціональні відносини існуючих властивостей і законів, що не перебувають у генетичній єдності один щодо одного [33]. Це положення спонукає інших дослідників акцентувати увагу на структурному підході до розгляду педагогічної взаємодії різних систем. Зокрема, М. Поташнік пропонує, перш за все, враховувати системи та їх основні характеристики у взаємодії останніх одна 3 одною. Б. Вульфов і Б. Ширвіндт, конструюючи «модель взаємодії» соціальних інститутів, виділяють цільовий, змістовий, якісний і процесуальний компоненти. За такого підходу до вивчення взаємодії предбачається, що модель взаємодії з вираженою причиннонаслідковою залежністю може включати умови, за яких можлива дія функціональних і технологічних відносин сторін.

Німецький фрілософ Г. Хакен розглядає взаємодію з позиції синергетичних зв'язків. Виходячи з розуміння синергетики як науки про взаємодію багатьох елементів у межах єдиної системи, Г. Хакен довів, що навіть незначні зміни зовнішніх умов можуть призвести до раптових і радикальних змін у системі. Автор докладно обґрунтував синергетичні зв'язки в різних системах, у тому числі соціальній. Основною умовою досягнення синергетичного ефекту $є$ фізіологічна, психологічна та духовна спільність людей, які складають даний колектив [31].

Такої ж думки дотримується й В. Корабльова, яка застосувала синергетичний підхід до вивчення ефективності функціонування педагогічного колективу та відвела синергетиці роль нового світоглядного орієнтиру, що допомагає пізнати соціальну дійсність в умовах динамічного функціонування соціальних процесів. На відміну від традиційних сфрер наукового пізнання, синергетика розкриває 
загальні закономірності еволюції різних систем, у тому числі й соціальних. В. Корабльова зазначає, що синергетика формує якісно нову картину світу, де акцент припадає на становлення, когерентність (взаємопов'язаність) і кооперативність елементів суспільства, і відносить освіту до соціальних інститутів, що найбільш виразно трансформуються в динамічному світі. На думку І. Дедю, синергетика пов'язана, в першу чергу, з упорядкуванням поведінки: просторовими кореляціями, параметрами порядку, взаємною координацією (синхронізацією) підсистем [9].

Отже, взаємодія в певній соціальній системі не може спиратися виключно на причинно-наслідкові зв'язки між ії структурними компонентами. Взаємодія має більш складну природу, зумовлену динамічними перетвореннями у сучасному суспільстві, потребою в мобільності та кооперативності внутрішніх зв'язків у соціальній системі. Особливістю взаємодії $€$ взаємопідтримка, що гармонізує стосунки суб'єктів взаємодії. Взаємодія, що відбувається у площині синергетичних зв'язків, має елемент обґрунтованої спонтанності, на відміну від взаємодії, зумовленої причинно-наслідковими зв'язками.

До такої взаємодії можна віднести полісуб'єктну, що на ній наголошував І. Вачков. Ідеться про безпосередню взаємодію суб'єктів один 3 одним, яка $€$ взаємно зумовленою і характеризується особливим типом спільності - полісуб'єктом. Полісуб'єкт розуміється як цілісне динамічне психологічне утворення, яке відображає феномен єдності розвитку суб'єктів, які складають цю цілісність і перебувають у суб'єкт-суб'єктних відносинах. Сутність полісуб'єкта виявляється в здатності:

$>$ до творчої активності, створення загального творчого простору;

$>$ до перетворення навколишнього світу і себе;

$>$ до формування цілісного суб'єкту, який може встановлювати суб'єкт-суб'єктні відносини з іншими спільнотами.

Таким чином, у педагогічній взаємодії як полісуб'єкт можемо розглядати спільноту вчителів, учнів, батьків.

Проблема педагогічної взаємодії широко досліджувалась науковцями. У сучасній науковій педагогічній літературі досить часто вживається термін «педагогічна взаємодія» але водночас рідко зустрічається тлумачення самої дефініції. Так, у «Педагогічному енциклопедичному словнику» під педагогічною взаємодією розуміють процес, який відбувається під час навчально-виховної діяльності між вихователем і вихованцем і передбачає розвиток особистості останнього. У процесі педагогічної взаємодії, на думку К. Шамлян, відбувається своєрідний обмін, від якого залежить очікуваний результат навчально-виховної діяльності. Сам процес взаємодії вважається ефективним лише тоді, коли обопільно навчаються та виховуються всі її учасники [34]. 
Педагогічну взаємодію М. Подберезський розглядає як детермінований освітньою ситуацією, опосередкований соціальнопсихологічними процесами зв'язок суб'єктів (і об'єктів) освіти, що спричиняє кількісні та якісні зміни властивостей і станів зазначених суб'єктів і об'єктів [19].

Методичну взаємодію школи і сім'ї обґрунтувала Л. Вороніна, охарактеризувавши іï як процес, унаслідок якого відбувається дотримання обома соціальними інститутами однакових, науково обґрунтованих вихідних позицій щодо виховання учнів, узгоджений добір виховних впливів на учнів (у шкільному та сімейному виховному середовищі), що ґрунтується на психологічному механізмі формування цінностей особистості.

Отже, педагогічна взаємодія - це процес спільної діяльності суб'єктів і об'єктів навчально-виховного процесу, який характеризується їх кількісними й якісними змінами та ґрунтується на гуманістичних суб'єкт-суб'єктних відносинах, узгодженості дій, навчанні та вихованні всіх учасників 3 метою досягнення очікуваного педагогічного результату.

У працях В. Бочарової, М. Поташнік, В. Семенова наголошується, що про різні підходи до проблеми взаємодії виховних інститутів свідчать спроби дослідників створити «єдину структуру виховного процесу, у якому кожен інститут виступатиме як частина цілого» [24, c. 9]. 3 огляду на дослідниця запропонувала модель взаємодії школи та позашкільного навчального закладу, основними компонентами якої є: об'єднаність виховних інститутів цілями і завданннями на підставі загальної програми з виховної роботи; ставлення до дітей, як активних суб'єктів системи взаємодії; виділення оптимальної територіальної одиниці для життєзабезпечення системи взаємодії [24].

Взаємодію школи та громадських організацій досліджувала В. Гарнійчук, розглядаючи ії як «феномен впливу, зв'язку, розвитку будь-яких явищ, об'єктів під впливом взаємної дії одного на іншого; спільна організація взаємних дій; процес цілеспрямованого взаємного впливу» [5, с. 300]. Автор вважає, що взаємодія має дворівневу структуру, де перший рівень - суб'єктивний, а другий - процесуальний. Суб'єктивний рівень розглядає суб'єктів виховного процесу, а процесуальний - взаємодію цих суб'єктів [5].

Здійснений аналіз дозволив нам з'ясувати, що в психологопедагогічній літературі немає єдиного тлумачення поняття «взаємодія». Проте можна стверджувати, що взаємодія - самостійна категорія педагогіки, відмінна від «спільної діяльності», і проблема взаємодії виховних інститутів є більш багатоплановою, ніж аспект об'єднання виховних сил у спільній діяльності.

Загалом, необхідність і плідність різних підходів у працях згаданих авторів полягає в тому, що вони сприяють більш глибокому дослідженню взаємодії на різних рівнях і мають велике значення для 
подальших розробок. Крім того, ці праці охопили широке коло питань, що дозволяє досить чітко висвітлити вихідні позиції взаємодії у шкільному педагогічному процесі; спрямували загальну методологічну концепцію дослідження; увиразнили провідні тенденції передового досвіду взаємодії виховних інститутів.

Школа і сім'я мають працювати так, щоб діти постійно відчували єдність, оскільки різні, а інколи протилежні вимоги дорослих, як зазначає Т. Кравченко, призводять до невпевненості дитини [14]. Поняття єдності виховання має психологічний і педагогічний аспекти. Психологічний передбачає з'ясуваня реальних можливостей і повне розуміння всіма педагогами виховних завдань. Педагогічний аспект має на меті створення виховної ситуації як у школі, так і в сім'ї, яка ставить учнів перед необхідністю поводитися відповідно до норм поведінки. Безперечно, виховні завдання не повинні суперечити одне одному.

Ґрунтуючись на досягненнях сучасної психолого-педагогічної науки, враховуючи практичний досвід і особливості нинішніх реалій, сучасні дослідники роблять спробу визначити найбільш актуальні проблеми сімейного виховання дітей різних вікових категорій і знайти оптимальні шляхи розв'язання проблем виховання шляхом залучення батьків до співпраці із загальноосвітніми навчальними закладами.

На думку вчених Т. Кравченко, В. Постового, сім'я - одна 3 найбільших цінностей, створених людством за всю історію його існування. Жодна нація, жодна культурна спільнота не обійшлась без сім'ї. У її позитивному розвитку, збереженні та зміцненні зацікавлені і суспільство, і держава. Кожна людина, незалежно від віку, потребує міцної та надійної сім'ї [14; 21]. Як специфрічна форма спільноти людей, сім'я поєднує в собі індивідуальні та колективні начала, $\epsilon$ першоджерелом соціальних ідеалів і норм критеріїв поведінки. Цінність сім'ї зумовлена відтворенням життя та підтримкою культурних і духовних цінностей, вихованням дітей, передачею їм трудових навичок, фрормуванням соціальної й індивідуальної свідомості.

Особливе значення для забезпечення ефективної взаємодії 3 батьками має період навчання дитини в початкових класах, коли батьки «залюбки відвідують навчальний заклад, цікавляться навчанням і поведінкою дитини» [23, с. 74]. Найбільш поширеними формами роботи з батьками учнів молодших класів О. Пухта вважає батьківські збори, батьківський всеобуч, родинні свята, спортивні та культурно-масові заходи. Дослідниця наголошує на необхідності впровадження в роботу з батьками елементів освітніх технологій, що «допоможе розкрити нові грані співпраці, збагатить батьків психологопедагогічними знаннями, розвине навички продуктивного спілкування» $[23$, с. 74]. Такий підхід створить позитивні передумови для надання батькам психолого-педагогічної допомоги щодо виховання дитини, зокрема у формування екологічно доцільної поведінки. 
Як і будь-яка система, взаємодія школи і сім'ї має свої функції. Функції взаємодії початкової школи та сім'ї висвітлені в науковому доробку О. Докукіної. До них автор відносить: конструктивну; допоміжну; інформаційну. Функції взаємодії школи і сім'ї виділяє Т. Кравченко, а саме: діагностичну; прогностичну; ціннісну; організаційно-управлінську; рефрлексивну. На думку Т. Кравченко, «взаємодія - це процес впливу різних суб'єктів один на одного, який визначає взаємний зв'язок і взаємозаміну, внаслідок чого відбувається поєднання окремих елементів у певну систему, фрормування ії цілісності» $[14$, с. 167].

Дослідниця дає визначення поняття «форми i методи взаємодії», потрактовуючи їх як способи продукування дій педагогів і батьків, їх поєднання та реалізацію з метою надання батькам кваліфрікованої педагогічної допомоги в складних життєвих ситуаціях; ознайомлення батьків 3 концепцією розвитку школи, освітньою програмою, з проектами, до участі в яких залучається школа; змістом навчальних курсів. Найбільш поширеними серед них $є$ : лекції, бесіди, педагогічні практикуми; конференції 3 обміну досвідом, диспути, дискусії, зустрічі «за круглим столом», вечори, консультації; відкриті уроки; виконання батьками конкретних доручень, пов'язаних із вихованням дітей; спільні заняття батьків і дітей (гуртки, секції, студії, походи, екскурсії) тощо [14, с. 169-170].

Технологія взаємодії сім'ї та школи, розроблена Т. Кравченко, має основні складові, що реалізуються в таких блоках: об'єктивні умови; стратегія; тактика. На думку автора, інформація про об'єктивні умови фрункціонування сім'ї можна одержати за такими напрямами: наявність у батьків знань, умінь і навичок сімейного виховання дитини; наявність у вихованні дитини певних проблем і способи їх розв'язання; ставлення батьків до співпраці зі школою. Одержання такої інформації дасть змогу сформувати групи батьків залежно від їхнього ставлення до виховання дитини та до надання педагогічної допомоги з боку вчителя, школи; рівня сформованості практичних і педагогічних умінь і навичок. Належне знання об'єктивних умов сприяє виробленню продуманої та цілеспрямованої стратегії педагогізації батьків як «найбільш важливого і складного елемента взаємодії школи та сім"ї» [15, с. 61].

Зазначену стратегію Т. Кравченко пропонує розробляти, ґрунтуючись на таких принципах: акумуляційному, інноваційному, мобілізаційному, принципі конкретності та якості. Важливою складовою розробленої технології $€$ тактика «як сукупність засобів і методів досягнення ближніх, швидко досяжних, а також віддалених у часі результатів». Від вибору тактичних прийомів, продуманості їхнього застосування «багато в чому залежить реалізація стратегічної мети» [15, с. 61-64]. 
Прикладні аспекти взаємодії школи і сім'ї також були висвітлені в працях О. Хромової. Надаючи важливого значення взаємодії школи і сім'ї у вихованні дітей, дослідниця акцентує увагу на необхідності забезпечення допомоги вчителям і пропонує ії методичне забезпечення, яке містить рекомендації щодо вивчення сімей учнів, розкриває зміст і сутність різних фрорм проведення занять із батьками (лекція, бесіда, семінар, практикуми диспут, конференція, консультація). Зокрема, алгоритм заняття, якого вчитель має дотримуватися, незважаючи на обрані ним фрорму і зміст, $є$ таким:

1) визначення мети заняття;

2) визначення форми організації та проведення заняття;

3) вибір місця і часу проведення заняття;

4) питання для обговорення;

5) основні та допоміжні засоби;

6) можливі труднощі;

7) очікувані результати [32, с. 9].

Взаємодію школи і сім"ї як один із головних принципів організації освіти розглядає Т. Виноградова. Дослідниця акцентує увагу на тому, що взаємодія полягає не лише в допомозі соціальних інститутів одне одному, а й у «розумному об'єднанні можливостей, зусиль в організації життєдіяльності школярів» [2, с. 52]. Проте це стає можливим лише за умови організації такої взаємодії, яка враховуватиме потреби, інтереси дітей і батьків, специфіку конкретного навчально-виховного закладу; забезпечуватиме демократичність, рівноправність у взаєминах усіх партнерів цього процесу.

На думку Т. Виноградової, для ефективної взаємодії школи і сім'ї педагоги повинні розробити стратегії з урахуванням актуальних проблем школярів, вибудовувати роботу 3 батьками на випереджальному принципі, готувати їх до розуміння дитячих стосунків та їхніх проблем. У контексті досліджуваної нами проблеми на особливу увагу заслуговує те, що дослідниця надає важливу роль пропаганді педагогічних знань серед батьків. Розв'язувати це завдання рекомендується під час організації та проведення позаурочних заходів відповідного спрямування [2].

У контексті спільної діяльності розглядає взаємодію школи і сім'ї О. Коберник. Він зазначає, що ця взаємодія має бути націлена на те, щоб завдяки спільним зусиллям досягти справжнього взаємопорозуміння школи і сім'ї, без якого неможливо розраховувати на будь-яку ефективність виховного процесу. Для цього, на думку автора, необхідні два важливі чинники: зацікавленість і готовність взаємодіючих сторін відповідально розв'язувати виховні завдання і рівність партнерів. Із стосунків педагога з батьками «слід виключити командування і підкорення. Вчитель не повинен стояти над ними, його завдання - бути поруч і разом. У співдружності найавторитетніших для школяра людей має пере 
важати співробітництво, ділове і сердечне» [11, с. 189].

Аналізуючи сучасний стан взаємодії школи і сім'ї, науковець доходить висновку, що переважна більшість батьків не готова до активної ії реалізації через недостатній рівень педагогічної культури. Саме вона «є важливим чинником успішного сімейного і суспільного виховання дітей у нових умовах, їхнього інтелектуального розвитку та духовного збагачення ...» [11, с. 190]. 3 метою вдосконалення системи формування педагогічної культури батьків О. Коберник пропонує проводити роботу з постійним складом слухачів. Для цього необхідно організувати цілісне й послідовне вивчення педагогіки та суміжних наук, акцентувати увагу на набутті конкретних умінь і навичок, що мають значення для успішного виховання дітей у сім'ї.

У зв'язку з посиленням уваги до взаємодії сім'ї і школи питання щодо ії організації, принципів, фрорм і методів стають предметом усебічного дослідження. Так, А. Низова, а за нею В. Постовий розробили концепцію взаємодії виховних інститутів, у якій висвітлюється організація дослідження взаємодії сім'ї та школи. Сутність даної концепції полягає в тому, що підґрунтям взаємодії сімейного та суспільного виховання дітей і молоді повинна бути консолідація всіх виховних сил за умови чіткого визначення місця і функцій кожного інституту виховання; сім'я - це первинний виховний колектив і водночас об'єкт для виховного впливу з боку суспільства, яке здійснює свій вплив на сім'ю через школу, засоби масової інформації, трудові колективи. Роль школи науковці вбачають у здійсненні різноманітних форм індивідуальної та колективної роботи 3 батьками, залученні їх до суспільної діяльності з виховання дитячого колективу, в організації педагогічного всеобучу, підвищенні педагогічної культури та соціальної активності батьків.

Таким чином, школа функціонує як організаційний і керівний центр. Саме вона домагається відповідності змісту виховної роботи в сім'ї змістові суспільного виховання. Виховуючи дітей, школа справляє виховний вплив і на сім'ю, організовує систематичну роботу 3 підвищення педагогічної культури батьків, залучає їх до загального процесу, використовує творчі можливості батьків у позакласній роботі.

Безумовно, таке педагогічне просвітництво відіграє значну роль у вихованні, однак воно не дасть бажаного результату без використання додаткових фоорм роботи, які забезпечать тісний зв'язок школи та сім'ї, а саме: класних зборів; днів відкритих дверей; батьківських комітетів; відвідування батьками школи, а вчителями - сімей; участі батьків у позакласній роботі; прес-конференцій та ін.

Особливо важливе значення має безпосередня участь батьків у шкільних справах. Це підвищує інтерес дітей до заходів, надає їм особливого значення. Відзначаючи важливість такої форми взаємодії, Л. Вороніна зазначає: «Іноді батьки $є$ керівниками гуртків... Це допомагає школі ширше розвернути позакласну роботу і разом з цим 
зміцнює зв'язок школи та сім'ї» [4, с. 10]. Гурткова робота, організована школою за безпосередньої участі батьків, на нашу думку, найбільше сприяє формуванню екологічно доцільної поведінки, розвиває інтерес до природи, розширює та поглиблює знання про неї, фрормує відповідні почуття, спрямовує практичну діяльність. Гурткові заняття, на думку авторки, «відіграють суттєву роль у закріпленні та поглибленні отриманих раніше моральних знань, у розвитку моральних почуттів, у створенні умов для проявів ініціативи та творчості» [4, с. 13].

Питання взаємодії школи і сім'ї висвітлено в працях П. Лесгафтта, в яких основна увага приділяється підвищенню педагогічної культури батьків. До аналізу сутності педагогічного всеобучу батьків як важливого напряму просвітницької роботи в батьківському середовищі в сучасних загальноосвітніх закладах звертається В. Вершинін. Він наголошує на важливих аспектах, які останнім часом привертають підвищену увагу і тому мають бути враховані у процесі взаємодії школи і сім'ї, а саме: зацікавленості батьків навчальним процесом, їх налаштованості на оцінку вчителя, усвідомленні власних дидактичних можливостей. Наслідком цього стає «виведення сім'ї 3 нинішньої незручної для неї позиції вічно винного невправного підмайстра вчителя на більш привабливий і продуктивний рівень» [1, с. 187]. Його можна образно визначити як відносини професіоналів, які, хоча i перебувають «у різних вагових категоріях», проте поважають одне одного [1, с. 187].

Сутність підходу до взаємодії школи та сім'ї, запропонованого Г. Кочетовою, полягає в тому, що в основу цього процесу покладено принцип «вплив на сім'ю через дитину». В центрі педагогічної уваги перебуває дитина, яка завдяки цьому стає своєрідним вихователем власних батьків, хоча не завжди усвідомлює це. Дитина - це «сполучна ланка у співпраці школи та сім'ї, консолідуючий центр, головна фогура колективної педагогічної творчості, навколо якої вибудовується цілісний навчально-виховний процес, організовується мікросоціум» [12, с. 196]. За цих умов дитина стає суб'єктом не лише навчальної, а й виховної діяльності, власного виховання. Більше того, дитина «стає активним суб'єктом спільної діяльності всіх учасників педагогічного процесу - вчителів, учнів, батьків і зацікавленої у вихованні дітей громадськості» [12, с. 197].

Проблемою взаємодії початкової школи (щодо учнів шестирічного віку) і сім'ї займається Н. Стаднік, яка розглядає їх взаємодію як взаємоспрямовані дії цих виховних інститутів, що сприяють вирішенню взаємно необхідних завдань щодо виховання дитини. На думку автора, підвищенню ефективності взаємодії школи та сім'ї у вихованні молодших школярів сприятиме запровадження батьківського педагогічного всеобучу із застосуванням інтерактивних методів. Серед них важливе місце відводиться різноманітним виховним вправам, тестам і роботі в групах за участю батьків і учнів. 
Взаємодію загальноосвітньої та дитячої музичної шкіл у справі виховання молодших школярів досліджувала О.Грисюк. Було встановлено, що взаємодія цих навчальних закладів у широкому розумінні $є$ цілеспрямованим двобічним процесом безпосереднього й опосередкованого впливу двох типів шкіл і фрормою організації навчання й виховання учнів. Взаємодія у вузькому розумінні (між учителем і учнем, учнями в колективі, учнем і колективом учнів) забезпечує створення належних умов для розвитку молодших школярів, ефрективне вдосконалення навчально-виховного процесу. Як пріоритетні методи взаємодії дослідниця застосувала метод художньопедагогічного аналізу; метод «забігання» вперед і «повернення» до пройденого; метод організації активної творчої діяльності, бесіду, розповідь, ігровий метод, створення проблемних ситуацій. Підґрунтям взаємодії школи і сім'ї у вихованні учнів початкових класів О. Штихалюк вважає їх навчальну діяльність. Це провідна діяльність учня молодшого шкільного віку, основа формування моральних переконань особистості, тому в ній мають бути сорокусовані педагогічні, виховні процеси школи та сім'ї. Дослідниця організовувала взаємодію шляхом залучення учнів до процесу ведення уроку або заходу, де дорослі були лише радниками, які доповнювали, розширювали їх моральні знання. Взаємодія школи і сім'ї простежується в розробці та проведенні бесід, прослуховуванні аудіота перегляді відеозаписів з певних тем, складанні мінітворів-описів, проведенні дослідів, слуханні музики та доборі музичних фррагментів як фонового забарвлення уроку, малюванні - створенні колективних картин наприкінці вивчення теми тощо.

3 огляду на те, що екологічно доцільну поведінку учнів початкових класів варто формувати під час безпосередньої й опосередкованої взаємодії з природою, яка відбувається протягом усієї повсякденної діяльності учнів, і враховуючи надзвичайний авторитет дорослих для учнів цього віку, актуальним буде поєднання виховних впливів школи i сім'ї шляхом налагодження педагогічної взаємодії. Теоретичні та практичні аспекти взаємодії школи і сім'ї в процесі екологічного виховання досліджували Л. Вороніна, Н. Пустовіт, Л. Руденко.

Характеризуючи методичну взаємодію школи і сім'ї в екологічному вихованні учнів, Л. Вороніна зазначає, що взаємодія - це не використання спільних фрорм і методів екологічного виховання, а партнерська виховна життєдіяльність, що ґрунтується на рівноправності, спільності та взаємоповазі у досягненні цілей екологічного виховання [4].

Авторка виділяє принципи та педагогічні умови організації методичної взаємодії школи та сім'ї в екологічному вихованні учнів. Провідним, на її думку, є принцип комплексного підходу. В організації методичної взаємодії школи та сім'ї він передбачає охоплення всіх ланок педагогічного процесу, залучення якомога більшої кількості 
суб'єктів, які мають виховний вплив на учнів. Принцип варіативності вможливлює організацію методичної взаємодії залежно від конкретних умов школи, особливостей її соціального оточення, професійного й освітнього складу батьків, контингенту учнів тощо. Принцип результативності виявляється в залученні до таких конкретних екологічних справ, проектів, які реально можна здійснити.

До педагогічних умов ефективності методичної взаємодії школи та сім'ї в екологічному вихованні Л. Вороніна відносить:

$>$ дотримання організаційного циклу діяльності (визначення мети, планування і контроль);

визначення спільних і розмежування специфічних фрункцій i засобів впливу школи та сім'ї в екологічному вихованні учнів;

$>$ диференційовану організацію методичної взаємодії школи та сім'ї залежно від фаху батьків, характеру впливу їхньої трудової діяльності на навколишнє середовище [4, с. 10].

У контексті спільної екологічної діяльності розглядала взаємодію вчителів і батьків Л. Руденко, зазначаючи, що вона буде успішною за умови дотримання єдиних вихідних позицій і співпраці. Автор виділила такі принципи взаємодії школи і сім'ї в процесі екологічного виховання учнів:

$>$ поєднання форм масової, групової й індивідуальної роботи;

$>$ опора на позитивний досвід екологічного виховання дітей у сім'ї;

послідовність і неперервність;

$>$ принцип паралельного впливу вчителів на батьків, батьків на вчителів і батьків один на одного [25, с. 26].

Сфрормульовані Т. Кравченко фрункції взаємодії школи і сім'ї були конкретизовані щодо фрормування екологічно доцільної поведінки учнів початкових класів:

$>$ діагностична (знання про рівень ссрормованості екологічно доцільної поведінки дитини, потенційні можливості її розвитку, труднощі, 3 якими вона стикається в процесі фрормування екологічно доцільної поведінки; про роль сім'ї у формуванні екологічно доцільної поведінки);

прогностична (усвідомлення учасниками взаємодії результатів, яких вони прагнуть досягти в процесі фрормування екологічно доцільної поведінки учнів, а також визначення напрямів подальшої взаємодії);

ціннісна («екологічний ціннісний внесок» кожного з учасників взаємодії, адресований як окремим учасникам цього процесу, так і всій спільноті батьків, дітей, учителів);

організаційно-управлінська (упорядкування процесу взаємодії з метою організації екологічно доцільної діяльності);

рефрлексивна (повнота й адекватність розуміння кожною із сторін взаємодії важливості обопільного фрормування екологічно доцільної поведінки учнів). 
Взаємодія двох вихователів - батьків і педагогів - крок до взаєморозуміння, до набуття довіри, обміну духовними та емоційними цінностями, засвоєння педагогічного досвіду, знань, які вчитель і батьки передають один одному. Школа і сім'я мають єдину «виховну територію» і байдужість або зневага хоча б однієї із сторін до цих питань негативно позначаються на фрункціонуванні складових педагогічного трикутника «батьки - дитина - вчителі», гальмують екологізацію зростаючої особистості.

Отже, можна стверджувати, що загалом основна мета, завдання, функції, форми і методи взаємодії сім'ї і школи в плані виховання молодого покоління на сьогодні визначені і проблема полягає в тому, щоб забезпечити їх належну реалізацію в плані екологічного виховання дітей молодшого шкільного віку.

\section{Список використаних джерел}

1. Вершинин В. Педагогический всеобуч родителей. Народное образование. 2005. № 8. С. 186-192.

2. Виноградова Т. Взаємодія батьків і педагогів - необхідна умова для виховання нового покоління. Педагогічна скарбниця Донеччини. 2010 . № 2. C. 51-52.

3. Волкова Н. П. Педагогіка : посіб. для студ. вищ. навч. закл. Київ : Академія, 2003. $576 \mathrm{c}$.

4. Вороніна Л. П. Теоретичні основи організації методичної взаємодії школи та сім'ї у екологічному вихованні учнів. Теоретико-методичні проблеми виховання дітей та учнівської молоді : зб. наук. праць / за ред. І. Д. Беха. КиївЖитомир : Волинь, 2013. Кн. І. С. 282-288.

5. Гарнійчук В.М. Взаємодія школи і громадських організацій у вихованні патріотизму старших підлітків. Теоретико-методичні проблеми виховання дітей та учнівської молоді : зб. наук. праць / за ред. І. Д. Беха. Кам'янецьПодільський : Видавець ПП Д. Г. Зволейко ; Інститут проблем виховання НАПН України, 2009. Вип. 13, кн. 1. С. 299-307.

6. Голод С. И., Клецин А. А. Состояние и перспективы развития семьи. СПб. : Питер, 1995. 273 с.

7. Гребенников И.В. Взаимодействие школы и семьи в воспитании учащихся. Москва : АПН СССР, $1977.56 \mathrm{c.}$

8. Державна національна програма «Освіта» (Україна XXI ст.). від 03.11.1993 р. № 896.

9. Дедю И. И. Экологический энциклопедический словарь. Кишинев : Гл. ред. МСЭ, 2000. $408 \mathrm{c}$.

10. Дьяконов Г. Спілкування і взаємодія: діалогічний підхід. Соціальна психологія. 2004. № 3 (5). С. 82-96.

11. Коберник О. М. Управління виховним процесом у загальноосвітньому закладі : монографрія. К. : Науковий світ, 2003. 230 с.

12. Кочетова А. От ребенка - к семье и к совместному сотрудничеству. Новые аспекты взаимодействия семьи и школы. Народное образование. 2005. № 8. C. 196-202.

13. Кравченко Т. В. Категоріальне поле соціалізації. Вища освіта України № 2 (додаток 1): тематичний випуск «Педагогіка вищої школи: методологія, теорія, технології». Рівне : РДГУ, 2007. Т. 1. С. 98-100.

14. Кравченко Т. В. Соціалізація дітей шкільного віку у взаємодії сім'ї і школи : монографрія. - К. : Фенікс, 2009. 416 с. 
15. Кравченко Т.В. Учитель і сім'я: технологія співробітництва. Педагогіка $і$ психологія. 2007. № 2. С. 57-64.

16. Корнєв М. Н., Коваленко А.Б. Соціальна психологія : підручник. К. : АТ «Київська книжкова фрабрика», 1995. 304 с.

17. Ломов Б. Ф. Психические процессы и общение. Методологические проблемы социальной психологии. М. : Наука, 1975. С. 106-123.

18. Орлянський В. С. Конфрліктологія. К. : Центр навчальної літератури, 2007. $158 \mathrm{c.}$

19. Подберезський М.К.Характеристика особливостей педагогічної взаємодії. Вісник Дніпропетр. ун-ту імені Альфреда Нобеля : Серія «Педагогіка і психологія». 2011. № 2. С. 31-35.

20. Позняк Д. Рефлексивні механізми свідомості виборців. Соціальна психологія. 2004. № 3. С. 22-38.

21. Постовий В. Г. Сучасна сім'я і її педагогіка. К. : Освіта, 2004. 64 с.

22. Про освіту : Закон України від 05.09.2017 р. № 2145-VIII. Голос України. 2017. 27 верес. (№ 178-179). С. 10-22.

23. Пухта О. Співпраця батьків та школи у вихованні дітей. Педагогічний пошук. 2006. № 3 (5). С. 74-75.

24. Работа с родителями : пособие для учителей нач. классов общеобразоват. учреждений / М. П. Осипова и др. Мн. : Экоперспектива, 2016. 480 с.

25. Руденко Л.Д. Взаємодія школи і сім'ї як умова формування екологічної компетентності підлітків. Теоретико-методичні проблеми виховання дітей та учнівської молоді : зб. наук. праць / за ред. І.Д.Беха. К. : Інститут проблем виховання НАПН України, 2005. Вип. 8, кн. 2. С. 25-27.

26. Савка В.І., Уманець Н. А. Сім'я та соціум : проблеми взаємодії : монографрія. Львів : Нац. ун-т «Львівська політехніка», 2008. 177 с.

27. Семейное воспитание : краткий словарь / сост. : И.В. Гребенников, Л. В. Ковинько. М. : Политиздат, 1990. 319 с.

28. Семенов В.Д. О педагогическом взаимодействии. Магистр 1. 2002. № 11. C. $16-19$.

29. Сухомлинська О.В. Сучасні цінності у вихованні : проблеми, перспективи. Шлях освіти. 1996. № 1. С. 3-6.

30. Харчев А.Г. Исследования семьи : на пороге нового этапа. Социс. 1986. № 3. C. 25-28.

31. Хакен Г. Тайны природы. Синергетика : наука о взаимодействии / пер. с нем. А. Р. Логунова. Москва-Ижевск : Институт компьютерных исследований, 2003. $320 \mathrm{c}$.

32. Хромова О. Л. Сучасні форми взаємодії педагога і батьків молодших школярів. Робота з батьками молодших школярів / упоряд. Т. М. Бишова. К. : Шкільний світ, 2008. С. 4-14.

33. Цикін В. О. Філософрія самоорганізації складних систем : монографрія. Суми : СДПУ, 2001. $196 \mathrm{c.}$

34. Шамлян К. Психологічні проблеми наставництва у вищій школі. Педагогіка $i$ психологія профресійної освіти : наук.метод. журнал / за ред. Н. Г. Ничкало. 2001. № 1. С. 93-105. 


\title{
ОСОБЛИВОСТІ МИСТЕЦЬКОЇ ОСВІТИ УЧНІВ В УМОВАХ НОВОЇ УКРАЇНСЬКОЇ ШКОЛИ (ЗА ПІДРУЧНИКАМИ «МИСТЕЦТВО», 1 ТА 2 КЛАСИ)
}

\author{
Лобова О. В. \\ доктор педагогічних наук, профресор, \\ Сумський державний педагогічний університет імені А.С.Макаренка
}

У нашій державі вже два навчальні роки йдуть під знаком Нової української школи. Згідно з теорією поколінь, з 2010 року у світ приходять діти покоління «альфа». Їх не можна примусити щось робити, натомість потрібно домовлятися; вони навчаються, якщо розуміють, для чого це потрібно; для них важливі співпраця i партнерство... Ці діти потребують педагога, який володіє навичками ненасильницького спілкування, має підкреслювати сильні сторони учнів і не сварити за помилки. Близько півмільйона таких дітей стали першокласниками у вересні 2018 року. Тож цілком закономірним $\epsilon$ великий інтерес до актуальних проблем забезпечення освітніх потреб нового покоління школярів.

Сучасна початкова школа зазнала суттєвих змін, пов'язаних 3 упровадженням у закладах загальної середньої освіти концепції Нової української школи [4]. Глибокий і конструктивний аналіз зазначеної концепції та пов'язаних з нею державних документів, зроблений на етапі їх громадського обговорення провідними фахівцями відділу початкової освіти Інституту педагогіки НАПН України Н.Бібік, О.Онопрієнко, О.Савченко, українськими вченими та педагогамипрактиками $[1 ; 9 ; 10]$, дозволив виявити позитиви і вчасно виправити негативні риси нової освітньої стратегії. У результаті було вибудовано струнку педагогічну концепцію, що визначила нові підходи та орієнтири навчання школярів, стосовно галузі мистецької освіти зокрема.

Метою нашої публікації є висвітлення нормативних, організаційних і дидактико-методичних особливостей мистецької освіти учнів в умовах Нової української школи (зокрема, за авторськими підручниками «Мистецтво» для 1 і 2 класів).

Для вирішення поставленої проблеми у підрозділі схарактеризовано специфіку організації викладання інтегрованого курсу мистецтва у закладах загальної середньої освіти, схарактеризовано окремі види, форми та методи інтеграції змісту початкової мистецької освіти, розкрито можливості посилення виховного та розвивального компонентів мистецького навчання, фрормування на уроках мистецтва культурної, мовленнєвої, інформаційної компетентностей учнів тощо. Наведено приклади конкретних завдань, які ілюструють можливості реалізації ідей Нової української школи у процесі початкової мистецької освіти. 
Відповідно до чинного державного стандарту початкової освіти [2] мета навчання мистецтва у сучасній школі передбачає формування культурних цінностей у процесі пізнання мистецтва та художньотворчого самовираження в особистому та суспільному житті; плекання пошани до національної та світової мистецької спадщини. Відповідно до загальних цілей навчання, учні мають:

1) виявляти художньо-образне, асоціативне мислення у процесі художньо-творчої діяльності через образотворче, музичне та синтетичні види мистецтва;

2) пізнавати мистецтво, інтерпретувати художні образи, набуваючи досвіду емоційних переживань, виявляти ціннісне ставлення до мистецтва;

3) пізнавати себе через художньо-творчу діяльність та мистецтво.

Сформульовані у стандарті мета і завдання загальної мистецької освіти знайшли певну конкретизацію у типових освітніх програмах для закладів загальної середньої освіти [11].

За програмою, створеною під керівництвом доктора педагогічних наук, профресора, дійсного члена НАПН О. Савченко, метою навчання мистецтва у школі $\epsilon$ всебічний художньо-естетичний розвиток особистості дитини, освоєння нею культурних цінностей у процесі пізнання мистецтва; плекання пошани до вітчизняної та зарубіжної мистецької спадщини; формування ключових, мистецьких предметних та міжпредметних компетентностей, необхідних для художньотворчого самовираження в особистому та суспільному житті.

Досягнення поставленої мети передбачає виконання таких завдань:

$>$ розвиток почуттєвої сорери учнів, набуття ними досвіду емоційно-естетичних переживань, фрормування мистецьких уподобань та особистісних художніх цінностей;

> поглиблення мотивації до пізнання творів вітчизняного i зарубіжного мистецтва; виховання гордості за здобутки рідного мистецтва та толерантного ставлення до мистецтва інших етносів і народів;

формування умінь художнього сприймання, аналізу художньої мови та оцінювання творів мистецтва, аргументування думки відповідно до вікових можливостей з використанням мистецьких термінів;

оволодіння способами художньо-творчої діяльності в різних видах мистецтва, комунікації з іншими в художній творчості;

досягнення розуміння учнями можливостей цифрових технологій щодо їх застосування у мистецькій творчості;

розвиток здатності самопізнання і самовираження, коригування власних емоційних станів через мистецтво і різні види художньої творчості; розвиток креативності й мистецьких здібностей; 
формування здатності встановлювати зв'язок між видами мистецтва, між мистецтвом та іншими сферами знання (літературою, математикою, знаннями про природу, історію тощо);

мистецтвом і явищами довкілля;

усвідомлення значення мистецтва в житті людини та художнього пізнання для власної успішності;

формування культури глядача-слухача;

> соціалізація учнів через мистецтво, фрормування здатності об’єктивно оцінювати творчі здобутки свої та інших [11].

За програмою, створеною під керівництвом кандидата біологічних наук, доцента Р. Шияна, метою навчання мистецтва для загальної середньої освіти $€$ формування культурних цінностей у процесі пізнання мистецтва та художньо-творчого самовираження в особистому та суспільному житті; плекання пошани до національної і світової мистецької спадщини.

Відповідно до окресленої мети, головними завданнями навчання мистецтва у початковій школі є:

$>$ збагачення духовного світу учня / учениці під час сприймання мистецтва та художньої творчості; виховання шани до національної і світової культурної спадщини;

$>$ набуття досвіду творення художніх образів через опанування елементарними мистецькими вміннями; розвиток загальних i спеціальних мистецьких здібностей;

$>$ розкриття творчого потенціалу особистості; стимулювання художньо-образного мислення, художніх інтересів; виховання естетичного смаку; сприяння творчому самовияву та розвитку індивідуального стилю учня / учениці через мистецтво;

$>$ розвиток уміння інтерпретувати твори мистецтва, висловлювати враження та особистісне ставлення до них; засвоєння початкових знань про види мистецтва, особливості їхньої художньо-образної мови, зокрема у взаємозв'язках;

$>$ формування вміння презентувати й оцінювати власну творчість, плекання потреби у самовдосконаленні;

$>$ формування вміння взаємодіяти 3 іншими через мистецтво, виявляти зв'язки мистецтва з природним і соціокультурним середовищем;

виховання здатності застосовувати мистецтво для отримання задоволення та емоційного самопізнання [11].

Реалізація зазначених цілей і завдань у програмах здійснюється за трьома змістовими лініями: «художньо-творча (у програмі Р. Шияна - художньо-практична) діяльність», «сприймання та інтерпретація мистецтва», «комунікація через мистецтво».

У обох програмах цілком доцільно передбачено можливість реалізації мистецької освітньої галузі через інтегровані курси або предмети вивчення за окремими видами мистецтва: наприклад, 
музичне мистецтво, образотворче мистецтво тощо за умови реалізації упродовж циклу навчання всіх очікуваних результатів галузі та інтегрування навчального змісту.

Попри зазначене положення, за державним замовленням для Нової української школи було видано лише підручники з інтегрованого курсу «Мистецтво», створені різними авторами й авторськими колективами (Л. Аристова, О. Калініченко; Г. Кізілова, О. Шулько; Л. Кондратова; Н. Лємешева; О. Лобова; Л. Масол, О.Гайдамака, О.Колотило; Т.Рубля, І.Мед, Т.Щеглова та ін.). Підручники з музичного та образотворчого мистецтва навіть не були внесені до переліку навчальних предметів для подання рукописів на конкурс.

Отже, найсуттєвішою тенденцією мистецької галузі за концепцією Нової української школи стала чітка орієнтація на інтеграцію поєднання раніше автономних навчальних предметів «Музичне мистецтво» та "Образотворче мистецтво» в інтегрований курс, на вивчення якого у типовому освітньому плані виділено 2 години тижневого навантаження. Цей фракт викликав неоднозначний відгук у педагогічних колах, наріжним каменем якого стала проблема кадрового забезпечення процесу викладання інтегрованого курсу.

Безумовно, українські заклади педагогічної освіти готують вчителів початкових класів, які вивчають методики викладання i музичного, і образотворчого мистецтва, тож мають нормативні підстави викладати інтегрований мистецький курс. Проте не можна не враховувати той фракт, що студенти-«початківці» вивчають лише ази зазначених методик і не володіють у повній мірі усім комплексом професійно важливих умінь і навичок мистецької освіти (наприклад, не навчаються спеціалізовано постановки голосу, хорового диригування та гри на музичному інструменті). Водночас, за умов упровадження інтегрованого курсу незалученими до мистецького навчання школярів залишаються спеціально підготовлені «вузькі» педагоги-фрахівці 3 музичного або образотворчого мистецтва, адже в Україні гостро бракує кваліфікованих педагогів, які можуть викладати (i, відповідно, інтегрувати) обидва ці предмети.

Як показала практика впровадження концепції Нової української школи, наразі у закладах загальної середньої освіти склалися різні варіанти кадрового забезпечення процесу викладання інтегрованого курсу «Мистецтво»:

предмет викладається як єдиний інтегрований курс учителем початкових класів;

> інтегрований курс умовно поділяється на два предмети («Музичне мистецтво» та "Образотворче мистецтво»), які викладають два учителі-фрахівці з відповідних мистецьких напрямів;

курс умовно поділяється на два предмети, один з яких викладає учитель початкових класів, а інший (найчастіше «Музичне мистецтво») - учитель-фрахівець мистецького профрілю; 
$\epsilon$ поодинокі випадки викладання інтегрованого курсу одним учителем-фрахівцем, який має одночасно спеціалізовану музично-педагогічну та художньо-педагогічну освіту.

Відповідно до нової парадигми навчання, у 2018-2019 роках видано низку підручників «Мистецтво» для 1 та 2 класів, створених різними авторами й авторськими колективами (Л.Аристова, О.Калініченко; Г.Кізілова, О.Шулько; Л.Кондратова; Н.Лємешева; О.Лобова; Л.Масол, О.Гайдамака, О.Колотило; Т.Рубля, І.Мед, Т.Щеглова та ін.). Незважаючи на спільну нормативну базу, зміст і навчально-методичний апарат кожного підручника позначений яскраво вираженими особливими, авторськими підходами до впровадження ідей зазначених державних документів. Розуміння цих підходів $є$ важливою умовою успішної роботи вчителя за певною, представленою у кожному підручнику, дидактико-методичною системою.

Зупинимось детальніше на дидактичних i методичних особливостях авторських підручників «Мистецтво» для 1 і 2 класів, що вийшли друком у видавництві «Школяр» у 2018 і 2019 роках.

Головною особливістю цих нових навчальних книг $\epsilon$ інтеграція, спрямованість їх змісту на опанування інтегрованого мистецького курсу, «досягнення цілісності сприймання світу дитиною через переживання мистецтва, відчуття дітьми єдності загальної мистецької палітри» [2, с.4].

Цю ознаку яскраво підкреслено вже у віршованому вступі до підручника для 1 класу, де у художній фрормі згадано різні види мистецтв, з якими зустрінуться на сторінках підручника учні (літературу, музику, образотворче мистецтво, хореографрію, кіно, театр):

Мистецтво - світ виразних слів,

музичних звуків, кольорів,

яскравих танців красота,

чарівність фрільмів і вистав...

Тож просимо тебе ласкаво

в цей світ прекрасний і цікавий! [3, с. 3].

Зміст підручників побудовано на основі систематизованого ознайомлення дітей із сутністю і видами мистецтва й особливостями різних галузей мистецької діяльності. Загальну тематичну структуру підручників за навчальними семестрами відображено у таблиці 1.

Таблиця 1.

Семестрово-тематична структура підручників «Мистецтво» для 1 та 2 класів

\begin{tabular}{|l|l|l|l|}
\hline \multicolumn{1}{|c|}{ Клас } & \multicolumn{1}{|c|}{ Семестр } & \multicolumn{1}{c|}{ Тематичні блоки } & $\begin{array}{c}\text { Кількість } \\
\text { годин }\end{array}$ \\
\hline $\mathbf{1}$ & I & Здрастуй, мистецтво! & 16 \\
& II & Мистецтво навколо нас & 19 \\
\hline $\mathbf{2}$ & I & Світ мистецьких творів & 16 \\
& II & Чарівна мова мистецтв & 19 \\
\hline
\end{tabular}


Домінуючими у змісті підручників $€$ сорери музичного та образотворчого мистецтв, відповідно до цього передбачено висвітлення різновекторних зв'язків між ними. Підпорядкованість змістової побудови підручників такій логіці вивчення мистецтва можна простежити, наприклад, за назвами навчальних тем у змісті 1 семестру «Здрастуй, Мистецтво!» підручника для учнів 1 класу:

1. У нас урок незвичний

2. Що таке Мистецтво

3. Світ, що зветься Музика

4. Як сприймати мистецтво

5. Хто створює мистецтво

6. Музиканти-чаклуни

7. Щоби правильно співати

Сторінка-повторинка

Твої мистецькі канікули
8. Осіння мозаїка

9. Від слова - до пісні й малюнка

10. Мистецтво відображає

11. Не просто бачить, а відчути

12. Мистецтво музики і руху

13. Мистецтво театру

14. Новорічні персонажі у мистецтві

Сторінки-повторинки

Твої мистецькі канікули

Як бачимо, подані теми спрямовані на ознайомлення із загальними відомостями про мистецтво, зі специфікою музичного та образотворчого, а також інших видів мистецтв: хореографрічного, театрального тощо. Зміст кожної навчальної чверті завершено блоком завдань для тематичного контролю («Сторінкиповторинки»), де подано не лише різноманітні запитання, а й практичні завдання щодо різних видів мистецтва. Інноваційна рубрика підручників «Твої мистецькі канікули» містить пропозиції щодо організації мистецької діяльності школярів у вільний час, орієнтує учнів на цікаву самостійну мистецьку діяльність або підготовку для виконання певних наступних завдань.

Розподіл навчального матеріалу в підручниках є зручним для використання, адже кожному навчальному тижню відповідає одна навчальна тема. Зважаючи на вікові особливості дітей, теми містять невеликі за обсягом, короткотривалі та різнопланові завдання. Дифреренціювати їх допоможе застосована у підручнику система орієнтування, що складається з графрічно чітких і лаконічних сигналів-символів:

$>$ «Пізнаємо мистецтво»;

$>$ «Музично-творча діяльність»;

$>$ «Образотворча діяльність»;

$>$ «Зверни увагу, запам'ятай»;

$>$ «Знаки для пошуку творів мистецтва в інтернеті (QR коди)».

Цими умовними позначеннями передбачено загальномистецьку, музично-творчу та образотворчу діяльність дітей; унаочнено зміст різних видів мистецької діяльності за допомогою малюнків; запропоновано роботу з QR кодами до музичних і деяких візуальних творів. 
Згідно з вимогами програм, у змісті підручників передбачено багатогранне висвітлення зв'язків між музичним і образотворчим мистецтвами і відповідною діяльністю школярів. Як же відбувається це поєднання і чим забезпечується інтегративний характер курсу?

Найочевидніший тип такої інтеграції ґрунтується на змістовообразній спільності мистецьких (зокрема музичних і візуальних) творів. Насамперед, діти сприймають образно споріднені музичні та візуальні твори (про школу, пори року, природні явища, тварин тощо). Прикладом такої інтеграції у підручнику для 1 класу може слугувати тема «Мистецтво відображає», де представлені вірші, картини, фоото, інструментальна п'єса, поспівка, пісня, творче завдання, поєднані образами дощу. До речі, у змісті цього підручника цілеспрямовану увагу приділено формуванню уявлення про художній образ, що $є$ основою розуміння поняття образотворче мистецтво.

На змістово-образній спільності музичних і візуальних творів базується і низка образотворчих завдань. Наприклад, ознайомлення 3 «Маршем дерев'яних солдатиків» П.Чайковського органічно продовжується створенням малюнка за змістом фортепіанної п'єси, а ознайомлення з піснею «Перший дзвоник» Наталії Май спонукає дітей передати свої шкільні враження кольорами.

На сторінках підручників представлена й інтеграція більш складного рівня - поняттєва, коли певне мистецьке явище (поняття) розглядається у контексті різних мистецтв. Наприклад, у темі «Ритмічний дивограй» (1 клас) інтегроване поняття ритм розглянуто на прикладі природи, архітектури, живопису, вокальної і танцювальної музики, а потім запропоновано дітям створити власну ритмічну композицію з простих елементів.

У підручнику для 2 класу зміст другого семестру «Чарівна мова мистецтв» просякнутий численними «поняттєвими паралелями» між певними елементами і засобами виразності мов музичного та образотворчого мистецтва. Уявлення про таку інтеграцію починає складатися з усвідомлення школярами функціональної спільності між простими одиницями мистецьких мов: крапка - звук, лінія - мелодія тощо. Згодом вибудовується система паралелей між основними засобами виразності музичного та образотворчого мистецтва: тембр колорит, лад - світлотінь, динаміка - перспектива, музична фрорма композиція художнього твору тощо. Послідовність уведення такого матеріалу можна простежити за переліком навчальних тем підручника:

\begin{tabular}{|l|l|}
\hline 1. Як «розмовляють» мистецтва & 10. Барви і ритми весни \\
2. Слухаємо, дивимось & 11. Гучно-тихо, далеко-близько \\
3. Мовою крапок і звуків & 12. Тембр і колорит \\
4.Які бувають звуки & 13. Про висоту і горизонт \\
5. На що схожа нота & 14. Мажор-мінор і світло-тінь \\
6.Які бувають кольори & 15. Про музичну форму і художню \\
\hline
\end{tabular}




\begin{tabular}{|l|l|}
\hline Перетворення кольорів і звуків & композицію \\
7.Ритм - мистецький чарівник & 16.Мовою театру та кіно \\
8. Мовою мелодій і ліній & Сторінки-повторинки \\
Сторінка-повторинка & Твої мистецькі канікули \\
Твої мистецькі канікули & \\
\hline
\end{tabular}

Наведемо приклади узагальнювального та контрольного завдань на порівняння засобів виразності музичного та образотворчого мистецтв (рис. 1) у підручнику для учнів 2 класу [6, с.124, 132].

Розплутай малюнок-загадку і дізнайся, як «товаришують" засоби виразності музичного та образотворчого мистецтв.

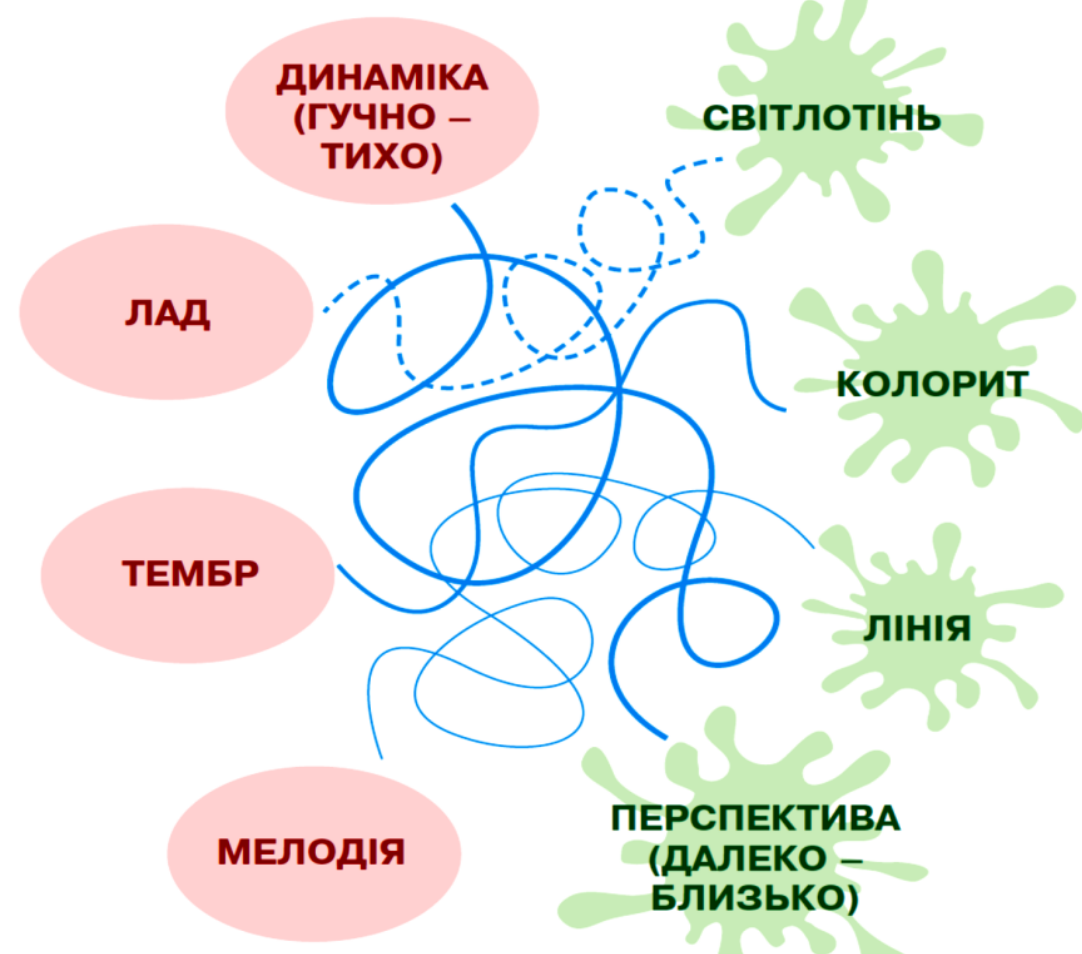

3. Звірята записали засоби виразності музичної та художньої мови. Які слова вони записали не там?
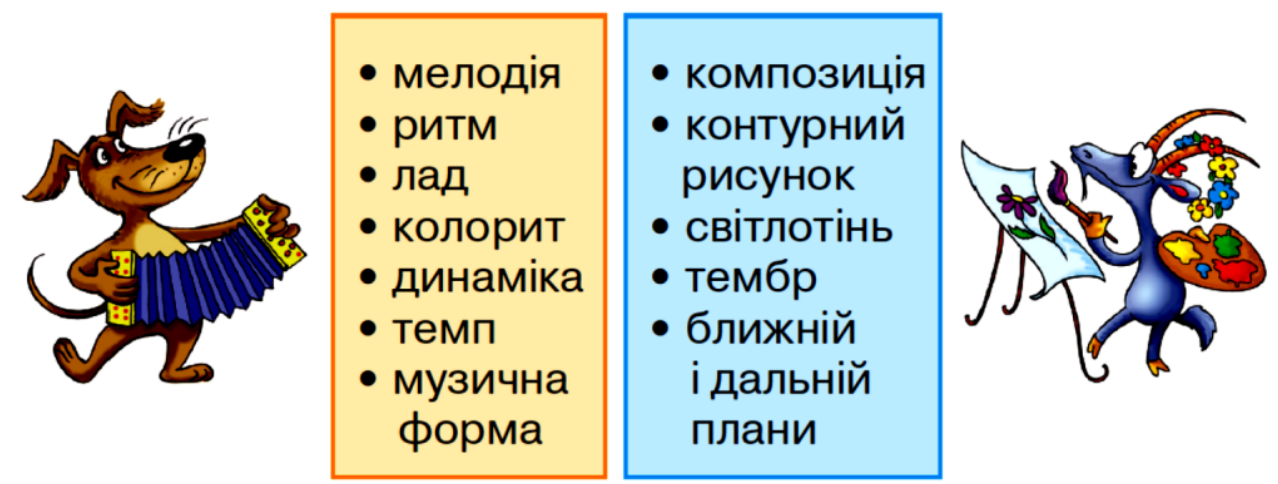

Puc. 1. Приклади завдань на порівняння засобів виразності музичного та образотворчого мистецтв 
Цікаві приклади практичних завдань щодо поняттєвої інтеграції можемо спостерігати у темі «Барви зимових розваг»: на початку навчальної теми діти ознайомлюються з поняттями теплі і холодні кольори, на закріплення цього матеріалу слухають пісеньку сніговика Олафра з мультфрільму «Крижане серце», де він мріє про літо, а потім малюють композицію «Олаф і літо», використовуючи відповідно холодні та теплі кольори. У темі, присвяченій театру, дітям запропоновано розіграти виставу за піснею «Два півники», виконати у ролях пісню «Ходить гарбуз по городу» та, на прикладі цієї пісні, придумати й, можливо, виготовити свої фрігурки для пальчикового театру.

Подібними завданнями забезпечується вимога нової освітньої концепції щодо пріоритетності практичної діяльності учнів. На формування умінь і навичок практичної роботи з образотворчого мистецтва спрямовано нову рубрику підручників «Мистецькі підказки», де подано стислі покрокові рекомендації щодо виконання певного практичного завдання. Наведемо приклад таких «підказок» щодо виготовлення другокласниками новорічного віночка (рuс. 2) [6, с. 61].

\section{МИСТЕЦЬКІ ПІДКАЗКИ}

\&: Підготуйте аркуші паперу зеленого кольору, бажано різних відтінків.

\&: Обведіть свої долоньки та обережно виріжте їх зображення ножицями за контуром.

* Зберіть усі «долоньки» у віночок і склейте, накладаючи одна на одну.

*f Прикрасьте віночок на свій смак: паперовими фігурками, стрічками, конфетті тощо.

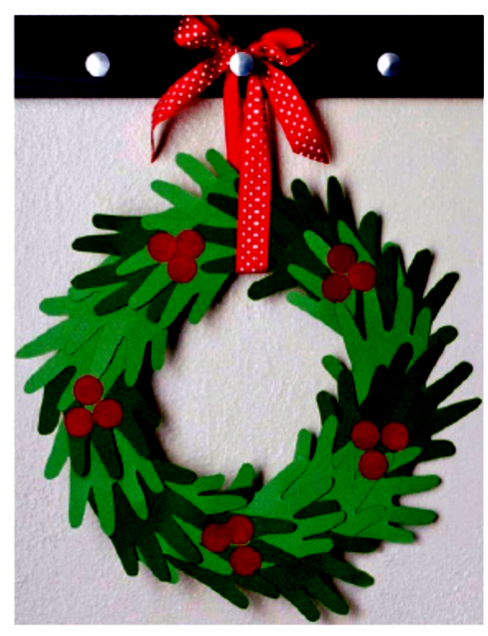

*f Прикрасьте новорічним віночком свою класну кімнату.

Puc. 2. «Мистецькі підказки» з підручника для учнів 2 класу

Щодо розвивальних фуннкцій підручника, пріоритетним $є$ творчий розвиток дітей. Для цього в усіх видах діяльності передбачено завдання креативного типу: ритмічні, вокальні, пластичні імпровізації; театралізація музичного матеріалу, різноманітні види малювання, ліплення, аплікації тощо.

Навчально-методичний апарат підручника розроблено так, щоб постійно підтримувати увагу та стимулювати пізнавальну діяльність школярів. Цьому сприяють спонукальні фрормулювання навчальних 
завдань (послухай, виконай, проплескай, подумай...), а також подання матеріалу у формі гри, з використанням казкових образів і «завданьцікавинок», зокрема ребусів, головоломок, кросвордів. Урахування різних рівнів розвитку учнів забезпечується різноманітністю навчального матеріалу, наявністю завдань на вільний вибір. Разом із тим, у підручнику з етично-психологічних міркувань не позначені завдання низького рівня. Зміст підручника надає можливість планувати роботу таким чином, щоби кожна дитина мала змогу проявити себе i досягти успіху у різних видах мистецької діяльності.

Інтеграція мистецтв надає нові можливості для впливу на свідомість і почуття дитини. Наприклад, у темі «Від слова - до пісні й малюнка» [5, с.40-43] національне виховання дітей здійснюється за допомогою мистецьких образів калини - традиційного символу українського народу. Дітям запропоновано ознайомлення з віршом Т. Шевченка «Тече вода з-під явора» та відповідною українською народною піснею, «калиновими мотивами» петриківського розпису й малюнком семирічного ніжинського школяра «Пишається над водою червона калина». Перебіг практичної роботи передбачає розучування «Калинової пісні» (муз. В. Верменича, сл. М.Сингаївського) та малювання калинового грона.

За допомогою таких і подібних навчальних завдань у підручнику активно реалізовано виховний компонент змісту мистецької освіти, що має на меті залучення дитини до ідеалів краси, духовності, добра, фрормування високих моральних якостей: патріотизму, любові до батьків, рідного краю, природи тощо.

Багато завдань мають українознавче спрямування, адже націлені на ознайомлення дітей з фольклором і творчістю українських митців, культурними традиціями та пам'ятками нашої країни тощо. Наприклад, у контексті рубрики «Твої мистецькі канікули» другокласникам запропоновано ознайомитись з українськими традиціями зимових свят або здійснити «віртуальну подорож» театрами різних міст України (Київ, Львів, Тернопіль, Чернігів) тощо [6, с. 64, 134].

Важливою $€$ спрямованість навчального змісту на фрормування культури спілкування з мистецтвом і реалізацію виховного потенціалу колективної мистецької діяльності (колективізм, взаємоповага, дружба тощо). Для цього передбачено низку завдань, зокрема у рубриках «Хвилинка-говоринка» та «Попрацюймо разом». Наприклад, школярам запропоновано разом з однокласниками знайти і виправити «шкідливі поради» у вірші (рис. 3) [6, с. 9] або виготовити ялинку дружби (рис. 4) [5, с. 63].

Протягом усього терміну навчання значну увагу приділено формуванню мовленнєвої компетентності молодших школярів. 3 цією метою до змісту підручників уведено рубрику «Хвилинкаговоринка», зміст якої спонукає учнів до розмірковування, висловлювання власної думки, діалогу зі співрозмовниками. Задля 
збагачення словникового запасу дітей спеціальною термінологією подано «Словнички» до окремих тем і «Сторінки-підказки» - загальний словник наприкінці підручника.

Низка завдань сприяє розвитку зв'язного мовлення. Наприклад, дітям пропоновано скласти продовження казки або додати пропущені слова у вірші та казці за малюнками. Наведемо приклад такого завдання (фрагмент казки «з пропусками») з теми «На що схожа нота» для учнів 2 класу (рuc. 5) [6, с. 82].

\section{Хвилинка-говоринка}

Послухайте вірш. Яких мистецтв він стосується?

Які поради у вірші: корисні чи шкідливі?

На концерт, як і до школи, вчасно не приходь ніколи. Увійдеш - гукай з порогу: «Запізнивсь! Звільніть дорогу!»

Тільки музика поллється, крикни: «Тихо! Хто сміється?» І отак кричать годиться, доки музика скінчиться.

От на виставці картина, та якась, здається, дивна... Варто голосно сказати: «Прошу цю картину зняти!».
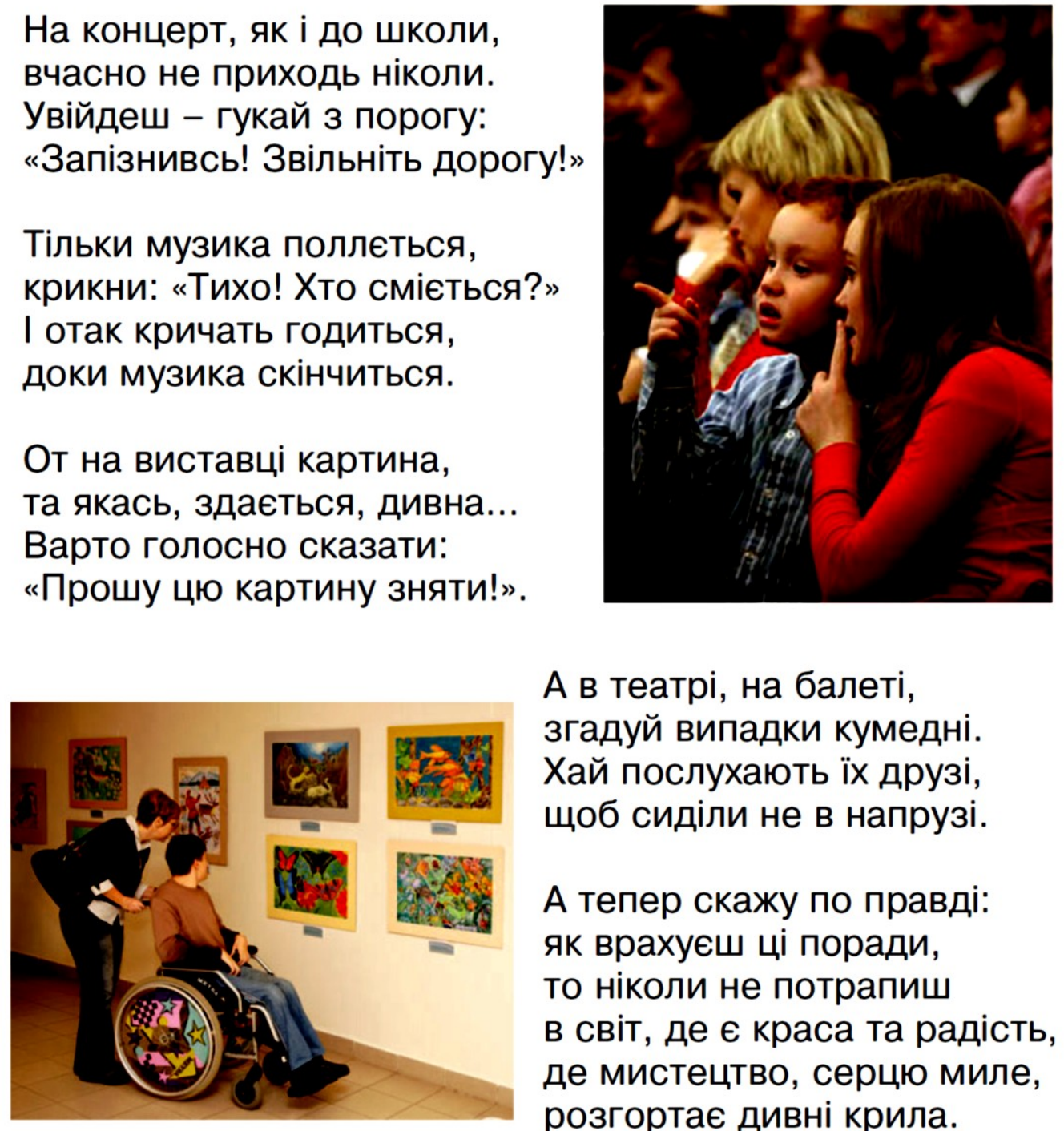

А в театрі, на балеті, згадуй випадки кумедні. Хай послухають їх друзі, щоб сиділи не в напрузі.

А тепер скажу по правді: як врахуєш ці поради, то ніколи не потрапиш в світ, де є краса та радість, де мистецтво, серцю миле, розгортає дивні крила.

Об'єднайтеся у пари. Один знаходить у вірші шкідливу пораду, інший - виправляє помилку.

Puc. 3. Приклад завдання на реалізацію виховного потенціалу колективної мистецької діяльності у рубриці «Хвилинка-говоринка» для учнів 2 класу 


\section{Попрацюймо разом!}

\section{Зробіть Ялинку дружби вашо-}

го класу:

※ візьміть папір зеленого кольору різних відтінків;

* обведіть на папері контури своїх долоньок;

\% обережно виріжте "долоньки" ножицями, за бажанням на-

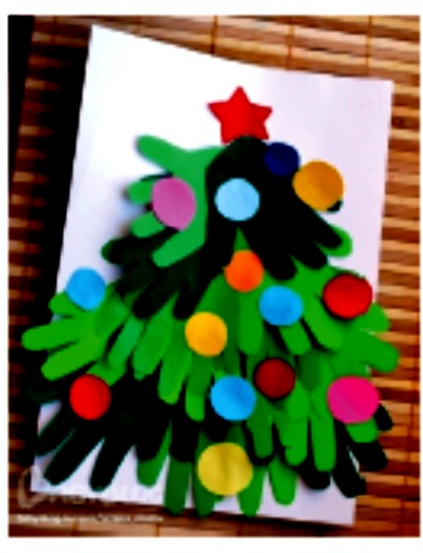
пишіть на них свої імена.

Разом з учителем складіть паперові долоньки у веселу лапату ялинку. Прикрасьте їі кольоровими "кульками" .

Puc. 4. Приклад завдання на реалізацію виховного потенціалу колективної мистецької діяльності у рубриці «Попрацюймо разом» для учнів 1 класу

Прочитай казку, замінюючи малюнки словами.

Простеж, із чим переплутали ноту.

Жила-була О. Якось набридло ій сидіти на $\overline{\bar{\equiv}}$.

Зіскочила О з лінії, стрибнула на "ै, й заспівала:

«Як чудово все навкруг!

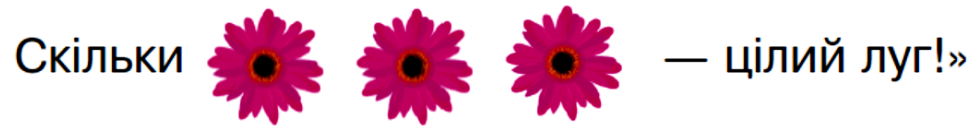

«Хто це співає?» - продзижчала трудівниця

I раптом побачила О. «Ох, яка маленька до свого вулика».

«Hi, не хочу!» - зойкнула О і спорхнула на

Puc. 5. Приклад завдання на розвиток зв'язного мовлення

У підручниках «Мистецтво» знайшла відображення ще одна інновація концепції - вимоги щодо формування інфоормаційної компетентності учнів. Відповідно до цього у змісті навчальних книг подано низку завдань, які орієнтують дітей на роботу із сучасними 
медіа-ресурсами: знайти у мережі Інтернет і послухати пташиний спів, переглянути мультфільми або театральні вистави, створити малюнок за допомогою комп'ютерної програми Paint тощо. До усіх музичних i деяких візуальних творів підручника подано QR коди, які надають доступ до відповідної наочності за допомогою смартфона і знімають потребу у використанні дисків.

Для тематичного контролю у кожному підручнику подані 4 комплекси контрольних завдань і запитань "Сторінки-повторинки», де уміщено не лише різноманітні запитання, а й практичні завдання щодо різних видів мистецтва. Наводимо приклади завдань такого комплексу до 2 чверті підручника «Мистецтво. 1 клас» (рис. 6).

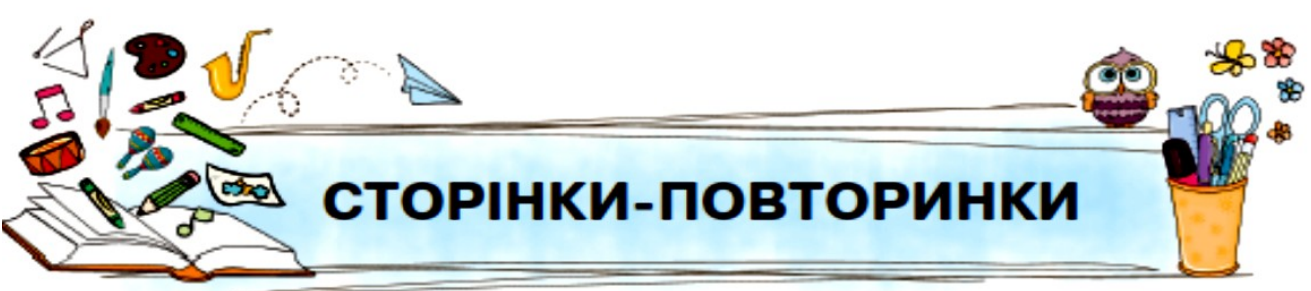

1. Скажи, чи може мистецтво відображати

1. довкілля, життя людей? Наведи приклади творів про осінь, дощик, зимові свята.
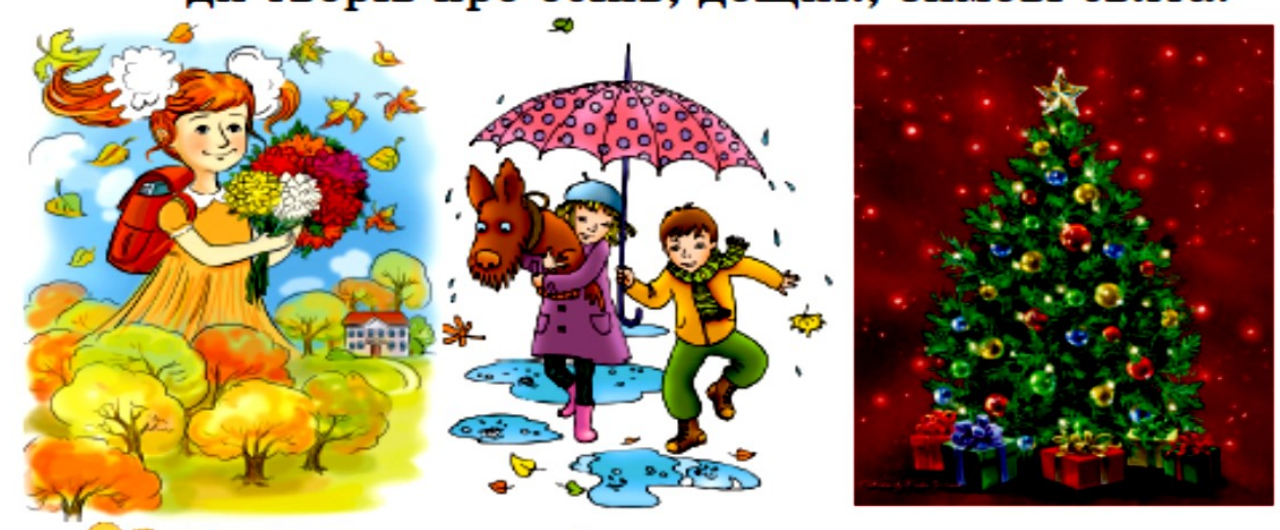

2. Вибери з переліку спочатку твори музичного мистецтва, а потім - образотворчого:

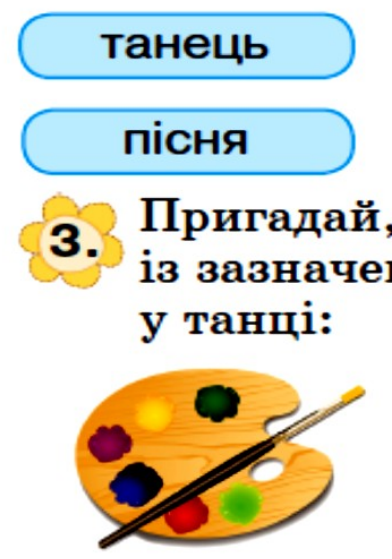

ОБРАЗОТВОРЧЕ

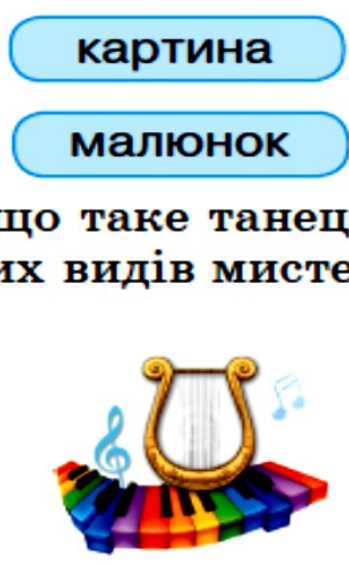

МУЗИКА витинанка

скульптура

Puc. 6. Приклади завдань для тематичного контролю з рубрики «Сторінки-повторинки» 
I ще одна інновація підручника - рубрика «Твої мистецькі канікули», що орієнтує учнів на цікаву самостійну мистецьку діяльність, або підготовку для виконання окремих видів подальшої діяльності на уроках. Наведемо приклад завдань з рубрики «Твої мистецькі канікули» для учнів 1 класу (рис. 7).

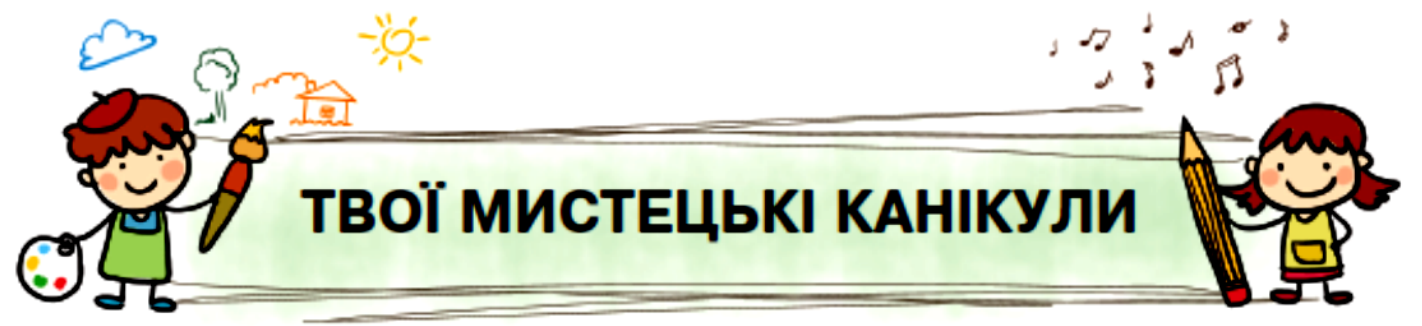

1. Послухай шурхіт осіннього листя.

Збери листки різних дерев, загорни їх $\mathrm{y}$ папір і висуши.
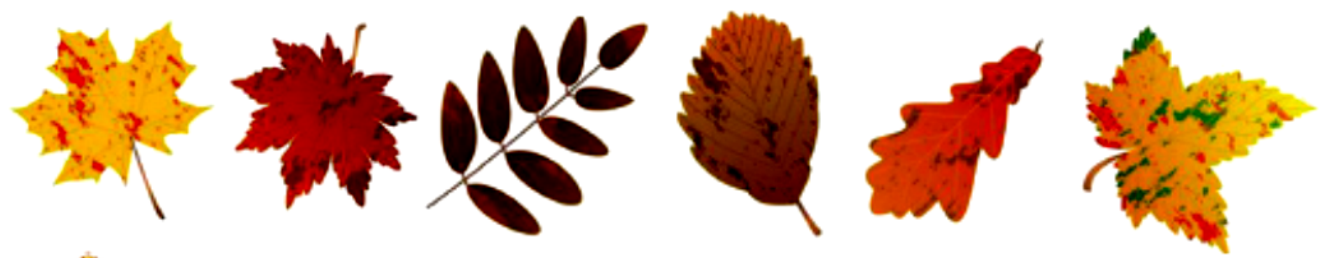

2. Виготов саморобний музичний інструмент:

- налий у склянку трохи води;

- опусти у воду трубочку-соломинку та подмухай у неї;

- слухай спокійну музику і доповнюй іï «бульканням» .

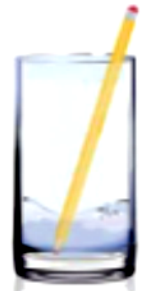

3. Переглянь мультфільми «Ходить гарбуз по городу" i "Бременські музики" .

Визнач. яка мvзика v них звучить:

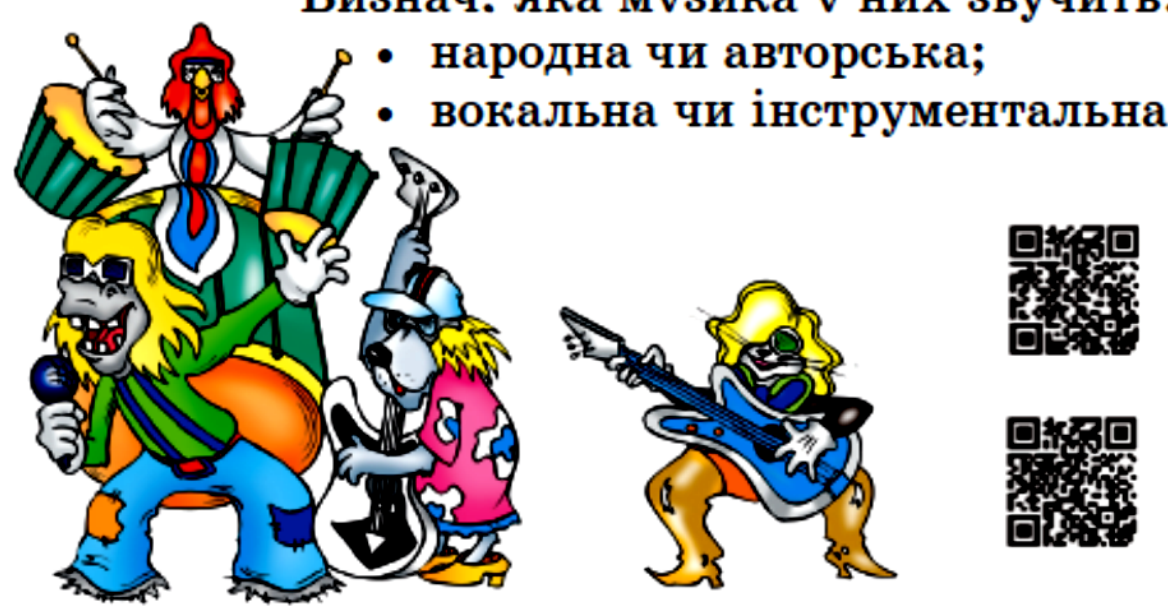

Puc. 7. Приклади завдань з рубрики «Твої мистецькі канікули» для учнів 1 класу

Логіка змістової побудови змісту підручника робить його придатним як для «сольного», так і для «дуетного» викладання 
навчального предмета одним або, відповідно, двома вчителями. У випадку «дуетного» викладання урок музичного спрямування (за певною темою) має передувати образотворчій діяльності: на ньому діти насичуються враженнями і здобувають необхідні знання, а на другому уроці втілюють їх у художній композиції, принагідно звертаючись до повторного прослуховування або виконання музичних творів за темою.

Багате змістове наповнення підручника передбачає можливість вільного вибору запропонованого матеріалу (у т.ч. й на засадах диференціації), створює передумови для урізноманітнення і оптимізації навчальної діяльності учнів. Придатність книг для самостійної роботи дозволяє максимально вивільнити урочний час для активного спілкування дітей з мистецтвом: слухання музики, співу, малювання, ліплення тощо.

Для оптимізації самостійної роботи дітей, на доповнення до підручників підготовлено робочі зошити-альбоми, спрямовані на практичне опрацювання навчального матеріалу [7; 8]. Їх тематична структура повністю відповідає тематичній побудові підручників, а зміст складається з різнопланових завдань на закріплення, повторення, поглиблення, творче опрацювання начального матеріалу, на розвиток творчих здібностей графрічних умінь, схеми малювання тощо (рис. 8).

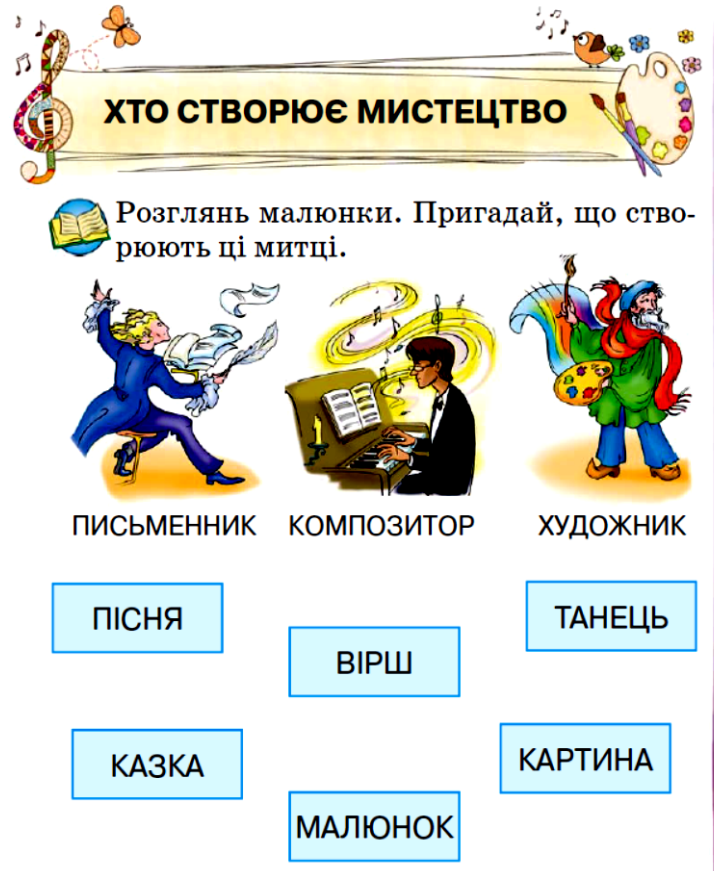

Поєднай лініями зображення митців 3 відповідними творами мистецтва.

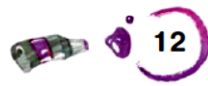

Пригадай пісню за текстом. Поміркуй, що створюють діти.

Малюєм пташечки, квітки-ромашечки, співаєм радісно, ти, пісенько, лети! Приспів:

Ми - першокласники ми - однокласники! O, як нам весело разом до школи йти.

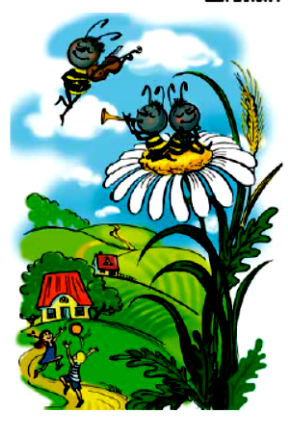

Познач $\checkmark$ що ти любиш більше:

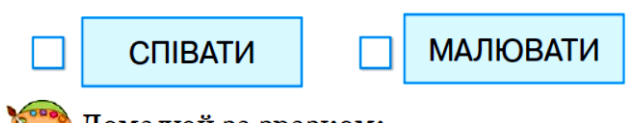

Домалюй за зразком:
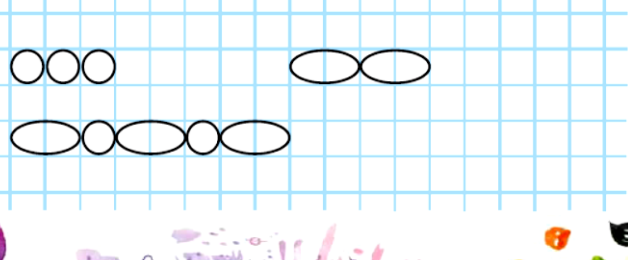
3 робочого зошита-альбому «Мистецтво. 1 клас» [7, с. 12].

Таким чином запропоновані в робочому зошиті завдання сприяють не лише фрормуванню предметних мистецьких компетент- 
ностей школярів, а й їх загальному, культурному та творчому розвитку.

Висновки. Отже, у підрозділі розглянуто нормативні, організаційні та дидактико-методичні особливості мистецької освіти учнів 1 і 2 класів в умовах Нової української школи. Зокрема, схарактеризовано специфіку організації викладання інтегрованого курсу мистецтва у закладах загальної середньої освіти, окремі види, форми та методи інтеграції змісту початкової мистецької освіти, можливості посилення виховного та розвивального компонентів мистецького навчання, формування на уроках мистецтва культурної, мовленнєвої, інформаційної компетентностей учнів тощо.

Проаналізовано дидактико-методичні особливості організації навчання за авторськими підручниками «Мистецтво» для 1 і 2 класів закладів загальної середньої освіти. Згідно з сучасними вимогами до мистецької освіти молодших школярів, зміст підручників спрямовано на всебічний художньо-естетичний розвиток та гармонійне виховання особистості дитини, освоєння нею цінностей вітчизняної та зарубіжної мистецької спадщини, формування ключових, предметних і міжпредметних компетентностей, необхідних для художньо-творчого самовираження школяра.

У підручниках наскрізно реалізовано принципи інтеграції змісту освіти й пріоритету практичної діяльності учнів, значно посилений виховний і розвивальний компоненти, забезпечено можливості для формування не лише мистецьких, а й мовленнєвої, інформаційної компетентностей учнів тощо. Наведено приклади конкретних завдань, які ілюструють можливості реалізації ідей Нової української школи у процесі початкової мистецької освіти.

Навчально-методичний апарат підручників допомагає постійно підтримувати увагу та стимулювати пізнавальну діяльність школярів, передбачає можливість вільного вибору запропонованого матеріалу, створює передумови для урізноманітнення і оптимізації навчальної та плідної самостійної роботи учнів. Логіка змістової побудови змісту підручника робить його придатним як для «сольного», так і для «дуетного» викладання навчального предмета одним або, відповідно, двома вчителями.

Для оптимізації самостійної роботи дітей, на доповнення до підручника підготовлено робочий зошит-альбом, спрямований на практичне опрацювання навчального матеріалу. Запропоновані у зошиті завдання сприяють не лише фрормуванню предметних мистецьких компетентностей школярів, а й їх загальному, культурному та творчому розвитку.

Перспективи подальших наукових розвідок полягають у детальному висвітленні різних аспектів навчально-методичного апарата підручників «Мистецтво» з метою надання вчителям допомоги в реалізації перспективних ідей сучасної педагогіки. 


\section{Список використаних джерел}

1. Від «пілоту» до польоту / Валентина Сорока. Освіта України. 2017. № 44. 13 листопада. С. 8.

2. Державний стандарт початкової освіти школи: https://www.schoollife.org.ua (дата звернення: 11.01.2019).

3. Комаровська О.А. Мистецькі досягнення учнів: що і як оцінюємо. Мистецтво ma ocвima. 2018. № 4. С. 2-6.

4. Концепція нової української школи : https://www.slideshare.net/tsnua/ss70132344 (дата звернення: 11.01.2019).

5. Лобова Ольга. Мистецтво : підручник інтегрованого курсу для 1 класу закладів загальної середньої . Київ : Школяр, 2018. 144 с.

6. Лобова Ольга. Мистецтво : підручник інтегрованого курсу для 2 класу закладів загальної середньої освіти. Київ : Школяр, 2019. 144 с.

7. Лобова Ольга. Мистецтво : робочий зошит-альбом з інтегрованого курсу для 1 класу закладів загальної середньої освіти. Київ : Школяр, 2018. 72 с.

8. Лобова Ольга. Мистецтво : робочий зошит-альбом з інтегрованого курсу для 2 класу закладів загальної середньої освіти. Київ : Школяр, 2019. 72 с.

9. Лобова О.В. Розбудова нової української школи: позитиви і проблеми. Scientific Journal Virtus. 2017. \# 19, Desember. C.82-84.

10. Савченко О. Переваги та ризики. Освіта України. 2017. № 44.13 листопада. C. 9.

11. Типові освітні програми для закладів загальної середньої освіти: https://mon.gov.ua (дата звернення: 11.01.2019). 


\title{
ОСОБЛИВОСТІ ФОРМУВАННЯ ЕСТЕТИЧНИХ СМАКІВ МОЛОДШИХ ШКОЛЯРІВ ЗАСОБАМИ ФОЛЬКЛОРУ
}

\author{
Павлущенко Н. М. \\ кандидат педагогічних наук, доцент, \\ Сумський державний педагогічний університет імені А. С. Макаренка
}

На сучасному етапі політичні перетворення в Україні спрямовані на входження нашої держави до європейської співдружності. Відтак, нагальним постає питання вдосконалення вітчизняної педагогічної освіти стосовно ії̈ відповідності до вимог європейського освітнього простору. Особлива увага в процесі реформ приділяється проблемі створення умов всебічного розвитку підростаючого покоління.

На особливу увагу заслуговує питання фрормування естетичних смаків та естетичної культури саме дітей молодшого шкільного віку. Таке соціально-психологічне замовлення вимагає цілеспрямованого педагогічного впливу на зростаючу особистість.

Проблеми розвитку естетичного смаку та прищеплення його особистості досліджуються представниками різних галузей знання: фрілософрів, соціологів, істориків, психологів, педагогів. В історії естетико-фрілософської думки проблема смаку висвітлювалася в працях Б. Грінченка, Г. Сковороди, Л. Виготського, А. Макаренка, К. Ушинського, В. Сухомлинського та інших. Психолого-педагогічні основи фрормування цілісної особистості обґрунтовано у працях І. Беха, Є. Бондаревської, О. Газмана, Н. Щуркової, І. Якиманської та інших дослідників.

Теоретичні засади художньо-естетичного виховання розроблено І. Зязюном, О. Комаровською, С. Коновець, Н. Миропольською, О. Щолоковою та іншими вченими. Фундамент художньої інтеграції у навчанні і вихованні особистості закладено у працях Л. Масол, О. Рудницької, М. Сови, Г. Шевченко, Б. Юсова та ін. Проблеми естетичного виховання розвитку і фрормування естетичного смаку розкриті також у працях вітчизняних науковців І. Донецької, Н. Калашник, М. Киященка, Н. Волкової та в дослідженнях зарубіжних авторів Г. Айзенка, М. Бредслі, В. Кенника та ін.

Аналіз психолого-педагогічної та методичної літератури дав змогу стверджувати, що питання виявлення особливостей формування естетичних смаків молодших школярів було і залишається в наукових колах актуальним.

Експериментальна робота передбачає послідовність, взаємопов'язаність і взаємозалежність усіх етапів дослідження, на кожному 3 яких вирішувались певні завдання, застосовувались відповідні методи.

Задля виявлення рівня естетичних смаків молодших школярів на уроках естетичного циклу проводився констатувальний етап 
педагогічного експерименту. Зміст цього етапу передбачав визначення експериментальної бази, добір діагностичних методик вивчення рівнів естетичних смаків молодших школярів засобами фольклору.

Завданнями констатувального етапу експерименту було визначено:

1.Добір методики, щодо визначення рівня естетичних смаків молодших школярів.

2. Аналіз результатів констатувального експерименту.

3. Встановлення рівня естетичних смаків учнів 2-4 класів.

У педагогічному експерименті брали участь 94 учні початкових класів, який тривав протягом 2018-2019 навчального року. До експериментальної групи належало 49 учнів, до контрольної 45 учнів 2-4 класів. В експериментальному класі виховний процес був організований з урахуванням визначених педагогічних фракторів і розробленої методики. У контрольному класі робота проводилася за типовим планом навчально-виховним планом.

Упродовж педагогічного експерименту використовувались різні підходи: інтуїтивно-емпіричний на основі соціального досвіду; підхід на засадах узагальненої практики та передового педагогічного досвіду; науковий підхід з опорою на об'єктивні принципи виховання та 3 урахуванням провідних положень вікової та педагогічної психології.

Під час констатувального етапу експерименту використовувалися такі методи як: спостереження, інтерв'ю, анкетування, кількісної та якісної обробки результатів та методики, адаптовані відповідно до специфріки дослідження («емоційне полотно» Л. Дрофрмана, «колірного моделювання музики» Т. Баришевої; завдання щодо інтерпретації художнього образу різними художніми мовами).

За традиційними дослідженнями психологів та педагогів визначено рівневі характеристики сформованості естетичних смаків молодших школярів.

Високий рівень сформованості естетичних смаків молодшого школяра має такі характеристики: учень (учениця) проявляє інтерес до різних жанрів усної народної творчості і видів мистецтва, має уявлення про естетичні цінності, втілені у творах усної народної творчості і мистецтві; знання, уявлення про різні жанри усної народної творчості і види мистецтва та художні асоціації; проявляє власне емоційноціннісне ставлення до різних видів мистецтва через різноманітні художньо-мовні засоби; самостійно обирає художньо-мовні засоби у створенні художнього образу, виявляє творчу активність у різних видах мистецтва.

Середній рівень сорормованості естетичних смаків характерний для молодших школярів, у яких виявлено: інтерес до різних жанрів фольклору і видів мистецтва; знання та уявлення з різних видів мистецтва і усної народної творчості, наявність у них елементарних художніх асоціацій; за умови цільової установки чи допомоги 
дорослого (педагога): наявність уявлень про естетичні цінності, втілені у творах мистецтва і усній народній творчості, прояв емоційноціннісного ставлення до різних видів мистецтва і фольклору; виявлення творчої активності в різних видах мистецтва.

Низький рівень сорормованості естетичних смаків характеризується: інтересом до одного з видів мистецтва, може проявляти інтерес до усної народної творчості тому, що так каже вчитель, але 3 недостатньою зацікавленістю; наявністю окремих знань та уявлень 3 різних видів мистецтва, незначною кількістю (або відсутністю) художніх асоціацій; навіть після допомоги педагога - недостатністю прояву власного емоційно-ціннісного ставлення до творів різних видів мистецтва; відсутністю уявлень про естетичні цінності, що втілені у і у творах фрольклору, і у творах мистецтва, недостатньою активністю в різних видах мистецтва і пасивністю в художній діяльності.

Для визначення естетичних смаків учнів на основі сформованих дослідницею О. Гайдамакою [2] критеріїв (за емоційно-ціннісним; за когнітивно-асоціативним та творчо-діяльнісним критеріями) естетичного виховання: нами було сфрормовано такі показники, як: інтерес до різних жанрів фольклору і музичного мистецтва; емоційно-ціннісне ставлення до різних видів мистецтва (за емоційно-ціннісним критерієм); здатність до художнього асоціювання (за когнітивноасоціативним критерієм); творча активність учнів на уроках естетичного циклу; здатність до самовираження у позаурочній художній діяльності (творчо-діяльнісним критеріями).

Отже, перший показник це - інтерес до різних жанрів фольклору і музичного мистецтва - який характеризується спрямованістю особистості на ознайомлення з новими творами фольклору, музики і виявляє себе в емоційному тоні, у підвищеній увазі до творів різних жанрів фольклору і мистецтва.

Для визначення інтересу молодших школярів до різних жанрів фрольклору була застосована методика педагогічного спостереження та методика «Інтерв'ю».

Педагогічне спостереження було здійснено з урахуванням таких питань:

$>$ Чи проявляють учні інтерес до фольклору? Як це виявляється?

$>$ До яких жанрів фольклору виявляється більший інтерес?

$>$ Як діти реагують на взаємодію фрольклору з мистецтвом? Чи розуміють вони ії?

Спостереження виявило, що молодші школярі проявляють інтерес до різних жанрів фольклору у активній формі - переважна більшість дітей $(89,8$ \%) любить загадки, лічилки, скоромовки, українські народні казки, пісні та ігри. Але і були такі діти, які не виявили інтересу і цікавості творами фрольклору (10,2\%). На взаємодію різних жанрів фольклору і мистецтва більшість дітей реагують, як на цілком природнє явище, проявляють до нього інтерес. 
3 метою виявлення естетичних смаків учнів початкових класів було ураховано: інтерес дітей до жанрів музичного мистецтва, зокрема до українських пісень; бажання (небажання) учнів співати, танцювати; зацікавленість творчими видами діяльності (малювання, ліплення); інтерес учнів до виявлення веселого (сумного) настрою через певний музичний інструмент чи пензель з фарбами.

За методикою «Інтерв'ю» було запропоновано дітям такі запитання:

$>$ Яка музика за характером тобі найбільше подобаються? Чи є у тебе улюблені українські пісні?

> Що тобі цікавіше робити - співати, танцювати чи малювати і ліпити?

$>$ Які українські народні казки тобі подобаються? Чому?

$>$ Перед тобою - інструменти митців - пензель з фрарбами, ручка і листочок паперу, трикутник (бубон або інший музичний інструмент). Якщо у тебе сумний настрій, чим би ти скористався для його поліпшення?

Важливою характеристикою інтересу до музичного мистецтва і жанрів фрольклору (зважаючи на вік дітей) було не стільки те, що дитина відповість (у більшості дітей одного віку відповіді, як правило, дуже схожі), скільки емоційне забарвлення відповіді дитини, те, як дитина дає відповіді на запитання.

Аналіз відповідей також засвідчив, що у дітей даного віку існує певний інтерес до жанрів фольклору і музичного мистецтва. Більшість дітей виявили високий - 17,6\% експериментальна група і $22 \%$ контрольна група, середній - $75 \%$ експериментальна група і $65 \%$ контрольна група рівень інтересу, тобто усе, що пов'язано 3 мистецтвом у поєднанні з народним фольклором, викликало у них яскравий емоційний відгук, бажання творити тощо. Проте у більшості дітей інтерес проявлявся до одного з жанрів фольклору і видів художньої діяльності (співу чи малюванню), що свідчило про їх попередній художній досвід у цьому виді діяльності. Це ж стосувалося дітей, які виявили низький рівень інтересу - 7,4 \% експериментальна група і $13 \%$ контрольна група.

Наступним показником виявлення рівня естетичних смаків молодших школярів $є$ прояви емоційно-ціннісного ставлення до різних видів мистецтва, здатності дітей молодшого шкільного віку до емоційного «занурення» в образний зміст художнього твору. Учням було запропоновано висловити власне ставлення до творів різних видів мистецтва та їх взаємодії з народним фольклором («Про що «розповів» твір мистецтва?» метод «Інтерв'ю»), у процесі сприймання творів мистецтва через його «опредмечування», у відтворенні власних вражень, емоцій і почуттів словами, кольорами тощо.

Молодшим школярам пропонувалося розглянути твори

образотворчого (Ю. Мацик «Напарники», І. Буканов «Райдуга», В. Бредлі «Ліс») та прослухати твори народного музичного (українська 
народна пісня «Щебетала пташечка», Й. С. Бах «Жарт») мистецтв, серед яких потрібно було визначити, який (які) сподобалися найбільше, і пояснити чому саме.

Самостійне «занурення» в образний зміст художнього твору, намагання пояснити його, висловити власні враження від сприймання твору визначалося як високий рівень виконання даного завдання. Його показали 8,6 \% дітей. У таких дітей звучали пояснення і власна оцінка твору. Після прослуховування музичних творів учні, які виявили високий рівень, відгукувалися у відповідності до втіленого у музиці настрою: «Весела музика, під неї можна танцювати», «Звучить, наче співає пташка» тощо (про «Жарт» Й. С. Баха); «Нагадує колискову», «Під цю музику мама заколисує дитину» тощо (про «Щебетала пташечка»).

Про середній рівень здатності «занурення» в образний зміст художнього твору свідчило виконання молодшими школярами завдання за допомогою дорослого (через спеціальні запитання та обговорення). Такий рівень показало 63,7 \% учнів.

Низький рівень виконання запропонованого завдання визначався при небажанні дитини виконувати завдання («Я не знаю як його виконувати», «Я не умію» тощо). Такий рівень було визначено у 27,7 \% молодших школярів.

3 метою виявлення рівня осягнення вражень, емоцій і почуттів від сприймання творів музичного мистецтва, визначення, наскільки глибоко діти переживають художні образи і яскраво й емоційно можуть перекласти їх відповідними художніми засобами, молодшим школярам було запропоновано завдання: «Відтінки емоцій» (методика «емоційне полотно», адаптована відповідно до вікової категорії респондентів; «Відобрази кольорами свої емоції, викликані музикою» (метод «колірного моделювання музики»).

3 метою визначення здатності дітей тонко відчувати й ідентифрікувати емоційні стани, розрізняти нюанси у зоні настрою, що переживається ними у процесі сприймання творів фольклору, молодшим школярам пропонувався розширений перелік емоцій та їх відтінків для ототожнення пережитих ними емоцій після сприймання творів музичного (українська народна пісня « Котику сіренький»), образотворчого (Ван Гог «Зоряна ніч») і театрального (П. Чайковський «Хвороба ляльки», «Битва з мишами» з балету «Лускунчик») мистецтв (завдання «Відтінки емоцій»). Діти мали позначити у запропонованій таблиці слова-емоції (у таблиці - ліворуч: радість, печаль, гнів), або відтінки емоцій (у таблиці - праворуч: радісно, грайливо, сумно, трагічно, схвильовано, гнівно), що найбільше відповідають емоційному стану, який вони відчули під час сприймання.

Виконання цього завдання засвідчило, що певна частина молодших школярів здатна за допомогою педагога визначити емоції, втілені у творі мистецтва (28,7 \%), проте у переважної більшості дітей відсутній досвід у визначенні їх відтінків (71,3 \%). 
3 метою визначення емоційного стану під час сприймання творів музичного мистецтва через усвідомлене ставлення до кольору як засобу емоційної виразності, молодшим школярам було запропоновано виконати завдання «Відобрази кольорами свої емоції, викликані музикою» (метод «колірного моделювання музики». Дітям пропонувалося прослухати з певним інтервалом музичні твори без оголошення назви (Ж. Колодуб «Лялька співає», Д. Кабалевський «Клоуни») та відтворити власні враження від них створенням художнього образу відповідного настрою.

Під час оцінювання виконання завдання бралося до уваги те, наскільки яскраво було втілено учнем музичний настрій у кольоровому образі. Дітей, які після прослуховування музичного твору відразу почали малювати і створювати художні образи (відповідно - ліричний, спокійний та веселий, грайливий) було віднесено до високого рівня виконання цього завдання. Музика навіяла їм яскраві веселі образи, що свідчило про здатність дітей адекватно усвідомлювати відповідні емоції і втілювати їх у художніх образах. Проте такий рівень показали лише 12,7 \% молодших школярів.

Більшість учнів почали виконання цього завдання тільки після обговорення прослуханого твору разом з педагогом. Такий рівень виконання завдання визначався як середній, його показали $47,4 \%$ молодших школярів.

Низький рівень виконання завдання показали учні, які відмовилися виконувати завдання або заповнили аркуш паперу довільними лініями, плямами або просто улюбленими зображеннями (машинки, танки, роботи, ляльки тощо) без відтворення відповідного настрою і будьяких пояснень. Такий рівень показали 39,9 \% молодших школярів.

Наступним розкривався показник «здатності до художнього асоціювання», коли молодшим школярам пропонувалося виконати такі завдання: «Створи квітку» (інтерактивний метод «асоціативний кущ» або «Гірлянда асоціацій і метафор», адаптований відповідно до специфріки дослідження та вікової категорії дітей).

Завдання «Створи квітку» передбачало добір понять «пелюсток квітки», що асоціюються у дитини з основним (запропонованим у «середині квітки»). Кожному школяру пропонувалася «середина квітки» із надписом одного 3 жанрів усної народної творчості (наприклад, «українська народна казка»), та розрізнені «пелюстки квітки», із зображеннями та написами, що можуть асоціюватися 3 цим поняттям (наприклад, цікава, захоплююча, 3 яскравими картинками, можна самому придумати інший кінець, можна інсценувати тощо). Крім цього, додавалися «пелюстки» 3 написами або зображеннями, які переважно не можуть асоціюватися з основним (наприклад, зло перемагає добро, не має дійових осіб тощо) та «пелюстки», на яких нічого не зображено. Дітям потрібно було створити квітку, додавши необхідні, на їхню думку «пелюстки», а також домалювати або дописати інші, що асоціюються у них 3 
поняттям, зображеним в центрі «квітки».

Високий рівень визначався, якщо молодші школярі самостійно виконували завдання, намагалися дописати або домалювати власні асоціації на чистих «пелюстках». Саме спроби (намагання, прагнення) самостійно виконати завдання свідчило про наявність у дитини художніх асоціацій. Такий рівень виявили $10,6 \%$ учнів. Середній рівень визначався виконанням завдання за допомогою педагога і тільки із запропонованих матеріалів. Такий рівень виявила переважна більшість - 64 \% молодших школярів. Це свідчило про наявність в учнів певних уявлень щодо запропонованого поняття та про те, що запропоновані орієнтовні відповіді (слова або зображення на «пелюстках квітки») викликали в учнів елементарні художні асоціації відповідно до основного поняття (написаного у «середині квітки»). Про низький рівень засвідчив довільний непродуманий вибір молодшими школярами слів-понять (із запропонованих), що свідчило про відсутність (або незначну кількість) в учнів художніх асоціацій щодо запропонованого поняття. Такий рівень виявило 25,4 \% опитаних.

Аналіз проведеного дослідження показав, що народний фрольклор і мистецтво викликає у дітей яскравий емоційний відгук, інтерес і бажання творити, фантазувати. Проте у більшості молодших школярів інтерес проявляється до одного з жанрів фольклору - зокрема це музика - українські народні пісні, казки або загадки і мистецтво.

Для визначення наступного показника - творчої активності учнів на уроках естетичного циклу було обрано метод спостереження.

Спостереження за дітьми проводилося за такими напрямками:до якого з видів художньої діяльності учень виявляє активність на уроках (музична, образотворча, театралізована) та чи проявляє учень на уроці ініціативу самостійно щось створювати у різних видах художньої діяльності (створювати казки, загадки, пісеньки, рухатися під музику, малювати, придумувати сюжети тощо.

Високим рівнем творчої активності молодших школярів на уроках визначалося, коли під час уроків учні активно проявляли ініціативу щодо спроби своїх можливостей у різних видах діяльності: виявляли бажання придумати мелодії до віршиків, малювати художні образи, зокрема, навіяні музикою, створювати казочки або придумувати загадки у ході уроку тощо. Такий рівень виявило 10,6 \% молодших школярів.

Середній рівень творчої активності визначався, коли молодші школярі під час уроків виявляли бажання виразити себе в різних видах мистецтва, але при наявності цільової установки учителя (виконання певного творчого завдання). Такий рівень показали 38,3 \% учнів, що свідчило про значний потенціал розвитку творчої активності дітей.

Низьким рівнем виявлення молодшими школярами творчої активності на уроках визначалося, якщо учні були готові до копіювання за педагогом того чи іншого виду діяльності без виявлення будь-якої власної творчої ініціативи. Такий рівень виявили 51,1\% учнів. 
Активне прагнення виразити себе у різних видах художньої діяльності, прояв творчої ініціативи (створення малюнків, добір (або придумування) віршиків, мелодій, казок тощо за темами, що опановувалися ними на уроках) у вільний від уроків час визначалося високим рівнем здатності до самовираження у позаурочній художній діяльності. Такий рівень на початок дослідження виявили 10,6 \% молодших школярів. Бажання учня виразити себе в різних видах художньої діяльності, але при наявності цільової установки дорослого визначалося середнім рівнем здатності до самовираження у позаурочній художній діяльності. Його виявила переважна більшість - 74,4 \% молодших школярів. Небажання або пасивне ставлення до творчої діяльності визначалося низьким рівнем, який виявило 15\% учнів 2-4 класів. Це було підтверджено і проведеним методом спостереження.

Аналіз результатів показників сформованості естетичних смаків засобами фольклору та мистецтва молодших школярів виявив наступне: діти достатньо добре виконують поставлені завдання після обговорення характеристики художніх образів, навіюванням особливостей його виконання за допомогою вчителя або за запропонованим зразком. Згідно 3 аналізом спостереження було визначено, що більшість учнів 2-4 класів виявляють творчу активність, але виражають себе переважно в одному виді художньої діяльності (образотворчості чи музиці); молодші школярі у переважній більшості під керівництвом дорослого придумують, вибирають сюжети для майбутніх образів i із задоволенням виконують запропоновані творчі завдання.

Отже, за результатами констатувального етапу педагогічного експерименту, у молодших школярів (за середніми показниками контрольної та експериментальної груп) виявлено такі рівні сформованості естетичних смаків: високий - його проявляють $10 \%$ учнів експериментальної групи і $13 \%$ контрольної групи. Учні проявляли інтерес до різних жанрів усної народної творчості і видів мистецтва, мали уявлення про естетичні цінності, втілені у творах усної народної творчості і мистецтві; мали знання, уявлення про різні жанри усної народної творчості і види мистецтва та художні асоціації; проявляли власне емоційно-ціннісне ставлення до різних видів мистецтва через різноманітні художньо-мовні засоби; самостійно обирали художньо-мовні засоби у створенні художнього образу, виявляли творчу активність у різних видах мистецтва.

Середній рівень показали $62 \%$ учнів експериментальної групи і $61 \%$ контрольної групи. Вони виявили інтерес до різних жанрів фольклору і видів мистецтва; мають знання та уявлення з різних видів мистецтва і усної народної творчості, наявні елементарні художні асоціації; за умови цільової настанови чи допомоги педагога: наявність уявлень про естетичні цінності, втілені у творах мистецтва і усній народній творчості, прояв емоційно-ціннісного ставлення до різних 
видів мистецтва і фольклору; виявлення творчої активності в різних видах мистецтва.

Низький рівень показали 28 \% учнів експериментальної групи і 26 \% контрольної групи, такі учні характеризуються: інтересом до одного з видів мистецтва, можуть проявляти інтерес до усної народної творчості тому, що так каже вчитель, але 3 недостатньою зацікавленістю; наявністю у них окремих знань та уявлень з різних видів мистецтва, незначною кількістю художніх асоціацій; навіть після допомоги педагога - недостатністю прояву власного емоційноціннісного ставлення до творів різних видів мистецтва; відсутністю уявлень про естетичні цінності, що втілені у творах фольклору, і у творах мистецтва, недостатньою активністю в різних видах мистецтва і пасивністю в художній діяльності. Це свідчить про потенційні можливості дітей, але відсутність у них різноманітного художнього досвіду.

Аналіз педагогічного досвіду, визначення теоретичних положень дослідження, психолого-педагогічні аспекти зазначеної проблеми в теорії і практиці початкової школи, а також врахування результатів діагностування зумовили напрямки роботи щодо розроблення експериментальної методики та її впровадження в сукупності 3 наступними педагогічними фракторами: спрямованість навчальновиховного процесу на опанування молодшими школярами естетичних цінностей мистецтва і фольклору, актуалізація виховного потенціалу засобами фольклору і творами різних видів мистецтва, залучення молодших школярів до різних видів особистісно-орієнтованої мистецької діяльності. Зазначені педагогічні фрактори враховуватимуться під час здійснення й апробації методики.

Перший педагогічний фрактор - спрямованість навчальновиховного процесу на опанування молодшими школярами естетичних цінностей мистецтва і фрольклору було визначено, як процес формування здатності в учнів визначати естетичну цінність твору мистецтва, усної народної творчості або продукту власної діяльності здійснюється через поступове набуття ними художнього та естетичного досвіду - уміння заглибитися у зміст твору під час його сприймання та опанування сумою художніх знань і уявлень, визначити художні якості твору, такі як гармонійність, виразність мови, пропорційність, симетричність. Розуміння цих якостей веде до розуміння та реалізації їх у навколишньому світі та повсякденному житті, що незмінно втілюється у формуванні у дітей естетичних смаків, їх особистісно-ціннісного ставлення до мистецтва, усної народної творчості і явищ оточуючої дійсності.

Заглибитися у зміст твору, відчути його естетичну цінність, сорормувати особистісно-ціннісне ставлення, естетичний смак, здійснювалося у процесі сприймання та аналізу-інтерпретації школярами творів фольклору і мистецтва, а також у їхній художньотворчій діяльності. 
На початку формувального етапу педагогічного експерименту 3 метою привчання дітей до уважного споглядання або слухання творів усної народної творчості і мистецтва у процесі їх сприймання використовувалися міні-бесіди, міні-розповіді або запитання із «залученням» безпосереднього змісту творів.

Метод переконання художніми засобами застосовувався шляхом організації цілеспрямованої уваги молодших школярів під час сприймання творів мистецтва і усної народної творчості, роз'яснення теми, змісту, естетичних цінностей і смаків, втілених художніми засобами. Адже «цінність, що привноситься у колектив учнів, залучаючи у проживання ціннісного ставлення членів колективу, сприяє перетворенню всієї сукупності ставлень у групі дітей».

За допомогою словесних пояснень, бесід можливо викликати певну спільність думок, переживань і спрямувати увагу дітей на особливості засобів художньої виразності, які надають творам відповідний характер і створюють відповідний настрій, таким чином заохочуючи позитивні реакції на твір усної народної творчості і мистецтва - поступово фрормуючи в них здатність розуміти естетичну цінність твору.

Усвідомленість естетичної цінності твору відтворювалася і у виконавській діяльності дітей. Роль педагога полягала у тому, щоб діти добре розуміли, що вони будуть виконувати, наперед продумували зміст, осмислювали характер, відчули настрій - і тільки тоді виконання було виразним, щирим і доступним, осмисленим. Осмислене виконання чинить на дітей сильний вплив, викликаючи у них різні почуття, збагачує враженнями. Тому різними були виконання пісень А. Мігай «Дощик» (весело, грайливо), М. Балеми «Козацькому роду нема переводу» (урочисто, святково) або настроєвих пейзажів різних пір року, портретів клоунів, казкових героїв чи образу богатиря. Таким чином, метод переконання засобами фольклору був спрямований на сприяння розвитку в учнів почуттів, естетичного смаку, розуміння виконуваних чи сприйнятих творів.

За допомогою методу порівняння творів різних жанрів усної народної творчості і видів мистецтва встановлювалися доступні для розуміння молодшими школярами зв'язки між окремими жанрами усної народної творчості і видами мистецтва. Співставлення виразових засобів музики, образотворчого мистецтва, літератури на прикладі втілення художніх образів, їх характеристика базувалася на звукових (фонетичних) і зорових асоціаціях у сорері мистецтва, взаємодії різних мистецтв, що здійснювалося не тільки у діяльності сприймання, але і в творчій художньо-практичній діяльності, підводило учнів до більш глибокого переживання і розуміння специфіки мистецтва як особливої форми відображення дійсності.

Перед молодшими школярами ставилися завдання порівняти характер використаної у малюнку лінії і характер руху мелодії; настрій, викликаний музикою у поєднанні 3 кольоровою гамою у творі 
образотворчого мистецтва, і поступово учням пропонувався пошук звукових, зорових, пластичних, мовних асоціацій у сфрері різних видів мистецтва. Так, у процесі аналізу творів, що сприймалися, учням ставили запитання, зокрема: «Якщо б вам запропонували намалювати почуту українську народну пісню чи казку, який колір ви б обрали для цього? Поміркуйте, кого 3 персонажів можна охарактеризувати пісенною мелодією, кого - танцювальною?»

Процес формування здатності визначати естетичну цінність твору мистецтва тісно пов'язаний з опануванням учнями сумою необхідних художніх знань, яке відбувалося системно і послідовно. При цьому процес здійснювався у двох векторах: набуття відповідних знань 3 окремого виду мистецтва та через виявлення «універсальних понять естетики та мистецтвознавства, таких як ритм, гармонія, композиція, форма, динаміка, контраст, симетрія тощо, які $є$ фрундаментом єдності й взаємодії мистецтв, фактором художньо-дидактичної інтеграції. Естетичні смаки та уявлення молодших школярів формуються із застосуванням словесних (пояснення), наочних (ілюстрація, демонстрація) методів, та системи практично-спрямованих завдань.

Зокрема, на початку формувального етапу експерименту молодші школярі опановували особливості художньої мови різних видів мистецтва: на уроках музичного мистецтва знайомилися із властивостями музичних звуків (висота, тривалість, гучність), основними типами музики «пісня, танець», музичними засобами (темп, тембр, ритм, динаміка, фрактура, лад), особливостями мелодії, інтонацій щодо передачі настрою та характеру музичного образу. На уроках образотворчого мистецтва діти поступово знайомилися 3 мовою графріки (крапка, лінія, пляма), живопису (колір та його різновиди і властивості), скульптури і декоративно-ужиткового мистецтва та способами втілення цими мовними засобами різних настроїв, почуттів тощо.

Також на уроках музичного та образотворчого мистецтва діти 3 цікавістю складали загадки, пояснювали зміст прислів"їв (з допомогою педагога), придумувати власні кінцівки українських народних казок. Поєднання засобів фрольклору з мистецтвом на уроках естетичного циклу дає можливість фрормувати у дітей молодшого шкільного віку естетичні смаки.

Поступово молодші школярі поглиблювали отримані знання у контексті естетичних цінностей: прекрасне, потворне, франтастичне, комічне, героїчне, трагічне, знайомилися з можливостями музичної й художньої форми та різних мистецьких жанрів щодо втілення художнього образу. Водночас здійснювалося фрормування розуміння того, що кожен вид мистецтва і не тільки мистецтва, а й кожен жанр фольклору притаманними лише йому мовними засобами відтворює знайомі, близькі і зрозумілі дитині образи Людини, Природи, Добра.

Наступним педагогічним фактором, який ураховувався була актуалізація виховного потенціалу засобами фрольклору і творами 
різних видів мистецтва (на засадах інтеграції). Він передбачає акцентування уваги на виявленні та реалізації виховного потенціалу художнього матеріалу, що посилювало виховну сутність естетичного циклу через: актуалізацію виховної спрямованості основних видів діяльності (пізнання мистецтва, опанування практичних умінь у галузі мистецтва); активізацію виховної функції вчителя завдяки збагаченню його методичного інструментарію виховними елементами.

Одним із інтеграторів художнього змісту було обрано спільну тематику творів різних видів мистецтва. Завдяки ії використанню створювалися можливості розкриття цінності кожного 3 видів мистецтва, знаходячись в єдиному тематичному просторі, виявити загальнолюдські та естетичні цінності, втілені у творах різних видів мистецтва, розширити коло художніх інтересів молодших школярів, формувати їхнє асоціативне мислення тощо.

Під час добору художнього матеріалу для змістового наповнення естетичного циклу у контексті спільної тематики використовувався метод монтажу художніх текстів.

Добір художнього матеріалу для кожного з уроків предметів естетичного циклу здійснювався нами у відповідності до методу «створення художнього контексту», спрямованого на художній розвиток молодших школярів через інтеграцію одного домінантного мистецтва з іншими видами мистецтва.

Спільна тематика була обрана основою для об'єднання форм навчання та виховання в естетичний цикл, що сприяло повноцінній реалізації виховних можливостей художнього матеріалу: під час планування уроків та позаурочних заходів, об'єднаних спільним тематизмом, враховувався значний виховний потенціал художнього змісту творів мистецтва і на його основі здійснювався системний виховний вплив. Це реалізовувалося завдяки актуалізації виховної спрямованості основних видів художньо-естетичної діяльності молодших школярів як на уроках, так і у позаурочний час (пізнання i творення мистецтва).

Провідним прийомом наповнення естетичного циклу виховним змістом та актуалізації виховного потенціалу творів різних видів мистецтва стало створення виховних ситуацій на основі змісту мистецького матеріалу і постійне їх застосування на уроках та у позаурочній естетико-виховній діяльності. Адже через зміст творів мистецтва - від невеликої поспівки до визнаного шедевру - була можливість виявити у кожної людини власну естетичну, моральну позицію на рівні свідомості через оцінку своїх спонукань, вчинків, особистих якостей; сорормувати мотиви, ціннісні орієнтації через співвідношення з моральними нормами та ідеалами.

Виховні ситуації створювалися, зокрема, через інсценізацію. Молодшим школярам пропонувалося перевтілитися у різних казкових героїв: Круть, Верть, Півник, Лисичка, Журавель, Пан Коцький і зіграти ïx у ролях. Таким чином, діти засвоювали не тільки знання про 
предметний світ і способи оволодіння цим світом, а й певні способи поведінки людей (у ролях казкових героїв), їх взаємини, розуміння того, що таке добре, а що таке погано, що красиво, а що потворно тощо. Це означало, що учні долучалися до морального, естетичного та інших видів людського досвіду.

Наступний педагогічний фактор, який ураховувався під час введення методики - залучення молодших школярів до різних видів особистісно-орієнтованої мистецької діяльності - здійснювався через створення для учнів можливості опанування художньої мови різних видів мистецтва на уроках та стимулювання їх до художньо-творчого самовираження у позаурочний час.

Це відбувалося через системне фрормування у дітей виконавських умінь, характерних для кожного окремо взятого виду художньої діяльності: опановувалися графічні, живописні, декоративні техніки, відбувалося знайомство з правилами композиції, кольорознавства, ліплення тощо (з образотворчого мистецтва); фрормувалися вокальні та хорові навички (з музичного мистецтва); акторські та елементарні хореографрічні уміння під час театралізацій, інсценізацій, рольових ігор та рухів під музику.

У ході формувального етапу експерименту діти на початковому рівні практично опановували особливості художньої мови музичного та образотворчого мистецтва, набуваючи елементарні графрічні, живописні, вокальні уміння. Одночасно їм пропонувалися елементарні творчі завдання для створення можливості самовиразитися: наприклад: «Уяви себе в чарівному лісі, де живуть чарівні фреї-фрарби. Намалюй квіти, які ці фееі можуть виростити»; «Створи за допомогою справжніх листочків композицію «Танок осінніх листочків»; «Пофрантазуй і виконай куплети пісні по різному»; «Створи ритмічний супровід до пісні» тощо.

Також впродовж фрормувального етапу експерименту у молодших школярів під час виконання художньо-практичних завдань була можливість обирати один 3 варіантів їх виконання, пропонувалися більш складні творчі завдання для виконання їх у позаурочний час; індивідуальні і групові фрорми роботи, що мотивували творчу активність дітей і створювалися можливості самовираження кожного учня у різних видах мистецтва (наприклад: «Намалюй одного з героїв української народної казки «Півник і двоє мишенят», «Намалюй 3 товаришами фрагменти до власного мультфільму про сміливого пана Коцького»; «Намалюй веселих та вигадливих козаків. Разом з друзями створіть власну «козацьку» історію в малюнках», «Уяви себе диригентом оркестру і спробуй «розповісти» рухами про музичний твір».

Формування естетичних смаків молодших школярів, в основі яких лежить співвідчуття - явище сприймання, коли в процесі подразнення певного органу чуттів поряд із специфічним для нього відчуттям, виникають і відчуття, які відповідають іншим органам чуттів. Піднята до 
рівня естетичного сприймання, ця особливість простягається на твори різних видів мистецтв у поєднанні 3 народним фрольклором просторових і часових, що дає можливість знаходити схожість між предметами і явищами, які сприймаються різними органами чуттів. Уміння, що базуються на співвідчуттях, допомагають проводити аналогії між творами різних видів мистецтва разом з народним фольклором, знаходити схожість та відмінність, імітувати звукові явища життя, перетворювати музичні інтонації тощо.

3-поміж таких виділяють уміння: створення художніх образів засобами різних видів мистецтва у поєднанні з народним фольклором; перекладу художнього образу у своєму (власному) продукті мовою різних видів мистецтва.

Крім опанування художніх якостей твору мистецтва, на таких уроках діти визначали правила поведінки у ставленні «мешканців лісу» одне до одного, обговорювали їх, що в результаті перекладалося у формування певних духовних цінностей людини щодо стосунків між собою: взаємоповагу, гуманність, дружбу, тощо. Так, під час виконання-інсценізації пісні «Прилетів комарик» розв'язувалася ситуація взаємодопомоги, дружніх стосунків комах під час грози. У процесі сприймання та обговорення твору Д. Кабалевського «Зайчик дражнить ведмедика» діти, об'єднавшись у пари, і уявивши себе героями музичного твору, спочатку відтворювали цю музичну п'єсу рухами, жестами, мімікою, а потім, обговорювали ситуацію, відповівши на запитання: Хто з героїв вам сподобався? Як ви вважаєте, чи правильно чинить зайчик? Чи добре дражнитися? Які можуть бути наслідки? тощо.

Лясолька, знайомлячи дітей з музичними звуками різної гучності (дидактичне завдання - динаміка в музиці), приводила дітей до думки, що усе в музиці, як і в природі - гармонійно і злагоджено: шерех листя, гудіння комах не може звучати гучно й заклично, і тому в музиці такі образи втілено переважно тихою динамікою і навпаки. А Барвик цю гармонійність і злагодженість у природі й мистецтві показував завдяки засобам образотворчого мистецтва - кольорів, і вчив не порушувати цю гармонійність у власній художній діяльності. Крім того, під час цього циклу уроків казкові герої показували роль динаміки у створенні різних за характером образів Під час виконання поспівки «Павук», окрім розвитку вокальних навичок, дітям пропонувалося уявити і продовжити історію про павука і мушку, яку «розповідає» поспівка. Причому уявити варіанти розвитку подій зі слухняною і неслухняною мушками. Як може змінитися динаміка щодо відтворення образу неслухняної мушки? А після історій, розказаних дітьми, ситуація переводилася у реальний світ, коли дорослі (тато, мама, учитель) говорить дитині, як потрібно чинити у тій чи іншій ситуації. Як потрібно діяти? I так творче завдання перетворювалося на виховну ситуацію засобами мистецтва.

Художні образи та зміст творів сприяли розширенню виховних впливів. Так, зокрема, у контексті циклу уроків було здійснено вихід 
на виховання бережного ставлення до природи та її мешканців. Адже діти, перетворившись у казкових метеликів, джмеликів, уявляли і відчували емоційний стан цих маленьких істот під час нападу сильного вітру або зливи («Створення звукових картин») або поганого ставлення до них людини (була запропонована проблемна ситуація: діти гуляли на квітковій галявині, де було багато красивих різнобарвних метеликів, вони наловили їх, склали у коробку і понесли додому... Що сталося з метеликами? Чи вірно вчинили діти? Як би ви діяли у цій ситуації? Можливо, краще помилуватися красою довкілля, відтворити різнобарв'я метеликів на папері i поділитися цією красою з оточуючими?)

Дидактичні казки, подані у підручниках, поряд з навчальними вирішували також виховні завдання. Зокрема, у казці «Як сопілка флейтою стала» проблемним питанням в обговоренні було: «Що потрібно робити, щоб стати справжнім музикантом?» Завдяки музичним казкам (цикл К. Сен-Санса «Карнавал тварин») створювалася можливість об'єднання в єдиний казковий сюжет декілька циклів уроків, що сприяло ефективнішій реалізації виховних завдань, у виховних ситуаціях «червоною лінією» проходила проблема дружби, хоробрості, бережного ставлення до усіх живих істот, які нас оточують.

Вищеозначене засвідчило, що введення визначених педагогічних факторів естетичного виховання молодших школярів ефективно може здійснюватися із застосуванням методики, спрямованої на стимулювання художніх інтересів молодших школярів, фоормування у них емоційно-ціннісного ставлення до творів фрольклору та різних видів мистецтва, естетичних знань та вмінь, актуалізації здатності до асоціювання та художнього самовираження, і яка втілюється у межах естетичного циклу: на уроках мистецтва, що тісно взаємодіють 3 формами позаурочної художньо-естетичної діяльності учнів.

Вона включає методи виховання (привчання дітей до виявлення естетичних цінностей творів мистецтва, переконання художніми засобами), що тісно пов'язані з методами навчання (словесними, фрормування способів самостійних дій) на основі актуалізації виховного потенціалу художнього матеріалу різного за способом сприймання (візуальний, аудіальний). Методи конкретизувалися через систему практично-спрямованих завдань (художньо-творчих, інтегративних) та виховних ситуацій.

Результати експериментальної перевірки педагогічних фракторів та методики формування естетичних смаків учнів початкової школи засвідчили позитивну динаміку рівнів сфрормованості естетичних смаків молодших школярів.

Про позитивний вплив формувальної методики можна судити по якісних і кількісних змінах у формуванні естетичних смаків молодших школярів експериментальної групи за допомогою порівняння результатів діагностики на констатувальному та контрольному етапах 
експерименту. Воно свідчить про позитивну динаміку рівнів сорормованості естетичних смаків молодших школярів у художньоестетичній діяльності. Так, у експериментальній групі, за середніми показниками, кількість респондентів, віднесених до високого рівня сформованості естетичних смаків, підвищилася на 10,4 \% (з $10 \%$ до $20,4 \%$ ); віднесених до середнього рівня - на $8 \%$ (з $62 \%$ до $70 \%$ ); значно знизився відсоток респондентів низького рівня сфрормованості естетичних смаків - на 18,4 \% (з 28 \% до 9,6\%).

Що ж стосується контрольної групи, то (за середніми показниками наприкінці педагогічного експерименту) виявлено такі рівні сорормованості естетичних смаків молодших школярів: показник високого рівня підвищився на $1 \%$ - $313 \%$ до $14 \%$; кількість респондентів, віднесених до середнього рівня підвищилася на 3 \% (з $61 \%$ до 34 \%); частково знизився відсоток респондентів низького рівня сорормованості естетичних смаків - на $4 \%$ (з $26 \%$ до $22 \%$ ), що свідчить про відсутність введення пропонованої методики у навчальний процес контрольної групи.

Саме тому слід зазначити, що результати контрольного зрізу формувального етапу педагогічного експерименту показали підвищення рівнів сорормованості естетичних смаків молодших школярів засобами фольклору експериментальної групи за усіма показниками.

Отже, під час педагогічного експерименту було ураховано педагогічні фрактори формування естетичних смаків молодших школярів: спрямованість навчально-виховного процесу на опанування молодшими школярами естетичних цінностей мистецтва і фольклору, актуалізація виховного потенціалу засобами фольклору і творами різних видів мистецтва, залучення молодших школярів до різних видів особистісно-орієнтованої мистецької діяльності. Саме ці педагогічні фрактори враховувались під час здійснення й апробації пропонованої методики педагогічного експерименту.

\section{Список використаних джерел}

1. Андрощук І. В. Методика виховної роботи: навчальний посібник. Тернопіль : Навчальна книга - Богдан, 2014. 320 с.

2. Гайдамака О. В. Критерії, показники та рівні поліхудожньої вихованості учнів початкової школи. Постметодика. 2015. № 1. С. 29-31.

3. Гайдамака О. Інтегративна мистецька освіта - крок у майбутнє. Мистецтво та ocвima. 2006. № 4 (42). С. 2-4.

4. Гайдамака О. Особливості методики поліхудожнього виховання молодших школярів на уроках інтегрованого курсу «Мистецтво». Початкова школа. 2015. № 12. C. 26-31.

5. Кузьмінський А. І. Педагогіка у запитаннях і відповідях: навч. посіб. К. : Знання, 2006. $311 \mathrm{c}$.

6. Савченко О.Я. Дидактика початкової школи: підручник для студентів пед. факультетів. К. : Генеза, 2002. 368 с. 


\title{
ТЕОРЕТИКО-МЕТОДИЧНІ ЗАСАДИ РОЗВИТКУ ЛІТЕРАТУРНО-ТВОРЧИХ ЗДІБНОСТЕЙ молодших школяРІв
}

\author{
Парфілова С. Л. \\ кандидат педагогічних наук, дочент, \\ Сумський державний педагогічний університет імені А. С. Макаренка
}

У Національній доктрині розвитку освіти визначено основну мету державної політики щодо розвитку освіти, яка полягає у створенні умов для розвитку особистості і творчої самореалізації кожного громадянина України, вихованні покоління людей, здатних ефективно працювати і навчатися протягом життя. Це вимагає переходу від директивної до особистісно зорієнтованої моделі навчання й виховання, що націлює на пошук нових шляхів і засобів, які забезпечуватимуть розвиток внутрішніх можливостей учнів, їхніх потреб, інтересів, творчих здібностей. Тому творчість, творча діяльність і здібності до творчості були і залишаються предметом аналізу багатьох учених (Г.Костюк, В.Моляко, О.Савченко, М.Холодна, Л.Богоявленська, Ф.Вернон, Дж.Гілфорд, О.Матюшкін, Я.Пономарьов, Ч.Спірмен, Е.Торренс та ін.). Дослідниками аналізуються різні аспекти проблеми здібностей: їх природи, компонентного складу, критеріїв та показників розвитку, методів і прийомів формування. Більшість з цих питань досі залишається дискусійними, що свідчить про складність та багатозначність природи цього френомена.

Літературна творча діяльність посідає особливе місце серед проявів творчості молодших школярів. 3 одного боку, вона вимагає роботи таких психічних процесів, як сприймання, образне мислення, уява, мовлення, емоції, активізує почуттєву та інтелектуальну складові пізнавальної діяльності молодшого школяра. 3 іншого - дітям цього віку властива надзвичайна емоційність та чутливість до образних вражень, багатство уяви, невтомна допитливість, відкритість до оточуючого світу. Це підтверджує важливість цілеспрямованого художньо-словесного розвитку саме молодших школярів.

На сучасному етапі розвитку педагогічної науки українськими дидактами та методистами досліджуються різні аспекти проблеми розвитку мовленнєвих і літературних творчих здібностей учнів у навчальному процесі (А. Богуш, М. Вашуленко, І. Гудзик, В. Мартиненко, В. Науменко, О. Савченко, О. Хорошковська, М. Чумарна та ін.). Вони наголошують на тому, що у початковій школі фрормується мовна особистість, вдумливий, естетично розвинений читач, а не просто учень, який уміє читати і писати. Посиленої цілеспрямованої роботи у початковій школі вимагає комунікативний і літературний розвиток молодших школярів. 
Передусім підкреслимо, що протягом останніх років у галузі початкового навчання склалася принципово нова ситуація щодо реалізації вимог до літературно-творчого розвитку молодших школярів. Важливий крок у посиленні значущості даної проблеми зроблено у Державному стандарті початкової загальної освіти , в якому зазначено, що за роки навчання у початковій школі учні мають набути достатній особистий досвід самовираження у творчих видах завдань. Оновлений зміст включає в себе такі компоненти, як досвід творчої діяльності, досвід емоційно-ціннісного ставлення до навколишнього світу, що передбачає посилення літературно-творчої спрямованості навчання молодших школярів.

Вивчення досвіду роботи вчителів початкових класів показує, що останнім часом спостерігається підвищення інтересу до літературнотворчого розвитку учнів: використовуються різноманітні творчі завдання, підготовчі вправи перед написанням письмових творчих робіт, які стимулюють основні психічні процеси, задіяні в літературній творчості. Водночас як показують результати педагогічного експерименту, оволодіння учнями доступними способами літературної творчої діяльності залишається переважно некерованим, спонтанним процесом, спостерігається недооцінка почуттєвого та процесуального аспекту літературно-творчої діяльності молодших школярів.

Таким чином, у дидактиці початкової освіти проблема розвитку літературно-творчих здібностей учнів в умовах оновленого змісту і методичного забезпечення не отримала цілісного відображення. Ії зростаюча актуальність, теоретична та практична значущість і водночас недостатня розробленість зумовили вибір теми дослідження.

Проблема творчих здібностей дитини та їх розвитку в різних видах діяльності належить до найбільш актуальних у сучасній психологічній та педагогічній науках. Ї̈̈ розв'язок неможливий без осмислення змісту однієї з найдавніших категорій - творчості.

Переважна більшість науковців визначає сутність поняття «творчість» як продукт людської діяльності, що породжує якісно нові матеріальні і духовні цінності суспільного або індивідуального значення (В. Андреєв, Г. Балл, Дж. Гілфорд, О. Леонтьєв, І. Лернер, В. Моляко та ін.). Поширеною серед науковців $€$ думка про те, що творчість $€$ формуванням нових комбінацій зі старих елементів. Однак, поза ціннісним аспектом творчість утрачає сенс. Її значущість - у позитивній продуктивності, що $є$ головним стрижнем усіх творчих пошуків.

Різні погляди існують і щодо визначення характерних ознак творчої особистості. Серед науковців поширеним $є$ твердження про те, що творча особистість свідомо займається творчою діяльністю 3 метою вираження свого світобачення, почуттів, емоцій тощо. Деякі дослідники, навпаки, наголошують на неусвідомленості творчого акту, його спонтанності. Дослідник проблеми творчості Я. Пономарьов, 
вважає, що психологічний механізм творчого процесу полягає у єдності першосигнального компоненту (інтуїтивного, оригінального, неусвідомленого) та другосигнального компоненту (логічного, рефрлексивного, усвідомленого) [13, с.10].

Більшість дослідників творчості оперують такими поняттями, як креативність та обдарованість (Н. Лейтес, О. Кульчицька, О. МелікПашаєв, В. Моляко та ін.). Творча обдарованість (креативність) рівень розвитку творчих здібностей, функція цілісної особистості, яка залежить від комплексу її психологічних характеристик. Високі показники креативності у дітей не гарантують їх творчих досягнень у майбутньому, а лише вказують на можливість таких досягнень за наявності високої мотивації до творчості та оволодіння необхідними творчими уміннями [11, с.181].

Отже, вихідними положеннями тлумачення сутності творчості у контексті нашого дослідження $€$ такі: творчість - надзвичайно складна форма людської активності, що породжує якісно нові матеріальні і духовні цінності суспільного або індивідуального значення. Ознаками творчості $€$ зв'язок інтуїтивного і логічного; відчуття натхнення, бажання творити; діалектична єдність продуктивної і репродуктивної діяльності, усталеного і нового; позитивна цінність результатів. Творчість - необхідна умова людського існування. 3 одного боку, вона $\epsilon$ оптимальною фрормою глибокої реалізації індивідуальності, 3 іншого - $€$ необхідною умовою соціального прогресу.

Серед усіх видів творчості особливе місце посідає літературна, що пояснюється унікальною роллю мовлення у життєдіяльності окремої людини і людства в цілому. У педагогічному аспекті важливим $\epsilon$ те, що літературна творча діяльність сприяє вихованню емоційноціннісного ставлення до світу як особистісної характеристики, яка передбачає здатність людини бути співпричетною до духовного світу іншого. Літературна творчість у дитинстві виступає не як самоціль, а в першу чергу як засіб духовно-творчого розвитку, як важлива умова всебічного гармонійного розвитку зростаючої особистості.

Літературна творчість дітей - складання казок, оповідань, віршів, сценаріїв, діалогів тощо - визначається науковцями як самостійний, специфічний та унікальний вид художньої творчості, що дістає своє втілення у процесі мовлення. Поняття «літературна творчість» та «мовленнєва творчість» уживаються деякими дослідниками як синоніми (Л. Вороніна, Н. Орланова, В. Сухомлинський та ін.). Погоджуючись із думкою методиста Н. Гавриш, ми визнаємо другий термін ширшим за перший, адже мовленнєва творчість не вимагає відповідності складеного твору літературно-мовним нормам [2, с.14].

У контексті нашого дослідження поняття «літературно-творча діяльність школярів» використовується у значенні спеціально організованої, зумовленої мотивацією діяльності, в якій через створення різних типів текстів відповідно до літературно-мовленнєвих норм 
дитина відображає почуття, уявлення, враження, образи уяви, що виникли під час сприйманням довкілля, читання художніх творів тощо.

Для ефективного розвитку літературно-творчих здібностей молодших школярів перш за все слід з'ясувати, що вони собою являють. У психологічній літературі термін «здібності» трактується вченими по-різному, однак його значення має більш-менш визначені межі. На початку XX століття у вітчизняній психології і педагогіці активізувались пошуки джерел, розробки структури, шляхів і методів розвитку здібностей учнів.

Значним внеском у теорію здібностей, і зокрема творчих, $\epsilon$ дослідження вчених на засадах діяльнісного підходу (Ю. Гільбух, Г. Костюк, В. М'ясищев, Б. Теплов, Л. Рубінштейн та ін.). У їх працях наголошується, що на відміну від інших якостей особистості, здібності не тільки проявляються і формуються у певній діяльності, вони поза нею не існують.

Здібності - це така сукупність вроджених або набутих індивідуально-психологічних функціональних якостей, яка дозволяє за рівних умов успішно оволодіти знаннями, уміннями, навичками, суттєво важливими для продуктивної діяльності, і $€$ внутрішньою умовою їі успішного виконання. Одним із найбільш суперечливих у межах досліджуваної проблеми є питання обумовленості здібностей вродженими індивідуальними особливостями та сукупністю соціальних умов, у яких відбувається формування особистості. Розмірковуючи про біологічне і соціальне у здібностях, Б. Теплов підкреслював, що вродженими можуть бути тільки анатомо-фізіологічні особливості, тобто задатки. Для того, щоб задатки перетворились у здібності, необхідна зустріч вроджених якостей з певними соціальними умовами. Проте принципова позиція представників діяльнісного підходу виступає досить чітко: провідним фактором їх фоормування та розвитку $\epsilon$ соціальні умови - умови життя і діяльності.

Недооцінка генетичного фактору зумовила появу іншого підходу - функціонально-генетичного, за яким велике значення надається ролі природних задатків у розвитку здібностей (Е. Голубєва, В. Шадриков та ін.).

Однак попередні підходи недооцінювали активність особистості як суб'єкта розвитку. Здібності, і зокрема творчі, тлумачилися переважно як психічне утворення, а не як особистісна характеристика. За особистісного підходу (Т. Артем'єва, М. Холодна та ін.) вивчення здібностей відбувається не лише шляхом їх аналізу у структурі особистості, а в першу чергу у процесі життєдіяльності людини. Розглядаючи здібності й задатки як властивості особистості, можна вести мову передусім про розвиток суб'єктів діяльності, яким ці властивості притаманні. 3 точки зору психолога Т. Артем'євої, такий підхід дозволяє розглянути особистість як активний суб'єкт розвитку здібностей, здолати відому дистанцію між «діяльнісним» та «особистісним» розумінням здібностей [1, с.49]. 
Дотримуючись особистісно-діяльнісного підходу у дослідженні літературно-творчих здібностей школярів, ми тлумачимо розвиток здібностей як багаторівневий процес, у якому на кожному рівні здібності синтезуються з іншими психічними утвореннями, надаючи особистості більш широкі можливості для здійснення власної життєдіяльності. У межах цього підходу детальної розробки набуває питання взаємозв'язку досліджуваних здібностей з характеристикою мотивів, інтересів, потреб та їх ролі в успішному оволодінні школярами певною діяльністю, що знайшло відображення у методиці експериментального дослідження.

Здібності традиційно поділяють на загальні та спеціальні. Творчі здібності відносяться до загальних, оскільки виявляються у багатьох видах діяльності на тому чи іншому рівні. Літературні здібності $\epsilon$ спеціальними і характеризуються як система властивостей особистості, яка допомагає досягнути високих результатів у певній спеціальній галузі діяльності - літературній. Різниця між спеціальними та загальними здібностями відносна: загальні творчі здібності закладені в основі спеціальних здібностей і $€$ однією 3 головних умов розвитку останніх.

Стосовно молодшого школяра, основною сферою діяльності якого $€$ навчання, недоцільно різко протиставляти загальні та спеціальні здібності. В умовах загальноосвітньої школи формуються переважно загальні здібності, однак на фоні різних навчальних предметів відбувається спеціалізація процесу навчання, коли специфіка навчального предмета визначає i спрямовує розвиток багатьох спеціальних здібностей.

Літературні здібності трактуються дослідниками у двох значеннях: як здібності до сприймання творів художньо-словесного мистецтва, а також здібності власне до створення творчих продуктів. У нашому дослідженні ми розглядаємо літературні здібності як здатність до творчості засобами художнього слова, а отже, розглядаємо десрініцію «літературно-творчі здібності». Вони представляють собою сукупність множини певних психічних властивостей, які забезпечують у своїй функціональній єдності успішність виконання літературнотворчої діяльності. В структурі цієї здібності $€$ утворення, які забезпечують ії «профріль», специфрічність саме літературної діяльності, і $є$ утворення, що формуються як «родові» якості, загальні для будь-якої творчої діяльності.

У розумінні літературно-творчих здібностей як «ансамблю властивостей особистості» необхідним $€$ знання структури цієї інтегральної якості: які компоненти є провідними, якою $є$ їх ієрархія. Без цього неможливо зрозуміти, як розвиваються окремі структурні елементи з віком під впливом навчання, як правильно оцінювати здібності та керувати процесом їх розвитку. 
У педагогіці та психології компонентний склад творчих здібностей $€$ об'єктом різнобічних досліджень. Це питання розглядалось у контексті вивчення спеціальних творчих здібностей, які визначають успішність у конкретних видах творчості, а також загальних творчих здібностей, від яких залежить успішність у багатьох видах діяльності.

У психологічній літературі традиційно підкреслюється тісний взаємозв'язок між творчими здібностями і потребами, емоціями, нахилами, інтересами. Так, психолог Н. Лейтес зауважує, що заглибленість у певну діяльність «не може не сприяти розвиткові відповідних здібностей. Разом з тим більшою мірою захоплює, дає більше задоволення та діяльність, яка відбувається успішніше, тобто до якої людина більш здібна» [6, с.11]. У працях Г. Костюка наголошується, що здібності особистості фрормуються у тісному зв'язку із розвитком повноцінних мотивів їі діяльності. Тому турбота про розвиток здібностей передбачає цілеспрямоване формування мотивів діяльності учнів [5].

Деякі дослідники розуміють схильність, спрямованість або потребу у заняттях будь-яким видом діяльності теж здібністю, але не інструментальною, а мотиваційною. Зокрема, дослідник творчої обдарованості А. Матюшкін розглядає їі як комплекс інтелектуальних, творчих і мотиваційних фракторів, наголошуючи на домінуванні пізнавальної мотивації та творчої активності у структурі обдарованості [7, с. 23-33]. Відомий український психолог В. Моляко серед компоненттів творчих здібностей називає такі: оригінальність у рішеннях; пошуки нового; наполегливість у досягненні мети; самокритичність і критичність; гнучкість мислення; сміливість і міцність; енергійність [10].

В. Андреєв та О. Яковлєва вважають, що творчі здібності - це якості й властивості особистості, які виявляються у синтезі мотиваційної, інтелектуальної, організаційної та комунікативної сторін творчої діяльності, від яких залежить можливість та рівень їі успіху [3, с.199].

Отже, розглядаючи творчі здібності до певної діяльності як цілісну властивість особистості, більшість дослідників виділяють в ній серед інших компонентів мотиваційний.

Мотиваційний аспект творчої діяльності школярів докладно розглядався у працях психологів другої половини XX століття Д. Богоявленської, Г. Костюка, В. Крутецького, О. Лука, А. Матюшкіна а ін.

Ґрунтовне експериментальне дослідження психолога В. Ягункової щодо проблеми індивідуальних та вікових особливостей формування літературних здібностей школярів показало, що «...слабка мотивація літературно-творчої діяльності, зниження інтересу до неї призводить до того, що розвиток здібностей уповільнюється, незважаючи на високий рівень як загального розвитку, так і окремих інтелектуальних процесів» [14, с. 24].

До мотиваційного компоненту творчих здібностей В. Андреєв, О. Яковлєва, Л. Шелестова відносять допитливість, творчий інтерес, 
почуття захопленості, емоційний сплеск, радість відкриття; прагнення до творчих досягнень, лідерства, отримання високої оцінки; почуття обов'язку, відповідальності; особиста значущість творчої діяльності; прагнення до самоосвіти, самовиховання [3, с. 200]. Психолог П. Мазур серед мотивів літературної творчості школярів виділяє суспільні, особистісні, пізнавальні, утилітарні мотиви, мотив наслідування, мотив захоплення зовнішніми ознаками літературної діяльності, мотив особистісної зацікавленості. Найбільшу цінність, на його думку, становлять пізнавальні мотиви, які в молодшому шкільному віці набувають форми допитливості.

Ґрунтуючись на дослідженнях мотивації творчої та літературнотворчої діяльності школярів, представлених В. Андреєвим, О. Яковлєвою, 3. Юрченко, а також дослідженнях мотивації учіння молодших школярів (Н. Бібік, О. Савченко та ін.), ми виділяємо у структурі мотиваційного компоненту літературно-творчих здібностей молодших школярів зовнішні та внутрішні мотиви. Зовнішні мотиви безпосередньо не пов'язані з діяльністю, але впливають на ії успішність (довіра до вчителя; прагнення отримати гарну оцінку, похвалу дорослих, позитивний відгук від слухачів тощо). Внутрішні мотиви пов'язані безпосередньо із самим процесом художньо-творчої діяльності, її результатами (схильність до занять літературною творчістю, бажання висловитись, поділитись враженнями, допитливість, творчий інтерес, почуття захопленості, емоційний сплеск тощо).

Внутрішня мотивація молодшого школяра нестійка, інтерес виявляється переважно до результату. Вольові зусилля до подолання труднощів, наполегливість у досягненні мети, завершенні творчого продукту учні виявляють залежно від ситуації: цікаве завдання; приваблива, внутрішньо хвилююча тематика твору, підтримка дорослих, товариша, орієнтація на слухачів тощо.

Головну роль у мотиваційному компоненті літературно-творчих здібностей молодшого школяра відіграють внутрішні мотиви, а саме схильність до занять літературною творчістю, бажання висловитись, поділитись враженнями, допитливість, творчий інтерес. Вони за умови належної організації творчої діяльності у більш дорослому віці можуть перетворитися у стійкі мотиваційні утворення: потребу втілювати власні переживання у художній формі; бажання зайняти авторську позицію у мистецтві; прагнення самовираження, самопізнання та пізнання інших.

На думку педагога В. Левіна, стратегічне завдання керівництва літературним розвитком молодшого школяра полягає в тому, щоб сорормувати у нього прагнення спілкуватися засобами мистецтва слова. Цей провідний інтегративний мотив літературної творчості, що має здебільше внутрішні характеристики, ми визначаємо як художньокомунікативний мотив. Його формування в учнів початкових класів $€$ необхідною умовою успішного розвитку їх літературно-творчих 
здібностей. Водночас лише за умови взаємодії внутрішніх і зовнішніх чинників фрормування мотивації можливі суттєві зрушення у розвитку комплексної здібності до літературної творчості.

Мотиваційний компонент літературно-творчих здібностей кожного учня глибоко індивідуальний та має складну ієрархічну структуру: одні мотиви займають відносно стійке домінантне місце, інші - підпорядковане. Літературно обдаровані школярі характеризуються тим, що в основі їх діяльності переважають мотиви (потяги, бажання, схильності, інтереси, потреби), безпосередньо пов'язані з її змістом. Літературна діяльність, яка виконується не для отримання гарної оцінки, не для того, щоб перемогти на конкурсі, а тому, що хочеться «перекладати життя своє у слово», висловлюватись засобами художнього слова, обов'язково пов'язана з роботою центра позитивних емоцій.

3 точки зору розвитку дуже важливо, що останнім часом більшість дослідників визначають провідною характеристикою потенціалу особистості саме мотивацію, зацікавленість певною діяльністю. У нашому дослідженні мотиваційний компонент здібностей розгляддається у ролі своєрідного центру, який організовує літературно-творчі здібності в єдину структуру на особистісній основі саморуху.

Перейдемо до аналізу інструментальної складової літературнотворчих здібностей школярів. Ґрунтовного розгляду вона зазнала у

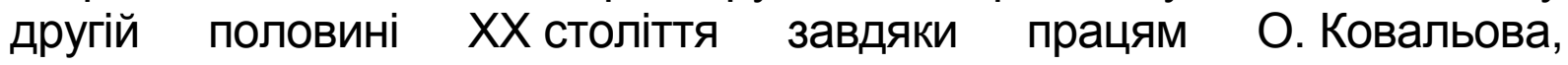
О. Никифорової, Н. Орланової, Н. Чернікової та ін.

Узагальнюючи різні погляди на структуру літературних здібностей до 60-х років XX століття, можна виділити наступні складові літературних здібностей, на які частіше всього $€$ прямі вказівки у психолого-педагогічній літературі: 1) поетичне сприйняття дійсності; 2) емоційність; 3) добра пам'ять; 4) спостережливість; 5) образне мислення; 6) творча уява; 7) багатство мови.

Після зазначеного періоду з'явились дослідження психологів i літературознавців Л. Айдарової, П. Мазур, Н. Молдавської, Г. Цукермана, В. Ягункової, П. Якобсона, які значно розширили уявлення про компонентний склад здібностей до літературної творчості.

Компоненти літературних здібностей визначаються дослідниками по-різному. Деякі з них досліджують читацькі літературні здібності, інші - творчі літературні здібності. Наприклад, Н. Молдавська досліджує літературні здібності як здатність до засвоєння навчального предмету «література», тобто ті, які фрормуються у процесі систематичного шкільного навчання і виявляються передусім у сприйманні літературно-художнього твору. На ії думку, структура спеціальних літературних здібностей утворюється як індивідуальне поєднання певних психічних якостей. «Ця структура у всіх своїх типологічних та індивідуальних варіантах виростає на основі загальної здібності мислити словесно-художніми образами» [9, с. 82]. 
Дослідження психолога $\quad$ В. Ягункової присвячені проблемі індивідуальних та вікових особливостей фрормування літературних здібностей, що мають вияв насамперед у літературній творчості самих школярів (у процесі створення віршів, казок, творів, описів тощо). У ході експериментальної роботи дослідниця дійшла висновку, що компоненти літературних здібностей - складні психічні утворення, результат узагальненої діяльності, яка здійснюється за допомогою мови та формується в результаті літературно-творчої діяльності. Серед компонентів літературних здібностей В. Ягункова виділяє такі: вразливість, поетична зіркість, добре розвинена образна та словеснологічна пам'ять, здібність створювати нові оригінальні образи, легкість виникнення творчих станів, багатство словникового запасу та чуття мови, багатство словесних асоціацій, які забезпечують легкість словесного вираження думок та образів [14, с. 21].

Дослідник О. Мелік-Пашаєв розглядає літературну обдарованість як різновид художньої обдарованості особистості. Він представляє художню обдарованість у єдності та взаємообумовленості трьох рівнів: перший рівень - естетична позиція особистості, другий - здібність до створення образів, що розкривають внутрішній зміст творів у адекватній йому чуттєво-сприйнятливій фоомі, третій - складають якості, що сприяють оволодінню засобами того чи іншого виду мистецтва, сукупністю спеціальних знань, умінь та навичок [8, с. 14].

Аналіз загальних підходів до окресленої проблеми, представлених дослідниками художніх, літературних та мовленнєвих здібностей О. Мелік-Пашаєвим, 3. Новлянською, Н. Гавриш, 3. Юрченко, дозволив сорормувати авторський погляд на структуру літературно-творчих здібностей школярів. Інструментальна складова літературно-творчих здібностей особистості школяра розглядається нами у вигляді ієрархії трьох компонентів: емоційно-ціннісного, креативного та мовленнєвого.

I. Емоційно-ціннісний компонент - емоційно-ціннісне ставлення особистості до світу (цілісне художньо-чуттєве сприймання, художня спостережливість, емоційна вразливість, увага до внутрішнього світу інших, здатність до співпереживання). Художнє сприймання, спостережливість передбачають свіжість погляду на навколишню дійсність, поетичну зіркість. У поєднанні зі здатністю до емпатії ці якості утворюють інтегративну емоційно-ціннісну характеристику особистості. 3 одного боку, вона виявляється у неповторному внутрішньому змісті літературних творів, з іншого - створює гостру необхідність у засобах реалізації цього змісту, в матеріалізації художнього задуму.

Сам автор спочатку невиразно уявляє зміст, образи, задум. Лише за умов розвиненої довільної уяви, образного мислення можлива їх конкретизація та матеріалізація. Таким чином, школяр буде здатний створити художній образ, якщо він, крім емоційно-ціннісного ставлення 
до світу, має здібності створювати нові образи, сюжети.

II. Креативний компонент - здібності до створення образів (творча уява, художньо-образне та асоціативне мислення). Творча уява характеризується, по-перше, довільністю, по-друге - достатньо багатим запасом вражень від навколишнього світу, по-третє, свободою і гнучкістю у використанні цього запасу вражень, i, нарешті, у підпорядкуванні емоційно-ціннісному ставленню до світу. Ці характеристики перетворюють нейтральну психічну якість в уяву як творчу здібність. Уява породжує оригінальні образи з матеріалу попередніх вражень, а мислення встановлює істотні зв'язки в середині нього. У розвиненому художньому мисленні важливими $є$ операції абстрагування-асоціювання під час сприйняття художнього образу та абстрагування-узагальнення у процесі творення власного художнього смислу.

Для того, щоб художній задум, створений учнем за допомогою уяви та мислення, успішно реалізувався в літературній фоормі, необхідними є мовленнєві здібності.

III. Мовленнєвий компонент - якості, що сприяють оволодінню засобами літературного мистецтва. Спеціальними якостями, уміннями та навичками, необхідними для літературної творчості, $€$ такі: чутливість до слова, відтінків його значень, звукових якостей; багатство словникового складу; поетичний слух; навички римування; володіння засобами художньої виразності тощо. У дослідженнях Г. Ковальова, 3. Новлянської, Н. Миропольської, 3. Юрченко та ін. відзначається, що цінним продуктом літературно-творчої активності школяра $є$ така літературна форма, в якій відчувається нерозривний, безпосередній зв'язок слова з думкою, почуттями.

Перший компонент - це, власне, внутрішня сутність особистості, другий компонент являє собою загальні творчі здібності особистості, третій компонент включає спеціальні літературні здібності, якості. Така ієрархія рівнів пояснюється тим, що в художній творчості, як визначають дослідники, головну роль відіграє емоційно-ціннісне ставлення особистості. Перші два рівні $є$ провідними, загальними для всіх видів мистецтва, останній рівень специфічний саме для мистецтва слова.

Отже, загальну структуру літературно-творчих здібностей можна представити у вигляді єдності мотиваційної та інструментальної складової.

Такий підхід до структури здібностей на теоретичному рівні пояснює деякі аспекти проблеми співвідносності та взаємозв'язку мотиваційних, загальних та спеціальних компонентів у структурі творчих здібностей школярів до певної діяльності, що є важливим для побудови діагностичних та розвивальних методик. Виділені компоненти дозволяють припустити, що процес розвитку здібностей $є$ керованим, тобто розвиток кожного з компонентів частково підлягає 
змінам. Учитель може цілеспрямовано впливати на певний компонент з метою підвищення загального рівня розвитку літературно-творчих здібностей школярів.

На сучасному етапі спостерігається тенденція, яка полягає у цілісному підході до дитячої творчості як могутнього чинника становлення особистості, усвідомленні необхідності розвитку творчої спрямованості, загальної креативності, що забезпечує дитині успішність у пізнанні й активних перетворювальних діях.

Аналізуючи сучасні підходи до розвитку творчих здібностей, ми дотримувались цілісного підходу до розвитку літературно-творчих здібностей учнів. Він розуміється нами як створення умов для системного впливу на духовне, інтелектуальне становлення школярів, формування рис творчої особистості. Такий підхід не виключає розвитку літературної обдарованості в усіх молодших школярів, особливо у дітей з нахилами, інтересами, природними задатками до літературної творчості. Дотримуючись гуманістичних поглядів, ми розуміємо, що потенційну здатність до творчості мають усі діти. Незалежно від вихідного рівня розвитку літературно-творчих здібностей кожен учень за умов спеціального навчання може піднятися на більш високий щабель творчих досягнень.

Ґрунтуючись на ідеях особистісного та діяльнісного підходу до розвитку здібностей, ми співвідносимо їх 3 відповідним видом діяльності. Таким чином, головною умовою розвитку літературнотворчих здібностей молодшого школяра $\epsilon$ його мовленнєва та літературна діяльність у взаємозв'язку з іншими видами творчої діяльності (образотворчою, музичною, театральною тощо), в якій ці здібності розвиваються і проявляються, перетворюються із потенційних в актуальні.

Визначимо, у чому полягає сутність поняття «розвиток літературно-творчих здібностей молодших школярів».

Поняття «розвиток» у педагогіці тлумачиться як необхідні, послідовні прогресивні зміни людської живої системи, пов'язані 3 певними етапами ії̈ життєвого шляху, що характеризують її рух від нижчих до вищих рівнів життєдіяльності [5, с.56]. Розвиток здібностей охоплює переробку, систематизацію, узагальнення того, що засвоїв індивід у процесі різних видів діяльності і являє собою цілісні якісні зміни особистості, що передбачають виникнення ії̈ можливостей засвоювати складніші знання і вміння, включатися у самостійне здобуття знань. Розвиток літературно-творчих здібностей молодших школярів розуміється нами як прогресивні зміни складної, багаторівневої системи особистісних утворень учнів, пов'язаних 3 процесами їх емоційно-чуттєвого сприймання, художньо-образного та раціонального мислення, уяви та мовлення. Такий підхід дозволяє аналізувати новоутворення функціональної системи компонентів зазначених здібностей як ознаки літературно-творчого розвитку молодших школярів. 
У психолого-педагогічній літературі відзначається важливість вивчення вікової чутливості, тобто вибіркової активності певного періоду як ґрунту, на якому зростають здібності. В. Сухомлинський у роботі 3 розвитку творчих здібностей дітей неодноразово наголошував, що для правильної організації дитячої творчості урахування вікових особливостей має винятково важливе значення.

Ґрунтовне вивчення «вікового фону» періоду від 6 до 9 років дозволило виділити вікові передумови розвитку літературно-творчих здібностей молодших школярів. Їх вияв полягав у визначенні особливої чутливості психіки у цьому віці до певного роду впливів, у зв'язку з чим розвиваються психічні якості, задіяні у літературній творчості (сприймання, творче мислення, уява, мовлення тощо). Отже, обумовлені віком підвищені можливості літературно-творчого розвитку молодших школярів становлять їх своєрідну готовність до цього виду діяльності.

Сприймання молодших школярів переважно мимовільне, фррагментарне. На початку навчання у дітей виявляється слабка диференціація сприймання (помічають не головне, а те, що впадає у вічі), невміння самостійно аналізувати та синтезувати ознаки предметів. Разом з тим, сприймання учнів початкової школи характеризується яскравістю, гостротою, рухливістю та готовністю до отримання нових вражень. Молодші школярі виявляють сильний емоційний відгук на все, що безпосередньо сприймають органи чуттів (колір, звук, ритм тощо). Така невимушеність сприймання школяра характеризується особливою «новизною», свіжістю погляду, воно індивідуальне, емоційно насичене.

Суттєвою особливістю сприймання учнів цього віку, яка пов'язана з їх емоційно-ціннісною сферою, є персоніфрікація навколишнього світу. Для дитини центром всесвіту $€$ вона сама, тому у дитинстві виявляється схильність уподібнювати оточуючу дійсність собі, наділяти світ людськими якостями. Це пояснює психологічну готовність молодших школярів сприймати метафоричність мовлення та створювати художні тексти.

Зазначені особливості сприймання молодших школярів співпадають з рисами художнього сприйняття та пізнання світу. У літературній творчості здебільше задіяне чуттєве сприймання, яке характеризується великою емоційністю. Тому особливості сприймання молодшого школяра можна назвати одними з основних вікових передумов розвитку їх літературно-творчих здібностей.

Важливо врахувати в організації літературного розвитку учнів початкової школи властиву для цього віку яскраву уяву та схильність до франтазування. Уява молодшого школяра, як і сприймання, емоційна та мимовільна за своєю суттю - ії предметом стає те, що найбільше схвилювало дитину. У процесі активної творчої діяльності у школярів фрормується довільна уява, в результаті чого 
вони поступово оволодівають уміннями втілювати в літературнотворчу фоорму певний задум [4, с. 48].

Від 1 до 4 класу реалізм дитячої уяви збільшується, уява стає більш керованою, образи її виникають у зв'язку із задачами діяльності. Важливим завданням у розвитку уяви $є$ стимулювання ії природної яскравості, кольоровості, а також навчання керувати уявою для реалізації задуму у творчому продукті.

у молодшому шкільному віці, поки не з'явились нові стійкі інтереси, пов'язані зі статевим дозріванням, коли вразливість, готовність засвоювати, наслідувати дорослих складає саме життя, потреба дитини у розумових враженнях та зусиллях може виступати у вигляді надзвичайної схильності до інтелектуальної праці.

Слід зазначити, що недостатність сфрормованості мислительних операцій (аналіз, порівняння, абстрагування, узагальнення тощо), конкретність та образність пізнання характеризують слабкість логічного мислення цієї вікової категорії в цілому. Це заважає дитині будувати логічно завершені розповідь, опис, міркування тощо, втілювати задум в адекватну літературну форму. Однак у молодших школярів дуже виразно виявляються елементи творчого мислення, необхідні для будь-якого виду творчості, в тому числі і літературної. У них виникають раптові зіставлення та узагальнення, народжуються оригінальні продукти мислення, що пояснюється недостатньо відпрацьованими способами аналізу, відсутністю готових штампів, новизною для них розумової роботи [6, с. 46]. Молодший школяр часто об'єднує враження від предмету на основі «емоційного знаку», оскільки в процес мислення втручаються емоції. Це виявляється слабкою стороною логічного мислення, але сильною стороною художнього мислення дитини.

Таким чином, елементи художньо-образного мислення, а також сміливість думки, готовність до вольового напруження, спрямованість на творчість визначають важливі вікові передумови розвитку досліджуваних здібностей.

У дітей 1-2 класів спостерігається підвищена мовленнєва активність. Діти цієї вікової категорії виявляють схильність більшу частину своїх думок, вражень висловити вголос (іноді напівголос та пошепки), оскільки внутрішне мовлення у них недостатньо сорормоване. Саме тому у 1-2 класах літературна творчість в усній формі, особливо ії організація в парах, групах, яка дає можливість висловитись кожному, $€$ необхідною і корисною для загального розвитку молодшого школяра.

У навчанні літературній творчості важливим $є$ також урахування індивідуальних відмінностей у психічному розвитку дітей, зокрема, пов'язаних 3 переважанням у деяких учнів словесно-логічних компонентів, а у інших - образних. Дослідження психолога В. Ягункової показують, що вищий рівень розвитку літературно- 
творчих здібностей виявляється у дітей «художнього» типу, в яких переважає перша сигнальна система. Однак дослідження останніх років підтверджують, що діти «мислительного» типу також потенційно здатні до успішної мовленнєвої творчості. Це свідчить про те, що міряти творчі прояви дітей однією міркою, не помічаючи їх своєрідності, недоцільно.

Загалом дитячий вік відрізняють якості, які більшою мірою близькі до особливостей «художнього» типу. Молодший шкільний вік характеризується емоційністю сприймання, наочно-образною пам'яттю, яскравою уявою та схильністю до франтазування, підвищеною мовленнєвою та розумовою активністю, переважанням образного мислення над абстрактним, що $є$ віковими передумовами літературно-творчого розвитку.

Урахування вікових та індивідуальних особливостей психічного розвитку дитини в нашому дослідженні дає можливість визначити оптимальні періоди того чи іншого психічного утворення у структурі літературно-творчих здібностей 3 метою побудови ефективної системи їх розвитку. У навчальному процесі це дозволить спрямувати педагогічні зусилля на розвиток тих структур, для яких ці періоди $€$ оптимальними; відповідно до цього спроектувати та організувати діяльність учнів.

Розглянемо найважливіші фрактори розвитку літературно-творчих здібностей молодшого школяра: задатки (біологічний фрактор), освітній процес (соціальний фрактор) та власну активність дитини.

Найчастіше під задатками розуміють анатомо-фрізіологічні риси індивіда (особливості будови нервової системи та органів чуття) як природні передумови розвитку його здібностей [12, с. 59].

Під літературними задатками психологи розуміють в першу чергу надзвичайну вразливість, тобто жвавість і гостроту сприйняття та силу емоційності, яка обирає для самореалізації вербальну форму вираження Літературно обдарованих людей з раннього дитинства хвилює природа, музика, люди, події, особисті переживання, тобто вони від народження наділені вразливістю до чуттєвої сторони дійсності, до внутрішнього світу інших людей.

Отже, більшість дослідників вважає, що індивідуальні внутрішні умови розвитку, які мають свої вроджений характер, формуються під дією зовнішніх умов - у процесі взаємодії дитини із зовнішнім світом, під впливом виховання (в широкому значенні цього слова) та навчально-виховного процесу, відводячи останньому вирішальну роль.

Аналіз психологічних досліджень та педагогічної практики дозволяє зробити висновок, що значний вплив на розвиток літературно-творчих здібностей молодших учнів має зміст навчання за умов, якщо він орієнтований на оптимальну реалізацію їх творчих можливостей у літературній діяльності. Зміст по-різному впливає на 
розвиток залежно від методів навчання, способів дій з навчальним матеріалом, побудовою навчання як творчого процесу розв'язання пошукових завдань, що поступово ускладнюються.

Навчання впливає на творчий розвиток молодших школярів своїми організаційними формами, які дають учням змогу включатись у різні види співпраці з учителем та один з одним.

Творчий розвиток школяра відбувається протягом певних періодів, які послідовно змінюють один одного і кожний 3 них характеризується своїми особливостями, формуванням певних якостей, задіяних у літературно-творчому процесі. Попередній етап цього розвитку готує його новий ступінь. Від того, наскільки успішно розвинулись літературно-творчі здібності дитини на попередньому етапі, як повно реалізувалися її можливості, залежить подальший творчий розвиток молодшого школяра. Якщо психічні якості, задіяні в літературно-творчій діяльності, не дістали належного розвитку своєчасно, коли вони легше піддавались педагогічним впливам, пізніше їх розвиток потребуватиме значно більших зусиль і не завжди є успішним.

У процесі навчання у дитини розвивається і сама активність, i можливості її регуляції, що відіграє дуже важливу роль у розвитку досліджуваних здібностей. Активність учня пов'язана зі схильністю, тобто стійким прагненням до певного виду діяльності. Вона значно більша, ніж інтерес, який може не передбачати потяг до особистої діяльності у даній галузі. Схильність до літературної творчості може починатись 3 інтересу, але обов'язково виявляється у великому бажанні займатися цим видом діяльності. Схильність - це прагнення, здібності - це можливості; між ними існує глибокий взаємозв'язок та постійний взаємовплив.

Отже, важливе значення у розвитку літературно-творчих здібностей мають внутрішні умови розвитку молодшого школяра - природні задатки, схильність та інтерес до літературного виду діяльності, особистісні якості самого учня (розумова активність, працелюбність, саморегуляція). Однак вирішальне значення у повноцінному розвитку досліджуваних здібностей відіграють зовнішні умови, а саме спеціально організований процес включення молодшого школяра у творчу діяльність засобами художнього слова, його організація, зміст та методи навчання.

Досить неоднозначні погляди дослідників на питання щодо повноцінного літературного розвитку учнів початкових класів. Досліджуючи цю проблему, Н. Молдавська стверджує, що молодшому школяру незрозуміла мова художньої умовності, оскільки у нього ще недостатньо розвинена здібність мислити словесно-художніми образами [9, с.41]. Іншої думки дотримується дослідник цієї ж проблеми М. Качурін. Він стверджує, що дітям у третьому класі доступне елементарне розуміння умовності літератури. Маленькі читачі добре розуміють вигадку казки, самі часто застосовують її у грі, що дає підстави для фрормування початкового рівня художньо-естетичного ставлення до літератури. 
Наші погляди на цю проблему збігаються з твердженням відомого дослідника здібностей Н. Лейтеса, який підкреслює, що у молодшому шкільному віці розвивається і міцніє передусім формальна сторона здібностей [6, с.26]. Водночас це не означає, що дитину слід привчати до наївного, ігрового ставлення до літературної творчості. У початкових класах відкривається можливість і необхідність по-новому застосовувати продукти художньої творчості - використовувати їх не тільки для гри, а в якості засобів спілкування.

Розвиток літературно-творчих здібностей молодших школярів $€$ одним з напрямів розвивального навчання. Можна виділити такі ключові положення розвивального навчання, які мають важливе значення для організації процесу розвитку літературно-творчих здібностей: навчання має орієнтуватися на «зону найближчого розвитку»; розвиток особистості дитини полягає в якісній зміні їі діяльності; розвивальний вплив навчання найбільшою мірою визначається тим, як воно організоване; найбільш значущою для ефективності навчання $€$ мотивація, зумовлена інтелектуальною активністю та пізнавальними інтересами учнів.

Оригінальну систему розвитку літературно-творчих здібностей молодших школярів створив видатний вітчизняний педагог В. Сухомлинський.

Головний принцип його роботи у школі - пробудження дітей до творчості. Однак вчений був далекий від думки, що поетичне натхнення приходить до дитини лише як природний дар. Він вважав, що основним завданням вчителя у цій роботі є збагачення чуттєвого досвіду учнів, пробудження в них почуття прекрасного, щоб спалах творчого вогника перетворився на постійну духовну потребу.

Шляхом здійснення творчого розвитку дітей були їх «мандрівки до джерел живого мовлення»: екскурсії на природу, уроки милування, які викликали бажання висловлювати свої почуття і переживання, розповідати про красу. В. Сухомлинський, як тонкий психолог і методист, вважав суперечність між багатством образів, почуттів молодших учнів та недостатністю мовних засобів для їх вираження поштовхом до розвитку мовленнєвої творчості дітей. Цю педагогічну «знахідку» ми вважаємо дуже важливим прийомом стимулювання мотивації дітей до літературнотворчої діяльності.

Отже, на основі аналізу педагогічної спадщини В. Сухомлинського можна виділити такі основні ідеї розвитку літературної творчості молодших школярів:

1. Необхідність використання емоційно-чуттєвих чинників для створення ситуацій естетичних переживань, у яких учні, захоплені красою, хотіли сказати своє образне слово.

2. Потреба у навчанні літературної творчості школярів. При цьому В. Сухомлинський використовував певну методику: спочатку він самостійно створював твір, коли був з дітьми на природі. Вчитель намагався, щоб вихованці зрозуміли і відчули, як наочний образ можна 
передати словами. На другому етапі використовувалися прийоми колективної творчості вчителя з учнями, на третьому - діти переходили до індивідуальної творчості.

3. Гуманне, доброзичливе ставлення до всіх дітей. Не було негативних оцінок за творчі роботи, цінувалась оригінальність, винагороджувалась працелюбність, коректно виправлялись помилки.

Досліджуючи зарубіжний досвід розвитку літературно-творчих здібностей дітей, ми звертаємо увагу на систему навчання словесної творчості італійського письменника і педагога Джанні Родарі. Його книга «Граматика франтазії» була першою в світі, яка містила систему прийомів словесної творчості. Головна думка його методики полягає в тому, що всім дітям подобається творити, кожен має здібність до творчості, але для цього необхідно пробудити франтазію. 3 цією метою Дж. Родарі застосовує прийоми активізації уяви, які допомагають зробити навчання цікавим, продуктивним процесом, наповнюють урок живою роботою дитячої думки, розкривають нові смислові можливості слів, стимулюють мовленнєву свободу дитини.

Усього Д. Родарі запропонував близько тридцяти прийомів. Серед них найбільш цікавими, з нашого погляду, є прийоми франтазування («Біном франтазії», «Фантастичні гіпотези» та ін), прийоми створення казок («Салат із казок», «Казка навпаки», «Вигадування історії 3 шостим словом» та ін.). Прийоми виконують роль стимулів до літературної творчості, не обмежуючи творчу думку учнів, а лише спрямовуючи ії̈ у певне русло.

Отже, узагальнення досвіду навчання літературної творчості дітей дозволило виділити принципові положення, на основі яких можна побудувати ефективну систему завдань та прийомів з метою розвитку літературно-творчих здібностей молодших школярів: стимулювання мотивації літературної творчості шляхом активізації чуттєвого сприймання оточуючої дійсності, в результаті яких у дитини виникне бажання висловити свої почуття і спостереження у слові; навчання доступним прийомам літературної творчості; використання різноманітних форм співпраці між учителем і учнем та між учнями в процесі навчання творчості; створення доброзичливої атмосфери підтримки творчих зусиль дітей.

Аналізуючи напрацювання педагогів та психологів 3 проблеми творчого та літературного розвитку учнів, які здійснювались протягом XX століття та в останні роки, ми ставили за мету визначення типів та видів творчих завдань, які були б корисні для розвитку літературнотворчих здібностей молодших школярів.

Аналіз завдань, що пропонують дослідники 3 метою творчого розвитку учнів, свідчить про різноманітність їх видів та типів. Серед представлених завдань $є$ чимало таких, що стимулюють основні психічні процеси, необхідні для будь-якої творчості (відгадування предмета за парою інших предметів; складання асоціативних ланцюжків; уявлення 
наслідків подій; добір синонімів до слова та ін.), а також $є$ завдання, спрямовані на завершення, створення та удосконалення творчих продуктів (доповнити діалогами оповідання; написати есе-франтазію на запропоновану тему; скласти твір-мініатюру за опорними словами та ін.).

Отже, вивчення вікових передумов розвитку літературно-творчих здібностей молодших школярів (особливості перебігу процесів сприймання, уяви, творчого мислення, мовлення тощо), фракторів впливу на цей розвиток (задатки, навчально-виховний процес, власна активність дитини), аналіз практичного і теоретичного досвіду навчання літературної творчості дітей дозволив зробити наступні висновки про психолого-педагогічні засади розвитку літературно-творчих здібностей молодших школярів:

1. Для того, щоб «запрацювали» психічні процеси, задіяні у літературній творчості, необхідним є сенсорне виховання молодших школярів. Дитина захоче про щось образно розповісти, якщо надавати їй можливість побачити красиве, незвичайне, захоплююче, розширювати чуттєвий та емоційний досвід, фрормувати художнє сприймання дійсності.

2. Правильно організоване чуттєве сприймання стимулює емоції, почуття, переживання дитини. Вони є природною рушійною силою літературного-творчого розвитку молодших школярів, підґрунтям для мотивації цього виду діяльності. Досвід В. Сухомлинського переконує, що подолання суперечностей між яскравістю дитячих вражень у цьому віці й недостатністю мовних засобів для їх реалізації спричиняє до мовленнєвого та загального розвитку дитини.

3. Наступним кроком $є$ розвиток уяви, творчого мислення, тобто загальної креативності школяра з метою фрормування у нього творчих умінь. Досліджено, що уява займає центральне місце у процесі створення художніх образів. Паралельно відбувається розвиток образного мовлення, яке необхідне для адекватної реалізації дитиною образів, вражень у слові. Це передбачає розширення словникового складу, знайомство із засобами художньої виразності тощо.

4. Повноцінний розвиток перерахованих психічних процесів можливий у процесі розв'язування учнем творчих проблем. Виконуючи завдання творчого характеру, учень проявляє компоненти літературно-творчих здібностей, завдяки чому вони у нього формуються.

\section{Список використаних джерел}

1. Артемьева Т.И. Проблема способностей: личностный аспект. Психологический журнал. 1994. №3. С.46-56.

2. Гавриш Н.В. Розвиток мовленнєвотворчої діяльності в дошкільному дитинстві: автореф. дис. ... д-ра. пед. наук: 13.00.02. Київ, 2002. 32 с.

3. Гуманізація процесу навчання в школі: навч. посіб. / С.П.Бондар та ін. 2-ге вид. Київ : Стислос, 2001. 256 с.

4. Карпенко 3.С., Савчин 3.Я. Вивчення і розвиток уяви в дитячому віці: навч.-метод. посіб. Коломия : Вік, 2002. 48 с.

5. Костюк Г.С. Здібності та їх розвиток у дітей. Київ : Знання, 2013. 93 с. 
6. Лейтес Н.С. Способности и одаренность в детские годы. М : Знание, 2004. 80 с.

7. Матюшкин А.М. Концепция творческой одаренности. Вопросы психологии. 1998. №6. C.23-33.

8. Мелик-Пашаев А.А. Педагогика искусства и творческие способности. М.: Знание, 1991. $96 \mathrm{c}$.

9. Молдавська Н.Д. Літературний розвиток школярів у процесі навчання. Харків : Право, 2009. 224 с.

10. Моляко В.А. Психологія дитячої обдарованості. Київ: Знання, 2005. 83 с.

11. Психологічна енциклопедія / за ред. О.М.Степанов. Київ: Академвидав, 2006. 424 c.

12. Психологічний словник /за ред. В.І.Войтка. Київ : Вища школа, 2012. 214 с.

13. Роменець В.А. Психологія творчості: навч. посіб. 2-ге вид. Київ : Либідь, 2001. 288 c.

14. Ягункова В.П. Индивидуально-психологические особенности школьников, способных к литературному творчеству. Вопросы психологии. 1998. №8. С. 13-24. 


\title{
РОЗДІЛ 3 \\ АКТУАЛЬНІ ПРОБЛЕМИ ПІДГОТОВКИ МАЙБУТНІХ ФАХІВЦІВ У ГАЛУЗІ ДОШКІЛЬНОÏ ТА ПОЧАТКОВОÏ ОСВІТИ
}

\section{ФОРМУВАННЯ ГОТОВНОСТІ МАЙБУТНЬОГО ВЧИТЕЛЯ ДО РОЗВИТКУ ТВОРЧОГО МИСЛЕННЯ МОЛОДШИХ ШКОЛЯРІВ ПРИ ВИВЧЕННІ МАТЕМАТИКИ}

\author{
Васько О. 0. \\ кандидат педагогічних наук, доцент, \\ Сумський державний педагогічний університет імені А. С. Макаренка
}

Реформування вищої освіти України вимагає нових підходів до підготовки фрахівців початкової освіти. Останнім часом актуальності набула проблема підготовки майбутніх вчителів початкових класів до розвитку творчого мислення молодших школярів, оскільки метою початкової освіти $€$ всебічний розвиток дитини, ї̈ талантів, здібностей, компетентностей та наскрізних умінь відповідно до вікових та індивідуальних психофрізіологічних особливостей і потреб, формування цінностей, розвиток самостійності, творчості та допитливості.

Ефективність розв'язання зазначених завдань багато в чому залежить від професіоналізму вчителя щодо побудови такого процесу навчання в початковій школі i, перш за все, на уроках математики, який зміцнював би інтерес дитини до пізнання, відкриття нового, забезпечував би міцність та надійність засвоюваних знань, і водночас, сприяв формуванню в кожній дитині рис пізнавальної активності, реально й творчо мислячої, самокритичної особистості. Педагогічна наука і практика переконливо доводять, що тільки творча особистість може виховати таку ж творчу особистість. Тому, проблема формування готовності майбутнього вчителя до розвитку творчого мислення молодших школярів при вивченні математики $є$ актуальною.

Питання формування творчого потенціалу особистості, розвитку творчого мислення висвітлюються у багатьох фундаментальних працях. Можна відзначити внесок науковців у дослідження окремих аспектів творчості: загальних проблем творчості (С. Л. Рубінштейн, Л. С. Виготський, Б. М. Кедров, А. В. Брушлінський, Я. А. Пономарьов, О.К. Тихомиров); формування творчої особистості, ії потенційних можливостей, здібностей, якостей, властивостей, характерних рис (Б. Г. Ананьєв, Д. Б. Богоявленська, М. О. Лазарєв, В. О. Моляко, 
М. М. Поташник, Н. Ю. Посталюк). Проблема формування творчої особистості вчителя початкової школи на уроках математики, його підготовки до професійної діяльності знайшла відображення у працях учених Н. В. Кузьміної, Л. Л. Хоружої, Л. П. Кочиної, Н.М.Бібік, М.В.Богдановича, О. Я. Митника, К.ІІ. Волинець та інших. Проблемі розвитку творчого мислення присвячені дослідження видатних вітчизняних та зарубіжних психологів і педагогів, таких як Л. С. Виготський, П. П. Блонський, Г. О. Люблінська, Л. В. Занков.

Готовність майбутніх вчителів до профресійної діяльності на сьогодні широке висвітлення в теорії і практиці в різних напрямках: готовність як психологічний феномен (А. Д. Ганюшкін, М.І.Дьяченко, Л. О. Кандибович, М. В. Козак, Н. Д. Левітов, В. А. Моляко, О.В. Проскура); готовність майбутніх учителів початкової школи до освітньої діяльності (О.О.ББла, С. М. Бреус, К. І. Волинець, Л. В. Заремба, Д. І. Іванова, Н. О. Ковальова, І. І. Ковальчук, Л. О. Хомич, Т. Я. Цибулько).

Аналіз науково-педагогічною літератури свідчить, що проблема розвитку творчого мислення як молодших школярів так і студентів широко висвітлюється в психолого педагогічній літературі. Проте проблема готовності майбутніх вчителів початкових класів до розвитку творчого мислення молодших школярів потребує теоретичного i практичного обґрунтування.

Майбутнє України будуть вирішувати фрахівці, які зможуть швидко адаптуватися в сучасних умовах розвитку суспільства, творчо підходити до вирішення складних професійних ситуацій та виявляти вміння діяти не за зразком, а оригінально, передбачати новизну в прийнятті рішень. Адже саме зараз, як ніколи, нашій країні потрібні люди, здатні приймати нестандартні рішення, які вміють творчо мислити. Це вміння залежить від творчих умінь та навиків особистості, яка повинна не тільки мати високий коефіцієнт розумового розвитку, але й вміти реалізувати свій творчий потенціал. Як бачимо, провідними стають комунікативні навички, соціальна адаптованість, особистісні компетентності, що можуть бути гарантом успіху в профресійному житті.

Отже, головна мета вищої педагогічної освіти - формування високоморальної, соціально зрілої, освіченої, інтелектуально розвинутої та професійно компетентної особистості, здатної успішно реалізовувати свої творчі можливості в умовах сучасної школи.

Під системою підготовки майбутніх вчителів початкових класів до розвитку творчого мислення молодших школярів розуміємо взаємодію і взаємообумовленість цілей і завдань; форм, методів, педагогічних умов, які сприяють створенню у майбутніх фрахівців комплексу професійно-значущих спеціальних знань і вмінь, фрормуванню творчих здібностей, прагненню до самовдосконалення і розвитку творчого мислення школяра. 
Освітній процес з підготовки майбутніх вчителів початкових охоплює аудиторну і позааудиторну діяльності.

В методико-математичній підготовці майбутніх вчителів до розвитку творчого мислення молодших школярів можна виділити три етапи: мотиваційно-цільовий, організаційно-діяльнісний, оціннорезультативний.

1 етап - мотиваційно-цільовий. Основний напрямок цього етапу $€$ включення студентів в активну діяльність 3 оволодіння науково-теоретичною базою, тобто тією основою, що $є$ фундаментом теоретичної підготовки майбутнього вчителя. Відбувається це шляхом засвоєння знань про вивчення закономірностей, принципів, форм, засобів і методів навчання математики і методик навчання предметів початкової школи.

Важливою передумовою для організації пізнавальної діяльності студентів $€$ наявність мотивації та цілеспрямована постановка планомірної діяльності, передбаченої в межах створення комфортного освітнього середовища.

Для мотивації до пізнавальної діяльності, упорядкування отриманої інфрормації, моделювання навчально-пізнавальних ситуацій освітнього процесу початкової школи, розвитку пізнавальної ссрери студентів застосовуємо комплекс когнітивних методів евристичного навчання таких як методи евристичних запитань, емпатії, смислового бачення.

C.I. Архангельський зазначає, що евристичні методи - це система принципів і правил, які задають найбільш ймовірні стратегії і тактики діяльності, стимулюють інтуїтивне мислення в процесі розв'язання, генерують нові ідеї і тим самим значно підвищують ефрективність розв'язання певного класу творчих завдань [2, с. 133-134].

Отже, основною характеристикою евристичних методів $\epsilon$ спрямованість на активний пошук розв'язання пізнавальних завдань під керівництвом педагога або на основі евристичних програм i вказівок. Процес мислення набуває продуктивного характеру. А прагнення до самостійної діяльності $є$ одним із компонентів структури активності. Тому методи евристичного навчання $\epsilon$ одним із засобів активізації навчально-пізнавальної діяльності.

Когнітивні методи евристичного навчання спрямовані на активізацію розумової діяльність майбутніх вчителів початкових класів шляхом створення проблемних ситуацій, які потребують швидкого аналізу інформації, її відпрацювання і як результат - відшукання творчого вирішення завдання, 3 одночасним формуванням особистісних якостей студента [5, с. 161-165].

На практичних заняттях з «Методики навчання освітньої галузі «Математика»» де одним із видів завдань $є$ проектування фррагментів уроку, застосоваємо метод емпатії. Який дозволяє вирішити кілька завдань: по-перше, мотивувати студентів до активної діяльності; по- 
друге, змоделювати навчально-пізнавальні ситуації освітнього процесу початкової школи.

Метод емпатії (метод особистої аналогії) - це один із евристичних методів розв'язання творчих завдань, в основі якого лежить процес емпатії, тобто ототожнення себе 3 об'єктом і предметом творчої діяльності, усвідомлення функцій досліджуваного предмета на основі «вживання» в образ винаходу, якому приписуються особисті почуття, емоції, здатність бачити, чути, міркувати тощо. В основі методу емпатії лежить принцип заміщення досліджуваного об'єкта, процесу іншим [1, с. 197].

Метод емпатії має великі можливості для розвитку франтазії, уяви, творчого мислення та отримання оригінальних ідей щодо розв'язування задачі, але вимагає багато часу. Найчастіше за його використання можна знайти тільки ідею розв'язання творчого завдання [4].

В методико-математичній підготовці одним із видів завдань $\epsilon$ завдання на розробку дидактичних завдань, фррагментів уроку, відшукання дієвих методів і форм навчання.

Для того, щоб з'ясувати, наприклад, ефрективність спроектованого фррагменту уроку, студентам пропонується об'єднатися в групи:

1 група - вчителі (показують фррагмент спроектованого уроку).

2 група - учні (входять в роль учня, для цього перед фррагментом уроку студенти пригадують, який запас знань, умінь і способів діяльності уже наявний на цей момент). Пропонуємо студентам уявити себе наприклад учнем 1 класу. Далі, з'ясовуємо, як мислено присвоїти собі досліджувані якості? 3 цією метою студенти повинні пригадати, який учні 1 класу мають наявний запас сформованих знань, умінь, способів діяльності на момент вивчення розглядуваної теми; знати особливості сприйняття навчального змісту дітьми 6 років; знати вікові особливості дітей 6 року тощо.

3 група - експерти (контроль студентів які виконують ролі вчителя та учнів, встановлення переваг і недоліків роботи обох груп).

Тобто в умовах застосування методу емпатії студентам пропонується вжитися в ролі: вчителя, учня, експерта. Цей метод потребує гарної фантазії і уяви.

Після роботи над завданням організовуємо рефлексію діяльності. 3'ясовуємо:

1. Чи сподобалося завдання? Чому?

2. Що викликало ускладнення?

3. Що вдалося легко?

4. Висновок про ефрективність спроектованого фррагменту уроку.

Таким чином, застосування методу емпатії дозволяє в умовах лекційно-практичної організації процесу навчання у вищій школі апробувати спроектований фррагмент уроку, розроблені завдання тощо, знайти переваги і недоліки і виправити їх, а також залучити до активної діяльності. 
2 етап - організаційно-діяльнісний. Особлива увага, на цьому етапі, приділяється ознайомленню студентів 3 методами, організаційними формами та засобами роботи 3 молодшими школярами при вивченні конкретних тем курсу, виявленню можливостей навчального матеріалу для розвитку творчості учнів: включення до змісту практичних занять завдань, спрямованих на вироблення у студентів уміння розвивати творче мислення молодших школярів засобами математики.

Розвиток творчого мислення молодших школярів здійснюється через включення їх в активну діяльність. Саме застосування діяльнісного методу при вивченні математики в початковій школі дозволяє розв'язати цю задачу. Оскільки діяльнісний метод навчання - це метод навчання, при якому учні не лише отримує знання від вчителя у готовому вигляді, але й здобуває їх самостійно у процесі власної навчально-творчої діяльності [12]. В основі технології діяльнісного методу лежить метод рефрлексивної самоорганізації i разом з тим, вона включає в себе усі етапи глибокого і міцного засвоєння знань, що сприяє, в першу чергу, їх свідомому застосуванню на практиці.

Для вироблення в студентів уміння використовувати технологію діяльнісного методу для розвитку творчого мислення молодших школярів, одним із видів завдань $є$ завдання типу: спроектувати фррагмент уроку, наприклад введення нових знань за технологією діяльнісного методу.

Із визначеною вище метою в методико-математичну підготовку майбутніх вчителів початкових класів включили завдання на вироблення уміння застосовувати цей метод при вивченні математики. Наприклад, при роботі над розділом «Методика навчання нумерації $\mathrm{i}$ арифрметичних дій додавання і віднімання в концентрі «Десяток»» пропонуємо наступне завдання: «Спроектувати фррагмент уроку введення нових знань з математики за технологією діяльнісного методу на тему «Лічба предметів. Об'єднання предметів у групи за певною ознакою. Множина. Елемент множини» для 1 класу.

Ще одним методом, що впливає на розвиток творчого мислення молодших школярів $€$ евристичний метод. Опанування студентами уміння застосовувати його на уроках математики становить зміст їх підготовки до розвитку творчого мислення молодших школярів при вивченні математики.

Скаткін М. М. називає три варіанти евристичного (частковопошукового) методу. Перший варіант полягає в тому, що 3 метою поступового наближення учнів до самостійного розв'язання проблем їх необхідно спочатку вчити виконувати окремі кроки розв'язання, окремі етапи дослідження, формуючи їх уміння поступово. Прикладом такої організації може бути: 1) для того щоб учні побачили проблему, пропонується поставити питання, наприклад, до картини, документа, 
викладеного змісту; 2) побудувати самостійно знайдене доведення; 3) зробити висновки із запропонованих фактів; 4) висловити здогадки; 5) побудувати план перевірки здогадки тощо [6, с. 199].

Другий варіант цього методу - розчленування складеної задачі на серію доступних підзадач, кожна з яких полегшує наближення до розв'язання основної задачі [6, с. 200].

Третім варіантом $є$ побудова евристичної бесіди, яка складається із серії взаємопов'язаних питань, кожне з яких $є$ кроком на шляху до розв'язання проблеми і більшість яких потребує від учнів не лише відтворення знань, але і здійснення невеликого пошуку [6, с. 200].

Найбільш поширеною формою цього методу в початковій школі $€$ евристична бесіда. Тому умінням організовувати евристичну бесіду на уроках математики в початковій школі входить до змісту готовності студентів до розвитку творчого мислення молодших школярів при вивченні математики.

І.П. Підласий виокремлює такі головні особливості методу евристичної бесіди [10, с. 475]: знання не пропонуються у готовому вигляді, а їх треба здобувати самостійно; учитель організовує не повідомлення чи викладання знань, а їх пошук за допомогою різних засобів; учні самостійно доходять висновків під керівництвом учителя.

Схема динаміка інфрормації має такий вигляд [10, с. 477]:

$$
\text { вчитель } \rightarrow \text { учні } \rightarrow \text { вчитель } \rightarrow \text { учні ... }
$$

Відповідно до схеми постановка запитань не $€$ прерогативою тільки вчителя, учні також можуть задавати запитання, потрібні їм для осмислення матеріалу.

У процесі застосування евристичної бесіди вчитель уміло поставленими запитаннями спрямовує думку учнів на розуміння суті матеріалу, що вивчається. Розумову роботу, яку при цьому виконують учні, можна розглядати в такій послідовності:

$>$ перед учнями ставиться проблема, запитання, предмет для спостереження, порівняння, що примушує їх мислити, шукати відповіді, дає поштовх думці;

$>$ аналізуються різні відповіді, висловлені під час розгляду питання: відкидаються неправильні, доповнюються або уточнюються неповні й неточні, фрормулюється правильна відповідь;

$>$ установлюються логічні зв'язки між окремими думками, положеннями, формулюються висновки й узагальнення, установлюється система нових знань.

Отже, від постановки запитання, досліду, спостереження вчитель в евристичній бесіді веде учнів до порівняння і зіставлення, аналізу i синтезу, знаходження правильної відповіді і встановлення логічних зв'язків, виведення висновків й узагальнень. 
Докладно сутність евристичної бесіди розкрита у праці C.I. Бризгалової [3]. Вона визначає ознаки евристичної бесіди та її структуру. Скористаємося висновками, зробленими дослідницею.

У якості основних ознак евристичної бесіди вчена називає наступні: кожне питання логічним кроком пошуку; усі питання взаємопов'язані; пошук відбувається за часткової самостійності учнів під керівництвом учителя: вчитель спрямовує шлях пошуку, а учні розв'язують часткові задачі, тобто кроки цілісної задачі; пошук зорієнтований на здобуття знань і способів отримання знань або на доведення істинності останніх; успіх пошуку забезпечується наявністю запасу вихідних знань [3, с. 57].

Отже, важливою складовою евристичної бесіди $\epsilon$ запитання. Запитання повинні утворювати логічний ланцюжок так, щоб відповідь на перше запитання дала можливість поставити друге запитання та ін. Запитання в евристичній бесіді виконує функцію спонукального мотиву до перетворення знання про незнання у знання сутності. Кожне питання в евристичній бесіді $є$ кроком у досягненні мети.

Евристична бесіда має на меті спрямувати учнів на активні роздуми, самостійне просування їх у засвоєнні нових знань, висловлювання припущень про причини явищ, про зв'язки між поняттями на основі порівнянь, логічних роздумів. Вона застосовується для розвитку самостійності мислення, дослідницьких умінь, творчого підходу до справи.

Проте запитання і відповідь не $\epsilon$ основними ознаками евристичної бесіди. Існує кілька різновидів методу бесіди, і саме тому потрібно чітко виокремити місце евристичної бесіди серед них. Типовими для шкільної практики є такі види бесід: евристична, репродуктивна, узагальнювальна, контрольно-корекційна, аналітикосинтетична. Для того, щоб відрізнити евристичну бесіду від інших, слід орієнтуватися на її структуру.

Аналіз літератури з проблеми організації евристичної бесіди дозволяє визначити орієнтовну структуру евристичної бесіди. Основними етапами її використання на уроці $є$ :

1. Актуалізація опорних знань.

2. Створення проблемно-пошукових ситуацій.

3. Спонукання учнів висловити припущення про розв'язання проблеми.

4. Вимога довести свою точку зору.

5. Спрямування розумової діяльності учнів, коректування відповідей.

6. Узагальнення і систематизація знань.

Указана структура евристичної бесіди не є чимось незмінним, необхідно творчо підходити до підготовки і проведення евристичної бесіди. Характер елементів структури визначається завданнями, які постійно треба розв'язувати на уроці.

Можна зробити висновок про те, що сутність евристичної бесіди полягає у тому, що це є метод навчання, за якого учні під час 
бесіди старанно підготовленої вчителем, самостійно доходять запланованих висновків.

Діяльність учителя у процесі використання евристичної бесіди можна представити двома етапами: організаційно-підготовчим та виконавчим. Сутність організаційно-підготовчого етапу полягає в тому, що кожного разу, виходячи 3 конкретних дидактичних цілей конкретного уроку, вчитель здійснює логіко-теоретичний аналіз навчального матеріалу для того, щоб з'ясувати, чи дозволяє цей матеріал застосовувати евристичну бесіду. Виконавчий етап розпочинається 3 постановки шуканого: 1) шукане може висунути і сорормувати сам учитель; 2) учитель може створити ситуацію, у процесі якої учні під його керівництвом будуть підведені до шуканого; 3) учні вбачають і фрормулюють шукане самі [3, с. 65].

До змісту практичних занять 3 навчальної дисципліни «Методика навчання освітньої галузі «Математика»» включено серію завдань спрямованих на опанування умінням її застосовувати.

До теми «Методика вивчення додавання і віднімання в межах ста» запропонували завдання підготувати евристичну бесіду для ознайомлення із способом додавання круглих чисел. Приступаючи до розробки бесіди скористайтесь наступними вказівками: 1) визначити на якому навчальному матеріалі вона розгортатиметься; 2) встановити, які знання, попередні відомості, спостереження можуть бути використані під час бесіди; 3) продумати мету бесіди та висновки, «відкриття», до яких слід підвести учнів; 4) окреслити основні запитання з теми бесіди, приклади; визначити необхідні наочні посібники та інші додаткові джерела; 5) намітити учнів, на відповіді яких спиратиметеся.

В подальшому до інших тем курсу включаємо аналогічні завдання. Поряд 3 тим, звертаємося до студентів із проханням оцінити, чи грамотно сорормульовані питання до бесіди. Для оцінки формулювання запитань, пропонували орієнтуватися на такі вимоги: 1) виразність, чіткість і визначеність; 2) відсутність складних запитань, що містять два чи більше запитань; 3) відсутність запитань з підказкою й альтернативних запитань, які не стимулюють учнів до активного мислення, а лише спонукають до відгадування відповіді або повторення їі за вчителем; 4) ускладнення запитань ближче до кінця бесіди (спочатку ставляться запитання конкретні і такі, що потребують меншого інтелектуального напруження, а потім вони ускладнюються); 5) активізація учнів (для активізації учнів під час бесіди доцільно також заохочувати змагання між учнями за кращу і швидшу відповідь шляхом постановки запитань зі словами: «Хто швидше дасть відповідь?», «Поміркуйте, чому ми так робили?», «Хто дасть найточнішу відповідь?» та ін.).; 6) емоційність постановки запитань.

Отже, специфічними ознаками методу евристичної бесіди щодо подачі матеріалу $\epsilon$, по-перше, детальна підготовка до неї за 
наведеною схемою, ретельний підбір запитань; по-друге, вміння ставити запитання таким чином, щоб вони ставали збудниками процесу мислення; по-третє, підтримання у класі робочої атмосфери дискусії і пошуку, оскільки цей метод потребує як невимушеності для активної інтелектуальної роботи, так і зосередженої спрямованості на результат.

Ще одним засобом розвитку творчого мислення молодших школярів $є$ інтерактивні технології.

Інтерактивна технологія навчання - це організація навчального процесу, за якої неможлива неучасть школяра у колективному взаємодоповнюючому, заснованому на взаємодії всіх його учасників процесі навчального пізнання: або кожен учень має конкретне завдання, за яке він повинен публічно прозвітуватись, або від його діяльності залежить якість виконання поставленого перед групою та перед усім класом завдання [11, с. 19].

Інтерактивна діяльність на уроках припускає організацію і розвиток діалогового спілкування, яке веде до взаєморозуміння, взаємодії, до сумісного вирішення загальних, але значущих для кожного учасника завдань.

Інтерактив виключає домінування як одного виступаючого, так і однієї думки над іншим. В ході діалогового навчання учні вчаться критично мислити, вирішувати складні проблеми на основі аналізу обставин і відповідної інформації, зважувати альтернативні думки, ухвалювати продумані рішення, брати участь в дискусіях, спілкуватися з іншими людьми, що і сприяє розвитку творчого мислення дитини.

Інтерактивні технології навчання Пометун О., Пироженко Л. поділили на чотири групи [7, с. 100]: групове навчання (робота учня 3 учителем чи однолітком один на один, трійками, четвірками), фронтальне навчання, навчання у грі, навчання у дискусії.

Кооперативна (групова) навчальна діяльність - це форма (модель) організації навчання у малих групах студентів, об'єднаних спільною навчальною метою. До групового (кооперативного) навчання можна віднести: роботу в парах, ротаційні трійки, «Два-чотири-всі разом», «Карусель», роботу в малих групах, «Акваріум».

Для опанування технологією групового навчання до змісту методико-математичної підготовки включили завдання на розробку і організацію вправ для учнів початкових класів відповідно до теми заняття із застосуванням технологій групового навчання.

Працюючи над темою «Методика навчання нумерації i арифметичних дій додавання і віднімання в концентрі «Десяток»» пропонуємо студентам завдання запропонувати 2-3 вправи для роботи учнів у малих групах, які сприятимуть формуванню понять: над, під, на, поза, поруч, зверху, знизу, між, зліва, справа, поза, у середині, навколо. 
Названа тема стосується підготовчого періоду у вивченні нумерації чисел першого десятка. Студентам пропонується описати методику організації роботи учнів у малих групах при виконанні цієї вправи. Для того, щоб виконати завдання студентам не достатньо дібрати завдання, а ще слід продумати його організацію. Таким чином, відбувається формування готовності до реалізації творчої діяльності студентами на основі компетентнісного підходу.

До фронтальних технологій інтерактивного навчання О. Комар відносить такі, що передбачають одночасну спільну роботу всього класу. Це і обговорення проблеми у загальному колі (ії застосовують 3 іншими технологіями), і «Мікрофрон» (надається можливість кожному сказати щось швидко, по черзі, висловити свою думку чи позицію), і незакінчені речення (поєднується з вправою «Мікрофон»), і «Мозковий штурм» (відома інтерактивна технологія колективного обговорення, широко використовується для прийняття кількох рішень 3 конкретної проблеми), і «Навчаючи-вчуся», і «Ажурна пилка», i «Case-метод», і «Дерево рішень» [8].

Для опанування студентами цими технологіями пропонуємо завдання виду: продемонструвати можливий варіант реалізації однієї із фрронтальних технологій інтерактивного навчання при вивченні конкретної теми.

В методико-математичній підготовці при вивченні теми «Методика вивчення арифметичних дій додавання і віднімання в концентрі «Сотня»» студентам запропоновано завдання: продемонструвати можливий варіант реалізації однієї із фронтальних технологій інтерактивного навчання для фрормування усних прийомів додавання i віднімання в концентрі «Сотня». Завдання представити в такому вигляді: назва технології, підготовка до проведення, мета використання, організація діяльності.

На підставі аналізі психолого-педагогічної і методичної літератури встановили, що використання творчих завдань при вивченні математики сприяє розвитку їх творчого мислення.

Тому, в методико-математичну підготовку майбутніх вчителів початкових класів було включено завдання на добір творчих вправ до відповідних тем курсу.

Наприклад, до теми «Методика вивчення додавання і віднімання в межах 10» пропонуємо завдання: доберіть вправи творчого характеру для формування табличних випадків додавання і віднімання в межах 10.

До теми «Методика вивчення нумерації чисел в межах сотні» пропонуємо дібрати або створити ребуси для закріплення знань нумерації чисел в межах ста.

3-ий етап - оцінно-результативний, він передбачає перевірку рівня сформованості готовності майбутнього вчителя початкових класів до розвитку творчого мислення молодших школярів при вивченні математики. 
«Готовність майбутнього вчителя до розвитку творчого мислення молодших школярів» трактуємо як стійке особистісне утворення, в якому інтегровані мотиви, цінності, знання, вміння та особистісні якості майбутнього фахівця, необхідних для здійснення розвитку творчого мислення молодших школярів.

До структури готовності майбутнього вчителя до розвитку творчого мислення молодших школярів включено такі компоненти [9, с. 305]:

Мотиваційно-цільовий компонент - найважливіший компонент процесу підготовки майбутнього вчителя до фрормування творчого мислення молодшого школяра. Він відображає систему потреб, мотивів і цілей організації творчої діяльності молодших школярів, профресійну спрямованість особистості вчителя на розвиток творчого мислення учнів. Ефрективність підготовки студентів до організації навчального процесу з розвитку творчого мислення учнів неможлива без усвідомлення майбутніми учителями важливості даної проблеми. Розвинути таке ставлення можна шляхом розвитку відповідних потреб, мотивів і інтересів особистості. Для того, щоб виник інтерес, необхідно створити мотив, який приведе до досягнення мети. У діяльності, яка сприяє виникненню інтересу, головне місце відводиться змісту конкретного предмета й унаслідок цього відбувається легке його запам'ятовування. Встановлено, що реалізація мотиваційної складової готовності майбутнього вчителя до розвитку творчого мислення молодших школярів у навчальному процесі у вищому навчальному закладі відбуватиметься за умови створення на заняттях ситуацій розмірковування й успіху. Організація більшості лекцій проблемного характеру, семінарів і практичних занять у формі дискусій, рольових ігор, тренінгів мають допомогти викладачам виховати в кожного студента ставлення до себе як до суб'єкта діяльності.

Отже, елементами мотиваційно-ціннісного компоненту готовності майбутнього вчителя до розвитку творчого мислення учнів $\epsilon$ сорормовані потреби і професійний інтерес, що виражає потяги до професійної діяльності, організації творчої діяльності молодших школярів; мотиви розвитку творчої особистості; бажання розвивати творче мислення учнів в процесі навчання. Мотиваційно-цільовий компонент можна розглядати як одну із важливих складових професійної підготовки майбутніх учителів початкових класів, навколо якого концентруються когнітивний і операційний компоненти.

Когнітивний компонент - передбачає наявність у студентів знань з теорії та методики розвитку творчого мислення молодших школярів. Обсяг когнітивного компоненту готовності включає: знання суті творчої діяльності, методів і прийомів організації творчої діяльності учнів в процесі навчання; знання суті творчого мислення молодших школярів; знання умов творчого розвитку учнів; знання методики розвитку творчого мислення школярів, а саме пізнавального інтересу, інтуїції та творчої уяви; знання методики діагностики творчого мислення молодших школярів. 
Важливою складовою когнітивного компоненту є предметні знання і знання методики викладання предмету. Формування когнітивного компоненту готовності майбутніх учителів здійснюється на міжпредметній та міждисциплінарній основі. У процесі підготовки студентів до розвитку творчого мислення молодших школярів можуть бути застосовані окремі цикли дисциплін у педагогічному вищому навчальному закладі, окремі предмети, які спрямовуються на досягнення цієї мети, розділи і теми різних навчальних дисциплін, види навчальних занять (лекції, семінарські, практичні заняття).

Отже, засвоєння студентами знань з теорії та методики розвитку творчого мислення молодших школярів відбувається у процесі вивчення психолого-педагогічних та методичних дисциплін. Крім цього, з ними дуже тісно пов'язані всі ті фундаментальні та інші дисципліни, що стосуються творчості, творчої діяльності, творчого мислення особистості, а також шляхів їх розвитку. Саме вони сприяють опануванню майбутніми учителями необхідними знаннями розвитку творчого мислення молодших школярів.

Операційний компонент - визначається системою умінь та навичок розвитку творчого мислення молодших школярів у процесі навчання. Зміст операційного компоненту визначається: системою умінь і навичок організації творчої діяльності у процесі навчання; практичними уміннями та навичками створення творчої атмосфери в класі, залученні дітей до активних методів навчання, а саме ігрових, проблемних, евристичних, дослідницьких, інтерактивних методів; володінні методикою створення творчих завдань; комбінуванні колективної, групової, індивідуальної форм навчальної роботи; уміннями та навичками діагностики творчого мислення молодших школярів. 3 метою забезпечення готовності майбутнього вчителя до формування творчого мислення молодшого школяра впроваджується більшість лекцій проблемного характеру. Наприклад: лекція пресконференція, дискусії з розбором конкретних ситуацій, консультації. На семінарських (практичних) заняттях - домінування дискусійних фрорми роботи, які стимулюватимуть самостійність, ініціативність, активність, рефрлективність студентів при обговоренні проблем.

Зміст практичної підготовки виражається в зовнішніх уміннях, тобто в діях, які можна спостерігати. До них відносяться організаторські і комунікативні уміння. В свою чергу до організаторських умінь як загальнопедагогічних відносяться мобілізаційні, інформаційні, розвиваючі та орієнтаційні. До практичних умінь і навиків відносять: загально педагогічні (інформаційні, мобілізаційні, розвиваючі, орієнтаційні), загально трудові (конструктивні, організаторські, дослідницькі), комунікативні (спілкування з людьми різних вікових категорій), самоосвітні (систематизація і узагальнення знань і їх застосування при рішенні педагогічних задач і отриманні нової інформації). 
Отже, операційний компонент готовності майбутніх учителів початкових класів з розвитку творчого мислення учнів забезпечується придбанням інтелектуальних, організаційних та комунікативних умінь.

Були визначені наступні рівні готовності студентів до розвитку творчого мислення молодших школярів при вивченні математики.

Високий рівень: студент усвідомлює важливість розвитку творчого мислення молодших школярів, цілеспрямовано будує власну творчу діяльність відповідно до вікових та індивідуальних особливостей учнів, володіє ключовими компетентностями, вмотивований до здійснення практичної діяльності на уроках математики; може вільно оперувати теоретичними знаннями, практичними вміннями та навичками, застосовувати елементи творчості, розробляти власні творчі завдання з математики, спираючись на власний досвід. Компетентний щодо специфріки розвитку творчого мислення молодших школярів на уроках математики в початковій школі.

Середній рівень: студент виявляє позитивне ставлення до розвитку творчого мислення учнів молодшого шкільного віку, зацікавленість в поетапному формуванні та подальшому розвитку творчого мислення. Але студент не в повній мірі відчуває самостійність та впевненість у власних силах, потребує допомоги з боку викладача. Студент на достатньому рівні володіє теоретичними та практичними знаннями щодо розвитку творчого мислення молодших школярів, але не має повного уявлення про те, як правильно застосувати ці знання в професійній діяльності.

Низький рівень: спостерігається низький рівень мотивації до розвитку творчого мислення молодших школярів на уроках математики, студент не може обґрунтувати основних положень щодо специфіки фрормування творчого мислення молодших школярів, потребує постійної допомоги викладача. У студента не достатньо ссрормовані теоретичні та практичні знання, які мають фрагментарний характер, низька мотивація до навчально-пізнавальної діяльності, має ускладнення до самостійного застосування знань на практиці.

Для перевірки сфрормованості компонентів готовності студентів до розвитку творчого мислення молодших школярів, таких як мотиваційно-цільовий, когнітивний та операційний, застосовано анкетування.

До експериментального впливу визначено рівні готовності студентів до розвитку творчого мислення молодших школярів, його результати представлено на рисунку 1.

Аналіз результатів анкетування свідчить, що у студентів виявлено домінуючим середній рівень щодо когнітивного i операційного компонентів готовності студентів до розвитку творчого мислення молодших школярів, проте мотиваційний компонент у більшості студентів $(66,7 \%)$ сфрормований на високому рівні. 


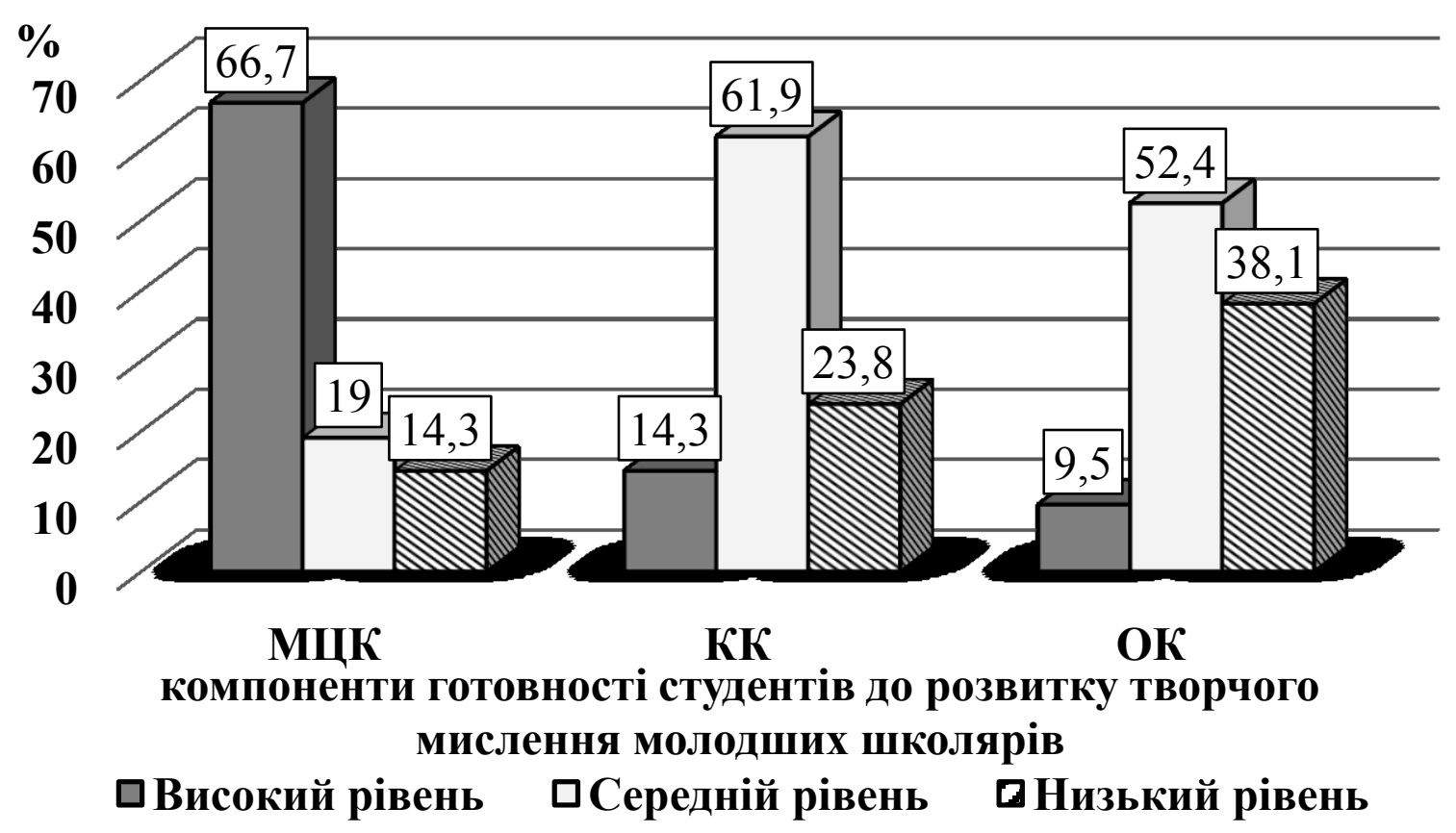

МЦК - мотиваційно-цільовий компонент, КК - когнітивний компонент, ОК - операційний компонент

Рис. 1. Розподіл студентів за рівнями сформованості компонентів готовності студентів до розвитку творчого мислення молодших школярів до експериментального впливу

Після експериментального впливу повторно проведено анкетування його результати представлено на рисунку 2.

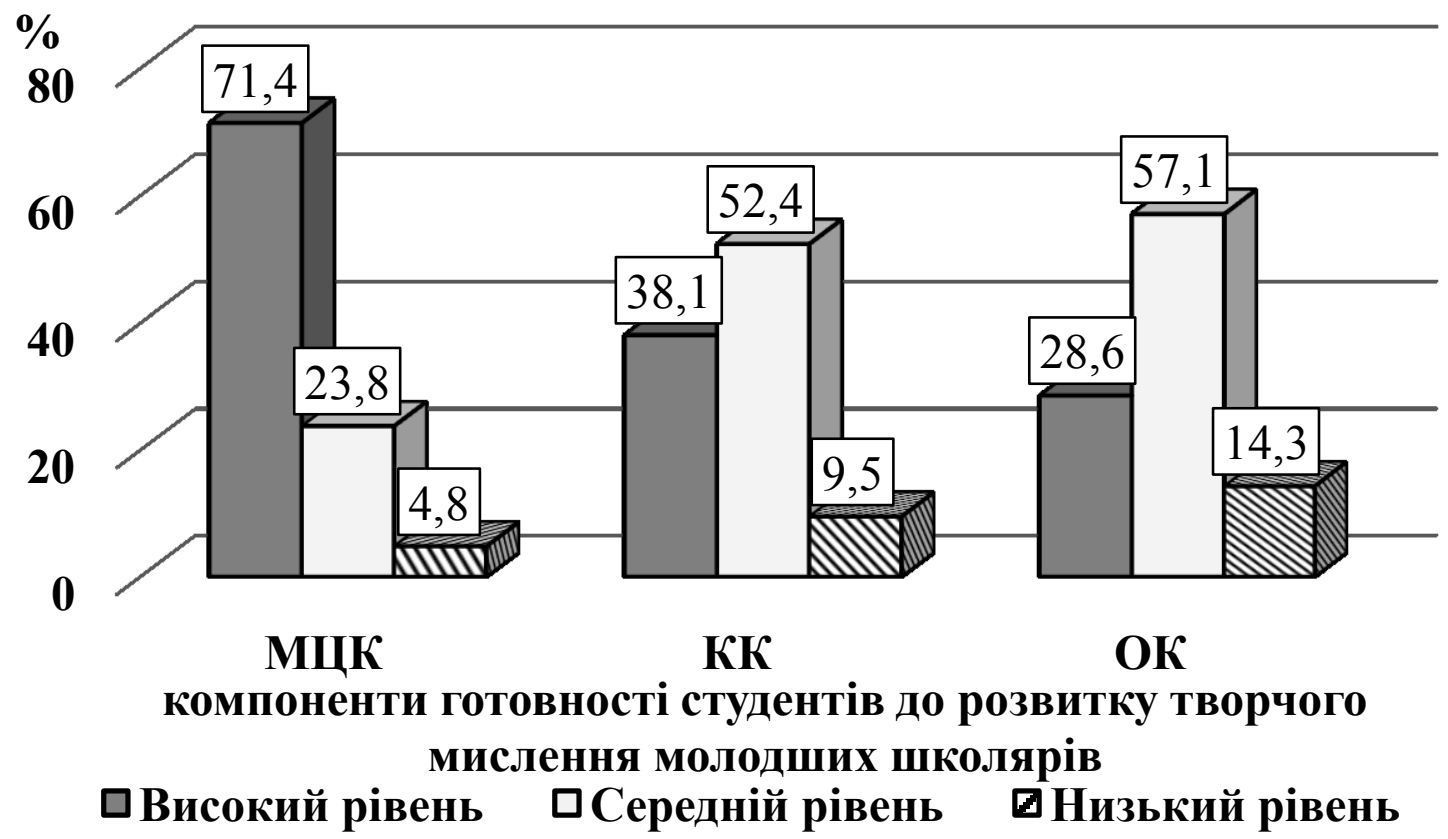

МЦК - мотиваційно-цільовий компонент, КК - когнітивний компонент, ОК - операційний компонент

Рис. 2. Розподіл студентів за рівнями сформованості компонентів готовності студентів до розвитку творчого мислення молодших школярів після експериментального впливу 


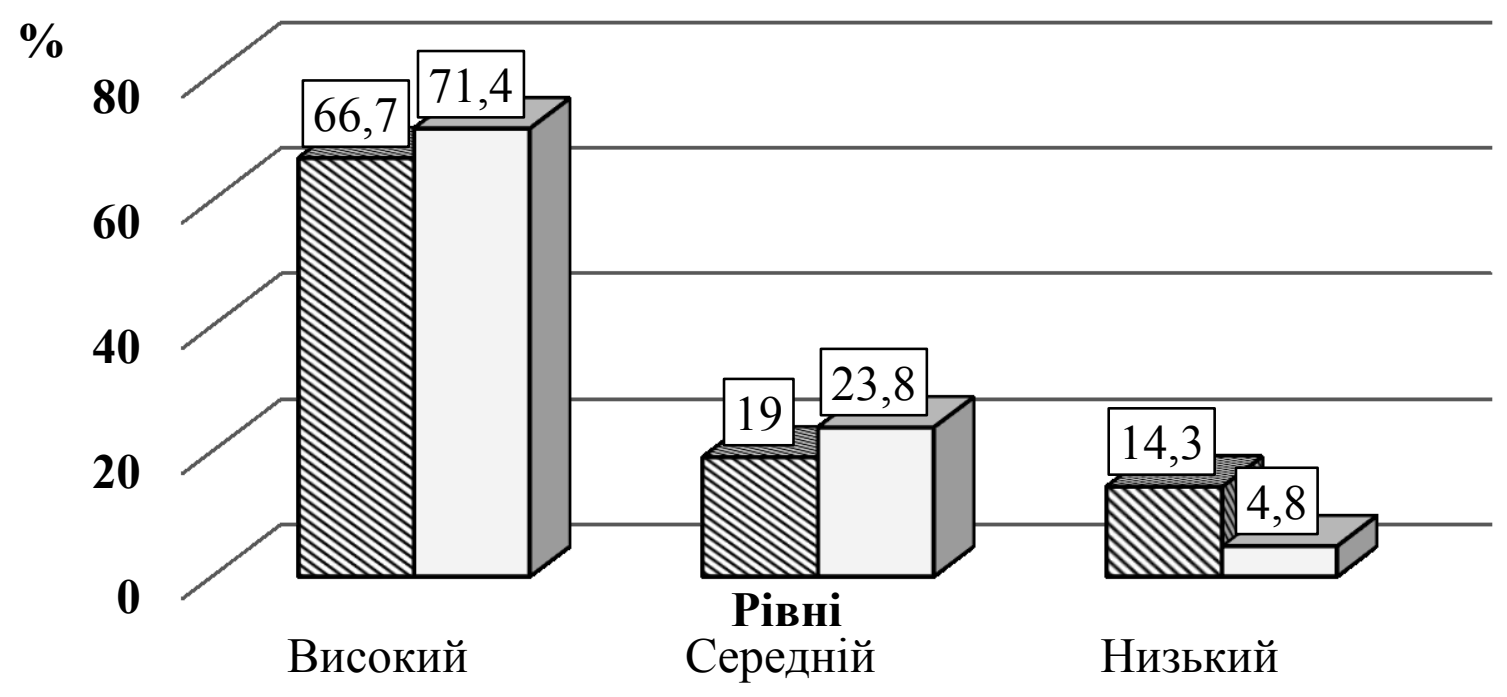

\section{च До експериментального впливу ШПісля експериментального впливу}

Рис. 3. Динаміка розподілу студентів за рівнями сфрормованості мотиваційно-цільового компоненту готовності студентів до розвитку творчого мислення молодших школярів до і після експериментального впливу

Сфрормованість мотиваційно-цільового компоненту готовності студентів до розвитку творчого мислення молодших школярів до експериментального впливу була у більшості студентів на високому рівні $(66,7 \%)$ проте, як видно 3 рис. 3. після експериментального впливу збільшилася кількість студентів з високим рівнем на 4,7\%, 3 середнім рівнем на 4,8, а студентів з низьким рівнем стало менше на 9,5 \%, що є свідченням дієвості експериментального впливу.

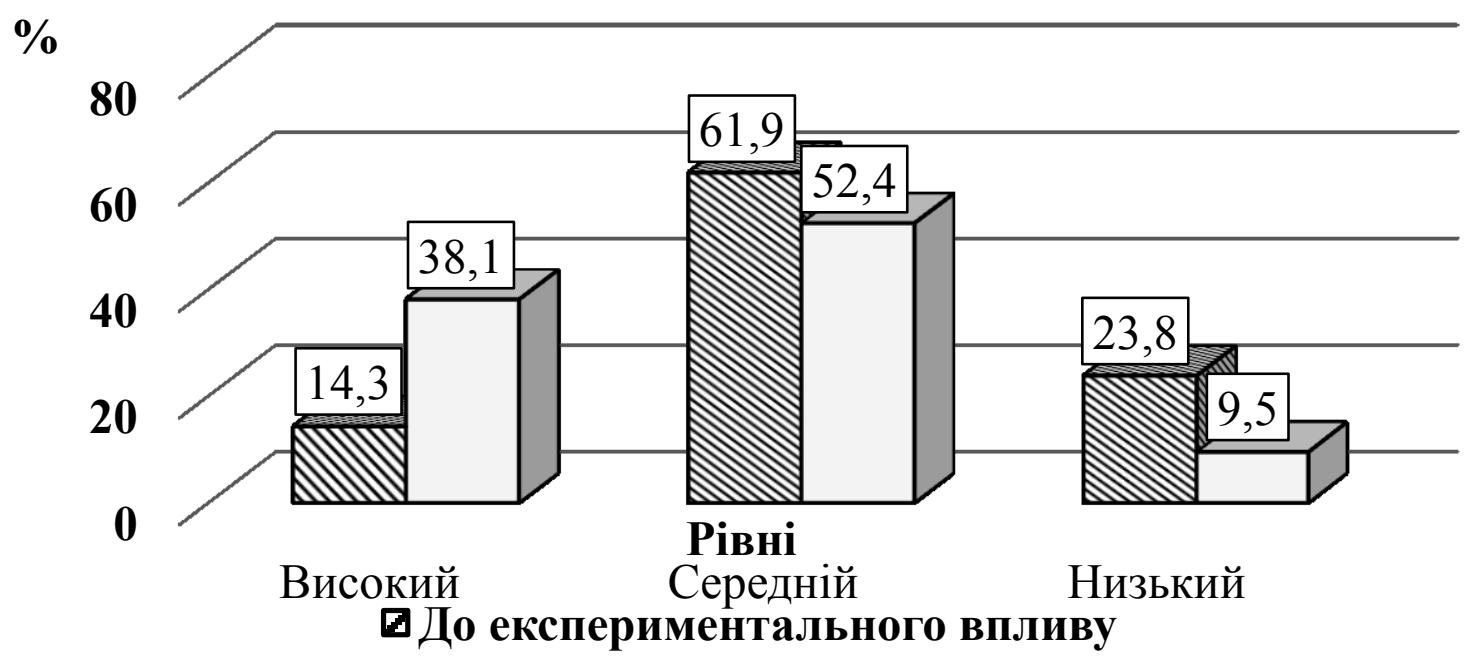

Рис. 4. Динаміка розподілу студентів за рівнями сформованості когнітивного компоненту готовності студентів до розвитку творчого мислення молодших школярів до і після експериментального впливу 
Для когнітивного компоненту готовності студентів до розвитку творчого мислення молодших школярів спостерігаються також позитивні зрушення. 3 рис. 4 бачимо, що студентів з високим рівнем сфрормованості когнітивного компоненту стало на 23,8 \% більше після експериментального впливу порівняно 3 їх кількістю до експериментального впливу, студентів з низьким рівнем сформованості розглядуваного компоненту стало менше на $14,3 \%$. Такі результати вказують на перехід студентів 3 нижчих рівнів сфрормованості когнітивного компоненту готовності студентів до розвитку творчого мислення молодших школярів на вищі, що вказує на ефективність визначених педагогічних умов фрормування готовності студентів до розвитку творчого мислення молодших школярів при вивченні математики.

Аналіз рисунка 5 свідчить про збільшення студентів з високим і середнім рівнями сфрормованості операційного компоненту готовності студентів до розвитку творчого мислення молодших школярів при вивченні математики відповідно на $19,1 \%$ і $4,7 \%$ і зменшення низького рівня на $23,8 \%$, що також підтверджує ефеективність фрормального впливу.

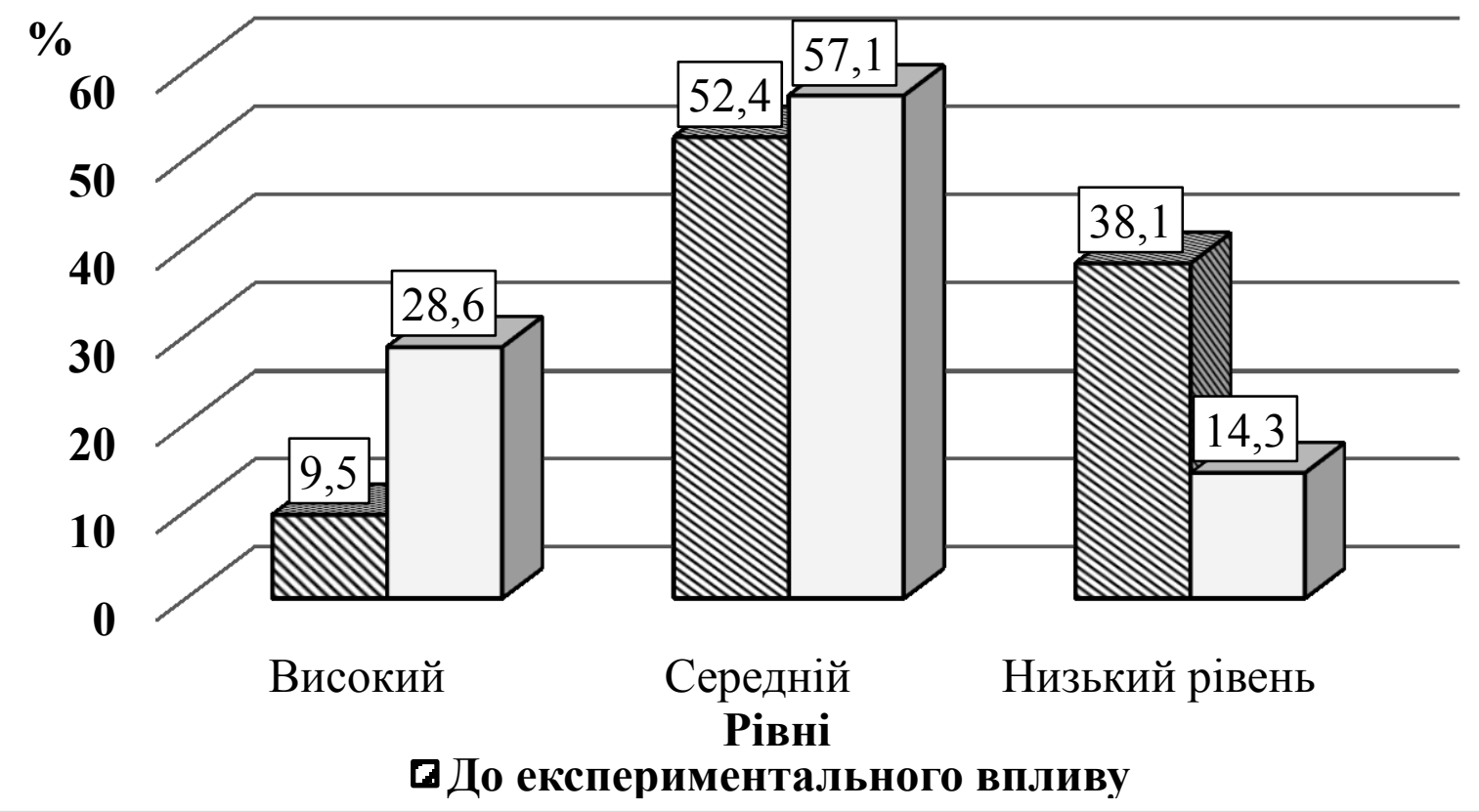

Рис. 5. Динаміка розподілу студентів за рівнями сфрормованості операційного компоненту готовності студентів до розвитку творчого мислення молодших школярів до і після експериментального впливу

Отже, підготовка майбутніх вчителів початкових класів до розвитку творчого мислення молодших школярів передбачає таку організацію освітнього процесу яка спрямована на вмотивування пізнавальної діяльності студентів, що досягається використанням когнітивних методів евристичного навчання. Окрім цього діяльність 
включає набуття студентами досвіду застосування методів, форм, завдань тощо, які $є$ засобом розвитку творчого мислення молодших школярів.

\section{Список використаних джерел}

1. Андреев В.И. Педагогика высшей школы. Инновационно-прогностический курс: учеб. пособие. Казань: Центр инновационных технологий, 2013. 500 с.

2. Архангельский С.И. Учебный процесс в высшей школе, его закономерные основы и методы. М.: Высш. шк., 1980. 368 с.

3. Брызгалова С.И. Проблемное обучение в начальной школе : учеб. пособие / Калининград. ун-т. [2-е изд.]. Калининград, 1998. 91 с.

4. Васько О.О. Когнітивні методи евристичного навчання в методикоматематичній підготовці майбутніх вчителів початкових класів: сутність, реалізація. Фізико-математична освіта : науковий журнал. Вип. 4 (14) / Сумський державний педагогічний університет імені А. С. Макаренка, Фізикоматематичний фракультет редкол. : О.В. Семеніхіна (гол.ред.) [та ін.]. Суми : [СумДПУ ім. А.С. Макаренка], 2017. С. 161-165.

5. Васько О. О. Методико-математична підготовка майбутніх вчителів початкових класів у контексті рефоормування початкової освіти. Навчання й виховання дітей дошкільного та молодшого шкільного віку у викликах сьогодення: [монографія] / за заг. ред. О.В. Лобової, І.П. Рогальської-Яблонської. Суми: ФОП Цьома С.П., 2018. С. 323-339.

6. Дидактика средней школы: Некоторые проблемы современной дидактики : учеб. пособие [для слушателей ФПК, директоров общеобразоват. школ и в качестве учеб. пособия по спец. курсу для студ. пед. ин-тов] / [под ред. М.Н. Скаткина]. [2-е изд.]. М. : Просвещение, 1982. 319 с.

7. Інтерактивні технології навчання: Теорія, досвід: метод. посіб. авт.- уклад.: О. Пометун, Л. Пироженко. К.: А.П.Н.; 2002. 136 с.

8. Комар О. Уроки математики - за інтерактивними технологіями. URL: http://dspace.udpu.org.ua:8080/jspui/bitstream/6789/378/1/urok_matematuku_za_in t.pdf.

9. Митник О.Я. Формування культури мислення молодшого школяра: теорія і практика: монографрія / Олександр Якович Митник. Тернопіль: Мандрівець, 2009. $400 \mathrm{c}$.

10. Подласый И. П. Педагогика. Новый курс : учеб. [для студ. высш. учеб. заведений] : в 2 кн. М. : Гуманитар. изд. центр ВЛАДОС, 2004. Кн. 1: Общие основы. Процесс обучения. 574 с.

11. Сучасний урок. Інтерактивні технології навчання: Наук.-метод. посібн. / О. І. Пометун, Л. В. Пироженко. За ред. О. І. Пометун. К. : Видавництво А.С.К., 2004. $192 \mathrm{c}$.

12. Теорія та практика змішаного навчання : монографія / за ред. В. М. Кухаренка. Харків: «Міськдрук», НТУ «ХП|», 2016. 284 с. 


\title{
СУЧАСНІ ПІДХОДИ ДО НАВЧАННЯ В МЕТОДИЧНІЙ СИСТЕМІ ФОРМУВАННЯ ПРАВОПИСНОЇ КОМПЕТЕНТНОСТІ МАЙБУТНІХ УЧИТЕЛІВ ПОЧАТКОВОї ШКОЛИ
}

\author{
Вітюк В. В. \\ кандидат педагогічних наук, доцент, \\ Східноєвропейський національний університет імені Лесі Українки
}

Сучасні вимоги до профресійної кваліфрікації конкурентноспроможного педагога передбачають мовно-мовленнєву компетентність у процесі професійної діяльності. Майбутні учителі початкової школи, з одного боку, усвідомлюють соціальне значення обраного фраху, уявляють перспективи його здобуття й власної самореалізації, що є першочерговим завданням закладів вищої освіти в контексті вимог Нової української школи та в умовах інтеграції в європейський освітній простір, а з іншого - можуть вільно самовиразитися літературною державною мовою в усній та писемній формі, аргументовано висловлювати власні думки, дотримуючись правописних норм сучасної літературної мови, стежити за власним мовленням і культурою спілкування оточення. Досягнути бажаного результату можна, на нашу думку, за умови врахування сучасних підходів до навчання української літературної мови, зокрема її правописної системи.

У методичній системі навчання правопису української мови виокремлюють компоненти, які взаємопов'язані між собою та утворюють цілісність, - мета й завдання, підходи до навчання, зміст, процес навчання, принципи, фрорми, методи, прийоми, засоби й результати навчання. Важливим для нашого дослідження $€$ аналіз i врахування основних дидактичних та лінгводидактичних підходів до навчання української мови 3 метою фрормування правописної компетентності в майбутніх учителів початкової школи, що базується на графрічних, орфографрічних, пунктуаційних уміннях і навичках. Підхід до навчання - одна з основних лінгводидактичних категорій, що посідає найвищий щабель з-поміж інших понять і реалізується через певні принципи, форми, методи. прийоми й засоби навчання.

Окреслена проблема хоч і має давню історію дослідження, проте набуває актуальності й у сучасних науково-методичних дослідженнях. У своїх працях її порушували чимало дидактів і лінгводидактів XX-XXI століть. Підходи до навчання української мови у закладах загальної середньої та вищої освіти розглянуто в дослідженнях 3. Бакум [3; 4], Л. Варзацької [9], М. Вашуленка [10], Н. Голуб [14; 15], О. Горошкіної [18; 19], Г. Дідук-Ступ'як [24], І. Дроздова [26], Л. Дружененко [28], С. Карамана [35], К. Климової [36], О. Копусь [39], 
І. Кучеренко [43], О. Кучерук [45], Г. Лещенко [47], Л. Мамчур [49], Л. Мацько [50], А. Нікітіної [55], М. Оліяр [59; 60], С. Омельчука [63], Н. Остапенко [64], М. Пентилюк [65; 66], О. Попова [70; 71], А. Попович [72], О. Потапенко [73], Л. Рускуліс [80], О. Семеног [83], І. Хом'яка [90; 91], Г. Шелехової [93] та ін.

Передусім уточнимо поняття «підхід» у лексикографрічних і лінгвометодичних дослідженнях. За Великим тлумачним словником, підхід це «сукупність, способів, прийомів розгляду чого-небудь, впливу на кого-, що-небудь, ставлення до кого-, чого-небудь [11, с. 969].

У педагогіці Г. Селевко трактує це поняття як методологічну орієнтацію вчителя, який спонукає до використання певної характерної сукупності взаємопов'язаних ідей, понять і способів педагогічної діяльності [82, с. 48], доводячи, що воно $€$ комплексним і до його складу входять три компоненти: основні поняття, що використовуються в процесі навчання; принципи як вихідні положення чи головні правила здійснення педагогічної діяльності; методи й прийоми структурування освітнього процесу [82, с. 48].

Н. Голуб переконує, що підхід - світоглядна категорія, яка «відображає соціальні настанови суб'єктів навчання як носіїв суспільної свідомості; як глобальна й системна організація й самоорганізація освітнього процесу; як стратегія навчання, що поєднує в собі методи, фрорми, прийоми навчання» [15, с. 2].

С. Омельчук трактує поняття «підхід» як найвищий щабель в ієрархії лінгводидактичних категорій, що об'єднує інші категорійні поняття. Учений розглядає «підхід» як методологічну категорію лінгводидактики, що позначає складне багатовимірне явище, системну сукупність якого становлять принципи, технології, методи, прийоми, засоби й форми навчання, яке характеризується концептуальністю, процесуальністю, системністю, керованістю й дієвістю [63, с. 3-4]. Дослідник спроектовує «підхід» на різні сфрери застосування: «підхід $€$ категорією фрілософською, підхід до навчання - терміном педагогічним, підхід до навчання мови - терміном методичним (лінгводидактичним)», а також подає класифікацію та предметний покажчик підходів до навчання української мови [63, с. 5-6]. С. Омельчук зауважує, що українська методична наука й практика оперує понад 40 видами підходів до навчання мови, які зазнають змін, оновлюються й удосконалюються та вимагають наукового обґрунтування й розроблення методичного супроводу для ефективного втілення їх у практику навчання. Підходи до навчання дослідник об'єднав у тематичні групи: 1) за способом суб'єктної організації навчальної діяльності (з погляду суб'єкта навчання мови) - діяльнісний, індивідуальний, компетентнісний, особистісний, особистісно орієнтований, особистісно діяльнісний підходи; 2) за способом організації засвоєння навчального матеріалу з мови - дедуктивний, диференційований, індуктивний, когнітивний, комунікативно- 
діяльнісний, системний, системно-лінгвістичний (системно-мовний); 3) за характером добору й подання лексико-граматичного матеріалу професійно спрямований, соціокультурний, текстоцентричний, текстоцентрично-дискурсивний, ффункційний, функційно-стилістичний; 4) за новизною - традиційні й інноваційні (дослідницький, компетентнісний, крос-культурний, аксіологічний, інтегрований, синергетичний (системно-синергетичний)) підходи [63, с. 7].

Студіювання наукових праць засвідчує різні трактування поняття підхід до навчання (рис. 1). Часто термін підхід до навчання ототожнюють із такими поняттями, як «технологія», «принцип», «тип навчання». Заслуговує на увагу думка Н. Голуб про те, що «...хаос у терміносистемі - явище досить типове, спричинене почасти несфрормованістю цілісного бачення ії у розрізі конкретної проблеми чи в загальнонауковому контексті. А отже, нерідко запуск у вжиток нового терміна здійснюється без усвідомлення його місця в ієрархії термінів» $[15$, с. 2].

Схема 1

\section{У психології}

I. Зимня: а) «світоглядна категорія, у якій відображено соціальні настанови суб'єктів навчання як носіїв суспільної свідомості; б) глобальна й системна організація і самоорганізація освітнього процесу, що містить усі його компоненти і передусім самих суб'єктів педагогічної взаємодії: учителя (викладача) i учня (студента)» [30, с. 75].

\section{У педагогіці}

Н. Бордовська: «Провідна наукова ідея, що лежить в основі організації вишівського освітнього процесу, ідея, яку дослідник розвиває, обгрунтовуючи можливі способи реалізації іiі на практиці» $[86$, с. 20$]$.

\section{Підхід до навчання}

\section{У лінгводидактиці}

Н. Голуб: «Загальна концептуальна позиція, що визначає системну організацію й самоорганізацію освітнього процесу, домінувальну ознаку, роль, статус та особливості взаємодії всіх компонентів його відповідно до конкретних навчальних і виховних цілей» $[15$, с. 5].

М. Пентилюк: «Спрямування, що визначають закономірності, методи, прийоми, засоби навчання [65, с. $18-19]$.

С. Омельчук: «Методологічна категорія лінгводидактики, що позначає складне багатовимірне явище, структурними компонентами якого є принципи, технології, методи, прийоми, засоби й форми навчання і якому властиві концептуальність, процесуальність, системність, керованість та дієвість» [62, с. 3].

Рис. 1. Погляди дослідників на поняття «підхід до навчання» 
Ми вважаємо, що найбільш ґрунтовно термін підхід до навчання висвітлено у наукових працях Н. Голуб, М. Пентилюк, С. Омельчука. У науковій розвідці ми будемо оперувати терміном «підхід до навчання української мови», або лінгводидактичний підхід. У межах нашого дослідження визначаємо лінгводидактичний підхід як провідну наукову ідею, опорну методичну категорію, що визначає систему навчання й способи організації навчального матеріалу, як системно-інтеграційний комплекс взаємопов'язаних принципів, форм, методів, прийомів навчання відповідно до конкретної освітньої мети - фрормування правописної компетентності майбутніх учителів початкової школи у контексті вирішення завдань Нової української школи.

Аналіз наукових праць засвідчив, що сьогодні в педагогіці й лінгводидактиці вищої школи немає єдиної класифікації підходів до навчання. Так, в «Українському педагогічному словнику» виокремлено індивідуальний, особистісний і системний підходи [17]. У підручниках із педагогіки представлено особистісний, діяльнісний, системний, гуманістичний, ресурсний, синергетичний, психологічний, аксіологічний, компетентнісний та ін. У підручнику «Методика навчання української мови в середніх освітніх закладах» за редакцією М. Пентилюк подано класифрікацію підходів: традиційних (лінгвістичний, педагогічний, психологічний, моральний, естетичний) та інноваційних (народознавчий, етнопедагогічний, культурологічний, діяльнісно-орієнтований та ін.) [52]. У «Словнику-довіднику з української лінгводидактики» наголошено на необхідності врахування під час навчання мови діяльнісного, когнітивно-комунікативного, компетентнісного, комунікативнодіяльнісного, особистісно орієнтованого, фрункційного, фрункційностилістичного підходів [85]. У поглядах лінгводидактів спостерігаємо різні класифікації видів підходів до навчання української мови (табл. 1).

Таблиця 1

\section{Погляди лінгводидактів на класифрікацію підходів} до навчання української мови

\begin{tabular}{|c|c|c|}
\hline Рік & Автор & Види підходів до навчання української мови \\
\hline 2005 & М. Пентилюк & 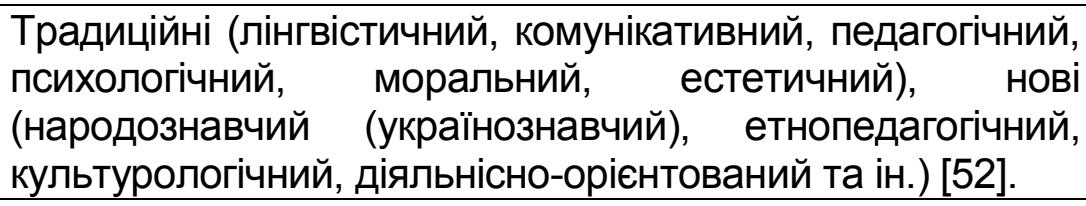 \\
\hline 2005 & О. Семеног & 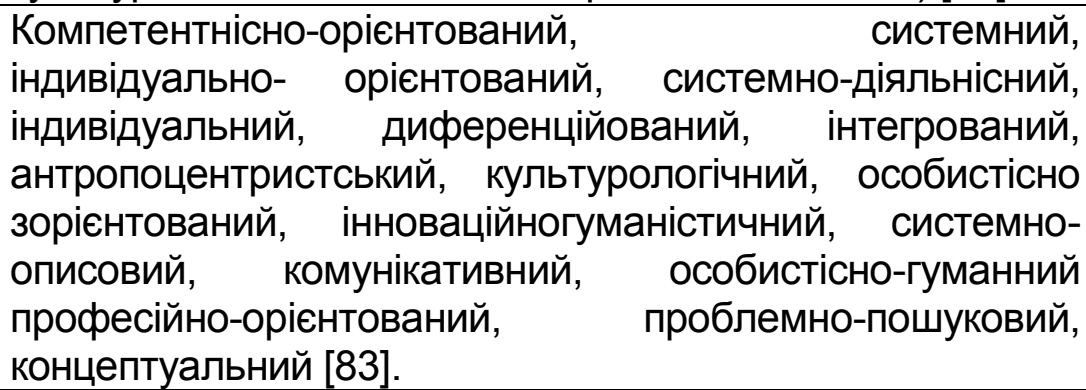 \\
\hline 2006 & О. Попова & Когнітивний, когнітивно-комунікативний [70]. \\
\hline
\end{tabular}




\begin{tabular}{|c|c|c|}
\hline 2008 & Н. Голуб & $\begin{array}{l}\text { Особистісно орієнтований, компетентнісний, діяльнісний } \\
\text { [13]. }\end{array}$ \\
\hline 2008 & Н. Остапенко & $\begin{array}{l}\text { Компетентнісно } \\
\text { технологічний [64]. }\end{array}$ \\
\hline 2008 & 3. Бакум & $\begin{array}{l}\text { Особистісно зорієнтований, компетентнісний, системний } \\
\begin{array}{l}\text { (системно-лінгвістичний), комунікативно-діяльнісний, } \\
\text { етнокультурологічний, } \\
\text { стилістичний [4]. }\end{array}\end{array}$ \\
\hline 2010 & І. Дроздова & $\begin{array}{l}\text { Когнітивно-комунікативний, професійно-орієнтований } \\
\text { компетентнісно-діяльнісний, прагматичний, гносео- } \\
\text { логічний, аксіологічний, комунікативний, текстоцент- } \\
\text { ричний [25]. }\end{array}$ \\
\hline 2010 & С. Караман & $\begin{array}{l}\text { лінгвістичний, етнокультурознавчий, } \\
\text { стилістичний і методологічний [35]. }\end{array}$ \\
\hline 2012 & О. Копусь & $\begin{array}{l}\text { Компетентнісний, особистісно-зорієнтований, суб'єктно } \\
\text { діяльнісний, комунікативно-діяльнісний [74].. }\end{array}$ \\
\hline 2012 & Л. Овсієнко & $\begin{array}{l}\text { Компетентнісний, комунікативний, українознавчий, } \\
\text { діяльнісно-орієнтований, текстоцентричний [56]. }\end{array}$ \\
\hline 2013 & О. Горошкіна & Креативний [19]. \\
\hline 2013 & Г. Шелехова & $\begin{array}{l}\text { Компетентнісний, } \\
\text { Комунікативно-діяльнісний, соціокультурний [93]. }\end{array}$ \\
\hline 2013 & А. Нікітіна & $\begin{array}{l}\text { Лінгводидактичний, суб'єкт-суб’єктний, психолінгвіс- } \\
\text { тичний, когнітивний, } \quad \text { функційно-стилістичний, } \\
\text { комунікативно-діяльнісний, риторичний, соціокуль- } \\
\text { турний, особистісний, компетентнісний, технологічний, } \\
\text { українознавчий, етнопедагогічний, культурологічний [55]. }\end{array}$ \\
\hline 2014 & С. Омельчук & $\begin{array}{l}\text { 1) за способом суб’єктої організації навчальної } \\
\text { діяльності (діяльнісний, індивідуальний, компетент- } \\
\text { нісний, особистісний, особистісно орієнтований, } \\
\text { особистісно діяльнісний підходи; 2) за способом } \\
\text { організації засвоєння навчального матеріалу з мови } \\
\text { (дедуктивний, диференційований, індуктивний, } \\
\text { когнітивний, комунікативно-діяльнісний, системний, } \\
\text { системно-лінгвістичний; 3) за характером добору й } \\
\text { подання лексико-граматичного матеріалу (професійно } \\
\text { спрямований, соціокультурний, текстоцентричний, } \\
\text { текстоцентрично-дискурсивний, функційний, функційно- } \\
\text { стилістичний); 4) за новизною (традиційні й інноваційні } \\
\text { (дослідницький, компетентнісний, крос-культурний, } \\
\text { аксіологічний, інтегрований, синергетичний (системно- } \\
\text { синергетичний)) підходи [62]. }\end{array}$ \\
\hline 2015 & $\begin{array}{l}\text { С. Караман, } \\
\text { О. Горошкіна, } \\
\text { 3. Бакум, } \\
\text { О. Караман, } \\
\text { О. Копусь }\end{array}$ & $\begin{array}{l}\text { Особистісний, компетентнісний, } \\
\text { контекстний, синергетичний, } \\
\text { діяльнісний, фоункційно-стилістичний, } \\
\text { дослідницький }[74] .\end{array}$ \\
\hline 2015 & М. Оліяр & $\begin{array}{l}\text { Когнітивний, крос культурний, комунікативно- } \\
\text { діяльнісний, системно-синергетичний, культурологічний, } \\
\text { особистісно-прагматичний [61]. }\end{array}$ \\
\hline 2015 & І. Кучеренко & $\begin{array}{l}\text { Компетентнісний, } \\
\text { орієнтований, діяльнісний [44]. }\end{array}$ \\
\hline 2016 & I. Нагрибельна & Особистісно зорієнтований, комунікативно діяльнісний, \\
\hline
\end{tabular}




\begin{tabular}{|c|c|c|}
\hline & & $\begin{array}{l}\text { компетентнісний, контекстний, дослідницький, текстово- } \\
\text { комунікативний, інтегративний, диференційований, } \\
\text { індивідуальний [54]. }\end{array}$ \\
\hline 2016 & Р. Дружененко & $\begin{array}{l}\text { Етнопедагогічний, } \\
\text { прагматично-діяльнісний, } \quad \text { когнітивний, фонально-прагматичний, } \\
\text { комунікативний, особистісно орієнтовй, } \\
\text { ричний, дискурсивний, текстоцентричний [27]. }\end{array}$ \\
\hline 2017 & М. Греб & $\begin{array}{l}\text { Компетентнісний, комунікативно-діяльнісний, особис- } \\
\text { тісно зорієнтований, системний, словоцентричний, } \\
\text { функційностилістичний, контекстний, проблемний, } \\
\text { соціокультурний текстоцентричний [20]. }\end{array}$ \\
\hline 2017 & Н. Грона & $\begin{array}{l}\text { Когнітивно-комунікативний, особистісно о орієнтований, } \\
\text { компетентнісний, системно-діяльнісний, текстоцент- } \\
\text { ричний [21]. }\end{array}$ \\
\hline 2018 & А. Попович & $\begin{array}{ll}\text { Особистісно зорієнтований (науково-дослідницький як } \\
\text { складник), діяльнісно-компетентнісний } \\
\text { зорієнтований як складник) [72]. }\end{array}$ \\
\hline 2018 & О. Кулик & $\begin{array}{l}\text { Ключові (особистісно орієнтований, компетентнісний), } \\
\text { допоміжні (функційно-стилістичний, комунікативно- } \\
\text { когнітивний, структурно-семантичний, соціокультурний } \\
\text { (або українознавчий), проблемний (або проблемно- } \\
\text { пошуковий), системний (або системно-мовний), дослід- } \\
\text { ницький, лінгвістичний, текстоцентричний та інші) [41]. }\end{array}$ \\
\hline 2018 & Л. Рускуліс & $\begin{array}{l}\text { Компетентнісний, } \\
\text { текстоцентричний, фрукнційно-стилісістичний [80]. }\end{array}$ \\
\hline 2019 & Т. Груба & $\begin{array}{l}\text { Особистісно орієнтований, комунікативно-діяльнісний, } \\
\text { комунікативно-функційний, когнітивно-комунікативний, } \\
\text { функційно-стилістичний, професійно спрямований [22]. }\end{array}$ \\
\hline
\end{tabular}

Із матеріалів таблиці постає очевидним, що найбільшу перевагу дослідники надають особистісно орієнтованому, компетентнісному та комунікативно-діяльнісному підходам до навчання української мови в закладах загальної середньої та вищої освіти. На нашу думку, саме інтеграція традиційних та інноваційних підходів може забезпечити об'єктивний результат сучасних наукових досліджень.

Необхідно відзначити, що кожен окремо взятий підхід $€$ якісно новим способом вивчення досліджуваного явища, але жоден із них не $€$ універсальним. Правописна компетентність майбутніх учителів початкової школи $€$ складним цілісним особистісним утворенням, всебічне дослідження якого неможливе засобами одного методологічного підходу. Лише комплекс підходів, на наше переконання, дасть змогу вийти за межі звичних стереотипів наукового мислення, всебічно проаналізувати реальну проблему, одержати об'єктивні дані щодо іiі сутності, визначити закономірності, принципи та стратегію вирішення, а це, у свою чергу, дозволить забезпечити належний профресійної рівень освіти.

Аналіз педагогічних і лінгводидактичних джерел дає підстави визначити низку підходів, що стали пріоритетними в процесі формування правописної компетентності майбутніх учителів 
початкової школи в площині мовознавчих дисциплін: компетентнісний, комунікативно-діяльнісний, когнітивно-комунікативний, особистісно орієнтований, системний, синергетичний, текстоцентричний, аксіологічний, соціокультурний.

У сучасній вищій освіті одним із пріоритетних підходів визначено компетентнісний, про необхідність урахування якого наголошують педагоги (І. Бех [6; 7], Н. Бібік [8], О. Локшина [48], О. Овчарук [58], О. Пометун [68], І. Родигіна [78], О. Савченко [81], В. Химинець [89] та ін.) й лінгводидакти (3. Бакум [4], Н. Голуб [14], О. Горошкіна [74], І. Дроздова [26], О. Караман [74], С. Караман [35], О. Копусь [39], Л. Овсієнко [57], Н. Остапенко [64], М. Пентилюк [65], О. Семеног [83], І. Хом'як [90; 91] та ін.).

Компетентнісний підхід представляє в освіті вищої школи перехід від етапу здобуття знань до етапу їх самореалізації, кінцевою метою якого $\epsilon$ усвідомлення значущості вибраного фраху, а його визначальними процесуальними ознаками, як уважає Н. Голуб, $є$ суб'єкт-суб'єктна співпраця учасників навчання; збагачення діяльнісного компонента; відповідальність здобувача освіти за якість виконаної роботи, його самонавчання й самовиховання; впровадження індивідуальних технологій і обґрунтоване прийняття нестандартних шляхів розв'язання завдань; використання прикладів із власного життя, проектування; диференціювання завдань і методів $[15$, с. $]$ ]. Науковець доводить, що в основі компетентнісного підходу - спільна, взаємозлагоджена праця викладача й студента, за якої перший координує й спрямовує освітній процес, є мотиватором, створюючи проблемні ситуації й демонструючи неординарні способи їх розв'язання, тим самим спонукаючи брати активну участь у процесі навчальної діяльності. Студент сприймає інформацію, аналізує й переробляє ії на основі окресленої проблеми, продукуючи власні думки й висловлюючи особисту позицію, яка не завжди збігається 3 поглядом педагога, обґрунтовує її. В основі компетентнісного підходу підготовка якісного фрахівця, який здобуває освіту протягом усього життя, самовдосконалюється в умовах швидкозмінного суспільства.

Модернізація вищої освіти вимагає сформувати модель фрахівця, затребуваного на ринку праці й спроможного працевлаштуватися [491, с. 19]. Ключовими поняттями цієї освітньої парадигми $є$ компетентності й очікувані результати навчання. Відтак, змінюються акценти 3 отримання знань на компетентнісний підхід до освіти, тому основним результатом здобуття вищої освіти стає формування компетентностей. Відповідно до «Методичних рекомендацій щодо розроблення стандартів вищої освіти» визначаються такі види компетентностей: інтегральна компетентність («здатність розв'язувати складні спеціалізовані задачі та практичні проблеми у певній галузі професійної діяльності або у процесі навчання, що передбачає застосування певних теорій та методів відповідної науки і 
характеризується комплексністю та невизначеністю умов [77, с. 13-14]; загальні компетентності, які не залежать від предметної галузі та обираються $з$ переліку проекту TUNING [77, с. 15-16]; спеціальні (фрахові, предметні) компетентності, які спрямовані на успішну підготовку фахівців за певною спеціальністю [77, с. 17]. Н. Голуб стверджує, що «в загальноосвітній школі формуємо предметні й ключові компетентності, а у вищій - професійні (загальнопрофесійні) й специфрічні [16, с. 105].

Єдиного підходу до структурних компонентів компетентності немає. Так, Н. Голуб виділяє ціннісно-мотиваційний, пізнавальний (когнітивний), емоційний, поведінковий [14], М. Пентилюк визначає складовими комунікативної компетентності мовну, мовленнєву, соціокультурну, діяльнісну [85], Н. Остапенко складовими чинниками лінгводидактичної компетентності називає мотиваційні, когнітивні, операційно-технологічні [64], М. Оліяр до комунікативно-стратегічної компетентності відносить ціннісно-мотиваційний, когнітивний (інформаційно-комунікативний), операційно-дієвий, рефлексивно-емпатійний, афрективний, фрактичний [61], Л. Мацько, Т. Груба, О. Семеног, Т. Симоненко до ключових і предметних компетентностей включають такі компоненти: когнітивний (знаннєвий), праксеологічний (діяльнісний), аксіологічний (ціннісний), інтерактивний (поведінковий) [50; 64].

У дослідженнях І. Ґудзик, І. Дроздової, А. Петрова та ін. висловлена думка про об'єднання компетентнісного й діяльнісного підходів, тому що оволодіння компетентностями неможливе без набуття досвіду діяльності (знання $\rightarrow$ уміння $\rightarrow$ навички $\rightarrow$ досвід практичної діяльності $\rightarrow$ компетентність) [23; 26; 67]. А. Петров наголошує, що діяльнісний підхід «закцентовує на результаті освіти, до того ж результатом вважається не сума засвоєної інформації, а здатність людини ефрективно діяти в різних проблемних ситуаціях» [67]. І. Дроздова пропонує об'єднати компетентнісний та діяльнісний підходи, оскільки «сутність такого підходу полягає в тому, що оновлений зміст освіти буде основою фрормування компетентностей (або комплексу компетентностей) студентів, а процес засвоєння відібраного змісту матиме діяльнісний характер» [26, с. 143]. Н. Іваницька зауважує, що «за такого підходу до мовної освіти той, хто навчається, має діяти як мовець, а для цього він повинен бути здатним виконувати певну послідовність дій у різних видах рецептивної і продуктивної мовленнєвої діяльності на рівні вмінь» [33, с. 27].

Комунікативно-діяльнісний підхід є одним із провідних у мовній освіті, що забезпечує усвідомлену реалізацію комунікативної фрункції мови. Він полягає в такій організації навчання, коли засвоєння мови відбувається безпосередньо в процесі комунікативної (реальної чи модельованої) діяльності 3 метою оволодіння комунікативними вміннями і навичками [85]. Комунікативно-діяльнісний підхід спрямований на формування комунікативної компетентності - здатності 
користуватися мовою залежно від конкретної ситуації спілкування. М. Пентилюк стверджує, що комунікативно-діяльнісний підхід «передбачає врахування: 1) потреби у спілкуванні; 2) мотивів акту спілкування; 3) обставин, за яких здійснюється комунікація» [85, с. 47].

I. Кухарчук розглядає комунікативно-діяльнісний підхід до вивчення мови як «цілеспрямовану, суб'єкт-суб'єктну організацію навчального процесу, основою якого $€$ комунікативна діяльність студентів, що зорієнтована на вивчення мови в динамічному аспекті мовотворення, дослідження мовних одиниць в умовах мовленнєвого акту, встановлення відмінностей функціонування засобів мови в різних ситуаціях спілкування» [42, с. 9].

Комунікативно-діяльнісний підхід вимагає від викладача створення таких умов під час опрацювання правописного матеріалу, які б спонукали студентів спілкуватися, доводити свої переконання, впливати на позиції учасників комунікації, враховуючи мотиви, умови, обставини, за яких здійснюється комунікація, кількість комунікантів, їхні вікові, соціальні та психологічні особливостей. Форма подання теоретичних відомостей 3 правопису та їх опрацювання за комунікативно-діяльнісним підходом орієнтує студентів не стільки на запам'ятовування, скільки на усвідомлене засвоєння способів застосування теорії в мовленнєвій діяльності.

Комунікативно-діяльнісний підхід знаходить своє відображення в теорії мовленнєвої діяльності (створення тексту), тому він тісно пов'язаний із текстоцентричним, який, на думку М. Пентилюк, О. Петрук, Г. Шелехової, має дещо вужчий дидактичний діапазон, ніж комунікативно-діяльнісний [93, с. 33].

Основою когнітивно-комунікативного підходу $є$ положення Загальноєвропейських рекомендацій з мовної освіти, де визначено підходи до навчання мови; рівні володіння мовою; розвиток комунікативних мовленнєвих компетенцій (комунікативні складники) на основі різних контекстів, для яких характерна когнітивна організація й спосіб зберігання (когнітивні складники) [29, с. 164-165]; Концепція мовної освіти, в якій заявлено, що «в Україні функціонує система неперервної мовної освіти, підкріплена виваженою мовною політикою держави, спрямованою на досконале володіння рідною мовою кожним ії носієм, обов'язкове оволодіння державною українською мовою всіма громадянами» [38]; концептуальні засади когнітивної й комунікативної методики (М. Пентилюк, О. Горошкіна, А. Нікітіна), де визначено, що «мова існує в свідомості людей і реалізується в мовленні $\langle.$.$\rangle , доля$ мови залежить від її носіїв» [65, с. 18].

Оскільки важливою умовою комунікативно-діяльнісного підходу $є$ діяльність особистості загалом і комунікативної зокрема, то це зумовлює його тісний зв'язок із особистісно орієнтованим підходом, в центрі якого постає студент як особистість, унікальна індивідуальність, що має право на повагу, моральну й інтелектуальну свободу, розвиток 
природних здібностей, творчого потенціалу, здатності до самовдосконалення і самоосвіти.

Особистісно орієнтований підхід базується на положеннях, які сорормувалися завдяки працям I. Беха [6], С. Гончаренка [17], І. Зязюна [31], Г. Костюка [40], О. Леонтьєва [46], С. Рубінштейна [79], І. Якиманської [94] та ін. У цих дослідженнях особистість сприймається як джерело соціально значущої діяльності. У наш час особистісно орієнтований підхід розглядається як методична основа для гармонійного та всебічного розвитку особистості в умовах сучасної системи освіти. Ми поділяємо думку І. Зязюна про те, що «смислом і ціллю освіти $є$ Людина в постійному (впродовж життя) розвитку. Кінцевий результат освіти - внутрішній стан людини на рівні потреби пізнавати нове, здобувати знання, виробляти матеріальні і духовні цінності, допомагати ближньому, бути добротворцем. Вищий результат освіти - духовний стан нації, зростання національної самосвідомості, коли в суспільстві існують ідеї, які мають загальний інтерес і можуть бути доступними для кожного громадянина» [32, с. 22-23].

Вихідні положення особистісно орієнтованого навчання визначила І. Якиманська, виділивши такі основні компоненти: 1) усвідомлення особистості учня як суб'єкта пізнавальної й предметної діяльності; 2) забезпечення кожному учневі (з огляду на його здібності, нахили, інтереси, ціннісні орієнтації та суб'єктивний досвід) можливостей реалізувати себе в різних видах діяльності; 3) зміст освіти, її засоби й методи організовуються так, щоб учень міг вибирати предметний матеріал, його вид і форму; 4) освіченість як сукупність знань, умінь, індивідуальних здібностей $є$ важливим засобом становлення духовних та інтелектуальних характеристик учня і має бути основною метою сучасної освіти; 5) освіченість фрормує індивідуальне сприйняття світу, можливості творчого вдосконалення його, широке використання суб'єктного досвіду в інтерпретації й оцінюванні фрактів, явищ, подій навколишньої дійсності на основі особистісно значущих цінностей і внутрішніх настанов; 6) найважливішими чинниками особистісно орієнтованого навчального процесу $\epsilon$ ті, що розвивають індивідуальність учня, створюють умови для його саморозвитку й самовираження; 7) особистісно орієнтоване навчання будується на принципі варіативності [94].

3 огляду на те, що в аспекті особистісно орієнтованого навчання в центрі процесу за метою, змістом і формами організації постає студент як особистість, то саме студент є визначальним у виборі на способи висвітлення мовної теорії, добір засобів, вибір методів і прийомів, що відбувається крізь призму особистості студентів, їх потреб, мотивів, рівня інтелекту, здібностей, шкільної мовної підготовки і т. ін.

У контексті нашого дослідження особистісно орієнтований підхід передбачає визначення процесу формування правописної компетентності майбутніх учителів початкової школи 3 позиції 
спрямування на особистісний розвиток студента засобами навчальної діяльності, з урахуванням індивідуальних психологічних особливостей кожного студента, його потенційних здібностей до навчання, прагнення до самовдосконалення. В особистісному аспекті цей підхід передбачає розроблення для кожного студента індивідуальної (особистої) траєкторії фрормування графрічних умінь і навичок, удосконалення орфографрічної та пунктуаційної грамотності.

В основі системного підходу покладено поняття «система», тому для розкриття сутності системного підходу необхідно уточнити розуміння дефініції «система». У сучасних довідникових джерелах система трактується як ціле, складене з частин; з'єднання; безліч елементів, що перебувають у відносинах і зв'язках один з одним, які утворюють певну цілісність, єдність [11].

Найбільш повно розуміння системного підходу і його аналіз представлений в роботах В. Афанасьєва, який визначив систему як сукупність об'єктів, взаємодія яких викликає появу нових інтегративних якостей, невластивих окремо взятим [1, с. 30], та окреслив взаємозалежні аспекти, що в сукупності та єдності складають системний підхід. Такими аспектами, на думку вченого, є: 1) системноелементний, що відповідає на запитання, з чого (яких елементів, компонентів) утворена система; 2) системно-структурний, який розкриває внутрішню організацію системи через спосіб взаємодії утворюючих ії компонентів; 3) системно-функціональний показує, які функції виконує система та компоненти, що її утворюють; 4) системнокомунікаційний розкриває взаємозв'язок даної системи з іншими по горизонталі і по вертикалі; 5) системно-інтегративний, що показує механізми, фрактори збереження, удосконалення і розвитку системи; 6) системно-історичний (еволюційний) відповідає на запитання як, яким чином виникла система, які етапи проходила у своєму розвитку, які її історичні перспективи [1, с. 43-55].

Системний підхід надає можливість сприймати і досліджувати процес формування правописної компетентності майбутніх учителів початкової школи як систему, єдине ціле в усій її складності, з усіма зв'язками і змінами, дає можливість структурувати цей процес й виділяти в ньому складові компоненти, їх системоутворювальні зв'язки і відносини; визначати, що в системі $є$ стійким, а що змінним, головним і другорядним. Ефективність і доцільність системного підходу у дослідженні фрормування правописної компетентності майбутніх учителів початкової школи полягає у тому, що він дозволяє схарактеризувати його як самостійну, відкриту багатокомпонентну цілісну систему, яка постійно розвивається і змінюється під впливом лінгвістичних і лінгводидактичних чинників.

Досвід викладання у закладі вищої освіти, достовірна інформація, зібрана під час проведення моніторингу якості правописної грамотності майбутніх учителів початкової школи в університетах України, аналіз 
отриманих показників свідчать про те, що той комплекс знань, який визначається навчальними планами 3 фахових фрілологічних дисциплін, не завжди системно відтворюється у свідомості більшості студентів педагогічних факультетів. Студенти, на жаль, не володіють цілісною системою філологічних знань. Однією із причин вважаємо те, що досить часто лінгвістичний матеріал подається фрагментарно, несистемно, відповідно студенти не володіють на належному рівні теоретичною базою знань i не можуть, або не намагаються, застосовувати їх практично. У таких випадках ми маємо несистемність знань, тому не варто сподіватися, що відомості з курсів «Сучасна українська мова з практикумом», «Українська мова (за професійним спрямуванням)», «Практикум 3 українського правопису» будуть засвоєні на високому рівні, тобто набуті студентами як якісні профресійні вміння та навички. Таким чином, системність знань $є$ головною умовою, що забезпечує результат цілісного засвоєння професійно важливих для студентів педагогічних факультетів знань, формування лінгвістичних умінь і навичок та правописної компетентності зокрема. Пропонуємо модель системного підходу формування правописної компетентності майбутніх учителів початкової школи (рис. 2.1).

3 позиції синергетики будь-яке природне чи соціальне явище можна розглядати як самоорганізовану, цілісну систему, що здатна переходити від хаосу до впорядкованості всіх елементів. Синергетика наповнює новим змістом поняття хаосу як деякої надскладної впорядкованості, що існує неявно, потенційно, і може проявитися у великому багатоманітті впорядкованих структур [84, с. 213]. Аналіз наукових праць (Б. Гершунський [12], В. Кремень [84], І. Пригожин [75], А. Урсул [87], Г. Хакен [88], О. Чалий [92] та ін.) свідчить, що синергетика допомагає зрозуміти, як виникають нові ідеї, знання, досвід як в окремої особистості, так і в групи. Синергетичний підхід орієнтує на зміну характеру взаємодії дослідника й учасників експериментальної роботи. Дослідник не протистоїть педагогічній системі як чомусь зовнішньому, а перетворюється у відповідний суб'єкт (частину) системи, на яку він впливає. Дослідник, що працює із системними педагогічними об'єктами (суб'єктами), в які він сам не включений, не тільки трансформує ці об'єкти, але й змінює свої власні зв'язки й функції [82, с. 264].

Синергетичний підхід дозволяє розглядати процес формування правописної компетентності майбутніх учителів початкової школи як систему, що є відкритою і здатною до самоорганізації і саморозвитку.

3 позиції синергетики будь-яке природне чи соціальне явище можна розглядати як самоорганізовану, цілісну систему, що здатна переходити від хаосу до впорядкованості всіх елементів. Синергетика наповнює новим змістом поняття хаосу як деякої надскладної впорядкованості, що існує неявно, потенційно, і може проявитися у великому багатоманітті впорядкованих структур [84, с. 213]. 


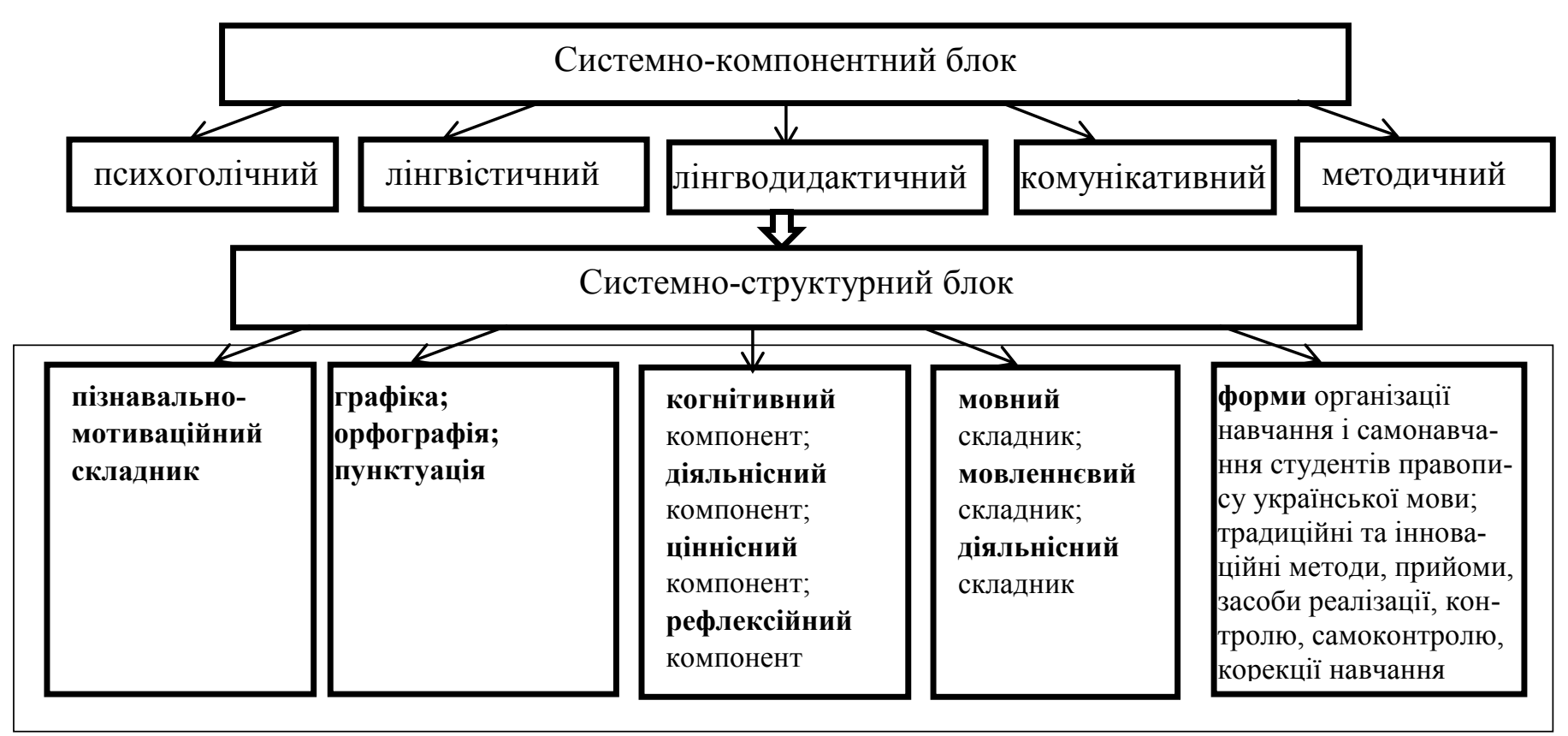

\section{$\sqrt{3}$}

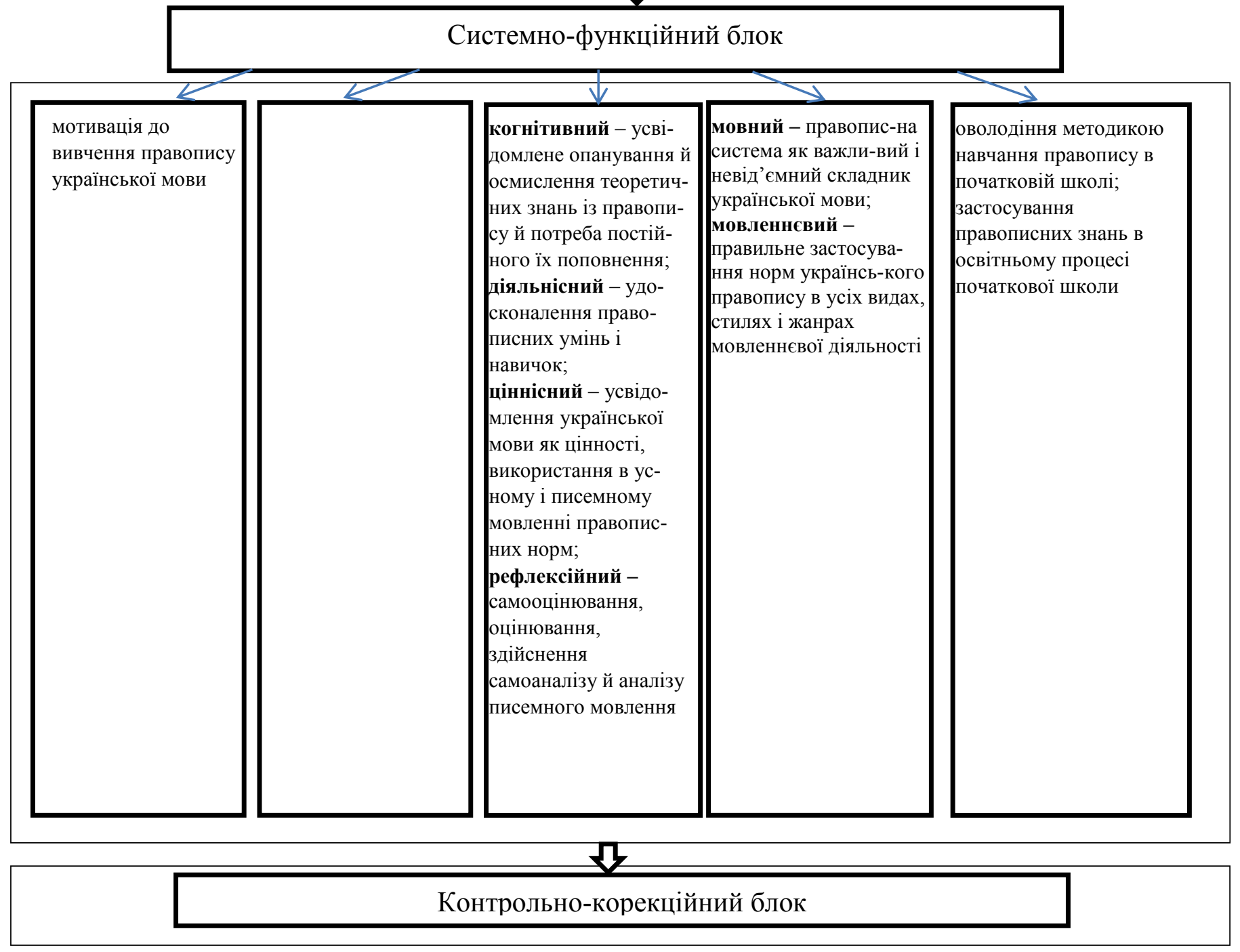

Рис. 2.1. Модель системного підходу формування правописної компетентності майбутніх учителів початкової школи 
Аналіз наукових праць (Б. Гершунський [12], В. Кремень [84], І. Пригожин [75], А. Урсул [87], Г. Хакен [88], О. Чалий [92] та ін.) свідчить, що синергетика допомагає зрозуміти, як виникають нові ідеї, знання, досвід як в окремої особистості, так і в групи. Синергетичний підхід орієнтує на зміну характеру взаємодії дослідника й учасників експериментальної роботи. Дослідник не протистоїть педагогічній системі як чомусь зовнішньому, а перетворюється у відповідний суб'єкт (частину) системи, на яку він впливає. Дослідник, що працює із системними педагогічними об'єктами (суб'єктами), в які він сам не включений, не тільки трансформує ці об'єкти, але й змінює свої власні зв'язки й фрункції [82, с. 264].

Синергетичний підхід дозволяє розглядати процес формування правописної компетентності майбутніх учителів початкової школи як систему, що є відкритою і здатною до самоорганізації і саморозвитку.

Синергетичний підхід пояснює механізм формування правописної компетентності майбутніх учителів початкової школи 3 позиції можливостей самих студентів і вимагає розглядати цей процес як відкриту систему, здатну до самоорганізації. Відповідно до визначеного підходу самоорганізація у формуванні правописної компетентності майбутніх учителів початкової школи відбувається через взаємодію і взаємний обмін інформацією учасників освітнього процесу між собою; активну синергетичну ініціативу студентів, їх прагнення до самовдосконалення, самореалізації, підвищення ефрективності профресійної підготовки; здатності педагогічної системи забезпечувати шляхи формування правописної компетентності студентів без примусу, натисків ззовні, тобто через діалогічну взаємодію суб'єктів освітнього процесу, зорієнтованість на їх творчий саморозвиток.

Дослідники сучасної методики навчання української мови (3. Бакум [3], Л. Варзацька [9], М. Вашуленко [10], Н. Голуб [13], О. Горошкіна [74], Л. Мамчур [49], Л. Мацько [50], В. Мельничайко [51], А. Нікітіна [55], М. Пентилюк [66], К. Пономарьова [69] та ін.) надають перевагу текстовій основі навчання мови, тому що текст $є$ не лише засобом долучення здобувачів освіти до матеріальної й духовної культури українського народу, його історії, звичаїв, розвитку духовного світу особистості, її національної свідомості, а на основі тексту як комунікативної одиниці мови пізнаються мовні явища та засоби, формується система мовних понять, а відтак і комунікативна компетентність, оскільки мовна теорія засвоюється не у вигляді окремих понять і правил, а цілісно в практично-діяльнісній формі на основі дібраних навчальних текстів, різноаспектній роботі з текстами та побудові на їх основі власних висловлень різних типів, стилів і жанрів мовлення.

3. Бакум вважає, що текстоцентричний підхід може реалізовуватися в таких напрямках: текст є засобом пізнання мови як поліфункційного явища; текст $є$ найважливішим засобом долучення до української культури; текст $€$ мовленнєвим витвором, результатом 
використання системи мови, оскільки на його засадах вивчається мова в дії; текст - основний засіб оволодіння усними й писемними формами українського мовлення, мовленнєвою діяльністю в усіх її видах (читання, говоріння, аудіювання, письмо), на його основі формується комунікативна компетентність; текст є засобом створення ситуацій, на основі яких здійснюється реальне спілкування [3, с. 85]. Робота 3 текстом містить декілька аспектів: аналіз готових (зразкових) текстів, робота 3 науковим текстом підручника та побудова власних висловлювань різних типів, стилів та жанрів мовлення. На сучасному етапі виокремлюють такі функції тексту: текст як дидактична одиниця, мовна одиниця, одиниця культури та мінімальна одиниця спілкування, текст як дискурс [49, с. 227]. Знання про текст засвоюються у процесі вивчення шкільного курсу української мови, в університеті поглиблюються на спецкурсах і спецсемінарах.

Текстоцентричний підхід передбачає використання тексту як основного дидактичного матеріалу, засобу засвоєння мови, створення власних висловлень (текстів) у конкретній мовленнєвій діяльності. Робота з текстом охоплює два аспекти: аналіз готових текстів i створення власних висловлень різних типів, стилів і жанрів мовлення. Майбутні учителі початкової школи повинні вміти аналізувати, інтерпретувати, досліджувати і створювати різностильові тексти змістовно глибоко й аргументовано, структурно чітко й послідовно, дотримуючись пунктуаційних і орфографрічних норм сучасної української літературної мови.

3 погляду педагогічних досліджень аксіологічний підхід спрямовує особистість на осмислення значущих цінностей, на їх вибір, що в перспективі будуть відповідати ії̈ інтересам, меті, імпонуватимуть майбутній професійній діяльності. На думку В. Ільїна, аксіологічний підхід розкриває цінності «як сутнісні сили особистості, їі інтелектуальний, моральний, творчий потенціал, що виражається в здатності вільно орієнтуватися в складних соціальних і професійних ситуаціях, обирати та здійснювати інноваційні процеси» [34, с. 101].

Аксіологічний підхід дозволяє розглядати фрормування правописної компетентності майбутніх учителів початкової школи крізь призму ціннісно-смислового ставлення особистості до правопису української мови як обов'язкової норми кожного свідомого громадянина, тому завданням закладу вищої освіти $€$ підготовка фахівців, які добре володіють нормами писемного мовлення.

Рівень правописної грамотності $€$ показником загальної культури особистості, яка не може існувати поза соціальним середовищем. Будь-яке суспільство неоднорідне за своїм складом: соціальним статусом людей, належністю їх до різних профресій, географрічним розташуванням населення, рівнем освіти, культури, економіки тощо. Відповідно зміни соціальної належності відображаються у мові, у тому числі й правописі, а відтак, і у мовленні студентів - еліти нації, носіїв мовної норми на всіх рівнях, які повинні вміти відтворювати на письмі 
загальновживані та нові, запозичені лексеми відповідно до норм чинного правопису, крім того, мовнокультурна освіченість майбутніх учителів початкової школи передбачає вироблення потреби вдосконалювати власне мовлення, збагачувати словник, підвищувати правописну грамотність.

Важливим у процесі фрормування правописної компетентності майбутніх учителів початкової школи є соціокультурний підхід, який зорієнтовує студентів на цілісне уявлення про мову як національнокультурний, соціальний феномен. Змістове наповнення соціокультурного підходу Г. Шелехова вбачає у «трансформації відомостей 3 мови, літератури, історії та інших предметів, власного життєвого досвіду в особистісно неповторний погляд на життя, у переконання, світоглядні установки, ідеали, у знання культурних реалій, які забезпечують органічне входження в суспільство, визначення свого місця в ньому, реалізацію потенційних можливостей особистості» [93, с. 34]. Для цього ретельно добираються тексти, спрямовані на формування патріотичних, морально-етичних, екологічних переконань та естетичних смаків, на розширення інтелектуального світобачення, власного життєвого досвіду студентів, на реалізацію потенційних можливостей особистості в суспільстві.

В основу застосування соціокультурного підходу покладено розуміння того, що становлення правописної компетентності майбутніх учителів початкової школи неможливе без урахування рівня духовної, інтелектуальної та особистої культури, поваги до рідної мови, соціальних умов, комунікативного середовища, в якому виріс i сорормувався чи в майбутньому працюватиме студент.

Отже, майбутні учителі початкової школи, 3 одного боку, усвідомлюють соціальне значення обраного фаху, уявляють перспективи його здобуття й власної самореалізації, що $€$ першочерговим завданням закладів вищої освіти в контексті вимог Нової української школи та в умовах інтеграції в європейський освітній простір, а 3 іншого - можуть вільно самовиразитися літературною державною мовою в усній та писемній формі, аргументовано висловлювати власні думки, дотримуючись правописних норм сучасної літературної мови, стежити за власним мовленням і культурою спілкування оточення. Досягнути бажаного результату можна, на нашу думку, за умови врахування лінгводидактичних підходів до навчання сучасної української літературної мови, зокрема ії̈ правописної системи. Складність і багатогранність формування правописної компетентності майбутніх учителів початкової школи обумовлює необхідність використання сукупності лінгводидактичних підходів, що забезпечують отримання об'єктивної, достовірної інформації і дозволяють створити цілісну картину визначеної лінгводидактичної проблеми, окреслити принципи та стратегію їі вирішення, щоб забезпечити належний профресійної рівень мовної освіти.

Застосування названих аспектів для профресійно спрямованої 
мовознавчої підготовки студентів педагогічної спеціальності, на наш погляд, $є$ цілком доречним, оскільки тоді процес навчання стане більш ефективним і професійно зорієнтованим, у ньому буде максимально враховано наукові та професійні потреби майбутнього фрахівця Нової української школи, міжпредметні зв'язки між лінгвістичними й фаховими дисциплінами, що відповідно зумовить пошук нових підходів до навчання мовознавчих дисциплін у сучасних закладах вищої освіти.

Підходи до навчання в методичній системі формування правописної компетентності майбутніх учителів початкової школи реалізуються через відповідні принципи навчання, добір оптимальних методів і прийомів вивчення правопису української мови.

\section{Список використаних джерел}

1. Афранасьєв В. Г. Системность и общество. М.: Политиздав, 1980. 368 с.

2. Бабич Н. Д. Основи культури мовлення. Львів: Світ, 1990. 232 с.

3. Бакум 3. П. Текстоцентризм у сучасній системі принципів навчання української мови. Зб. наук. пр. Педагогічні науки. Херсон : ХДУ, 2006. Вип. 47. С. 85-91.

4. Бакум 3. П. Теоретико-методичні засади навчання фонетики української мови в гімназії: монографія. Кривий Ріг: Видавничий дім, 2008. 338 с.

5. Батищев Г. С. Особенности культуры глубинного общения. Вопросы философрии. 1995. № 3. С. 109-129.

6. Бех І. Д. Особистісно орієнтоване навчання: науково-методичний посібник. Київ: Видавництво Інституту змісту і методів навчання, 1998. 204 с.

7. Бех І.Д. Компетентнісний підхід у сучасній освіті. Педагогіка вищої школи : методологія, теорія, технологія. Київ : Генезис, 2009. С. 21-24

8. Бібік Н. М., Вашуленко М. С., Мартиненко В.О. Формування предметних компетентностей в учнів початкової школи : монографія. Київ : Педагогічна думка, 2014. 346 с.

9. Варзацька Л. Особистісно зорієнтоване навчання української мови в старшій школі. http://litmisto.org.ua/. (дата звернення 10.06.2019).

10. Вашуленко М. С. Українська мова і мовлення у початковій школі. Київ : Освіта, 2018.

11. Великий тлумачний словник сучасної української мови (з дод. і доп.) / уклад. i голов. ред. В. Т. Бусол. К.; Ірпінь: ВТФ «Перун», 2005. 1728 с.

12. Гершунский Б. С. Готово ли современное образование ответить на вызовы XXI века? Педагогика. 2001. № 10. С. 3-12.

13. Голуб Н. Б. Риторика у вищій школі : монографрія. Черкаси : Брама-Україна, 2008. $408 \mathrm{c}$.

14. Голуб Н. Б. Ознаки компетентності мовної особистості учня. Вісник Прикарпатського університету. Педагогіка. Івано-Франківськ, 2013. Вип. XLVIII. C. 114-120.

15. Голуб Н. Підходи до навчання української мови в основній школі. Українська мова і література в школі. 2015. № 3. С 2-10.

16. Голуб Н. Б. Термінологічна система української лінгводидактики: особливості становлення і проблеми функціювання. Наукові записки Національного університету «Острозька академія». Серія «Філологічна». Острог, 2017. Вип. 68. C. 104-108.

17. Гончаренко С. Український педагогічний словник. К.: Либідь, 1997.

18. Горошкіна О. М. Лінгводидактичні засади навчання української мови в старших класах природничо-математичного профрілю. Монографія. Луганськ : Альмаматер, 2004. 362 c.

19. Горошкіна О. М. Шляхи формування креативності майбутніх учителів 
української мови. Науковий вісник Донбасу: електронне наукове фрахове видання, 2013. № 2. URL: http://nbuv.gov.ua/UJRN/nvd_2013_2_17.

20. Греб М. М. Теоретичні засади навчання лексикології і фразеології майбутніх учителів початкових класів: монографрія. Київ: Центр учбової літератури, 2017. $320 \mathrm{c}$.

21. Грона Н. В. Підготовка студентів педагогічних коледжів до фрормування у молодших школярів текстотворчих умінь: монографрія. Ніжин: ПП Лисенко М. М., 2017. 592 с.

22. Груба Т. Сучасні підходи до формування мовної особистості учнів на уроках української мови (профрільний рівень). Науковий вісник МНУ імені В. О. Сухомлинського. Педагогічні науки. 2019. № 1 (64). С. 65-71.

23. Ґудзик І. П. Компетентнісно орієнтоване навчання російської мови у початкових класах (у школах з українською мовою навчання): автореф. дис. ... канд. пед. наук: 13.00.02 «Теорія та методика навчання (російська мова)». Київ, 2008. 42 c.

24. Дідук-Ступ'як Г. І. Філософрсько-методологічні орієнтири лінгвометодичної технології «Інтеракція різнотипових підходів» до вивчення української мови. Теоретико-практичні аспекти сучасних лінгвістичних та лінгводидактичних парадигм: матеріали Всеукраїнської науково-практичної конференції: зб. наук. пр. Рівне - Острог : Вид-во НУ «Острозька академія», 2012. С. 80-86.

25. Дроздова І. П. Наукові основи формування українського професійного мовлення студентів нефрілологічних фракультетів ВНЗ: монографрія. Харків: ХНАМГ, 2010. 320 c.

26. Дроздова І. П. Зміст та основні підходи до навчання української мови як основи фрормування професійної компетентності студентів нефілологічного профрілю вищої школи. Наукові записки Тернопільського національного педагогічного університету імені Володимира Гнатюка. Серія: педагогіка. Тернопіль, 2010. № 2. С. 137-144.

27. Дружененко Р. Дидактичні основи фрормування комунікативно-прагматичної компетентності майбутнього вчителя української мови і літератури. Науковий вісник Миколаївського національного університету імені В. О. Сухомлинського. Педагогічні науки. Миколаїв, 2016. № 3 (54). C. 205-211.

28. Дружененко Р.С. Роль педагогічного системного підходу в офрормленні поняття «методична система навчання мови». Наукові записки Бердянського державного педагогічного університету. Серія «Педагогічні науки». 2018. № 1. C. 17-23.

29. Загальноєвропейські Рекомендації з мовної освіти: вивчення, викладання, оцінювання / наук. ред. укр. вид. С. Ю. Ніколаєва. К.: Ленвіт, 2003. 273 с.

30. Зимняя И. А. Педагогическая психология. Москва: Издательская корпорация «Логос», 2000. 384 c.

31. Зязюн І. А. Сучасна освіта у контексті гуманістичної фрілософрії. Діалог культур: Україна у світовому контексті. Філософрія освіти: Зб. наук. праць / Ред. кол. : І. А. Зязюн (голов. ред.), С. О. Черепанова (упоряд. і відп. ред.), Н. Г. Ничкало, В. Г. Скотний та ін. Львів : Світ, 1999. Вип. 4. С. 5-12.

32. Зязюн І. А. Філософські засади освіти : освітні і виховні парадигми, освітні технології, діалектика педагогічної дії. Педагогічна майстерність у закладах профресійної освіти : монографрія. Київ, 2003. С. 11-59.

33. Іваницька Н. Л. Сучасні тенденції розвитку мовної освіти в Україні. Наукові записки Вінницького державного педагогічного університету імені Михайла Коцюбинського. Серія: педагогіка і психологія. Вінниця, 2015. Вип. 44. C. 24-28.

34. Ильин В. В. Аксиология. М.: Изд-во МГУ, 2005. 216 с. 
35. Караман С. О. Сучасні підходи до лінгводидактичної підготовки майбутнього вчителя-словесника. Науковий вісник Ізмаїльського державного гуманітарного університету (фрілологічні науки). Ізмаїл, 2010. Вип. 29. C. $186-192$.

36. Климова К. Я. Формування мовнокомунікативної професійної компетентності студента як креативної особистості в умовах навчального середовища педагогічного вузу. Наукові записки Тернопільсьского національного педагогічного університету імені Володимира Гнатюка. Серія: Педагогіка. 2012. № 1. C. 66-72. URL: http://nbuv.gov.ua/ UJRN/NZTNPU_ped_2012_1_13 (дата звернення 19.06.2019).

37. Компетентнісний підхід у сучасній українській освіті: світовий досвід та українські перспективи / Під заг. ред. О. Овчарук. Київ : К. І. С., 2004. 112 с.

38. Концепція мовної освіти (12-річна школа) URL: http://osvita.ua/ legislation/Ser_osv/2712/ (дата звернення: 22.06.2019).

39. Копусь О.А. Теоретичні засади формування фрахової лінгводидактичної компетентності майбутніх магістрів-фрілологів у вищому навчальному закладі: монографія. Одеса: ТОВ Лерадрук, 2012. 429 с.

40. Костюк Г.С. Избранные психологические труды. Москва : Наука, 1988.

41. Кулик О.Д. Мовленнєвий розвиток учнів 5-9 класів закладів загальної середньої освіти в процесі навчання словотвірної системи української мови : монографрія. Київ : Інтерсервіс, 2018. 474 с.

42. Кухарчук І. О., Кухарчук Р. П. Використання інформаційно-комунікаційних технологій у мовній освіті вчителя-словесника. Науковий вісник Миколаївського національного університету імені В.О.Сухомлинського. Педагогічні науки. Миколаїв, 2015. № 3. С. 152-157.

43. Кучеренко І. Філософрсько-методологічні засади сучасної мовної освіти. Українська мова і література в школі. 2016. № 2. С. 23-26.

44. Кучеренко І. А. Теоретичні і методичні засади сучасного уроку української мови в основній школі: дис.. ... д-ра пед. наук: 13.00 .02 «Теорія та методика навчання (українська мова)». Херсон, 2015. 560 с.

45. Кучерук О. Соціокультурний розвиток учнів як лінгвометодична проблема. Українська мова і література в школі. 2014. №2 (112). С. 2-7.

46. Леонтьев А. А. Основы психолингвистики. Москва : Смысл, 1999. 287 с.

47. Лещенко Г. Сучасні комунікативно зорієнтовані підходи до викладання української мови в школі. http://irbis-nbuv.gov.ua/cgi-bin/opac/search.exe. (дата звернення: 22.06.2019).

48. Локшина О.І. Розвиток компетентнісного підходу в освіті Європейського Союзу. Шлях освіти, 2007. № 1. С. 16-21.

49. Мамчур Л. Текст як засіб фрормування комунікативної компетентності учнів. Теоретична і дидактична фрілологія. 2010. Вип. 8. С. 222-231.

50. Мацько Л., Семеног О. Компетентнісні підходи і програмні засади в навчанні української мови в 10-12 класах середньої школи (профріль - українська фрілологія). Українська мова в освітньому просторі. Київ : Вид-во НПУ імені М. П. Драгоманова, 2009. С. 44-60.

51. Методика вивчення української мови в школі / О. М. Біляєв, В. Я. Мельничайко, М.І.Пентилюк, Г.Р.Передрій, Л.П.Рожило. Київ : Рад. школа, 1987.

52. Методика навчання української мови в середніх освітніх закладах / М.І. Пентилюк, С. О. Караман, О. В. Караман, О. М. Горошкіна, 3. П. Бакум, І. В. Гайдаєнко; за ред. М. І. Пентилюк. Київ : Ленвіт, 2005. 400 с.

53. Методичні рекомендації щодо розроблення стандартів вищої освіти. https://mon.gov.ua/storage/app/media/vishcha-osvita/rekomendatsii-1648.pdf. (дата звернення: 20.06.2019).

54. Нагрибельна І. А. Самостійна робота в системі підготовки майбутніх учителів 
до навчання української мови в початкових класах: дис. ... д-ра пед. наук: 13.00.02 «Теорія та методика навчання (українська мова)». Херсон, 2016. $483 \mathrm{c}$.

55. Нікітіна А. В. Педагогічний дискурс учителя-словесника: монографрія. Київ: Ленвіт, 2013. 338 с.

56. Овсієнко Л. Основні підходи до засвоєння лінгвістики тексту студентами фрілологічних спеціальностей педагогічних університетів. Теоретична $i$ дидактична фрілологія. Переяслав-Хмельницький, 2012. Вип. 12. С. 85-90.

57. Овсієнко Л. М. Теоретичні основи навчання лінгвістики тексту студентів фрілологічних спеціальностей на засадах компетентнісного підходу: монографрія. Київ: Інтерсервіс, 2017. 354 с.

58. Овчарук О. Компетентності як ключ до оновлення змісту освіти. Стратегія реформування освіти в Україні: Рекомендації з освітньої політики. Київ : «K.I.C.», 2003. C. 13-41.

59. Оліяр М. П. Підготовка майбутніх учителів до здійснення когнітивного підходу в методиці навчання української мови. Збірник наукових праць. Педагогічні науки. Випуск 52. Херсон: Видавництво ХДУ, 2009. С. 328-330.

60. Оліяр М. Комунікативно-діяльнісний підхід як основа формування комунікативно-стратегічної компетентності майбутніх учителів початкових класів. Науковий часопис НПУ ім. М. П. Драгоманова. Серія 17 : Теорія і практика навчання та виховання. Київ : Вид-во НПУ ім. М. П. Драгоманова, 2012. Вип. 20. С. 141-148.

61. Оліяр М. П. Теорія і практика формування комунікативно-стратегічної компетентності майбутніх учителів початкових класів: монографія. ІваноФранківськ: СІМИК, 2015. 476 с.

62. Омельчук С. Навчання морфології української мови на засадах дослідницького підходу: теорія і практика: монографія. Київ: Ґенеза, 2014. 368 с.

63. Омельчук С. «Підхід до навчання» як базова категорія сучасної лінгводидактичної науки. Українська мова і література в школі. 2013. № 2. C.2-8.

64. Остапенко Н. М. Теорія і практика фрормування лінгводидактичних компетентностей у студентів фрілологічних фракультетів ВНЗ: монографія. Черкаси: видавець Чабаненко Ю., 2008. 330 с.

65. Пентилюк М., Горошкіна О., Нікітіна А. Концептуальні засади комунікативної методики навчання української мови. Українська мова і література в школі. 2006. № 1. С. 15-20.

66. Пентилюк М. І. Текстоцентричний аспект формування риторичних умінь і навичок учнів. Актуальні проблеми сучасної лінгводидактики : зб. статей. Київ : Ленвіт, 2011. С. 96-108.

67. Петров А. В. Компетентностно-деятельностный подход в системе современного образования: рекомендации международной научнопрактической конф. Горно-Алтайск: РМНКО, 2010. 35 с. URL: http://amnko.ru/Inform/rewenie\%20konferencii.pdf. (дата звернення: 15.06.2019).

68. Пометун О. І. Реалізація компетентнісного і діяльнісного підходів у сучасному підручнику історії. Український педагогічний журнал. 2015. № 2. С. 146-156.

69. Пономарьова К. І. Нестандартні форми організації навчання української мови в початкових класах. Початкова школа. 2015. № 12. С. 1-6.

70. Попова О. А. Когнітивний підхід до розвитку граматично правильного мовлення майбутніх учителів у двомовному середовищі. Педагогічні науки / наук. ред. Барбіна Є. С. та ін. Херсон, 2006. Вип. 43. С. 332-337.

71. Попова О. А. Когнітивно-комунікативний підхід до роботи над граматичними нормами української мови. Українська мова і література в сучасній школі. 2012. № 1. С. 72-75. 
72. Попович А. С. Методична система навчання стилістики майбутніх учителів української мови і літератури : дис. ... д-ра пед. наук : 13.00 .02 / Київський університет імені Бориса Грінченка, Київ, 2018.

73. Потапенко О. І., Кожуховська Л. П., Товкайло Т. І., Чубань Т. В. Лінгводидактика : навч. посіб. для студ. фрілолог. спец-й ВНЗ. Київ : Міленіум, 2005. 401 с.

74. Практикум з методики навчання мовознавчих дисциплін у вищій школі: навч. посіб. О. М. Горошкіна, С. О. Караман, 3. П. Бакум, О. В. Караман, О. А. Копусь; за ред. О. М. Горошкіної та С. О. Карамана. К.: «АКМЕ ГРУП», 2015. 250 с.

75. Пригожин И. Сетевое общество. Социс. 2008. № 1. С. 24-27.

76. Профресійна педагогічна освіта: акме-синергетичний підхід / за ред. О. А. Дубасенюк. Житомир: Вид-во ЖДУ імені І. Франка, 2011. 389 с.

77. Рашкевич Ю. М. Болонський процес та нова парадигма вищої освіти: монографрія. Львів: Видавництво Львівської політехніки, 2014. 168 с.

78. Родигіна І. В. Компетентнісний підхід в освіті : синергетичний вимір. Наукова скарбниця освіти Донеччини. 2014. № 1. С. 44-49.

79. Рубинштейн С. Л. Избранные фрилософско-психологические труды. Основы онтологии, логики и психологии. Москва : 1997. 463 с.

80. Рускуліс Л. Методична система фрормування лінгвістичної компетентності майбутніх учителів української мови у процесі вивчення мовознавчих дисциплін : монографія. Миколаїв, 2018. 419 с.

81. Савченко О. Компетентнісний підхід у сучасній вищій школі. Педагогічна наука : історія, теорія, практика, тенденції розвитку. 2010. № 3. http://intellectinvest.org.ua/pedagog_editions_emagazine_pedagogical

science_vypuski_n3_2010_st_16/ (дата звернення: 19.06.2019).

82. Селевко Г. К. Энциклопедия образовательных технологий: в 2 т. М.: НИИ школьных технологий, 2006. Т. 1.816 с.

83. Семеног О. М. Професійна підготовка майбутніх учителів української мови і літератури. Монографія. Суми : ВВП «Мрія», 2005. 403 с.

84. Синергетика і творчість / за ред. В. Г. Кременя. К. : Ін-т обдаров. Дитини. 2014. $312 \mathrm{c}$.

85. Словник-довідник з української лінгводидакти: навч. посіб. / кол. авторів за ред. М. І. Пентилюк К.: Ленвіт, 2015. 320 с.

86. Современные образовательные технологии / кол. авт.; под ред. Н. В. Бордовской. Москва: КНОРУС, 2013. 432 с.

87. Урсул А. Синергетика и ноосферный подход. Синергетика и управление. Москва : РаГС, 2001. С. 114-128.

88. Хакен Г. Основные понятия синергетики. Синергетическая парадигма : многообразие поисков и подходов. Москва : Прогресс-Традиция, 2000. C. 28-55.

89. Химинець В. Компетентнісний підхід до професійного розвитку вчителя. http://zakinppo.org.ua/2010-01-18-13-44-15/233-2010-08-25-07-10-49. звернення: 19.06.2019).

90. Хом'як І., Каркич І. Компетентнісний підхід до навчання лексики в загальноосвітніх навчальних закладах. Дивослово. 2019. № 10. С. 2-5.

91. Хом'як І., Самсонюк О. Компетентнісний підхід до навчання синтаксису в умовах нової української школи. Українська мова $і$ література в школах України. 2019. № 10. С. 3-6.

92. Чалий О.В. Синергетичні принципи освіти та науки. Київ : Національний медичний ун-т ім. О. О. Богомольця, 2000. 253 с.

93. Шелехова Г. Т. Сучасні підходи до навчання рідної мови в загальноосвітній школі. Українська мова і література в школі. 1998. № 3. С. 33-35.

94. Якиманская И. С. Личностно ориентированное обучение в современной школе. Москва: Сентябрь, 2000. 176 с. 


\title{
ФОРМУВАННЯ ХУДОЖНЬОЇ ЕТНОКУЛЬТУРИ МАЙБУТНІХ ФАХІВЦІВ ПОЧАТКОВОЇ ОСВІТИ ЗАСОБАМИ НАРОДНОГО МИСТЕЦТВА (НА ПРИКЛАДІ РІЗЬБЛЕННЯ)
}

\author{
Гулей О. В.
}

Заслужений майстер народної творчості України, старший викладач Сумський державний педагогічний університет імені А. С. Макаренка

Никифоров А. М.

кандидат педагогічних наук, скульптор, незалежна професійна діяльність

На сучасному етапі відродження національної культури й пошуку шляхів вдосконалення вітчизняної освіти актуальним постає питання дослідження традиційних художніх вітчизняних промислів, важливе місце серед яких займає художня обробка деревини. Деревообробництво $€$ важливою складовою частиною історично обумовленої художньої системи та мистецького феномену національної культури, у виявленні фрорм використання національних традицій різьблення по дереву сучасними майстрами. У змісті підготовки педагогічних кадрів важливе місце посідає всебічне вивчення та осмислення культурної спадщини українців. Народна художня обробка дерева - перш за все це різьблення по дереву - як один з видів декоративновжиткового мистецтва, поряд з випилюванням, токарною обробкою деревини тощо, поступово втрачає свою популярність. Тому дослідження і виявлення національних традицій у різьбленні по дереву сучасних майстрів видається актуальним і доцільним у контексті фрормування художньої етнокультури майбутніх фрахівців початкової освіти засобами народного мистецтва. Актуальність дослідження також передбачає розширити коло знань студентів про давню мистецьку спадщину українців та шляхи розвитку сучасного традиційного деревообробництва як у духовно-сакральному, так і в побутовому аспектах.

У контексті вивчення декоративно-прикладного мистецтва України особливості художнього різьблення деревини в історикомистецтвознавчому аспекті розглядали науковці: $Є$. Антонович, Б. Бутник-Сіверський, Я. Запаско. Питанням про витоки побудування дерев'яних виробів українців переймалися Г. Грінь, Р. Кирчів, С. Павлюк, В. Наулко, особливості виготовлення художніх виробів 3 дерева описали в своїх розвідках К. Кавас. Н. Каплан, Т. Матвєєва, Т. Мітлянська, Г. Федотов та інші. Значення занять з різьблення по дереву у прилученні дітей та молоді до національної культури й фрормування в них національної самосвідомості висвітлювали на сторінках своїх праць А. Абросімова, І. Білевич, Б. Тимків та інші. 
Деревообробництво - виготовлення виробів 3 дерева для побуту, церковного богослужіння, знарядь господарської діяльності тощо. Це найдавніший вид українського народного мистецтва. Перші пам'ятки народного різьблення на території сучасної України, що дійшли до нас, належать до епохи палеоліту (кам'яний вік, близько 20 тис. років до н. е.). Це вироби з кістки, оздоблені різьбленими геометричними мотивами. Їх знайшли археологи під час розкопок Мізенської стоянки на Чернігівщині. Предметів з дерева з тих давніх часів не збереглося [2]. Пізніше, в епоху неоліту, розвилися: кераміка, ткацтво, художня обробка кістки, а потім, із вдосконаленням знарядь праці, з'явилася можливість виготовляти вироби з дерева, а також прикрашати їх [3; 12].

Літописні відомості й археологічні знахідки підтверджують широке застосування у давні часи дерев'яного посуду, простих меблів, засобів транспорту тощо. Декотрі з них, крім доброї конструктивної форми, мали різьблений і розписний декор. Тодішні майстри вже володіли плоским різьбленням, рельєфним, контррельєфним, ажурним і круглим. Спочатку осередки деревообробних ремесел були розташовані в поселеннях лісистої важкодоступної місцевості [20, с. 28-30].

У XIV - XVI століттях деревообробництво поширилося в Україні повсюдно [3]. Для власних потреб селяни виготовляли деякі предмети хатнього обладнання, господарський реманент тощо. Складніші вироби або деталі вони замовляли в місцевих майстрів. Сільські деревообробні промисли, як і інші ремесла, все більше відокремлювалися від рільництва. Характерною особливістю була спеціалізація у виготовленні міського та дрібного бондарського посуду, ложок тощо. Однак селяни не полишали хліборобства, для багатьох з них заняття ремеслом залишалося допоміжною галуззю в осінньо-зимовий період. Теслярі, бондарі, столярі виготовляли і вивозили на ярмарки знаряддя праці, засоби транспорту, меблі, хатнє начиння, оздоблене різьбленням та розписом [21; 22]. Народні майстри XIV - XV століть успадкували і розвинули традиційні прийоми деревообробництва Київської Русі. До рідкісних пам'яток різьблення XV століття належать ручні двораменні хрести, оздоблені орнаментальними мотивами, написами і мініатюрами: «Розп'яття», «Зняття з хреста», «Омивання ніг», «Причастя» та інші. Від XVI століття походять ікони, частина яких орнаментована різьбленням [2; 4]. В орнаментації переважали хвилясті, прямі, скісні та перехресні лінії-жолобки. Ікони, декоровані рослинними мотивами, мають аналогії серед давніх книжкових мініатюр та гравюр. Творча праця народних майстрів-деревообробників застосовувалась у багатьох галузях. Теслярі-будівничі водночас володіли різними техніками різьблення і профрілювання.

Теслярі Подніпров'я, Поділля і Прикарпаття виготовляли й оздоблювали різьбленням дерев'яні предмети господарського вжитку: вози, сани, ярма та ін. Лави, різьблені скрині, столи, різноманітні 
стільці, полиці та божниці, тобто основне хатнє обладнання, виготовляли на замовлення. Пам'ятки дерев'яного сільського транспорту, оздоблені різьбленням, що дійшли до нашого часу, зберігаються у Київському та Львівському історичних музеях (зокрема це чумацькі вози). У народному побуті XII - XIII століть поряд 3 керамічним посудом часто застосовувався дерев'яний (миски, тарілки, салатниці, ступки, сільнички, бочечки тощо), який виготовляли на продаж бондарі Подніпров'я, Слобожанщини, Поділля та інші [19]. Особливо цікавими були миски для косарів - яндови та ковганки для замісу тіста. Вони завжди були круглої форми і мали два або чотири вушка для перенесення і навішування на стіну. Їх орнаментували 3 зовнішнього боку, і декор добре «читався», коли миски завішували догори дном або ставили на поличці. 3 середини великі миски найчастіше розписували фрарбами. Дотепер таких виробів збереглося небагато. У Рівненському краєзнавчому музеї $€$ велика дерев'яна миска-корець XII століття, ручку якої оздоблено скісними лініями плоского різьблення; у Чернігівському історичному музеї - мискакорець XIII століття, ручку якої прикрашено великою розеткою, виконаною виїмчастим різьбленням. Так само оздоблено й дерев'яні посудини для каші та солі.

У XII - XIII століттях набуло поширення ажурне різьблення церковних іконостасів та інших предметів культового призначення. Кіоти, аналої, свічники, ручні хрести, панікадила, скриньки виробляли переважно монастирські майстри та сільські деревообробники. Ручні та напрестольні хрести виготовляли 3 місцевих порід дерева, іноді 3 кипариса. Їх прикрашали плоским різьбленням геометричних мотивів і фігурних зображень.

Провідними регіонами художніх деревообробних промислів у XIX столітті були Подніпров'я, Полісся, Поділля, Карпати. У багатьох місцевостях оздоблювали профілюванням та площинним різьбленням дерев'яні деталі архітектури, виготовляли транспортні засоби та знаряддя праці, прикрашені різьбленням або розписом, продавали на ярмарках предмети хатнього вжитку, зокрема начиння [2, с. 184]. Від середини XIX до першої третини XX століття у Полтаві працювала родина майстрів Юхименків. Вони виготовляли іконостаси, меблі, побутові предмети, вміло використовуючи мотиви народного орнаменту. У деяких селах Західного Полісся покрівля часто завершувалася «шпилями». Їх вирізували у вигляді сонця, півника або коника. Усі ці фрігурні зображення мають давнє коріння, яке сягає, мабуть, поганських часів. Тоді ці мотиви наділялися магічною силою відвертали все зле від житла.

У XVIII - XIX століттях на Гуцульщині ажурним і круглим різьбленням декорували іконостаси, свічники; контурним - ікони, скрині, сволоки, токарний та бондарський посуд. У гуцульських селах тоді працювали десятки талановитих майстрів художньої обробки 
дерева. Однак лише в другій половині XIX століття, 3 початком творчості династії Шкрібляків з Яворова Косівського району, у традиційному художньому деревообробництві сталися важливі зміни. Юрій Шкрібляк (1822 - 1885 рр.) вважається засновником сучасної школи художнього деревообробництва. Початкові навички отримав у батька-бондаря. Згодом самостійно опанував токарство, різьблення і випалювання. Гладку поверхню геометричних мотивів орнаменту на тарілках, баклагах, коробках, пляшках він поєднував з «кільчастим письмом», досягаючи фрактурного контрасту, і тим самим значно посилював декоративну виразність [2, с. 186].

Гуцульські майстри розробили оздоблення виробів різнокольоровим бісером - «кораликами», або - інкрустацією деревом з доповненням оздоблення бісером, металом і перламутром.

На Бойківщині у селах перед фасадною стінкою хати прибудовували піддашок з масивними одвірками, які звужували i заокруглювали догори та прикрашали різьбленням у вигляді орнаментальних смуг, розташованих у нижній частині. Тут також профілювали стовпи, що надавало спорудам чарівної легкості та привабливості. Меблі, посуд та дрібні господарські речі бойківські майстри оздоблювали гравірувальним різьбленням, створюючи чіткі та лаконічні геометричні орнаменти 3 невеликої кількості елементів та мотивів (клинці, «кривулі», ромби, очка, розети). На Лемківщині наприкінці XIX - на початку XX століття набуло поширення кругле, рельєфне та ажурне різьблення. Лемківські різьбярі, крім малої скульптури, виготовляли посуд, попільнички, рамочки, палиці, іграшки, прикрашаючи їх рельєфними орнаментами у вигляді листя калини, каштана, клена, соняшника тощо.

На початку XX століття і в наступні десятиріччя художня обробка дерева на Україні залишалася на високому рівні передусім у регіонах, багатих на ліс, де збереглися давні традиції деревообробництва. У цей період працювали майстри-одноосібники, які виготовляли ложки, дерев'яний посуд, скрині та інші побутові речі, необхідні в господарстві. Особливим попитом користувалися скрині. На Полтавщині їх розписували квітковим орнаментом, іноді різьбили, а на Поділлі обковували металевими ажурними бляхами. Внаслідок примусової колективізації, зокрема передачі коней у колективну власність, відбувався відчутний занепад виготовлення транспортних засобів у традиційних осередках: Лохвиці, Гайсині, Поташні та ін. Цілком припинилося вироблення культових різьблених предметів, закривалися іконостасні майстерні.

У 30-ті роки XX століття все більшої ваги набирали деревообробно промислові артілі. На меблевих фабриках Полтави, Києва, Житомира та інших міст України створювалися різьбярські цехи, де займалися декоруванням продукції [12]. У повоєнні роки відновили діяльність деревообробні артілі в Косові, Львові, Ужгороді, Чернівцях. 
Вони випускають шкатулки, скриньки, декоративні тарілки, баклаги, бочечки, обкладинки до альбомів, топірці, свічники, жіночі прикраси та інші вироби на токарній і столярній основі. Поверхня виробів щедро, іноді суцільно вкрита різьбленим орнаментом симетричної будови з чітко виділеним центром. Витонченість і фрілігранність геометричної «сухої різьби» надає предметам декоративності, святковості. Для більшої пластичної вишуканості й мальовничості геометричну різьбу підсилюють, збагачують інкрустацією цінними породами дерева, мідним дротом, перламутром і бісером. У Чернівецькій області виробляють предмети з дерева техніками виточування, столярства, різьблення, оздоблюючи їх при цьому переважно розписом, інкрустацією та геометричною різьбою. На Закарпатті створюють декоративні вироби з плоскорельєфною та об'ємною різьбою.

У 60-x - 70-х роках XX століття художні вироби з дерева на Гуцульщині зазнали помітних змін: оновилася форма, декор став стриманішим. Різьблений та інкрустований орнамент уже не заповнював фрорми. Залишалися вільні від декору площини, що виявляло природну красу деревини, полегшувало сприйняття твору. Значно розширився асортимент бондарського посуду. Взагалі 3 відкриттям храмів відновлювалось виготовлення з дерева традиційних церковних атрибутів.

На Львівщині в художній обробці дерева успішно розвиваються традиції різних шкіл і регіонів. Тут особливо популярні об'ємно різьблені, анімалістичні скульптурки. Побутові речі - коробочки, хлібниці, цукерниці, ложки, вази, шкатулки, «скрині», декоративні тарелі й маленькі сувенірні тарілочки виконують найрізноманітнішими формотворчими й оздоблювальними техніками. Широкий технічний діапазон майстерності показують різьбярі Львівщини, де впроваджено випуск дитячих іграшок на зразок колись широко відомих «яворівських» коників, пташок, метеликів, свищиків, їх окремі частини виточують, вирізують і розписують орнаментальними мотивами розеток, зірочок, «вербичок» яскравими аніліновими фрарбами.

На Поділлі, у Вінницькій. Хмельницькій і Тернопільській областях виготовляють твори дрібної пластики, декоративно-ужиткові вироби, хатні прикраси тощо.

Кращі художні твори з дерева центральних областей України (Полтавської, Кіровоградської, Черкаської) мають традиційну утилітарну фрорму, декоровані виїмчастою різьбою та розписом. Широкий асортимент точених з липи художніх побутових речей, оздоблених квітковими візерунками, випускав цех художньої обробки дерева Миргородського лісгоспзагу Полтавської області.

У Дніпропетровській, Херсонській, Миколаївській та інших областях у зв'язку з відсутністю відповідного місцевого матеріалу виготовлення виробів з дерева носить випадковий, нерегулярний характер, інколи дерево поєднують з іншими матеріалами, в яких 
дерев'яні деталі комбіновані 3 металевими, створюють 3 дерева шкатулки і скриньки, інкрустовані соломкою тощо.

Послідовність виконання робіт процесу різьблення по дереву:

$>$ створення ескізу композиції;

$>$ підготовка дерев'яної поверхні;

$>$ перенесення малюнка;

$>$ процес різьблення;

оздоблювальні операції.

Варто зазначити, що різьблення - народне мистецтво, яке розвинулося 3 деревообробних ремесел як допоміжне. Різьбярі застосовували методи випилювання, випалювання, художньої різьби для нанесення символічних візерунків на вироби, які, крім утилітарного призначення, мали й естетичні функції. Найбільшого застосування мистецтво різьблення по дереву набуло у виготовленні й оздобленні речей господарського призначення ложок, тарілок, кухлів, ступок, ковганок, кухонних дощок, свічників, хлібниць, таць, скринь та скриньок, поличок, столів, стільців і табуретів, рамок для дзеркал та картин.

Весь асортимент виробів за його функціональним призначенням умовно ділиться на три групи. Перша група - побутові речі, в яких переважає утилітарність. Це кухонний дерев'яний посуд із чітко вираженою функціональністю: миски, сільнички, ступки, салатники, масниці, ложки, ополоники, черпаки та ін. Другу групу складають вироби, в яких гармонійно урівноважені ужитковість з естетичною красою фрорми і декору, наприклад, шкатулки, письмове приладдя, хлібниці, цукерниці, кухонні дошки, набори для сипучих продуктів, прянощів, меду, полички тощо. До третьої групи належать декоративні вироби: настінні прикраси, декоративні вироби: іграшки, скульптура малих фрорм (декоративна пластика), жіночі прикраси. Якщо колись головна увага приділялася виробам, необхідним у побуті, то в останні десятиріччя художні твори з дерева дедалі більше набувають декоративного характеру.

Композицію в різьбі відрізняє раціональна простота, ніжний світлотіньовий узор. Характер різьби може бути лінійно-контурним або проробленим тонально. В ескізах для геометричної різьби необхідно щільно затонувати тіньовий бік узору, затушовуючи у півтонах частини орнаменту, також заведено ділити на декілька композиційних частин, кожну з котрих заповнюють різьбою. У творчих роботах встановлені канони можуть бути відправною точкою для вільного створення композиції. Малюнок при контурній композиції будується на лінійному ритмі. Чітка геометрична побудова зображення в цілому і кожного елемента окремо необхідна при тригранно-виїмчастому способі. Таку композицію на початку малюють, а потім викреслюють за допомогою циркуля, лінійок і трикутників. Чіткість узору - одне із основних вимог, що пред'являють до геометричної різьби [20-22]. Всі зображення будують з простих азбучних фрігур. 
У тригранно-виїмчастій техніці можна застосовувати не тільки геометричні орнаменти [25]. Спрощення та смілива стилізація природних об'єктів у відповідні образи дозволяють використовувати рослинні, зооморфні та антропоморфні мотиви. Досить важливим моментом $€$ знання символіки зображень. Водночас символи порізному відображаються в окремих видах різьблення, і це підкреслює їх національну своєрідність. Як правило, символічне значення деяких елементів відтворює образи, що склалися в українських піснях, усній народній творчості, малюнках (образ дівчини, землі-годувальниці, сонця) [23, 24]. Використання орнаменту як декоративного оформлення виробів, необхідних людям у побуті та практичній діяльності, складає основу декоративно-прикладного мистецтва. Орнамент відрізняється розмаїттям мотивів, характер яких залежить як від природних, так і від національних образів, уявлень, звичаїв [19].

Деревину можна обробляти вручну і на верстатах - рубати, різати пилою і різцями, стругати, точити, шліфувати, свердлити, склеювати, пресувати, розпарювати, гнути. Якщо дерево, покрите барвниками, оліфами і лаками, воно надійно захищене від вологи і має посилене декоративне звучання текстури [16].

У художній обробці дерева одні технічні засоби і прийоми застосовують на основі функціонального спрямування фрорми предметів, інші мають суто декоративне призначення і завершують, переважно, зовнішнє художнє оформлення виробів. До формотворчих технік слід віднести видовбування, вирізування, виточування, бондарні та столярні прийоми [3, с. 62-68].

Видовбування - одна з найдавніших технік, що полягає у поступовому вибиранні деревини, внаслідок чого утворюється заглибина, порожнина або отвір. 3 допомогою сокири, долота майстри виготовляли побутові предмети човни-довбанки, корита, ступи, черпаки, сільнички тощо.

Вирізування (витесування, вистругування) - це різноманітні технічні прийоми, за допомогою яких майстри вручну моделюють 3 дерева фрорму побутових предметів і декоративних виробів. Необхідні інструменти: сокира, ніж, тесак, різці та ін. Цією технікою сьогодні виготовляють дерев'яні ложки, черпаки, декоративні твори дрібної пластики.

Виточування - це і техніка обробки дерева, і самостійна галузь художнього промислу. Для приведення заготовки виробу в круговий обертовий рух використовується токарний верстат, у процесі обертання дерев'яну заготовку обробляють плоскими і фігурними різцями.

Бондарство - окремий вид деревообробницького промислу, техніка виготовлення великого посуду: бочок, діжок, цеберок, барил, коновок тощо.

Столярство - найпоширеніше ремесло по виробництву з дерева будівельних виробів, меблів, музичних інструментів та художньої сувенірної продукції. 
Профрілювання - декоративна техніка, яка полягає у вирізанні геометричних орнаментів по краях дощок: прикраси будівель, меблів тощо; об'ємне профрілювання балок кронштейнів тощо.

Прийоми і техніки виготовлення виробів з дерева значною мірою посилюються застосуванням відповідного оздоблення: різьблення, інкрустації, інтарсії, мозаїки, розпису, випалювання тощо [2; 5].

Інкрустація - техніка орнаментального оздоблення шматочками твердих матеріалів (дерева, металу, слонової кістки, перламутру, бісеру та ін.), які врізають у поверхню виробів. Декоративний ефект основується на контрастному зіставленні різноколірних, різнохарактерних твердих матеріалів.

Інтарсія - вид інкрустації. Цією технікою виконують зображення або візерунки зі шматочків кольорового дерева (шпону), які врізають урівень з поверхнею виробу або суцільно вкривають його поверхню (маркетрі). Найчастіше в техніці інтарсії і маркетрі виготовляють портрети, пейзажі тощо.

Розпис на дереві технічно мало чим відрізняється від розпису на інших матеріалах. Орнамент наносять пензлями на поверхню виробу темперою, гуашшю, олійними та аніліновими фрарбами, нітроемалями. Після висихання розпису виріб вкривають лаком.

Випалювання роблять на світлих породах дерева: ялині, смереці, сосні, клені та ін. Розрізняють два види випалювання електрописаком, що дає чіткий контурний малюнок, і штампами («смужки», «ромбики», «кружальця», «зірочки» та ін.), з відбитків яких складають різноманітні орнаменти. Крім розглянутих традиційних прийомів і технік, зустрічаються їх різновиди й поєднання, наприклад, «штампування», контурна різьба й тонування площин, викладання соломкою тощо.

Різьблення - найдавніша техніка художнього декорування виробів із дерева.

Розрізняють п'ять основних видів різьби: плоско-виїмчасте, плоско-рельєфне, рельєфне, плоско-прорізне, об'ємно-скульптурне. Кожний вид поділяється на багато різновидів і їх поєднань.

Плоско-виїмчасте різьблення характеризується поглибленими виїмками і тлом одного рівня на поверхні деревини [14].

Ця група різьблення вважається досить простою за технікою виконання і $€$ найбільш стародавньою. Ї̈̈ форма - плоска поверхня, а малюнок утворює різноманітної фрорми заглиблення-виїмки. (Це геометрична і контурна різьба).

Техніка контурного різьблення ґрунтується на вибиранні в дошці контурного поглиблення у вигляді клина.

Контурне різьблення з точки зору виконання вважається найпростішим. Матеріал для контурного різьблення не має великого значення, тому що поверхня майбутнього виробу тонується. 
Геометричне різьблення - різьблення із фрігурних клиноподібних виїмок, що утворюють на поверхні деревини візерунок, складений із геометричних фрігур: трикутників, прямокутників, квадратів, ромбів, сегментів кіл тощо.

Геометричне різьблення за технікою виконання поділяється на два різновиди: тригранно-виїмчасте і скобельне.

Тригранно-виїмчасте різьблення - найбільш поширений і улюблений в Україні вид декорування виробів 3 дерева. Цим різьбленням декорують ложки, ополоники, миски, сільнички, кухонні дошки, хлібниці, цукорниці.

Скобельне різьблення характеризується округлими формами у вигляді вузьких однакових скобок, подвійних скобок-пелюсток чи нігтиків. Вирізаються елементи напівкруглою чи пологою стамескою та ножем-косяком. Скобельне різьблення майже завжди використовують у поєднанні з тригранно-виїмчастим та контурним.

Плоско-рельєфне різьблення має площинне зображення на одному рівні, ступінчате чи поглиблене із заоваленими краями, часом з подушковим, підрізаним або вибраним тлом. Це різьба з маленьким умовним рельєфом, розташована на одній площині на рівні поверхні, на якій вирізають візерунок [11].

Плоско-рельєфне різьблення поділяється на такі різновиди:

Заовалене різьблення, коли малюнок і тло виконують в одній площині, а інші краї плавно заовалені.

$>$ Різьблення з підрізним тлом, коли фон навколо зображення підрізається в глибину з нахилом до зображення.

$>$ Різьблення з вибраним тлом, коли тло вибирається на певну глибину і може мати різну фактуру.

$>$ Плоско-прорізне різьблення виконується в одній площині сверлінням або випилюванням [9].

За своїми різновидами воно буває контурно-силуетним, скрізнимпрорізним і ажурно-прорізним.

Контурно-силуетне різьблення - площинне силуетне зображення, вирізане по зовнішньому контуру.

Скрізне-прорізне різьблення - площинне зображення зі скрізними прорізами чи сверлінням, але з перевагою тла над отворами.

Ажурно-прорізне різьблення - площинне зображення 3 численними прорізами чи свердлінням, нагадує ажурні візерунки.

Технологія прорізного різьблення досить проста - свердлять наскрізні отвори і випилюють необхідні частини за допомогою необхідного інструмента.

Прорізне різьблення може проглядатися наскрізь і не мати спеціального тла, мати накладне тло з різних матеріалів, накладатися в один чи декілька шарів, поєднуватися з іншими видами різьблення.

Рельєфрне різьблення - це вирізане на деревині зображення випукле відносно тла і повністю оброблене по всій поверхні. Це 
різьба, де зображення $€$ випуклим по відношенню до фону. Рельєфне різьблення широко використовують в оздобленні меблів, фронтонів будинків.

У свою чергу воно поділяється на кілька видів [1]:

$>$ барельєфне - різьблення 3 низьким рельєфом, який не перевищує середини об'єму зображуваних елементів;

$>$ горельєфрне - різьблення з високим рельєфом, який перевищує середину об'єму зображення;

$>$ ажурно-рельєфрне - різьблення 3 високим рельєфним зображенням, доведеним до об'єму з частково або повністю видаленим тлом;

$>$ контррельєфрне - різьблення зі зворотнім рельєфним зображенням у глибині деревини з чітко вираженим рельєфним контуром по периметру зображення.

Об'ємно-скульптурне різьблення дуже поширене в Україні. Техніка виконання об'ємно-скульптурного різьблення потребує великого досвіду, знань і технічних навичок. Різьбяр повинен володіти об'ємно-просторовим баченням, композиційним відчуттям та художнім смаком $[4 ; 8 ; 14]$.

Для різьблення застосовують різноманітні породи деревини. Вибір тієї або іншої породи залежить від призначення виробу та виду різьблення:

деревина липи легко ріжеться, мало піддається розтріскуванню та деформації, використовується для виготовлення скриньок, рамок, поличок, а також для різьблення іграшок та посуду;

$>$ деревина вільхи також легко ріжеться, легко сприймає оздоблення й імітує інші породи, наприклад, червоне дерево, чорне дерево. Застосовується для всіх видів робіт;

деревина верби має однорідну структуру та товстий стовбур, що дозволяє виконувати великі речі, наприклад, ночви для купання дітей;

деревина берези твердіша за липу й вільху й ріжеться важче, але якість різьблення краща. Деревина берези добре фарбується й оздоблюється;

деревину осики й тополі застосовують для різьблення дрібних виробів - посуд, сувеніри;

деревину дуба застосовували для великих декоративних різьблених робіт і для виготовлення меблів з різьбою;

$>$ деревина бука використовується для виготовлення меблів, посуду тощо;

деревина горіха чудово ріжеться у всіх напрямках і дозволяє виконувати найтонше різьблення, гарно оздоблюється, особливо поліруванням. Ії̈ використовують при виготовленні меблів, виробів малих форм і станкової скульптури; 
деревина груші добре фрарбується, особливо в чорний колір, імітуючи чорне дерево, гарно оздоблюється. 3 груші виготовляють дрібні сувенірні вироби, мініатюрну дерев'яну скульптуру тощо;

деревину яблуні, черешні, платану, самшиту застосовують для дрібних різьблених виробів;

з деревини сосни виготовляли прикраси для наличників вікон, карнизів, простінків будинків, воріт (домове різьблення).

Основними інструментами для виконання різьби колись служили сокира, ніж, долото. Тепер для різьблення по дереву використовують різної форми ножі, різці, стамески або долота різного профрілю [13]. Прямі стамески з шириною полотна 3 - 30 мм застосовують в основному для зачистки фону в рельєфному різьбленні, інколи їх використовують у контурному різьбленні. Напівкруглі стамески з шириною полотна 3 - 25 мм. Це основний інструмент при виконанні всіх видів різьблення, крім геометричного, де його застосовують лише для вирізування напівкруглих лунок. Стамески-кутики з шириною полотна 5 - 15 мм використовують для вибірки вузьких ліній канавок. Ніж-косяк - ніж із скісним лезом, основний інструмент для виконання тригранно-виїмчастої різьби. Вершину леза косяка називають носком, а задню частину - п'яткою. Бажано мати три ножі-косяки: широкий, середній, вузький. Ширина вузького різака становить 7 - 10 мм, середнього - 15 - 20 мм, широкого - понад 30 мм. Щоб уникнути ламкості леза ножа при виконанні глибокої різьби, особливо на твердих породах деревини, товщина полотна повинна становити 3 - 5 мм.

Для навчальних вправ достатньо мати один ніж - вузький або середній. Перед початком роботи необхідно облаштувати ручку для зручного тримання. Це роблять намотуванням ізоляційної стрічки чи медичного пластиру. Перед намотуванням потрібно підкласти з обох боків півкруглі дерев'яні пластини.

Види обробки деревини в процесі підготовки поверхні до різьблення: 1) сушка, 2) маскування тріщин і сучків, 3) виведення сучків, 4) виправлення сколів, 5) склеювання, 6) фаніровка, 7) обробка поверхні захисною плівкою, 8) шліфовка і поліровка, 9) прозоре покриття, 10) тоніровка.

1. Сушка. Дерево розташовується на свіжому повітрі під навісом від дощу, снігу та від прямих сонячних променів, але сохне дуже повільно від декількох місяців до декількох років.

2. Маскування тріщин і сучків. Спосіб маскування тріщин: вставити в них шматочок такої ж деревини, по можливості з того ж місця, де знаходиться щілина.

3. Виведення сучків. Місце від сучка треба замаскувати одним з елементів різьби. 
4. Виправлення сколів. За допомогою клею відповідний шматочок доклеюють непомітно міцно. Треба намагатися не загубити той самий шматочок, який відколовся.

5. Склеювання. Для склеювання застосовують столярний або водний клей ПВА (ні в якому разі не слід використовувати синтетичний).

6. Фаніровка. Фанерувати вироби тонкими шарами деревини (фанерками) - це покривати поверхню виробу більш цікавою по текстурі деревиною. Тонким шаром клею намазують обидві склеювані поверхні.

7. Обробка поверхні. Обробка поверхні містить вирівнювання поверхні, поліровку і нанесення захисного, а разом з тим і декоративного покриття.

8. Шліфровка і поліровка. Поліровка поверхні, або шліфовка робиться в тих місцях, де це необхідно для контрасту 3 необробленою поверхнею. Ці операції можуть виконуватися по всій поверхні різьби, частково або взагалі не виконуватися.

9. Прозоре покриття. Олійний лак, рослинна олія, нітролак, віск - це основні матеріали, якими можна покривати поверхню деревини.

10. Тоніровка - це зміна природного кольору деревини. Найстаріший спосіб - моріння, а також тоніровка олійною фрарбою. Це не фрарбування, а протирання майже досуха невеликою кількістю фрарби. Тонування поверхні виробу потребує від майстра основних знань технології лаків і фрарб.

Дерев'яна поверхня під різьбу може бути підготовлена вручну (рубанком, фруганком), або на токарних, фругувальних, рейсмусових станках. Широкі заготівки під різьбу склеюють з декількох вузьких ділянок. Підготовлену поверхню можна залишити природного кольору або затонувати в темний, в залежності від задуму композиції. Рекомендується на перших заняттях дощечки фрарбувати чорною тушшю і на них переносити малюнок. На темному тлі чіткіше помітні недоліки та помилки [21; 14$]$.

Ряд типових помилок, які допускають початківці в процесі проектування виробів:

$>$ відсутність пропорційності окремих елементів форми;

$>$ невдале розміщення композиційного центру;

п порушення пропорції між основними і другорядними елементами, що мають підкреслювати виразність основних;

$>$ надмірне ускладнення окремих ділянок композиції;

$>$ перенасиченість поверхні виробу елементами оздоблення;

$>$ невідповідність розмірів декоративних елементів розмірам виробу.

Рекомендуємо орієнтовні початкові практичні заняття з різьблення по дереву для професійної підготовки фахівців початкової освіти. 
Практичне заняття № 1

Тема: Ознайомлення з художньою обробкою дерева. Оволодіння основними техніками різьблення по дереву.

Мета: Розширення знань студентів про художню обробку дерева один із видів народної творчості, оволодіння основами зображальних засобів різьблення по дереву, засвоєння технічних прийомів під час виконання вправ, виховувати інтерес, поважне та пізнавальне ставлення до стародавнього промислу.

Послідовність виконання вправ для практичного завдання:

1. Виконати вправи для освоєння найпростішої техніки різьблення по дереву контурної різьби:

$>$ підготувати невелику дощечку для різьби;

> розробити ескіз рослинного стилізованого мотиву;

$>$ перенести рисунок на дощечку за допомогою копіювального паперу;

> тримаючи під нахилом різець, стамеску, підрізати - провести 3 натиском по лініях узору;

$>$ у протилежному напрямку знову підрізати за лініями узору, але вже з іншого боку надрізаного контуру. В результаті повинна утворитися тригранна дерев'янна смужка, вийнята в процесі різьблення з фрігурної канавки.

2. Виконати вправи для освоєння техніки контурної різьби, що переходить у площинний рельєф (зображення та тло залишаються в одній площині):

> підготувати невелику дощечку для різьби;

> розробити ескіз зооморфного стилізованого мотиву;

$>$ перенести рисунок на дощечку за допомогою копіювального паперу;

тримаючи під нахилом різець, стамеску підрізати - провести 3 натиском по лініях узору;

змінити нахил інструмента і знову підрізати по лініях узору, але вже інший бік надрізаного контура. В результаті повинен утворитися контраст ліній - з боку зображення тонка канавка, 3 боку фону широка канавка;

3. Виконати вправи для освоєння найпростішої техніки різьблення контурної різьби з «подушковим» тлом:

$>$ підготувати невелику дощечку для різьби;

$>$ розробити ескіз рослинного стилізованого мотиву;

$>$ перенести рисунок на дощечку за допомогою копіювального паперу;

тримаючи під нахилом різець, стамеску підрізати - провести 3 натиском по лініях узору;

підрізати по лініях узору, але вже інший бік надрізаного контура. Вибрані заглиблення повинні створити ефрект «подушкового» фону за допомогою широкої смужки, вийнятої в процесі різьблення із фрігурної канавки. 
4. Виконати вправи для освоєння найпростішої техніки різьблення по дереву контурної різьби з вибраним тлом:

$>$ підготувати невелику дощечку для різьби;

$>$ розробити ескіз рослинного стилізованого мотиву;

$>$ перенести рисунок на дощечку за допомогою копіювального паперу;

тримаючи під нахилом різець, стамеску, підрізати - провести 3 натиском по лініях узору;

$>$ у протилежному напрямку знову підрізати по лініях узору, але вже інший бік надрізаного контуру. Відповідними інструментами вибрати тло на 3-4 мм.

5. Виконати вправи для оволодіння прийомами геометричного різьблення, а саме - тригранно-виїмчастого різьблення:

$>$ підготувати невелику дощечку для різьби;

розробити ескіз геометричного мотиву в основі якого $\epsilon$ трикутники різні за розміром;

> перенести рисунок на дощечку за допомогою копіювального паперу;

$>$ тримаючи під кутом $45^{\circ}$ різець, підрізати кожен елемент послідовно з кожного боку в залежності від напрямку волокон, врізаючись до центра фрігури (трикутника, ромба тощо), обертаючи при цьому дощечку за годинниковою стрілкою.

6. Виконати вправи для освоєння техніки скобельного різблення, яке має вигляд заглиблення-нігтика, що утворюється завдяки відповідній фрормі стамески:

$>$ підготувати невелику дощечку для різьби;

$>$ розкреслити сітку з квадратів, обвести циркулем так, щоб вписати цей квадрат у коло;

відповідно заточеною стамескою, що має серповидний край і відповідає розміру лунок, виконати різьбу;

$>$ косячком виконати підріз кожної лунки.

Прилади та матеріали для виконання вправ: дерев'яна дошка заданого розміру, різці різних профрілів, стамески різних розмірів, ножікосячки, папір, олівець, копіювальний папір, лінійка, циркуль.

Практичне заняття № 2

Тема: Виконання індивідуальної практичної роботи. На основі стилізованого рослинного мотиву: розробити ескіз та виконати роботу в матеріалі - вирізьбити дошку-манеру для вибійки $13 \times 25 \mathrm{~cm}$.

Мета: Застосування теоретичних знань про закони створення декоративної композиції та закріплення практичних вмінь при виконанні індивідуальних творчих робіт в техніці художнє різьблення по дереву, засвоєння технічних прийомів послідовного виконання різьблених виробів, розвивати художній смак в практичній роботі. 
Послідовність виконання практичного завдання:

1. Виконати замальовки рослинних мотивів в природі.

2. Виконати малюнки рослинних природних об'єктів, перероблених у спрощене, або схематичне зображення.

3. Розробити ескіз рапорту на основі обраного стилізованого рослинного мотиву, вписати його в задані розміри 13×25 см.

4. Підготувати поверхню дерев'яної дошки заданого розміру (13×25 cм).

5. Перенести малюнок ескізу на поверхню майбутнього виробу за допомогою копіювального паперу.

6. Відповідними різцями, стамесками, косячками технікою контурного різьблення опрацювати всі деталі орнаменту.

7. За допомогою відповідних інструментів вибрати тло орнаменту, заглибившись рівномірно на 3-4 мм.

8. По периметру роботи зрізати всі зайві виступи на манері, щоб у процесі друку на тканині не залишилися плями.

9. Позначити на дошці місця стикування рапортного узору (вказати верх, низ).

Прилади та матеріали для виконання практичної роботи: дерев'яна дошка заданого розміру, різці різних профрілів, стамески різних розмірів, ножі-косячки, папір, олівець, копіювальний папір.

Крім цього, рекомендуємо короткий словник термінів до занять 3 різьблення.

Інкрустація - [лат. incrustatio] - оздоблення із шматочків різного матеріалу (кості, дерева, перламутра та ін.), врізаних в поверхню предмета що оздоблюється.

Інтарсія - [іт. intarsio] - дерев'яна відполірована інкрустація, зіставлена із різнокольорових шматочків дерева різних порід.

Маркетрі - [фрр. margueterie] - інкрустація по дереву з дрібних шматочків металу, дерева та інших матеріалів.

Шпон - [нім. spon] - тонкий лист деревини, отриманий у результаті лущіння чи стругання кряжів різних порід: берези, сосни, вільхи, бука та ін.; використовується в столярній справі для виготовлення багатошарової франери.

Таким чином, різьблення по дереву як один із традиційних видів народної творчості з художньої обробки деревини потребує детального вивчення задля актуалізації його в сучасному культурноосвітньому просторі.

Вважаємо, що ознайомлення студентів 3 особливостями становлення і розвитку художнього деревообробництва на Україні матиме позитивний вплив на вдосконалення фрахової підготовки педагогічних кадрів у контексті формування художньої етнокультури майбутніх фрахівців початкової освіти засобами народного мистецтва.

\section{Список використаних джерел}

1. Абросимова А., Каплан Н., Митлянская Т. Художественная резьба по дереву, кости и рогу: учебное пособие для проф.-тех. училищ. Москва: Высшая школа, 1984. $159 \mathrm{c}$. 
2. Антонович Є.А., Захарчук-Чугай Р. В., Станкевич М. $Є$. Декоративноприкладне мистецтво. Львів : Світ, 1993. 272 с.

3. Антонович Є. А., Проців В. І., Свид С. П. Художні техніки у школі : навчальнометодичний посібник для студентів художньо-графрічних фракультетів вищих навчальних закладів. Київ : ІЗМН, 1997. 312 с.

4. Білевич І. Прилучення студентів до національної культури у процесі різьблення деревини. Трудова підготовка в закладах освіти, 2001. № 3. C. $52-55$.

5. Бутник-Сіверський Б. Українське радянське народне мистецтво. Київ : Мистецтво, 1966. 224 с.

6. Гевко О. Національно-патріотичне виховання студентів вищих педагогічних закладів засобами декоративно-ужиткового мистецтва : автореф. ... дис. канд. пед. наук : 13.00.07. Київ, 2003. 21 с.

7. Данченко О. С. Народні майстри. Київ : Радянська школа, 1982. 128 с.

8. Данченко Л. Невмируще джерело. Київ : Радянська школа, 1975. 190 с.

9. Драган М. Українська декоративна різьба XVI - XVIII століття. Київ : Наукова думка, 1970. 109 с.

10. Запаско Я. Нариси з історії українського декоративно-прикладного мистецтва. Львів : ЛУ, 1969. 192 с.

11. Кавас К. Самовчитель різьбяра. Тернопіль : Підручники і посібники, 2006. 48 с.

12. Кара-Васильева Т. В. Декоративно-прикладне мистецтво України : XX століття. Київ : Либідь, 2005. 276 с.

13. Кириченко Л. М. Художня обробка деревини: методична розробка. Суми: ОІППО, 2018. 30 c.

14. Кисельов О. Гусяча лапка. Суми : Винниченко М. Д., 2018. 54 с.

15. Ковальов О. Декоративно-прикладне мистецтво в школі. Суми: Університетська книга, 2006. 144 с.

16. Матвеева Т. А. Мозаика и резьба по дереву: учебник для проф.-тетн. Училищ. Москва: Высшая школа, 1981. 80 с.

17. Лозко Г. Українське народознавство. Харків : Дивосвіт, 2005. 270 с.

18. Орел Л. Мальоване дерево. Наївний живопис українського села. Київ: Родовід, 2003. $231 \mathrm{c}$.

19. Потапкін В. С. Народні традиції художньої обробки деревини як складова частина естетичного виховання https://dspace.udpu.edu.ua/jspui/bitstream/6789/8246/1/NARODNI_TRADYTsII\%20 .pdf (дата звернення : 2.10.2019).

20. Прокопович Б. А. Проблеми підготовки майбутніх вчителів трудового навчання до ознайомлення учнів з художніми народними ремеслами. Трудова підготовка в закладах освіти, 1999. № 4. С. 28-30.

21. Тимків Б. М., Кавас К. М. Виготовлення художніх виробів з дерева. Ч. 1. Мозаїка. Випалювання. Розпис / за ред. Б. М. Тимківа. Львів : Світ, 1996. 144 с.

22. Тимків Б. Формування художньої етнокультури студентів засобами народного декоративно-прикладного мистецтва. Народне мистецтво, 2004 . № 1/2. С. 54-55.

23. Федевич Л. К. Мовою орнаментів Сіверщини. Суми і сумчани, 2011. № 14. С. 8-9.

24. Федевич Л. К. Інтерпретація орнаментів Сіверщини у різьбленому дереві Ігоря Білевича. Сіверщина в історії України. Глухів-Київ: Центр пам'яткознавства України, 2017. Вип. 10. С. 493-497.

25. Хворостов А. С. Геометрическая (трёхгранно-выемчастая) резьба. Школа и производство, 1995. № 1. С. 75-80. 


\title{
ТЕАТРАЛЬНО-ІГРОВА ДІЯЛЬНІСТЬ ЯК ЗАСІБ ФОРМУВАННЯ МУЗИЧНИХ КОМПЕТЕНЦІЙ ФАХІВЦІВ дОшКІЛЬНОї ОСВІТИ
}

\author{
Пушкар Л.В. \\ кандидат педагогічних наук, доцент, \\ Сумський державний педагогічний університет імені А.С. Макаренка
}

Зважаючи на суттєві політичні, економічні та соціокультурні зміни, що відбуваються, перед сучасною освітньою системою вищої школи стоїть важливе завдання підготувати фрахівця, який прийматиме самостійні нестандартні рішення, відрізнятиметься грамотністю, конструктивним та творчим мисленням. 3 огляду на це, важливою проблемою нинішньої вищої освіти залишається підготовка майбутніх спеціалістів дошкільного виховання, фрормування їх педагогічної майстерності й компетентності, без набуття яких неможлива реалізація гармонійного розвитку дітей у сенситивному періоді їх особистісного становлення.

Сучасні вимоги до особистості вихователя, його професійної компетентності ґрунтуються на засадах Законів України «Про освіту» (2017 р.), «Про вищу освіту» (2014р.), «Про дошкільну освіту» (2019 р.), у «Базовому компоненті дошкільної освіти» (2012 р.), у «Концепції дошкільного виховання в Україні» (2018р.), у Базовій програмі розвитку дитини дошкільного віку «Я у світі» та у програмах виховання дітей дошкільного віку «Малятко», «Дитина», «Українське довкілля» та. $[24,26,27,28]$, які в свою чергу скеровують освітні заклади на підвищення якості вищої загалом та дошкільної освіти зокрема.

Значним внеском у дослідження проблеми професійної підготовки педагогічних кадрів на основі компетентнісного підходу знаходимо у працях В. Байденка, А. Бермуса, М. Голованя, І. Зимньої, І. Зязюна, В. Козирьова, В. Краєвського, Н. Кузьміної, А. Маркової, О. Овчарука, О. Пометуна, Р. Уайта, А. Хуторського та інших. Проблему професійної підготовки та формування особистості фрахівців дошкільного профрілю в контексті компетентнісного підходу розглянуто в працях Л. Артемової, Г. Бєлєнької, А. Богуш, Л. Кідіної, О. Кононко, Т. Поніманської, О. Проскури, Т. Танько.

Питання ролі музичної підготовки та формування профресійних якостей і музичної компетентності майбутніх вихователів дошкільної освіти досліджували Г. Аніщенко, О. Бєлікова, А. Желан, І. Газіна, Л. Коміссарова, С. Нечай, О. Мальцева, Р. Савченко та ін.

Загальні методичні основи музичного виховання дітей дошкільного віку, його форми, методи та прийоми висвітлено в працях Н. Вітлугіної, А. Зиміної, Н. Кононової, А. Шевчук. Основою до нових 
розробок стають звернення до класичних методик музичного виховання дітей дошкільного віку, до праць видатних учених, зокрема О. Апраксіної, Б. Асаф'єва, Л. Баренбойма, А. Гогоберідзе, О. Кенєман, Е. Костіної, О. Радинової, В. Шацької.

Сучасна педагогічна наука, як і практика, використовують різноманітні ресурси освітньої дії на підростаюче покоління. Серед педагогічних ресурсів досить активно використовується сфера мистецтва. Як вважають науковці, які досліджують проблеми дошкільної освіти, найбільшою мірою для розкриття внутрішніх якостей особистості і самореалізації їі творчого потенціалу можна вважати синтез мистецтв. Тому не залишається осторонь такий могутній засіб освіти й виховання дошкільників як сфера театрального мистецтва (Л. Артемова, Л. Виготский, Р. Жуковськая, Н. Карпінська, Д. Менджерицкая, О. Олійник, Б. Теплов, Е. Трусова). Проблему використання цих явищ театрально-ігрової діяльності в музичному, музично-естетичному вихованні дітей та молоді досліджували Е. Абдуллін, Л. Артемова, В. Верховинець, Л. Волошина, Л. Іщенко, О. Комаровська, В. Кузьмін, О. Ніколаєва, Г. Ніколаї, К. Орф, М. Шароніна та ін.

На сьогоднішній день вже накопичений певний досвід підготовки вихователя, проте залишається актуальною проблема професійної компетентності майбутнього педагога закладу дошкільної освіти. Зокрема особливої уваги набуває формування музичних компетенцій майбутніх вихователів дошкільної освіти через залучення їх до різноманітної музичної та театрально-ігрової діяльності, пов'язаної із художньою літературою, музикою і грою. Це різного роду музичні ігри (дидактичні, рухливі), змістом яких є художні тексти (ігри-інсценування у музичному супроводі, театралізовані ігри, народні хороводні ігри зі співом, діалогами, рухами), дитячі інсценування казок, пісень, театралізація та ін.

Мета публікації - здійснити аналіз особливостей використання театрально-ігрової діяльності у процесі фрормування музичних компетенцій майбутніх вихователів закладів дошкільної освіти.

Важливим складником галузевих стандартів за спеціальністю 012 Дошкільна освіma (21.11.2019 р. № 1456) є загальні та фахові компетентності. Серед останніх визначено такі, як: «КС-11: Здатність до формування в дітей раннього і дошкільного віку елементарних уявлень про різні види мистецтва і засоби художньої виразності (слово, звуки, фарби тощо) та досвіду самостійної творчої діяльності; КС-13: Здатність до організації і керівництва ігровою (провідною), художньо-мовленнєвою і художньо-продуктивною (образотворча, музична, театральна) діяльністю дітей раннього і дошкільного віку» [27]. Означені позиції орієнтують освітній процес до певного рівня формування певних предметних компетенцій випускників. Актуалізація театральної, мовленнєвої, музичної 
складової у професійній діяльності майбутнього вихователя закладу дошкільної освіти (ЗДО) вимагає переосмислення не тільки підходів, змісту, мети й завдань фахової підготовки, але й упровадження у практику сучасних методик і технологій.

Нагадаємо, що модель музичних компетенцій має наступні структурні компоненти: історико-теоретичні, аудиційні, оцінноаналітичні компетенції - когнітивно-перцептивний компонент); вокально-мовленнєві, елементарно-інструментальні, ритмічно-рухові компетенції - музично-виконавський компонент; імпровізаційні, компонувальні, проектувальні компетенції - креативно-інтеграційний компонент [17]. На наш погляд, театрально-ігрова діяльність, її види допоможуть підвищити рівень сформованості вокально-мовленнєвих, ритмічно-рухових, імпровізаційних, компонувальних та проектувальних музичних компетенцій.

На думку І. Зязюна, саме професійна компетентність є підвалиною педагогічної майстерності - комплексу властивостей особистості, що забезпечує самоорганізацію високого рівня професійної діяльності на рефрлексивній основі. Саме спрямованість і професійні знання становлять той кістяк високого професіоналізму в діяльності, який забезпечує цілісність системи, самоорганізується. До змісту профресійної компетентності науковець відносить знання предмета, методики його викладання, педагогіки і психології [16, с. 32]. Ми вважаємо, що для досягнення високого рівня загальної професійної компетентності майбутнього фрахівця, в тому числі дошкільної освіти, важливими $€$ й інші елементи педагогічної майстерності, зокрема здатність до педагогічної діяльності, гуманістична спрямованість, педагогічна техніка. Наприклад, складові зовнішньої педагогічної техніки як втілення внутрішнього переживання педагога в його тілесній природі - міміка, голос, мовлення, рухи, пластика - стають функціональними елементами у набуті музичних компетенцій (вокально-мовленнєвих, ритмічно-рухових) через залучення до театрально-ігрової діяльності.

Дослідження професійної компетентності з акцентами на музичну або театральну інтерпретацію представлено у науково-педагогічній літературі досить варіативно. Як результат підготовки вихователя дошкільного навчального закладу досліджує музично-педагогічну компетентність Т. Танько. Автор стверджує, що це «складне поліфункціональне та індивідуально-психологічне утворення на основі інтеграції профресійних теоретичних знань, ціннісних орієнтацій і практичних умінь вихователя у сфрері музичної педагогіки, а також особистісних якостей, емоційно-ціннісного ставлення до педагогічної діяльності, які у своїй сукупності забезпечують вибір вихователем свідомої поведінки, що відображає музично-естетичні профресійні засади та гуманістичну спрямованість його педагогічної дії» [20, с. 178]. 
М. Михаськова розглядає фрахову компетентність майбутнього вчителя музики як особистісну якість, яка ввібрала в себе результати попереднього психічного розвитку. Автор розуміє цю категорію як «здатність до музично-освітньої діяльності на основі знань, умінь, досвіду емоційно-ціннісного ставлення до явищ музичного мистецтва, музично-педагогічних здібностей, набутих у процесі музичнопедагогічної діяльності» [12, с. 37]. Сутність фрахової компетентності майбутнього вчителя музики розглядається автором як здатність до музично-освітньої діяльності на основі музично-педагогічних знань і умінь, досвіду емоційно-ціннісного ставлення до явищ музичного мистецтва, у відповідності з суспільними вимогами та цінностями [там само]. На нашу думку, проекція означеної компетентності на фрахівця дошкільної освіти корегується саме музичними компетенціями через засоби театрально-ігрової діяльності.

Фаховий рівень підготовки студентів $є$ головним критерієм роботи вищого навчального закладу. Цей рівень залежить від багатьох чинників, вважає В. Мішедченко. Але основним 3 них $€$ науково обґрунтована модель фрахівця, яка визначається навчальними планами та програмами. Від того, наскільки обґрунтовані ці два документи, залежать рівень і якість підготовки фрахівців. У результаті засвоєння теоретичних і практичних дисциплін випускник повинен осягнути естетичну сутність музичного мистецтва, набути виконавських умінь і навичок, оволодіти музично-історичними знаннями, методами організації музично-пізнавальної діяльності учнів, навчитись розуміти зміст, форму і стиль музичного твору [11, с.252].

Музично-педагогічну компетентність вихователя дошкільного навчального закладу розглядає Р. Савченко, яка трактує ії як інтегративну особистісну якість, що виражає здатність до самостійної успішної реалізації завдань музичної освіти дітей на основі системної взаємодії загальногромадянських, психолого-педагогічних та музичнофахових компетенцій. Музично-педагогічна компетентність вихователя передбачає високий рівень їх загальнокультурного розвитку, ерудиції в галузі профресійно-фрахових знань (з педагогіки, психології, музичного мистецтва, методики музичного навчання), наявність досвіду та спроможність до аналітико-оцінювальних і творчо-ініціативних дій у виховній роботі з дітьми [19, с.393].

Згідно розвідок О. Лобової, спрямованих на дослідження музичної культури молодшого школяра, «феномен музичної компетентності постає в своїй частковій і спрощеній фрормі - як музична обізнаність, що передбачає оволодіння певним колом музичних знань, умінь $i$ навичок з проекцією цього теоретичного та практичного надбання на різні види музично-творчої та життєвої діяльності» [9, с. 172]. За висновками науковця, у більшості сучасних досліджень музична компетентність розуміється як невід'ємна властивість музичнокультурної людини, «невипадково фрормування музичної культури 
особистості розглядається через призму набуття комплексу музичноестетичних компетенцій» [9, с. 173].

Сьогодні педагогічна підготовка кадрів вихователів дошкільних закладів розглядається як така, що спрямована, передусім, на розвиток творчої особистості, розмаїття її виявлення, нестандартності, на вміння молодого фрахівця дошкільного профілю реалізувати власний креативний потенціал у кожній освітній ситуації. За визначенням Т. Танько, підготовка студентів дошкільного фракультету в педагогічних університетах проходить у багатьох напрямах, найбільш визнаними з яких $€$ розробка й уточнення завдань, змісту доступних для дітей дошкільного віку видів діяльності, удосконалення форм i методів виховної роботи [21, с.43-44].

С. Нечай пропонує готувати майбутніх фрахівців дошкільної освіти до застосування музики в аудіальному розвитку дошкільників. Дослідниця доводить, що обґрунтування педагогічних умов і розробка методики формування в дітей дошкільного віку звукової картини світу $\epsilon$ одним із важливих завдань професійно-педагогічної підготовки майбутніх вихователів у вищому навчальному закладі. Це, на її думку, має забезпечити формування педагогічних кадрів нової формації творчих особистостей, здатних забезпечувати сприятливі умови для повноцінного розвитку суб'єктів освітнього процесу [13].

Таким чином, музична (музично-педагогічна або музичноестетична) компетентність як інтегративна особистісна якість, передбачає сорормованість певного рівня знань, умінь, навичок, ставлень, досвіду, поведінкових реакцій, а також здатності самостійно вирішувати завдання у конкретній сфері діяльності. Крім того, означені нормативно-правові акти орієнтують підготовку майбутніх фрахівців дошкільної освіти на оволодіння певними компетенціями (у нашому випадку - музичними) з метою утворення такого інтегрального утворення особистості, результативного блоку, як компетентність.

К контексті нашого дослідження слушною пропозицією І. Зязюна $є$ необхідність послуговуватися сучасній системі освіти і виховання двома найважливішими завданнями будь-якої театральної школи: формування творчої особистості актора і розкриття глибинних можливостей його дії (діяльності) на сцені. «Перше завдання охоплює ідейне, естетичне і дисциплінарно-етичне виховання актора (формування світогляду, художнього смаку, морального складу). Другого досягають шляхом професійного виховання актора» [16, с. 82]. Ці завдання з урахуванням театральної специфіки, реалізуючись у практиці освіти і виховання в цілому, - значуще нововведення, що потребує методологічного осмислення, вважає науковець. I першою вимогою методології нововведення визначає синтезування теорії, прикладного керування педагогічним процесом і його алгоритмами відповідно до особливостей мистецтва театру взагалі і театральної педагогіки зокрема [там само]. 
О. Олійник зазначає, що виклики сьогодення зумовлюють появу нових завдань в системі професійної освіти, які спрямовані на формування спеціалістів, здатних до гнучкого, оперативного реагування на постійні зміни й потреби суспільства, конкурентоспроможність, розвиток освітніх технологій та неперервно оновлюючого інфрормаційного простору. Необхідним, вважає науковець, стає постійне удосконалення змісту і фрорм навчання, готовність до конкурентоспроможності, оскільки постійно зростають вимоги до професійної компетентності, якості та ефективності роботи вихователів. Автор у своїх дослідженнях приділяє значну увагу розвитку мобільності та фрормуванню ігромайстерності в процесі професійної підготовки педагога дошкільної освіти [14, с. 105-106].

В широкому сенсі під «мобільністю», констатує О. Олійник, розуміють здатність швидко перебудовуватися, змінюватися та взаємодіяти під впливом нових умов діяльності, які висуває особистості сучасне суспільство (швидкість, темп, ефективність, оперативність). «Мобільність у руслі компетентнісного підходу, визначається як ключова компетенція, яка забезпечує самореалізацію та самовдосконалення особистості у різних ситуаціях повсякденного, професійного або соціального життя» [14, с. 107]. Ми підтримуємо думку автора, що у дошкільному закладі доцільно використовувати у практиці систему детального ознайомлення педагогів з засобами театрального мистецтва та формуванні ігромайстерності. Адже процес формування творчих умінь дошкільників багато в чому залежить від спрямованості педагогів на застосування в освітньому процесі засобів театральної діяльності, практичних занять для вдосконалення власних акторських та режисерських умінь.

Як відомо, театральне мистецтво - це синтетичний вид мистецтва, що зображує життя в сценічній дії, яку виконують актори перед глядачами. Театр об'єднує у собі і художню літературу, музику, хореографрію, живопис, дизайн, моделювання одягу, перукарську майстерність, макіяж, спорт (акробатика, фехтування тощо), народнодекоративні промисли і т.ін. Театр $є$ видом мистецтва, специфічним засобом виразності якого є сценічна дія, що виникає у процесі гри актора перед публікою. Тобто, гра $є$ основним елементом мистецтва театру, який через неї стає певною формою суспільної свідомості.

у сучасній психології та педагогіці акцентується увага на значення та вплив театральної діяльності як на розвиток особистості дитини дошкільного віку, так і на важливість готовності майбутніх педагогів - фахівців дошкільної освіти до забезпечення відповідного розвитку малечі.

На спільне і відмінне в театральному й педагогічному мистецтві вказував І. Зязюн. Науковець проводить паралель між педагогічним мистецтвом і театром одного актора, тому для усвідомлення принципів театральної дії та ії законів пропонує звернутися до системи 
К. Станіславського, який розглядає органічну природу театральної творчості через природу людини-творця, актора. У цій системі вперше вирішується питання свідомого оволодіння підсвідомим, довільним процесом творчості, виявом таланту особистості в діяльності. І. Зязюн звертає увагу на таку основоположну ідею у системі К. Станіславського, яка уособлює закономірність фрункціонування мистецтв, в основі яких - людське спілкування, тобто мова йде про фізичну дію, про метод фрізичних дій. «Жива фрізична дія з відповідною естетичною почуттєвістю, підсвідомою сфрерою потребує тренувань передусім органів сприймання в умовах педагогічної навчальновиховної дії. Зі сприймання починається органічна дія як актора, так i педагога. $€$ потреба також у методиках розвитку творчої уяви, волі, пам'яті, вербальної сугестії тощо» [16, с. 94].

Спільні особливості у професії актора і вихователя зазначає також О. Олійник. Зокрема в драматургії заняття чи в організації іншого виду дитячої діяльності присутні як використання розмовного матеріалу (читання, розповідь, бесіда, пояснення тощо), так і мінімальні декорації - інтер'єру групової кімнати, дидактичних матеріалів (ілюстрацій, макетів, моделей, елементів одягу конкретного персонажа тощо), музичного супроводу, і при цьому вихователь $є$ самим собою особистістю, яка цілеспрямовано виховує і навчає. Науковець вважає, що п'ять принципів, на яких ґрунтується виховання актора, можуть використовуватися в адаптованому вигляді також у підготовці вихователя: Це такі принципи:

1)принцип життєвої правди (у педагогіці - це зв'язок навчання i виховання з життям);

2)принцип ідейної спрямованості: учення про надзавдання (цей принцип відіграє велику роль у конструктивній діяльності педагога, адже режисура заняття, гри, праці, спостереження передбачає постановку завдання, надзавдання, яке й розв'язує вихователь);

3) принцип дії - підґрунтя переживання й матеріалу для творчості, він $€$ основним у системі К.С. Станіславського (творче переживання й матеріал для творчості $є$ провідним компонентом в організаторській діяльності вихователя);

4)принцип органічної творчості (розкриває нерозривний зв'язок психічного і фрізичного, суб'єктивного переживаного почуття педагога з його зовнішнім об'єктивним вираженням, тобто говорить про рівень психотехніки вихователя, володіння своїм організмом -- головним інструментом впливу на вихованців);

5)принцип творчого перевтілення в образ - це стан сценічного переживання, на ґрунті якого розв'язуються завдання всіх попередніх принципів (цей принцип знаходить своє відображення в гностичній діяльності вихователя як засадовій для всієї професійної діяльності педагога) [14, с. 94]. Ми також виходимо з того, що формування музичних компетенцій фахівців дошкільної освіти 
засобами театрально-ігрової діяльності базується на законах, принципах театральної дії.

Крім того, О. Олійник у своїх працях розглядає систему підготовки фахівця дошкільної освіти до театрально-ігрової діяльності та професійної майстерності. Автор окреслює елементи театральної педагогіки саме в професійній діяльності вихователя дошкільного навчального закладу: «Тільки в царині театральної педагогіки кожен майбутній вихователь може знайти для себе засоби розкриття власних педагогічних здібностей, творчого потенціалу» [14, с. 93]. Сьогоднішній інтерес до театральної педагогіки автор пояснює низкою соціокультурних і освітніх факторів: по-перше, - це потреба особистості, яка здатна до адекватної культурної самоідентифікації, до вільного вибору власної позиції (елементи театральної педагогіки $€$ органічною складовою навчально-виховного процесу у вузі, універсальний засіб розвитку творчих, артистичних здібностей майбутнього педагога); по-друге, - перехід від способу простого нарощування кількості навчальних програм до пошуку інтенсивних підходів до іiі організації (саме театральна педагогіка покликана розкрити внутрішній потенціал педагога); по-третє, це педагогічний артистизм, важлива риса професійної майстерності, творчості педагога (адже гарний педагог повинен володіти мистецтвом самовираження, здатністю до перевтілення, співтворчості з колегами, вихованцями, співпереживання з ними) [14, с. 92-93].

Зауважимо, що У Базовому компоненті дошкільної освіти визначено державні вимоги до рівня освіченості, розвиненості та вихованості дитини 6 (7) років та кінцевий показник набутих дитиною компетенцій перед її вступом до школи. Кожна освітня лінія Базового компонента дошкільної освіти завершується узагальненим визначенням результату освітньої роботи - сформованістю певного виду компетенцій. Зокрема, серед останніх визначені художньопродуктивна компетенція (Освітня лінія «Дитина у світі культури») та ігрова компетенція (Освітня лінія «Гра дитини»). За результатами освітньої роботи дитина напередодні вступу до школи має орієнтуватися в основних видах театрального мистецтва, вирізняти гуманний зміст і колективний характер театральної вистави; виявляти власну позицію, інтегровані навички під час перевтілення у сценічний образ (позитивний, негативний), створювати його за допомогою експресивних засобів (мовлення, міміки, жестів, рухів, музики, танців, співів); творчо співпрацювати з дітьми і дорослими заради спільного успіху в музично-театралізованих розвагах і святах [24]. Тому спрямування майбутніх фрахівців дошкільної освіти на використання театрально-ігрової діяльності у процесі формування музичних компетенцій не повинне залишатись поза увагою.

У працях сучасних науковців виокремлюється, що театралізована діяльність - це найпоширеніший вид дитячої творчості, яка дозволяє 
формувати досвід соціальних навичок поведінки дитини, вирішувати багато педагогічних та психологічних проблем, пов'язаних 3 мистецькою освітою та вихованням дітей, формуванням естетичного смаку, моральним вихованням, розвитком комунікативних якостей особистості (навчанням вербальним та невербальним видам спілкування), вихованням волі, розвитком пам'яті, уяви, ініціативності, мовлення; створенням позитивного емоційного настрою, зняттям напруження, вирішенням конфліктних ситуацій через гру [10, с.5-6].

У науковій літературі театралізована діяльність визначається як художня діяльність, що пов'язана зі сприйманням творів театрального мистецтва і відтворенням в ігровій фрормі набутих уявлень, вражень, почуттів, $є$ одним із найефективніших засобів педагогічного впливу на розвиток особистості дитини. Водночас, вона виступає як специфічний вид дитячої активності, один із найулюбленіших видів творчості [14, с. 9].

Серед видів театрально-ігрової діяльності, на нашу думку, у процесі формування музичних компетенцій майбутніх вихователів важливо використовувати такі як інсценізація, драматизація, театралізація та ін. Опанування ними допоможе фрахівцям дошкільної освіти реалізувати свій творчий потенціал та результатів освітньої роботи - сфрормувати певні компетенції дітей перед вступом до школи.

У словникових джерелах термін «інсценізація» (від лат. in - на i scaena - сцена) тлумачиться як переробка літературного твору (прозового, поетичного) для постановки його на сцені або для радіо- чи телевистави; інсценізація має на меті засобами драматургії передати ідейно-художній зміст інсценізованого твору, тут можлива і його інтерпретація [15]. Проте, поряд з інсценізацією літературного твору існує сценічне відтворення пісень, а також інструментальних творів.

Інсценізація пісні - одна з найулюбленіших для дітей форм роботи на музичних заняттях. Якщо ця робота проводиться цілеспрямовано й систематично, це дозволяє максимально реалізувати той педагогічний потенціал, який містить пісенний матеріал як засіб музичного розвитку, музичного виховання й навчання учнів. На думку Е. Абдуллова і О. Ніколаєвої дітей приваблює те, що театралізація пісні - це не тільки виразне й грамотне виконання ії̈ в музичному відношенні, а створення сценічного художнього образу засобами різних мистецтв [1, с. 155]. Автори обґрунтовують необхідність у музичній діяльності об'єднання декількох видів мистецтва в одному завданні. Найбільш частим таке об'єднання відбувається під час інсценізації пісні й створенні музично-сценічних композицій на основі інструментальних музичних творів [1, с. 145].

У театрознавчій науці й театральній практиці, режисурі термін «інсценізація пісні» часто називають «зримою піснею» й визначають як вид сценічної вистави. Видима пісня навчає мислити пластичними 
образами, вмінню орієнтуватись у сценічному просторі і знаходити видиме вираження музично-емоційному строю твору. Зробити пісню видимою означає створити на матеріалі пісні маленьку виставу. Тоді ми пісню чуємо й бачимо. Це дуже підсилює емоційне враження за допомогою очей актора, міміки, жесту, мізансцен. Виникає синтез музики, вокалу й акторської майстерності.

Синтез акторського мистецтва, музики й тексту у пісні не можна розуміти буквально - виключно у значенні створення пісні-сценки, де театральними засобами розігрується якийсь сюжет. Це спрощений підхід до проблем режисерського рішення пісні, хоча й повністю його виключити на можна. Важливіша умова під час роботи над піснею полягає в тому, щоб правильно і точно визначити, текстовий та мелодійний зміст пісні, її жанр та стиль дозволяють привнесення в неї прийомів власне театральної виразності [8, с. 7].

Серед можливостей впливу музично-ігрової інсценізації або інсценізації пісні на виховання та розвиток дітей, назвемо такі: беручи участь в такій діяльності, діти ознайомлюються з навколишнім світом, а вміло поставлені вчителем запитання спонукають учнів думати, аналізувати, робити висновки та узагальнення; музично-ігрова інсценізація розвиває емоційну сферу дитини і $€$ важливим засобом розвитку у дітей емпатії - здібності розпізнавати емоційний стан людини за мімікою, жестами, інтонацією, вміння ставити себе на її місце в різних ситуаціях, знаходити адекватні засоби сприяння; музично-ігрова інсценізація дає змогу формувати досвід естетичних навичок поведінки й має психологічний вплив на фрормування естетичної культури дитини, що має велике значення в процесі естетичного виховання.

У грі-інсценізації, імпровізаціях на задану тему-образ, в етюдах на перевтілення формуються здатність суб'єкта художнього спілкування до розуміння інших людей (характерів, вчинків), збагачується емоційна чутливість, розвиваються комунікативні здібності дитини. 3 точки зору набуття молодшими школярами емоційного досвіду важливо також, що створення художнього образу протікає на очах у глядачів, особливо це стосується дітей сором'язливих, скутих, яким музичнотеатралізована діяльність може допомогти перебороти невпевненість у собі, підвищить їх самооцінку, навчить вільно і невимушено триматися на людях [2, с. 116].

Для нашого дослідження важливими $є$ ідеї інсценізації у музичному навчанні та вихованні видатного представника плеяди творців української національної музичної освіти і культури В. Верховинця - композитора, хорового диригента, хореографа, фольклориста, етнографра, педагога, основоположник жанру «театралізована пісня» в Україні.

Результатом та вершиною багаторічної етнографрічнодослідницької роботи, педагогічних пошуків і композиторської 
творчості В. Верховинця, вважають дослідники, стало створення репертуарно-методичного посібника «Весняночка» (1924р.). Його основу становить український музично-ігровий репертуар для дітей.

Працюючи над «Весняночкою», педагог поставив конкретні завдання: «виховання фрізично здорового, етично стійкого, інтелектуально розвинутого майбутнього члена суспільства», адже «завдяки іграм можна виховати в дитині всі властивості, котрі ми шануємо у людей і котрі нам хотілося б прищепити малечі» [5, с.21, 144, 181]. Одним із потужних засобів досягнення бажаного результату у вихованні та забезпеченні гармонійного розвитку особи автор «Весняночки» вважав рухливі музичні ігри [5, с.342].

Н. Дем'яненко зазначає, що кожну гру педагог подає в інсценізованому вигляді, який передбачає наявність певної драматургії, реквізиту, розподілення ролей між учасниками. Для більш повного розкриття художнього образу, передачі національного характеру, посилення емоційного та естетичного впливу на вихованців він доповнює засоби театралізації (рухи, міміку, пантоміміку) пісенним супроводом і елементами народної хореографії. Автор, детально аналізуючи репертуар цього збірника, конкретизує, що до репертуарно-методичного посібника увійшли сто п'ятдесят шість рухливих музичних ігор і пісень, серед яких - дев'ять народних ігор, етнографрічний запис яких зробив сам В. Верховинець. Більшість ігор він створив на основі етнографрічного матеріалу: 1) українських народних пісень - дев'ятнадцять ігор; 2) народних мелодій - дев'ять; 3) поетичного фрольклору - вісімнадцять. Чотирнадцять рухливих музичних ігор і шістнадцять пісень написані педагогом на слова українських поетів: Т. Шевченка, Л. Українки, І. Франка, П. Тичини, О. Олеся та інших. «3 метою прилучення підростаючого покоління до кращих зразків українського музичного мистецтва Василь Миколайович інсценізує твори М. Лисенка, М. Леонтовича, К. Стеценка, П. Козицького, П. Демуцького» [6., с.63-66].

У нашому дослідженні доречно звернути увагу на такі види, засоби розвитку особистості, фрормування музичних компетенцій як пантоміма, гра, інсценізація під музику, основані на методиці К. Орфа, яка являла собою цілісну та ефективну систему музичного виховання, засновану на різних формах колективного музикування, дитячої творчості, активної виконавської діяльності. Для цього німецького педагога і музиканта основоположними засобами виховання дітей була елементарна музика, елементарний інструментарій, елементарні словесні тексти. Завданнями музичного виховання К. Орф вважав стимулювання й спрямовування творчої франтазії, уміння імпровізувати, творити у процесі індивідуального і колективного музикування, спираючись на зв'язок музики з жестом, словом, танцем, пантомімою. А головними засобами навчання і виховання стала єдність слова, музики і руху. 
Ідея К. Орфа полягає в тому, що в основі навчання лежить «принцип активного музикування» i «навчання у дії», на думку педагога-музиканта, дітям потрібна своя музика, спеціально призначена для музикування на первинному етапі, первинна музична освіта повинна мати сповнена позитивних емоцій і радісного відчуття гри. Комплексне навчання музиці надає дітям широкі можливості для творчого розвитку здібностей. Основний напрям в методиці К.Орфа ігрові моделі занять. Оволодіваючи мовою музики, поступово пізнаючи засоби її виразності і застосовуючи їх в своїй виконавській практиці, діти і розумом, і відчуттями залучаються до створення музики.

Як свідчить Л. Баренбойм, елементи системи музичного виховання спрямовані на розвиток творчих здібностей і навичок дитини, вони гармонійно вплітаються в структуру занять. Науковець наводить приклади використання методики К.Орфа на заняттях різного спрямування: мовні вправи; поетичне музикування; музично-рухові вправи; ігри з інструментами; елементарний музичний театр. Зокрема, останній елемент являє собою інтегративну ігрову форму діяльності, яка передбачає одночасний вплив музики, руху, танцю, мови та художнього образу в образотворчій грі. У якості особливих прийомів організації театралізованої діяльності використовуються ігрові тренінги, ссрормовані незалежно від розвиваючих завдань допомагають вирішити проблему корисного і цікавого дозвілля [3, с. 376].

Наступний різновид театрально-ігрової діяльності, який можна застосовувати у процесі підготовки майбутніх вихователів та формування їх музичних компетенцій, це - театралізація. У «Словнику театру» П. Паві дається таке визначення: «Театралізувати подію або текст означає інтерпретувати їх сценічно, з використанням сцени та акторів для того, щоб поставити ситуацію. Візуальні елементи сцени i постановка дискурсів - суть ознак театралізації. Драматизація навпаки спрямована виключно на текстову структуру: постановку діалогів, створення драматургічного напруження та конфрліктів між персонажами, динаміки дії» [15, с. 364]. Іншими словами, театралізація - це і $\epsilon$ сценічне перекладення погляду митця на подію, відображене засобами мистецтва.

На сьогодні митці, режисери, науковці, практики масових театралізованих свят поняття «театралізація» трактують неоднозначно. Крім того, відбувається постійна інтерпретація цього терміну у зв'язку з визначенням мети проведення, завданнями, способами використання цього явища у тій чи іншій сфері діяльності: а) театралізація може означати лише органічне поєднання нетеатрального, життєвого, безпосередньо пов'язаного з виробничою практикою та побутом людей і художнього матеріалу, образного; це поєднання, цей сплав документального та художнього створюється з метою певного впливу на публіку $[7$, с. 7]; б) театралізація як окреме явище означає 
синтез елементів театру, музики, хореографії, живопису, пластичних мистецтв та світла [22, с. 47]; в) це засіб утілення тієї або іншої ідеї на сцені в образній фрормі [23, с. 42]; г) це прийом, основою якого $є$ використання тих або інших (або всіх разом) характерних для театру виразних засобів для створення неповторного, яскравого, характерного тільки даному концерту художнього сценічного образу [18]. Тобто, поняття «театралізація» через свою універсальність потребує контекстного уточнення: театралізація життя, театральність у романі, театральний початок живопису, естетика театру в прозі. Кожного разу, коли використовується цей термін, враховують певні особливості її проведення і здійснюється театралізація специфічними прийомами.

Невипадково О. Бувалець звертає увагу на важливу якість театралізації - іï головну виховну мету, яка полягає у створенні на емоційній основі реакцій на ті чи інші явища, події суспільного життя, стереотипи їх сприйняття. Саме ці соціальні емоційно забарвлені образні стереотипи здатні певним чином впливати на свідомість людей. Автор вказує, що театралізація є продуктом реалізації творчого начала в людині, проявом природної необхідності, розумної доцільності їі діяльності й виходом за межі відомого [4].

Театралізація виступає як специфічний вид дитячої активності і $\epsilon$ однією $з$ найулюбленіших видів творчості. Це спосіб відтворення творів театрального мистецтва з набутими уявленнями, навичками, почуттями та досвідом. Вона сприяє естетичному вихованню дітей, прилучає їх до мистецтва, розвиває вміння бачити, чути, розуміти красу слова, дії. Театральне мистецтво близьке і зрозуміле дітям, адже в його основі - гра, що для малюка $є$ найголовнішим аспектом діяльності. Під час театралізації реалізуються потреби дитини у самовираженні, спілкуванні, пізнанні себе через відтворення різних образів. У відвертому, щирому ставленні до художнього образу, утіленні його у різних фрормах театралізації, дитина виявляє рівень художньо-естетичного сприймання, мовленнєву компетенцію, певні знання, вміння, навички, здобуті нею раніше в умовах спеціально організованого навчання.

У закладах дошкільної освіти використовують театралізацію у процесі різноманітної театрально-ігрової діяльності. Зокрема під час такого синтетичного виду діяльності дошкільників як ігридраматизації. Гра-драматизація - це відтворення сюжету літературного твору власними діями виконавців ролей, використання ними засобів виразності - інтонації, міміки, пантоміми. В ній дитинаартист, самостійно створює образ за допомогою комплексу засобів виразності, проводить власні дії виконання ролі. У грі-драматизації дитина виконує який-небудь сюжет, сценарій якого заздалегідь існує, але не $\epsilon$ сталим каноном, а служить канвою, в межах якої розвивається імпровізація. Ці ігри можуть проводитись або баз глядачів, або у вигляді концертного виконання. У випадку, якщо вони 
розігруються в звичайній театральній фрормі (сцена, завіса, декорації, костюми і так далі) або у формі масового сюжетного видовища, їх називають театралізаціями [14, с. 25].

Таким чином, не викликає сумніву необхідність готовності майбутніх вихователів до використання театралізації у своїй майбутній професійній діяльності. А такі види театрально-ігрової діяльності як імпровізація, драматизація, театралізація необхідно враховувати під час підготовки фахівців дошкільної освіти, зокрема формування їх певних компетенцій.

Для фрормування музичних компетенцій бакалаврів дошкільної та початкової освіти на лекційних, семінарських та практичних заняттях 3 дисциплін «Теорія та методика музичного виховання» та «Організація театралізованої діяльності в ДНЗ» (у ННІПП СумДПУ імені А.С. Макаренка) здійснюються наступні завдання (ті, що корелюються з театрально-ігровою діяльністю): вивчення основних положень систем музичного виховання Е. Жака-Далькроза, К. Орфа, З. Кодая, Д. Кабалевського; презентація теоретичних та методичних розробок В. М. Верховинця, його рухливих ігор та забавок; ознайомлення 3 поняттям театралізованої діяльності; вивчення методики та технології різних видів театру в дитячому садочку; набуття студентами вмінь проектувати, організовувати і реалізовувати пізнавальні, розвивальні і виховні аспекти педагогічної взаємодії в дошкільних навчальних закладах; фрормування у студентів вміння застосовувати в навчальновиховному процесі в дошкільних навчальних закладах надбань класичних і сучасних педагогічних досліджень, новаторських ідей; розвиток самостійності, творчої активності студентів; розширення загальнопедагогічного і загальнокультурного світогляду студентів.

Лекційні теми курсів підпорядковані закладанню теоретичного підґрунтя процесу формування музичних компетенцій фрахівців дошкільної освіти. Теми курсу «Теорія та методика музичного виховання» за мету ставлять ознайомлення студентів з найвідомішими методиками музичного виховання, з дитячим музичним фольклором, 3 формами організації музичної діяльності дітей, 3 активними технологіями навчання музики. Означений зміст спрямовано на фрормування історико-теоретичних, оцінно-аналітичні компетенціій.

Програма дисципліни «Організація театралізованої діяльності в ДНЗ» враховує у лекційному курсі та практичній частині поєднання «музичної» та «театралізованої» складової театрально-ігрової діяльності. Такі теми, як «Театральна педагогіка та її роль у вихованні дітей дошкільного віку», «Досвід зарубіжних та вітчизняних педагогів по організації театрально-ігровій діяльності», «Організаційні аспекти театралізованої діяльності в дитячому садочку», «Організація самостійної театралізованої діяльності та розвиток творчої активності дошкільнят» передбачають фрормування ритмічно-рухові, імпровізаційні, компонувальні, проектувальні компетенції. Наявність цих та 
інших компетенцій значно підвищує ефрективність фрормування художньо-продуктивної компетенції (Освітня лінія «Дитина у світі культури») та ігрової компетенції (Освітня лінія «Гра дитини») дітей дошкільного віку. Суттєвою складовою курсів є експериментальнопроектна діяльність студентів, яка спрямована на опанування досвідом проведення музичних вправ, ігор, забавок в умовах закладів дошкільної освіти. Контроль ступеня сорормованості музичних компетенцій здійснюється шляхом складання заліку у формі захисту творчого міні-проекту.

Таким чином, на основі аналізу нормативно-правових та нормативно-методичних актів, науково-педагогічної та психологічної літератури визначено важливість та необхідність формування музичних компетенцій фрахівців дошкільної освіти засобами театральноігрової діяльності. Серед особливостей використання театральноігрової діяльності у процесі фоомування музичних компетенцій майбутніх вихователів закладів дошкільної освіти зазначимо наступні позиції: застосування принципів та законів театральної педагогіки; комплексне використання сучасних методик та технологій музичного виховання та використання їх у театрально-ігровій діяльності; урізноманітнення видів театрально-ігрової діяльності, як то інсценізація, театралізація, драматизація; створення міні-проектів.

\section{Список використаних джерел}

1. Абдуллин Э. Б., Николаева Е. Б. Музыкально-педагогические технологии учителя музыки: Учебное пособие. М.: Прометей, 2005. 232 с.

2. Артемова Л. Театр і гра: вдома, у дитячому садку, у школі К. : Томірс, 2002. 291 c.

3. Баренбойм Л. А. Элементарное музыкальное воспитание по системе Карла Орфра М.: Советский композитор, 1978. 376 с.

4. Бувалець О.О. Еволюція поняття «театралізація» в культурному просторі масових видовищ: Історія та сучасність. Культура України. Випуск 38, 2012.

5. Верховинець В.М. Весняночка: Ігри з піснями для дітей дошк. і мол. шк. В. -5-те вид. - К.: Муз. Україна, 1989. - 324 с.

6. Дем'яненко Н.Ю. «Весняночка» В.М. Верховинця та ї̈ педагогічне значення // Збірник наукових праць Полтавського державного педагогічногог університету імені В.Г. Короленка. Серія «Педагогічні науки». - Вип. 2 (35) - Полтава: ПДПУ, 2004. - С. 63-66

7. Конович А. А. Театрализованные праздники и обряды в СССР . М. : Высш. шк., 1990. 208 C.

8. Кузьмин В.В. Зримая песня. Учебно-методическая рекомендация. - СанктПетербург: СПбГИК, 2017. - 28 с.

9. Лобова О. В. Формування основ музичної культури молодших школярів: теорія і практика: [Монографрія]. Суми: ВВП «Мрія» ТОВ, 2010. 511 с.

10. Мигунова Е.В. Организация театрализованной деятельности в детском саду: Учеб-метод. Пособие. Великий Новгород, 2006. 126 с.

11. Мішедченко В. Формування профресійної компетентності майбутнього вчителя музики в умовах вищого навчального. Проблеми підготовки сучасного вчителя, 2012. - № 6(1). С. 251-257.

12. Михаськова М.А. Формування фрахової компетентності як особистісної якості майбутнього вчителя музики. Наукові записки: Психолого-педагогічні науки: 
НДУ імені Миколи Гоголя, 2004. №2. С. 35-38.

13. Нечай С.П. Теорія і практика підготовки майбутніх вихователів до поліфункціонального застосування музики в аудіальному розвитку дошкільників: автореф. дис... д-ра пед.наук: 13.00.04; 13.00.08. К., 2015. 42 с.

14. Олійник О. М. Театрально-ігрова діяльність в умовах дошкільного навчального закладу : навч.-метод. посіб. Кам'янець-Подільський: Волощук В. О., 2017. $163 \mathrm{c}$.

15. Пави П. Словарь театра. М. : Прогресс, 1991. 504 с.

16. Педагогічна майстерність: Підручник / Зязюн І.А., та ін. 2-ге вид. К.: Вища шк.., 2004. 422.

17. Пушкар Л.В. Методичні засади формування музичних компетенцій студентів педагогічних університетів: автореф. дис. на здобуття наук. ступеня канд. пед. наук: спец. 13.00.02 - «Теорія та методика музичного навчання» Київ, 2009. $24 \mathrm{c}$.

18. Рубб А. А. Феномен эстрадной режиссуры М.: Луч,2001. 384 с.

19. Савченко Р. А. Музично-педагогічна компетентність майбутнього вихователя та музичного керівника дошкільного навчального закладу: теорія та методика: навч.-метод. посіб. для студ. вищ. пед. закл. III та IV ступенів акредитації .Нац. пед. ун-т ім. М.П. Драгоманова. - Київ, 2015. - 299 с.

20. Танько Т.П. Музично-педагогічна компетентність майбутнього вихователя дошкільного навчального закладу. Х.: Нове слово, 2003. 248 с.

21. Танько Т. П. Особливості ігрового навчання в музично-педагогічній підготовці майбутніх вихователів дошкільних навчальних закладів . Актуальні питання мистецької освіти та виховання. 2016. Вип. 2. С. 43-51.

22. Туманов И. М. Режиссура массового праздника и театрализованного концерта М. : Просвещение, 1978. 87 с.

23. Чечетин А. И. Искусство театрализованных представлений М. : Просвещение, 1981. $192 \mathrm{C}$,

24. Базовий компонент дошкільної освіти / Науковий керівник: А.М. Богуш. К.: Видавництво, 2012. 26 c. URL: http://mon.gov.ua/activity/education/doshkilna/ basic1/;

25. Державний стандарт вищої освіти. 012 Дошкільна освіта від 01.11.2019 р. № 1456. URL: https://mon.gov.ua/storage/app/media/vishcha-osvita/zatverdzeni\% 20standarty/2019/11/22/2019-11-22-012doshkilna-B.pdf

26. Про вищу освіту: Закон України від 01.07.2014 р. № 1556-VII. Дата оновлення: 28.09.2017. URL: http://zakon0.rada.gov.ua/laws/show/1556-1;

27. Про дошкільну освіту: Закон України від 06.07.2010 р. № 2442-VI. URL: http://zakon4.rada.gov.ua/laws/show/2628-14

28. Про освіту : Закон України від 05.09.2017 р. № 2145-VIII. Голос України. 2017. 27 верес. (№ 178-179) URL: http://www.golos.com.ual 


\title{
ОСОБЛИВОСТІ ВИКОРИСТАННЯ НАДБАНЬ ЕТНОПЕДАГОГІКИ У ПРОФЕСІЙНІЙ ПІДГОТОВЦІ МАЙБУТНІХ ВИХОВАТЕЛІВ ДІТЕЙ ДОШКІЛЬНОГО ВІКУ
}

\author{
Рогальська Н. В. \\ кандидат педагогічних наук, професор \\ Миколаївський національний університет імені В.О.Сухомлинського
}

Актуальність обраної проблеми обумовлена новими концепціями дошкільної освіти, реалізація яких вимагає від вихователя дітей дошкільного віку високого рівня компетентності, готовності до реалізації у практичній роботі освітніх інновацій та творчого їх використання в освітньому процесі закладу дошкільної освіти. Важливим $€$ те, що аналіз сучасної педагогічної практики засвідчує наявні протиріччя між сучасними вимогами до роботи вихователя у закладі дошкільної освіти, трансформуванні наукових ідей у педагогічну практику та рівнем сформованості професійних компетентностей у майбутніх вихователів дітей дошкільного віку, які покликані організовувати та забезпечувати освітній процес у таких освітніх установах. Таким чином, необхідність оновлення процесу профресійної підготовки дошкільних педагогів у системі вищої професійної освіти обумовлена не тільки необхідністю формування професійної компетентності майбутніх вихователів, а й гострою потребою удосконалення науковометодичного забезпечення професійної підготовки таких фрахівців.

Тому насамперед зосередимо увагу на навчальній дисципліні «Педагогіка дошкільна», яка за своїм змістом і призначенням $€$ базовою в теоретичній підготовці майбутніх фахівців дошкільної освіти. Наголосимо, що вона, як наука і навчальна дисципліна, повинна враховувати всі соціальні зміни в житті суспільства, прогностичні тенденції його розвитку, суспільні вимоги до компетентності дитини дошкільного віку, сучасні особливості її соціалізації у соціальному довкіллі. Сучасна дошкільна педагогіка досліджує закономірності та особливості розвитку, виховання і навчання дітей дошкільного віку в освітніх установах на засадах взаємодії з сім'єю. Загальними засадами дошкільної педагогіки $€$ їі предмет, особливості та організація педагогічного дослідження в галузі дошкільної педагогіки, розвиток теорії та практики дошкільної освіти, характеристика сучасної системи дошкільної освіти. Дошкільна педагогіка за своїм змістом та призначенням $€$ базовою і визначає своєю метою забезпечити теоретичну та практичну підготовку до виконання кваліфікаційних обов'язків вихователя закладу дошкільної освіти. Основними завданнями навчальної дисципліни $€$ - формування у майбутніх фахівців знання про мету, завдання зміст і методи розвитку, виховання і навчання дітей раннього і дошкільного віку, ознайомлення з педагогічними традиціями українського народу, сучасними педагогічними 
теоріями виховання і розвитку дитини-дошкільника, формування здатності до педагогічного усвідомлення явищ виховання, навчання і розвитку вихованців на засадах взаємодії з сім'єю, підготовка до компетентної реалізації усіх освітніх завдань, розвиток умінь та навичок педагогічного проектування освітнього процесу. Зазначимо, реалізація сучасних вимог до підготовки вихователя нової генерації повинна базуватись на компетентнісному підході. Дошкільна педагогіка як навчальна дисципліна у великій мірі покликана забезпечувати формування ключових компетентностей майбутнього фахівця дошкільної освіти. Як наука, дошкільна педагогіка покликана реалізовувати цілу низку функцій, а саме: теоретичну (обґрунтовування нових теорій розвитку дитинства), практичну (програмно-методичне забезпечення, розробка інноваційних технологій дошкільної освіти), прогностичну (вивчення тенденцій впливу суспільства на становлення особистості дитини дошкільного віку), аналітичну (діагностика відповідності стану педагогічної практики закономірностям організації педагогічного супроводу розвитку дітей). Зазначимо, сучасний розвиток освіти вимагає теоретичного обґрунтування нових галузей дидактики дошкільної освіти, теорії і практики громадянського та правового виховання старших дошкільників, гендерного, економічного та екологічного виховання дітей, виховання в дусі миру, превенції негативних і шкідливих звичок, збереження життя і здоров'я дитини.

У цьому руслі важливе наповнення професійної підготовки майбутніх вихователів інноваційними технологіями дошкільної освіти. Також варто переосмислити певні застарілі підходи у власному професійному досвіді викладачів закладів вищої освіти, змінити їхні пріоритети у власній професійній діяльності, у формуванні мотивації майбутніх вихователів дітей дошкільного віку до саморозвитку та рефлексії.

Насправді сучасний вихователь закладу дошкільної освіти повинен уміти долати в своїй діяльності монологічність, спрямованість на один рівень розвитку дітей, низьку активність дітей, репродуктивні методи роботи з ними, відсутність творчих підходів при організації освітнього процесу. Отже, майбутнім фахівцям важливо керуватися не лише нормативно-методичними документами, що регулюють організацію психолого-педагогічного супроводу в закладах дошкільної освіти, а й бути мотиваними до усвідомленого набуття професійних знань, умінь, навичок, формування ключових компетенцій у власній професійній діяльності. Відтак, головною проблемою забезпечення високоякісної дошкільної освіти є підготовка компетентних вихователів дітей дошкільного віку. Справді демократичне суспільство змінюється, а отже, змінюються освітні парадигми, нові підходи до організації освітнього процесу в закладах дошкільної освіти. Як було зазначено вище, значну роль у професійній підготовці вихователів дошкільної освіти відіграє викладання курсу дошкільної педагогіки. Фахова підготовка майбутнього вихователя дітей дошкільного віку традиційно 
починається з вивчення педагогічної теорії, яка фрормувалась протягом багатьох сторіч розвитку суспільства. Усвідомлення студентами культурно-педагогічного досвіду українського народу обумовлює формування у них власної педагогічної позиції стосовно майбутньої практичної діяльності в закладі дошкільної освіти. У процесі вивчення дошкільної педагогіки студенти оволодівають знаннями про усебічний розвиток, виховання, навчання дітей дошкільного віку, основні закономірності, принципи, методи і форми організації освітнього процесу у закладі дошкільної освіти. Чітке розуміння цих педагогічних категорій дає можливість компетентно проектувати освітній процес 3 вихованцями та їхніми батьками, методично правильно організовувати власну педагогічну діяльність. Усе вищезазначене вимагає від викладача дошкільної педагогіки здатності презентувати педагогічний процес закладу дошкільної освіти як реалізацію спеціально організованої динамічної взаємодії вихователя, дітей і батьків, спрямованої на забезпечення гармонійного всебічного розвитку, виховання і навчання вихованців. На нашу думку, важливо зосередити увагу майбутніх педагогів дошкільної освіти на необхідності набуття вмінь та навичок реалізовувати професійні фрункції у їхній нерозривній єдності та системі. Тому необхідно фоомувати у майбутнього фрахівця мотивацію до навчально-пізнавальної діяльності, засвоєння системи наукових знань, формування відповідних компетентностей. Також важливо, щоб кожний студент усвідомив ціннісні орієнтації у контексті майбутньої роботи з дітьми дошкільного віку, здійснював власний саморозвиток і самовиховання, збагачував власну духовність. Вартісною для фрахівця дошкільної освіти $\epsilon$ також реалізація розвивальної функції, яка забезпечує формування i розвиток власних психічних процесів i якостей. Зазначимо, сучасні тенденції розвитку дошкільної педагогіки передбачають збагачення ії змісту новим спрямуванням та підходами, розмаїттям інноваційних методів та технологій розвитку, виховання і навчання дітей. Ватро також зважати на те, що сучасні діти вирізняються своїми особливостями. Як стверджують освітяни, наші найменші сучасники більш обізнані в інформаційному просторі, надають перевагу віртуальному життю, швидко опановують технічні пристрої. Також серед них збільшується кількість гіперактивних дітей. Як стверджують психологи, поведінка нових дітей часто має ознаки демонстративної, вони прагнуть привернути до себе увагу дорослих, презентують свої переваги і водночас, виявляють ознаки тривожності або агресії при спілкуванні.

Отже, дошкільний педагог покликаний у своїй діяльності брати до уваги всі новоутворення сучасного дошкільника - становлення основ дитячого світогляду, особистісної свідомості, елементарної рефрлексії внутрішнього плану дій, супідрядності мотивів внутрішніх етичних інстанцій [1, с.10-20]. Сучасний вихователь закладу дошкільної освіти повинен усвідомлювати, що для кожної дитини він має стати значущим 
дорослим, духовно близькою людиною, яка розуміє і підтримує дитячу індивідуальність та самобутність. Як стверджує І. Бех, актуальним сьогодні $є$ забезпечення особистісно зорієнтованого виховання, яке дає можливість кожній дитині вільно саморозвиватися і самовиражатися згідно своїх задатків, нахилів та інтересів [2]. У зв'язку з цим, викладачам дошкільної педагогіки доцільно актуалізувати такі теми як організація педагогічного процесу на засадах оновлення змісту та урізноманітнення форм і методів взаємодії з дітьми як суб'єктами життєдіяльності; забезпечення психолого-педагогічних умов для індивідуалізації, соціалізації та гармонійного розвитку дитини дошкільного віку; організація психолого-педагогічного супроводу фрормування базових якостей особистості дитини, її компетентності, самостійності, активності тощо. Наголосимо: стратегія педагогічного супроводу полягає в тому, що вихователь повинен проектувати зону найближчого розвитку своїх вихованців, бачити їхні можливості, допомагати їм, за словами М. Монтессорі, зробити це самому.

Отже, професійна підготовка майбутніх вихователів повинна забезпечувати глибокі та системні знання в галузі педагогіки дошкільного дитинства.

Профресійну підготовку фахівців дошкільної освіти досліджують вітчизняні вчені Л. Артемова, А. Бєлєнька, А. Богуш, Н. Гавриш, Л. Зданевич, І. Дичківська, Т. Поніманська, І. Княжева, К. Крутій, Н. Лисенко, І. Луценко, Н. Мельник, Т. Степанова, О. Трифонова та ін. Вивчення і аналіз наукових джерел та власна педагогічна практика дають підстави стверджувати що в освітньому процесі закладу вищої освіти великого значення набуває навчально-методичне забезпечення кожної навчальної дисципліни. Значну увагу цій проблемі присвятили вітчизняні вчені Л. Артемова, А. Богуш, Г. Бурма, А. Алексюк, Г. Бєлєнька, Т. Поніманська, С. Вітвіцька, І. Княжева, С. Сисоєва та ін. Зазначимо, що сучасні тенденції розвитку дошкільної педагогіки передбачають оновлення їі змісту й методів, а відтак і науковометодичного забезпечення курсу «Педагогіка дошкільна». Особливості викладання дошкільної педагогіки полягають у тому, що викладач покликаний організовувати різні способи навчальної діяльності студентів - слухання лекцій, самостійну роботу під час процесі семінарів та практичних занять, виконання індивідуальних навчальних дослідницьких завдань, розробку різних конспектів, вирішення педагогічних ситуацій, тощо. Це потребує розробки необхідного навчально-методичного забезпечення процесу викладання дошкільної педагогіки. У повній мірі тут прислужиться підручник з дошкільної педагогіки Т. Поніманської, який забезпечує усвідомлення студентами сучасних підходів до організації розвитку, навчання і виховання дітей дошкільного віку та ролі вихователя у цьому процесі [3]. Також цим же автором розроблено посібник для організації семінарських і практичних занять з дошкільної педагогіки, який широко використовується в 
освітньому процесі вищої школи. Водночас можна погодитись 3 твердженнями викладачів дошкільної педагогіки про те, що зростає потреба у сучасному навчально-методичному забезпеченні, яке покликані розробляти науковці відповідних кафедр.

Загальноприйнятим $€$ те, що до змісту навчально-методичного супроводу дошкільної педагогіки розробляється навчальна і робоча програми з методичними вказівками до семінарських, практичних, лабораторних занять, завдання до самостійної роботи студентів, індивідуальні навчально-дослідницькі завдання, контрольні роботи, білети до екзамену, тестові завдання, завдання для виконання під час практики. Специфічною особливістю засвоєння курсу дошкільної педагогіки $€$ необхідність вивчення студентами різних психологопедагогічних джерел, які висвітлюють погляди та педагогічні ідеї видатних вчених минулого та сучасності, репродукують надбання народної педагогіки. У цьому руслі особливої актуальності набуває питання про роль і місце, зміст, методи і форми української родинної етнопедагогіки та їх використання в традиційному комплексі соціалізації молодшого покоління українців та в освітньому процесі закладів дошкільної освіти.

В умовах сьогодення ідеї, принципи та засоби української народної етнопедагогіки знаходять своє гідне місце у практиці виховання сучасної родини, закладів дошкільної та початкової освіти. Фактично у виховній практиці нашого народу знаходять реалізацію всі завдання різнобічного виховання дітей раннього та дошкільного віку. При цьому враховували результати досліджень провідних учених (Л. Артемова, І. Бех, А. Богуш, М. Стельмахович) про те, що народний досвід, створений емпірично, має достатню наукову основу, що дає підставу для його використання в сучасних умовах. Зокрема, в народній педагогіці криються витоки завдань, змісту та методів фізичного, морального, трудового та естетичного виховання дітей дошкільного та молодшого шкільного віку. Проте, у надбаннях народної етнопедагогіки є такі чинники впливу на дитину, які з позицій наукової педагогіки мають лише пізнавальне значення або зовсім архаїчні, консервативні, марновірні, навіть жорстокі і не можуть бути використані в сучасних умовах.

Проведений ретроспективний аналіз надбань української етнопедагогіки дає підстави виокремити такі основні положення, на яких варто зосередити увагу майбутніх вихователів.

1. Український народ з глибокої давнини шанує здоров'я як найважливіший феномен буття. У народі вважали, що фрізичне здоров'я - дар божий наші предки прагнули його берегти і заповідали робити це своїм дітям. Безперечно саме чинники природного оздоровлення дитини слід брати до уваги сучасним педагогам. Так, народна педагогіка всіляко заохочувала до перебування на свіжому 
повітрі, яке має величезний вплив на організм, дає тілу гнучкість, силу, а душі - радісний настрій.

Цінним також $є$ досвід народу стосовно збереження навколишньої природи спілкування про культурно-гігієнічні навички дітей.

Заслуговує на увагу в практичному застосуванні на сьогоднішній день різномаїття прийомів, які використовували в родині з метою загартування і розвитку рухів дітей, що мало на меті зберетти та зміцнити здоров'я дітей раннього та дошкільного віку. Так, достатньо продуманими можна вважати ряд пристосувань, які створювались у народі для полегшення дитині оволодіння рухами при ходьбі.

Зміцненню здоров'я дітей слугуватиме обізнаність родини та педагогів з тим, як в українській етнопедагогіці використовувались народна медицина та засоби лікування дітей. У фрізичному вихованні в сучасних закладах повною мірою можуть бути використані народні рухливі ігри, як з метою розвитку та вдосконалення основних рухів, так і для вдосконалення фізичних якостей, а також малі форми фольклору для фрормування культурно-гігієнічних навичок. Деякі заборони й певні правила були примітивними. Вони відображали ілюзорні уявлення про навколишній світ. Однак усі вони ґрунтувались на бажанні запобігти шкідливим і небезпечним для здоров'я дитини впливам. Проведений аналіз надбань української народної педагогіки з фрізичного виховання дітей дошкільного віку засвідчує про доцільність використання народних засобів у педагогічному процесі дошкільних закладів. Це буде сприяти поєднанню народної і академічної дошкільної педагогіки та підвищить ефективність фрізичного виховання дітей.

2. Українська родина створила свою систему розумового виховання підростаючого покоління. Історична цінність цієї системи полягає у тому що в ії основу покладені емпіричні, але цілком достовірні уявлення і про те, що розумово розвивати дитину потрібно 3 перших місяців життя. У народній педагогіці склалися та диференційовано застосовувались різноманітні засоби розумового виховання дітей з урахуванням їх особливостей розвитку. Сьогодні для розумового розвитку дітей раннього віку можуть використовуватись створені народом колискові, пестушки, потішки, замовлянки, мовнорухові ігри, а в роботі з дітьми дошкільного та молодшого шкільного віку доцільно застосовувати народні оповіді казки, легенди, прислів'я, лічилки і скоромовки. Ефективними для використання, на нашу думку, $€$ також народні шляхи доступного ознайомлення дітей з метеорологією, астрономією, характерними ознаками сезонних змін в природі відповідно до річного народного сільськогосподарського календаря. Не залишилося поза увагою в народі і здійснення спеціальної підготовки дітей до школи. Вживані народом прийоми залучення дітей до читання та залучення їх до народної математики можуть бути використані у сучасному педагогічному процесі закладів дошкільної освіти. 
Проте, архаїчними можна вважати народні уявлення, які свого часу були доцільними, про необхідність початку навчання дитини першого грудня в день святого Наума. Вони засвідчують місце навчання в загальній життєдіяльності дитини в умовах прилучення їі до сільськогосподарських робіт. Нині такі уявлення втратили сенс і мають лише пізнавальне значення. Здійснений аналіз переконує, що у народній педагогіці находимо реалізацію всіх завдань розумового виховання дошкільної педагогіки. Зміст роботи, яка проводилась 3 дітьми, відповідає сучасному розумінню сутності забезпечення інтелектуальної готовності дитини до шкільного навчання.

3. У всі віки народна педагогіка в основу морального виховання закладала засади гуманістичної та колективістської спрямованості дитини, її позитивних моральних рис характеру та волі, виховання важливих моральних якостей, необхідних для досягнення успіху у будь-якій діяльності та первинних засад майбутнього громадянина. Формування вищеназваних моральних якостей дитини залишається надзвичайно важливим і на сьогоднішній день. Головними чинниками, завдяки яким родина реалізовувала всі напрямки морального виховання, виступали відповідна організація побуту сім'ї та дотримання народних традицій, звичаїв, обрядів народу відповідно річного сільськогосподарського календаря Поряд з цим не менш актуальними для сьогодення $€$ методи, які застосував народ для формування у дітей лицарства і жіночності, оптимізму гумору, виховання бережливого ставлення до хліба та інших результатів праці людей.

Зазначимо, що у родинному вихованні дитини дошкільного віку народом використовувались такі методи: призвичаювання, приклад, повчання, догляд, заохочення, покарання. 3 перерахованих методів виховання фізичне покарання, як відомо, науковою педагогікою не визнається. Застарілими і такими, що втратили своє значення, є залякування дітей, привчання їх до такого морального етикету, як народний звичай «бити чолом», тобто цілувати старших людей в руку, звертатись до найрідніших на «Ви», що сьогодні звично тільки у віддалених стосунках. На наш погляд, всі інші з названих методів можуть застосовуватись в сучасному сімейному та суспільному вихованні.

До системи використання здобутків української дошкільної етнопедагогіки також слід включити завдання фрормування емоційноціннісної сфери, представлене народною деонтологією. Це прищеплення любові до рідних, близьких, народної культури, мови, Батьківщини, вшанування народних звичаїв, традицій. Важливо при цьому привнести в психологічний мікроклімат дошкільних закладів духовність українського народу, милосердя, працелюбність, пошану до жінок, старших і батьків.

4. Досвід трудового виховання дітей в українській народній педагогіці містить багато цінного. Зокрема, вже у дошкільний період життя у дітей виховували трудову спрямованість і, в першу чергу, у 
формуванні такої важливої якості, як працьовитість, яка визнана однією 3 ознак менталітету українського народу. Життєздатними сьогодні $€$ не лише зміст і методи виховання в дітей працелюбності, а й форми залучення їх до праці. Проведений аналіз етнографрічних матеріалів свідчить, що у народній педагогіці фактично вирішувалися всі завдання трудового виховання дітей, які визначені сучасною дошкільною педагогікою. У народній скарбниці трудового виховання тонко диференційовано засоби прищеплення дітям інтересу до праці стосовно віку дітей та їх статі. У роботі з дітьми молодшого дошкільного віку батьки та практики комплексу можуть використовувати набір засобів, що народ застосовував у ознайомленні 3 працею дорослих шляхом гри-імітації, показу спостереження, маніпуляції, вправляння, навчання способу дій з елементарними предметами, знаряддями. Доречно застосовувати також пестушки, утішки, коротенькі казочки, повчання, заклички, які прославляють працю людини та фрормують у дітей любов і повагу до трудящих, викликають бажання їх наслідувати. У роботі з дітьми середнього дошкільного віку має сенс ширше використання гри для посилення інтересу дітей до трудових процесів дорослих та прагнення їм допомогти. Зокрема, як це робилося в народі: безпосереднім відображенням праці дорослого у народній грі, відбиттям елементів трудових дій у грі та використанням ігрових моментів у процесі праці. У роботі $з$ дітьми старшого дошкільного віку, крім розширення та закріплення уявлень дітей про працю дорослих, доцільно використовувати застосовувані народом прийоми 3 метою формування трудових умінь і навичок, щоб дитина ставала помічником у родині. На наш погляд, деякі звичаї неприйнятні з погляду сучасності. Вони лише цікаві, як історичний матеріал, який характеризує наївну віру родини, що прагнула забезпечити майбутнє дитини, прогнозуючи ӥй матеріально забезпечену роботу. Саме тому в колиску клали відповідні знаряддя праці, які, безумовно, не могли виправдати сподівань батьків і позначитися на долі дитини.

Загалом вивчення народних традицій трудового виховання засвідчує, що вони можуть відповідно застосовуватись у дошкільних закладах та родині для фрормування і розвитку у дітей працелюбності, переконаності в необхідності трудитися. А це фактично і складає забезпечення психологічної готовності дитини до праці.

5. Українська народна педагогіка використовувала весь комплекс естетичних впливів на дитину з перших місяців життя. Естетичне виховання, комплексно поєднувалося з трудовим, моральним, розумовим, фрізичним, проте мало і свої організаційні фрорми. Яскрава народна іграшка, мелодійна пісня, граціозний танець, вишивання, розписування писанок, народні урочисті свята, що супроводжувалися цікавими обрядами, залишали у душі дитини глибокий слід естетичних почувань, краси і духовності. Величезна заслуга української етно- 
педагогіки у тому, що вона поетизувала працю (свято першої ріллі, свято обжинок). Проведений аналіз засвідчує, що в народній педагогіці українців у вихованні дітей фрактично вирішувались такі завдання естетичного виховання: фрормування уявлення про прекрасне в навколишньому житті і в мистецтві, виховання естетичного смаку, розвиток індивідуальних творчих здібностей, навичок і вмінь у різноманітній художній діяльності. Засоби естетичного впливу на дітей, які використовувались у народній педагогіці в певній послідовності і системі, з врахуванням віку дітей були спрямовані на їхнє різнобічне виховання. А названі завдання і засобами естетичного виховання дошкільників у народній педагогіці співзвучні сучасній дошкільній педагогіці.

Отже, тисячолітній досвід дав можливість народній системі виховання відібрати найкращі засоби впливу на дитину в час ії становлення як особистості. В основі цієї системи виховання лежать зважені і вивірені часом принципи: природовідповідності, гуманності, послідовності й наступності, емоційності і активності дитини. Засобами реалізації цих принципів ставали різні види усної народної творчості, побут, національні звичаї і символи, елементи історії свого краю, народне мистецтво, ремесла і промисли, дитячі ігри та іграшки, мудрі заповіді народної моралі, народні правила взірцевої поведінки і спілкування між людьми. Громадська думка мала сильний вплив на підростаюче покоління. Увага членів родини та інших дорослих сільської громади у процесі виховання зосереджувалася на повноцінному розвитку фрізичних і інтелектуальних сил дітей, поглибленні їхнього соціального досвіду і практичних умінь, потрібних для майбутнього життя і діяльності. Відтак, проведений нами аналіз традицій батьківської виховної практики в різнобічному вихованні української дитини дав можливість встановити їх актуальність, значущість і життєздатність для сьогодення. Багато в чому вони ідентичні із засобами різнобічного виховання особистості дитини в сучасній дошкільній педагогіці.

Нами було розроблено навчально-методичний посібник «Розвиток надбань української дошкільної етнопедагогіки та їх використання у сучасному закладі» [5], який становить теоретико-методичні засади використання спадщини виховного досвіду народу при викладанні дошкільної педагогіки. Зважаючи на матеріали, які у ньому представлені, посібник доцільно використовувати для вивчення студентами розділів «Фізичне виховання дітей дошкільного віку», «Розумове виховання дітей дошкільного віку», «Морально-трудове виховання» та ін.. Таким чином, викладання дошкільної педагогіки забезпечили теоретичними розробками і науково обґрунтованими методичними рекомендаціями з проблем розвитку і виховання дітей дошкільного віку засобами української народної педагогіки та можливостей їх застосування у практиці сучасних закладів дошкільної освіти і родинного виховання. При цьому акцентуємо на важливості 
донесення до свідомості студентів думки про те, що фрактично у народній педагогіці знаходимо реалізацію всіх завдань виховання дитини-дошкільника, які передбачаються сьогодні сучасною дошкільною педагогікою. Тому і традиції народної педагогіки, її надбання у вихованні сучасних дітей є актуальними й ефективними. Але звичайно у традиційній педагогічній системі минулого, поряд 3 цінними методами і засобами були такі, які мають сьогодні лише пізнавальне значення, або є зовсім архаїчні, консервативні, марновірні, навіть жорстокі. Тому слід дуже продумано відбирати та доцільно використовувати надбання української дошкільної етнопедагогіки у освітньо-виховній роботі з дітьми.

\section{Список використаних джерел}

1. Кононко О.Л. Картина світу сучасного дошкільника. Вихователь-методист. 2014. №1. С.10-20.

2. Бех І.Д.Виховання особистості: підручник. К.: Либідь, 2008. 848 с.

3. Поніманська Т. І. Дошкільна педагогіка: Навчальний посібник для студентів вищих навчальних закладів. К.: Академвидав, 2006. 456 с.

4. Матеріали до українсько-руської етнології. T. VIII. Дитина у звичаях i віруваннях українського народу: 3 полудневої Київщини / Зібрав Мр. Г. Львів, 1907. $110 \mathrm{c}$.

5. Рогальська Н. В. Розвиток надбань української етнопедагогіки та їх використання в сучасному дошкільному закладі: Навчальний посібник. Вид. 3 перероблене і доповнене. К.: Міленіум, 2008. 124 с.

6. Рогальська Н. В Українське народознавство у вихованні дітей: навчальнометодичний посібник для студентів вищих навчальних закладів спеціальності «Дошкільна освіта». Умань: ФОП Жовтий О. О., 2014. 129 с.

7. Сявавко Є.І. Українська етнопедагогіка в її історичному розвитку. К.: Наукова думка, 1974. $152 \mathrm{c.}$

8. Українське дошкілля: Пісні, ігри, танці, вірші, загадки. Краків: Українське видавництво, 1941. 


\title{
КОМПЕТЕНТНІСНИЙ ПІДХІД ДО ПРАКТИЧНОЇ ПІДГОТОВКИ ВЧИТЕЛЯ ПОЧАТКОВОЇ ШКОЛИ В КОНТЕКСТІ ЗАВДАНЬ МУЗИЧНО-ЕСТЕТИЧНОГО ВИХОВАННЯ МОЛОДШИХ ШКОЛЯРІВ
}

\author{
Тарасенко Г.С. \\ доктор педагогічних наук, профресор, \\ Вінницька академія неперервної освіти; \\ Нестерович Б.І. \\ кандидат педагогічних наук, доцент, \\ Вінницький державний педагогічний університет ім. М.Коцюбинського
}

Учитель початкової школи є тією особою, на професійну діяльність якої покладена найперша відповідальність за інтелектуальну, морально-ціннісну та художньо-естетичну підготовку школярів. Розбудова початкової освіти у відповідності з концептуальними засадами Нової української школи спонукає систему фрахової підготовки педагогів тісно пов'язати ії із суспільним замовленням. Соціальна детермінованість професійної освіти вчителя, оцінка його фрахової спроможності, важливість виокремлення професійно й соціально значущих особистісних характеристик педагога сучасної школи зумовили зростання інтересу дослідників до вивчення шляхів покращення його фахової підготовки в контексті компетентнісного підходу.

Вчитель нової української школи повинен мати не формальнотеоретичний рівень готовності до роботи, а бути здатним до варіативного втілення набутих знань в освітянську практику на компетентнісній основі. В той же час процес фрормування практичних умінь та навичок не є плідним, якщо відбувається лише в умовах аудиторного навчання. Світоглядний принцип єдності теорії і практики, дидактичний принцип зв'язку навчання з життям, соціальний запит на зміцнення інтеграції закладу вищої педагогічної освіти зі школою - все це зумовлює абсолютну необхідність посилення ролі педагогічної практики в процесі фрахового зростання майбутніх учителів початкових класів.

Педагогічна практика допомагає майбутньому вчителю не лише поглибити теоретичні знання й отримати досвід їхнього застосування у роботі 3 дітьми. Тут коригується ціннісно-мотиваційна основа майбутньої педагогічної діяльності, що згодом детермінує успішний перебіг становлення професійної культури вчителя. Саме практична робота в школі закладає міцний фундамент професійно-педагогічної культури як інтегративного соціально-психологічного утворення в структурі особистості вчителя, яке визначає світоглядні орієнтири, ціннісні установки, загальну концепцію життєвих прагнень і позицій. 
Зрозуміло, що профресійну культуру педагога ніяк не можна спрощувати до системи спеціальних, вузькопрофесійних знань, умінь і навичок. Це поняття $€$ ширшим і включає весь духовний потенціал особистості вчителя, інтелектуальні, емоційні та практично-дійові компоненти його свідомості.

Аналіз стану дослідження означеної проблеми засвідчує, що останнє десятиліття ознаменовано посиленням інтересу науковців до проблем реалізації компетентнісного підходу в системі загальної середньої освіти. Ці аспекти результативно досліджують вітчизняні науковці - Н. Бібік, Н.Воропай, С.Гончаренко, Я.Кодлюк, О.Локшина, Ю.Мальований, О.Овчарук, О.Онопрієнко, О.Пометун, К.Пономарьова, О.Савченко, С.Трубачова, О. Ярова та ін. Значна увага компетентнісному підходу приділена у дослідженнях учених близького зарубіжжя, зокрема М.Авдєєвої, В.Байденко, В.Болотова, Є.Бондаревскої, В.Введенського, Н.Вовнової, А.Войнова, А.Вербицького, Г.Дмитрієва, Д.Іванова, І.Зимньої, В.Краєвського, С.Кульневича, К.Митрофранова, А.Петрова, В.Сєрікова, О.Соколової, А.Хуторського, С.Шишова та ін. Як методологічна основа забезпечення цілей, змісту і якості освіти компетентнісний підхід активно вивчається дослідниками з дальнього зарубіжжя, серед яких найвідоміші - це А.Армстронг, А. Бермус, П. Блек, Дж. Боуден, Д.Вільям, Дж. Гордон, С.Маслач, Б. Мейл, А. Мішель, М. Лейтер, Д. Пеппер, Дж. Равен, Е. Тофффлер, Р. Уайт, Р.Хайгерті, Г. Халаш та ін.

У той же час, не зважаючи на велику кількість публікацій з цієї проблеми, актуальність подальших досліджень лише нарощується, оскільки розуміння сутності компетентнісного підходу залишається недостатньо обґрунтованим, а деколи й суперечливим. Особлива увага науковців прикута до ролі практичної підготовки майбутнього педагога задля успішної реалізації ним завдань компетентнісно орієнтованої освіти (О. Абдуліна, В. Барабаш, А.Береза, В.Горленко, О.Дубасенюк, С.Мартиненко, О. Матвієнко, М. Сметанський, Є.Спіцин, Л.Хомич, О.Ярошенко та ін.). Сьогодні актуалізувались дослідження, присвячені розробці естетограми вчителя (Д.Баран, В.Орлов, О.Отич, Г.Петрова, І.Полякова, О.Рудницька, А. Федь, А.Щербо та ін.), оскільки розвинена художньо-естетична позиція вчителя та готовність до ії ефрективного транслювання в освітньо-виховному просторі як ніколи затребувана в контексті компетентнісного підходу до професійної підготовки педагога. Утім відчувається брак спеціальних досліджень 3 проблем організації практичної підготовки вчителя початкових класів до музично-виховної роботи з молодшими школярами на засадах міжпредметної інтеграції.

Спробуємо обґрунтувати педагогічні умови успішної практичної підготовки майбутніх учителів початкової школи до музично-виховної роботи з учнями в контексті компетентнісного підходу. Ми виходимо $з$ того, що компетентність фрахівця $€$ динамічною комбінацією знань, 
умінь, навичок, цінностей, емоцій, поведінкових програм, інших особистісних утворень, що в комплексі визначає здатність особи успішно здійснювати професійну (навчальну) діяльність [2; 9; 20].

Для розуміння суті компетентнісного підходу до освітніх процесів варто усвідомити різницю між поняттями «компетентність» i «компетенція». Компетентність майбутнього вчителя як здатність застосовувати набуті знання, вміння, навички, способи діяльності, власний досвід в нестандартних ситуаціях з метою розв'язання певних профресійно важливих проблем $€$ особистісним утворенням, яке проявляється в процесі активних самостійних дій студента.

Компетенція - це відчужена від суб'єкта, наперед задана соціальна норма (вимога) до освітньої підготовки студента, необхідна для якісної продуктивної діяльності в певній сфрері з орієнтацією на соціально очікуваний результат. Компетенція сама по собі не $є$ характеристикою особистості. Нею вона стає в процесі засвоєння навчального матеріалу і рефлексії учнівської молоді, перетворюючись у компетентність [3]. Компетенція для студент - це образ його майбутньої профресії, орієнтир для освоєння професійних знань.

Таким чином, компетентність майбутнього педагога ми розуміємо як оволодіння ним компетенцією, що поєднується з його особистісним ставленням до предмета діяльності. Компетенції ж позиціонуються як реальні вимоги до засвоєння студентами сукупності знань, способів діяльності, досвіду ставлення до певної галузі, якостей особистості, яка діє в певному соціумі. Вони втілені в Державних стандартах освіти, в програмах, критеріях навчальних досягнень тощо. Поняття «компетенція» варто розуміти як категорію об'єктивну, тобто як норму, вимогу, ціль, а «компетентність» - як категорію суб'єктивну, особистісну, як результат оволодіння певною компетенцією [17; 21; 22].

Компонентами змісту компетентності $€$ складові відповідної компетенції, якою оволодіває студент. Однак компетентність не зводиться до знань, до вмінь, до способів діяльності, хоч вони є ії структурними елементами і належать до соери відношень між знаннями і дією в реальній практиці. Їх можна розглядати як можливість встановлення зв'язку між знаннями i педагогічною ситуацією, а в ширшому розумінні, як здатність знайти шляхи (знання, ціннісно запліднені емоції і дії), що придатні для розв'язання певної педагогічної проблеми.

Отже, основним результатом фрахової підготовки майбутнього вчителя не повинна стати система знань, умінь і навичок сама по собі, а сфрормованість ключових компетенцій студентів в інтелектуальній, морально-естетичній, інформаційній та інших сорерах становлення особистості, а також створення умов для їх профресійної реалізації. Необхідно на перший план висувати не інформованість студента, а вміння вирішувати виниклі у його професійній діяльності проблеми 
різної складності. Результатом же фрахової підготовки слід вважати не суму завчених знань, умінь і навичок, а здатність майбутніх педагогів компетентно діяти в різноманітних інтелектуально-практичних і духовно-світоглядних ситуаціях.

Згідно ідей дослідників (Н. Бібік, І.Зимняя, А.Хуторський та ін.), можна виділити ключові компоненти професійної компетентності вчителя: це інформаційна компетентність (володіння інформаційними технологіями, вміння опрацьовувати різні види інформації); комунікативна компетентність (уміння вступати в комунікацію і бути зрозумілим); автономізаційна компетентність (здатність до саморозвитку, творчості, самовизначення, самоосвіти); соціальна компетентність (уміння жити та співпрацювати в соціумі); моральна компетентність (готовність, спроможність та потреба жити за традиційними моральними нормами); психологічна компетентність (здатність використовувати психологічні знання, уміння, навики задля оптимізації взаємодії в освітній діяльності); предметна компетентність (готовність ефективно застосовувати знання у сфері конкретного навчального предмета); особистісна компетентність (доброзичливість, людяність, чуйність, урівноваженість, толерантність, розвинена рефрлексія, здатність до емпатії та ідентифікації тощо). Зважаючи на такий синтез, сучасна наука невипадково вивчає профеесійну компетентність учителя як сукупність багатьох складових: предметнотехнологічної, психолого-педагогічної та загальнокультурної [2; 8; 20].

Не можна ігнорувати той факт, що у процесі якісної фахової освіти майбутні вчителі початкової школи повинні осягнути виховний потенціал музики і навчитись якнайширше оперувати ним у системі освітньої роботи з молодшими школярами. Втім реалії розвитку професійної підготовки вчителя початкових класів свідчать про те, що викладання музично-художніх дисциплін часто звужується до загального ознайомлення студентів з мистецьким матеріалом та формування певного кола художніх навичок (вокальних, гри на музичному інструменті, ансамблевого музикування тощо). I хоча традиційно майбутній учитель початкової школи у процесі фрахової підготовки отримує музичну підготовку (як в педагогічних коледжах, так і в педагогічних університетах), проте у практичній виховній роботі він дуже епізодично звертається до музики як до виховного інструмента.

Опитування студентів випускного курсу фракультету дошкільної початкової освіти і мистецтв Вінницького державного педагогічного університету імені Михайла Коцюбинського (78 респондентів) засвідчує, що в загальній масі $(67 \%$ опитаних) випускники остерігаються включати музику до власного виховного арсеналу. Так, серед пропонованих засобів виховання найчастіше (59\%) вони обирають слово, книгу, природу, гру тощо. Мистецьким засобам віддають перевагу лише ті студенти, які отримують освіту в умовах відповідної додаткової спеціалізації (музичне виховання - 26\%). 
Решта (наприклад, практичні психологи - 34\%) обирають музику лише в контексті артпедагогіки (музикотерапії).

Аналіз творчих робіт вербально-графрічного характеру продемонстрував загальну невпевненість випускників у власній художньо-педагогічній компетентності. Зокрема, студенти самостійно підготували виховні проекти (фрорми використання улюблених музичних творів у виховній роботі з учнями; логотипи «Диригент дитячих сердець», «Музика дитячої душі»), в яких намагались чітко змоделювати процес трансформації власних художніх уподобань у практичну виховну роботу з молодшими школярами. Втім лише поодинокі проекти містили алгоритмізовану методичну пропозицію. Натомість більшість зосереджено описувала власні художні переживання без конкретного виходу у практично-виховну площину. Показовою у цьому контексті є думка студентки-випускниці:

«Про музику мені говорити дуже важко. Це ніби говорити про любов. Але я розумію, що діти чекають моєї компетентної думки. На жаль, я так і не навчилась інтерпретувати музичні образи доступно і яскраво, аби це стало цікаво для дітей. Це виявилось набагато складніше, ніж розповісти про композитора або історію написання твору» (Марія Л.).

3 огляду на це, ми вважаємо необхідним посилити компетентнісний підхід до організації педагогічної практики майбутніх учителів початкових класів за рахунок її змістового розширення [11]. 3 нашого погляду, вчитель початкової школи, (незалежно від того, чи буде викладати музику як предмет) повинен уміти компетентно «вплести» музичний матеріал в освітній процес, тобто оптимально інтегрувати його з іншими дидактичними блоками. Утім першочергово варто сфрормувати готовність студентів до включення музичного мистецтва в методику позакласної музично-виховної роботи з дітьми.

Музично-виховну роботу в початковій школі ми тлумачимо як системне включення молодших школярів у художньо-творчу діяльність зі сприймання, оцінки, творчої інтерпретації музики на основі оптимальної реалізації її ціннісно-виховного потенціалу, варіативного пошуку організаційно-виховних форм подачі музичного матеріалу, постійного емоційного збагачення виховних ситуацій та забезпечення рефлексивної реакції вихованців на зміст музичних образів.

Неабиякого значення набуває проблема критеріального підходу до естетико-педагогічної підготовки вчителя. Зокрема, готовність майбутніх учителів до музично-виховної роботи можна визначити за такими показниками: ціннісне ставлення до педагогічної профресії; знання об'єкта і суб'єкта професійної діяльності; наявність широкої палітри високоякісних музично-художніх уподобань; бачення змісту навчальних дисциплін у системі культури; оволодіння принципами і методами естетико-виховної реалізації змісту навчального предмета; рівень музично-творчої самореалізації вчителя в 
позакласній роботі; розвиток рефлексії як основи постійного профресійного самотворення тощо.

Треба зазначити, що останнім часом пожвавилась розробка авторських програм педагогічної практики, які так чи інакше враховують необхідність спеціальної підготовки вчителя до музичновиховної роботи 3 дітьми. Так, заслужений науково-методичний інтерес викликає система організації педагогічно-виконавської практики студентів музичних спеціальностей, розроблена А. Березою [1]. Дослідник пропонує чіткий алгоритм підготовки і проведення в школі музично-освітнього заходу на основі фрормування в студентів готовності до художньо-педагогічного аналізу музичних творів, інтерпретаційного мислення та музично-педагогічного артистизму.

3 нашого погляду, слід всіляко підтримувати інваріантну розробку програм з педагогічної практики за умов адаптації їх до специфріки майбутньої спеціальності. Це сприятиме посиленню їі компетентнісного спрямування. Серед педагогічних умов успішної практичної підготовки майбутніх учителів початкової школи до музично-виховної роботи з учнями в контексті компетентнісного підходу ми виокремили наступні [16] :

Оптимальна професіоналізація естетико-виховного блоку змісту педагогічної практики в діапазоні контекстного навчання майбутнього вчителя початкових класів.

Уведення в програми педагогічної практики «загальноприйнятних» форм музично-виховної роботи з учнями не $\epsilon$ ефективним поза врахуванням специфіки майбутньої спеціальності. Зміст музичновиховної роботи студента-практиканта повинен визрівати як результат контекстного навчання (А.Вербицький), оскільки лише в такий спосіб параметри минулого (теоретично-методичні знання студента) й майбутнього (проектування навчально-виховних технологій) детермінуються конкретно-фраховим і соціальним змістом освоюваної професійної діяльності.

Слід пам'ятати, що перехід від учіння до практики є складним процесом трансформації учбової діяльності в професійну, що пов'язана з перетворенням знань з предмету учбової діяльності на засіб регуляції діяльності профресійної, із заміною одного провідного типу діяльності іншим, а також із зміною соціальної позиції [5, с.32 ]. 3і студента, що у закладі вищої освіти освоював різні блоки знань, під час практики майбутній учитель, ніби метелик із лялечки, повинен перетворитися на реального вихователя у широкому значенні цього поняття.

> Аксіологічна спрямованість музично-виховної роботи студента-практиканта з метою їі особистісної орієнтації.

Педагогічна практика майбутнього вчителя повинна орієнтувати його на врахування особливостей психосоматичного і ціннісноорієнтаційного впливу музики на дитину. Студенту недостатньо лише 
інформувати учнів про існування в світовій культурі тих чи інших музичних шедеврів. Замало потурбуватись лише про емоційний фон сприймання музики дітьми. Забезпечення цих, з одного боку, необхідних, а з іншого, доволі фрормалізованих умов усе ж таки не розв'язує проблему реалізації виховного потенціалу музики до кінця. Створення хвилюючих виховних ситуацій $є$ найважливішим етапом у музично-виховній роботі студента-практиканта. Він повинен уміти постійно збагачувати мистецько-виховні ситуації новими емоційними відтінками, уміло включаючи учнів у рефлексивну діяльність, допомагаючи «привласнити» музичний образ на особистісному рівні сприйняття та оцінки.

\section{$>$ Забезпечення «музично-естетичного} студента-практиканта з учнями.

В контексті ідей «Нової української школи» велику увага приділяється педагогіці партнерства. Суттєвим для музично-виховної роботи $€$ методологічне положення про необхідність адекватного міжособистісного контакту вчителя й учнів, який має ґрунтуватися на рівноправності учасників освітнього процесу. Студент-практикант повинен розуміти, що мистецтво має гранично демократичну природу, тому навчати мистецтву варто лише на послідовно гуманістичній основі, яка передбачає паритет стосунків між суб'єктами педагогічної взаємодії. Музично-естетичне партнерство передбачає уміння студента вислухати учня, стати на його позицію, вважати її такою ж самоцінною, як і власну, поважати його смаки і уподобання - все це $є$ необхідною умовою створення естетико-виховного простору як на уроках мистецтва, так і в позакласній роботі.

В процесі музично-естетичного співробітництва дуже важливим $\epsilon$ надання учням вільного вибору у всьому, де $є$ для цього можливість і доцільність. Студент-практикант повинен бути готовим до творчої взаємодії з вихованцями (наприклад, запропонувати учням одну 3 кількох рівноцінних пісень на вибір; дати можливість самостійно створити «програму художнього виконання», тобто визначити його темпові та динамічні особливості; дозволити учням обрати домашнє завдання за уподобаннями тощо). Студент повинен демонструвати дітям зразки творчого підходу до мистецтва, а також фрормувати креативний потенціал учнів у різних видах художньо-творчої діяльності за їхнім добровільним вибором.

\section{Реалізація зв'язку музично-естетичної ma психолого- педагогічної підготовки студента-практиканта до роботи 3 молодшими школярами.}

Основними складниками музично-естетичної вихованості вчителя $\epsilon$ володіння методикою викладання предметів психолого-педагогічного та музично-естетичного циклів, наявність глибоких знань з психології, педагогіки, музичних дисциплін, здатність до координації своєї роботи (в умовах класної, позакласної, позашкільної діяльності), вміння 
презентувати навчальний матеріал на засадах між предметної інтеграції, встановлювати психологічний контакт з аудиторією тощо. Студент-практикант, використовуючи музичні образи у виховній роботі з дітьми, повинен добре орієнтуватися не лише в мистецькому матеріалі, але й в психофізіологічних особливостях сприймання його дітьми певної вікової категорії. Добір художніх зразків повинен враховувати не лише наявні музичні інтереси дітей, але й зону їх найближчого розвитку. Ознайомлюючи учнів з музичним матеріалом, студент-практикант повинен грамотно створювати установки на художнє сприймання та оціночну інтерпретацію музичного образу, адже саме завдяки цим механізмам відбувається суб'єктивація отриманих естетичних вражень.

\section{Впровадження інтегрованого підходу до естетико-виховної роботи студента-практиканта 3 учнями на основі синтезу мистецтв.}

Педагогічна практика повинна якнайкраще налаштувати студентів на синтезування музично-педагогічних умінь. Упродовж навчання майбутні вчителі поступово вчаться поєднувати знання та уміння, отримані в ході вивчення фахових дисциплін (теорії та історії музики, основного музичного інструмента, основ вокального мистецтва, методики музичного виховання, теорії та методики виховної роботи). Під час практики студент повинен виявити набуті вміння на компетентнісному рівні, тобто інтегративно. Зокрема, контрольний виховний захід в системі педагогічної практики, з нашого погляду, повинен обов'язково включати мистецький етап і проводитись на чітко окресленій аксіологічній основі. 3 цією метою кожний студент повинен обрати тему-концентр, навколо якого вміло згрупувати художній матеріал (музичний, літературний, візуально-пластичний) і в експресивній вербально-оцінній та виконавській діяльності репрезентувати основну виховну ідею.

Таким чином, компетентнісний підхід до організації педагогічної практики майбутніх учителів початкових класів уможливлює успішну екстеріоризацію набутих музично-педагогічних знань i навичок у виховні технології. Саме так музична освіта вчителя отримує закономірне продовження i реалізацію в контексті грамотно організованої позакласної естетико-виховної роботи з молодшими школярами. Компетентний педагог завжди віднайде в освітньому просторі час і місце для втілення у виховну практику того духовного скарбу, якого набув у процесі фахової підготовки.

У висновку зазначимо, що компетентнісний підхід до освіти передбачає зміну їі моделі і вимагає, перш за все, зміну самого вчителя, готового досягати соціальних, комунікативних, інформаційних компетенцій, готового засвоїти практико-орієнтовані знання і уміння. Серйозною перешкодою для впровадження компетентнісного підходу в систему вищої педагогічної освіти $є$ недостатність нормативно- 
методичного забезпечення та неготовність частини освітян усвідомити важливість практико-орієнтованої педагогічної освіти. Проте не слід забувати, що компетентнісний підхід - лише один із чинників, що сприяють модернізації змісту вищої освіти, він лише доповнює низку освітніх інновацій, не применшуючи значення класичних підходів.

Результатом ефективної практичної підготовки майбутніх учителів початкової школи до освітньої роботи з учнями можна вважати формування компетентної особистості сучасного педагога, який:

$>$ успішно вирішує власні інтелектуально-практичні проблеми, виявляючи ініціативу, творчість, самостійність і відповідальність; усвідомлює мету компетентнісно орієнтованої освіти школярів;

$>$ планує уроки з використанням усього розмаїття методів і форм організації навчальної діяльності, віддаючи перевагу інтерактивним, евристичним способам взаємодії з учнями на засадах партнерства;

> щільно пов'язує навчальний матеріал з повсякденним життям та інтересами учнів на рівні врахування їх вікових потреб і можливостей;

актуалізує попередній емоційно-образний досвід школярів, формує емоційний інтелект з метою мотивування пізнавальної та морально-ціннісної діяльності вихованців;

демонструє учням переконливі моделі інтелектуальнопрактичного розв'язання різноманітних навчальних ситуацій, а також високоморальні поведінкові програми;

> оцінює навчальні досягнення школярів з обов'язковою увагою до практичного застосування учнями знань і умінь у навчальних і життєвих ситуаціях.

Окремо хочемо зупинитися на плідності контекстного підходу до фрахової підготовки майбутніх учителів початкової школи. Успішність музично-виховної роботи, яку здійснюватиме педагог, на нашу думку, уможливлюється не лише і не стільки суто музичною підготовкою. Як показує практика, навіть уміючи грати на музичному інструменті, вчитель доволі не часто прагне сповна використати це уміння у виховній роботі з дітьми. Це результат «локального» формування таких умінь у процесі музичної підготовки, яка більшою мірою спрямована на формування технічної вправності поза професійновиховним контекстом майбутнього педагога.

Якісна освіта в контексті загальноцивілізаційних змін потребує постійного коригування пріоритетів фрахової підготовки студентів у системі вищої освіти [10]. Сьогодні, у часи загального реформування вітчизняної освіти і розбудови Нової української школи, повинно відбуватись переосмислення цілей, методів і форм музичної освіти вчителя і підпорядкування її широкому освітньо-виховному контексту конкретної спеціальності (О.Вербицький). Контекстне середовище закладу вищої освіти повинно моделювати умови майбутньої 
профресійної реальності [4]. Контекстна підготовка майбутніх учителів до професійної діяльності $\epsilon$, по суті, освітньою моделлю, в якій етапно моделюється предметний та соціальний зміст майбутньої професійної діяльності студентів [12, с.16]. Це система навчальних ситуацій, гранично наближених до майбутньої профресійної діяльності. У процесі спільної фрахово орієнтованої діяльності, в ході проходження педагогічної практики в школі, шляхом розв'язання професійних ситуацій студенти активно засвоюють соціальний зміст фахової діяльності.

Створення професійних ситуацій, за О.Вербицьким, повинно передбачати моделювання реальних або квазі-професійних обставин та умов, що вміщують суперечність [4, с. 68]. Усвідомлення цієї суперечності спонукає студента до активного пошуку шляхів для ії̈ оптимального вирішення. Тому такий підхід вважаємо потенційним ресурсом для плідної фрахової підготовки майбутніх учителів початкової школи..

Художня підготовка педагога повинна обов'язково корелюватися із його загальнопедагогічною підготовкою, що дозволить системно формувати різноманітні уміння - художньо-аксіологічні, загальнопедагогічні й виконавські.

На основі теоретичного аналізу та вивчення досвіду фрахової підготовки вчителів початкової школи нами конкретизовані умови їхньої ефрективної підготовки до музичного виховання учнів у позакласній роботі:

забезпечення цілепокладальної активності студентів у процесі формування у них мотивів музично-виховної діяльності;

формування музично-професійного мислення майбутніх учителів у контексті інтегральної дії антиципації та рефлексії;

розвиток здатності студентів до комплексної реалізації художньо-аксіологічних та загальнопедагогічних умінь в умовах контекстного підходу до підготовки майбутніх учителів початкової школи.

Якщо художньо-аксіологічні уміння вчителя забезпечують грамотний художньо-педагогічний аналіз музичних творів, адекватне тлумачення художнього образу і оптимальне цілепокладання щодо використання його в освітньому процесі, то загальнопедагогічні (дидактичні, сугестивні, перцептивні та ін.) уміння забезпечують необхідну виразність подачі художнього матеріалу і трансляцію власного (рефлексивного) ставлення до музичного образу. Лише комплекс цих умінь дозволить учителю створити адекватну ситуацію художньо-естетичного спілкування дітей $з$ музикою, уможливити необхідне «емоційне зараження» в процесі її сприймання.

Художньо-аксіологічні уміння уможливлять рефллексивні та антиципаційні процеси в ході аналізу вчителем музичного матеріалу i проектування змісту і форм його подачі дітям. Проте загально- 
педагогічні уміння, до яких відносимо вербальну і пантомімічну виразність, дозволять вчителю втілити власний художньо-емоційний відгук у виховні технології [15].

Елементарні виконавські уміння $€$ незамінною ланкою в системі готовності вчителя до виховної роботи. Крім використання аудіозапису, «мінусовок» (або модного нині караоке), в позакласній роботі доволі часто виникає необхідність включення «живого» звучання музики. Таку музику діти сприймають і виконують активніше і зацікавленіше. Авторитет учителя, який хоча б в елементарних фрормах виконує музику (голосом чи на музичному інструменті), гранично зростає, що посилює відкритість вихованців до його музичновиховного впливу [14].

Формування ж елементарних виконавських умінь вчителя варто чітко пов'язати з художньо-аксіологічними і загальнопедагогічними уміннями. Саме тоді виконавське мислення педагога отримає необхідний психологічний і педагогічний контекст і не звузиться лише до тренажу голосу чи пальців.

У якості додаткових умов успішної підготовки майбутніх учителів до музично-виховної роботи з дітьми набуває формування комунікативної виразності педагога на основі оригінальності індивідуального проектування позакласної музично-виховної роботи з учнями.

Музично-виховна робота з дітьми може бути ефективною, якщо вчитель зуміє виразно донести художньо-ціннісний зміст музичного твору, на основі якого проектується виховний вплив на учнівську аудиторію. Як слушно зауважує Н.Миропольська, педагог має бути комунікативно виразним, щоб учні не тільки розуміли, а й позитивно сприймали як мовлення учителя, так і паралінгвістичний контекст мови (доречність жестів, міміки, зовнішній вигляд тощо) та опановували це мистецтво самі [13, с.336].

Комунікативну виразність у контексті реалізації завдань музичновиховної роботи ми розуміємо як належну експресивність вербальноповедінкових реакцій учителя в процесі художньо-виховного діалогу 3 учнями; послідовне уникання ним інформаційної надлишковості; забезпечення варіативності форм і методів виховного впливу на ціннісну свідомість школярів на основі домінування музично-ігрової діяльності. Такий підхід зумовлений віковими потребами учнів, які не можуть статично, логізовано сприймати музику, яка їм подобається. Вчитель зобов'язаний побудувати художньо-виховний діалог саме так, як того вимагає природа учнів певного віку. Безперечно, шкідливою тут може стати перевантаження дитячої уваги номінативною інформацією про музичний твір, його автора, історію створення тощо. Крім того, вибір методів і прийомів опрацювання музичного матеріалу також повинно корелювати з віковими особливостями дітей. Для школярів, наприклад, молодшого шкільного віку завжди бажаними $\epsilon$ ігрові методи і прийоми на основі експресивно побудованих сюжетів. 
Індивідуальне проектування вчителем позакласної музичновиховної роботи повинно відбуватись на основі максимальної активізації його творчого потенціалу, який являє собою сукупність педагогічних ресурсів, що дозволяють створювати нові - оригінальні, якісно інші, але вищого рівня художньо-виховні цінності. Педагоги 3 високим творчим потенціалом відрізняються розвиненою уявою, сильною інтуїцією, прагненням до самовираження, нестандартним i продуктивним мисленням, новаторством, умінням мобілізувати свої ресурси в процесі виховної діяльності. Ресурсна відновлюваність їх творчого потенціалу забезпечується за рахунок належної пізнавальної активності і освоєння креативних виховних технологій [7, с.201-202].

Психологи (В.Рибалка, В.Роменець, С.Сисоєва та ін.) неодноразово підкреслювали, що найвище вираження своєї індивідуальності людина знаходить у творчій діяльності, причім не лише у сфрері художньої творчості, але й у педагогічній творчості. Зокрема, творчість вихователя не може відбутись інакше, як шляхом використання індивідуальної методики, побудованої на основі індивідуального таланту.

Послуговуючись ідеями В.Роменця, можемо стверджувати, що творцем справжніх виховних цінностей вважаємо того, хто, спираючись на об'єктивні закономірності людського життя, вміє відтворювати їх з неповторною індивідуалізацією. Ми переконані у тому, що духовне багатство педагога уможливлює глибину індивідуального осягнення ним світу і подальшу трансформацію цього у виховні технології. Отже, незаперечною $є$ думка В.Роменця про те, що «багатство світу - передумова розкриття об'єктивних рис дійсності. Лише оригінальний підхід дає змогу побачити смисл, красу довколишніх явищ, предметів» [18, с.127].

Комунікативна виразність учителя також забезпечується його творчим потенціалом. В.Роменець, розмірковуючи з цього приводу, підкреслює, що оригінальність і комунікація не заперечують одна одну. I хоча комунікація передбачає певну спільність у спілкуванні, а оригінальність становить усе те, що істотно відрізняє одну людину від іншої, незважаючи на цю докорінну протилежність оригінальності та комунікації, вони виявляються двома органічно пов'язаними моментами єдиної творчої діяльності. Поглиблення оригінальності, на думку психолога, веде до розширення комунікації, а комунікація, що розширюється, означає інтенсифікацію оригінальності. Те, що на перший погляд здається парадоксом, насправді в своїй глибокій суті показує, що творчість має суспільний характер і $\epsilon$ взаємодією індивідуальностей [там же, с.128].

Саме оригінальність проектування музично-виховної роботи забезпечить зацікавленість нею учнів і зумовить належний авторитет учителя. Лише за його наявності трансльовані педагогом художньоестетичні цінності успішно привласнюються учнями. М.Сметанський 
слушно обстоював ідею особистісної рефрерентності педагога. На його думку, референтний учитель спроможний «врости», тобто органічно увійти у внутрішній світ своїх вихованців. Трансльовані ж ним норми, цінності, смаки сприйматимуться дітьми як свої власні [6, с.18-25].

Отже, музично-виховна робота може бути результативною лише на фоні належної особистісної референтності педагога. Діти приймуть і полюблять ті зразки музичного мистецтва, які виразно, захоплено та оригінально транслюватиме авторитетний учитель 3 опорою на власний художній досвід, смакові уподобання і культурні інтереси.

Важливого значення набуває аксіологічна та технологічна культура музично-виховної роботи майбутнього вчителя у процесі педагогічної практики. В ході практичної роботи з дітьми студент отримує досвід реалізації культуротворчих фрункцій виховання. Музично-виховна робота змусить майбутнього вчителя по-іншому осмислити суть виховного процесу в цілому. Це щонайменше відмова від абсолютизації нормативно-регулюючих функцій, тобто відмова від догматичного нав'язування дітям норм поведінки у певних ситуаціях (у ситуаціях художньо-педагогічного спілкування це неприпустимо). Студенти повинні отримати досвід створення емоціогенних виховуючих ситуацій (І.Бех, С.Сисоєва, А.Чебикін), які сприяють творчому освоєнню дітьми музичних образів. Підвищення ефеективності творчого розвитку учнів, влучно зазначає С. Сисоєва, значною мірою визначається професійними уміннями вчителя створити сприятливі умови для розвитку їх творчих можливостей, само реалізації особистості учнів у процесі навчання. Головною при створені сприятливих умов для творчого розвитку учнів виступає умова забезпечення реалізації учнем своїх творчих можливостей у навчально-виховному процесі як на уроці, так і у позаурочній діяльності [19, с.375].

В процесі педагогічної практики майбутній учитель повинен отримати реальну можливість творчого цілепокладання музичновиховної діяльності, адже це удосконалить уміння творчого планування своєї діяльності з урахуванням можливостей як індивідуального особистісного розвитку, так і розвитку учнів; сприятиме формуванню індивідуального стилю творчої профресійної діяльності.

Саме під час педагогічної практики студент повинен осмислити необхідність аксіологічної культури музично-естетичного виховання дітей, яка зорієнтує його на надання виховній роботі яскраво вираженого ціннісного характеру на основі гуманістичних цінностей, змусить відмовитись від безособистісної, безоцінної позиції щодо мистецтва і стати транслятором естетично виправданих ціннісних підходів до музики.

Орієнтація на технологічну культуру музично-виховної роботи допоможе студенту віднайти нетривіальні фрорми трансляціїі художніх цінностей на основі грамотної організації музично-художньої творчості 
дітей. Організація творчого діалогу з вихованцями повинна активізувати конструювання студентами не окремих «виховних заходів», а комплексних форм впливу на мотиваційні компоненти ставлення учнів до музики на основі створення оригінальних виховуючих ситуацій.

На нашу думку, якість професійної підготовки майбутнього вчителя до музично-виховної роботи безпосередньо залежить від культуроємкості змісту та організаційних форм педагогічної практики, в ході якої майбутній учитель зможе реалізувати власну індивідуальність із сфрормованими культурно-ціннісними орієнтаціями і виховним кредо. Успішність музично-виховної роботи студента-практиканта, таким чином, залежатиме не лише від кількості загальнопедагогічних знань, але й від багатства суб'єктивної рефлексії на музичне мистецтво, від креативності методичного мислення, від оригінальності самовияву педагогічних позицій у позакласній роботі з дітьми.

У підсумку зазначимо, що контекстний підхід до фрахової підготовки учителів музичного мистецтва безпосередньо пов'язаний $з$ реалізацією магістрально важливого на сучасному етапі реформування української освіти компетентнісного підходу. Обидва підходи тісно пов'язані між собою, а їх реалізація є взаємно корельованою.

Конструювання освітнього процесу в сучасній педагогічній практиці закладів вищої освіти повинно здійснюватись не стільки через інфрормацію, скільки на основі навчання через діяльність. Саме контекстне навчання $€$ концептуальною основою для інтеграції різних видів фрахової діяльності майбутнього вчителя - практичнодидактичної і творчо-розвивальної. Контекстний підхід орієнтує викладачів 3ВО на те, що художні знання, уміння, навички даються студенту не як предмет, на який повинна бути направлена активність студента, а як засіб розв'язання фрахових завдань. Побудова освітнього процесу на компетентнісному підході і на технології контекстного навчання дозволяє максимально наблизити зміст i процес навчальної діяльності студентів до їх майбутньої профресії.

\section{Список використаних джерел}

1. Береза А.В. Педагогічно-виконавська практика майбутнього вчителя музики / А.В.Береза. - Вінниця, 2003. - 178 с.

2. Бібік Н. М. Компетентнісний підхід: рефрлексивний аналіз застосування / Н. М. Бібік // Наукові записки Вінницького державного педагогічного університету імені Михайла Коцюбинського. - Серія: Педагогіка і психологія: 36. наук. праць. - Вінниця: ТОВ фірма „Планер». - 2011. - Випуск 34. C. $220-224$.

3. Бібік Н. М. Компетентність і компетенції у результатах початкової освіти / Н.М. Бібік // Науковий часопис НПУ ім. Михайла Драгоманова. - серія 17 (вип. 17). 2010. - C.16-22.

4. Вербицкий А. А. Активное обучение в высшей школе : контекстный подход / А. А. Вербицкий. - М. : Высш. шк., 1991. - 207 с.

5. Вербицкий А. А. Концепция знаково-контекстного обучения в вузе / А. А. Вербицкий // Вопросы психологии. - 1987. - № 5. - С. 31-39. 
6. Галузяк В. М. Проблема личностной референтности педагога / В. М. Галузяк, Н. И. Сметанский // Педагогика. - 1998. - № 3. - С. 18-25.

7. Деркач А. А. Акмеология : учебное пособие / А. Деркач, В. Зазыкин. - СПб. : Питер, 2003. - 256 с.

8. Зимняя И. А. Ключевые компетентности как результативно-целевая основа компетентностного подхода в образовании: авторская версия / И.А.Зимняя. М. : Исслед. центр проблем качества подготовки специалистов, 2004. - 40 с.

9. Компетентнісний підхід у сучасній освіті : світовий досвід та українські перспективи : бібліотека з освітньої політики / [Бібік Н. М., Ващенко Л. С., Локшина О. І. та ін.] ; під заг. ред. О. В. Овчарук. - К. : К.І.С., 2004. - 112 с.

10. Кремень В. Г. Якісна освіта в контексті загальноцивілізаційних змін / В. Г. Кремень // Педагогіка і психологія. - 2007. - № 2 (55). - С. 5-17.

11. Матвієнко О.В. Організація педагогічної практики з виховної роботи в початковій школі / О.В.Матвієнко - К.: Стилос, 2003. - 124 с.

12. Мирончук Н.М. Контекстна підготовка майбутніх викладачів вищої школи до самоорганізації у професійній діяльності на засадах проблемно-ситуаційного підходу / Н.М.Мирончук // Професійна освіта: проблеми і перспективи / ІПТО НАПН України. - К. : ІПТО НАПН України, 2016. - Випуск 11. - 136 с. - С. 15-20.

13. Миропольська Н. Є. До проблеми визначення базових компетентностей учнів старшої школи / Н. Є. Миропольська // Педагогічна і психологічна науки в Україні : збірник наукових праць до 15-річчя АПН України : у 5 томах. - К. : Педагогічна думка, 2007. - Т. 1 : Теорія та історія педагогіки. - С. 330-338.

14. Мистецтво у розвитку особистості : монографрія / за ред. Н. Г. Ничкало. Чернівці : Зелена Буковина, 2006. - 224 с.

15. Нестерович Б.І. Контекстний підхід до фахової підготовки майбутніх учителів музичного мистецтва / Б.І.Нестерович, О.Ю. Теплова // Наукові записки Вінницького державного педагогічного університету імені Михайла Коцюбинського. Серія « Педагогіка і психологія». - 2019. - Вип. 57. - С.119 -125.

16. Нестерович Б.І. Педагогічні умови практичної підготовки майбутніх учителів початкової школи до музично-виховної роботи з учнями в контексті компетентнісного підходу / Б.І. Нестерович, Г.С.Тарасенко // Педагогічна освіта: теорія і практика: Збірник наукових праць / Кам'янець-Подільський національний університет імені Івана Огієнка. - Випуск 24 (1-2018). - Ч.2. C. 124-131.

17. Равен Дж. Компетентность в современном обществе. Выявление, развитие, реализация / Дж.Равен. - М.: Когито-Центр, 2002. - 396 с.

18. Роменець В. А. Психологія творчості : навч. посібник / В. А. Роменець. - 2-ге вид., доп. - К. : Либідь, 2001. - 288 с.

19. Сисоєва С. О. Підготовка вчителя до формування творчої особистості учня / С. О. Сисоєва ; АПН України, Ін-т педагогіки і психології проф. освіти. - К. : Поліграфкнига, 1996. - 406 с.

20. Хуторской А. Ключевые компетенции как компонент личностно ориентированной парадигмы образования / А.Хуторской // Народное образование. - 2003. - № 2. - C.58-64.

21. Armstrong A. Scotland: Education, curriculum and learning. The strengths, challenges and solutions in lifelong learning / Alan Armstrong. - Geneva: UNESCO International Bureau of Education, 2014. - 13 p.

22. Gordon J. Key Competences in Europe: Opening Doors for Lifelong Learners / Jean Gordon, Gabor Halasz, Magdalena Krawczyk, Tom Leney, Alain Michel, David Pepper, Elzbieta Putkiewicz, Jerzy Wiśniewski. - CASE Network Reports № 87. Warsaw: CASE - Center for Social and Economic Research, 2009. - 328 p. 


\title{
МОДЕЛЬ ФОРМУВАННЯ ГОТОВНОСТІ МАЙБУТНІХ ВИХОВАТЕЛІВ ЗАКЛАДІВ ДОШКІЛЬНОЇ ОСВІТИ ДО ВИКОРИСТАННЯ ІНТЕРАКТИВНИХ ТЕХНОЛОГІЙ
}

\author{
Харькова Є.Д. \\ кандидат педагогічних наук, доцент, \\ Сумський державний педагогічний університет імені А.С.Макаренка
}

Стратегічною метою дошкільної освіти, визначеною в Законі України «Про дошкільну освіту» [18], $€$ «...збереження та зміцнення фрізичного, психічного і духовного здоров'я дитини, ... форомування особистості дитини, розвиток ії творчих здібностей, набуття нею соціального досвіду; виконання вимог Базового компонента дошкільної освіти, забезпечення соціальної адаптації та готовності продовжувати освіту...» [2]. Сучасна модель освітнього процесу в закладах дошкільної освіти, представлена в Базовому компоненті дошкільної освіти в Україні, Базовій програмі розвитку дошкільників «Я у Світі» [4] (далі Програма), Програмі виховання і навчання дітей від двох до семи років «Дитина» [16], Програмі розвитку дитини дошкільного віку «Українське дошкілля» [3], Програмі розвитку дітей старшого дошкільного віку «Впевнений старт» [32], вимагає від вихователів зміни домінуючого принципу в ставленні вихователя до дитини: відмови від позиції впливу (коли дитина є об'єктом спостереження, перетворення) до освоєння механізмів реалізації принципу взаємодії, що онтологічно властиво дитині дошкільного віку, з психофізіологічними особливостями, структурою і змістом реальних вікових змін.

Натомість, практика свідчить, що вихователі переносять у заклади дошкільної освіти зміст, методи та форми організації, властиві навчально-виховній роботі початкової школи. Програма розвитку дитини ставить перед вихователями нову мету - взаємодія дорослого й дошкільника в основних сорерах життєдіяльності дитини: природа, культура, соціум, «Я». У Програмі основну увагу приділено провідній діяльності дошкільників - грі, адже цей вид діяльності збагачує знання дитини про довкілля, фрормує важливі якості особистості, започатковує вміння та навички розумової діяльності, розвиває інтелект, логічне мислення. Відповідно до Програми у взаємодії вихователя та дитини мають переважати ігрові завдання, практичні дії, спостереження, а не тривалі пояснення, притаманні навчальній формі організації занять.

Актуалізація проблеми підготовки майбутніх вихователів до використання інтерактивних технологій пояснюється декількома причинами, по-перше, економічними (відповідь на вимоги ринку праці, адже інформаційне суспільство потребує вже не лише системного й систематичного пізнання, оновлення інфрормації особистістю, а й 
активного освоєння нових видів діяльності професіоналом упродовж його фрахової життєтворчості); по-друге, соціокультурними (конструювання соціокультурних відносин між вихователями та дітьми на основі врахування особистісних та культурологічних фракторів); по-третє, науковими (урахування нового типу раціональності для осмислення духовної та матеріальної діяльності, а також цінностей); по-четверте, освітніми (реалізація основних положень чинних програм розвитку дошкільників).

У сучасній педагогічній літературі проблему впровадження Програми розвитку дошкільників «Я у Світі» розглядають у своїх працях знані педагоги - Н. Баглаєва [3], Г. Бєлєнька [5], А. Богуш [6], Н. Гавриш [10], Н. Глухова [11], Н. Дичківська [15], О. Кононко [22], Т. Піроженко [28], 3. Плохій [29], Т. Поніманська [27], та ін. Дослідники наголошують, що впровадження Програми викликало багато труднощів як у вихователів, так і в методистів та завідувачів закладів дошкільної освіти. Як засвідчує практика, ці труднощі зумовлені тим, що у вихователів існують уже сформовані стереотипи, подолати які дуже важко, зокрема, їм складно не тільки освоїти зміст, технології реалізації інновацій в умовах закладів дошкільної освіти, а й продукувати оновлений зміст, технології в реалії виховного процесу. Це пояснюється тим, що вихователі послуговуються засвоєними раніше методами впливу, які ґрунтуються на суб'єктно-об'єктних відносинах.

Аналіз педагогічних досліджень показав, що предметом уваги науковців були різноаспектні проблеми професійної підготовки майбутніх вихователів у вищій школі, зокрема: праця О. Вашак [8] розкриває проблеми підготовки майбутніх вихователів до екологічного виховання дошкільників на засадах етнопедагогіки; дисертаційну роботу С. Дяченко [17] присвячено проблемі підготовки майбутніх вихователів до фоомування основ комп'ютерної грамотності старших дошкільників; А. Залізняк [19] розкриває організаційно-педагогічні засади підготовки майбутніх вихователів до роботи з батьками 3 морального виховання дітей старшого дошкільного віку; Р. Кондратенко [21] вивчила проблему готовності майбутніх вихователів дошкільних навчальних закладів до виховання відповідальності в дітей старшого дошкільного віку; Н. Левінець [23] розглянула питання формування професійної готовності майбутніх вихователів до здійснення фрізичного виховання дошкільників на засадах народних традицій; Н. Сайко [33] розробила модель професійно-педагогічної підготовки майбутніх вихователів щодо соціалізації дошкільників; роботу Т. Слободянюк [35] присвячено проблемі становлення та розвитку профресійної підготовки фахівців із дошкільного виховання в Україні в кінці XIX - на початку XX ст. та ін.

Доведено, що використання інтерактивних технологій у закладах вищої освіти сприяє розвитку в студентів творчості, ініціативності, 
самостійності, уміння давати оцінку педагогічному процесу, уміння робити власний вибір та коригувати недоліки. Дослідники підкреслюють, що інтерактивні технології дозволяють створити умови для суб'єктно-суб'єктної взаємодії, у яких освоюються всі рівні пізнання (знання, розуміння, аналіз, синтез, оцінка), а також за допомогою цих технологій можна вирішити поставлену перед викладачами дидактичну мету навчання в процесі підготовки майбутніх вихователів, як-от: вдосконалення теоретичних основ професійної діяльності; формування та удосконалення професійних умінь та креативності; вивчення та узагальнення передового педагогічного досвіду; розвиток здатності до самоосвіти.

Узагальнюючи педагогічні праці, у яких розкриваються питання теорії і практики інноваційних технологій загалом та інтерактивних технологій зокрема, виділимо декілька напрямів здійснення наукових досліджень: фрілософський аспект дослідження (В. Андрущенко [3], І. Зязюн [20], управлінський (В. Бондар [7], Г. Дмитренко [15], О. Єльнікова [35], Л. Калініна [21], В. Луговий [14] та ін.); дидактичний (С. Гончаренко [13], Р.Гуревич [14], В. О. Савченко [34], концептуальні дослідження проблеми упровадження інтерактивних технологій (М. Кларін, Є. Коротаєва ， Т. Мухіна [27], В.Паламарчук [26], О. Пометун та ін.).

Соціально-економічні зміни спонукають до модернізації системи освіти в напрямі визначення оптимальних умов формування особистості майбутнього фахівця, здатного самостійно й вільно орієнтуватись у культурному просторі. Профресійна підготовка майбутніх вихователів в Україні складається з елементів, частина яких $\epsilon$ позасистемними, але такими, що достатньо впливають на процес підготовки. Сутність і взаємозв'язки цих елементів свідчать про те, що професійна підготовка залежить від розвитку й своєрідності всіх сфрер суспільства - політичної, економічної, соціально-культурної, духовної. Ïх постійний вплив потребує адекватного реагування освітньої практики. Елементи професійної підготовки, зазнаючи зовнішнього впливу, трансформуються. Як елемент професійної підготовки, готовність майбутнього вихователя до використання інтерактивних технологій є водночас імперативом, обов'язковою похідною від апріорі сформульованої моделі випускника. На етапі модернізаційних змін у професійній підготовці фрахівців актуальним і значущим завданням $\epsilon$ обґрунтування моделі фрормування готовності майбутніх вихователів до використання інтерактивних технологій, що дасть змогу вибудувати зміст, структуру, організаційно-педагогічні умови. Ураховуючи це, варто зосередити увагу на описі принципів розроблення внутрішньосистемних елементів моделі.

У контексті нашого дослідження та проведеного аналізу навчально-виховного процесу закладах вищої освіти розроблено модель, спрямовану на фрормування готовності майбутніх вихователів до використання інтерактивних технологій. 
Термін «модель» походить від латинського modulus - міра, мірило, зразок. Існує значна кількість трактувань цього терміна в педагогіці. К.Борін вважає, що «модель - це створена або вибрана суб'єктом система, яка відтворює істотні для цієї мети пізнання сторони (елементи, властивості, відносини, параметри) об'єкта визначення та через це знаходиться з ним у такому відношенні заміщення й схожості, що ії дослідження служить опосередкованим способом отримання знання про цей об'єкт» [ 7,c. 28].

Ю. Тарасенко пропонує таке визначення моделі - «це об'єкт, що заміщує оригінал і відбиває найважливіші риси та властивості оригіналу для даного дослідження, даної мети дослідження за обраної системи гіпотез» [37, с. 44]. Ю. Сурмін зазначає, що в широкому розумінні модель - це «образ (у тому числі умовний або уявний зображення, описання, схема, креслення, графрік, план, карта тощо), або прообраз (зразок) якого-небудь об'єкта або системи об'єктів (оригіналу моделі), що використовується за певних умов як їх заміщення або представник» [36, с. 294]. Загалом модель у педагогіці слугує концептуальним інструментом, аналогом певного фррагмента соціальної дійсності. Модель використовується для збереження й розширення знань про особливості та структуру модельованих процесів, орієнтовані насамперед на управління ними [36].

Прийнято умовно розділити моделі на три види: фрізичні (що мають природу, схожу з оригіналом); математичні (їх фрізична природа відрізняється від прототипу, але можливо математичний опис поведінки оригіналу); логіко-семіотичні (конструюються з спеціальних знаків, символів і структурних схем) [39].

Між названими типами моделей немає жорстких кордонів. Педагогічні моделі в основному входять у другу й третю групу перерахованих видів.

Моделювання в педагогіці, на думку В. Машкіна [25], має декілька аспектів застосування: гносеологічний, у якому модель відіграє роль проміжного об'єкта в процесі пізнання педагогічного явища; загальнометодологічний, який дозволяє оцінювати зв'язки й відношення між характеристиками стану різних елементів навчально-виховного процесу на різних рівнях їх опису та вивчення; психологічний, який дозволяє вести опис різних сторін навчальної й педагогічної діяльності, виявляти на цій основі психологопедагогічні закономірності.

Кожен аспект моделювання дає змогу формалізувати досліджуваний педагогічний процес чи явища з метою вивчення, змістовного наповнення, технологічної інтерпретації, а також розроблення механізмів управління об'єктом чи процесом.

За характером створення моделей прийнято розрізняти два основних способи моделювання: 
1)предметне моделювання, під час якого дослідження проводиться на матеріальній моделі, що відтворює певні геометричні, фрізичні, динамічні чи фуннцціональні характеристики об'єкта;

2) знакове (інформаційне) моделювання, під час реалізації ідеальними моделями слугують схеми, креслення, графріки й фрормули, запропоновані в деякому алфравіті [14].

До основних етапів побудови педагогічної моделі відносять:

Перший етап: постановка завдання. Цей етап вважається найбільш важливим, адже від чіткої постановки завдання залежить вирішення педагогічної проблеми. Другий етап: побудова моделі. Після постановки завдання відбувається визначення структурних елементів моделі та її побудова. Третій етап: перевірка моделі на достовірність. Після побудови моделі необхідно перевірити ступінь відповідності моделі реальному світу. Це виявляється в аналізуванні всіх релевантних змінних, що впливають на вирішення поставленого завдання. Ще один аспект перевірки - встановлення ступеня вірогідності та спроможності вирішення за допомогою даної моделі проблеми. Четвертий етап: використання моделі. За допомогою цього етапу визначається ступінь успішності побудованої моделі. Цей етап дає можливість модифрікувати модель відповідно до умов реального світу. Це пов'язано з тим, що на практиці проявляються слабкі сторони моделі або з'являються інші показники, які необхідно враховувати при розв'язанні проблеми.

У моделі фрормування готовності майбутніх вихователів закладів дошкільної освіти до використання інтерактивних технологій враховуємо гносеологічний, загальнометодологічний, психологічний аспекти процесу розроблення моделі та ґрунтуємося на принципах. У педагогічній науці принципи трактуються як вихідні положення, що визначають зміст, форми й методи навчальної роботи відповідно до мети виховання та закономірностей процесу навчання [27].

Методологічним підґрунтям, що вможливлює всебічність вивчення процесу фрормування готовності майбутніх вихователів закладів дошкільної освіти до використання інтерактивних технологій, слугує взаємозв'язок і взаємодія компетентнісного, особистісно-діяльнісного та культурологічного підходів до побудови моделі, реалізованих за допомогою принципів: цілісності - єдність фрорми, методів, умов, критеріїв, показників для досягнення поставленої мети; системності урахування внутрішніх та зовнішніх впливів, соціальних та педагогічних умов тощо; суб'єкт-суб'єктної взаємодії - спрямованість на співробітництво учасників навчально-виховного процесу; гнучкості та варіативності - спроможність змінюватись відповідно до запитів суспільства, його потреб та вимог; адекватності, що випливає з вимог достатньої повноти опису професійної діяльності; надійності, що потребує врахування професійних умов діяльності спеціаліста. 
3 огляду на здійснений аналіз структурних компонентів готовності майбутніх вихователів закладів дошкільної освіти до використання інтерактивних технологій, модель фрормування досліджуваного явища можна представити як змістово-структурне утворення (рис. 1).

В означеній моделі відображено структурно-функційну взаємодію мети; принципів (системності, систематичності, науковості, доступності, оптимізації, цілеспрямованості, взаємодії, активності, групової та індивідуальної роботи, рефлексії); компонентів (мотиваційний, пізнавально-когнітивний, конативний); організаційнопедагогічних умов реалізації моделі формування готовності майбутніх вихователів закладів дошкільної освіти до використання інтерактивних технологій (оптимізація педагогічної взаємодії викладача й студента на основі належної інтеракційної культури; впровадження самокерованого навчання в процес фахової підготовки майбутніх вихователів закладів дошкільної освіти; створення необхідного матеріально-технічного забезпечення процесу використання інтерактивних технологій у навчально-виховному середовищі закладі вищої освіти; варіативне використання методів і форм фахової підготовки студентів до оперування інтерактивними технологіями в процесі вивчення нормативних і спеціальних курсів); етапів підготовки (початковий, основний, заключний); критеріїв (диференціально-психологічний, інфрормаційний, результативний) та рівнів (високий, достатній, низький); фрорм роботи (лекції, практичні заняття, спецкурс «Формування готовності майбутніх вихователів до використання інтерактивних технологій», самостійна робота, педагогічна практика); методів підготовки: проблемно-пошуковий виклад теоретичного матеріалу; технології дискусійного характеру; моделювання казкової реальності; створення творчих проектів; ділові педагогічні ігри 3 подальшим обговоренням ефективності обраних методів, прийомів навчання; самостійне розв'язання педагогічних завдань із подальшим оцінюванням виконаної роботи.

Здійснюючи опис моделі, звернемо увагу на сутність кожного складника. Мотиваційний компонент передбачає мету:

1) стимулювати в студентів інтерес до набуття знань, умінь та навичок використовувати інтерактивні технології;

2) підготувати молодих спеціалістів до майбутньої професійної діяльності;

3) розвивати прагнення до самовдосконалення профресійноособистісних якостей.

Пізнавально-когнітивний структурний компонент передбачає перелік основних знань та вмінь, необхідних для ефективного використання інтерактивних технологій, як-от: сутність та значення інтерактивних технологій для пропедевтичної підготовки дітей старшого дошкільного віку до школи; місце інтерактивних технологій у навчально-виховному процесі закладу дошкільної освіти; особливості 


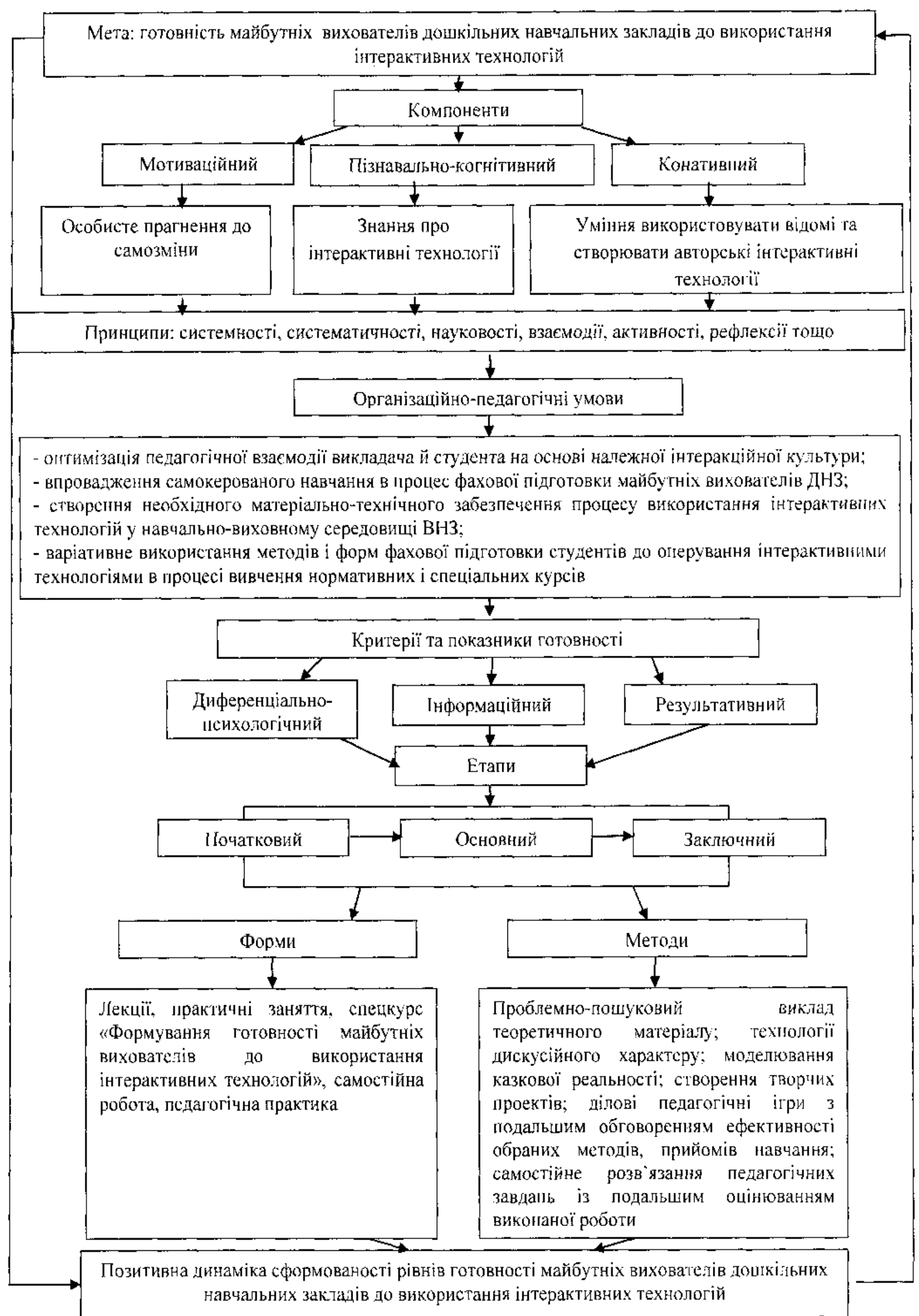

Рис. 1. Модель формування готовності майбутніх вихователів закладів дошкільної освіти до використання інтерактивних технологій 
використання інтерактивних технологій у навчально-виховному процесі з дітьми старшого дошкільного віку; особливості побудови інтерактивних занять; функції вихователя в організації інтерактивного навчання. Щодо вмінь, то майбутній вихователь повинен на практиці ефективно використовувати отримані знання щодо використання інтерактивних технологій; організовувати керівництво педагогічним процесом з урахуванням методики та ефективних умов використання інтерактивних технологій; підвищувати професійний рівень, педагогічну майстерність; використовувати не тільки вже відомі технології, а й розробляти власні; забезпечувати набуття дітьми життєвого досвіду, знань, умінь і навичок, необхідних для їх подальшого навчання в школі; сприяти навчально-пізнавальній діяльності дітей старшого дошкільного віку, виконуючи роль фасилітатора.

Конативний компонент відображає ссоомованість відповідної компетентності щодо використання інтерактивних технологій під час практичних занять, педагогічної практики та самостійної навчальнодослідницької роботи на основі засвоєння змісту нормативних навчальних дисциплін та спецкурсу, внесення новизни та підвищення профресійного рівня. Підготовка майбутнього фрахівця до використання інтерактивних технологій здійснювалась на основі низки принципів, які регулюють основні компоненти підготовки, визначають зміст навчання студентів, фоорми, методи та технології [24]. До них належать принципи: системності - загальнодидактичний принцип, що потребує досягнення єдності навчально-виховного процесу, інтегрування змісту нормативних навчальних дисциплін, спрямованих на підготовку майбутніх вихователів до використання інтерактивних технологій навчання з дітьми старшого дошкільного віку [30]; систематичності загальнодидактичний принцип, що полягає в раціональному плануванні пізнавального матеріалу про інтерактивні технології, дотриманні логічної послідовності під час подання лекцій студентам, у повтореннях вивченого матеріалу з метою глибшого його засвоєння; науковості - загальнодидактичний принцип, який стосується головним чином змісту навчального матеріалу про інтерактивні технології, їх значення, класифрікації та методики використання; доступності загальнодидактичний принцип, який ґрунтується на необхідності зважати на природні особливості й можливості студентів певних вікових груп, не забуваючи про індивідуальні особливості фрізичного й психічного розвитку кожної особистості; оптимізації - вимагає при розгляді проблеми виділення й опису умов, у яких запропоноване рішення буде оптимальним; цілеспрямованості - вимагає від викладача знання основної мети фрормування готовності майбутніх вихователів до використання інтерактивних технологій, завдань навчання в сучасному закладі вищої освіти, уміння в конкретній ситуації ставити оптимальні завдання навчання, розвитку й виховання, враховуючи реальні навчальні можливості студентів [29]; взаємодії - 
вимагає від викладача створення умов суб'єкт-суб'єктної взаємодії з студентами з метою їхньої активної діяльності під час заняття; активності - загальнодидактичний принцип, що орієнтує на використання інтерактивних технологій, які відкривають у студентах можливості бути суб'єктами процесу пізнання. Їхня активність виявляється в їхньому ставленні до пізнавальної діяльності, в готовності до сприймання й засвоєння нових знань, прагненні до самостійного пошуку, в ініціативі щодо вибору об'єкта й способів діяльності. Задоволення цих потреб породжує нові, значно вищі; рефрлексії - дозволяє студентам усвідомити процес навчання, осмислити його результативність, спрямованість, проаналізувати свої відчуття, переживання, розглянути особливості власного мислення й мислення інших учасників взаємодії, власні способи розумової діяльності, відкоригувати власні пізнавальні цілі, освітню траєкторію професійного розвитку [22].

Етапами процесу формування готовності майбутніх вихователів закладів дошкільної освіти до використання інтерактивних технологій $\epsilon$ початковий, основний та заключний. На початковому етапі має здійснюватись:формування позитивного ставлення студентів до майбутньої професійної діяльності загалом та стимулювання їхнього інтересу до використання інтерактивних технологій у професійній діяльності; мотивування потреби самовдосконалюватись, досягати рівня конкурентоспроможного фрахівця.

Завданнями початкового етапу в системі формування готовності майбутніх вихователів до використання інтерактивних технологій стали: формування позитивного ставлення студентів до професійної діяльності; виховання в них стійкого інтересу до оволодіння знаннями та методикою використання інтерактивних технологій у професійній діяльності; організація усвідомлення студентами значення суб'єктсуб'єктної взаємодії, атмосфрери взаємоповаги та ситуації успіху в навчально-виховному процесі вищої школи та в навчанні дітей дошкільного віку; засвоєння системи загальнопедагогічних знань як теоретико-методологічної основи готовності вихователів закладів дошкільної освіти до використання інтерактивних технологій.

Теоретичною базою початкового етапу $€$ вивчення загальних дисциплін циклу професійної підготовки, визначених галузевим стандартом вищої освіти: «Дошкільна педагогіка», «Етнопедагогіка», «Методика викладання дошкільної педагогіки», «Сучасні технології в дошкільній педагогіці», «Технології викладання методик дошкільного виховання», «Методика викладання дитячої психології», «Психологія особистості», «Основи педагогічної етики» та ін.

3 метою реалізації визначених цілей і завдань початкового етапу експериментальної перевірки підготовки майбутнього вихователя було передбачено комплекс заходів: проведення діагностики готовності майбутніх вихователів до використання інтерактивних технологій; 
уведення в курс психолого-педагогічних дисциплін матеріалу теоретичного та практичного змісту про використання інтерактивних технологій у професійній діяльності; уведення спецкурсу «Формування готовності майбутніх вихователів до використання інтерактивних технологій»; залучення студентів до активної суб'єкт-суб'єктної взаємодії під час лекцій, практичних занять, самостійної роботи та педагогічної практики.

Метою основного етапу експериментальної програми підготовки майбутніх вихователів до використання інтерактивних технологій $\epsilon$ закріплення та подальше формування мотиваційного компонента готовності до використання інтерактивних технологій, а також здійснення теоретичної та практичної підготовки студентів до професійної діяльності. Теоретична підготовка включає актуалізацію та узагальнення опорних знань і засвоєння нових теоретичних та методологічних знань про використання інтерактивних технологій. Практична підготовка спрямована на поетапне формування готовності майбутніх вихователів до використання інтерактивних технологій у практичній діяльності.

Завданнями основного етапу фрормування готовності майбутніх вихователів закладів дошкільної освіти до використання інтерактивних технологій $є$ : актуалізація отриманих знань 3 дис.циплін педагогічного циклу та знань щодо реалізації інтерактивних технологій у навчально-виховному процесі; засвоєння знань про сутність, значення, завдання, класифікацію та специфіку використання інтерактивних технологій у навчально-виховному процесі 3 дітьми дошкільного віку; формування вміння самостійно добирати інтерактивні технології відповідно до змісту та тематики занять, оцінювати їх доцільність та ефективність; забезпечення високого рівня узагальнення засвоєних знань і вмінь студентів.

Організаційними формами підготовки майбутніх вихователів закладів дошкільної освіти до використання інтерактивних технологій на основному етапі в умовах експериментального навчання стали лекційні та практичні заняття розробленого спецкурсу «Формування готовності майбутніх вихователів до використання інтерактивних технологій».

3 метою забезпечення оптимальних організаційно-педагогічних умов реалізації цілей і завдань основного етапу експериментального дослідження програмою передбачалось упровадження комплексу заходів:

1. Створення суб'єкт-суб'єктної взаємодії, атмосфрери взаємоповаги між викладачем та студентами, вихователем та дітьми.

2. Створення ситуації успіху.

3. Забезпечення ігрового простору під час навчально-виховного процесу. 
4. Забезпечення навчально-виховної взаємодії відповідним обладнанням та літературою.

5. Орієнтація на самокерованість навчання, надання студентам можливості самостійно планувати час для опанування того чи іншого навчального матеріалу.

6. Демонстрація можливості використовувати набуті знання в практичній діяльності, орієнтуючись на власний досвід.

7. Уведення в навчальний процес закладу вищої освіти спецкурсу «Формування готовності майбутніх вихователів до використання інтерактивних технологій».

8. Використання інтерактивних технологій на практиці.

9. Формування у викладачів закладів вищої освіти готовності застосовувати інтерактивні технології.

10. Забезпечення майбутнім вихователем навчально-методичного супроводу.

11.Упровадження інтерактивних технологій у вивчення дисциплін педагогічного циклу.

Заключний етап фрормування готовності майбутніх вихователів полягає в закріпленні отриманих знань, сформованих умінь та навичок із використання інтерактивних технологій у практичній діяльності, а також умінь самостійно створювати авторські інтерактивні технології. Реалізація визначених цілей і завдань здійснювалась шляхом залучення студентів до самостійної практичної діяльності щодо використання інтерактивних технологій.

3 метою автоматизації набутих умінь у фрорматі експериментального дослідження студентам пропонувалось використовувати інтерактивні технології на практичних, самостійних заняттях та під час педагогічної практики. Результати виконання розробленого комплексу завдань стали показником готовності майбутніх вихователів закладів дошкільної освіти до використання інтерактивних технологій.

Таким чином, поетапне формування готовності майбутніх вихователів до використання інтерактивних технологій здійснювалося за допомогою послідовного, систематичного оволодіння студентами теоретичними знаннями про інтерактивні технології, поглиблення, конкретизації та узагальнення вже отриманих знань та сформованих на їх основі вмінь та навичок.

Модель передбачає збагачення змістового й операційного компонентів навчальних дисциплін, самостійної діяльності, педагогічної практики та підготовку майбутніх вихователів у процесі вивчення спецкурсу «Формування готовності майбутніх вихователів до використання інтерактивних технологій». Студентам пропонується самостійно вивчати цікаві для них інтерактивні технології, методику їх використання та розробляти власні технології. Напрацьовано алгоритм використання інтерактивних технологій у самостійній діяльності студентів-майбутніх вихователів, яка має такі компоненти діяльності: концептуально-цільовий, змістовий, методичний та 
контрольно-оцінювальний.

Концептуально-цільовий компонент моделі містить мету застосування цієї моделі: формування готовності до використання напрацьованих інтерактивних технологій на практиці та створення авторських технологій.

Змістовий компонент складається з таких складових: умови (достатній рівень знань студентів та викладачів із теорії та практики використання інтерактивних технологій; наявність відповідної матеріальної бази щодо використання інтерактивних технологій; планування самостійної діяльності студентів; методичне керування викладачем самостійною діяльністю студентів; позааудиторний час; контроль самостійної діяльності студентів); інформаційні технології (використання комп'ютерів та користування мережею Інтернет); технології організації самостійної роботи («Портфоліо», «Кластер», «Сінквейн», «Есе» тощо); зміст самостійної діяльності (опрацювання теоретичного матеріалу; розробка студентами відповідного наочного матеріалу; наявність тем та ситуацій для самостійної роботи) та інструменти (інформаційно-навчальні ресурси; комп'ютерні ресурси; інтернет-ресурси). Цей компонент спрямовано на організацію самостійної діяльності студентів із використання інтерактивних технологій.

Методичний компонент зорієнтовано на вибір шляхів та методів навчання для самостійного використання інтерактивних технологій на практиці. До методів самостійної роботи належать: читання - робота 3 науковою літературою сприяє розширенню наукових знань студентів, формуванню вмінь самостійної пізнавальної діяльності. Метод застосовується для самостійного здобуття та розширення знань студентів про інтерактивні технології без участі викладача; використання інтерактивних технологій - під час використання інтерактивних технологій на практиці студенти повинні насамперед зрозуміти їх сутність, потім вибрати оптимальні умови впровадження й, нарешті, пояснити та довести їх правильність та доцільність; відеострічка - допомогти студентам побачити себе збоку, оцінити свою навчальну діяльність, свої дії навчального й професійного характеру. Для цього необхідно записати дії студентів на відеокамеру. Такий метод дає можливість майбутнім вихователям проаналізувати та оцінити свої дії зі сторони; сучасні інформаційні технології: аудіо- та відеоматеріали, комп'ютерні навчальні програми, електронні журнали, інтерактивні бази даних, інші навчальні матеріали, розміщенні в комп'ютерних мережах. Вищеназвані технології дозволяють студентам отримувати необхідну інформацію будь-де та в будь-який час; виконання наукових досліджень (написання статей, курсових та дипломних проектів) дозволяє студентам самостійно знаходити необхідну інформацію та розробляти авторські інтерактивні технології.

Контрольно-оцінювальний компонент спрямовано на контроль за навчальним процесом, вчасною перевіркою та оцінкою знань, умінь та 
навичок, результатом яких $є$ рівень навчальних досягнень студентів 3 оволодіння інтерактивними технологіями. Для цілісного процесу формування вмінь вихователів оптимальним $€$ введення спецкурсу «Формування готовності майбутніх вихователів до використання інтерактивних технологій». Цей курс містить і теоретичний, i практичний матеріал. Спецкурс передбачає завдання для самостійної роботи, оскільки деякі питання потребують осмислення, психологопедагогічного аналізу, пошуку правильних, оригінальних шляхів виходу з проблемних педагогічних ситуацій. Курс складається з лекційних, практичних занять, а також самостійної роботи студентів.

Тематичний контекст має на меті перегляд тем, які розкривають сутність та значення інтерактивних технологій, їх класифікацію та методику використання. Діяльнісний контекст дає змогу студентам на практиці використовувати отримані знання, а рефлексивний контекст подачі матеріалу містить аналіз й оцінку результатів власної роботи студентів, визначення причин недоліків і невдач із подальшою корекцією дій. Адже студент, здатний до рефрлексії, має можливість бути краще підготовленим до компетентної професійної діяльності. Під час лекційних занять студенти знайомляться 3 теоретичною основою спецкурсу: змістом поняття «інтерактивні технології», його завданнями та значенням, історією виникнення, умовами та особливостями їх використання 3 дітьми старшого дошкільного віку, а також досвіду організації навчальної взаємодії в педагогічній практиці видатних педагогів.

Під час практичної та самостійної роботи реалізовується система знань, які студенти отримали на лекційних заняттях. Вони не тільки закріплюють отримані знання, але й активізовують їх, тобто вчаться творчо мислити, аналізувати, діагностувати ситуацію в групі та необхідність застосування тієї чи іншої інтерактивної технології, використовувати різні форми самостійної пошуково-дослідницької роботи: ознайомлення з публікаціями педагогічної періодики, вивчення художньої та науково-популярної літератури, написання доповідей, рефрератів, дипломних досліджень.

На самостійне опрацювання студентами виносять виконання завдань, які потребують творчого підходу не тільки до теоретичної постановки питання, але й до практичного його вирішення. Студенти вчаться складати конспекти занять із використанням інтерактивних технологій, а також різноманітних видів діяльності протягом дня; використовувати власні розробки на практиці та діагностувати їх ефективність.

Вивчення спецкурсу проводиться у закладах вищої освіти на фракультетах дошкільної освіти, з студентами старших курсів, оскільки вони вже набули базових знань із педагогіки, психології, основ педагогічної майстерності, ознайомились із низкою сучасних інноваційних технологій, які використовуються в закладах дошкільної освіти, та спроможні до розроблення нових технологій на основі вже 
відомих. Окрім цього, такий спецкурс можна використовувати працівникам закладів дошкільної освіти у процесі підвищення кваліфікації методичних працівників і вихователів. Фундамент курсу становлять знання студентів з педагогіки, психології, педагогічної майстерності, знань інноваційних технологій, методик дошкільної освіти, одержаних у процесі навчання, а також практичні вміння, набуті під час різних видів практики.

Шляхами реалізації завдань спецкурсу $€$ різноманітні методи: проблемно-пошуковий виклад теоретичного матеріалу; технології дискусійного характеру (диспути, «мозкова атака», засідання експертної групи (або петельна дискусія), дискусія в стилі телевізійного ток-шоу тощо); моделювання казкової реальності; створення творчих проектів; ділові педагогічні ігри 3 подальшим обговоренням ефективності обраних методів, прийомів навчання; самостійне розв'язання педагогічних завдань із подальшим оцінюванням виконаної роботи.

Використання проблемно-пошукового підходу до викладання теоретичного матеріалу передбачає різний рівень активізації студентів залежно від їхньої підготовленості до засвоєння професійнопедагогічних знань, знань особливостей освітнього процесу з дітьми старшого дошкільного віку.

Технології дискусійного характеру дозволяють створити умови, коли студенти можуть не тільки висловити свої погляди й переконання, а й зіставити їх з позиціями опонентів, відстояти власну точку зору. Ця технологія дозволяє майбутнім вихователям побачити різні сторони проблеми, відчути свою причетність до ії вирішення. Така ситуація створює умови, коли рішення буде «не нав'язаним» [33].

Моделювання казкової реальності $€$ ефрективною технологією, оволодіння якою забезпечить майбутніх вихователів уміннями якнайкраще розвивати творчі здібності кожної дитини. М. Лещенко [24] та Н. Павленко [30] стверджують, що така технологія забезпечує активність кожної дитини, зупиняє негативні прояви, переводить при потребі плин казкового життя в потрібне русло. Залучаючись до різних видів діяльності, прописаних у сценарії навчальної діяльності методом казкової реальності, оволодівають комунікативними навичками, збагачують соціальний досвід.

Створення творчих проектів сприяє розвитку творчої уяви майбутніх вихователів, дає можливість усвідомити важливість теоретичних знань для успішної реалізації практичних умінь, сприяє формуванню вміння працювати в команді над спільною метою, відстоювати свої переконання (творчий проект), фрормує репрезентаційні вміння.

Ділові педагогічні ігри доцільно використовувати в ситуаціях, коли в студентів виникають суперечності між теоретичними знаннями й відсутністю досвіду їх реалізації в практичній навчальній діяльності. Як зазначає П.Щербань, ділові ігри - це метод навчання професійній 
діяльності шляхом ії̈ моделювання, близького до реальних умов, 3 обов'язковим динамічним розвитком ситуації, задачі чи проблеми, що розв'язується в суворій відповідності з характером рішень та дій її учасників [39]. Цей вид діяльності не тільки мобілізує резерви розумової діяльності, а й розширює діапазон мислення, бо студент вчиться не тільки бачити помилки, а й розуміти, чому вони з'явились $\mathrm{i}$ які будуть наслідки [39].

Самостійне розв'язання педагогічних завдань із подальшим оцінюванням виконаної роботи $€$ ефективним методом входження студентів у професійне життя, тому що дозволяє підготувати майбутніх професіоналів до використання отриманих знань на практиці. Вона сприяє глибшому узагальненню, осмисленню матеріалу, розвиває самостійність, самооцінку, оскільки результати самостійної роботи студента та відповідні рекомендації висвітлюються викладачем.

Під час організації педагогічної практики студентам пропонують, окрім традиційних форм та методів, використовувати інтерактивні технології, з якими вони знайомиться під час лекційних та практичних занять. Також студенти самостійно розробляють авторські інтерактивні технології, які вони можуть використовувати під час педагогічної практики.

Отже, модель формування готовності майбутніх вихователів до використання інтерактивних технологій - це системоутворювальний елемент у побудові моделі змісту професійної підготовки. В оцінюванні ефрективності функціонування розробленої моделі вагомим $\epsilon$ розроблення критеріїв і показників сформованості готовності майбутніх вихователів ЗДО до використання інтерактивних технологій.

Висновки. На основі теоретичного аналізу проблеми дослідження та аналізу результатів експерименту розроблено модель фоормування готовності майбутніх вихователів закладів дошкільної освіти до використання інтерактивних технологій. Основою розробленої моделі стали принципи, які регулюють процес розроблення моделі, як-от: цілісності (єдність методів, фрорм, умов, критеріїв, показників для досягнення поставленої мети); системності (урахування внутрішніх та зовнішніх впливів, соціальних та педагогічних умов тощо); суб'єктсуб'єктної взаємодії (спрямованість на співробітництво учасників навчально-виховного процесу); гнучкості та варіативності (спроможність змінюватись відповідно до запитів суспільства, його потреб та вимог); адекватності (випливає з вимог достатньої повноти опису професійної діяльності); надійності (потребує врахування професійних умов діяльності спеціаліста). У розробленій моделі відображено структурно-фрункціональну взаємодію мети, принципів, компонентів, організаційно-педагогічних умов, етапів підготовки, критеріїв та рівнів, форм роботи, методів підготовки до використання інтерактивних технологій у професійній педагогічній діяльності.

Також обґрунтовано структурні компоненти дослідноекспериментальної моделі: мотиваційний (стимулювання в студентів 
інтересу до набуття знань, умінь та навичок використання інтерактивних технологій; підготовка молодих спеціалістів до майбутньої професійної діяльності; розвиток прагнення до самовдосконалення профресійно-особистісних якостей), пізнавально-когнітивний (передбачає перелік основних знань та вмінь, необхідних для ефективного використання інтерактивних технологій) та конативний (відображає ссрормованість відповідної компетентності щодо використання інтерактивних технологій під час практичних занять, педагогічної практики та самостійної навчально-дослідницької роботи на основі засвоєння змісту нормативних навчальних дисциплін та спецкурсу).

У дослідженні сорормульовано рекомендації для ефективного впровадження моделі формування готовності майбутніх вихователів закладів дошкільної освіти до використання інтерактивних технологій: на рівні викладача вищої школи (проводити самодіагностику професійних можливостей, самонавчання та самовдосконалення; систематично поновлювати знання 3 психології особистості та педагогіки вищої школи з метою активізації інтелектуальної діяльності та наукового пошуку; проявляти інтерес до розвитку потенційних можливостей студентів і потреби в педагогічній діяльності з ними; проектувати цілі навчання й прогнозувати шляхи професійного становлення майбутнього фахівця; розвивати духовно-виховний вплив на особистість студента та організовувати розвивальну інтеракцію; створювати умови взаємоповаги та взаємодопомоги на заняттях; сприяти розвитку наукового інтересу та креативності в студентів; використовувати інноваційні технології навчання в процесі професійної діяльності; створити банк педагогічних інновацій з галузі); на рівні методичного кабінету закладу вищої освіти (здійснювати аналітикодослідну роботу щодо визначення рівнів готовності викладачів до використання інтерактивних технологій; створити банк науковопедагогічного досвіду викладачів закладу вищої освіти, вихователів 3 проблеми реалізації інтерактивних технологій; проводити постійні семінари, майстер-класи з проблем сучасних інноваційних технологій; інтегрувати діяльність кафредр із методичним відділом 3 метою створення інформаційно-методичного забезпечення педагогічного процесу; організовувати взаємовідвідування занять викладачами для обміну досвідом та з подальшою розробкою рекомендацій до використання інтерактивних технологій; узагальнювати та поширювати новаторський досвід роботи через засоби масової інформації, видання методичних рекомендацій); на рівні закладу вищої освіти (здійснювати інтеграцію науково-методичної діяльності закладу вищої освіти як цілісної динамічної системи з метою підвищення готовності науковопедагогічних працівників до професійної діяльності; запроваджувати модель фрормування готовності майбутніх вихователів закладів дошкільної освіти до використання інтерактивних технологій; створювати умови для вільного вибору студентами способів творчої самореалізації та саморозвитку; забезпечувати заклади вищої освіти 
новітніми інформаційно-телекомунікаційними засобами навчання та навчально-методичною літературою про інтерактивні технології та методику їх упровадження).

\section{Список використаних джерел}

1. Андрущенко В. Високі педагогічні технології : Вища освіта України. 2007. № 2. C. 70-76.

2. Базовий компонент дошкільної освіти (нова редакція). Дошкільне виховання. 2012. № 7. C. 4-19.

3. Баглаєва Н. Логіко-математичний розвиток дошкільнят: шлях оптимізації . Палітра педагога. 2002. № 2. С. 12-14.

4. Базова програма розвитку дитини дошкільного віку «Я у світі». М-во освіти і науки України, Акад. пед. наук України; наук. ред. та упоряд. О. Л. Кононко: Світич, 2008. 430 с.

5. Бєлєнька Г. В. Вихователь дітей дошкільного віку: становлення фахівця в умовах навчання : монографрія за ред. Наук. ред. Г.В.Бєлєнька. Київ: Світич, 2006. $304 \mathrm{c}$.

6. Богуш А., Гавриш Н., Котик Т. Методика організації художньо-мовленнєвої діяльності дітей у дошкільних навчальних закладах: Вид. Дім «Слово», 2006. $302 \mathrm{c}$.

7. Борин Г. В. Організаційно-педагогічні умови підготовки майбутніх вихователів до роботи з батьками дітей раннього віку: дис. ... канд. пед. наук: 13.00 .04 ; Прикарпатс. нац. ун-т ім. В. Стефраника. Івано-Франківськ, 2009. 251 с.

8. Вашак О. О. Підготовка майбутніх вихователів до екологічного виховання дошкільників на засадах етнопедагогіки : автореф. дис. ... канд. пед. наук: 13.00.04; Київ. ун-т ім. Б. Грінченка. К., 2010. 20 с.

9. Великий тлумачний словник сучасної Української мови / укл. і гол. ред. В.Т.Бусел. Київ.: Ірпінь: Перун, 2001. 1440 с.

10. Гавриш І. В. Теоретико-методологічні основи формування готовності майбутніх учителів до інноваційної профресійної діяльності : дис. ... д-ра пед. наук : 13.00.04; Харків. нац. пед. ун-т ім. Г. С. Сковороди. Х., 2006. 475 с.

11. Глухова Н. Базова програма «Я у Світі»: формування природничої компетентності дошкільника. Вихователь-методист дошкільного закладу. 2009. № 7. C. 4-8.

12. Гончар Н. П. Інтерактивні технології навчання як засіб фрормування пізнавальної активності дітей дошкільного віку. Дошкільна освіта у сучасних вимірах: мат. Міжнар. наук.-практ. конфреренції, 24-25 вересня 2013p. Хмельницький, 2013. С. 90-94.

13. Гончаров С. М. Інтерактивні технології навчання в кредитно-модульній системі організації навчального процесу: навч.-метод. посіб. Рівне: 2006. 172 с.

14. Гуревич Р. С. М. Ю. Кадемія, М. М. Козяр. Інформаційно-комунікаційні технології в професійній освіті. Львів: 2012. 506 с.

15. Дичківська І. М. Інноваційні педагогічні технології: навч. посіб. Київ: Академвидав, 2004. 352 с.

16. Дитина: Програма виховання і навчання дітей від двох до семи років / наук. кер. проекту: О. В. Огнев'юк та ін. 3-є вид.: Київ. ун-т ім. Б. Грінченка, 2012. 492 с.

17. Дяченко С. В. Підготовка майбутніх вихователів до формування основ комп'ютерної грамотності старших дошкільників: дис. ... канд. пед. наук: 13.00.04; Луган. нац. ун-т ім. Т. Шевченка. Луганськ, 2009. 225 с.

18. Закон України «Про дошкільну освіту». 2000. 20-27 лютого. С. 3.

19. Залізняк А. М. Підготовка майбутніх вихователів до роботи з батьками 3 морального виховання дітей старшого дошкільного віку: автореф. дис. ... канд. пед. наук: 13.00.04; ІІн-т вищ. освіти АПН України. К., 2009. 22 с.

20. Зязюн І. А., Сагач Г. М. Краса педагогічної дії: навч. посіб.: Укр.-фрін. ін-т 
менеджменту і бізнесу, 2007. 302 с.

21. Кондратенко Р. В. Формування готовності майбутніх вихователів дошкільних навчальних закладів до виховання відповідальності у дітей старшого дошкільного віку: автореф. дис. ... канд. пед. наук: 13.00.04; Черкаський нац. унт ім. Б.Хмельницького. Кривий Ріг, 2009. 20 с.

22. Кононко О. Л. Особистісний підхід: суть та шляхи втілення в державній базовій програмі. Дошкільне виховання. 2001. № 9. С. 10-14.

23. Левінець Н. В. Формування професійної готовності майбутніх вихователів до здійснення фрізичного виховання дошкільників на засадах народних традицій: авторефр. дис. ... канд. наук: 13.00.04; Нац. пед. ун-т ім. М. П. Драгоманова. К., 2007. 20 c.

24. Лещенко М. П. Щастя дитини - єдине щастя на землі: До проблеми педагогічної майстерності: навч.-метод. посіб. К.: АCMI, 2003. Ч. 1. 304 с.

25. Машкіна Л. А. Підготовка студентів педагогічних училищ та коледжів до використання інноваційних технологій в дошкільних закладах: дис. ... канд. пед. наук: 13.00.04; Рівн. держ. гуманіт. ун-т. Рівне, 2000. 268 с.

26. Паламарчук В. Ф. Як виростити інтелектуала: посіб. для вчителів і керівн. шкіл. Тернопіль: Навч. книга Богдан, 2000. 152 с.

27. Поніманська Т.І. Підготовка фахівців з дошкільної освіти за кредитномодульною системою організації навчального процесу: навч. посіб. для студ. вищ. навч. закл. Київ: Міленіум, 2007. 243 с.

28. Піроженко Т.О. Комунікативно-мовленнєвий розвиток дошкільника. Тернопіль : Мандрівець, 2010. 152 с.

29. Плохій 3. П. Виховання екологічної культури дошкільників. Дошкільне виховання. 2002. №5. 175 с.

30. Павленко Н.О. Підготовка майбутнього вчителя початкових класів до використання інтерактивних педагогічних технологій: дис. ... канд. пед. наук: 13.00.04 ; Полтавський держ. пед. ун-тет ім. В. Г. Короленка. Полтава, 2008. $332 \mathrm{c}$.

31. Програма розвитку дитини дошкільного віку «Українське довкілля». Тернопіль: Мандрівець, 2013. 264 с.

32. Програма розвитку дітей старшого дошкільного віку «Впевнений старт» / О.О. Андрієтті, та інші. Тернопіль : Мандрівець, 2013. 104 с.

33. Сайко Н. О. Профресійно-педагогічна підготовка майбутніх вихователів до соціалізації дітей дошкільного віку: автореф. дис. ... канд. пед. наук: 13.00.04; Ін-т пед. і псих. проф. осв. АПН України. К., 2004. -19 с.

34. Савченко О. Удосконалення професійної підготовки майбутніх учителів початкових класів Початкова школа. 2001. № 7. С. 1-4.

35. Слободянюк Т. Б. Становлення та розвиток професійної підготовки фрахівців 3 дошкільного виховання в Україні (кінець XIX - початок XX-го століття): автореф. дис. ... канд. пед. наук: 13.00.01; Нац. пед. ун-т ім. М.П.Драгоманова. К., 2000. 20 c.

36. Сурмін Ю. П. Майстерня вченого: підруч. для науковців Київ: Навч.-метод. центр «Консорціум з удосконалення менеджмент-освіти в Україні», 2006. 302 с.

37. Тарасенко Г.С., Тішик О.А. Використання педагогічної евристики у фаховій підготовці вчителя початкових класів: Вісник АПН України. 2009. № 4. С. 19-26.

38. Толмачова І., Дмитренко Г. Організація виховного процесу у групі продовженого дня : використання інтерактивних технологій. Київ. 2006. С. 17-28.

39. Щербань П. М. Активні методи підготовки майбутніх учителів. Київ: Знання, 2008. 48 c. 
Наукове видання

Наукові редактори

ЛОБОВА Ольга Володимирівна

КОНДРАТЮК Світлана Миколаївна

\section{ДОШКІЛЬНА ТА ПОЧАТКОВА ОСВІТА В СУЧАСНОМУ ПЕДАГОГІЧНОМУ ПРОСТОРІ}

Монографрія

Відповідальний за випуск В.І.Шейко

Комп’ютерна верстка С.П. Цьома

Підп. до друку 24.02.2020.

Формат 60x84/16. Гарнітура Arial.

Папір офрсетний. Друк цифровий. Ум. друк. арк. 20,46.

Ум. фрарб.-відб. 20,46. Обл.-вид. арк. 22,35.

Тираж 100 пр. Зам. № 17.

Виготовлювач:

ФОП Цьома С.П. 40002, м. Суми, вул. Роменська, 100.

Тел.: 066-293-34-29.

Свідоцтво суб'єкта видавничої справи: серія ДК, № 5050 від 23.02.2016. 